University of Kansas Publications

Humanistic Studies, 43 
The research reported herein was performed pursuant to a contract with the U.S. Department of Health, Education, and Welfare, Office of Education, Institute of International Studies, under Public Law 85-864, Title VI, Section 602 as amended.

U.S. DEPARTMENT OF HEALTH, EDUCATION, AND WELFARE

Office of Education

Institute of International Studies

PRINTED BY THE UNIVERSITY OF KANSAS PRINTING SERVICE. 


\title{
AN ADVANCED READER IN CHINESE HISTORY
}

\author{
Grace Wan and Wallace Johnson
}

With the assistance of Vivian Chang, Christopher Chi and Eva King

Lawrence: University of Kansas Publications, 1973 


\title{
Preface
}

My experience in teaching the Chinese language has led me to feel the need for a textbook which would prepare the student to read books and articles on Chinese history independently; that is to say, a textbook that would enable the student to go beyond simplified material glossed in English and to escape dependence on Chinese-English dictionaries. Such a book has to overcome two principal obstacles. The student must become familiar with the different prose styles used by modern Chinese historians, and he must likewise become accustomed to definitions given in Chinese-an essential if he is to use dictionaries written in the Chinese language.

Many persons have had a share in compiling this book. The responsibility for the attempt to divide modern historical prose styles into levels according to grammatical complexity and the decision to use Chinese to define new words and phrases lies with me. I directed the work during the first year and selected the contents of the lessons; Professor Grace Wan was in charge during the second year. Professor Wan also wrote most of the biographies and suggested the index and the charts. The assistants were Vivian Chang, Christopher Chi, and Eva King, who did the initial reading of all the lessons, picked out the new vocabulary, and wrote the definitions for the glossaries. Professor Richard L. Spear kindly served as pro forma director of the project while I was on leave of absence during the second year.

\author{
WALLACE JOHNSON \\ Project Director
}




\section{Introduction}

This book offers three main features. It contains a graded selection of writings on Chinese history by some of the best modern Chinese historians. Secondly, all new words and phrases encountered in the lessons are defined in Chinese, so that the reader becomes accustomed to the use of dictionaries written in the Chinese language. Lastly, a series of questions is appended to each lesson, which it is hoped will lead the student to use his knowledge of Chinese to discuss the leading points presented in the lessons.

The sixteen lessons in this reader consist of journal articles and selections from books on Chinese history. The lessons are divided into four groupseach of four articles or selections-concerned respectively with pre-Han China, the Han through the T'ang dynasties, the Sung through the Ming dynasties, and the Ch'ing dynasty to the present day.

All the lessons are written in modern Chinese, but they present several prose styles of differing complexity. The first lesson in each of the four groups is written in a relatively simple style which closely resembles that of the spoken language. Then follow two lessons in ascending order of difficulty which use the somewhat more complex grammatical constructions most often found in modern historical writing. The last lesson in each group confronts the student with a complicated style which approaches that of classical Chinese in difficulty but which is still favored by some scholars. Thus in each group of lessons the student progresses from the easiest to the most difficult level of modern historical writing.

Each lesson has five parts: a short biography of the author, a précis of the lesson, the lesson itself, a glossary of unknown words and phrases, and questions about the lesson. The text of each lesson is approximately ten pages long. No changes in either vocabulary or grammar have been made to reduce the difficulty for the reader. Explanation of the grammatical problems encountered in the lessons is left to the individual teacher, but it is hoped that such explanations will be given in Chinese so far as possible.

English is used in this reader only for certain proper nouns which could not otherwise be understood. The glossaries for the lessons assume that the student knows the approximately 1,200 single characters and 7,000 compounds introduced in the series of texts authored by John DeFrancis and published by Yale University Press. ${ }^{1}$ This basic Chinese vocabulary is used to define the new words and phrases contained in the present reader. The biographies, précis,

\footnotetext{
${ }^{1}$ This basic group of characters and phrases has probably been learned by anyone who has used a comparable serics of textbooks. But students who have used other textbooks might find the Index Volume of the DeFrancis series helpful.
} 
and questions are also written using the vocabulary and grammar learned through the DeFrancis series.

Vocabulary items are defined in the glossaries only on first occurrence, but there is also a complete index in the back of the reader. Since the level of prose given in this reader is that normally used by scholars, it is recommended that the student master the vocabulary of the lessons. Of course, many specialized words and proper nouns may be ignored, but the proper way to learn vocabulary is through its occurrence in a variety of contexts rather than through memorization in isolation.

The forms of definition and the guide to pronunciations used in this reader are those of the Gwoyeu tsyrdean (Shanghai: Commercial Press, 1937); a table of the syllabary with the English equivalents is included in the present volume. This is the best dictionary of modern Chinese currently available, and the first that a student should learn to use. A valuable introduction to its use is Grace Wan's A Guide to the Gwoyeu tsyrdean (Taipei: Ch'eng-wen Book Co., 1971).

Some of the lessons use simplified characters. The standard forms of these characters are given in the glossary as well as in a list at the back of the book. The lessons also unavoidably contain quotations written in classical Chinese. The vocabulary of these quotations is given in modern Chinese and where necessary the whole quotation is paraphrased in modern Chinese.

Within the limits of selection this reader tries to present a wide range of viewpoints, from that of the classicist, Ch'i Ssu-ho, to that of the revolutionary, Mao Tse-tung. Having reached this level of reading and discussing mature work written in the Chinese language the student can justifiably feel that his many hours of study have proved worthwhile. 


\section{CONTENTS}

Preface

Introduction

Lesson 1 中國上古史研究課第二祭期講義序目……顧颉㓮1

Lesson 2 中國社會的歷史的發展階段……郭涞若 15

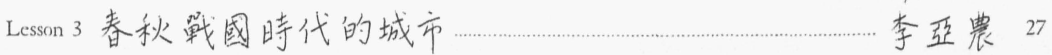

Lesson 4 封建制度之崩壞與儒家與墨家法家之受論……弯思和3 9

Lesson 5 秦漢時期之中國文化……勞 畭 57

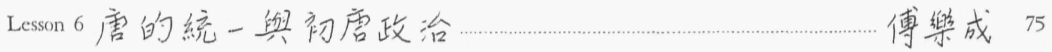

Lesson 7 唐代文化約論………嚴耕望 91

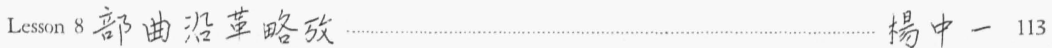

Lesson 9 論成吉思汗………暲儒林 137

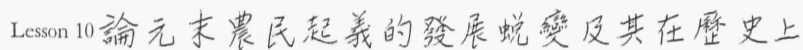

所起的進步作用……王崇武157

Lesson 11 略論宋代地方官繁和私等的消長…………銐子健 171

Lesson 12 宋代南方虚市………全漠界1 89

Lesson 13 毛澤东思想开辟了中国历史科学发展的道

路双拓 203

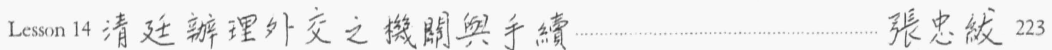

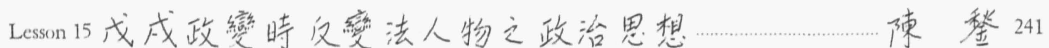

Lesson 16 道統與治統——錢穆 261

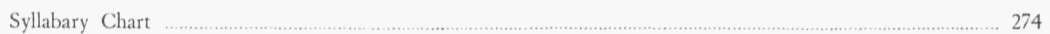

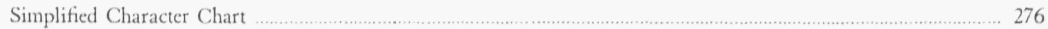

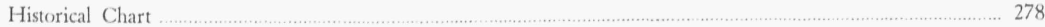

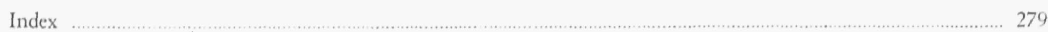




\section{第一課中國上㖛史研究課第二學期講義序目 \\ 顧頡用}

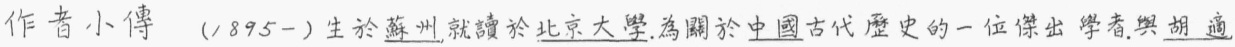

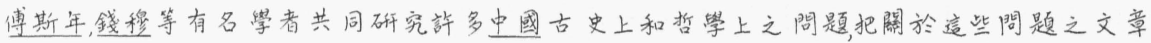

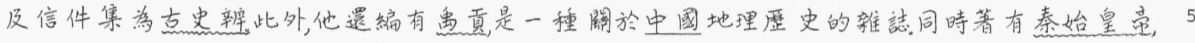

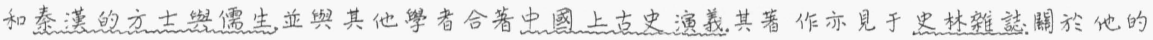

傳記可胃 Howard L. Boorman, Biographical victionary of Republican China, II, 245-247.

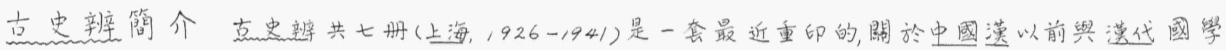
文草的書, 表现近代最好的中國學者治祭精神、第一, 三三册和第五册离僱頡㓮所编, 第四册和

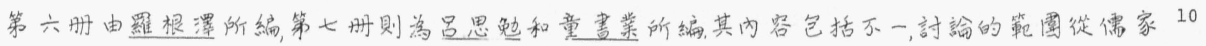

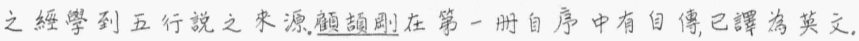

這一学期所講的, 乃是我們的古史中的一個最大的攡結。這個 㿂結自從發生以来, 大家莫名其妙地在信奉: 就是對它懷疑的人想要攻搫它, 也因各方面的材料都給弄㩊了, 寻不到一個頭緒, 無法下手。攻撃既不可能, 15 於是編起古史来, 雖明知它是荒謬, 也不得不依聲學舌, 照鈔一遍。

一方面, 又因帝統即是道統, 而道統是國性國本之所熬, 所以這一 個系統就成了國家的功令, 倫理的中心; 有不信的就是離紅畔道, 該在昩减之 列。因此, 即使有人能想出方法去解開這個澓結, 但在專制時代也是不敢做 的。

因為有遥雨個原因, 所以筀王莽時代直到清代, 這一千八百年之 中, 這個破綻甚多的系統郤能安稳地维持下去, 統一所有的歷史書.

不幸清代是一個整理古文籍的時代, 什麼古書都要呼究, 把它婀 的本子問題弄得一天比一天清楚。這樣一幹許多偽書及真書中窈偽的部 分就露出馬脚来了。書籍的著作時代䀣成了學街界中的重大問題, 㫜書籍2 25 衰邊紀载的古代史事自然聫带發生了問題。到了十八世紀之末, 崔東壁先 生(述)便把戰國以上的書和戰國以下的書分成雨組, 作比較的研究。結果, 他 指出戰國以下的書衰所述的古代史事的無數誤謬説明它們自智地或不自 覺地造偽的方式。他做了一部考信錄對于古史作澈底的考究, 去其妄而存 其真。他的考信的工具是孔子的綵, 因為遥些書出得早, 保存的原来栐子多。30 凡不合於綵的, 既為百家雜説, 不該信它。但是䌑中所記的古史本不很多, 如 何能把百家椎説- - 量度了呢? 所以他又收取了次一等的材料進去, 即是 解釋紅書的傅記和羽翼綵書的諸子。他這個工作做了四十年, 把串周以上 的歷史完全賽查遇了。逼是一次大清理, 自從有了䢣個㿂結之後所不曾有 
過的清理。

可是, 我們在這半年中所講的㵟結, 是綳學極昌盛的時代所發生 的, 故這些病菌蔓延在百家雍説裹的遠不及其莫延在經和傅記裹的多。崔 先生是信經的, 紅以外是信傅記的, 所以這個系統踓被他打了䇝拳, 但没有中 5 著要害,仍無礙其生存。

又過了一百年, 到十九世紀之末, 康長素先生(有為)起来, 大瞻作新 學伪經考把經傳中的一部分也排除出去。這絸鞭辟入裹, 打碎了追個系統。 這固然是他的成功, 但若汥有他以前的一班漢學家和今文學家專力把漠代 緼祭的派别- - 理清, 把久已忘記了的今古文問題重新提起, 則他也不能獲 10 得這個大受見。原来漠代的經学因發生時代的先後, 及其發生時代的社會 需要, 分為乏文和古文雨大宗。今文方面本来没有統一過。古文一派, 則在

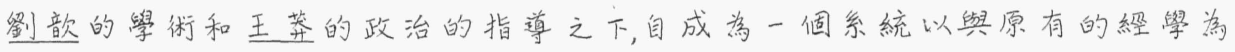
敵; 這原有的綵學就被名為今文。古文一派為適應時势的需要及攻擊今文 家起胃, 不但自有其䋑説, 亦且自有其緸書。這些紅書比了今文家的, 除了文 15 字異同之外, 又往往有所增益, 這就是他們的偽作品。逮先生既特為一書, 㗤 明此義, 於是往常看一切經傅同在孔子的意旨下的, 到這時便發生了大問题。 而崔先生所謂考信於公藝的考信録中所收的材料是否為真正的信史, 自然 也發生了問題了。

康先生告訴我們, 在今文家的歷史裹, 五帝只是黄帝, 颛垍, 帝覺, 堯,

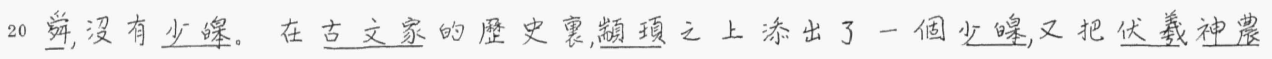
一起收入, 使得這個系統裹有八個人, 可以分作三皇五帝, 來證菑古文家的偶

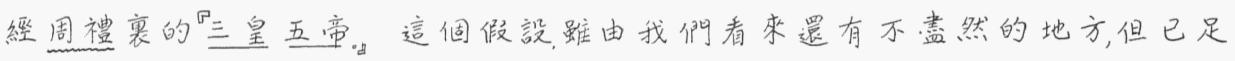
以制世經和县念的死命了。

康先生奔走政治, 對于新學偽經的研究工作汥有綎續做下去。於 25 是又有另一個崔先生一崔解甫先生(適)出来, 根據了他的學説作精密的呼究, 著成了一部春愁復始和一部史記探源。

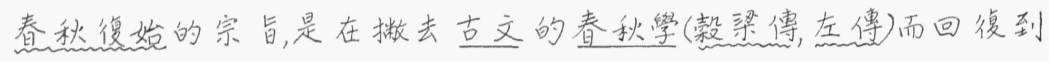
原始的春秋學(公美傅)。他的建設的部分是否得到李子作春愁的本意, 我倗

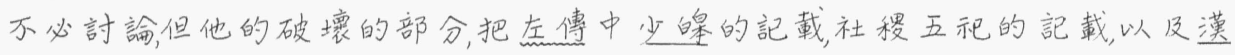
30 為克後的記載, 都以新莽時代的需要把它解釋明白, 實在足使後来研究古史 的人對于這些古史的来源有較深澈的瞭解。

史敦探源的作意也和上書一樣, 是要探求史記未被竄熖時的原

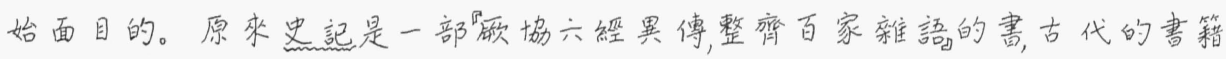
差不多都包括在裹邊它又是作在未有古文學派之時, 保存今文綵説最多。 
克文家既造了許多偽書, 又出了許多新主張當然舆史記所載的不合所以他 們連史記也要改動。崔先生這一部書, 分析出史記中含有乏文義的及古文 義的材料, 以今文義的為其原始的文字, 古文義的為其增窄的文字。他在全 書之前, 作了一卷序登立了幾個分析的標準。標準中的一個是終始五德。 他説, 追是劉歆欲明新之代湴, 迫於皇天威命, 非人力所能辤讓, 所以造出来的。5 他把世經的系統排給我們看, 説: 如果不插入少媓, 则漢不能质火德的枆的後

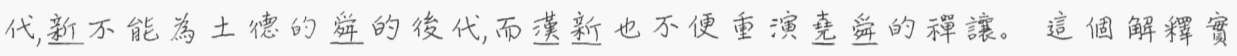
在比了康先生的增入少媓為要補足三皇五帝之説精密多了, 因為從集義到 舜為三皇五帝, 這是後人的解釋, 劉㰴方且以优羲至颛頊為五帝呢。但崔先 生説終始五德之説為劉㰴所造, 託之怱街我也不以為然。如果五德説為向10 本所無, 則新創此説之時必不能驟然博得多數民息的信仰, 且亦不當有許多 衝突的五德的歴史記載。現在王莽以前的五德記載既這樣多, 而王莽時的 五德系統和郇衍的五德系統又根本不同, 可見這是冒牌的而不是创作的。 他們這些著作, 都是在歴史界衰起革命的, 論理㢜當使通俗的歷 史大大地改觀。何以這三位先生倡導了一百餘年, 我們的歷史系統還是王 15 莽的歷史系統, 不但通俗的歷史書未改, 即整者們也不大理會呢? 説是社會 上不知道吧, 新孟偽經考已刻了七次版子, 考信錄也有五種版子, 史記探源也 有雨種版子, 其鉛印的一種已三版這種書惯在是很普及的3 ; 焦經考且因焚 禁三次之故而使人更注意了。説是他們的學説不足信吧, 郤也没有人起来

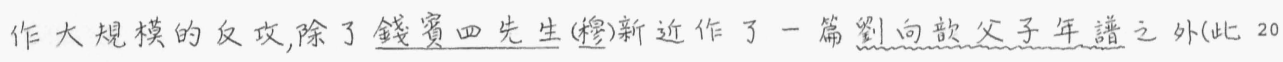
文利入燕京學乵第七期, 將出版。)

那麼, 這是什麼緣故呢? 依我猜想, 可分為三種原因。

其一, 這䉝十年中, 我國内夏外患紛至䍐來, 人民憔悴, 失其有生之 樂。又禹生活㻺迫, 只有临忙, 學問的事簡直談不到。所以這種很可以有為 的歷史問題, 雖䋎先輩鼓吹, 但大家為環境所限, 只能知道他們有追一回事而25 已, 不能自己起来繼縜努力。(這是一切攀問所公有的苦痛, 古史學當然不能 成為例外。

其二, 他們提出的問题, 幾乎率涉全部的經學和史學。假使我們 不能知道䢣些䋑史上的䦓題在當時如何一點- 滴地積成, 到後來如何一點 一滴地拆散的歷史, 則我們對于他們的結論将等法明瞭。不幸他們的書既30 不能通俗化, 又不甚能系統化。而今古文的問題又太複雜使得初學的人摸 不著一個頭路。大家看著他們的書, 只知道他們在创立一種新㽞説, 他們要 如何如何而已, 實際上不易得到很深的刺戟引起跟著他們工作的興趣。

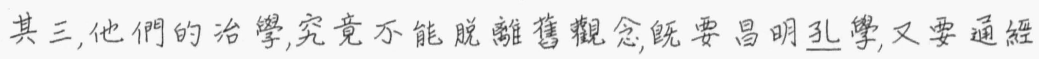


致用。考信錄一書固然不少客觀的研究, 但也不少主觀甚重的衛道議論。

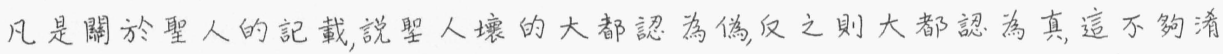
㩊事惯嗎? 古文家的經文固然是偽但他們的絙説出在今文家之後, 當然有 勝過今文家的地方。而且鉒我們看来, 今文綵説不過是西漠前期的經師所 5 説的話而已與孔子不自得能發生密切的關係。但康崔諸先生則先已認定 自己是今文家, 凡令古文經義有不合的必揚令而抑古。甚而至於春秋時的

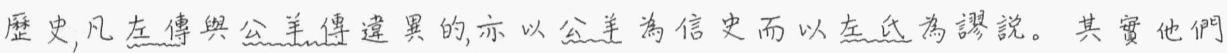
既説國語為左德的前身, 則左傳的記事出於古文家之前, 原不當因它学古文 家改編之故, 使它蒙了古文之名而與今文對墨。在這種地方, 很可使人懷疑 10 病門户之爭而非真理之采。又康先生是作政治運動, 鼓吹瘦法的人, 所以人

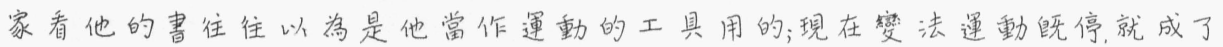
過時货了。

然而這三種原因, 在我們大致都可避免。

第一, 在這終年戰爭的國家之中, 我們逻能不罹敛鏑, 不受谏餒, 在

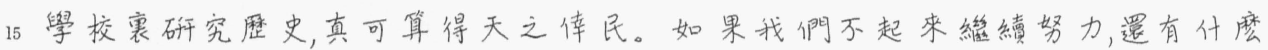
人幹?

第二, 我們固然程度不殻, 不能在短時間内有超越他們的成綪, 但 把他㑚的繁説通俗化, 系統化, 使得後来研究歷史的人容易摸出一個頭路来, 這是可以的。我們且得做了這步工夫再説。

第三, 從前人治祭的最大希望是為承接道統, 古文家所以造偽經 者为此清代的今文家所以排斥偽經者也為此。但時至今日, 弆子的勢力已 遠不如前了, 我們可以打破這種求正統的觀念而易以求真寞的觀念了。

因為這個緣故, 所以我在這半年中編了這一份講義。

想起我自己對于這方面的研究的䋑過也值得一説。當民國五 25 年, 崔解甫先生初到北京大學時, 我即上他的春愁公羊䁷一課。那時大繁裹 不行選科制, 所以這一課在必修。我先前已受了章太炎先生(炳麟) 的影響, 深

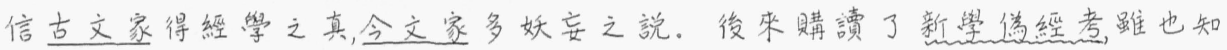
道令文家自有其立足點古文家亦有不可信處只因先入為主, 仍不能改嗃我 的薄今文而重古文的欟念。及至上了崔先生的課, 他把春秋復始和史記探 30 源一張張發給我們, 我繌領會了一個大概, 因煭今文學的代表著作是公羊傅 及春愁繁露, 故我開始點讀。万幸讀的結果, 這些漢人的迁謬的胃解已非我 荫的顽脂所能容受了, 看了只有頭痛, 故對于崔先生的課並無好感。那時的 見解, 似乎以为我既不想作今文家, 就不必理會這些。

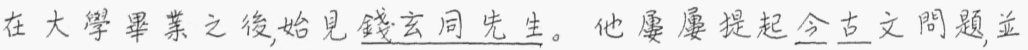


以為古文是假的, 今文是口説流德而失其真的。他以為立文家與支文家的 説話, 都是一半對, 一半不對不對的是他們自己的創造, 對的是他們對於敵方 的攻擊。所以我們要用了今文家的話来看古文家用了古文家的話桃看乏 文家。如此, 他們的真相就會給我們弄明白。我聽了這番話後, 眼前一亮, 知 道倘使不用了信仰的態度去看而用了研究的態度去看, 則這種迂謬的和偽5 造的束西, 我們正可利用了它們而認識它們的時代背景。

我雖有如此存想, 但今古文的問題究竟太複雜了, 單看载部近于 目錄學的書, 如含古學考, 新學偽經考等, 是不弇對于這個問題有澈底的瞭解 的。但是要一部經, 一部緸去砰究, 又苦於没有這個功夫。

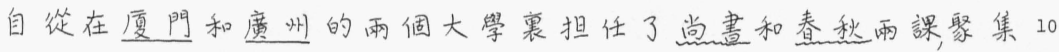
3 許多材料, 我方絻對于今古文問題有較深的認識。我知道我們一講到古 代學術, 即離不了漢學, 因煭现在所有的古書都是經過漢代人的筆削的而一 研究漢學, 今古文就是一個最大的關鍵, 因為古文祭發生時曾把所有的學問 從頭整理一過, 如果我們不把今古文的材料分清, 則未有不以古文䀯家整理 的結果認作當初的原状的, 於是就受了他們的欺騙了。

在廣州時, 又曾任上古史一課, 我始把上古史的材料作系統的收 集。(以前, 我雖有志研究古史, 但只希望作小問題的研究, 並不曾想建立一個 大系統而把所有的材料收来, 作㴜説明此系統之用。) 我便把康先生辩少䅨 的話鈔了出來, 以崔先生論終始五德的話校之, 更以其他的古史系統證之, 始 確知世䌊和会令的古史系統只是王莽的古史系統, 這個系統是為他受禪的20

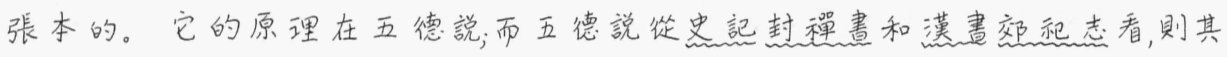

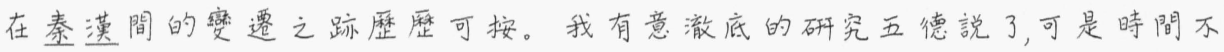
能許我。

自從去年秋後到了本校, 始得郤去數年来的無聊生活而一意研

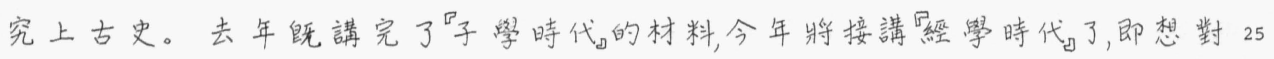
於王莽時的五德説下些功夫。本講義世經一章, 即是在寒假中葛的。開學

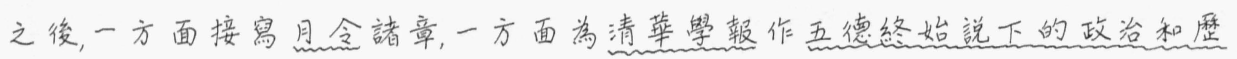
史一文, 即把講義之文放大。自開學起到现在, 已近四個月, 這篇論文只寫得 一半, 但已把清蕃學報占了三分之二, 不得不停止了。我非常的欣幸, 追半年 中竟給我専心砰究了這一個古史的中心的題目!

講義編在前, 論文作在後講義所説, 當然發现了許多錯誤之處。 待論文出版時, 再給諸君訂正吧。

這一繁期的講義, 我也知道太沉悶, 太單調, 不及去年講諸子時的 有趣味。可是, 漢的時代根本是個沉閣單調的時代呵! 我㑚如果要把現在 
成為常識的古史的來歷羙明白, 那麼, 這種討厭的柬西寛在有親手去檢視一 次的必要。

$$
\text { 曾有一位同學對我説: }
$$

有了科學就不該有迷信, 研究科學就不必研究迷信, 因爲它是 無根拵的妄誕的一件柬西, 我㑚枉费了精力去研究它幹嗎! 就如世媱, 完全是迷信的一個代表, 它的主要點是依據著什麼 五德五行, 相勝相生的把戲而出的。我們要去研究它, 證惯它, 批駁它, 的確是一樁徒勞而無益的事情! 䊺過我們研究以後 的它, 早已被我們證惯出假来了:更經過許多名人, 如崔述, 崔適, 康有虞等, 駁得劉歆走頭不是路了! 可是他們的結果是零加 一等於一, 零乘一等於一, 怕的是零减一而得出真來了呢! 那 本來是無闢重要的。

這位同學的意思是很好, 可惜他對于常識和學問的分别没有想清楚。凡是 科學家所考定的真的事惯, 一般人應當都明白的, 喚做常識。無論什麼好的 15 壞的, 真的假的, 對于這一大堆材料, 認定了一個目標, 畫出了一個範图, 而加以 研究的, 喚做學問。中国的上古史, 有那些是真的, 我們應當信它, 遥是常㵶範 圊内的事。中國的上古史, 究竟有多少真的有多少假的, 又有多少真假未分

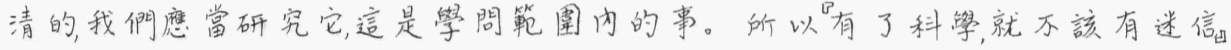
這就常識而言, 很説得通研究科學, 就不必研究迷信, 這就祭問而言, 則很説不

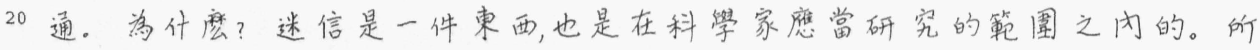
以扶乩巫祝, 十筮, 星相雖憵由政府下令禁止, 但心理學家還要收集了這種材 料去研究檪態心理學。上古時代的各種生活俄式, 在文明種族間早失去了, 但社會學家賟要到野蠜民族中去搜求了而研究古代社會。難道他們有啫 㾂之癖, 幹這種不值得幹的事嗎? 不, 追正因學問的目的在求知, 與常識的目

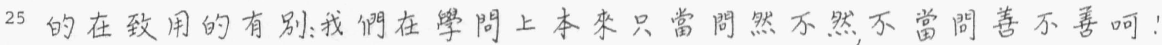

而且, 世䌊的基礎建策于迷信上, 這是我們的話, 一般人正以為這 是真歴史呢。試看去年商務印書館的中夢李國史教科書因不载三皇五帝 而被禁, 北平某文化機閵的圖書館, 主其事者不許㡚入崔東壁遗書, 可見這種 迷信的勢力還是很大。我們就是退一百步, 説我們研究祭問的目的不在求 30 知而在致用, 試問我們還是一聲不瑤, 讓人家去迷信世經的歷史系統好呢? 還

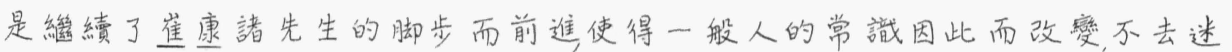
信世經的系統為好呢? 如果説是後者好, 那麼, 研究的事怎可説是徒勞無益。 並且這種五德五行, 相勝相生的把戲對于上古史固然是假的, 對 于漢代的史還是真的。漢代的社會是一個以院陽五行㼜中心思想的社會, 
這種把戲就是那個社會的真實産物。試問我們要研究漠代思想及其在上 古史上所發生的影響, 我們能不理畣這套把戲嗎? 這正如卜筮星相者所講 的話固然是假話, 但他們自己的生活郤是真的生活, 他們的假話就是他們的 真生活的反映(如何可以騙得人相信, 如何可以多騙取金錢, 如何可以安度他 自己的生活…。只他們也是社會上的一部分, 我們如果作社會調查, 對于追種5 真生活不當去調查清楚鸣?

\section{至于零加一得一, 零减一得負這種方式也不適用于莺古史的研} 究上。為什麼呢? 因為古史若是本來真有的給偊史弄糊塣了, 這就成為一 正一贫, 照代數的方式, 正頚相加應當得負現在我們把這些偶史清了出去, 就 恢復了原有的正數了。如其古史本来汥有, 偽史恣空結搆, 這本是贸數; 我們 10

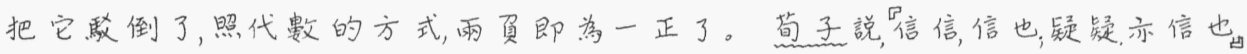
就是這㧽道理。

以上的話不但是舆這位同學责善, 也是希望消除一般人的誤解, 因為在這科學落伍的中國做研究工作的人大少, 一般人得不到觀感這種誤 解是最容易發生的。

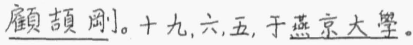

討論問題:

一、説説作者編遥份講義的源起,

二、討論史記對上古史的看法。

三、討論中國傅統上對其古史中傳説的人物之看法。

四、討論考證漢以前綵典的方法。

五、試述“疑古運動”對中国古史認識的梖㓺。 


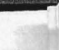

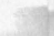


1.13 33 3

痽生射體裹的一偅結塊病

痽結团踓的地方

.14 莫哦够不

妙吆神奇

莫名其妙不知道原故

信奉 TIS口公深信不疑

懐下 $\times$ 更藏

懷疑心中藏有疑䦦

心緒必線的末尾

磌緒先後的次序

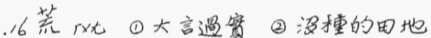

晹咇错誤的

䇣晹虚安错誤

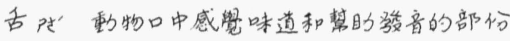

學告學别人説話, 傅逢别人説的話

鈔後把已窎的再留一次

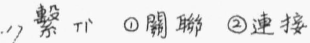

. 8 功令 $k x<$ HIC 法令

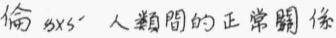

倫理人倫道德之理

畔奶同粄、背着

誅生殺死

誅減殺害消减

.19専制留好只照一倜人的意思去做大家的事

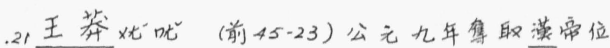

自立，國跣新後被殺、共在位十五年。

.22绽蚂哀服的線阙了

破綻事情或言語中的毛病

23 籍 41.

.24伪炡假

瓮像改换作假文字

25 脚41公等人有两手雨脚

馬脚破綻

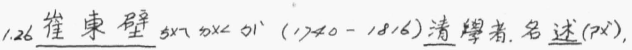

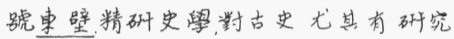

.27述矿刿東壁名。

29 考信 3 幺 $^{2}$ TS 考證

于山同於

澈脯(1)明白(2水清

澈底の詳細清楚徒面通到底、従外通到 裹

考究胎收考察研究

去其娈而存其直拿走不合道理的部份

而保存直赛的地方

.33釋ア 解説, 哾明

羽山鸟毛

翼门使岛艇行的部位

羽翼棉助

.34審25 詳細

蜜查詳細的撿查

2.1 清理整理

2 昌化县盛

了菌做一一程微生物

曼 $\mathrm{n} 3$ 指物細長的支幹

延13'引長

蔓延延長而不断

4 拳 $\angle D B$ 合起乎掌的樣子

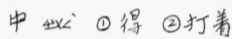

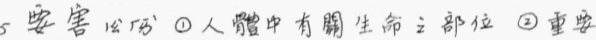
地勢

中要害打着最重要的地方

礙动限止阻止

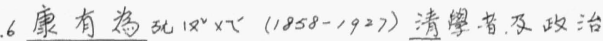

家, 字長素, 南海人, 青光緒二十四年推行新政 失欺, 亡命組織保皇黨层國成立後政治上無 大成就著有孔子改制考大同書等 膽吸”畐氮 


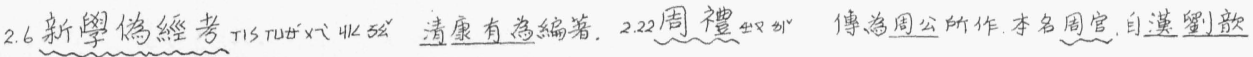
攻揧古文學指秦始皇燎皇而六經未損, 一切 始名周襍

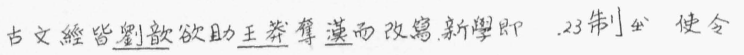

新朝之然全青共十四卷。

7 䋓动同、才㹝

鞭跠打牛馬之工具

鞭辟》13 努力, 酉力

鞭辟入裹努力研究

碎山地破成小塊

.9 猚「行”得到

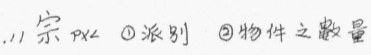

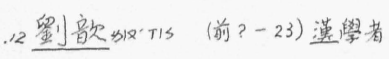

導汃指引

.14亦, 同口語之, 也

2.15其i不同

具同相同和不相同的地方

增益叫i增加

閔得明

閐明敦明白, 顥清楚。

16 往常忧彻平常或以前

旨必”志

意旨指意思之所在

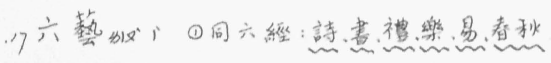

(2) 福祭、射、御、患、數、

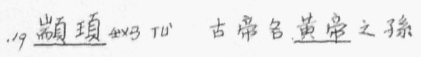

帝覺们列古带名

堯的古帝名

20 舜 $7 \times 5$ 古帝名

少媓弦厂古帝名

添动增加

伏羲的的古帝名, 教人民打魚牧牛、羊

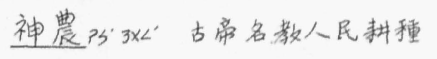

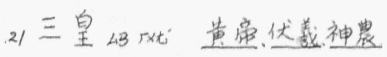

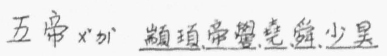

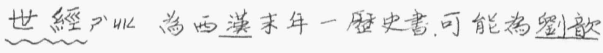
所窝

望令U士゙か心䄝熟中的篇名

.24 奔3 S 急走

奔走急於作某事

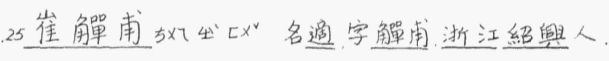

曾任教北京大學年七十病死

.27宗旨P X $<4^{*}$ 謂人行事之目標所在

捕父如”向遠處投去

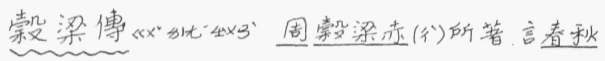

事

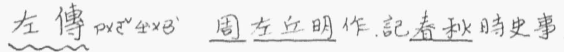

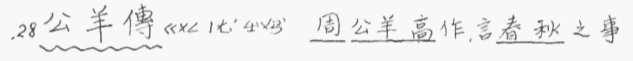

春秋三傳之一

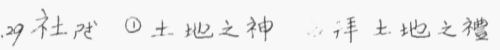

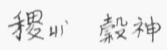

祀公供神䄳祖

五祀信神的人拜神的五㮔不同之典禮 31 源 43 水流之本

瞭始明白

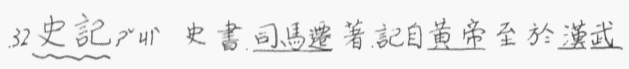
帝, 有本紀十二表十書八世家三, 列傅上十。

一百三十卷

.33 厥4 4 世

協化和合

敃括地包包含

3.2 析门解䆁

分析分解事物的根本然後加以瞭解

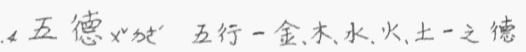

与辭讓与”昰推卻, 不接受

6 插行放在某些事物的中間 
3.7 禪 P 33 傳位

禪讓把皇位讓給别人

$$
\text { .9方且统《ば 尚且 }
$$

.10託云欢依靠

之的同

鄒衍阠1 $3^{2}$ 戰國峦人、著書立説, 名重諸侯 川驟阠 急速

驟然突然的意思

博吹”換取

博得獲得

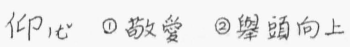

信仰信服敬愛

12 衝突往立区意胃相反

13冒呟四假借可不管一切勇敢向前

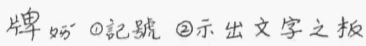

冒牌假借别人的事物當作自己的

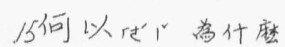

倡道忧聯”提倡領首

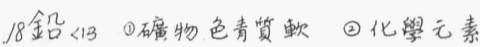

鉛印用鉛字印書

焚的燒

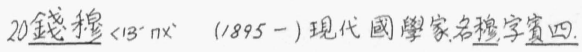

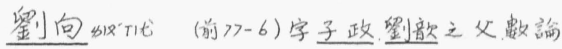

時政得失著有洪籁五行僙

譜奴 人物分類編列的記载

年譜某人每年行動之記载

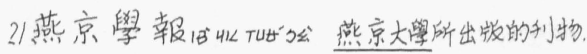

.22緣U3”起因

緣故原故

.23紛分的雜亂

沓动・多(2)重複

紛至沓来多而猺且不斷到来

憔《䍃圈苦

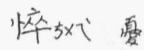

3.23 憔悴。奥苦, 受团苦(2)乾瘦病㹸

25 環5 $\times 3$ ○圈住四周(2圆形而中空的東西

環境謂四周之事物

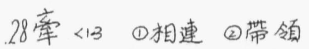

毫涉各部份互相發生關係

假使假如、要是

29 滴》水點

30拆行裂

拆散分解開来

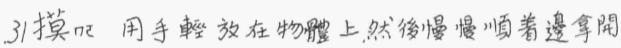

摸不着找不着

32頭路动”成”䫚緒

33 戟4 $1^{2}$ 古兵器

刺戟刺激

.34治过研究(2)治理

昌明待 M强掦光大

4.1 致代・推到極端(3)責力

致用合於宽用

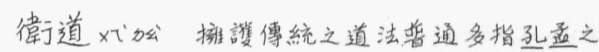

道

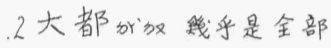

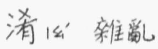

6 揚优稱讚

抑, 壓

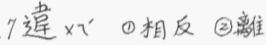

9 蒙口目認被藏在底下

畾加軍隊兵房的眚壁

對侽䶊立

10 門户做派别

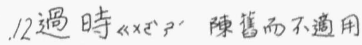

13 然而明儿可是

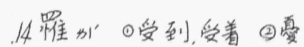

鋒的兵器最細薄的部分

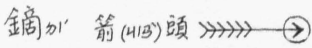


4.14 不䍜鋒鏑没有受到戰爭的偒害和痛苦5 4 相扰謂事物的樣子 凍加之水因冷結成冰謂谏, 用来表示很冷 番 53 次數

餒3飞之没有東西吃的時候的感學

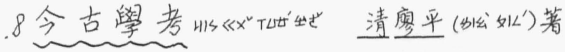

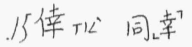

. 10 厦門 $T$ Ir'n'福建省市名

天之倖民受到上天特别愛顧的人

担䚮同擔

.17影《酒舆多句通

績41事業

12削似除去

筆削改正、除去

成績表示已綵有功效

13 鍵 413 - 一切事物的要點

.21斥公排除

排斥不能接受而想法除去

22 易i 換

.15欺《1 用心思使人上當

騙奶説好聛的話使别人相信

欺騙説假話使别人相信

26 童太炎地场沐(1868-1936)名俩麟, 字太炎精

䂺古學, 清末主張㮔族革命, 民国成立, 因反對

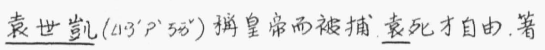

作很多。

27 妋么怪異的果西

妖妄奇㤏無知

睡《置

28 足 PX- 脚

立足點表示立埸的意思

先入为主㯖第一人之言後心中即有主晃。

不再信後人的話

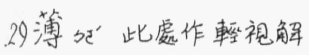

.19校忪謂考訂責籍或言語之正誤

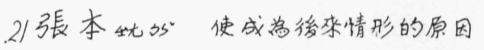

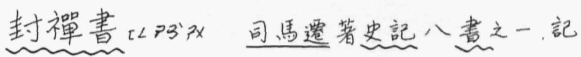

戴歷代帝王在泰山祭天地之事及福

郊祀志吆公球班固著前漠畫十志之一記

稆代帝王祭祀之福及事

22 秦《15 朝代名, (前246-20 朝之後

遷 $<13$ 搬動

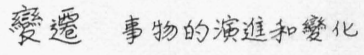

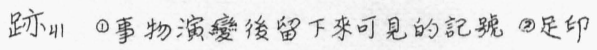
歴歷非常清楚的挵子

24 聊加自奥趣

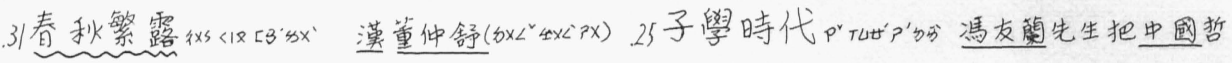

編著, 共十卷, 多記除陽之説。

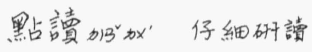

迁山謂言行好高遠而不合於事情

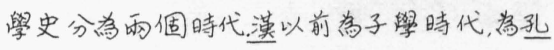

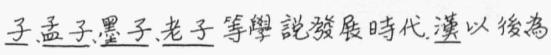

經學時代為破究經文之時代

迁謬形容言行不合事富而且錯誤極多. 26 寒 13 非常的冷

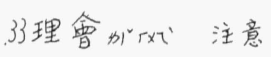

寒假學校中冬季之假

站始 $2^{2}$ 万オ

29 欣 ${ }_{T 1 S}$ 高舆

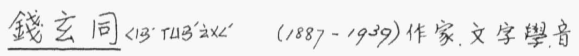

32 訂正刃讼出改正

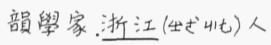

.33沉行落入水中

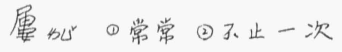

䍐的心中中不快㿟。不通氮

5.1 流傳的“做”傳開

沉愳不令人高興指精神或天氮而言 
5.33 盟調加加公形容少應化而無趣味

6./來摩的加来源

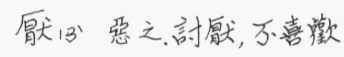

与涎加胡説八道。

枉昽向花力棌

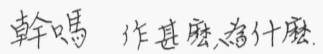

23 蠻 $73^{\prime}$ (1没有開化的人不請道理

搜汉仔細壆找

嗜ア喜好

24痂杵受小稘後表皮上所結的硬塊物

咾痂爱吃痂

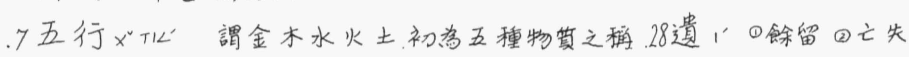

後来借用其豆相不合之理, 以解釋從古至今的

遗書謂死者遗留之文字

各偅生存原理和人生的幸舆不幸。

TA映以。影《光線的反照

8 、駁敢否定, 爭䢂

8 糊厂兄不明白

批駁批評反對

㴽动不明事理

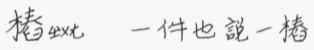

徒动空

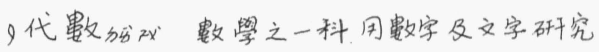

数的關係及其性算

徒勞炎白花力氪

10走頭不是路了表示無路可走

零加一等於一白花力崅而毫無效果。

10 恢江工失而復得

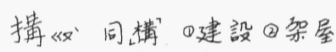

結措指文字上之組絨

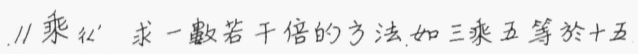

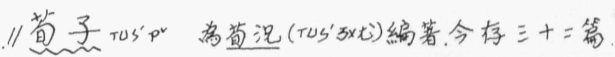

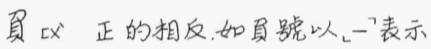

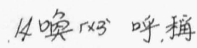

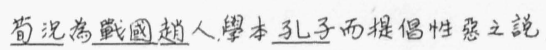

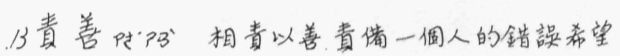
他改善。

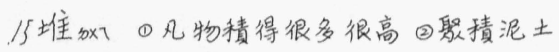

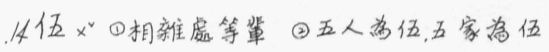

洛任思想行動笿後, 不能陵同等的人前進

扶乩迷信人的一種請神之法

巫区 替别人要求鬼神的祝福或消災的人

巫祝同巫

个 $3 x^{2}$ (1) 迷信的人用来预知以後的事 (2)预料

筮分用一種特别的算去预测好運堙遇的一

種方法

十筮各種预知將来事物方法的總粨

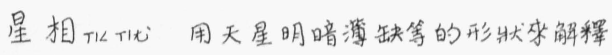

將来

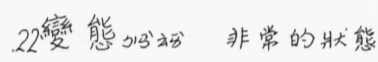

儀! 法則摽準

儀式謂舉行典禮之次序形式 


\section{第二課中國社會的歷史的發展階段 \\ 郭涑若}

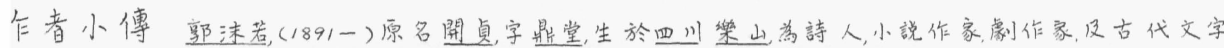

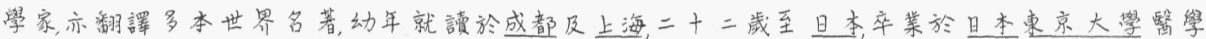

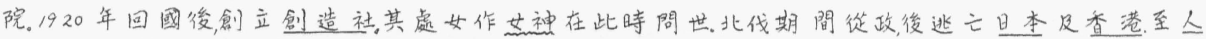

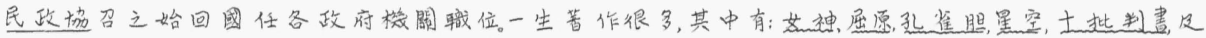

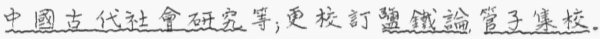

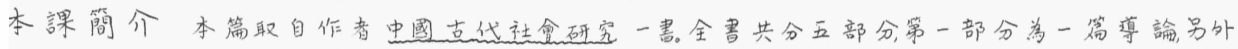
四部分各為一篇, 而各篇均非一時之作。本篇即書中之薯論, 曾於1 928 年於思想第四期上發表, 作

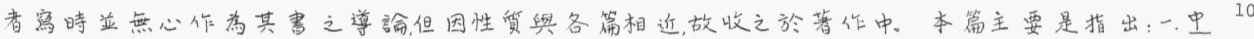
國古代社會婚姻的進化, 而且從而判定中国歴史開始的時候在商代二古代社會由母系到父系

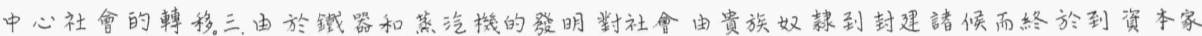
勞動看之進化的影響。

(1)

人類社會的發展是以綵濟基礎的發展為前提這已䋎是成了人 15 奥周知的事赛了。

而人類經濟的發展却依他的工具的發展爱前提。大抵在人颣 只知道利用石器或兼用銅器的時候, 他的産業是只能限於漁韈和牧畜, 他所 能加工於自然物的力量只能有這一點。當時的社會便是由動物般的㾕居 生活進化到以系為中心的氏族社會。

原始的人民只知有母而不知有父, 這在歐洲是前世紀的後半期

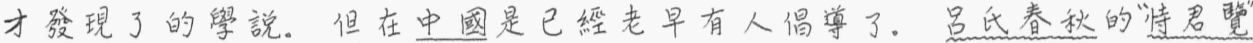
上説: “昔太古嘗繁君矣, 其民聚生群處, 知母不知父, 整親威夫妻男女之别。”所 以追種學説在我們中國應該是並不稀奇, 並不是那樣可以使人警駭的。万 過中國的古人只知道有那種生活的现象而没有人詳細地去研究遇那種原2 5 始社會的各種結構, 在遥兒我們仍然不能不多謝近代的學者, 特别是美國的 Morgan 舆德國的 Engels 3 .

穆爾㓮Morgan 费了他果生的精力研究美洲土人的生活而成点代

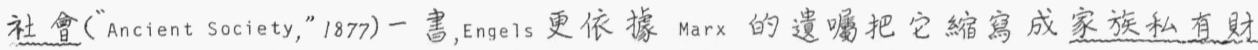
産及國家之起源( Der Ursprung der Familie,des Privateigentums und des Staats", 1884). 在 Engels 30 的書名上已綵表得很明白的這幾位先進是把古代社會的秘密—特别是由

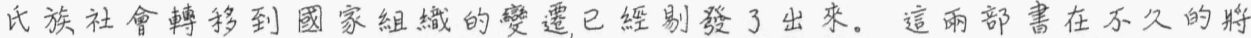
来一定有介紹到中國来的時候, 我們只就在本文的前進上有幾個必需知道 的準㒂智儎把它撮錄在下邊。 
第一, 婚姻的進化是由雜交而純粹的血族結婚而亞血族結婚而 成最後的一夫一婦。在氏族社會的初期是純粹的血族結婚. 就是在同一 母系之下的一切男女自然成為配偶, 這種交媾的方式經過不知若干年辰 的經驗, 知道了會發生不良的種子, 於是才漸濑的加以限制一含有優生學的 5 意味的限制。起初大約以年龄為限, 就是在儕輩同一的男女彼此配合, 就是同 胞的兄弟姊妹自然成為混合的夫婦。更進便成了有名的亞血族結婚逜在 Morgan 和 Engels 二氏的書中是稱病“彭那鲁亞家庭”( Punaluan family; Punalua familie)。 這是Morgan 氏的最大的一個發现。

Morgan 氏在研究美洲土人的家族制度的時候, 他發现出他們有一 10 種奇怪的遗習, 便是父之兄弟與母之岈妹之子皆质子, 彼此間亦稱学兄弟, 父

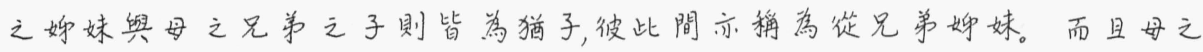
岈妹之夫, 母亦夫视之; 父之兄弟之妻, 父亦妻视之。美洲土人之生活早為歐

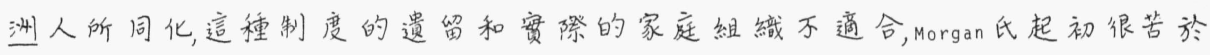
説明, 後来在檀香山的土人中才苗際發现了這種惯際的家庭組織。便是檀

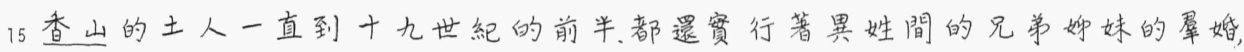
便是一切男子除開自己的同胞岈妹之外是一切女子的公夫, 而一切女子除 開自己的同胞兄弟之外是一切男子的公妻, 這些成了公夫公妻的男女便不

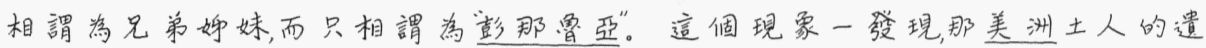
制便迎刃而解了。M 0 r g a n 氏便稻這栐的血族為“彭那鲁亞家族”。我因為我假 20 中國的雷雅上有“雨壻相謂為亞”的文献便隻關二意地譯為“亞血族結婚”。

這種亞血族結婚一發现了後, 寞在是並不稀奇的现象, 在現在的 野蜜民族中很多還菑行著, 我們中國的西藏人便是一例, 而且各文明族的祖 先都是綵過了這㧽階段来的, 這㧽階段事寞上是氏族社會的典型的婚姻。

第二, 代族社會是以母系捣中心的, 在當時男子要講”三從”, 便是 25 在家從母, 出嫁從妻, 妻死從女”。當時的社會是没有父子相承的習惯的, 婆子 的均要出嫁所以不能承父。反是兄弟可以相承因学兄弟是連扇出嫁。

第三, 那種社會是没有私有財産的, 一族内的財物都是共同享受, 一族人都是相互扶持, 但有一種民主的組織来管理族内的共同事務。大抵 一姓( Gens) 有一姓人的評議會, 由評議會共選出一個酋長以掌理一姓的事務; 30 遇有戰爭時更選出一個臨時的軍長。合數姓而学一宗(Fratrie), 宗又有評議 會, 由各姓的酋長或軍長組織而成, 以共裁一宗中各姓相閶的事務。合數宗 而為一族( Stamm) 族亦有族評議會, 其組織成分完全相同。合數族而為一大同 盟, 盟有同盟大評議會, 無單獨之元首, 而有二人平列之軍長。一這個組織是 M r r a n 氏 就 I l o c o i 人的研究所得的結果, 這兒自然是已綵紅過相當的長久的進 
化的。

就這槏在以石器銅器㾫工具以漁攃牧畜為生産本位的氏族社 弇, 是以母系学中心的原始共産社會。

但䢣種社會可以説因学鐵器的發明便完全破壤了。因為鐡器

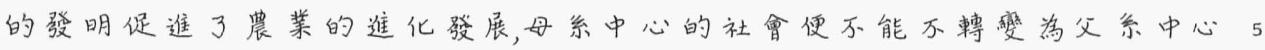
的社會。

牧畜和曹業的發明都是男子的事體。男子由漁䍀中發明出牧

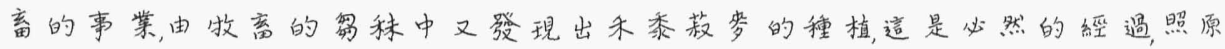
始的習惯各人隨身的工具便是各人的私有, 男子有漁獾用的弓兵, 女子便有

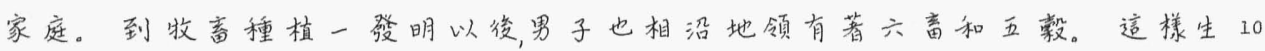
産的力量愈見增加, 女子的家庭生産便不能不降羔附庿, 而女子也就由中心 的地位一降而為奴隸的地位。這在社會的表现上便是男椎的抬頭, 私有財 産制的成立, 奴隸的使用, 階級的䙵分, 帝王和國家的出现。這兒是文明的開 始, 然而也就是人類搾取人類的悲劇的開始。

在國家初始成立的時候是純粹的一偅奴隸制。奴隸的来源是 15 什縻? 便是被征服的異民族和同族中的落伍的弱者。那時候的階級可以 敦就只有贵族和奴隸的雨偅。貴族是奴隸的所有主, 奴隸是贵族的所有物。 貴族是支配階級, 搾取階級; 奴隸是被支配階級, 被摍取階級。這時候的氏族 的成分可以説還是嚴密地保存著的就是贵族階級至少是一氏一族。

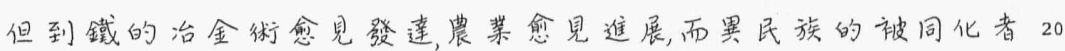
愈見加多, 同族中的落伍者也愈見增劇, 血族的成分漱渐稀薄了下来。以前

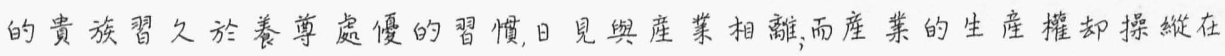
多量的奴隸階級的手裹。逼已經成了太阿倒持的形勢, 到這兒便不能不来 一個第二次的社會蓅革, 便是贵族的倒溃, 奴隸階級中的狡點者的抬頭, 追自

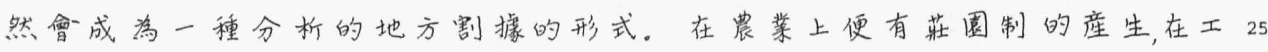
商菜上便有行帮制的出現, 在政治的反映上便成為封建諸候, 於是奴隸制的 社會又一算而為封建制的社鿖。

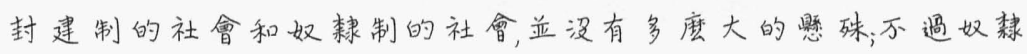
制是氏族社會的子遗, 多量的含有血族的成分, 而封建制則是多量地含有地 域成分的奴隸制罷了。蕽業上與地主對立的蕽夫, 行帮制下興所傅對立的3 0

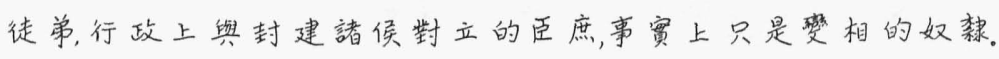

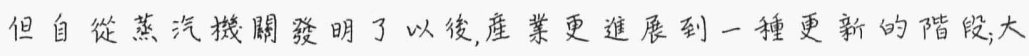
規模的生産, 大资本的集中, 海外大殖民地的發现等等—在封建社會的胎内 生出它怎麼也容納不下的一個胎兒, 於是社會上又来了一個第三次的革命。 
封建制度逐漸崩溃了, 在那封建社畣的廢墟中高算出近代資本制度的組織。 階級的分化成為了資本家與勞動者尖锐的對立。

以往的社鿖的進展就是追樣一切的社會现象決没有一成不㦄 的束西, 浐往可以察来, 這是一切科學的豫言的根本。社鿖科學也必然地能 5 暍豫言著社鿖將来的進行。社畣是要由最後的階級無産者超克那資本家 的階级, 同時也就超克了階级的對立, 超克了自己的階級而成虞整階級的一 個共同組織, 追是明如觀火的事情, 而且事寛上已經在着着的惯现了。现在 是電氣的時代。電氮的生應力不能為目前的资本制所包容, 现在已綵是長 江快流到崇明島的時代了!

以上我把社會發展的階段一般, 簡略地叙述了出来。這兒當然 有許多過於圖式化的地方, 然大抵是现在一般新興科學的正確的縮富。我 們根據咅個縮窎, 回頭来看我們中国的社會發展的程序罷。

(2)

我們中國的歴史素来是没有科學的叙述一般的人多半據古代 15 的神話德説以為正史, 這是最大的錯誤, 最大的不合理。

我們要論中國的歷史, 先要异明白中国的真正的歷史時代究竟 是從那兒開幕。這點如不弄明瞭簡直等於是海中撈月一樣了。

我們中國的歷史起源於甚麼時候? 常畫是開始於唐虚, 史記是 開始於黄帝, 但這些都是靠不著的。我們根搹最近考古繁的智識所得的結 20 果是:

(1)中國的古物只出到商代, 是石器, 骨器, 銅器, 青銅器, 在商代的末 年都還明明是金石並用的時期。

(2) 商代已有文字(三十年前在河南安陽影有鬼甲骨板上锲刻著 的真卜文字出现但那文字百分之八十以上, 是極端的象形圆畫, 而且腺法的 25 不一定, 一字有至四十五種寫法的, 於字的粠成上或倒畵或横書, 或左或右, 或 正或反, 或數字合書, 或一字拆書。而文的構成上亦或横行或直行, 横行亦或 左讀或右讀簡直是五花八阴。可以知道那時文字的産生還不甚久, 文字還 在形成的途中。(關於此项的文噳, 有志者可參看羅振王氏編的“殷虚慧契”)

(3) 商代的末年還是以牧畜為主要的生産卜鿷中用牲之數每每 30 多至三百四百以上, 即其證㨡。曹業雖已發明, 但所有的耕器還顯然是愿器

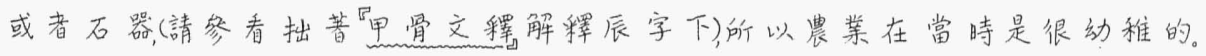
我們就根據著這三個結論, 可以㫁言的是商代才是中國歴史的 真正的起頭!

在商代都遇只是金石显用時代，那嗎在商代以前的社會只是石 
器時代的原始未開的野璧社會, 那是可以綮言的。

在商代都還在文字構造的途中, 那嗎唐盧時代絶對做不出甚麼 帝典泉陶謨禹息, 在黄帝時代更絶對做不出甚麼内䌊素閭以及已綵消減的 一切道書, 更在以前的甚麼三境豆典公索九邱, 那簡直是一篇鬼話。

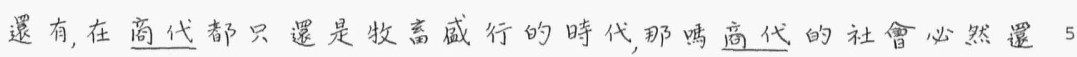
是一個原始共偟制的氏族社弇, 只要是對於新興科學稍稍受過剖練的人; 立 刻便可以得到這個暗示。

事實上竟是這樣!

《商代的王位是“兄終弟及”, 這是從來的歷史上已經有明文的.

《2) 㩚“段虚畫契”的研究, 商人尊崇先妣常常尃為先妣特祭(自周以10 後妣不特祭, 須附于祖) 。

(3)殷虚畫契”橡余所胃在殷代末年都有多父多母的现象。

從這些事惯上看来, 商代不明明還是母系中心的社會, 而且那時 候的家庭不明明還是一種“彭那鲁亞家庭”嗎?

在商代都還是這㧺的社弇那以前的社會就不言可知了。所以 15 黄帝以来的五帝和三王祖先的誕生德説都是“感天而生, 知有母而不知有父”, 那正表明是一個野合的䄱交時代或者血族壁婚的母系社弇。特别有趣味 的是堯舜的德説.

“有盧氏尚陶”直虞氏瓦棺, 追是説當時還僅僅是土石器時代。

窐皇帝的雨個女兒同嫁給舜皇帝, 舜皇帝和他的兄弟象却又共20 妻這雨位岈妹。孟子上有象説的話, 要“二嫂使治朕棲”; 楚辭的天問篇上竟直 説是“眙弟並淫。所以舜與象是娥皇女英的公夫, 娥皇女英也就是舜與象的 公妻。他們或她們正是互為“彭那鲁亞”。

更進尭皇帝不能傅位給丹朱, 舜皇帝不能傅位給商均, 禹也不能 遥直傅位給啟, 這表明是父㩲還没有成立, 父子還不能相承。

最後是那時候的禪榱了。尭舜禹都是由象人公選出来的。我 們在“舜典”中看那些“四岳”十二敃九官二十二人在皇帝面前你推選一個人, 我 推選一個人, 在那兒很客氣的討論。那不是一些各姓的酋長軍長在開氏族 評議弇, 在推選新的酋長或軍長的嗎?

又堯舜禹的傳説都是二頭政長。在党未退位以前是罣舜二頭, 30 在尭退位以後是舜禹二頭。堯時又有帝摮為對,均與西印度人之二頭盟主 相合。

(案) 帝舜毁是段人之先祖帝覺, 象封有原節天間之有婏有狄,

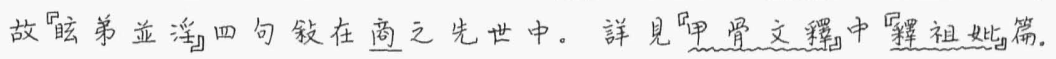


(二九年九月十六日後誌)

這些正是古代傅説上所保存著的一些氏族社會的影子。我們 看在商代以前的社會不明明還是氏族社會嗎?

由代族社會轉移到奴䘵制國家的這個關鍵, 古人也是注意到了 5 的, 用古代的話説來便是“由帝而王”。古時的人以学党舜傅賢, 夏禹傳子, 是家 天下的開始, 所以貶稻帝號学王。所以在夏禹以前都是帝, 在夏禹以後便成 了三王。但這帝王遞禪的時期也有更説得䐅一點的。據史敦毁李紀的末 尾説:

“周武王為天子, 其後世貶稱帝號, 號㪄王”。

10

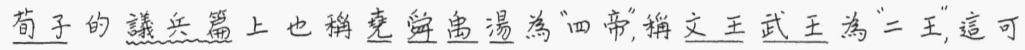
見古人把那第一次的社會革命的時期也有看在殷周之際的時候的。這種 見解據我們最近的研究, 可以説是得著寞物的佐證。便是由原始共産制到 奴隸制的轉察到段周之際才真正的完成。

本来一種自然發生的社會革命, 是要缓過很長久的一個時期的, 15 有殷一代或者都可以看成是一個变革的時期, 所以就在奴隸制全盛的周代 初年都還有氏族社會的子遺闢於這以後的論證, 我們為行文的簡便起見, 整 且把它們省略了罷。

總之, 中國的歷史是在商代才開幕。商代的業産是以牧育為本 位, 商代和商代以前都是原始共産社會。追是我們在這段裏得出的結諭。

討論問題:

一, 古代原始社會是怎㥞的?

二何謂严血族結婚。? 此名詞由何而来?

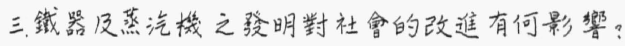

25

四.中國真正的壁史起源於何時?

五要研究中国上古史應從何著手: 
1.15礎㣗建筑物最下面的石顽

基礎 根本, 基本

前提〈 13 “云 $\left.\right|^{\prime}$ 應先注意之點

人勨农人

.16周出又日完全普遍

.17大抵多名 大概

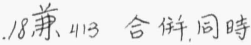

銅动如金展元素, 黄紅色, 性能伸展延長

漁山捉魚

獵多化捉殺動物

牧几養動物

畜灰善牛羊馬等

20 母系 $n x^{v}$ 在原始社㬝中, 結婚後男的嫁到

女家所生子女犀母方。

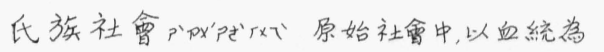

集團普遍以母系為中心

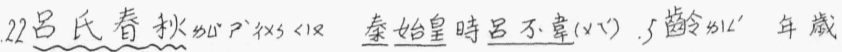

請其家客人所箸, 其宗旨多主張儒術而加以

道家、墨家的學説

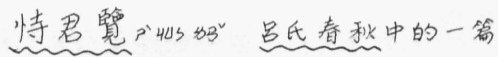

23 昔 $T 1^{\prime}$ 從前

嘗彻曾經

矣i同口語中之引

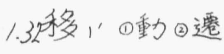

剔云選出

张智識出尘聰明才識

撮呅聚而取之

2.1姻15 因結婚的關係而成之親殿

婚姻嫁婜的事

粹5 5 个謂尃—不燓住

純粹 單純而不雜

亞们次一等的

了偶又。隻數

配偶男女成学正式的夫婦

媾《互为婚姻

交媾男女性交

辰行時間, 光陰

4 種子生 $2^{2} \mathrm{P}^{v}$ 植物延長生命最重要的部份, 在果 子襄

璃语䍵等

侪輩同监

彼が・那司他

彼此指人舆我隻方

.6月包幼謂同父所生

姑

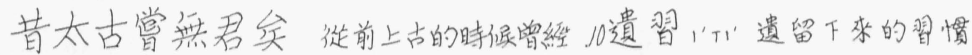

\section{是没有思王的。}

24 稀下，少有，稀奇，少有而奇㤏的。

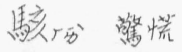

. 28 單外全, 果生, 一生, 一輩子

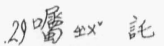

遗喔謂人將死時之遗言

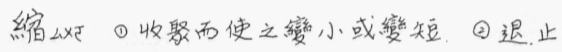

縮密把原来的文章简化。

.31秘等 凡不可知或不使人知者日秘

秘密謂不䝠意讓人知道的事情
.川猶汉似，如同

猶子父親兄弟的兒子

從P D 长次於最媇者如從兄弟即同祖兄弟

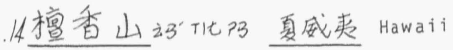

.19刃日兵器鋒利之虎俗言力口

迎刃而解形容事情非常容易處理 20 爾雅心14一考証名物通古今之異言, 傳釋 㨁 $\left(《 x^{2}\right)$ - 篇有周公所作, 其餘学孔阳人所

作. 共十九篇

壻仙。謂女之夫如女壻(2)妻畄夫如夫壻 


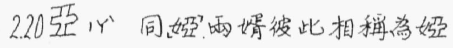

献 T13 同噳。奉上

文献×5 T13 文章書報等用来記载文化而

使文化得以保存者

隻關P P 化 《 x 語文含有表裹二㮔意思

23型 $T K^{\prime}$ 㨾式

典型足以表示一類事物特性的摽準形式 26 均识皆

翩如稳的很快

連謆連續不斷

27 毫 T 沋消受、享受

28 扶持的“行幫助

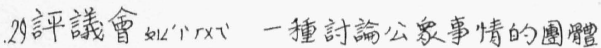

組䄉

酋《 $48^{\prime}$ 領頭的人

酋長一姓人中领顽的人

3/裁与号識别、決断

.33盟 $n L^{\prime}$ 彼此間的约定

同盟共結盟約

3.5 促故”要求很快的完成

促進使很快的發展

8 忽做用刀除草

秣䛲一種草生物, 用以桊馬

岛秣飬牛馬之草料

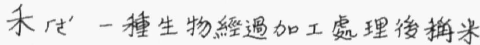

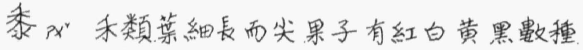

於夏日時偅之

叔 $\mathrm{X}^{\circ}$ 豆類之總桷

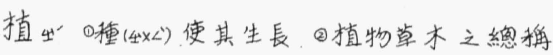
）隨身《次只謂日常随時需用者

弓《x<放箭( 是镝)之器具

矢, 20 箭

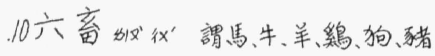

款《 $x^{v}$ 植物之一揰, 可供民食者

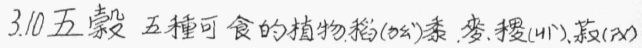
.//愈山同越。腾過②益甚

愈芫越来越

降崔自上而下

庸U 4 低下

附庸古時附畨於大國的小國叫附庸, 此 處表示次要的地位

.12奴3 7 賣身後噹主人呼唤, 供之使用的人

隸加・等人。附属

奴隸替人服務, 供人使用而無自由者

抬动高舉

抬頭形容漸澌走向好况

.14 宱出以壓縮而令其水出

搾取奞取他人之利益

16 征出人用武力解決事情

征服以武力使人服從

.20告 $1 \mathrm{H}^{2}$ 提取金雷

治金術呼究提取金屬之方法

. 21 增劇P L 岓增加得很快

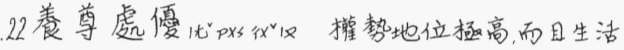

享受極好

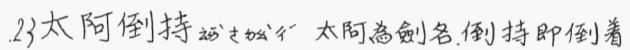

拿意指給别人獾力, 而自己卻失去做主人的

地位。

.24潰3 3 亿昔散

伩骀㮩明而壤

黠 $\pi Y^{\circ}$ 㮩明而險惡

.2搳割《さ分用刀切破

據岓佔有

割據自成一個㯰立的單位

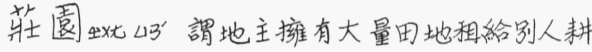

種因而形成一揰小型的社㬝

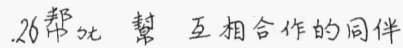

行幫作同樣事的人的組䋐 


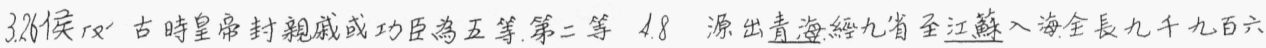

舡侯'

諸候粆封建時代之諸國君

.28懸TU3 掛在空中

殊双異、不同

懸殊謂完全不同

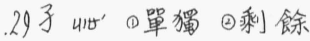

子遺遺留下来的

30域心地界或國界

地域地方

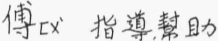

師傅追市之通稱

了庶砇百姓普通人民臣䳸, 即臣及民

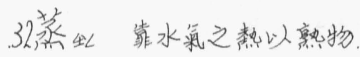

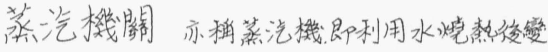
成氣體而珄生的力量来舞動的機器。

33殖出”謂舆生助利

殖民地一國將過剩之人口有系統的移

殖於虐業文化落後的地方, 而設統治譏鿰

於其地謂之殖民殖民之地域曰殖民地。

胎动動物在母體中浚育的地方

胎兒在母體中渗育未完而道未生出来 的小動物

4.1 崩 22 倒下

崩潰倒下四散即被消减

墟仙餕售之城

敢 $\triangle \times L^{\nu}$ 直立

2 尖4 13 細長物之媔端上顽小, 底下大

鋭昨计利

4 譻蚂往上看

5豫山同预

超克彵式超過並克服

7 着着的厸厸式一步一步的

. 8 長江肬㞨江名又名提子江中國第一大江。
十里.

9 崇明岛衫'nK'幼”在長江入海之口, 为江口堆

沙所精而成

10 叙仙陳述

叙述説明

17 幕nx戲台前懸掛的演戲時, 幕一拉開即表示覻

即開始

開幕開始

撈的從水中取物

海中撈月费力而無結果

18唐虞动山即唐堂虞舜古二帝

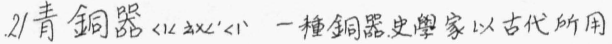

的器物來區分人類的進化, 使用青銅器的時

代是在金同器時代之後、鐵器時代之前

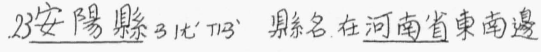

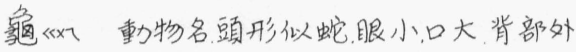

有很難打碎的保護物叫訐”

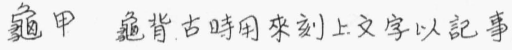

鐟く刻

22真出的問

真人用甲骨文个閭

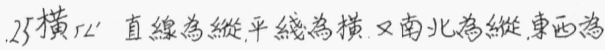

撗

.27五花八門形容其變化之多

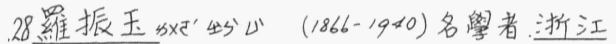
上盧人

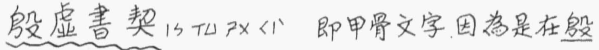

商)之古都發是的, 故名近人羅振玉編有殷虚

書契對毁代文字, 卜鲜、䀅制、都市、人名、地名

都有解釋説明

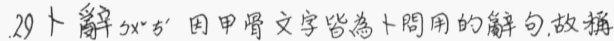

牲PL謂供人食用之家畜

. 30 蜃 35 海裹的一種動物其甲擪而不易打碎, 可 
製器具

4.31拙的“四不自霂之詞如拙箸

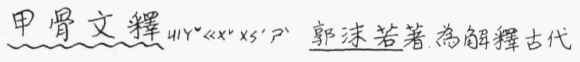

退甲獸骨上所刻文字的書

幼年少

稚出幼小晚熟

幼雅未成熟

5.3 帝典かか 即書經堯典及舜典

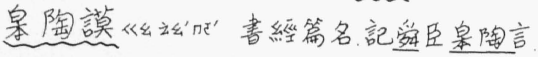

禹真山汹書經篇名

内經了で 412 最古之醫書, 亦名黄帝内䌊

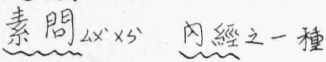

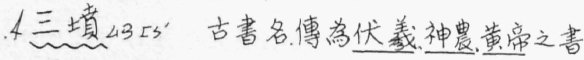

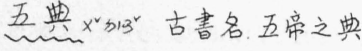

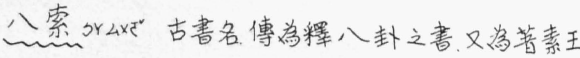

之法的書, 素王即聖而不王者, 如杂子

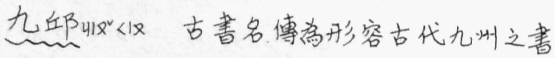
10 妣加 母已死稱妣,

先妣稱已經死去的母親

祭保拜神供祖

12 余山我

19 有12 助詞, 如上有虞”即虞”

虞山古國名舜之先國於虞即今山西平陸縣 虞城

尚捄尊重以学主

陶动用某種土焼成的用器。

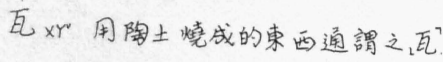

棺 $\ll \times 3$ 放死人的器具

瓦棺古時人死後别人為他穿上厚衣放

在野外燒掉到有虞氏才用瓦捾来放死人 21 孟子 $n L^{\prime} P^{\prime}$ 为孟子所著, 共七篇, 孟子(前372-289)

名連(万人)受業於孔子孫子思之門，提倡王道，重

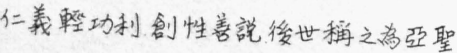

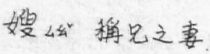

5.21 月关私我, 古代不分高貴低下自艘朕、秦始皇始 定为皇帝之自船

棲く1謂彇( 彻) 人睡學時應用之具。休息

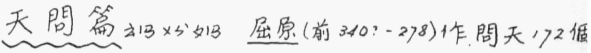
問題

.22目玄TUS 迷爱

淫以”謂男女不合䀅法而有夫妻閵係

眩弟並淫指舜與其迷毃的弟弟共妻

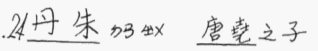

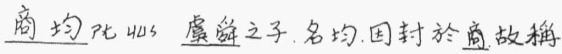

禹夏開國之君治洪水有功又幍夏禹

25 巡 $4 L^{\prime}$ 任意

售く”禹之子

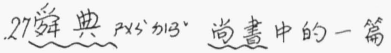

岳山甘'山

巴岳指各方的山、舜跟管山的人説話、艘 他們巻四岳

牧n“枆舜時照管各省公侯青族之官, 舜時有 $+=$

3/ 摰出古國名

帝摰以國为氏

33案分表示是作者自己的意見

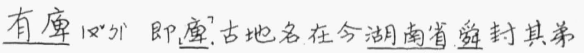

象於此

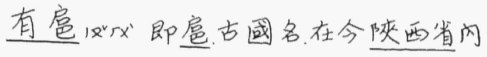

有狄汉加即悐, 古國名

6.5 賢 $\mathrm{T} 1 \mathrm{~B}^{\prime}$ 㛵多才者

. 6 眨万1 $3^{2}$ 减少, 降低

.7派兄先後一個一個的

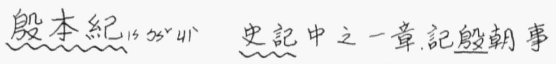
9天子䚮P 天之子为統治全國者之幍 10 議兵篇 130 如葛子之一篇討論用兵之術 晹动商朝開國之君

12 佐Px江幫助 
6.16行文T次的作文

暫私謂不久, 在目前短期間内; 或言暫且 



\section{第三課春秋戰國時代的城市}

\section{李亞農}

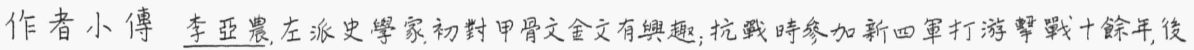
即研究古代史著有中國的奴隷制與封建制。周族的代族制與拓拔族的前封建制, 稞代社會

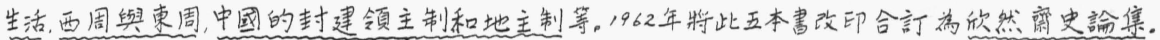
本課簡介本篇取自作者焎然踻史論集一書, 其中包括作者前淩發表的五本著作, 其名稳為

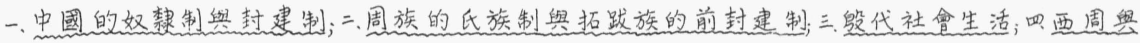
束周; 五虫國的封建領土制和地主制. 書前總序中提到發表的目的“在於依照一般社會發展 的规律来劃分中國歷史的弡展階段, 並嗇可能依照具體的史料采䦮述各階段的人民的生活 情况。本篇為中國的奴魏制舆封建制中的第二十一章, 詳述中国封建城市的㮔類, 性筫, 槚值 及规模, 春秋及戰國城市的情况, 更舆歐洲的封建制社會的城市在各黑上加以比較。

上面説過，中國的封建城市和歐洲的封建城市大不相同。在歐 洲封建主是住在鄉村中的自己的碉堡衰面, 碉堡鄰近的田地便是他的荻園。 而城市則是由工商業者建築和發展起来的。它是封建主的財産, 封建主可 15 以把城市拿來轉讓出賣和抵押。中國的封建城市則下然它是由封建主建 筑的, 封建主自身就住在裹面, 城市中万一但有工商業者的市㢈, 而且有大小封 建主的宫殿和邸宅, 城市就是保障封建主的安全和財富的堡墨。封建主們 是以城市為根攐地來統治農村, 剥削曹民的。

春秋時代許多城中都已有「市」。園天子所建都的王城就有「王城 20 之市(左傳照公二十二年)。各國較大的城也都有市, 如弯國在挛景公時, 因殘 暴鎮壓人民, 處刖刑的人很多, 以致國之諸市, 履( 草鞋) 賤踊(假足) 貴。當時各個

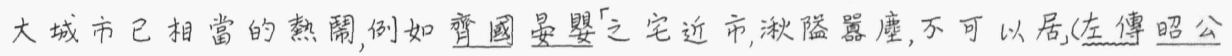

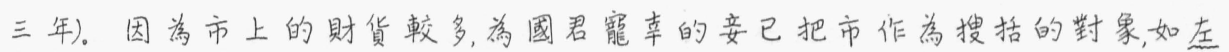

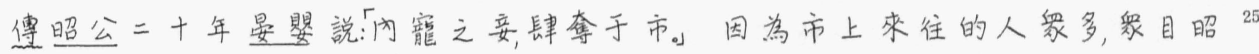
彰, 也已成为國家處死重要罪犯和陳列處死刑的屋體的場所如公元前六。

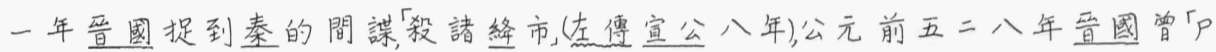
雍子與叔魚于市(左德昭公十四年) , 公元前五二 ０年周擒獲王子朝的属黨滒 胜、焚諸王城之市(左傳照公二十二年)。國家如果遇到大的炎難, 也已有市場 歇業的规定, 如公元前五二五年鄭的國都大火炎, 举下令巨主哭國, 不市、䏯30 德昭公十八年)。

到戰國時代城市更有擴大。一般的標準, 大概如墨子和孟子所 説的, 是決里之城, 七里之郭, 户口在一萬家左右, 即管子中説的萬家之都。离 什麼自三里之城是當時城市的標準呢? 墨子焦守篇説: 
凡不守者有五: 城大人少, 一不守也; 城小人覓二不守也; 亚食寞, 三不守也; 市去城遠, 四不守也; 畜積在外, 富人在虚五不守 也。丁

依照墨子的説法, 市塺、蓄積富人都必須在城享之内, 然後城可以守。當日各 5 國的城市, 大慨都是依照运㧽原則建立的。齊國孟嘗君的父親靖郭君筑的 蔀城, 大摡就是這梯大小的城市。孟賞君罷相之後, 曾絰回到他自己的采邑 即䈉城去住過一段時間。

到戰國時代, 除了箘成無數的「三里之城而外, 又由於商業的發展

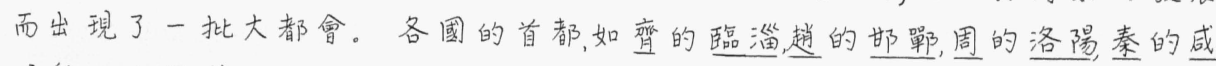
10 陽, 魏的大梁, 楚的漂虽, 韓的宜陽都是當時很大的城市。宣陽已是城方八里, 而脅的臨淄更要大得多, 為當時最大的都會。史記蘇秦傅説:

$$
\text { 臨畄之中七萬户, 臣竆度之, 万下户三男子, 三t二十一萬。 }
$$
不待發於遠縣, 而臨淄之卒固已二十一萬矣。臨淄甚富而寞, 其

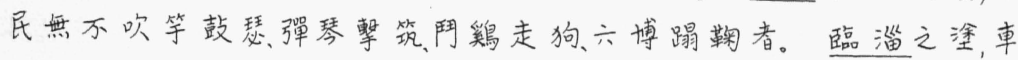
軗撃, 人肩摩, 連衽成帷, 舉袂成幕, 揮汗成雨, 家殷人足志高氯揚。 根據先秦的文獻閆於春秋末期和戰國時代的城市, 我們可以構 成如下的一幅蓝圖。

在繁萃富庶的都鿖中心, 地段爽塏之處, 首先築有大封建主諸侯 們的宫殿。規模之宏大, 和秦漢以後的皇宫比較起來, 僅僅是具體而微。

在宫殿的周園就是國家機關各部門的官署和有采邑的很大夫 們的住宅區。其规模也著曾不小, 邸宅相連台榭相望。堛樯之内, 巨木参天

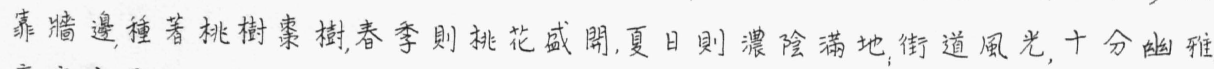
豪商富賈們在此地也有他們的館邸, 自不待言。

在封建主們的住宅區之外, 湫险㗊虚的地段就是手工辈區。逭 25 衰有鐵匠鋪、銅匠鋪、陶器作坊漆器作坊, 木匠、車匠、瓦匠、泥水匠等。此外, 就是 熙來攘往的商業區。也就是所謂市」。各國國都中的市區, 一般都設在宫殿 官署的後面, 所謂面朝後市(考工記)。市區已很有规模, 四周設有市門、韓非子 内信説上篇) , 市内街道浟横, 街上人碰人, 車碰車, 一片繁華景象。商店是一家 换一家的開著: 其中有牲畜店、糧食店、珠赛店、黄金店、珍玩店, 皮貨店、綢布店、監 30 號䇴藥鋪等, 也還有賣卜者。飲食遊樂方面, 則有旅館、妓院、酒家、賭場, 也還有

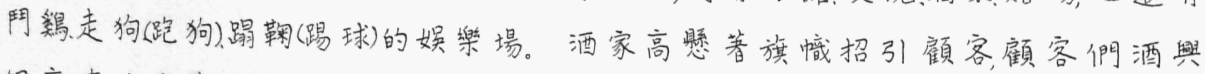
很高, 有的在奏樂, 有的在和唱源來的娱樂品六博, 這時已成為賭場中的賭博 工具賭徒們有的在喝采撙簿, 有的在下稘爭勝。當時的商人㑚為了發財致 富不顧旅途逢遠, 道路難難, 往来奔走, 轉運货物於各國大小城市之間。於是 
乎在各國的首都及其他大城市, 都展開了一危花花世界。

古代的封建城市, 除了上述世俗的煩嘿的地區而外, 罢有在戰國 時代新産生出來的文化區。在費國首都臨滥稷阴外集中了許多等者。如;

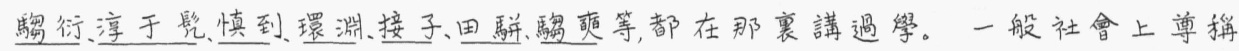
他們为噃下先生。器滥不僅是工商業城市, 同時也是文化城市。

城内生活, 如此繁萃, 可是一走到郭外, 就是另外一番景象。霂目

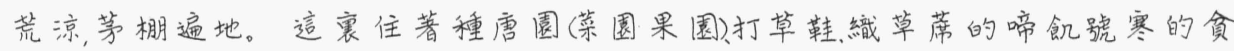
民階層。郭外是貧民窟地带, 並繁封建主的誑園。

封建主們絕少到郭外去的機會, 他們總是在城内聲色犬馬之場 遊玩淢了, 才間或到鄉村中的離宫去換一換環境。輁王的離宫就在臨滥城 10 外六里之處, 名叫雪宫。其他各國的諸侯也都各自有其離宫别苑, 如秦有甘

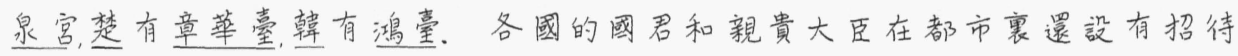

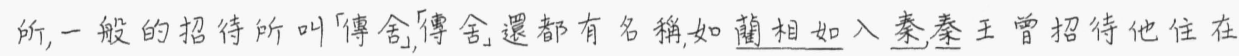
廣成傳舍。養食客, 多的親贵大臣、薎建築有好笺等招待所, 有各等不同的待 遇, 如孟賞君的上等食客被招待在代舍, 出入有車, 次等食客被招待在幸舍, 每 15 餐有魚, 一般食客才被招待在德舍。至於節大夫們在他們有官可做的時候, 是抵死不肯離開繁萃的首都的。只有在罷官退休之時, 才不得已回到自己 的采邑。如孟嘗君罷相之後回藍就是一個例子。但薜也不是鄉村, 而是有 巨里之城, 七里之部的小城市, 一樣地有工商業。

春秋戰國時代的封建主們始終是住在城市中。他們的含廪衰，20 面充満了鄉村的農民繳納上来的糧食, 府庫裹充满了農民繳納上来的布帛 温子所謂布緀之征即由農民副業生産中徵收布匹。既不愁食, 也不愁穿。 需要大興土木的時候, 在城内不但有御用工匠作坊, 還有民間作坊可供驅使。 至於鷄魚鴨、肉之類, 鄉下的震民雖然會貢納一些上来, 終不如到市場上去購 買的來得便利和新鮮。反正货幣是由封建主銡造的, 多花少花, 並不在乎。2 5

中國封建主的生活和九世紀初期歐洲最大的封建主佛郎克的 查理曼大帝的生活, 大異其趣、查理曼住在鄉村中的自己的碉堡裹, 離城市 極遠, 所以他必須把日常生活必需品的生産都控制在手裹, 以便自給自足。 於是乎他的碉堡周圈的土地, 都整成了荘園, 他過的是莊園湮湾生活。他的 荘園的情况, 可以從他的一道命令中看出来。他命令其管理人員嚴密監督30 各項日常生活必需品的製造, 如、麵包、蜂蜜蜂䗳、酒、油、乾酪、㱑芽、醋等等。他在 訓令中説我願每個管理人員, 在本人管轄之下, 有各種善良的工匠, 如琙匠、鞋

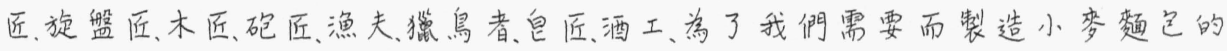
麵它匠, 以及善於編織㺘獸網撈魚網打鳥綢之人, 與夫其他服務人員。 
在鄉村中的查理曼大帝的菇園, 是一個閉關自守的自給自足的 整體。一切消費, 都由自己的莊園生産, 他自己躬親領㸂。可是, 住在大城市 襄面的春秋戰國時代的大小封建主們, 堂上一呼, 堂下百應, 在要什麼有什麼 的便利的生活條件之下, 是否有必要像查理曼那椂去經營誑園經濟呢? 完 5 全没有。只要有錢, 他們就可以購買需要的一切。事實上, 在春秋戰國的封 建制社會裹, 並没有存在遇歐洲式的誑圈經濟。當然我們否認春秋戰國時 代的萑園緸㴚不等於否認中國封建制社會中佔主要成分的自給自足的自 然䌊濟。毛澤柬同志説:

「自給自足的自然經濟佔主要地位。曹民不但生産自己

需要的震産品, 而且生産自己需要的大部分手工業品。地主和 貴族對於從曹民別削來的地租, 也主要地是自己享用, 而不是用 於交換。那時踓有交換的發展, 但是在整個經濟中不起决定的 作用。

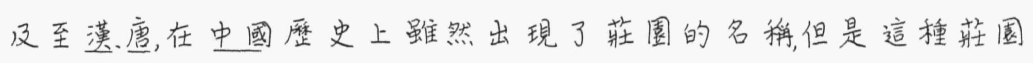

15 和歐洲的狅園相比, 除了雨者都駱使大批的震民或農奴替他們耕田種地, 向 他們繳納地租, 以供他們揮霍而外, 就没有计縻共同之處。漠需的㹥園並不 直接生産各種日常生活必需品, 因学這些必需品在城市裹是應有盖有的經 常生活在城市裹面的封建地主們是無須乎自己來生産的。蓬唐時代的䔩

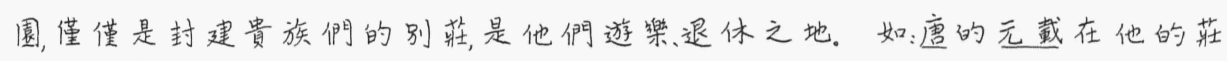
20 圈中, 蓄食歌妓竟達百稌人之多。間或也有綬營其他生産的, 如漠森重在他

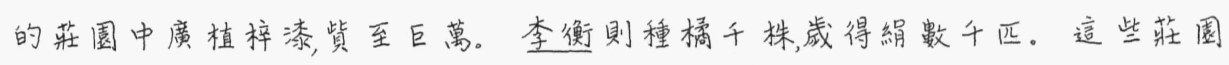
生産不但不是為了自給反而是為了交换, 這和歐洲式的蓕園真是風馬牛不

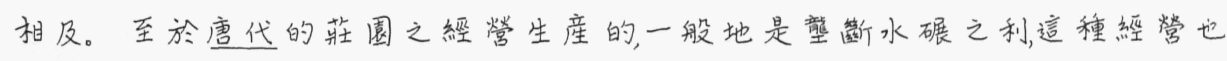
不是为了自給, 而是為了更進一步地樎取曹民的血汗。這和歐洲中世紀的 25 获圈也不相同。

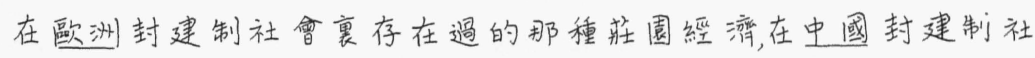
會裹從本就没有出現過。如果因㪄歐洲的封建制社會裹曾絓存在過荘固

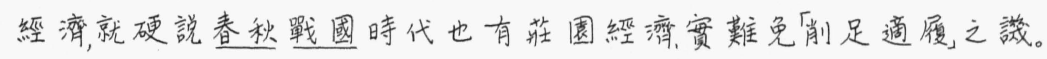

討論問題:

一春秋末期和碱國時代的城市是怎棣的?

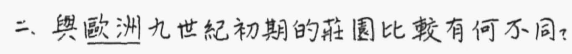

三試述春秋䈅國時城衰人的生活情形。 
四、那時候有什麼手工業?

五。試述當時講學、遊説之風的興起舆發展, 
1.1. 碉》石室

堡公小城

碉堡以石樯睢起来的小城市、以防止敨 人的圍攻

鄰为接近

\section{鄰近附近}

.16抵加向别人借錢時把自己的産物交之保管。

表示偠值相當。

押、在文件上简下自己的名字以保證之。

抵押用珄物作保證桃借鉞

17 黁行市内放東西的地方壱者置者皆有之

市贋 即商店舖子

18 殿 13 '堂之高大者

宫殿形容富责人家所住高大而美麗的

房子

邸要人居住的地方

宅地”富貴人家所住的地方

氏它有錢有勢者所住的地方

障此防德

保障保護防衛

堡壘胎”汃”为防衛而建的建筑物

19 剥距去皮

削地俙除

剥削碓取别人的財物

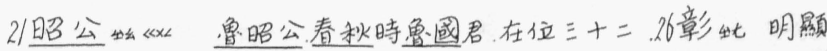

年(前5 41 - 510 ) 後被部將所攻打逃往变國

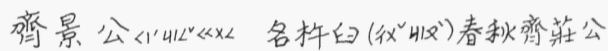

弟好治宫室, 聚狗馬、厚税重刑、在位五十八年

(前5 5 - 7 - 190 )

.22暴㕬非常惡

残暴 惐忍党惡

鎮䢺壓服

處㣗”判断決定

刖峨古時犯了某偅罪即要受到斷足的痛苦。

䝴山草鞋
1.22 㛵處则刑

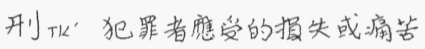

處……刑㜰定犯罪者應受的损失或痛筈。

鞋下脚上穿的底下厚而不易破。有算鞋布鞋 现代人多穿皮鞋

賤413 '便宜

蛹 $L^{2}$ 假足

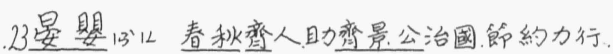

为當時名臣

湫茲謂低下細小之地

险分狭小

翼仙喊闌

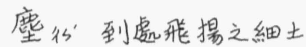

湫隘㽞虐低而陕小熱闌两糜上太多 .24寵 $4 \times L^{2}$ 受

寵幸天子所喜爱

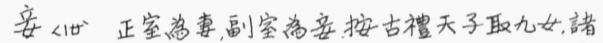

侯七, 大夫一妻二妾，士一曹一委

括《捜求

.25拃公任意

内寵之妾、肆奞于市”國君喜愛的妾、在市

面上任意搜求她想要的束西

昭妶光明

象目昭彰指为多數人所共見

屍》謂死人之身體

.27諜外探敵人舉動者

間諜 探聴㪣人軍事情報者

諸的“之”於合成諸

絳矿在今山西省

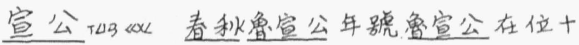
八年(前608.591)

$P$ P把屍體放在地上 


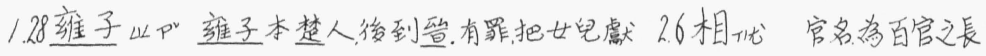

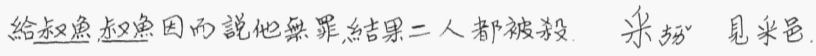

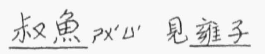

P㢈子與叔魚于市把雜子和叔魚

處死聁把他們的屍體陳列在市上 摛《淀

摛獲捉到

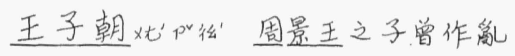

新䚽爪们周景王子之部下

焚諸王城之市把新㬳随列在市上, 活 活数死

30歇化停止、休息

歇業停止營丵

鄭出心春秋時國名

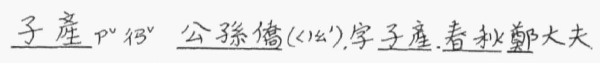

學問博, 息誐腐、長於政治, 為政時當丝楚爭霸。

鄭處雨大國之間, 偱楚不敢欺。

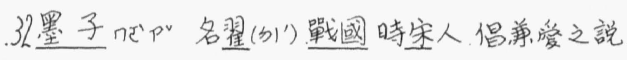

流行颇盛舆儒家立搯操行堅卓而專以利湾

端主者。

33郭《始奴城

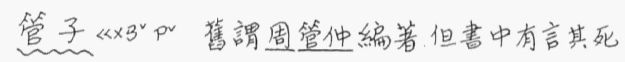

後事, 大概為後人所綗續編著的, 原本八十六

篇, 今已遺失十篇

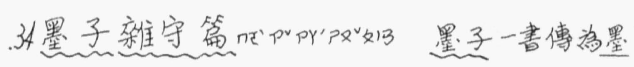

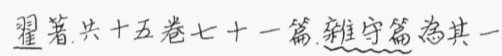

2.2 寞《xy 少

去《相離

虚TU同墟

富人在虚富人在外

4 蓄仙皘存

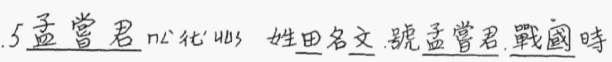

人田嬰之子。好湌士、食客數千人。

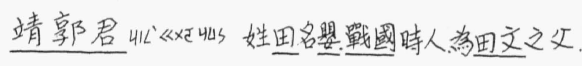

\section{㫕门市鎮}

采邑高級官所封之食邑, 封於某地即采 取該地之租税以自善, 故日采邑

9臣点淄必的在今山東省

趙出公戰國時國名，包括有河北南部及山西北部 甘戰地加了在今河北省

洛陽为“比”在今河南省

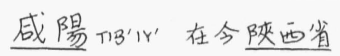

10 魏双戰國時國名

大梁加秘在今河南省

䣕虽江 $2^{2}$ 在今湖北省

啅乃”践国時國名, 有今河南中部及山西南部之

地

宜陽，沈在今河南省，洛陽夥西南

江篑《代厸下, 私自。

度汃量, 推算

不下户三男子平均每一家至少有三调成年的

男子

13待片等。

不待不必等不用等

發 $E Y$ 致, 使……来

不待發於遠縣而臨渵之卒固已二 十一葛矣不必到外縣去征求, 單是臨 淄的兵已有二十一莗了。

卒p 㚱士

14笔响竹子作的然器

瑟么ざ一種古䇣器

彈动以手玩哠

琴《约维器

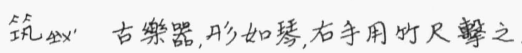

吹笔鼓瑟彈琴擊领表示在玩垪或 演奏啲器 


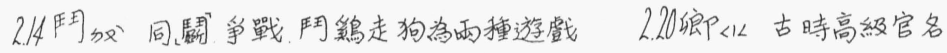

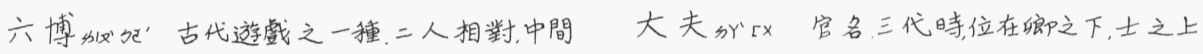

地方分福十二道, 用簿( 引飞”)

已不詳

巨屾大

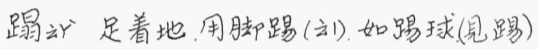

参㗐謂高出空際

鞖收用皮做的球, 襄面放满毛

蹋鞠古時習武的遊䈏如今之足球

塗动”同途”, 大街, 道路

.22桃出等形圆而長之植物, 春天開花, 白或紅色。

事呟”䈎似蛋形之植物, 花小而黄果富圆西長。

可食偅類甚多。

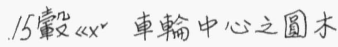

車敹擊来往車子的中心圆木碰来碰去、

濃 $3 \times L^{\prime}$ 深厚, 淡簿之反。

濃陰霂地遍地都是深厚的陰影。

形容車之多。

肩4 13 人手部與身體相接的地方。

風光風景

幽1 2 清新愉快

摩啾雨物相磁，切近而過

雅、滔淡美麗

人肩摩路上行人的肩相碰, 形容行人之多, 23 豪「幻謂才智過人者

衽㳖衣之雨旁

票《x 商人

帷入王用布園起来的地方, 可供臨時居住。

豪商富賈有錢有勢的商人。

袂叭衣袖, 哲

揮仅田舞動》散落

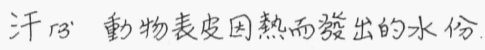

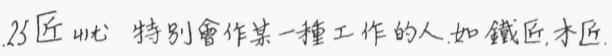

坊项工作場所

作坊工作埸所

殷的富

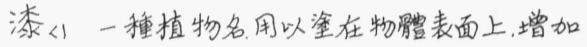

.19幅 $\mathrm{X}^{\prime}$ 紙張的長短大小此處用以算圖, 畫之數

如一幅畫, 一幅圆

美雚息

泳器油浗器具

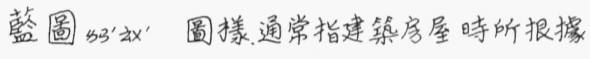

的圖樣

18 繁泊多, 简之相反

繁藮 形容商業興盛

庶戏勨多

富庶人民悉多而富足

整优清快

塏砀”高而乾

19宏私庴大

具體而微各部份都有，只是规摸較小 .20署 $2 x^{2}$ 作事的地方

官署官真辩公虎

26 熙个1快愁 (3) 光明

攘昽摠谣

熙来攘往很熱閶雅㖟的持子

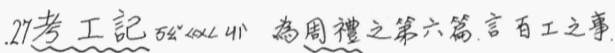

周裀傳为周公所作, 定周室之官制, 本名周宫

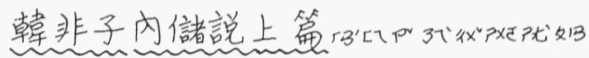

溒非子为戰國時人韓非箸, 共五十五篇, 肉信者

憝学其中一部份, 分上下 $=$ 篇

.28縱P X L 南北曰緃

街道縱撗表示街道之多。

.29挨历相靠近

珠出义一種銀白色球形物, 美麗可爱, 女子用之 
增加美篗見

珠瑟珠子赛石

229 珍私指赛貴的物品

珍玩窗貴而可供人玩賞的東西

綢㣔絲織物之一種

監沐作菜時用的一偅調味品, 色白

監躆監鋪

30藥㳂风可治病之物

飲么 心喝。喝酒示简稻飲

妓4 吉滛之婂女

妓院妓女住的地方

貝者加、以金錢計勝员之遊戲, 又㛵睹博

3/踢云! 用脚碰物，如用脚踢東西

娱山快瑔

娱樂場供人娱樂遊戲的地方

俄出旗之一種

旗掝旗

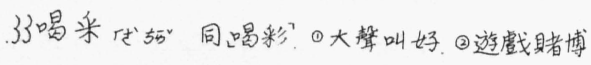

時大聲喊叫, 希望得来, 睹博者所放的龯也

叫喝采

擲出投

镈咥古玩六博時用竹子作共十二個, 六黑六白。

棋《遊戲的一偅工具限二人使用

下棋玩棋

外遥沙遠

遥遠 殁容很遠

鞎413 因蜼

鞎難图難

3.1 花花世界指繁等之地

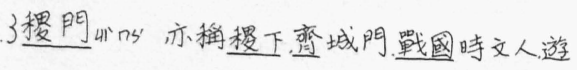

説之士聚集譒祭的地方

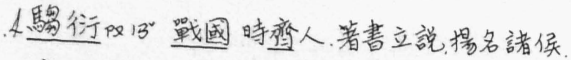

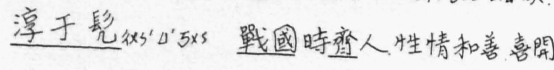
玩笑受命出使諸侯均能䞗成任務。

$2.29-3.13$
3.4 慎到岎公戰國時趙人學黄帝老子道德之

街著慎子四十二篇

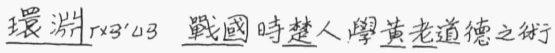

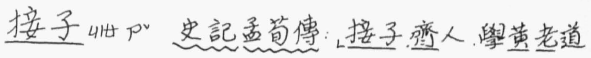
德之術?

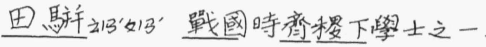

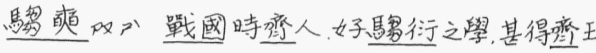

$$
\text { 之喜爱。 }
$$

. 7 涼为仳寒

荒涼空野無人的情形

第口草名, 可用来建屋

棚如架水以防太陽或下雨之物。

茅棚遍地到處都是用第草作的棚, 表示

没有精究的房屋

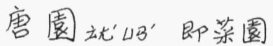

蓆T'可以坐或睡上去的草織物

啼云”哭叫

飢山1 餓(ざ)久没東西吃的時候的感㹂

號历”大哭大叫

啼飢號寒因湓餓和冷而哭喊。

.8曾古 $L^{\prime}$ 級

窟列在地下作的屋子曰窟

盆民窟窮人集居的地方

. 9 犬 $<43^{2}$ 狗

聲色犬馬指各揰娱的一歌戲妓女跑狗 赛馬等

.10月武31 嚈

. $/ 1$ 離宫

宫。

苑咇羪鳥曽的園子

别施在别的地方建設的園子

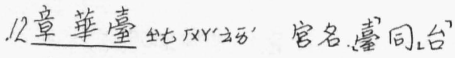

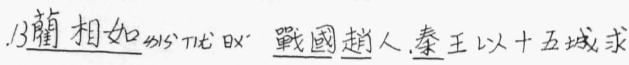

易趙和氏王，相如带往秦國，因秦王䈍意交换， 
乃安全的带回趙國，後為上㢃。 3.14 食客户”引过在國和大臣招待所住着的客人

白吃白住所以叫食客

$1 / 1$ 餐5 3 每食一次日一餐, 如早餐, 晚餐

每餐每一顿飯

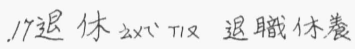

食故藏慓的地方

20 桌4 $13^{2}$ 藏米的地方

食桌放糧食的地方

211繳41年”謂交納

繳納交納

庫列藏物之處

府庫公家存放剘物之處

帛歼'絲織物之總偁

.22緀屾 線

征出税收

街致同征税收

匹外量度之單位如馬一匹, 布一匹, 長四十尺为

一匹

布匹布之通稳

. 23 御山對天子的敬粨, 御用即皇帝用的

驅《逼迫之意, 促

驅使使用

. 24 鴨、嘴長而平、足短之動物, 善游水, 雨翼小, 不

能高我, 普通家鴨多為白色, 野鸭雜色。

真《始進獻

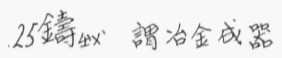

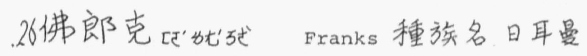

$$
\text { (German) 民族之一。 }
$$

27 查理曼行“们叭 Charlemagne 即查理大帝 Charles

$$
\text { the Great }\left(7^{42-814}\right)
$$

.28控3 5 亡 管制

控制管制

給4 $1^{2}$ 供應
328 自給自足自己供碓而霂足自己的需要不 必依靠他人。

30監㓦督查

監督督查管理

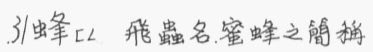

蜜叭蜜蜂取花中之粉所成之物味香甜如糖,

可以供食及入藥, 亦桴蜂密。

蠟汃取自蜂房, 可用来點火取亮

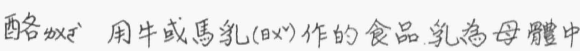

生出的液體,色白、給其初生者吃的柬西。

芽， 9 植物粑出生時艘第

麥第考之第, 用来製糖或醇酒

醋5 作菜時常用的一棰調味品

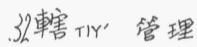

管轄管理督道

33旋TU3'使圆轉動

盤奶放物之器具

旋盤用以穿孔，削平面，曲面等之譏器，中

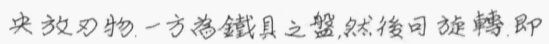
可制作器物

砲始兵器。古時以機墢石、今为鋼鐵所造,

㿝訟植物名, 其子可用以洗衣服

34編引乃連結, 䋨

哭犬口具有四足的動物之總猺

網沘捕捉魚鸟動物等的工具

4.1 閉か 不打開謂之閧閣着。

閉關自守䦥上大門，保守自己原来所有的，

不靨接受外来的。

2 身弓《媇自

身弓親 親身

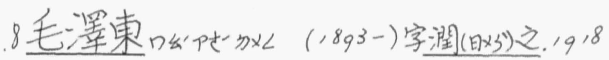

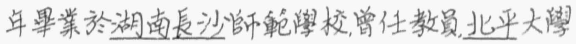

圖書館管理员等.中或共虐黨涂立人之一.1949年中

國共鷹黨佔據整個中国大陸，建立中集人民共和國。 
毛澤東為首任主席.1959年専任黨主席至今。

4.11 租P $x$ 田税皆曰相

16 霍「地分散的很快

揮霍很随便很快的用钱

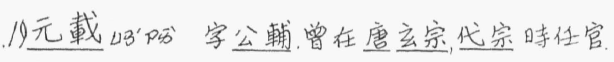

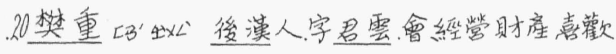

帮助别人，借給人錢:

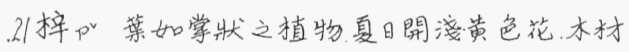

可供建䈥及器具用.

頃p 椇货

李衡的“字定叔平三國時虽人。

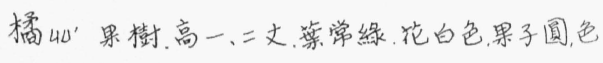
紅或黄可食。

株生区樹的單位。

絹妇”厚而細之絲䋨物

.22風焦牛不相及形容事情之毫篦關係

23 壟点加 $\check{L}^{v}$ 由中高虎

壟斷獨享利益

碾 $313^{\prime}$ 壓碎

水碾利用水力来碚物

.28硬心强

履加“鞋

削足適履把自己的脚削小来通合鞋，形容 勉强求合、反而害事

譏41用蜼㯖的話花取笑别人, 北評。 
第四課封建制度之崩壇及儒家與墨家迲家之単論

蛒思和

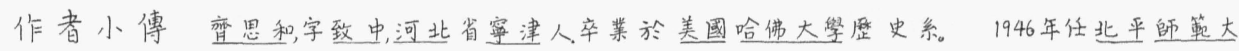

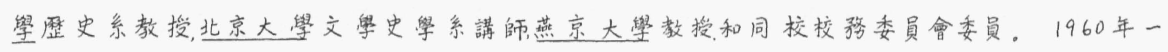

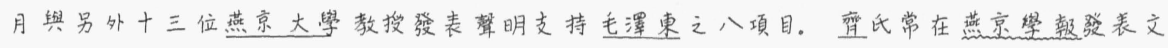
章。

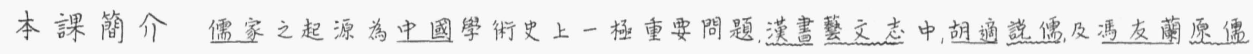

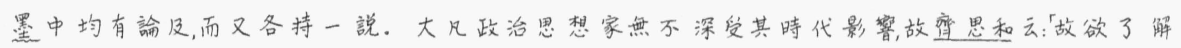

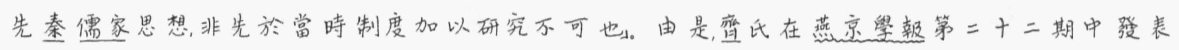
了封建制度舆儒家思想—文對西周與春秋時代社會制度作一研究。全文分三部分, 第一为 10

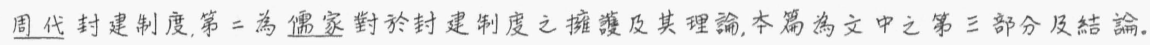

由上所論, 可知儒家之重要政治思想及其倫理哲學皆出於封建 制度。不特此也, 即其他學派之興起, 及其與需家之爭論, 亦皆有其社會經濟 的背景。孔子於封建制度雖極端雙護, 然孞之時此種制度已逐漸崩壤。

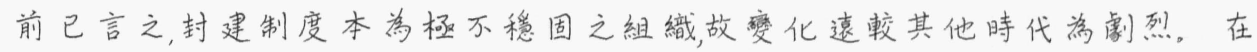
西洋, 封建制度起十世紀末年, 經十一十二雨世紀之变化, 至第十三世紀近代 國家即出现而封建制度遂廢。在中國此種制度當春秋末年即呈溃壞之像, 至戰國時期近代國家已起, 而此制度大體廢菜, 及至六國既亡, 天下一統, 則此 制完全橄除。此後踓封國之制, 相沿不廢, 而封建制度之䆓質已亡, 不得復以20 封建社會目之矣。研究封建制度困難之點, 在西洋其起源時史料太少, 在中 國其崩潰時史料缺乏。蓋后德國語與戰國策不相啣接。左德國語終於越 之霸, 而戰國策中已無越。在制度方面春秋末年, 封建制度尚未完全崩溃, 至 戰國策中則近代式中央集權圆家已出現。其演遍之步驟, 無同時代之記載, 誠中國史上之一大疑案也。

是故闢於中國封建之崩壞, 吾人僅可加以揣测。大略言之, 封建 制度本為一種不稳固的組織, 一旦天王之權稍弱, 宇内和平即不易維持. 橡 絰籍所載, 周初尚有千餘國。至春秋時所稌不過二百。是萧併之風, 自西周 而已然。造至春秋時代, 兼併更烈, 大國如晋、楚輁諸國, 皆隇國數十, 即如制、䓍 諸小國亦併數國。結果地圆化簡, 國家擴大! 而各國大夫之采地或以互相30 兼併, 或以君主賞睗, 亦隨國家擴大, 百邑之郷已漱寻常。至其大者, 如晋之暲 氐, 擁有七縣, 則較原来之諸候尤大。終至晋分於三家, 変篡於田氏。當春秋 之世, 鄉大夫家之政權, 以少世臣之故, 原較國為集中, 故晋架既亡, 中央集㩲之 國家遂脱封建式軀颉而出现。至於南方之楚, 其政㩲本較北方諸國虞集中。 
當其每减一國即化之虑影直屬於王。故王室絕非柳大夫之所能抗。是當 春秋末年, 至少在進步國家中, 中央集權式的政治譏構已漸出现矣。

此種政治圈體之擴大及政㩲之集中, 自有其經橓的背景。蓄當 春秋之季年, 吾國起一極大之經濟革命, 即牛耕與琙器之發明是也。在此時 5 代以前, 耕種之街, 純依人力木器, 費力罗而收效少, 一家所能耕之地極病有限。

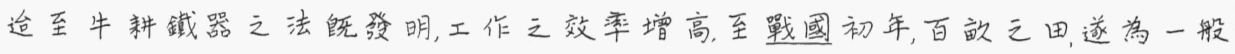
人之理想。依㩚人口學原理, 食物加增則人口增加之速率亦随之增高。夫

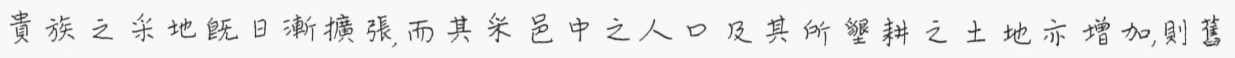
日複雜迁緩之田制( 所謂助法) , 益蜼指揮監督。反不若任農民自由耕種而課 10 以一定之税, 較差简單。故此後各國對於田制之改革極多、魯宣公十五年,

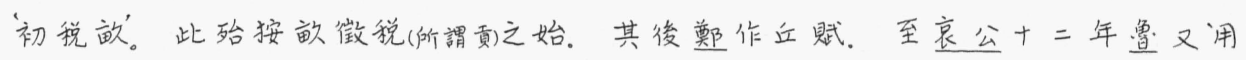
田賦則軍旅之征亦以農民所耕之田地羞標準, 而不復按照每家人口之多室。

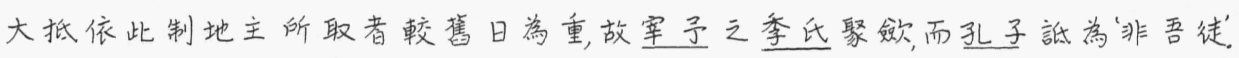
然籍田之法既已易助為貢, 則人多力强者可以多耕, 各家所耕之多少, 遂不復 15 一律, 而庶人間釡富之差以起。在此情形下, 税法亦有不容不改者矣。抑依 此制, 震民一絰完税, 即可自由工作, 不必復受地主之督责。其勤儉者, 或更可 出其儲蓄以購買貧莬地主之所有權。土地私有制遂起。至戰國土地可以 自由買䨘而封建制度之經濟柱石遂傾。同時社會既漸安定, 交通進步, 而商 業亦漸發達。春秋末年, 綘( 晋都)之富商已”金玉其車, 文錯其服。而貴族階級 20 則逐漸没落良以貴族須有封地始能維持其養尊處優之地位, 而諸侯大夫之 采地資産有限, 貴族之生殖繁行整窮, 勢不能人人得職人人得祿。故至春秋 季年, 即公子公孫亦有無祿者, 他人更不必論。是故子路至於衣敞緼祀, 顔回

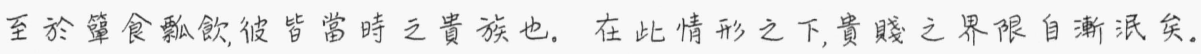

此皆緸濟革命所引起之社會影䇾也。同時, 各國之公布法律亦 25 於平民之解放大有關係。蓋在封建時代, 政治法律差在上者之秘密, 平民無 得知之機畣。迨至政治範圍擴大, 人口增多, 勢不能再家喻而户暸之。于是 鄭子産㿧刑畫。此在當時極引起守舊者之反對。叔向, 晋之賢大头佁畫 规之日:

始吾有虞於子, 今則已矣。昔先王議事以制, 不為刑辟, 眐 民之有采心也。猶不可禁繁, 是故閑之以義, 約之以政, 行之以䄚, 守之以信, 奉之以仁。制為祿位以勸其從, 嚴刑罚以威其淫。眐 其末也, 故誨之以忠, 算之以行, 教之以務, 使之以和, 臨之以敬, 淮之 以㢾斷之以㓮。猶求聖哲之上, 明察之官, 忠信之長, 慈惠之師。 民於是乎可使也, 而不生福熖。民知有辟, 则不忌於上, 竝有爭心, 
以徵於害, 而徼幸以成之, 弗可為矣。夏有毃政而作禹刑商有嫍 政而作湯刑,周有乳政而作九刑。三辟之舆皆叔世也。今吾子 相鄭國, 作封洫, 立謗政,制参辟, 鑄刑書, 将以靖民, 不亦難乎? …民… 知爭端矣, 將亲禮而徵於畫, 錐刀之末, 将畫爭之! 乳獄滋整, 賄賂 竝行。終子之世, 鄭其敗乎? 胗聞之, 國将亡, 必多制”。此之謂乎! 鄭士文伯亦日：

火芫。鄭其火乎? 火未出而作火, 以䦅刑器, 藏爭辟焉! 火如像之。不火何学?

但平民解放之潮流不可阻止, 故二十三年後叔向本國亦作刑鼎。孔子聞之, 曰:

嘼其亡乎? 失其度矣! 夫絪將守唐叔之所受法度, 以經 䋨其民, 绾大夫以序守之。民是以尃其貴, 贵是以能守其業, 黄绕 不衍, 所謂度也…今亲是度也, 而為刑鼎, 民在鼎矣, 何以尊贵? 貴 何業之守? 贵踐每序, 何以为國?

可見時人對於公佈法律閭題辩論之激烈。但大勢所䞶, 非人力之所克挽制。15 兼之, 晋列卿相爭, 为使庶人之效死, 不惜許以種種特權。如丕豹隸也, 般督成 而范宣子焚其丹畫。此種情形當不止於覓。至春秋末年, 趙氏與范氐中行 氏戰許其屬克㪣者, 上大夫受憬, 下大夫受郡、士田十萬, 庶人工商遂( 杜註: 得遂

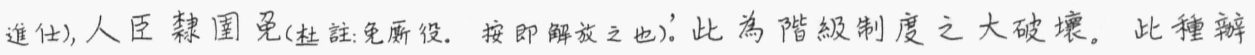
法, 亦為他國所採用。五十年後商鞅之治秦, 令民之有軍功者各以率受上爵2 0 …宗室非有軍功論, 不得為屬籍。於是将舊日之階級制度, 一筆鉤銷。秦用 商君之法, 以致富强。其法遂為他國所倣效。當戰國之時, 諸候力政, 得士者

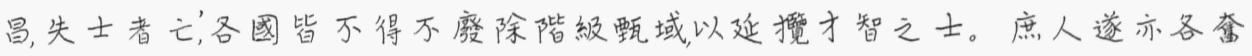
其才能, 以取即相。蘇秦無尺寸之土而佩六國相印, 繁罣山東之匹夫而逐應

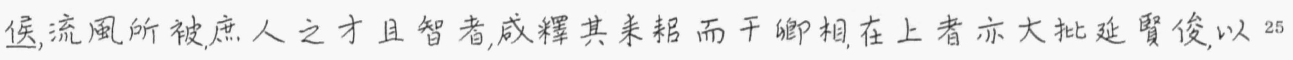
后已用。故四君養客至數千人。此為庶人之大解放。而社會階級遂㩔。

封建制度之社會經濟組織既已廢除, 其政治組織亦随之瓦解。 綵春秋時代兼並之結果, 至戰國僅稌十餘國, 政治組織愈加撗大, 同時各國内 部亦大抵刻畫虚郡縣, 政權集中於君主, 非復如春秋時代之政出於世绾。蓄 戰國之時, 商業已興货幣流行, 人君於臣宰除功臣貴威外, 用之則與以禄俸, 万 30 用則即關係斷絕不必復封以土地。於是公法舆私法分開而封建制度之政 治制度亦廢。且此等新贵之得勢全頼人主之寵信非如舊日世㶯之有傅世 之采地, 族黨之擁護也。人君之勢張則其地位穆固, 否别即蜼立足。故皆竭 其才智, 扶助君主排抑世㶯。是故商君入秦而㡻宗空之㩲立軍功之法。蔡 


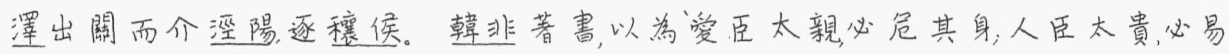
其主。主妾無等, 必危社檈。其對於君權擁護之熱烈, 猶西洋封建制度将潰 時之法家(如迲圈Zjurists, 英圈之baili if) 矣。職此之故, 贵族舆法家遂成不雨立之 势。溒非之所謂知法之士與當塗之人, 不可雨存之仇也。亦惟此等新貴之

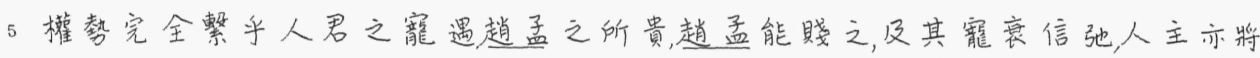

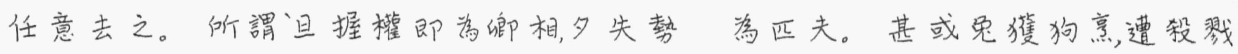
之福。故戰國時代殘殺大臣最多, 如商君之莗裂、李牧之賜死, 其事誠蒐, 然皆 死於君命, 而不能如趙值之武露公, 季孫之逐鲁侯者, 则時為之也。是以戰國 有虐君而無斌臣、其故誠可深思矣。

綜之, 践國時代為中國政治社會落化最劇烈之時代。在此期間, 封建制度逐漸壞隇近代政治社會因之而興。在此環境中而起之新學派其 主張遂與儒家不同, 且起而與之辩難。大抵孟軻以前與儒家抗頡最力者為 㛫墨二派。孟子謂掦朱墨翟之言盈天下, 天下不歸於揚, 則歸於墨, 可見其勢

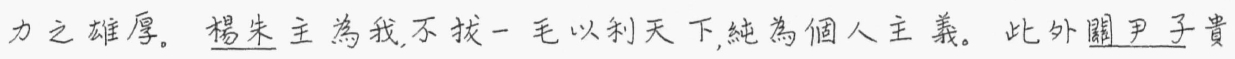

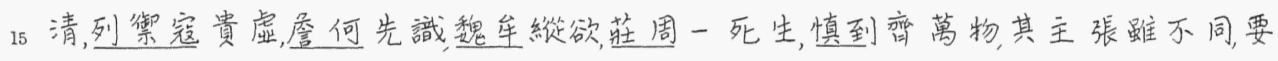
皆於世事持消極主義, 個人主義, 不肯以天下禹事。當時血流满野, 教人盈城,

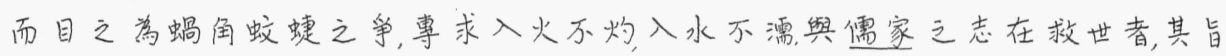
趣根本不同, 猶非需家之大患也。至若墨子则“叟需者之業, 受孔子之術, 以为

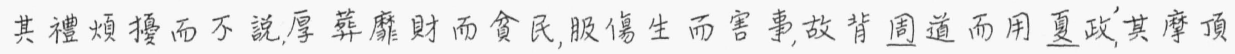
20 放踵, 舍身救世之精神, 殆較儒家猶遇之, 此真雷家之劲㪣矣。在戰國時代雷

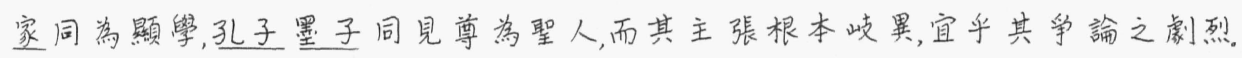
墨子非雷篇於儒家深加訫訶, 孟子則目墨子禹無父, 親與墨者夷子辯諭。皆 子闑墨之言, 較孟子为尤詳。墨家與偶家主張根本不同之點㪄“兼”别之辯此 即由於其對於封建制度態度之不同, 儒家擁護封建制度與宗法制度, 故注重尊

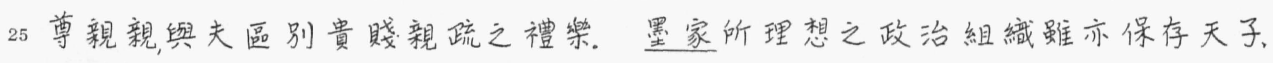
諸候大夫士之封建名稱, 然其運用為凡國之萬民上同乎天子而下不敢比。 天子之所是, 必亦是之, 天子之所非必亦非之。。則为極端的中央集權主義, 與 法家無别也。墨家既不智成封建制度宗法制度, 故主張必㼜其友之身若為 其身, 為其友之親若為其親( 所請兼) 。此舆雷家所主張之尊尊親親主義(所謂 30 别根本不同。故点氏春秋論諸子思想稱孔子貴仁, 墨子貴廉, 雷家之皆子亦 謂濹子有見於齊無見於畸。又謂其上功用, 大儉約而僈差等。曾不足以容 辩異, 縣君臣。可見此雨派主張根本差異之點。此種差異, 即係時代背景之

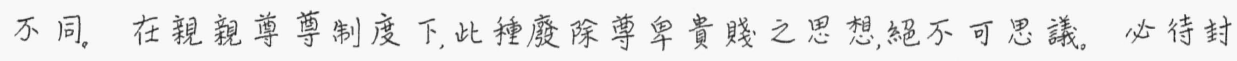

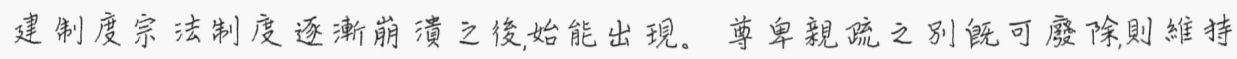




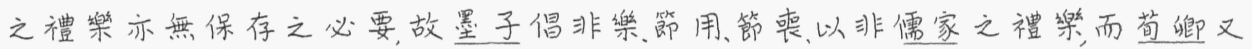
著䄤論想論以應之, 皆由其兼别之辯而起也。

墨子之後與儒辯論最烈, 而其勢又足以與需家相抗衡者瓷法家。 法家之中, 商子言法, 旦子言術, 慎到貴势, 至韓非始綜合奥説, 成一系統。故法 家之主張細言之亦不一致。然其中有一根本共同之點焉, 即張君權主法治5 是也。故法治與人治之辯, 儒法雨家主張根本不同之點。此種主張之不 同, 亦由時代使然。前已言之, 人治為封建制度之特點, 建政治集䨪漸大, 人口 漸多, 家喻户曉, 已不可能。故春秋之季鄭晉諸國皆公佈刑書。迨至戰國萬

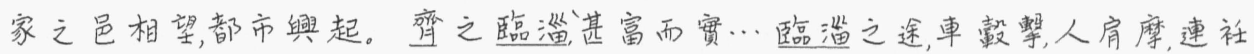
成帷舉袂成幕揮汗成雨。其人口之繁, 可以想見。在此情形下, 人治益不可10 能。兼之, 贵賤之分漸泯, 尊卑之別已廊, 法家之説, 即由此起。故曰其舆儒主 張之不同, 亦時為之也。至於儒家之法先王, 法家之倡留法, 尤可見雨派於封 建制度之態度。法術之士, 東則多出於弯西則出於三厽, 亦以弯至雨國䜌法 最早之故。傳稻太公之治唯尊賢上功。此未必可信。然至少可見尊賢尚

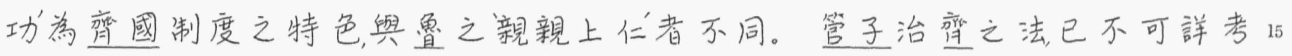
矣。國語管子諸書所記, 俱不可信。管子一書, 決非管仲所自作, 抑亦非春秋 時代或戰國初年之書, 前人考之詳矣。然韓非稱管商之書家有之, 則至少其 中之一部分成於暲非以前。蓋為变人慕管子政績者所為, 故於孪桓覇業, 言

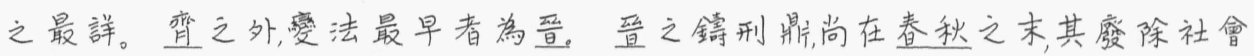
階級亦較各國為早。且郡影之制, 殆亦起於垤。故封建之廢, 以至禹早。因20 之三䌿多法術之士。

綜上所論: 儒家之政治思想受封建制度之影響甚深, 至於墨法二 家之起, 及其與需家之単論, 亦有其時代之背景。戰國之際諸子爭鳴, 學派息 矣。故司馬談析之羞六家班孟堅區之爰九流。然其中在政治思想上能舆 需家抗衡者, 亦惟墨法雨家。至於名家則專究名理鮮及政治。他若除陽五25 行之説, 縱横捭闑之辩, 㫜或申昜迂怪之談, 或邀一時之功莊周之所謂飾小説以 干影令者, 亦非儒家之比, 故不復論及焉。

\section{論結}

或日: 子以封建制度説儒家思想, 以封建制度之崩壤解釋墨家, 法 家之興起及其與儒家之爭論。信如是也, 㫜封建既廢, 儒家宜舆之俱亡。然30 自漢武以來, 百家罷絀, 儒街反而獨尊, 抑又何耶? 應之日; 自炎漢以來, 百家誠

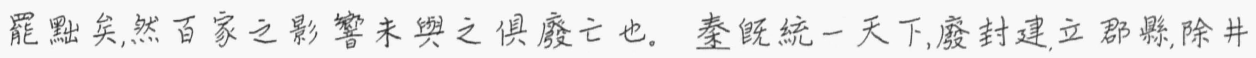
田, 開阡陌, 建尊號, 一制度, 此皆法家之教也。漢之制度, 大抵承秦之舊, 雖略封 諸功臣親族爰王, 已非古代封建制度之比。七國既平, 統一之局遂定。數千 
年来, 相沿不廢, 儒家雖尊, 其理想之制度終未惯现。不得以法家罷黜即謂其

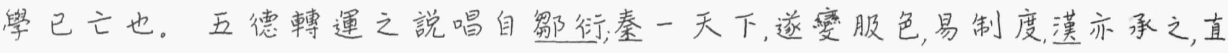
至至世始㩔。而五行之説, 深入人心成為中國思想之基礎不得以除陽家罷 黜而謂其術已亡也。至於儒家之成為中國正統學派, 雖曰由於在上者之提 倡利䘵使然。亦自有其原因。第一: 百家皆思以其學易天下, 惟儒家以六㢣

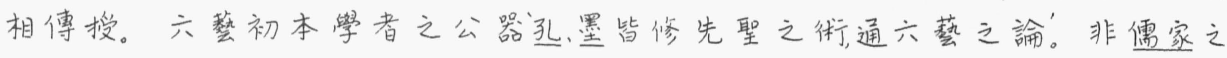
所獨有也。然各家皆以其翼德之弟子, 而弟子亦僅誦其先生之言, 服其先王

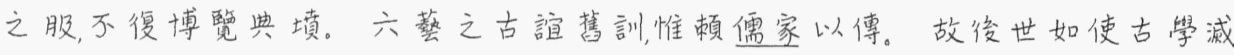
絶則已, 否則必於儒家求之。而中國人又為極富歷史性的民族, 絕不能任古

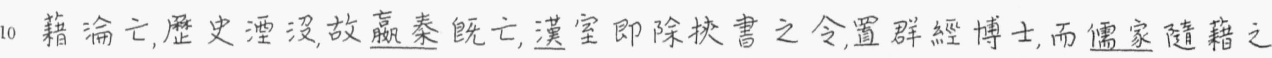
以興。第二: 百家中惟儒家研究中國之傳統道德思想禮節儀式。吾國傳統 的道德觀念雖虚封建宗法制度下之産物, 然苟非國家家族制度完全廢除此

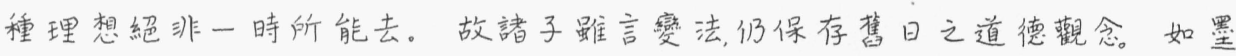
家雖倡節葬, 法家雖倡法不避親, 賞不避疏、然並不非孝弟忠信等德。蓋墨家 15 僅言節葬, 非主廢葬, 僅言“為人之親若為已親, 非言不為親也。孟子紫之為無

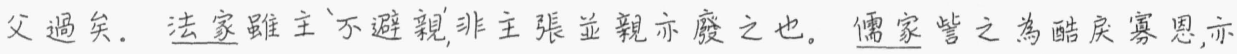

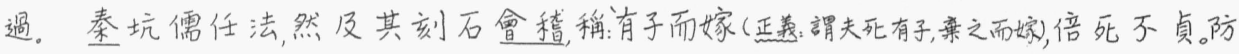
隔内外禁止淫佚。男女絜誠。夫為寄騢殺之無罪。男秉義程, 妻揙逃嫁, 子 不得母。其道德觀念舆儒家並無二致。故傳統的道德思想原亦非雷家所 20 獨有也。但諸子雖承認之, 並不以之有専學; 而雷家則發掩光大之, 遂成為道 德學之甫家。禮儀亦然禮敦儀禮諸書所載之禮節, 未必係西周之䳡典, 亦非 孔子時之典禮, 大抵戰國時儒家之所萑集删潤。行之者絕不限於雷家, 然惟 儒家以之脈尃鹏之研究, 遂又成為禮節之專家。漢高踓不信雷, 然必使叔孫 通定朝儀, 以非他家之所能也。故如欲保存奮日禮俗亦須向檑家求之。而 25 人類於䄚俗最富於保守性絕非一時之所能完全改易, 儒家遂亦不能廢矣。

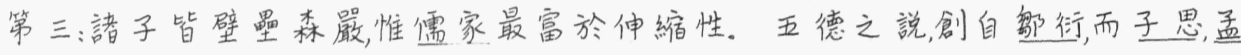
軻習用其説, 造漢董仲舒之流更制質文改制之説, 於是五行家遂合於雷。荀 垖非墨最力, 然取其尚婜節用之説, 於是墨家遂亦合於雷。儒家稱法家酷戻

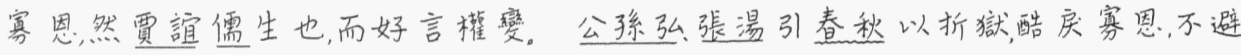

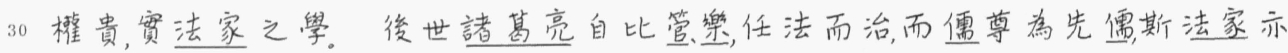
合於儒家。凡此之類, 舉不勝舉。總之儒家獨尊之後, 儒家本身亦經一極大 之濠化, 而諸宗亦附之以存。後世即佛老感行, 但予六綵一新的解釋, 即可附 於儒家旗幟之下。崔述之所謂“古之異端在儒之外, 後世之異端在需之中”。 然儒家獨尊之局所以能維持雨千稌年者, 惯亦由於此也。 
復次: 吾人雖以封建制度解釋儒家思想非謂封建既廢, 儒家思想 即失去其槚值也。蓋封建制度僅禹建造雷家政治思想之材料, 及其掉此材 料而搆成一完美而有系統之政治哲學其虞用已不限於封建制度矣。夫一 切政治思想皆其時代之産物, 然吾人不能因之而謂政治哲眐之研究即無其

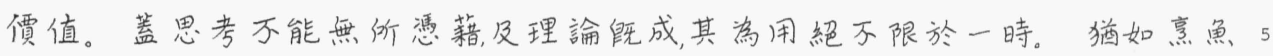

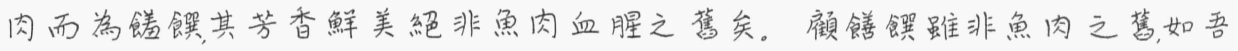
人欲研究此感饌之由来, 仍須於魚肉求之; 因之, 吾人如欲了解濡家思想亦須 研究其時代之背境。

$$
\text { 民国二十六年十一月二十八日於海淀. }
$$

討論問題:

一、略述中圈封建制度崩壤之過程。

二春秋時守搏者反對公佈法律之理由何在?

三、墨家舆需家的等説立端如何不同?

四法家是如何舆起的?

五儒家何以能成為中國正統繁派直德到今日? 



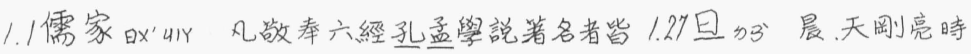

謂之儒家 一旦忽然有一天

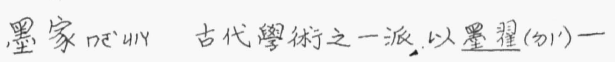

亦稱墨子省首, 倡, 事爱之説, 不鹤自身之利益、 宇山四方上下

專以社會象人的利益为前提, 在當時相當流、28隹年外同。这

行.

13哲出智

哲然即爱智之学

皆崔都

.16穏固×

.17西洋化化謂歐美各國

18遂4 40 於是

呈的现出

19亲《丢掉

弱亲廢除不用

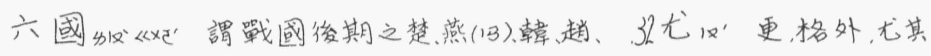

魏、齊六大國

21日叭視, 看

22 乏 $r Y^{\prime}$ 無

缺乏缺少

篮《矿因为

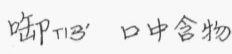

缶接形容相連接

.23覇多”諸侯之長
兼㐿謂合㐿他國

.29迨加及

制秋古國名、今山束省內

蓦岅春秋時國名，今山東省内

.31賜方謂上級人給下級人東西

賞睗同睗之意

百邑之很呀出《具有百色之地的卿大夫。

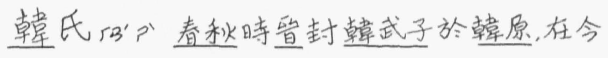

陕西省、其後代病晉大夫，周感烈王時與趙

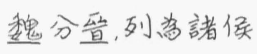

篡 $5 \times 3$ 奞取、特指臣奞君位

弿於……即被……基

巴五其先出自陳氏，後因國難奔弯子孫世

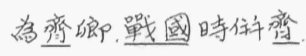

33世臣》行世代第一國之臣

34 身盾品《 身體

殻矿物之厚而不易碎的表皮

身區豰謂身體之外形

左傅國語終於越之覇左僡國語雨書2.4季山 未

記到越國的㛵覇

.24派点改浐

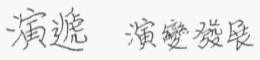

驟际次數

步驟進行之次序

.25誠彻”確, 真富

26 是故》《所以，因此

揣釛思量

揣測猜想
季年末年

即……是也是也为副詞語尾, 用以加强語 氧如即張三是也

.7夫秋發語詞; 這, 那

8 墾万沙開田, 用力翻土

. 9 緩 $1 \times 3$ 遮慢

迂緩遲慢而不䙲快

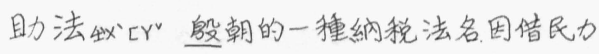
以助耕公田、故名。 
2.9 益1 更甚之意

指揮出双㻐令调派

課祀㳇税

課以一定之税收一定之税

.11殆加恐怕

殆按放徵税之始意即恐怕是按副計

算而收税之開始

椇武税

丘㒃春秋時尊䧕的田税名, 古田里之區劃

以。判有單位,十六井有一丘, 所繳納之悦租 稱丘賦

哀公历《澛哀公, 在位二十七年( 前493-466) 12 簐旅阰如单隊。

征运徽兵

軍旅之征軍隊兵士的徽收。

復的”再

13 窂予阿山春秋魯人, 名予字子我, 亦稱窝我, 孔

子弟子

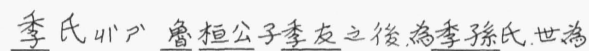

魯大夫，後掌握魯國行政大㩲

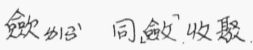

2.16 儉 $413^{2}$ 飾省

17 信者㣗“猜存

蓄 T心聚藏

信蓄耫存旗藏以偖用

篬 UUS 窮困

貧窘贫窮

.18柱出“謂房中直立而承受全屋之重量者

傾 $<12$ 偏向一邊然後倒下

拄石遂倾表示完全崩溃的意思

絳犹地名, 在今山西省

. 19 金玉其車、文錯其服用金和玉装飾他

㑚的車，用各種花文點綴他們的服裝

20 汥哦隇

没落欺亡, 衰落

良加化誠

良以窗在因為

衍的年延長，延廣

繁行生育象多

势不能按情形不能呴

祿加鸽國家政府做事而應得的钱。

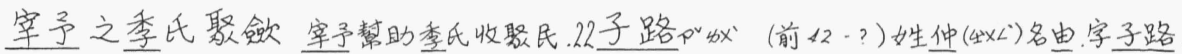

剘

訫吅責駡

吾 $x^{\prime}$ 我, 我的

非吾徒不算是我崣生

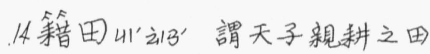

15 以と表示結果

以起因此而起

容炚么'或許, 答應

不容不改 即不得不改

抑i於是

抑依此制按照追種制度

.16勤<15'勞苦工作
春秋鲁國人，牲好勇，事新孝搌孔子弟子

利放”破壞

緼山麻布，粗布

袍始長衣

衣俅緼袍粗悪的交服。

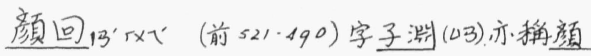

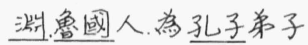

.23算加裝飯之圆形竹器。

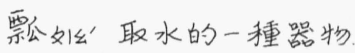

鉡食剽飲形容生活非常困苦。

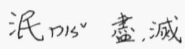

.26喻山告知通知 
2.26 家喻户曉傳告每家使每家都知道

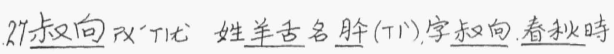

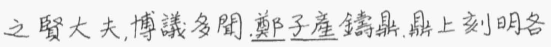

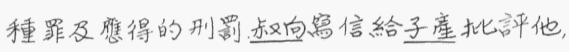

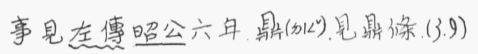

詒'”送

28夫思《邓1 以正言使人㯖從

詒書規之盅一封信去规正他

.29虞山, 度, 仰望

子 p v 代名詞、猶言汝、你

已㳊边。

始吾有虞於子, 今則已矣原先我以你

为摽準模範, 现在则不然了

先王T13 始前代之王者

辟外法(2)刑

刑辟刑法

顀山心 恐怕

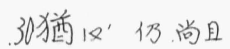

等山防止

闌小弓法、规律

約收改而正之

政出乵辛事之规则

約之以政以一定之规則改正人民之行 为

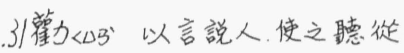

罰 $\left[Y^{\prime}\right.$ 責储處治

淫山過度, 放絽

嚴刑䍗以威其淫嚴格刑罢以制止騴

淫放縱

32誨厂代散道訓言
2.32忠坐以 畵已之心

䁈 $4 \times<$ “警動, 從旁鼓舞他人行事

教之以務教他㑚何者学首要之事。

臣点必居上视下

敬顿恭

臨之以敬以很港敬的態度對待人民。

涖办同熦臨到

33 彊<比同强

泣之以彊用强力監视行事者

圈耓《强也

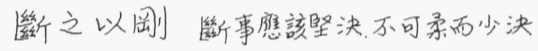
哲出さ賢智之人

聖哲聖婜之人

慈占謂上爱下

惠「×i 恩, 仁愛

34 忌41 曜、怕

竝优同道。

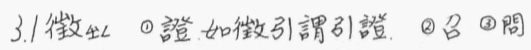

徼呟、徼幸、謂猚得意外之利益。

弗上文不

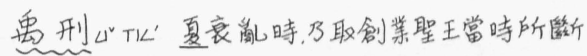

之獄而作之刑書

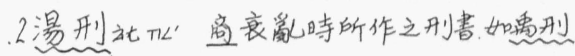

九刑 $41 Q^{*} T L^{\prime}$ 周京時所作之刑書

叔世秋户”末世近於衰亡之時代

. 封 LL 界限

洫屾田間水道

封洫開田間水道劃分土地界限

榢㕱斥他人之過失

立謗政建立制度, 使民皆可道官员或朝廷 之過失。

参5 3 約正或指责官吏之法

制參辟制定指正官吏之法

靖 4 L 治 
3.4 端加 3 原因

爭端謂開始隻方相爭之事因

錐出风7稱物之尖鋭者

錐刀之末喻微利小事

狺六争曲直是非於法庭

泫p 生長, 增加

具有 $5 \times$ 亿謂將財物送人而有所圆

具各新、以射物請託他人

6 士文伯ア”叭”春秋時鄭人。

. 7 火厂地星名、即心宿, 亦名天王西名 Antares

一等星近紅色, 别於火星 Mars

査 $T$ 品顯现

其く”如殆

鄭其火乎鄭國恐怕暑有火出现吧 8 火如像之, 不火向为如果火星是火的代表

象徵, 我們能不料想到火之即將渗生在尊国嗎? .9 潮柇海水定時高起下落之㛵。

潮流海水之高起下洛, 此處指時蔜之倾向。 鼎分 $L^{2} 三$ 三足雨耳的古器, 用銅或别的金屡所製。

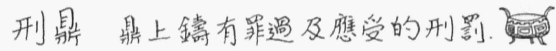

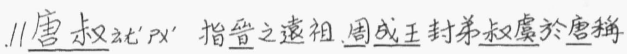

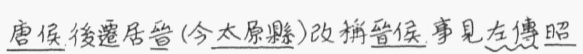
公二十九年

經4 12 直線日經, 南北日經绰之對。

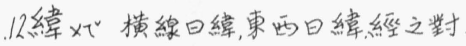

經緯有條理的計劃, 管理

是以因此

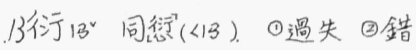

貴賤不行青挠的地位分得清楚不錯。 14 何業之守? 有什麼事業可守呢? 15 趁化傾向

克弍能

挽妈用力引之

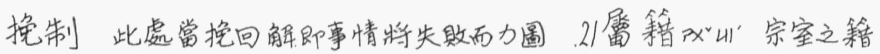

令其回到原来的狀況

3.16 兼之首而有之，即另外尚有之意

效死怡么”盡死力以報之

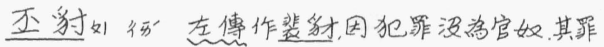
用紅色字記載。

隸加罪人, 賤者之稻

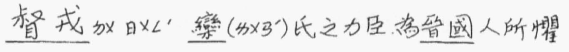

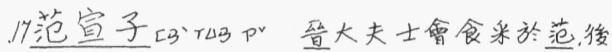
以邑学氏、不多才請於管宣子答能焼毁丹書, 他

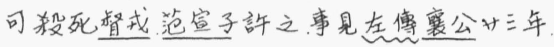
丹的以紅色塗物

丹書用紅筆曾罪的刑書。 趙氏出公”春秋時丝大夫，其祖封於趙城（在今 山西省) 遂以封邑為氏

范氏 范宣子之後

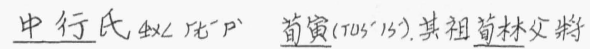
中行( 軍官名)，後以官雪比

.18郡4 古時地方之區域名, 一將系有四郡。 遂倠满足其志。

庶人工商遂工人，商人，平民，百姓都有識 會成为官员而满足他們的志向。

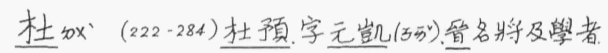

箸有春秋左停集解

.19囯山゙養馬者

禁隶固供人勞動使喚者

人臣隸圈免人臣边可以免除勞役。

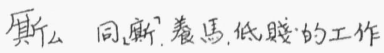

斯役勞啙的工作

. 20 商鞅陆龙公孫鞁、戰國時衛人，少好刑名

法術之學, 秦孝公時為相、行新法封於商, 栫

商君、孝公死、被殺

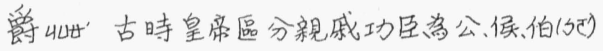

子、男五等爵位 
3.21 鈎《2 體曲, 有尖端之物, 3

銷下除去

一筆鈎銷 意即完全取消

22傚比效法

倣效整習效法

得士者昌, 失士者亡得到有㦛問人士的

諧助就可興盛，失去士人的同情就會減亡 .23垔瓦私察别

階級甄域只在某一階级中選用人才

延13 招進納取

攬加”取

延㹂招延收㹂

奮的猛然用力即益力的意思

. 24 䔡秦 $4 x<15$ 戰國時之缇撗家(九流之一), 字

季之洛陽人曾哾六國速合以抗秦为盟約

長秦兵不敢出關者十餘年。

佩多熬於衣上

印分印信, 印章用木或金石卷之, 上刻文字以

为信

相印百官之長的印信

佩六國相印表示其为六国的共同宰相

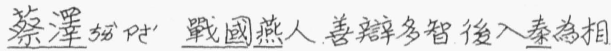

为人所惡遂退休，終老於秦

匹夫外坛庶人, 普通桑常之人

逐秋挥走除

應候心“汉”范睢( $(x 7)$ ）字叔戰國魏人曾为

秦昭王相、封應侯

蔡澤山東之匹夫而逐應候祭罣

是一個山東的平民, 趕走碓侯, 而自为秦之相

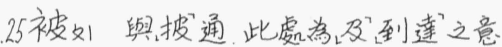

咸T13'皆

釋》”放下、妄

来かて 一種農具之手握部分

耤公農具装於来端, 起土時用。
3.25 来耤耕具耤学其刃以起土来为其手握部 千《注求

咸釋其未粘而干鄉相表示都不願 做蕽夫而爭相病官

俊4以 謂才智勝人者

堅俊婜人俊才

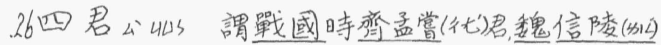

君, 趙平原君, 楚春申(PS)君, 皆以養客敬婜猺

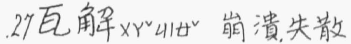

.29 畵5 $5 \gamma^{\prime}$ 分界

刻畫分劃

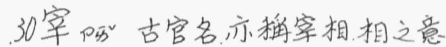

臣宰大臣官員

俸伿官員所得立学值䘵

.32束員炀依靠

33竭4 盎

4.1 个4 1 | 介畫, 此處有隔離之意

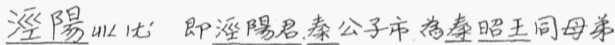

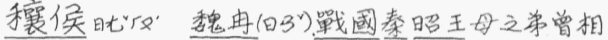

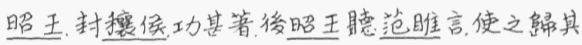

封邑

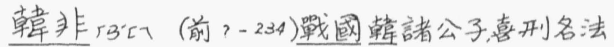

律之祭, 數以書諌昱王不兒用乃努力著書五十多

篇, 踫暿韭子

愛臣太魏必危其身, 人臣太貴必易其

，主主妾無等必危社穔過份爱謢手下的

臣子, 一定會危害到本身的安全、臣子過份顯

贵的話, 就會取代主人的地位、正副不分的㪗。

則必會危害到國家的安全

猶汉似

. 3 職出助詞, 惟也

不雨立不能同時並存

. 4 當塗犹埕握有政㩲的人

仇得㪣 


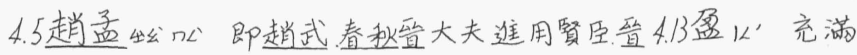

人稱其知人

衰双要謂由强盛而漸微弱

弛行低減少

寵衰信弛愛宰衰落信用减低

6 兔动動物名, 耳大尾短善跑, 毛可製筆

亭妅把東西放在水裹, 然後用火焼, 如作飯作策。 兔猚狗烹事情作宅後, 主人即不留養。

遭阴遇到

翏戈加殺

殺翏形容被殺得很残暴

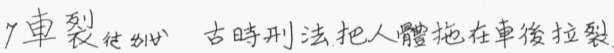

始於戰國, 宋以後廊,

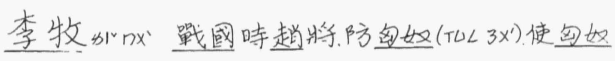

十餘年不敢犯及大破秦果，以功封为武安君後

秦用計，使趙王腶李牧。

寃 $\Delta$ B屈受到委曲。

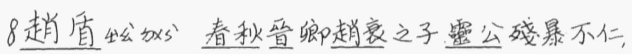

趙盾諌之公欲殺盾, 遂出奔, 後公被盾之姪所

殺, 睢乃回國。

弑” 臣殺君或下耓上曰武

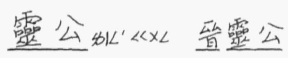

季孫北的即季氏

魯侯加”仅鲁昭公因季孫氏執大獾、很生氧, 舆

兵伐之, 結果反被逐逃到整國

.9虐3山甘 殘暴

10 綜P X i 總聚

綜之總之總而言之

.12孟軻叭的即孟子。

頡け世”直向上

抗颉反杭

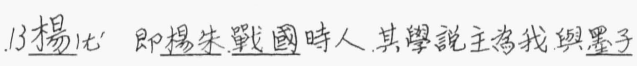

之, 兼爱相反。

楊墨楊未舆墨䍂

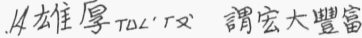

拔S 以 拿出来, 如拔牙, 拔草, 拔毛

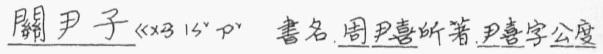

学函谷關吏，傳老子授以道德缓後二人同西去， 莫知所終.

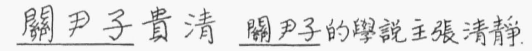

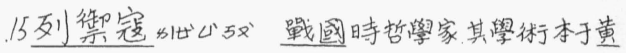
帝老子。

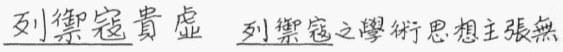

有

詹何出了战戰國時人善術數—日, 有牛在門 外叫, 他敦是黑牛白角, 使人到外頭一看果然

是一黑牛, 角上包着白布。

詹何先識庢何有先見之明

魏牟メ门叹”戰國時魏公子、封於中山。

委鬼牟縱欲鬿牟主張一切按自己所想所

願意的去作，不加約束。

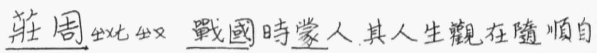

然社檑觀在歸於無治、舆老子为道家思想之

宗師著有莊子一書

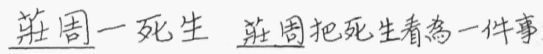

慎到防妐戰國趙人, 箸慎子。

慎到臂萬物慎到認为萬物皆平等

17 䖮《xץ蜡牛, 軟體動物, 外殻扁圆、對植物有害

䖮角螎牛之角, 形容其細小,

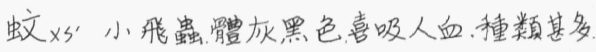

睫山世眼上下邊上的毛

蚊目建蚊目旁毛, 形容其極細微

蜳角蚊睷形容㮛微細小之事。

灼非焼

濡旰濕( ( ) 把東西放在水襄的自然結果

.18 猶1 8 仍。尚且(見4.2.30)還

患欧了福害 
4.19 説凶世 高興

葬优人死後把其身體入土

摩口, 多餘之消费

厚葬犘剘而貧民服为原等死人而花 楂很多錢剘令人民的衣服窝乏。

.20踵4 4 火”足後跟

摩顶放踵摩平顽顶下至於足跟，形容其

盢力工作以至於從頭到脚都摩平。

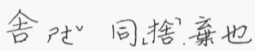

舍身救世放亲本身之一切以救世人。

到卟强

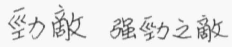

.21見413 被

査尊為被尊有

岐《!謂旁出之路

岐異 不相同

宜卜合適, 適當

宜乎合乎道理的

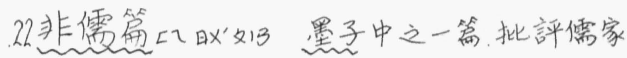

不對的地方

訶的大督責䚚

訫訶 批評責備
4.28学其友之身若学其身学其友之媇若 . 29 为其新對待明友像鄴自己一橉孝敬明友的

媇人像孝敬自己的親人一㨾

. 30 廉必不令, 不要不應得的时物

.31畸山1 不一㨾。不就

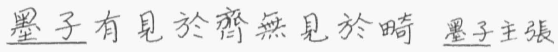
上同兼、爱故云見糹两不見畸要人人皆平等 一㨾而忽略人與人有不同處

僈n3 同慢。輕筑

上功用、大儉約而僈差等以功力為 上而過儉約並不注重差等, 欲使君臣上下

同紫答

曾不足以容辩具懸君臣上下同等则

不容分别而息隔君臣

33 卑か低下

5. 震化哀痛死者之事

食震䬦約的處理埋葬等事

. 2 應长相佩合

. 3 衡厂稻量之

抗衡相㪣, 不相上下

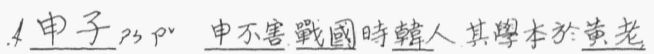
而主刑名、與溒非同檥有名後世奉有法家之 祖, 箸有电子二篇。

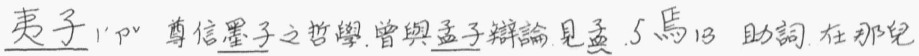

\section{子滕文公章向上}

辯引仍爭論是非對錯。

.23閣星青䚚

24 尊尊親媇尊重尊贵的人, 媇爱自己的媇人

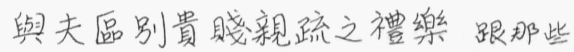

分别貴賤媇疏的禮察。

. 25 疏阠遠，不親近

. 26 上同乎天子而不敢下比舆天子之意

$$
\text { 思一樣, 不㦑與下面别人不一㨾。 }
$$

\section{.7逮䟚及，等到}

12 儒家之法先王儒家主張效法整舜固公等 先王之堅德

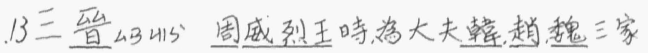
所分，故幍三丝

.14太公动《妅虽尚、本姓姜、因其先封於虽、故 姓從村，字子牙、固文王初遇之搯之为太公望 立为師、後封於淿營丘

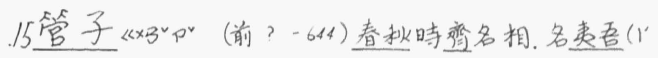

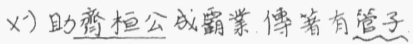


518 寒偊爱念敬仰

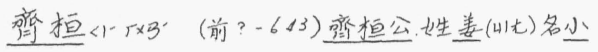

白春秋弯君，为五露之首。

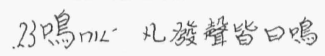

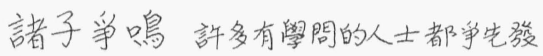

表自己的學術思想。

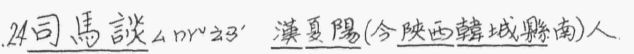

習道家之言, 漢武帝時曾为太史令, 司馬息之

父, 為開始箸作史記者。

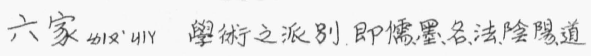
德六家。

班孟堅列哒《1 $3\left(32-9^{2}\right)$ 班固, 字孟堅、班彪

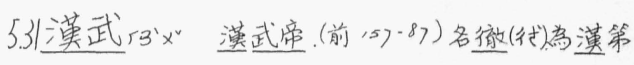
六帝, 舆學尊儒。平南越, 東越, 朝鮮, 下西南夷,

逐匈奴，通西域需一代雄主，在位五十四年。

絀㣗房免

罷絀 廢除

耶奻助言, 表示疑問語氮

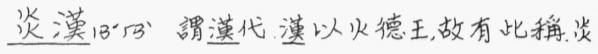

者火光也

32黑出㣗同絀

333 斗 13 田間南北方向的小路

陌叭由間東西方向的小路

開阵陌開田間小路，以啱分田地。

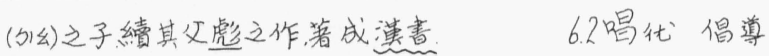

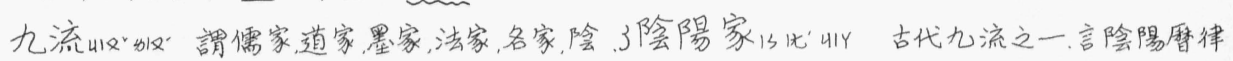

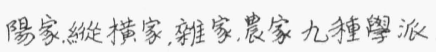

之事

25 名家DL'4 I Y 古代哲残思想之一派, 以正名義

為主, 尤以强辯著稻

鮮T及少也

鮮及政治 很少談論到政治

26 掉万矿開

闇借合

䍃横捭望之辩觀察時劸, 班别人心。 以適當的言詞與方法来説動他人

惕忧通達。

則或暢迁怪之談不時也提倡㡎表一 些策唐, 不合事理的言論

邀任招引

或邀一時之功或許暫時能討好世人

得到短時的功效。

飾方假訅之意

飾小説以干縣令者假託小説来諷

刺千涉當政者

子 p v 代名詞你, 此處指作者本身

信如是也果真如此
.7誦么优出督唸書

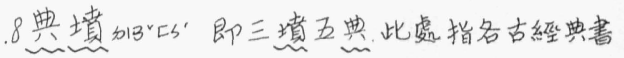
籍。

\section{博覽典填腐博的譆古籍}

誼人通義, 宜

古誼古訓

县已, 否則 ‥那就算了。要不然。

10 渝加咥減没

渝亡 隇亡

湮1 3 消失

赢泰《'《S'即秦代, 奉國姓赢, 故幍 挟H，藏，持。

挟書之令秦之禁令秦始皇從李斯之請、令 諸有文㲘詩書百家語的書, 都應除去, 若令

到满三十天㬊未除去、即要受罚

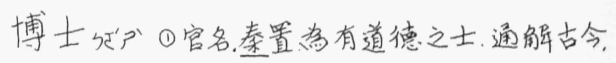

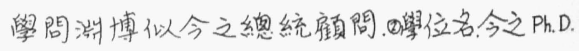

籍犹依靠, 依託

１2管《假若，如果 
6.15 些pv 青嘿

16 酷列惐暴

庈种暴密

恩s仁爱待别人好

酷实宣恩 残暴而然仁愛之心

.17坑张葬, 入土

坑儒把活的謮青人活活放在土裹處死

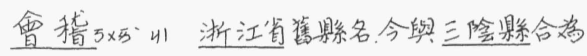

紹(訟)奥夥

正義私门即史熟正羔兽張守節著, 共三十卷。

昼私謂女子守婂道, 行有正當者

倍死不真倍同背、背死夫两号嫁有不直。

.18佚、任所欲为

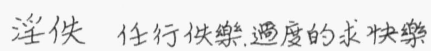

絜 41 清

絜誠清白誠宽

寄4 暫時居住

哌剧 男性的豬

寄雄男子到别的女人家去住

男秉義程, 妻为逃嫁子不得母程同徵

男人因公被徵、其曺亲之而逃嫁别人, 其子

不得以她学母

19 二致心出二種不同的情形，即不同

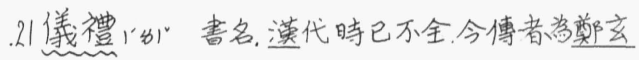

(TUB') 所注

22 漼厂们謂水會合

删邚削除

潤日领布

匯集删潤聚集材料，加以删改潤飭

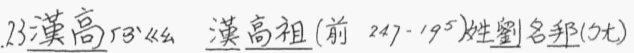

字李減秦為帝, 在位十二年

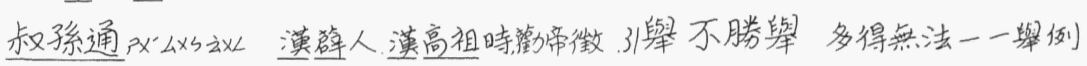

鲁諸生共定朝儀, 番古禮舆秦儀雜用之。 . 24 朝後君主治事之處
朝儀謂臣㫕君之禮制

6.26 森么 樹多。

壁量森嚴陣地整顥㩔密, 不容外人侵犯。

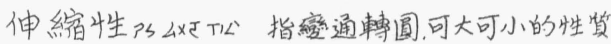

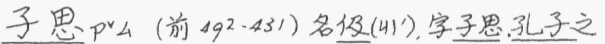

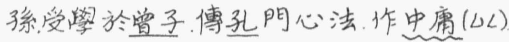

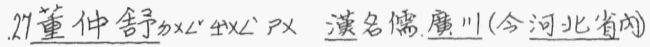

人.箬有春秋繁露等害。

流出、派别

…之流…䢣一類的

第很仙的《即筸㫛。

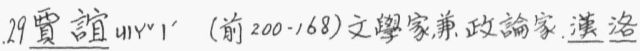
陽人，文帝召為博士聁升为大中大夫所論列

多昌施行, 但因遭忌出為長沙王太傅, 世幍曋 太博、又䂇曋生

公孫弘《 《 $4<4 \times 35 \times<$ (前200-1 27 ) 谟人, 習文法吏

事、飾以儒術, 武帝以为相、封平津侯。

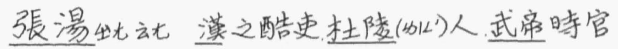

致御史大夫、後虚人所害，自殺而之。

獄心犯人所住的地方

折獄判決法律案件

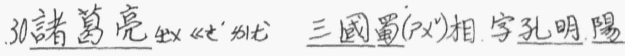

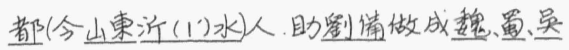

三國對立之劸。後伐魏病死軍中

管 $\ll \times 3$ 即管仲

樂山゙即樂毅( 以)戰國燕昭王之卿㹂而好

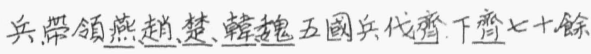

城，封昌國君，照王死，惠王使踦劫(山好)代之

毅奔趙趙封为望諸君

斯么逭, 那, 那麼

…之類 …那一類的

.32予山同與給與也

7.6 餙仅飯食。 
7.6 饌出 $\times$ × 飲食

飶饌作熟的飯菜

腥T以謂生肉魚類等之氣味。

血腥指生魚肉有血又有腥味。

顧《但

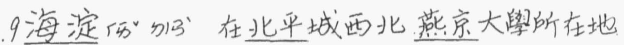


第五課秦漢時期的中國文化

勞翰

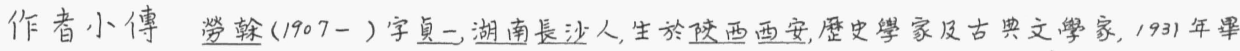

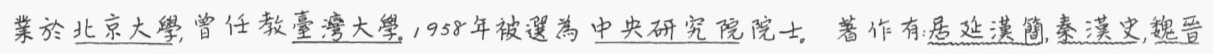

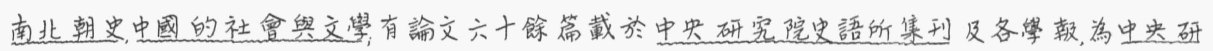
究院史語所集刊之主編。

本課簡介本文取自勞畭在太陸雜誌第四卷第三期上所發表的秦漢時期的中國文化一文, 此 文將中國文化發展史上的重要時代—秦漢時期一作一簡單之敍述。全篇共分四部分, 第一部

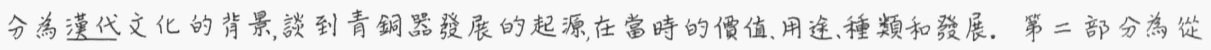

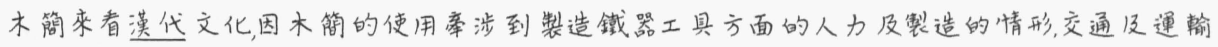
的問题。第三是拳漠雨代的思想和政治,討論秦圆大統一形成帝國形式的源起超势和搏展當

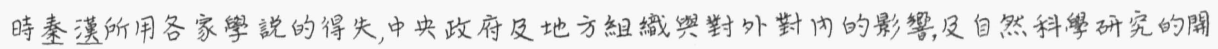

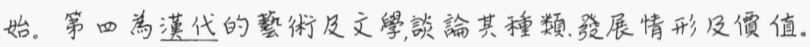

一 漢代文化的背景

今天所講的中國文化主要的是秦漠時代。秦漢雖然是雨個朝 代, 但就制度上説, 是一贯的。中國的過去光榮時代, 一般説來是漢和唐, 尤其 唐代最若著名。但是唐代的最為著名, 是因為當時全世界更無一個强有力 的國家和唐朝具有同等地位。因此唐代成為當時的唯一大帝國。漢代却 是束面是漠朝西面是羅馬束西輝映著。因此相形之下, 漠代在世界上的地 20 位不及唐代的特殊。

就特殊的世界地位來看, 是漢不及唐, 但就民族本身的成就来看, 却又是唐不及漢。漠代不論在政治上, 在軍事上, 在文化上, 都是純中國民族 做成的, 並未曾假借外力。所以不論在那一方面来比較, 漠代的成就, 自有其 特殊的意義。

漢代文化的特殊意義還不止只有這一點。中國文化從夏商以 来, 在春秋戰國時代曾萃集結成為一個最發掦光大的時期。所以漠代以前 萃夏民族的努力, 也就是使漢代的國力, 更将充惯的大原因。

中國的文化, 是曾經長期發展的。就我們比較明白的説是屬於 青铜器時代。青銅器時代的文化, 是漢代文化的重要背景。中國青銅器時30 代從那一個世紀開始, 中國青铜器的發展, 究竟是本地進化而成的, 還是從外 面傳播而成的現在都是一些謎。不過到了殷墟文化時代中, 铜器的製造技 術已經到了相當的高度了。因㐆中國銅器時代的進展, 似乎比埃及和雨河 流域晚些, 因此中國銅器的發展, 有從西方傅来的可能, 但是在没有確惯證據 
之前, 應當避免作任何的揣测。

這種銅器在殷代或以後的周代, 都是非常玨貴的。所以也稻庶 重器除用兵器之外, 大都是屬於重器的範圍。精製的銅器, 是當時㢣衔的一 㧽重要的代表, 他們大都屬於王家和貴族很少有平民鎆造的重器。重器大 5 都和福節有關, 现在尚存的重器, 有許多部分逻可以和周代的禮經中内容來 相印證。從這一點來説, 我㑚可以看出銅器的價值, 也可以看出三禮和他們 注疏的價值。

在殷商時代, 西周時代, 東周初期及春秋時代, 以及戰國時代, 一個 時代有一個時代的特殊作風, 我們可以從銅器的類别形状圆案、文字各方面

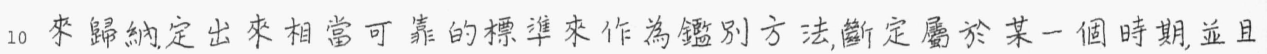

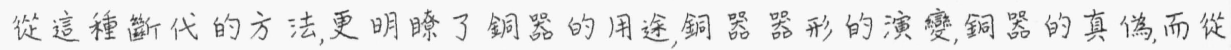
來的栽個錯誤觀念也可以約正了。

春秋戰國之際是中國文化史上的一個大皎革時代, 在政治方面, 舊時的封建貴族已經漸次崩溃, 容成了幾個新的君權國家, 至於世官, 井田等 15 等社會上和經濟上的重要成分, 也随同改革。好幾個國家, 因為他們的君主 開疆闔土, 和邊境的各民族更增加了和平與戰爭的新接觸。因此在文化上 也受了新的影䜾。倘若將漢畫中所表現的社會, 和春秋左愽所表现的社會 本相比, 那就很可看見春秋時代和革代, 其差具的程度也許比熯代和唐代的 差異程度還要大些。所以戰國時代, 真是中國歷史上的偉大時代。不過戰 20 國的史官紀録, 可能和左傅和史記一様詳細的, 都被秦始皇焼掉了。因此我 們對於戰國時代的歴史事惯, 除去看司馬僄根據秦紀所作的简單表格, 和根 㩚德聞和策士誇張的記錄作成了拼凑式的世家和烈傳之外, 他已絓發現非 常困難, 没有多少可靠的材料作為根據。但因為新史料的陸續發見, 使得我 們對這一個時代的重要性, 逐漸明瞭起來。

中國本本不是一個産銅的國家, 偶然有戴㧽銅礦也在江南和巴 蜀, 在江南的如丹陽和豫章的銅山, 在巴蜀的如嚴道和朱提的銅山。在殷周 時代, 雖然运些地方不是和中原没有交通但彼此的關係, 到戰國的時代更為 重要。西周時代, 賜金還是一個特殊的榮譽。春秋時代, 楚王贈給鄭伯的銅 也和他加上一個無以㿧兵的盟約。因学銅的貴重, 所以商代器物格外加工, 30 除此以外也只有兵器, 至於青銅的農器, 却琁本未曾發现過。綵過了西周, 經 過了春秋, 到了戰國, 銅産随著南方的開發而增加起來, 銅器的應用從國家大 事中的祀舆我之外, 推到一般人的日用上去。原来的貴重性質虔成了平凡

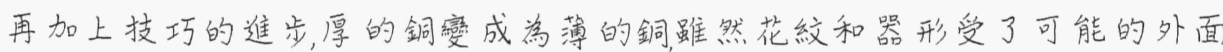

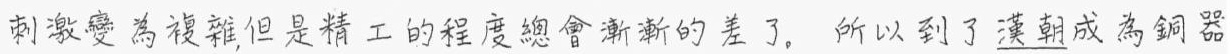


美術上的衰頽時期。

斯克泰㙯術的輸入, 的確是戰國時代銅器㢣術的一䀦新生命, 斯 克泰㢣術的發源地现在尚不能完全明瞭, 不過就现有材料而説, 大致東起西 伯利亞西至南俄的頓河(Don) 和聶伯河(D r i e p e r ) 之間至少在紀元前數世紀到 紀元後約一世紀之間, 有一種青銅器文化。在這一带的民族雖然有流動和5 移轉, 但在他們的文化上, 要保存著一種特點。這個以斯克泰人為中心的文 化, 和伊萿文化, 巴比侖文化, 西部亞洲文化, 以及希臘文化, 都有相關。他們都 是游牧民族, 在游牧生活之中, 有他們特殊的印象, 這就是用動物和植物的形 態來做装飾, 尤其鳥類和獸類䦥寽的形態在表现方面顯示出來, 動作和力量. 中國的圖案, 在殷商時代也常用動物但所用的是安静和諧平衡和充惯, 與這10 種的設計, 顯然是不相同的。

在中國和外國, 過去曾藏有許多斯克泰型的战國銅器, 例如 siren: A History of Early Chinese Art 和梅原末治的戰國青铜器研究中都舉出了万少的 器物。而民國以來大批出土的, 如同河南的新鄭影, 山西渾源影的李峪, 安徽 的壽縣, 以及洛陽全村古墓所發現的戰國銅器, 以及喕影的發现铜器, 都有不 15 少的斯克泰影響。自然, 其中不是没有中國式的成分, 但是将中國的固有成 分巧妙的舆外來成分配合為一, 這却是戰國作風中的技巧。這種作風是戰 國時代一個傅播相當廣的作風, 䇣前有人稱為秦式或淮式的, 都不能够正 確的指示, 目本梅原末治戰國式青铜器的研究, 定了戰國式铜器, 的名稱, 可以 説比較是對的。

春秋戰國之際鐵器發展了, 但所代替的不是铜器。鐡器所代替 的應當是石器, 他的應用處, 主要還是在耕種方面。戰國時代雖然可能已有

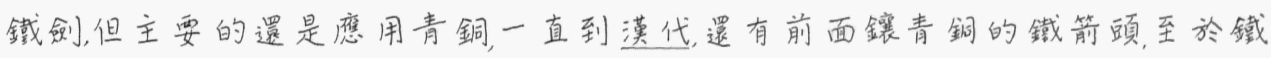

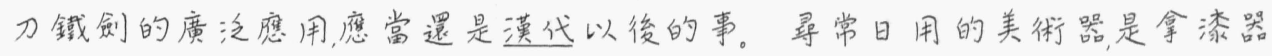

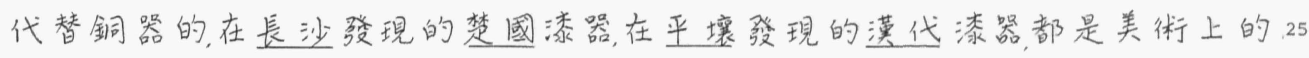
精品, 而代替了铜器成為殉葬物品的主體。

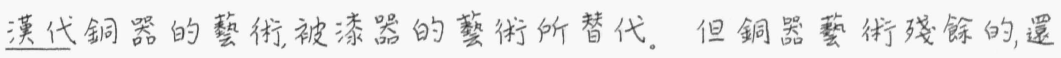
在镜爁方面。漢代的镜鑑經過魏晋南北朝長期的發展, 直到唐代, 直到且本

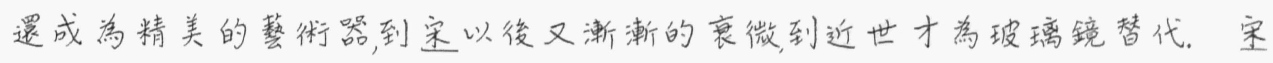
代是镜艦㢣術的衰微時期, 却是瓷器的發展時期, 此時除去瓷器有了一個墢3 0 展的新趨勢而外漆器也翻新了許多式樣, 显在佛教的㢣街上面, 也開闢了 新的地盤因此中國的特有㢣街, 便分配到瓷器, 絲紼和漆器上面去.

二從木簡來看漢代文化

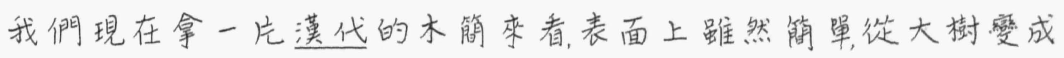


木簡, 便率涉了不少漢代的文化现象在内。先從大樹鋸下来, 需要大鋸子, 再 將木椿用大锯子解成木版, 然後再用小锯子将木版子解開, 再用削刀將版子 削平，鉋子見於正字通故古代應當没有鉋子。追種鋸子和削刀，就代表邁代 的工具。這些工具是鐵做成的, 因此就旁連到鐵的問題, 漢代鐵穬的分布, 鐵 5 鑛的開操方法, 鍊鐵的方法, 钿鐵的燃料鑛山和穬場的組織和管理, 鑛山和工

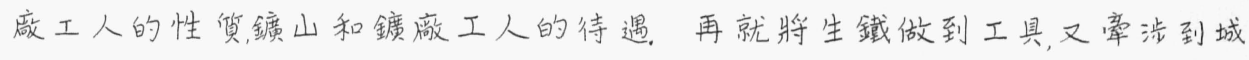
市中的鐵匠, 包括鐵匠的行業, 鐵匠的訓練, 鍊鋼的技巧, 琙匠铺的布置, 打鐵的 工具和方法, 鐵的成品的售賞(在本店舆市場) 售賞時所用的货幣, 以及市埸的 範嘖。此外還旁涉到燃料的運輸問題, 生鐵的運輸問題, 車的形製, 有牛車和 10 馬車, 道路的形式, 道路的管理。但是以上的種種, 有的是可以知道的, 有的却 因学史料不完全, 不能斷定了。

就以上所舉的來分析, 我們就大致知道的來説, 至少有以下的三 部門:

第一; 關於鐵的方面。漢代對於鐵是非常注意的。漠武帝時的

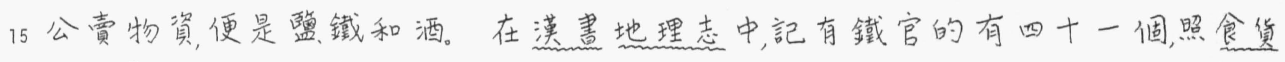

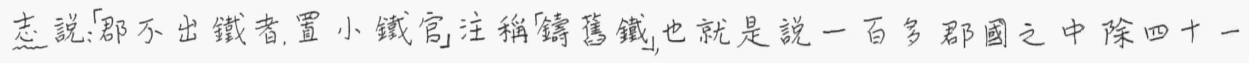
個鐵官以外, 罢有六十個小鐵官。這些鐵官管理著来鑄蕽器給農民, 蕽器之 中主要的是犁和鏮。

蕽耕的器具, 最早差小揫, 再進步為锄和犁, 而犁比锄逻要進步些。 20 在古埃及圖畫之中墢現了犁是由鋤進步而来, 尤其顯著的, 是犁和家畜的使 用, 多有密切的關係。牛耕一件事, 是最早起於埃及, 再次為巴比侖、印度, 中國 再次虞卧洲, 美洲的印第安人却一直没有牛耕的事實, 連袐魯的印加帝國也 算在内。中國對於牛的使用, 據説商朝的祖先想土開始, 但到了春秋戰國之 間, 因病一些不知道的原因使得牛耕, 臷器犁的使用, 都同時在中國被發明了。 25 (騎馬的騎術也是同時)。這些事實, 促成了中國蕽業的進步, 促成了糧食的增 産, 促成了人口的增加, 促成了君權國家的形成, 也促成了戰爭規模的擴大, 這 些條件的累穔, 又是秦漢大帝國能够形成的主要原因。

第二:關於人力方面。中國的地理狀况和人口分布狀况, 決定了 人力使用的性筫。就春秋以来的發展桃説, 開發地區大致都在黄河流域一 30 带, 追裹䋨度大致相同, 物産也相類似。地區相當的大, 而水路的交通却不發 達。這一個大的區域形成了同一的曹菜文化。商業雖然有, 但因虔地域分 工不過分顯著, 所以不能佔社會綵濟的最重要地位, 而商人階級對於社會和

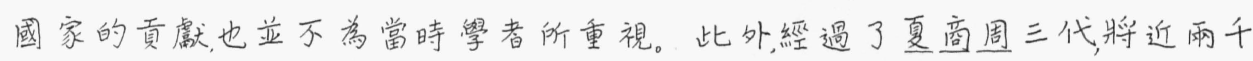
年的長期統治, 差不多等於束漠到现在的時間) 平衡而安定的時閒比較上還 
不少, 平民的人數增加, 奴隸的来源缺乏。矣㖤風的時代開始, 我們看見的蕽 丵, 便是以平民身分勞動的蕽民, 他們的自由, 可能比佃蕽的限制多些, 但似乎 還不及歐洲中古蕽奴的那梂多的限制。所以在這種情形之下, 是以自由人 的勞動絾主, 雖然不是没有奴相, 但奴隸只應當佔全部人數中的少數。只有 到秦代利用大量的俘虏和罪人, 作学奴隸桃使用。這是殷周以束歴史上的 5 特例, 漢代減轅刑法, 官家奴隸便只有不太憼人的數目了。

漢代初年工商的生産曾使用過奴粶, 漢畫食华志所舉出來的, 便 是顯明的證㨡。到漢武帝抑制商人, 使商人在社會的領尊地位減低, 亚且将

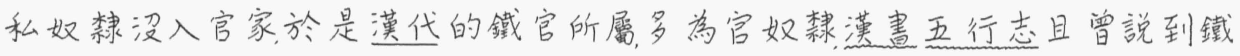
官徒的叛嚄。不過漠代採鐵是一回事, 鑄鐵是一回事, 鍊鐵和作器, 又是一回10

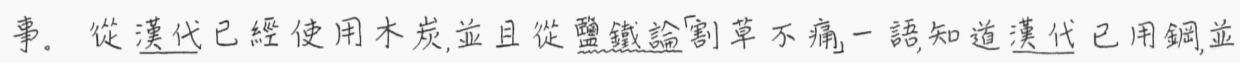
且是一種技巧上的事, 那就除去奴隸以外也用著治工了。

第三: 交通和運輸的問題。關於這一類的問題, 對漢代的關係, 甚 為重要。漢代是一個大陸的國家, 要維持一個有效的統治, 非有一個有效的 交通系統不可。美洲的印加及馬雅帝國, 西班牙人一到, 立即歸於毁减, 其結 ${ }^{15}$ 果還不如埃及和印度, 和他們不能充分利用㽞力的交通, 他們甚至連輸子也 没有, 關係很大。漢代便是利用有效的交通系統來克服他的困歏的。

漢代的陸路交通, 普遍涉及全國的各處。平原的運輸是從萑日 的許陌改䃞而成的。這種道路至少在周代時的周道己經是蒐直而平坦了。 在路的雨旁也有落樹, 不過這種道路只是利用原有的黄土筑成的, 並未曾修20 上碎石或石灰一類的材料。因此一遇大雨便有不便通行的苦㨫。在山中 的道路是用人力来開山的, 並且還利用木料作成找道。因病當時火㩰還未 發明, 所以開路相當困難。只是到了漢代, 域器已經普遍使用, 所以開山究竟 比從先要容易些了。尤其到了東漢, 更有許多開山修道的記載, 我們知道當 時不論長江流域和粤江流域都已紅開了大道, 不論東面到現在的浙江, 西面 25 到現在的四川, 南面到現在的腐東都可以行車, 因此邁人的文化, 也就成了車 的文化漢人所到也就是車的所到。

中國的政府, 最注意是民生的安定, 而不是貿易的發達。所以䦥 於交通的處理, 是政治上的理由迬遠的超過了商業的理由。縱有若干情况 是屬於經渓上的, 但經湾上的理由, 也是為的是國家的剘政和軍事, 而不是為3 0 對於商人的便利。假如鼡商業上的理由, 那中國的西北區域遠不如東方區 域的重要。但事實却不然全國道路的中心是在長安和洛陽。而這雨個地 方都是政治的意義重於綵濟的意義。因此除去純屬於政治上如官吏的循 行和調動, 軍隊的遣派和調防等等事項以外, 而軍隊上後勤的輸運, 以及各處 
税收向中央的提解, 和中央對於贫乏地嵒的資助, 也是政治上的理由較禹重 要。從這一點束看, 也就可以看出漢代的社會, 商人在中産階級中, 並不是一 個主要組織成分, 而組織中的重要成分, 却屬於和政治關係較密密切的知識 分子。

漢代的政治中心, 被限制在黄河流域, 而黄河流域的水運很䧼利 用, 這就限制了漢代商業的發展。中國沿海的交通開展已經很久, 我們看一 看沿海的國家, 例如吴越和費, 都有海上交通的事實, 但台演海陝以北海上貿

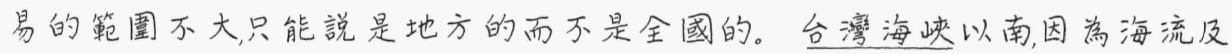
颱風的關係, 又使海上貿易受了大的限制。但是海道的險喼也擋不住留易 10 的開展, 在西漠晚期, 番禺已䌊成為重要的都會, 到了東漠到了南北朝, 番禺的 財富還是靠著海上的貿易。到了唐察仍然学市船使駐在的重要地方。

長江流域貿易的情况就遠比黄河流域学重要。黄河流域的城 市, 是由政治上的原因制建的, 多差正方形, 而長江流域的城市, 却由自然發展 而成, 都市的形式, 多半离沿河的不规則形, 並且往往有一道河街, 虚最繁成的 15 區域這一點從水緃注所記載的已弳是這樣了。然而中國都城究竟在北方, 而國防的重要和商業的利益也是衝突著, 因此還是迤緩的發展下去。

\section{三 秦漢雨代的思想和政治}

秦漢雨代是代表著中國大一統的成功。但中國大一統的趨勢, 却不始於秦漢雨代。很古以前踓然不能完全知道, 但至少在商代的後期, 帝

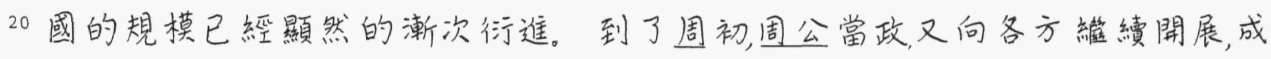

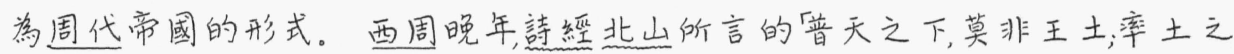
濱莫非王臣。成了後來一個廣泛德播的名句(到戰國時如莠子萬章篇, 戰國 周策萄子君子篇曈子敦林号覽慎人篇都引用過)。西周之亡對於大一統的 赹勢是一個逆流但却擋不住自然形勢的開展。不論挛桓晋文, 是一種亳相 25 統一的先導而春秋中的湷王正肘更顯然具有深厚的大一統意義。此外梚

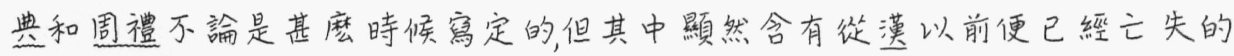
材料, 也就是漢朝人做夢也寫不出来的, 其中便也顯著的, 基於大一統的觀念 来窎定。

春秋時代的晉國㣣天子以令諸候, 對於周天子的關係, 可以説類 30 似旦本的幕府時代, 闕白與天皇的閏係。至國的成就是對外萧清了狄人雜 居萃夏的住地對外確立了集中的君權。憑著晋國的適當的環境澍立了法 律的觀念例如照公二十九年, 趙鞅銡的刑鼎)。等到三家分盍之後, 魏候承緼

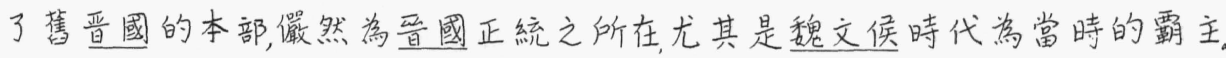
而李克, 吴起都是舊時主要主張農戰的人。這種主張後來就成営商君政策 
的背景。

秦國一般認為全是西戒之俗這是不確實的, 不錯秦國含有很濃 厚的西戎氯息。而住於草原文化及龩夏文化交滙之處, 但却不這樣簢單, 秦 的公族是和徐趙一樣的東方分子, 秦的中等分子又含著很顯著的西周遗民。 再因為和橿國世為婚姻, 又受到晋國文化重大的影響。譬如秦的文字, 便和5

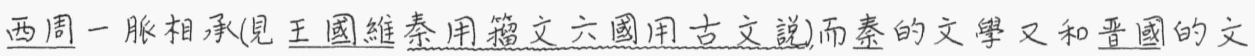
學非常相像(如秦的竩楚文便和左傳所載晋人号相的縃秦文同類)。這個束 西交錯的新國家, 雖然它的文化因素我們還不能做一個精磼而詳盡的分析, 但它所代表的時代意義决不是偶然的。

秦國在魏國盛極一時的時期雖然一時潛伏著。但是到了暲國 10 减鄭的第二年, 西元前三七四年, 秦獻公從雍(瞗翔)徙都祭陽(高陵東), 到了西元 前三六四年, 便大破三至之启, 這就表示著, 秦國的势力已紅開展了。等到秦 孝公任用商靯, 更使得日就强大的秦國, 得著更進一步的發展。所以秦的徽 法只是促進强大, 而不是轉弱小学强大。換言之, 秦的察法, 是由秦的發展, 在 客觀條件之下来促成的。

秦國的發展,使得他的政治條件成熟了。商君把三晋的法家的 觀念輸入到秦國来, 恰合秦國當前的需要。他的政治原則, 是强公室而杜私 門; 他的經濟原則, 是不重分配而重生産; 再將人民在國家領導之下組織起来, 在震和戰雨個原則之下, 向國家效忠然後定出來客觀的法律来支持他的政 策。這許多條件, 使得秦國成為一個有組織, 有效率的國家, 使秦無敵於天下。20 從魏惠王之敗到蟀涽王之死, 将近六十年之間, 東方發生了許多 璴化結果只落了寞力消耗了而各不相下。這是一個闕鍵的時代, 只有秦惠 王减蜀, 獲得了經流上的重要資源地带。此㣞秦更利用蜀地的上游形勢和 長江運輸奞獲了楚國的南郡(湖北省) 再利用他的騎兵和荆益的經㴒條件, 一 步一步的東進。到了始皇即位之前, 秦國已絰佔有南郡、南陽河内、上堂, 以至25 於太原。也就是從太行山以西再南大致沿現在平漢鐵路以西(除去洛陽附 近以外, 大致在西元前二六。左右, 都成了秦的領土了。

大一統的思想既然早已緸完成, 秦的統一天下赹勢已縉決定。 一統政治的窗现已經只是時間問題了。所成問题的, 只是法家的思想對於 秦國的前途應當如何處分和利用了。在國與國戰爭的時候, 法家誠然是一 30 個有效的思想但治理一個統一的帝國, 使他得到太平, 是不是一個最適當的 思想究竟還有問題。因此在西元前二四九年, 号不韋作了秦的相國就深切 考虑到這個事惯。他召集了天下的婜才, 兼儒运、合名墨而歸本於道家, 在他 取魏二十城置東郡的第四年, 也就是大敗東方各國( 除去砶以外) 的㖒軍第三 
年, 當秦始皇即位第入年的時候(西元前二三九年) 他和窗客們完成了他的巨

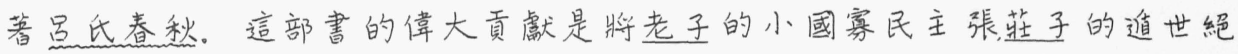

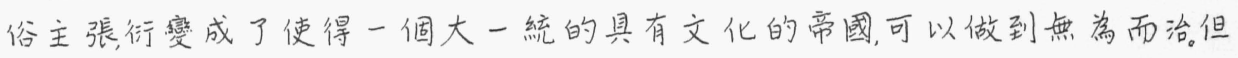
非常不幸的他的不朽的巨著完成了, 他的政治生命也就終止了。到了秦始

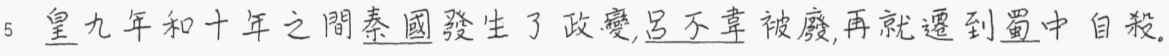

秦始皇的勝利, 号不韋的失敗, 自然政治上非轉労不可, 不論将來 用那一種主張至少莡不营的主張不會再用了。秦的傅統, 是一個商君政治 下的法家愽統, 但秦始皇親政以後的設施, 似乎並不全是這様, 秦國的 $t+$

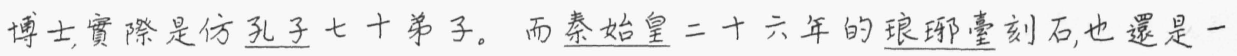
10 個堯典太繁和中庸的結合品。所以從秦始皇二十六年統一天下到三十四 年焚堼畫息家語, 追九年之中( 加上号不掌死後, 秦國統一之前, 還有十五年) , 走 的是漢武帝式的儒法兼用的䆶覇路線。直到三十四年焚書, 三十五年坑儒 並遣出太子扶蘇才完全是一個日暮途窮, 倒行逆施的现象。於是在一個絶 對尃制局面之下, 完全採用韓非的遺説國内無書簡之文, 以法离教, 無先王之 15 語, 以吏為師, 君主成学神秘石可捉摸的怪物, 而秦帝國再過六年也就崩溃了。 道家和法家的基本區别是道家把君主當作一個平凡的人, 而法 家把君主當成超人。道家憑著人生的縒騐而法家婆著分析的頭腦, 所以道 家世故深而运家理論密。倝非是講法和術的, 他對於法術的定義是: 術者因 任而授官, 循名而責惯, 操生殺之柄課群臣之能者, 此人主所际也。法者密令 20 著於官府, 刑罰必於民心賞存乎慎法, 而罰加乎茹令者也, 此人臣之所枊也定 法。但嘿氏春秋却主張、大聖無為而千官畫能(君守) 。古之王者, 其所為少, 其 所因多, 因者君街也, 禹者臣道也( (任數)。有道之君, 因而不為, 責而不詔去想去 意静虚以待(䓡度)。人主所惑者, 以其智强智以其能强能以其為强, 禹此處人 臣之職, 而欲無萑塞, 雖舜不能济(分職)。秦的菑騐失敗了, 漢初又回到道家去。 25 道家的主張下, 君主的運用技術, 較法家的技術退要困難, 但漢朝初年, 尤其是 在漢文帝時, 曾行成功了。

漢初政治的成功, 當然和漢文帝有閔, 他不僅能無点而且能守法。 他把握住無学而守法的中央, 使得一切政治順利推行下去。但是秦國自商 鞅以来, 立下的强固的政治組織有效的工作效率, 當然也是他能夠賏行無為, 30 的基礎。秦漠政治組織是中國政治史上一個偉大的㢣術品。它的特點是 制度簡, 員额少, 任務專, 權限明, 應付工作的機會多, 應付人事的機會少, 因此也 就可以達到工作較高的效率。秦漢政治的中心雖然集中中央, 但各郡的權 責却非常大, 太守雖然限於外郡人, 作為中央的代表, 他在一郡之中, 可以全權

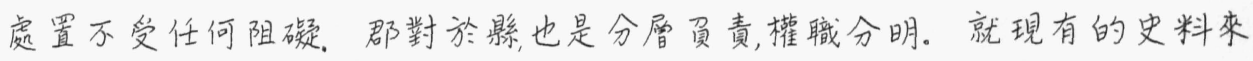


看, 漢代郡制之中造成了不少卓越的循吏, 而中央政府也就樹立在這個䖯固 的基礎上。

漢代對於域外的武功, 也是樹立在内政的基礎上。漢代對於最 大敵人匈奴; 在主力上並未曾假借外力或外國人的軍隊, 而是用著自己的力 量來和匈奴作一個生死的搏闘。這個博閂的成功, 可以説第一, 秦漢時代, 是 有計畫而没有例外的徵兵制唐代的府兵, 只是特殊區域兵, 不要誤會為徽兵) 第二, 秦漢時代, 是有一個嚴密的通輸系統( 它括道路、車輛、含庫、通信系統及管 理系統, 從這一個運輸系統出發, 使得可以對敵人作有效的䋑㴒戰。一但尤 其重要的摆是秦漢時代簡單而有效的中央及地方組織, 是一個最適於全體 動員的組織遇見戰事, 可以很容易將全部的國家力量用上去。

東漢雖然仍在宽行徵兵制度, 但廢除了大部分的外郡常備兵, 武 力要差了一些。不過政治效率仍然很强。只是東漢時代中央不如從前的 安定。到了東漢晚期外威和宦官丞相秉政, 清明的士大夫階級終於無可如 何。直到董卓入洛中榀覆敗為止。這是每可如何的事, 這也是中國傳統政

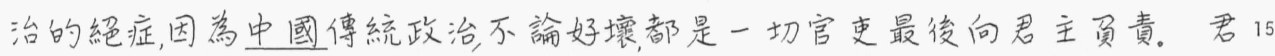
主一定有智有患, 有賢有不肖, 不走向民主之路綛對無法得到長治久安的。 漢代自從武帝以後儒家的思想格外抬頭。有人以羔便於統治, 這是不對的。周秦諸子, 不論那一家, 不論是道, 是法, 是墨都是尊君抑臣、为君 王設想豈僅儒家一家。而况講堯受説湯武也不是雷家以外各家所常道, 這 對於絶對君權並無好處, 當時儒家所以被尊萗的惯在是由於理論完整, 内容20 豊富, 逈非其他各家可比。因此為太子師傅的往往都是儒家, 這就注定了需 家一定成為學街的正統。到了西漠晚年, 許多新材料弡現了, 使儒家内容更 䏱整富, 於是到了光武以後, 支文舆更成了儒家的正統。

漢代還可注意的一件事, 便是自然科學已經開始在萌芽。尤其 數學的發展, 已經直追希臘而超過印度, 此外如潐南萬里術雖然是一個方 25 士的菑駺但西方化學也是從方士産生的。在應用科學上, 如努機的使用, 造 紙術的發明, 都是很有價值的事。中國文化對於科學是接近的。至於為甚 麼後來進展不快, 可能還是寞際問題和環境問題。中國的士大夫對於科學 只能認虚副業, 而寺院之中又缺乏研究科學的德統。

在這一點要附带説明的, 便是至少從上古雨漢的中國文化看来, 30 中國文化的本留是接近民主和科學而民主和科學在中國進展不呴成熟的 原因是由於環境上, 技術上, 及其他本留以外的因素。

總之, 秦漢時代是中國文化發展史上的一個非常重要的時代, 今 天作一個簡單敍述許多地方都説不到。但是我推想到, 中莱民族是一個具 


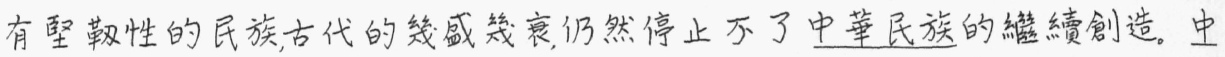
菜民族是一個富於吸收性的民族, 無論那一個新的文化到来, 都不至於深拒 固絶綵了一個相當時間, 一定可以融會貫通而造出一個新面目的文化束。 所以前途一定是光明的, 但责任也是繁重的。

討論問題:

一漢朝建立之主要原因為何?

二試論漢代之政治制度。

10 三漢代採用之政治哲祭澞法家思想或儒家思想?

四、漠朝在文化方面有何重要成就?

五、考古學對於研究漢代屡史有何功用? 
1.17贯《洨》通穿

一貫依照先後相連的

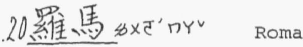

輝厂 $\times$ 光彩

輝映光彩明亮照射四方

相形之下互相比較的時候

.21特殊动”特别

.27筁 $5 \times 7$ 草木繁盛的樣子

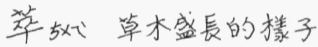

簀䈉形容舆盛的粶子

.32播功”散布、分散

傳播 散布推廣

謎》'需要猜想的事情

殷墟文化殷虚即殷代(1433-1/22)之故都、

清朝間, 安陽縣西(在今河南省)土人彊现鬼甲

牛骨等物, 上刻古文字、同時附近地方亦有出土

者、殷虚文化即指此㡎现所代表之文化

33埃及历 $41^{\prime}$ Egypt

张流域吸“山水流所經雨岸之地

雨河流域 Euphrates和Tigris 雨條河 之流域

2.6 印證分坐互相證明

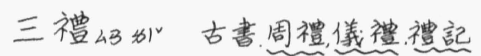

.7注疏生”秋解糬文字或意義謂注疏

. 9 圆案动”美街及建箱上所計書之形式舆色彩 .10鑑413 照

鑑别觀察而分别之

.11明瞭吅'多么“明白瞭解 12糾正418改改正差誤

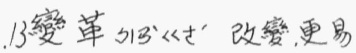

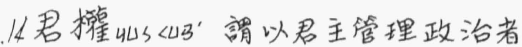

世官户”《3 世代相傳的官

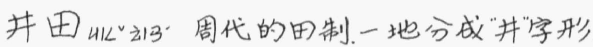

八家各取一塊, 中間为公田
2.16 疆4 4 界限䕗界

閚六開墾

開疆噼土摭張領土

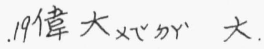

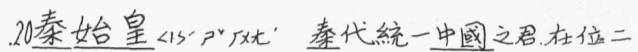

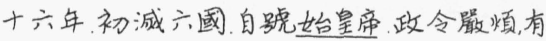

暴君之稻

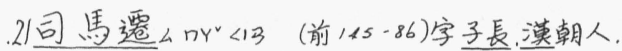

生於龍内，今山西，阵西之間，作太史公畫(後㛵

串熟)一百三十篇，世㛵良史。

秦紀《1s'41 秦國的史㫃。

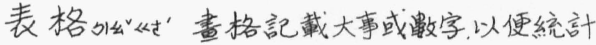

或比較。此處指史腺中之十年表

.2 2 傳闻 $4 \times 3^{\prime} \times 5^{\prime}$ 傅説㯖説的。

策士战户”有言十言某的人、游説者

誇5 XY 大言, 咵張、言過其富

凑战聚

洋凑 不整的聚合

世家ア”UIY史書中陪諸侯王之事者.謂之世家, 始 於史熟。

.25巴蜀SY P X $x^{2}$ 地名。四川的别稱

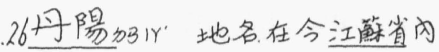

豫章山坑山名, 在今浙江省内。

嚴道1 3 ”汃地名, 在今四川省内。

朱提秋部地名, 在今品川省内

. 28 譽山美名

榮譽光栄的名聲、

贈肬謂送物给人

32或帐”謂用兵戰争之事

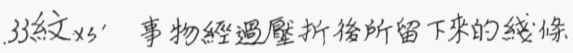

花紋花㨾

3.1颓真云比衰歇的滕子

衰頽 衰欺, 破落

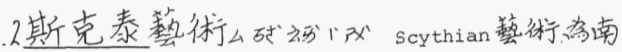




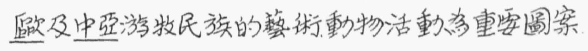
3.3 發源 r 43 , 謂河流之開始, 指事物之開端。

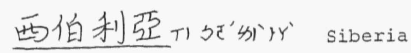

.6 移轉1 ‘出 $\times 3^{2}$ 移動改㘘。

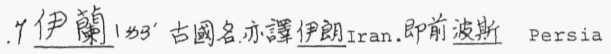

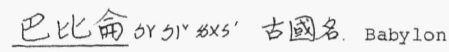

希臘门汃古國名, Greece或 Hellas

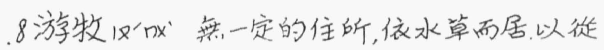

事畜牧謂游牧。

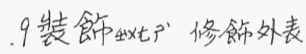
10 諧下世和、合.

和諧 相合而無衝突

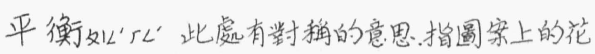

纹雨道一樣。

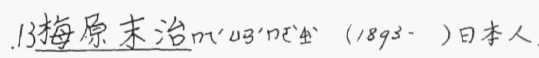

Unehara Sueji

.14出土㣗动、古器物從地中浚现取出謂出士

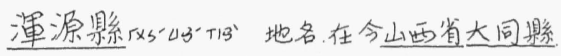
峪山雨山間流水之道

李峪地名。

. 15 墓等 $x^{\prime}$ 死者虔身之地。

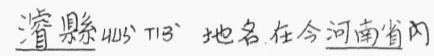

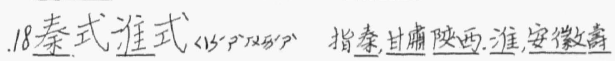

遭一带座物的式榚。

.23劍413”兵器名. 似力, 比力細長而有雨》。

錁衣化以物相配合

鑲青銅把青銅加進去而製成的器物 .24彾江”大

廣泛廣大。

. 25 長沙忧P Y 夥名, 在湖南省内

平壤如”昛在暲國现为北遧之首都。

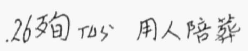

殉葬以人或器物與死者一塊是埋葬。 . 28 鏡4 $12^{\prime}$ 照形取影之器。中國古時多以銅製、今
用玻缡製（見玻璃保）

鏡鑑即镜子。

3.29 衰微队啝不奥盛。

玻璃纪外以礦物製的, 可以看穿過去的物筫, 可

製眼鏡, 水杯、鏡子等。

30 瓷与。陶器的一偅

瓷器中國之特産, 澌潤色白, 可上各偅顔色 花紋

了䞤勢《队時势的倾向

.32地盤表示特殊教力所佔的根㨡地。

絲么 熎( 53 万一種虽名) 所吐之物, 可用来製衣料, 㬎肃下用絲刺成的五彩花紋者。

絲繣用絲制成的五彩花紋

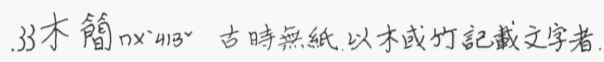

4.1 鋸山心光解木或石之器具㛵鋯子、鋸亦可當動詞

用, 表示使用鋸子。包

. 2 椿出炏圆而粗的木幹。

削刀介幼使本平滑的一堹工具

了削平使用削力把扳委平。

鉋弦削平木材的器具，又㛵鉋子，可當動詞用，

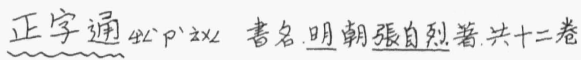

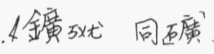

5 鍊为治金

燃明, 火燒

燃料可供火嗦的物算，如煤、材犲、煤油、 . 6 生鐵 $P L$ 云

.7行業「大'睋業

钼《七精練最堅之鐵

8 售P賣出

.15公党规定只由或家出糞

圤理志かが出漢書志之一。

食货志?'似式漠畫志之一。

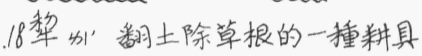


4.18 鐮为污農家收割及割算的工具

.19鍫<㲿起土之工具

鋤㣗除草翻土的工具

22印第安15宁了 American Indians

秘魯叮的 $x^{2}$ Peru

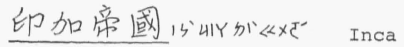

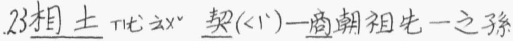

30 䋨度地球上各地之䋨線與赤道相堆的度

數

.33真鬳《XL“T1马 進奉或贈给

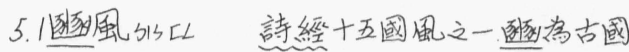

名、周之祖先公鄱所立

. 2 佃引代别人耕種

佃農租别人的地耕種的農民

.5 俘上义戰時簐隊所獲者

虜出 $x^{2}$ 捉到

俘虜戰時提到的敵人。

.8抑制出壓制

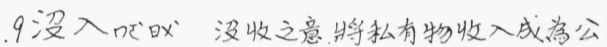

家所有

.10叛奶離背

叛茲以兵做亂反對

採扬擇、取、

採鐵寻取鐵礦

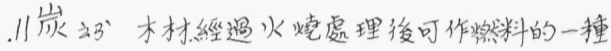

木岸以樹水放入密關着之器中, 烓之而成。 可作燃料

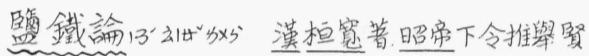

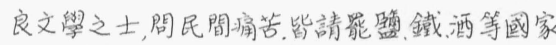

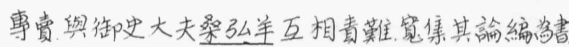

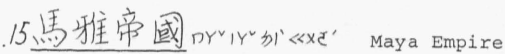

西班牙小加悟 Spain

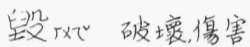

毁隇消減

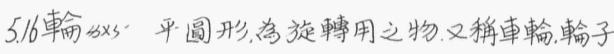

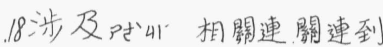

19 筧5 5 3 腐大

䈭直腐大而直

坦动、管平

平坦即很平

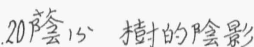

除樹即高大的樹

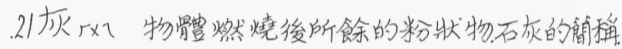

石方灰一種白色粉狀的化學物筫, 加水眇

等處理後能亳成非常堅硬的塊狀物

惱3 3 ” 恨, 怒

苦惱痛䇢煩惱

.22栈敌了在山上架木为路

栈道在險絕虎靠山架木所成之路

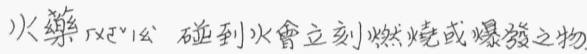

可以用来開山。

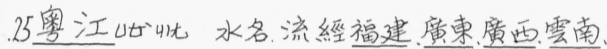

貴州等五省

.28留呟交易

貿易各處出座不同，互相交換

.29㬎筀陮”即使

縱有即使有

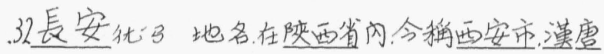

建都於此

汭吏加官

官更官員

循TUS'遵從，順序

循行官員到各地去考察部鹰的行為等謂

偱行或出巡

34後勤「冬く沙對於出征軍隊在後方给食補充等事。

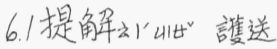

資助口䍀以剘物幫助。 


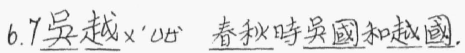

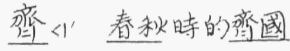

峽个Y雨山間之水道

海陝海水雨面为陸地所約束成細長形而

其雨端與海洋相通者

台灣海陝在台演與福建之間的海峽。

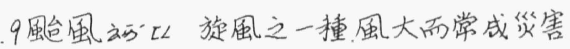

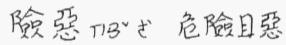

擋㕱阻止

.10番禺好山地名, 在腐東省

.11駐出风停留皆日駐

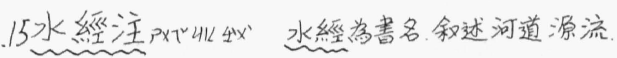

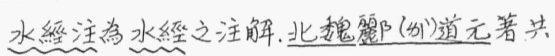

四十卷

20行進13 415 ”演進

周公秘《如名旦，周文王之子、相武王定天下

武王死，助成王定制造䄝楽而天下大治。

.22滨多水邉

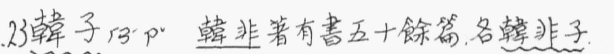

暲子説林説㷊為韓非子中之一篇。

克覽加“加

24 逆31 不順向相反的方向

逆流逆着流水的方向

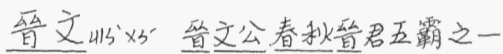

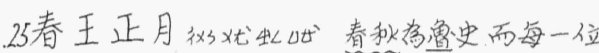

新魯君即位必云王正月，當世周王之正月，故云有

大一統意義

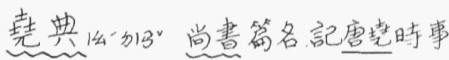

.29㣣天子以令諸侯控制住天子假借他的

名義来命令諸候。

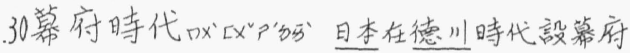

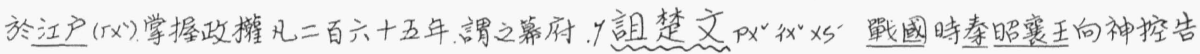

時代、幕府者將追等治事之所。

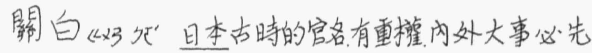

經關白然後轉天皇

6.30 天皇幻忧旦本㛵其成主日天皇。

肃倠故嚴, 整静。

俾清平定盜睋之乳

狄人顷㫜中國北方的一種民族。

32 昭公出幺《㖹昭公。

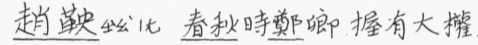

33骤及浾故

㵊照然筈重貌嚴重的樣子

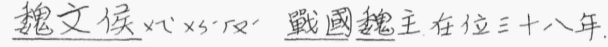

或富民穻。

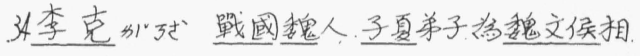

咸家富强。

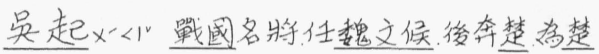

相楚日以强大, 後被害而死
7.2 西或川帐”中国两方邊境的民族。

了浄息くけ意味

交潐幽下江文流淮集

４徐TU古國名，在今安徽省

趙公公國名, 在今山西省。

譬妃比喻

譬如比方説

6月哌吨血管

一脈相承同一系統相傳下来

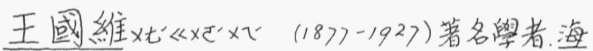

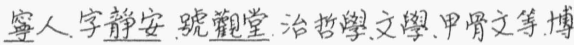

學深思，著述甚多

㨨的即笽文, 古文字之一
楚懷王犯罪之文今尚存有石刻

号相虬地优春秋至大夫虽錡( 


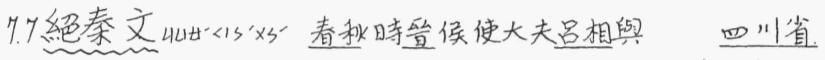
秦紦文之文。
7 . 35 南陽3 3 比在今河南、湖北之間

. 8 錯故”交互之意

河内地了在今河南省。

東西交錯東邊舆西息相至来往

. 9 偶对恰坅。

偶然不期然而然

10 潛《13, 藏起来。

伏功一藏起不现

潛伏即藏起不被弡现

上黨肬犹”在今山西省束南部。

. 26 太原动吗”在今山两省。

太行山动比际山各亦名五行山在河南

山西河北間

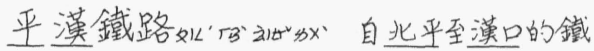

路、㛵京漢鐵路

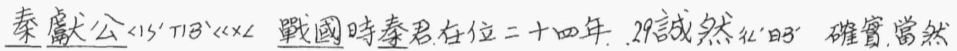

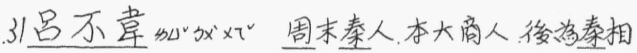

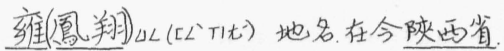

著有点氐春秋、後因畏罪自殺、

徙队迷移

徙都完都

摖陽为“北”地名、在今陕西省。

高陵《幺必傸两省夥各。

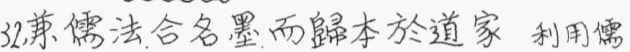

家和法家的主張，也同時考虑到名家和黑家的

思想最後以道家的䈍為清静桨整個治國平

天下的根本

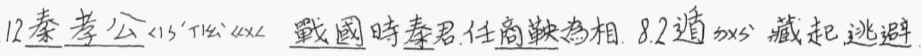

熟法改制，國家富强。

.17 杜汃阻止

近自世絕俗遠離烦雅的人群而居，不理世

强公室而杜私門增進皇家的㩲力而

阻止私人勢力的㥅展。

.19效忠出公厸㿿力服務。

人的風俗而活。

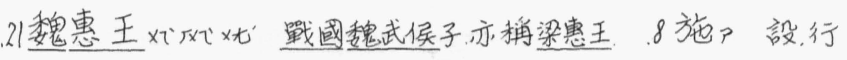

在位三十六年(前370-335)

設施规畫曾行。

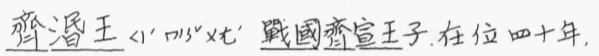

(前323-284)被殺而死

.22耗公 消费

消耗消费，用完，

各不相下彼此强弱差不多。

秦惠王〈以“汀”忧”即秦惠文王。在位二十七年。

(前337-311) 前316 減置.

23 蜀 $3 x^{2}$ 古國名在今四川省

資源町资材之源。

. 24 荆益4 42 1二州名, 荆州即今湖北省益州即今

.9琅躯加甘，山各。在山束省内、秦始皇曾建台於此 立石刻以明德意。

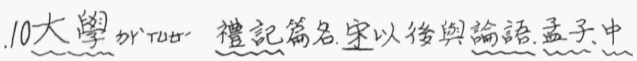

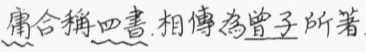

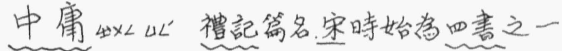

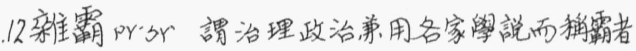

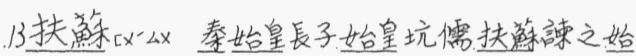

皇怒，派其监视北方的掌恬軍，後始皇死、相國趙

高假造始皇遗命睗死扶落。

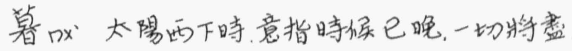




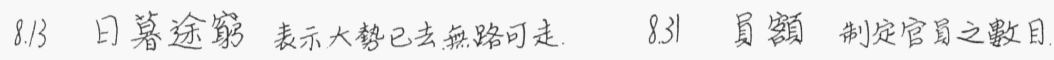

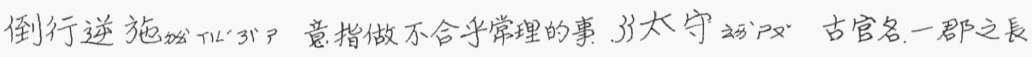

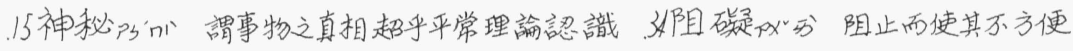

之外者

提摸地区叭一捉住摸到, 意指能明白瞭解

18 世故》゙《眭解世俗人情習惯。

.19 柄外權。物件之可以被抓住的部位

操生殺之柄握有生殺之㩲

課式考察。

課群臣之能有考察群臣的能力和才幹。 執出”持有、具有

此人主所勃也道就是皇帝所具有的 害仍 法令

憲令著於官府把法令窎在官府裹 . 20 慎P5，小心敬重

賞存乎慎法守法的人得到奖賞 䒵4 13 奸覀

而罰加乎茹令者犯法的人受到嶶罚

定法加 $\left[Y^{\circ}\right.$ 暲非子定法篇

.23惑欧迷乳

24 雍 $4 L^{\sim}$ 塞

雍塞阻塞不通

.23人主所惑者以其智强智以其能强能 以其考强者此處人臣之職而欲無焦 塞, 虽住舜不能学帝所团惑的就是自以为智 慧高智慧高就使他自以为比别人能力好, 能力 好而自以学点事比人强, 在這偅情形下要使 他的臣子能夠盡忠職守, 盡量磁揮人医的才幹 而整阻塞就是聖婜才德高如舜在世者，也是不 可能的.

君守、任數知度、分職虽氏春愁中之篇名

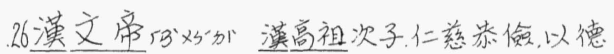

$$
\text { 化民在位二十二年( 前179.159) }
$$

引额真“制定之數目。
9.1 卓生煌高直貌

卓越超絶, 特出, 了不起。

循吏TUS'多”安份守法且有政綪的官更。

鞤《xく”堅固

洶奴TUL3 $x^{\circ}$ 古時北方揰族之一原居中國西北

部。

搏虚相鬥

. 6 徵兵制出 2 以出謂人民依法律, 在相當年齒令

内皆有服兵役之義務的一㮔制度。

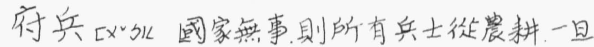

弡生戰事則者征戰之士兵

13外威、分<1帝王母媇, 或妻子的媇戚, 政治上多

指母黨或妻黨

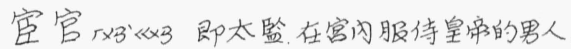

亟得舊稻輔佐之官曰丞

丞相古代輔助天子治政之官

秉引拿執

秉政握有政襍

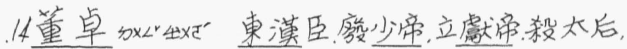

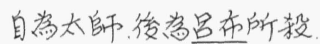

厤阦中央之譏關

中掳中央

.15症乱病之徵象病。

絕症無可救纂之病。

.2逈 $44 L^{v}$ 遠

.23光武《烧 $x$ 漢光武帝，東漢中舆之主，名秀、定都

洛陽天下大定在位三十三年(25-5)

.24明叫算木㓮開始生長的時候。

㹃第㓮開始生長, 意指㓮有頭緒

. 25 淮南葛果術即淮南子贸安所編之方術之 
書.

9.25 方士匚坴碅究神仙法術之人。

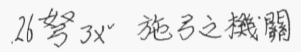

10.1鞓日分不硬但堅固。

堅䩲堅固而有绳性

. 2 拒岎不接受、抵抗

深拒固絕堅決的不接受。

了融日妙”調和

融售篹通深深的瞭解領禽而吸收。 

回去後湢血數升。元吉並曾企圖刺殺世民, 但因建成的勸阻而未果。此外 建成曾以財物收買秦府的驍將尉迤敬德也来成功; 於是建成等又向高祖進 言排除秦府的智略之士房玄龄杜如晦等。至於高祖他承認世民的大功, 但 又無有廢建成的意思顯然他没有看出問題的嚴重性。他一度想以隔離的 5 方法来解決這個問題, 命世民出鎮洛陽, 但因建成等的反對, 也沒有實行。

因虚不能得到高祖的支持, 自武德五年( 六二二年) 以来隻方的鬥 単中, 世民顯然居於劣勢。他似乎頗有出居洛晹經營束方的企圖, 九年( 六二 七年), 他曾派親信張亮赴洛, 結納山束豪傑以待蔡。其後高祖命他赴洛陽未

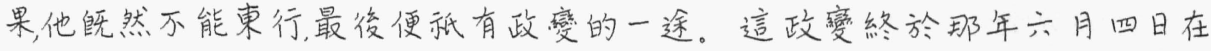
10 宫城的玄武門爆發。

這次政謇, 是經過長時間的佈置的。建成也是才智之人, 他具有 嫡長的名位, 又有高祖和宫闇的支持, 他的僚屬也有頗有幾位才德之士如魏 藢王珪等, 同時握有精锐的部隊至少二千餘人。至於元吉, 更是素以勇武著 稻的。所以就在京瞃的武力而論建成元吉方面的惯力, 遠超過世民。建成 15 等仅對高祖派世民赴洛陽, 也是怕世民一旦外出而不可制而在京儌他們有 足夠對付世民的力量。就這種情勢看来, 世民想消减建成元吉, 簡直是不可

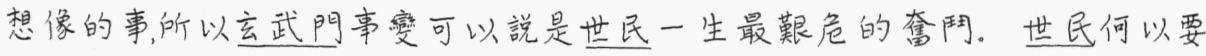
選擇玄武門作為發動政穈的地點呢? 原來玄武門是長安太極宫城的北門, 它是宫廷衙軍司令部的所在地, 具有堅强的工事與雄厚的兵力; 誰能將這㧽 20 地方據有並通用它的兵力誰便可以控制整個宫廷乃至整個首都, 因墌玄武

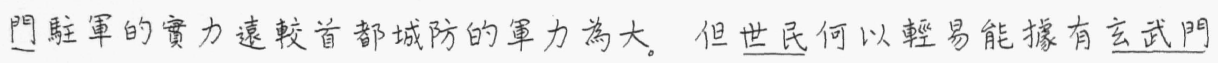
呢? 那是因為他與玄武門花軍將領有勾結的䦣係。

六月三日，世民向高祖密奏建成元吉淫乳後宫, 並訴説二人欲相 見害的情形高祖的回答是明天差他們處理這個糾紛。四日, 世民與他的妻 25 兄長孫無忌率兵埋伏於玄武門内。伏兵的數目不詳, 但必不會太多, 因為大 批人馬的調動, 是容易被弡现的。當時玄武門駐軍的將領是常何, 他本是建 成的舊霹而被世民於暗中收買因此世民等得以伏兵。世民告狀的事已被 張婕妤通知建成( 自然她不知伏兵的事) , 當日元吉勸建成不要入朝, 勒兵以觀 動静但建成認為随從的兵備已嚴同時因差玄武門的守將是他的舊部, 入玄 30 武門淩料想無事, 因而決定入参。當建成元吉二人入了玄武門到達臨湖殿

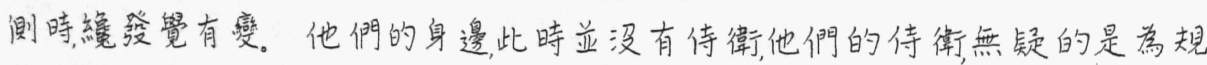
定所限被阻於玄武門外。二人正要策馬逃回, 世民從後面趕來, 與元吉以箭 互射結果建成首先被世民射死, 繼而尉䐅敬德率騎兵七十人趕來, 舆世民 雨面夾射元吉, 元吉墬馬; 但這時世民也因坐馬奔逸樹林中被樹枝掛礙而落 
馬, 元吉趕來要殺他, 為尉痋敬德所救免, 元吉也被敬德射死。接著東宫和䉡 府的精兵二千人由建成的僚屬溤立, 薜萬徹等率領趕来, 向玄武門進攻守兵 拒戰守将敬君弘, 吕世衡戰死, 嘠事的激烈可想但宫府軍終於無法攻入。最 後是尉虽敬德出示建成元吉的頭覻宫府兵緦潰散至此勝利完全歸於世民。

建成元吉被殺後, 世民派尉遲敬德入宫宿衛。那時高祖正在御5 湖中泛舟, 並不知情, 當他㯖到建成元吉因作谣, 而被殺的消息, 警愕萬分。在 他身邊的朝臣畫㻦, 随叔達告訴他把國務交給世民便可無事, 高祖説此吾之 凨心也, 於是立師下令内外諸軍都㯖秦王的節度, 當時尚有零星的戰鬥, 這 個敕令宣佈後絸完全平息。接著世民入見, 號慟良久。三天後, 高祖立世民 為皇太子, 處决一切軍國庶務。八月, 高祖愽位於皇太子, 自为太上皇以終其10 身。他死於貞觀九年( 六三五年) 。

此後唐室的許多次中央政誉, 其成敗仍然維慗在玄武門的得失 上。

\section{三、太宗的政治(真觀之治)}

世民於武德九年(六二七年)師位後, 是為太宗, 那時他祇有二十九 15 歲。明年, 改元為真觀元年。唐帝國經這位少年皇帝的適宜領導, 蔚成了中 國歷史上少有的感世, 也就是後世所謂的倬觀之治。真觀時代的本身雖不 過二十三年, 但這個時期的文治武功都足以震㹸千古。在這個時期中, 㡺帝 國的版圖擴大到史無前例社會秩序的安定人民生活的美满都不可多見, 同 時奠立了此後唐帝國長時期富强康楽的基礎。這衰祇説一下貞觀時期的20 内政。

初唐的各種制度大體是, 承襲隋朝的, 這一點颇像初漢的承襲秦 制。這固然由於當時對内對外的戰爭頻仍, 而致不遑制作同時也因隋制的 本身已相當完菕, 没有全部落更的必要。因此不但高祖時是率由舊章, 就是 到太宗時, 也没有什麼革命性的创作他祇是把隋制加以充宽或局部修改使 25 它更䞶完善嚴密而已。

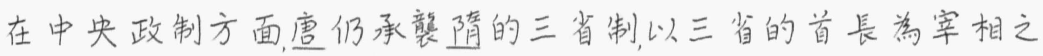
職。但進而確定三省的職權, 以中書省制定法令, 門下省害查法令, 尚書省執 行法令, 這種制度有似於近代的三權分立。但因權力的澈底分化, 中書與門 下有時因成見關係不免發生衝突, 太宗为補救這個流弊, 因而設政事堂作差30 三省首長聯席議政的機關。最初政事堂設在門下省, 後桃移到中書省, 而改 稻差中書門下, 至此分權的制度破壤。

三省長官雖為宰相之職但其他官吏也可由皇帝指派㚐決大政, 這個制度, 也是承襲隋朝的。唐室採用這個制度, 始於太宗時杜淹的以吏部 
尚害參議朝政。此後任何職官, 祇要在他的原有官衔之下, 加上一個参議朝

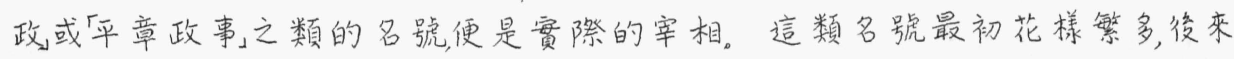
逐漸確定為同中書門下三品及同中書門下平章事雨個名稱。前者的意思 是表示任何擁有這個名號的官吏具有中書省首長中書令和門下省首長侍 5 中相同的品級三品) 和權力; 後者的意思是表示可以與中書令侍中共同平章 政事。(到高宗以後凡不加這雨個名啹之一的官吏, 雖是三省的長官, 也不得 入政事堂議政而致失去踤相的地位。)

關於地方行政區劃, 仍沿襲隋的郡影制。祇是唐高祖時把郡改 稱为州, 郡守改稱刺史。並在重要的州設置都督府, 以刺史兼都督統督數州, 10 這和隋文帝時所設的總管府的性留也没有雨樣。此外又把京邑(如長安洛 陽䁌陽等所在地的州稱作府, 但也祇是名稱的改弦而已。到太宗真觀元年 (六二七年) 把全國的府州劃分為十個監察區, 名之曰道。十道的名稱和轄嵒 是:

(一)關内道包括今陝西(秦嶺以北)綏遠南部, 䆟夏束南隅和甘畫 束北隅地區。

(二)河南道今黄河與淮水之間, 西到潼鬥事到沿海的地區。

(三)河東道今山西省及綏遠省東部, 察哈爾西部地區。

(四)河北道今太行山以柬, 黄河以北東到遼河流域一带地骂.

(五)山南道今漢水流域及長江中游沿岸地豆。

(七)進南道長江與淮水之間的地區。

(八)南道長江與南額之間的地區。

(九器南道今四川省。

(十)嶺南道五嶺以南地區, 包括今雨腐和越南一带。

25 由中央分遣使臣往各道巡察, 但當時出巡使者並不是定職, 巡察的地區也好 像不以道, 羞單位。(直到中宗神龍二年師西元七。六年, 設置十道巡察史, 二 年一替, 以監察各州府, 緦成定制。)

兵制方面, 也是承襲隋朝的府兵制, 不過組織更完備一些。真觀 時全國設立六百三十四個兵府, 名曰折衝府, 每府都有各自的名號。在關内 30 地嵒的折衝府就有二百六十個佔全國總府數的五分之二以上。全國的折 衝府, 分屬於十四個衛。十四個衛中有兩個衙各轄六十府, 其他各衛轄五十 四十不等, 剩下的隸屬於太子東宫的六㧽率府。

府共分三等, 上府有兵一千二百人中府一千人, 下府八百人。每 府的最高長官是折衝都尉, 其下有左右果毅都尉各一人, 長史兵曹、参軍事各 
一人校尉五人(或作六人)。士兵的編制是三百人為一團, 嘈专長, 五十人為 一榢隊有隊長十 十人茇一火火有火長。府兵的役龄是二十至六十。府兵能

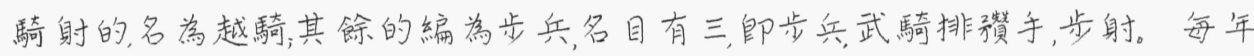
冬天, 折衝都尉率領未出勤務的府兵, 作攻防演習。凡調發府兵, 必須有中央 頒發的符契為哿經過州刺史和折衝都尉的勘驗屬䨘, 然後發兵。如果全府 調發, 則折衝都尉以下的官員全須随行; 如果調一部份, 則視其數目的多锶由 果教都尉或别將率領出發。凡折衝府筫宿衛京師任務的辦法是以各府所 在地距離京師的遠近來规定輪班次數。離京師五百里的府, 將應貧宿衙任 務的兵分成五批更番上班每月一輸。一千里的分七批一千五百里的分八 批二千里的分十批二千里以外的分十二批, 也都是每月一輪。換句話説, 五10 百里的府兵, 每年至少要輸雨次二千里以外的府兵每年祇輪一次。

總之, 唐的府兵制, 在惯質上仍是和隋没有雨様。府兵制制始於

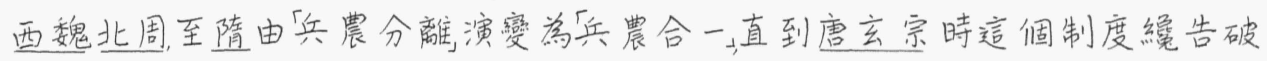
壤、太宗在這個制度的演瞢過程中, 恶不佔若何重要的地位。

田賦制度也與隋大同小異。男子十八歲以上者為丁男, 給田- 15

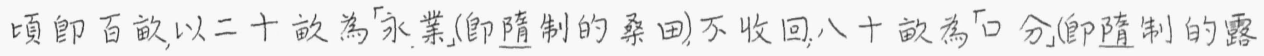
田) , 身死後仍由國家收回。至於人民對國家所應繳的賦税和應蒀的義務, 共

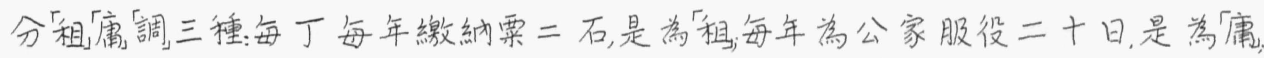
按照當地的出産, 輸納規定數量的絈和綿或布和麻, 是為調。

從政、軍、剘的各项制度看、太宗祇是遵循隋代的舊規但点觀時代20 的唐帝國, 仍然具有開國的新攻象這完全由於太宗的過人才識與氧度所造 成的。他知人善任, 用人不問出身而惟賢能是與; 尤其難得的, 是在這一方面 能夠摒除私人情感的好悪。此外他虚心好祭容納直諫; 他不特選拔了多方 面的人才, 同時更能與這些人相互切硅, 以求進步。因此他所寞行的蜼是隹 制, 其茓隋文帝時下距真雚不過四五十年, 不能算舊; 同時一種制度祇應論其2 5 完善及適合時代與否不應論其新舊, 但他和他的臣下的朝氧却能使舊制的 美點發揮盎致。且看桌觀時代那般文武將相的爽歴。

在真觀許多名臣中, 祇有長孫無忌是他的親戚房玄龄杜如晦是 秦府僚屬算是他的舊人外, 其他如魏徵王珪薛萬徹都是建成的舊屬, 尉遲敬 德原是宋金㓮的部下, 李棈程知節原是李密的部下, 戴昌原是王世充的部下, 30 岑文本原是萧銑的部下, 褚亮和他的兒子袸遂良原是薛舉的部下, 温彦博原 是羅㙯的部下( 羅也是隋末萃雄之一, 且與太宗不合) 李靖原是高祖的仇人, 封

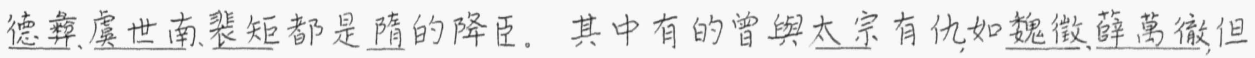
他能捐亲前嫌重加委任, 也颇有幾位堪稱位臣、的如封德睯, 裴矩, 但他也能充 
其短而用其長因此他的臣下包括多種的流品和多方面的人才。下面是有 關幾位点觀名臣才德的記述:

時房玄龄, 魏徵李靖温彦博戴冒與(王)珪同知國政。當因

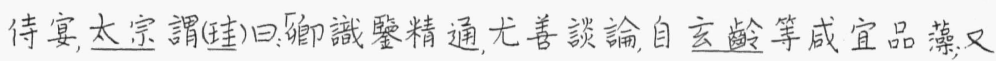
可自量, 就與諸子婜? 對日, 孜孜奉國, 知無不学臣不如玄龄; 以諫猙為心, 恥君不如堯舜, 臣不如魏徵; 才兼文武出將入相, 臣 不如李靖, 敷奏詳明, 出納惟允, 臣不如温彦博, 處繁理豦, 象務必

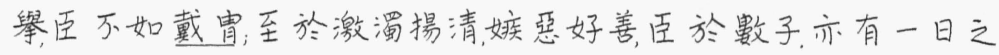

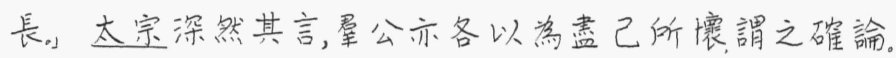

10 祇就這段記載, 便可看出太宗善於用人的一斑。此外他採納封德的建議, 命宗室登仕進之途, 出任官吏, 以革除宗室坐享富貴的惡習。這辩法自太宗 刢立後歷朝因之不替, 因而唐朝宗室人才之盛為古今所未有。

太宗的好學也是值得譛揚的。在他作秦王時, 因愛好文學而開

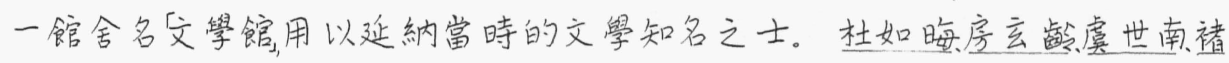
15 亮、姚思庸、玌頻達等, 都是文學館的學士, 他們分為三批輪流在館中值宿。太 宗每當傍晚到館中與諸人討論文籍, 有時談到夜半。在前人中, 他最喜歡陸 機的詩文, 和王義之的字。他師位後又改置弘文館巽任盧世南等各以本職 兼學士。在聽朝餘暇他把學士們引到内殿講論前言往行, 商討治道。点觀 君臣的論治, 傳為千載的美談。此外他並命五品以上的官吏, 輪流住宿於中 20 書省, 以便随時延見, 重詢民間的疾苦和政事的得失。

容納直誎也是太宗著名的美德。朝臣中最能直諌的是魏徵他 前後上疏數十, 直陳太宗的過失, 有時狝得太宗要找機會殺此田舍翁(指魏), 但每次他都容納。点觀十三年( 三九年) 魏又上一疏批評太宗志業比起苫 觀初年漸不克終者十食余條、宗也都接受。十七年(六四三年)魏徵死, 太宗嘆

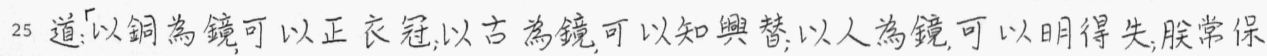
此三鏡, 以防已過, 今徵列逝, 遂亡一鏡矣。其後太宗伐高霹無功, 因而又思及 魏徵説到: 魏徵若在, 吾有此行耶! 從這些話裹可以看出魏對他的影響力。 此外如馬周、王珪、褚遂良等, 也都是以論諫知名的。不但如此, 他在師位之初, 師制定中書門下二省的首長, 和三品以上的官員入閣議事時, 要以諫官自 30 随遇有缺失立刻諫正。

在行政技術上, 太宗也有不少的改進。例如裁汰兄員, 親自簡選 刺史, 遣使巡察四方, 以黜陟官吏, 省民疾苦, 以及更定律定, 命中書門下二省四 品以上的官員與尚亩討論死刑罪案, 以免寃濫等, 這些事都是蔚成昼觀之治 的重要因素。㹉説當時社會安定到外户不閉, 道不拾遺, 物價便宜到米斗五 
錢。这類記載雖然不免令後人懷疑有些溢美, 但無可置疑的, 當時的政績定 然遠在水準之上。

自然太宗也未始没有他的缺點。例如奢侈便是其一。他也自 知這個毛病他曾對太子治説:

吾居位以來, 不善多矣。錦紼珠玉, 不絕於前; 宫室喜榭, 䨪有5 興作, 犬馬鹰隼, 無遠不致, 行遊四方, 供顿煩勞, 此皆吾之深過, 勿 以為是而法之。顧我弘濟荅生, 其益多; 壁造區夏, 其功大, 益多

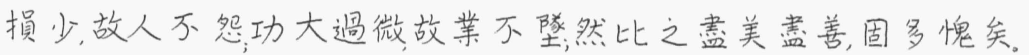
太宗这些話算得上是有自知之明的特錄於此, 算作他果生功過的總評。

討論問題

一, 論初店時皇位繼承整的問题。

二, 唐代採用何種考試制度? 試評此種延纳官更之制度,

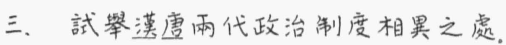

四、討論唐代之兵制(府兵制)。

五. 唐代有那些重要税收。 



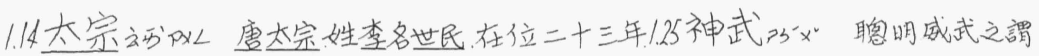

$(627.649)$

即位4⿲二丨匕言登帝王位

立武鹏序大明官北明

\section{太子建成，其弟元吉於比}

.15武德义“线”屡高祖年影(618-626)

空引屋, 示指其中之人。

唐室唐朝之皇家

却《U甘通部

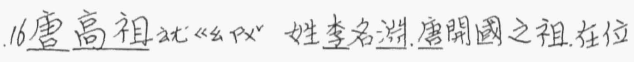

$$
\text { 九年 }(6,8-626) \text {. }
$$

18 擦5 个 以物如布等摩之

摩擦謂雨物相擦而過此唌用来形容隻方

$$
\text { 之不和。 }
$$

日开”昨似”漸漸的形成

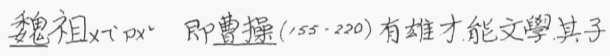

\section{奪漢建委鬼追封之学武帝, 㾰栫太祖。}

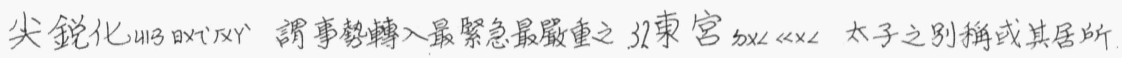

$$
\text { 狀態。 }
$$

.21㩊13。謂不可明見者

暲厂们恐犯忌而不説

歪炀不正

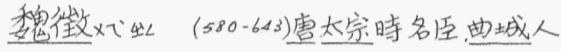

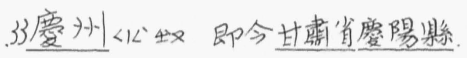

都督的加古統兵官各

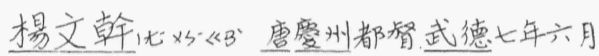

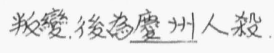

圆动計謀

34宴13以酒食招待

毒加有害或能致死者如毒物、毒檠

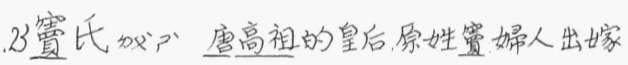

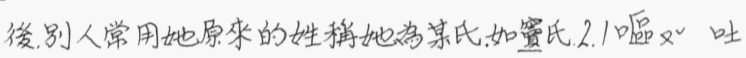

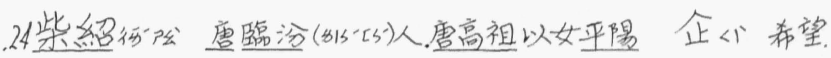

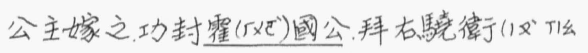

风败大將軍。

企圆想有所圆謀

果《x事之結局

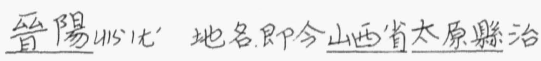

未果没有結果即没能窝行之意

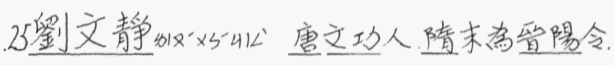

舆太宗友善, 共定起兵計後高祖即位, 不满其

官位而罷官。

害今人场”開通

害㕣達度量窗宏開通

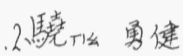

笔㸹勇敢之特軍

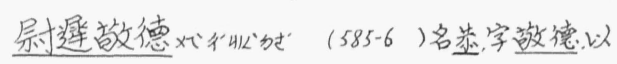

字行、倩末䠋曾, 通立大功。

了略多山゙計謀 
智略有智慧有計謀的

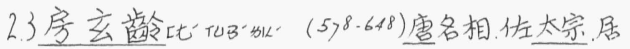

相位十五年

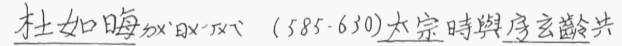

理朝政。

A 一度1 加”有一次, 有一個時期

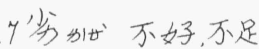

劣勢不好的地步

似乎公汉好像

皮真她”甚很

. 8 赴地往, 去、至

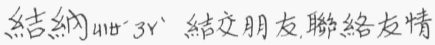

侮山 甘智過人

豪傑謂才智出象的人

10 爆㕬突然裂開

爆弡突然弦生

.12嫡加 即正妻或正妻所生的孩子

嫡長正妻所生之長子

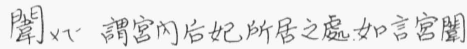

僚如，官位同等者

僚屬部下, 丞官

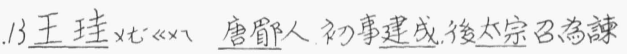

議大夫

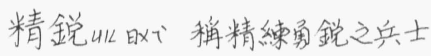

14 京官币 4 K 2 即國都

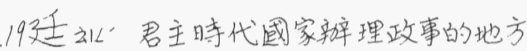

宫廷同廷之意

堅4 13 不容易破碎

整强腪固

22匤动”、駐兵而守

勾《邓舆鈎通, 鈎万體曲末尖而內向之物尖端

可插進事物而不易脱落此處用以表示, 連起不脱

勾結連接指不正當或不光明之結合 . 23 奏际謂哣對君之陳詞
2.23 後宫 $心 《 x<$ 謂富所居之處

2 秋4 412 連結

兹的雜碾

約㬎分率連不清的事情

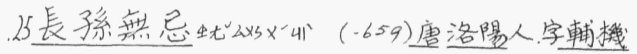

博涉書史, 有武略, 且力太宗定天下。

埋呵藏在土下如簘。

埋伏埋伏策隊待敵至起而擊之

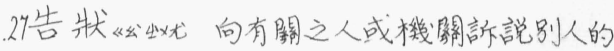

不是

.28勒媱停止, 阻止

勒兵停止軍隊進行。

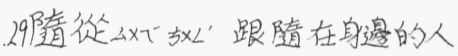

.30參5 5 以禮進見

引側式客

侍? 凡卑幼随從尊長之㑬者曰侍

侍衛在身旁保衛之士或保衛天子之禁兵

认策古等用物打馬使之前進

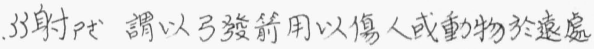

34爽顿左右挾持

榢城落下

逸; 奔逃跑

枝出樹水旁出之小條

3.2 溤立匹出零武将初酱建成太子車騎将軍, 後

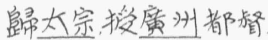

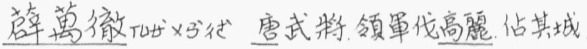
了拒崔抵抗

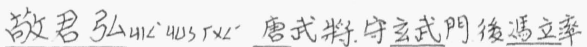

兵攻玄武师、帬弘出戰，死於陣中。

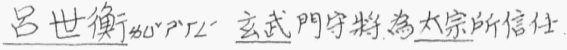

4 覤真加腦篮。

顽盧面 即頭

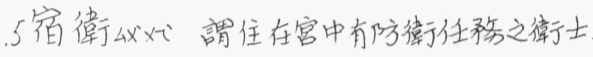
，6泛圾浮 
36 舟生 船

泛舟坐船遊玩

愕卡吃警的粶子

警愕萬分非常吃警

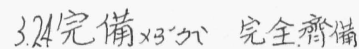

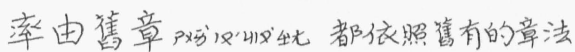

.25局4 部分

局部全體中之一部分

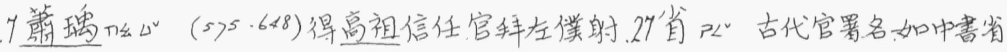

太宗時曾离御史大夫。

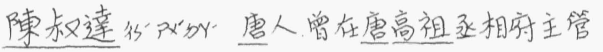

譏密太宗时曾为䄚部尚書

. 8 成么

此吾之同心也追是我早就有的心䝠

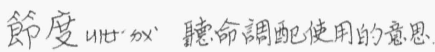

零星加“T人少而不整

. 9 敕公帝王所下的命令

慟云比悲偒極甚之意

躆慟悲傹痛哭

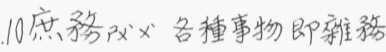

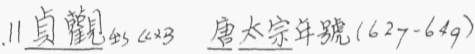

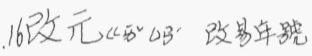

珎难繁盛的樣子

㐿成造成

18 文治帉出以文教施政

震佂威, 動

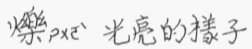

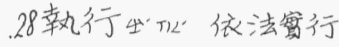

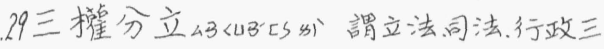

權各自獨立。不相侵犯。

. 30 補救3 30412 想辦法改正

慗が害虎，毛病

流弊相沿而成之害處

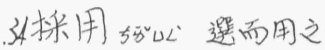

杜淹汃1 $3(-168)$ 为穈太宗的大臣杜如䀲之

叔父

吏部加的售官署名学舊官制六部之一管京外 文職的资格升降等政。

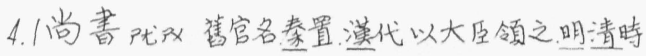

为各部長官

銜功謂官階

官銜即官階官職的名㛵

. 平章如地分别明白之意此處为官名。

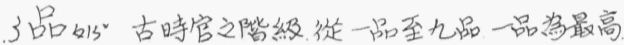

品級官階

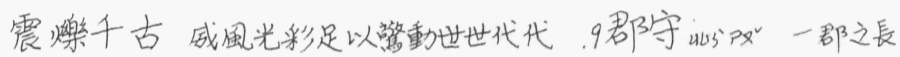

. 19 版圆3 $33^{2}$ 云 $x$ 国家的領土

秩出次序

秩序次序

20 奠 313 定

.22襲点相傅

刺史方”、古官名為地方長官之幍

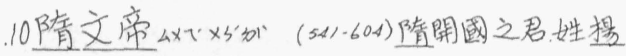

名堅菜㓌人, 在位二十四年 $(589$. 604$)$

. 14 陝西 $33^{\circ} \mathrm{T} 1$ 省名在中國中部黄河中游

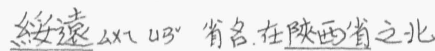

承襲承受前人之事物

.23頉攵15 屚次

頻仍次數很多

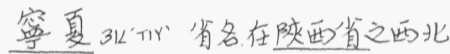

隅山邊倒之地, 角

甘肃《B 4 x 省名, 在陕西省之西察夏省之南

遑忧空閒

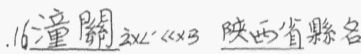

不遑制作没有時間制作 


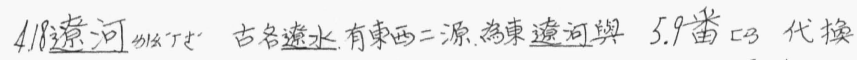

西遼河

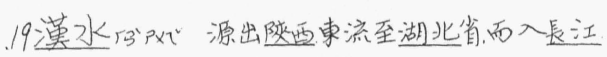

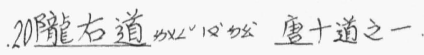
新疆虍㛧省名, 在甘肃省之西

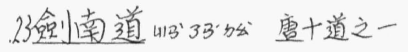
.253 《 005 謂往来视察

巡察往来各處察看

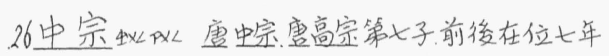

$(705-710)$

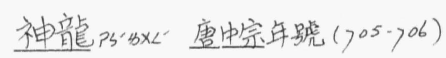

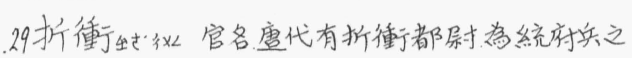

官諸府總曰折衝府

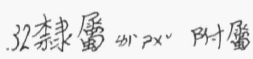

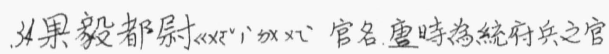
兵曹吅战一官名, 兽制每府置有之, 管軍防門禁田

䕎等事

5.2 役、觜公家勞作

役齡替公家服矛务之年嚙令

了预贊㑇即箭之矢也

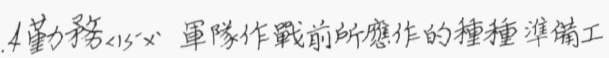

作及平日捻任之公共事弱

出勤務 擔任某些勤移

.5分真加給

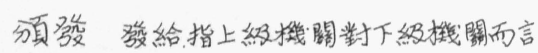

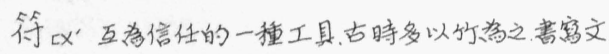

字分染二部、各拿一部、合而为一即表示足以信任

契<1合約。古十算的一璉工具

符券乫 即符

勘础检查

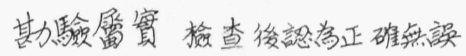

.8距岓“離

距離雨地相離之遠近

. 9 更《互換
更番互相替换

.10輸的以，從頭開始，顺次序替换

輪班按次序替換

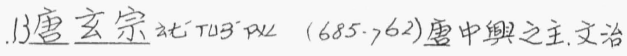

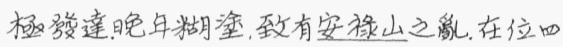

十三年(7,3.755)

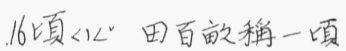

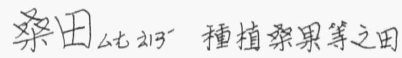

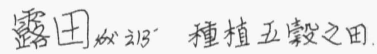

18 票 $\Delta x^{\prime}$ 一種敄類

19 綿 113 . 此處同棉”

麻次, 一種植物可用来䋨布

. 20 遵P P S 依從

遵循依昭顺從

21 氧象不优景象

氣度《加氣概

222知人善任知道别人之品行或才能而會任用。

出身㣗》謂人之家庭背景和瓷格。

賢能个沐“品格好而又有才能

惟掔能是與只考虑是否婜能

23探(据) 外除

摒除排除

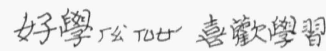

諫4 13 謂以直言指正在上者之非。

直諫謂直言规勸在上者之非。

不特万私云”不但

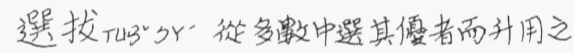
24 硡故岖以硬物與骨角不锟的互相摩擦

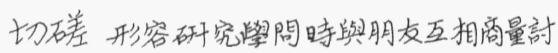

端

26 朝坐幺, 晨 


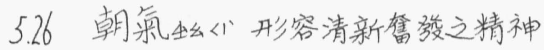

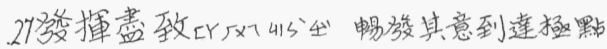

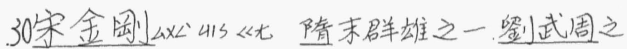
將领

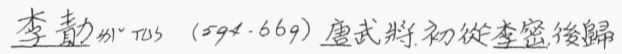

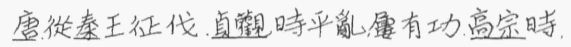
領兵打高麗，平其國（667-668)

程知食行坐4 11 - 雷人初助秦王平激, 高宗時 曾学岐《”州刺史

李密办叭! (582-618)唐人, 初为陵煬帝宿衛, 後

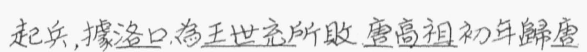
因失望復反㤫欺而被殺

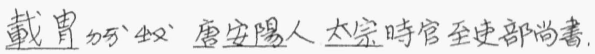

性堅正敢言

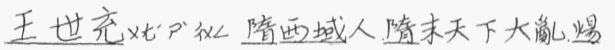

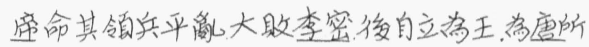
欺, 压服於雷後被殺。

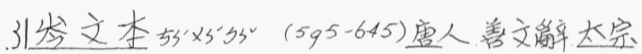
郭書皆其算定! 官至中書令

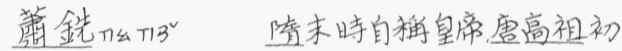

年選都立陵，後被店兵所欺

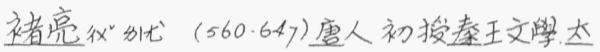

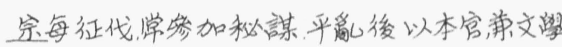

館整土

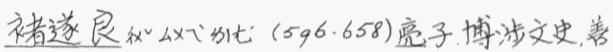

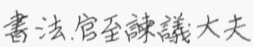

萨舉

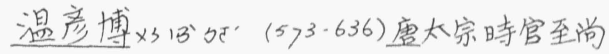

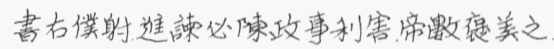

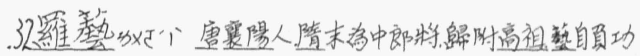

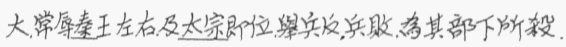

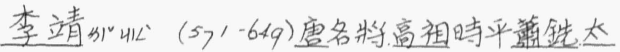
宗時大破匈奴、功桠極停。

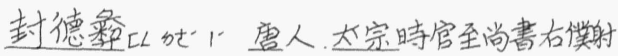

5.33 虞世南山゙ ア 33 ( 558 - 638 ) 店太宗時迅文館

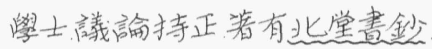

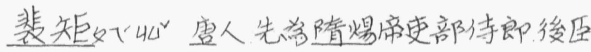

服於需官至民部尚書

降个化屈服蹛徒

. 䌶捐4 40 童去

嫌T19 㟲惡、不满意

捐紊前嫌除去以前的成思

堪5 3 可, 堪稳, 可稳掐。

倿312討好, 取悦别人

住压用嗇心機口才以取悦討好皇帝的 大压

6.3 知生主持

同知阈政共同主持國政

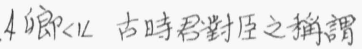

鉒413 見察

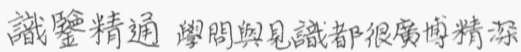
咸宜爪马切一切都道宜

藻阴謂文解

品簿品評人物察别流品

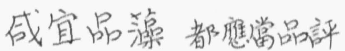

5自量队”外度量自己

敦双”誰

敦與諸子筫你跟那些人比, 嵟好?

孜p 勤勉

6 猙出人颜以直言止人之遇失

諌言采以直言改正警加上他人的遗失

恥行知道不對而心裹濑遇

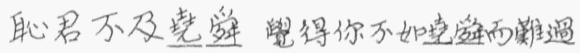

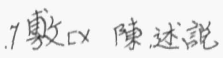

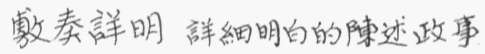

允 $4 S^{2}$ 得當, 畋許

出納惟允皇帝的話得當才宣於下, 下面人 的話得當才納於上。 
6.8 掔4 4 舆乵辛, 乵辛好

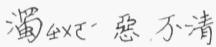

激㵻掦清除瑟舉善

应山上, 恨, 討厚犬

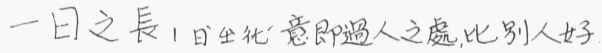
94 裹厂×万一蔵

畵已所懷説盡每人心中所想説的話 10 斑加雜色

一玟毛一小部分

川11 仕ア 作官

仕進進身学官

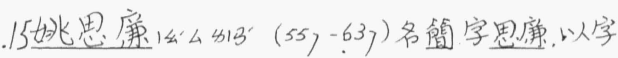

行好覐箸有梁畫焦畫

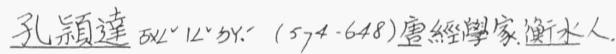

編著有五䈘正義

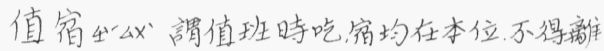

開

\section{6 傍加阽近}

傍晚大陽将落下前它刻時間

夜半代湢深夜

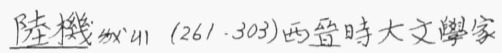

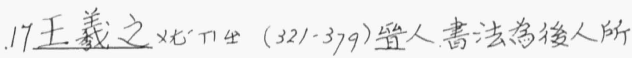

重

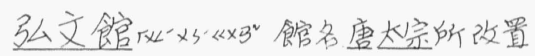
18服似空餘的時間

.19载印年

20重行自上施之於下

詢化查閣

重詢在上位者對F之查䦓

22疏阿”佟陳述敦

上疏對天子上書陳述意鬼

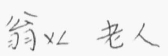

田告能謂偅田人家的老人, 鄉下老人 24 嗼云分同擹

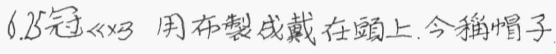

.26多目5 0 死亡

过升死

伐攻攻打

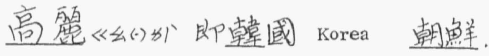

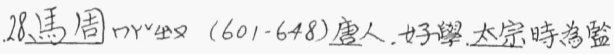

察御史、後为中書令

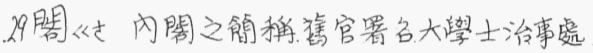

.31 沃动去其䁈用者

见炚“同坑”餘盛

见员多餘要用之官员

纪陟这進用

黑出陟罷免或進升。

省け人视察以瞭解

律㸝 法

更定律定更改定立法律

33 濫办遇度

7 . 1 溢! 满出

溢美籍美過度

無可置疑毫等疑閔, 万必懷疑。

了末始×べ並非未嘗

奢防用目才没有银制

侈行意同奢節敛的相及。

奢侈用助繁卸制

５錦４３２有粆，色花紋之織物

錦肅指非常高贵策美的衣服

６舆具作ＴK P X

鹰に一種我島體大而光可用以打幍

隼生×

犬、馬鹰集指出外打獵的光景

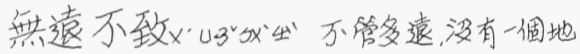

方不到過

顿妨飯餐

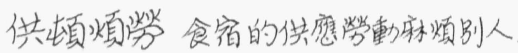


7.6 勿区 万要

勿以离是而法之不要認差對而效法

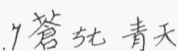

管生人民, 百姓

弘滦管生多方面的救澵老百姓

肇出開始

筆造愿夏開始建造大中國

.8 怨 $山 3$ 恨

愧5 50 自知不是而難過的感筧

. 9 自知这明對自己長彪缺黑有真正認識 



\section{第七課唐代文化約論}

嚴耕望

作者小傅嚴耕望( 1916 - ) 安徽桐城人, 號跙田。著作万少多為閆於中國各朝代之地方行 政、及官階制度之考證等。其中尤為重要者有: 中國地方行政制度、唐僕尚丞郎表、雨漠太守制

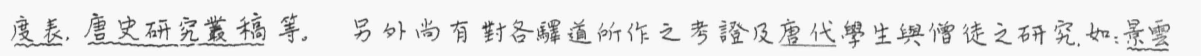

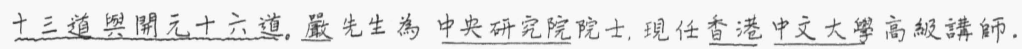

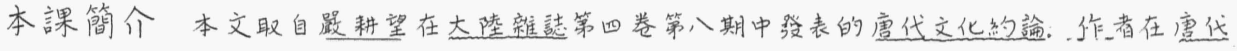

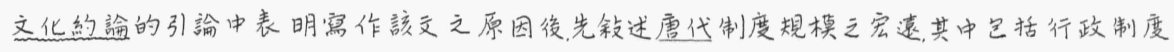

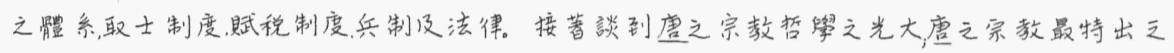

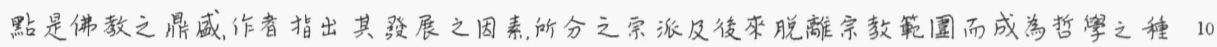

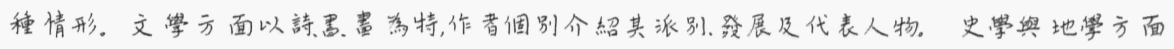

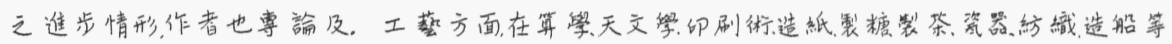
都比前代有相當的進步。人民的生活形式則非常胡化; 文化之普及和傅播是因國内水陸 交通發達、大都市之舆起、没科舉制度等的因素而形成的。本課僅節錄其中之引論, 制度规

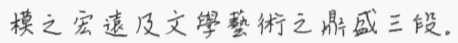

\section{一. 引論}

中國史上漠唐並稻, 而唐代立國規模之宏閣與文化各方面之弡

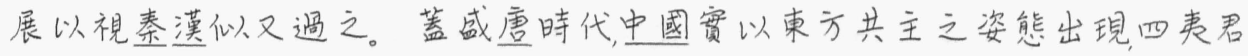

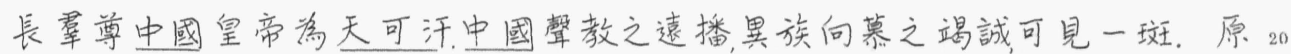
來中國愽統文化經數千年之弡展, 至此而國家統一,政治安定, 故文化發展得 作一大集結復以兼容並包達量宏忍之態度對待黑族文化, 故異文化示得在 中國順利傅播育長融和。如制度政治與文學史學, 中國傅統文化之結晶 也, 宗教哲學, 則, 承印度佛教文化, 光而大之中國化之者; 警術祭舞與科學, 則博 採西亞而䁶通遍應者。本源遠流長之優良傅統, 以宏忍之態度迎接黑文化 25 採彼所長補我所短洪流㕍合, 乳融轉化莱惯亚茂, 生氮蓝然此唐代文化之鼎 咸所以不可及也。年普及深入於社會之各階層, 轉播宣掦於遠近之諸異族, 影䇾國際指模後代不惟覀洲之輝光抑示第七八九世紀世界文化之日月矣。 章爾斯日第七, 八世紀中國13世界上最安定最文明之國家。其時殹洲人民 尚處於茅舍鸤壁宗教桎梏之境中國人民之生活已進於安樂慈愛思想自由3 0 身心舒爽之域。西人之言如此, 藍比觀束西, 優劣自影雖有偏見, 不能自蔽也

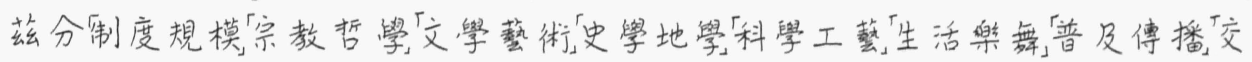
通舆文化諸端約罟論述之。

\section{二、制度规模之宏遠}




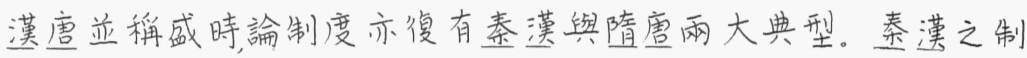
承封建時代之後制建之功甚倍, 而時雜封建餘䫓。跜魏晋南北朝三百餘年

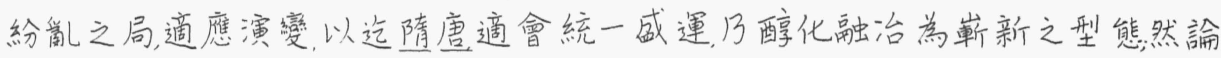

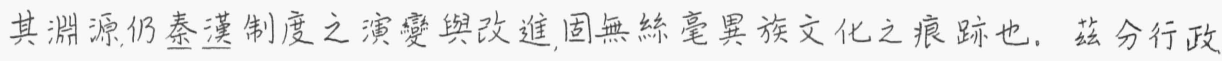
5 取士、財賦兵制法律諸大端畧論之。

- 行政制度之體系邁代國家政令, 丞相總其綱而九卿分掌

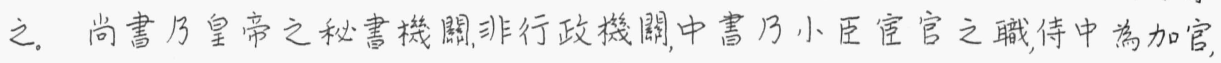

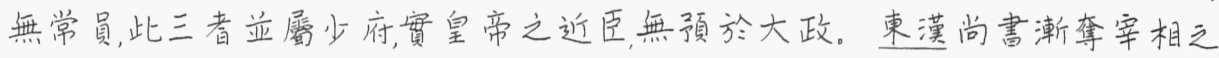
權, 槐晋以下中書又代尚書参樴密, 而北朝之制侍中之權獨重。方是時, 三公 16 九㑡仍沿置不承, 雜遇紛紜, 笺無體系可言。北魏孝文帝雖曾一度鳌整, 然其 制未精, 其效未宏。至唐雖尚書中書門下三省並置, 六部與九䐚諸監普設, 然

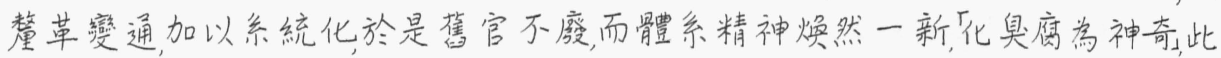
之謂矣。

茲先論㔬相與三省制衡之制。唐初承隋之鹤, 置尚書中書門下 15 三省, 其長官並為宰相。寻復以地位較低之官参察相事, 謂之參預朝政䅟知 政事, 高宗以後又有「同中書門下三品同中書門下平章事, 之目, 皆宰相之任也,

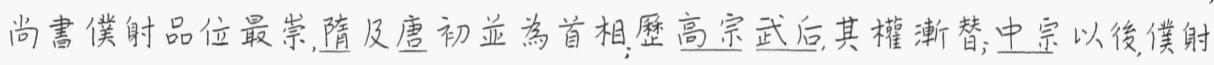
不加同三品者不为㔬相。肅代以後侍中, 中書令, 同三品並不常置, 军相之稻 惟问中書門下平章事而已。粗浅觀之, 唐世㔬相之名最為不正。然其演婆 20 結果組織體系精密有法度; 或以其名畄不正而訾議之謬矣。蓋蓸初三省長

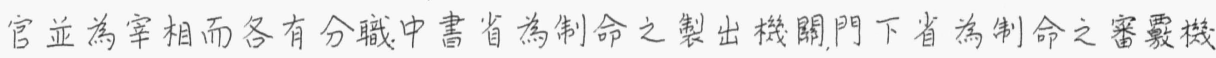

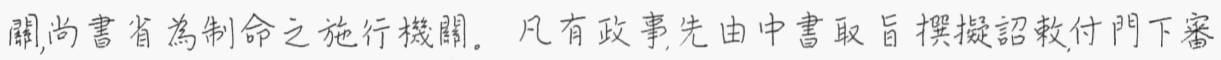
需, 再下尚書施行; 步驟精密, 且寓制衡作用, 立意本善。惟是事權分立, 往往弡

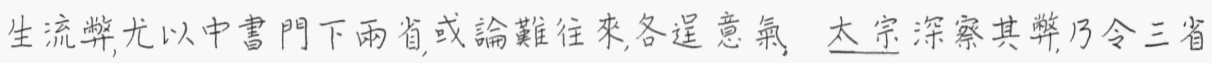
25 長官合署辩公, 是謂政事堂, 此惯唐代辛相制度之一進步也。政事堂始設於

門下省、武后初移於中書省, 至開元十一年, 改稱中書門下, 别為置印列五房於 其後, 一曰吏房, 二曰楅譏房, 三曰兵房, 四曰户房, 五曰刑禮房, 分曹以主象枒。

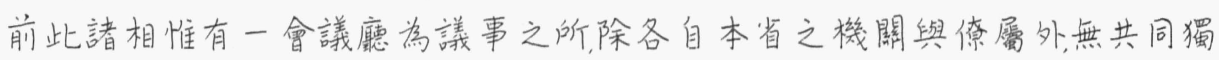

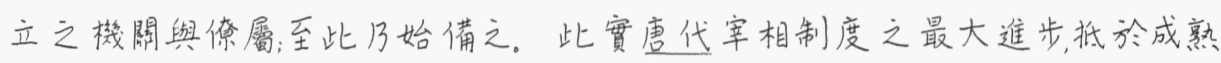
30 矣。於是㔬相機關脱離三省成為超然獨立之府署, 而中書門下二省之要職 惟中書舍人與給事中而已。凡百制命皆由仲書門下, 決議取旨, 付中書省由 中書舍人起草, 下門下省, 緸給事中審覈, 然後頒下尚書省施行之。此種制度, 晏相無揧时之感又不失中書起草, 門下封駁之遺意, 㔬相權隆而亦不能専, 且 無行政之權, 视革之大政一出丞相者, 似为精密矣。 
次論尚書六部與九唧諸監之關係。唐代最高行政機闕之尚書省置左右僕 射為之長, 有左右丞以佐之, 分轄吏户禮兵刑工六部, 各置尚書兂之長, 有侍郎

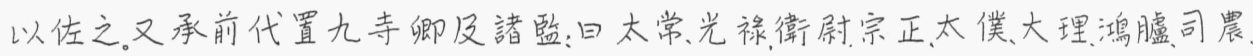
太府, 是為九寺卿, 日國子、少府、將作都水是為諸監。中央行政機關畫於此矣。 前云漠代國家政令, 丞相總其綱, 而九唧分掌之, 尚書乃皇帝之秘書機關, 非行5 政機關。漢季魏晋以下, 尚書漸奪宰相之權, 亦兼九唧之職然九很沿置不廢, 與尚書並立, 推行政務, 故職權常至重複混淆, 不能析辩。經過三百餘年之鳌 革調整, 至唐雖唧監與六部並存, 然其性啠職權及其在行政系統中所居的地 位已大有區别。蓋尚書六部二十四司承君相之制命製為政令下於九寺諸 監, 促其施行而為之節制, 九寺諸監則, 承尚書六部之政令親事執行, 復以成果 10 申於六部。故六部点上級機閣, 主政務, 寺監為下級機闢, 掌事㘯六部為政務

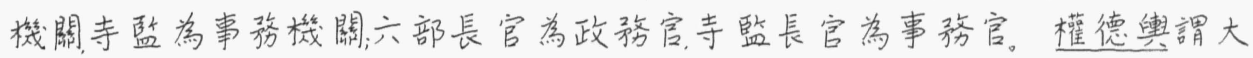
農事有恒規, 3 守之之才, 度支權其槧重, 必恃通識。此言確切説明度支與大 農性質職權之不同, 惯亦六部與九寺諸監性質職權之共同差異也。大抵尚 書六部於天下大政無所不綜然直接由六部執行者則甚少。凡事屬地方性 15 質者, 則下地方政府執行之, 尚書只處於頒令節制之地位。凡事屬中央性留 者, 小部分由六部自己執行, 如吏部铨選禮部筫舉是也复部分則下寺監等事 務譏關執行之, 尚書亦只處於頒令節制之地位如刑獄椇計馬政是最顯者。

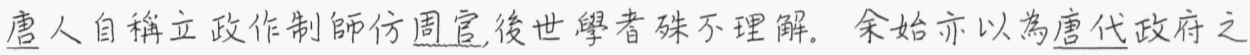
官司組織與南北朝絕無二致倒仿周官乃唐人妄自尊大, 虚鴣比附全非事寞; 20

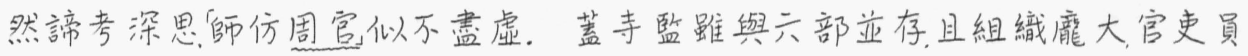
额超過六部數倍, 然皆事務執行機關, 非政令所自出, 政令所出惟在六部, 此正 周禮六官之遗意。然則唐人作制, 形式上雖承南北朝之舊貫, 而其體系與精

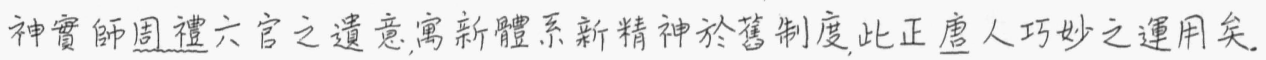
再次論地方政府。自秦漢統一政府崩溃之後, 中央政府皖無體 25 系而地方政府尤紊不堪言: 軍吏縱横豪强分割, 州郡疊架, 徒擁虚名, 至於百室 之邑便立州名, 三户之民空張郡目。至隋唐一統, 乃大事整頓为州縣二級制, 其後分全國為十道十五道, 置採訪使以監州縣終成觀察節度之制, 與漢世刺 史演篗学牧伯之制同出一敨故論漢唐之制, 地方政府最為近似。至於邊疆 檄外, 四夷君長既尊唐帝為共主稱天可汗故唐政府亦分置都護以盡綏和統 30 護之責。當麿盛時, 有六都護府, 日安東治平壤( 今北韓平壤) 領今全韓之地, 日 安南治交州( 今越南河内) 領今越南及南洋諸島, 日安北治金山( 今多蒙古科布 多境) 領大漠以北旧單于, 治雲中( 今歸綏境) 領大漠以南; 日安西治兔茲( 今新疆 庫車)領西域天山以南, 日北庭, 治庭州( 今新疆廸化) 領西域天山以北。統治範 
園遠較現今中國之版圆学遼闊。

綜觀唐代行政制度, 规模宏闊而組織精嚴。就中宰相制度與地 方制度是否優於漢制, 今難論定, 然尚書六部優於漢之九唧, 則䜌無可疑。蓄 漢之九卿惟廷尉大司農純為政府大臣、其餘皆皇室之宫官或兼治國事而已; 宫府一體殊富封建遺風。至唐之六部分掌國家大政, 於皇帝私事毫每關涉, 此無疑是中國政府之影著進步。而六部又僅振䋨絜領, 掌其政令, 除最重要 之行政外, 凡百事務皆下九唧諸監惯地虎理而自為之節制是以政策之研討 能精審, 事務之推行能贯澈, 此又唐制精密處, 非漢制疏闊所能及矣。

二取士制度行政體系規模之宏閤精密如此, 但如何運用, 則

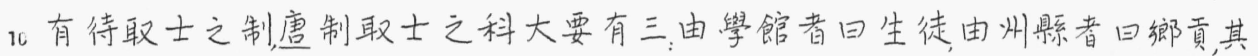
天子自詔者日制舉。制舉無定期無定員, 亦無定科(如堅良方正博通㫩典軍 謀宏遠, 詳明政術等凡百數十種) 唯天子随時所欲制詔徵求而親試之。生徒 者, 國子監之六學(國子學, 太學, 四門學, 律學、書學、算學)弘文崇文雨館及地方學 之生徒每歲仲冬由館監州縣舉其成者送尚書禮部分科考試之。其士之不 15 由學館者, 皆懷偞自列於州縣州縣亦每年仲冬送尚書禮部, 與生徒同試是謂 鄉爰。故生徒鄉責來源不同而分科考試則一事也。(近人著作往往述學館 生徒至監館送尚書而止, 而以分科考試專屬鄉意此大誤。其科之目有秀才。 明經、俊士、進士、明法、明字、明算一史、三史、開元禮道舉童子之别就中以進士、明 經為盛, 而進士尤爱社會所重。學館生徒, 自四門以上皆官僚貴遊子弟, 而鄉 20 梖無任何资格限制, 故為平民進身之階。唐初承南北朝門閥社會之後士人 以學館為重; 其後以鄉香為縈雖贵遊子弟亦捨學館而堨榔者, 此亦足微政治 社會風尚之轉誉焉。大抵制舉即漢之詔舉生徒猶漢之博士弟子, 而鄉梖亦 漢代郡國察舉孝廉之遺意。惟漢之察舉權在地方長官; 唐之鄉賁應試者自 我報名, 公開競選, 而考試之權又復收歸中央( 州縣雖試, 乃具文耳) 既可博採人 25 才, 兼收集權之效, 以視漢制, 又一大進步矣。此一純客觀且具有開放政㩲之 意義的取士制度, 寞為有唐一代人才運用之動脈, 文化普及之利器, 社會階级 頼以涺除平民知識因而啓誘, 凝成四方僻壤之向心力, 助成文學㢣術之鼎盛, 自宗迄清, 承沿不替, 雖運用時有露承, 然為政治之柱石文化之動脈固不異也。 錢启窗四於此制之美已深切論之, 無庸鳌言矣。

30

三賦税制度政治之運用既有頼乎人才, 亦有頼乎財賦。唐 之取財, 先之以租庸調, 救之以雨税法, 而監菜之利因附庸蔚為大宗, 中葉以後, 國家財政惯惟此是頼。租庸調之法始創於北魏鳌定於唐初武德間。凡丁 男給田百畧, 中八十散基口分田, 身死則入官, 更以給他人, 二十畧為世業, 身 死則當户者, 承之, 此丁户之權利也。丁已受田, 歲輸粟二石, 謂之租又随榔土 
所出輸絹綾布麻各有差, 謂之調, 用民之力歲二十日, 不役者日納絹三尺謂之 庸, 此丁户之義務也。綜觀租庸調之制亦猶漢之田租口錢力役也惟漢制不 授田, 丁户之於國家有義務無權利, 此唐制所以優於漢制, 為後人所憧憬稻道 耳。惟欲澈底推行此制, 勢必由政府控制全國之耕地, 然通觀唐籍, 絕無採取 如此非常手段之痕跡, 抑當時政治社會之情勢實不容路室君臣採取如此非 常之手段也。意者當時政府蓋聱其所能掌握之公由推行此制, 豪家之田固 未奞取以授平民也。其後丁口日滋更蜼久行此制於是租庸調徽賦之法存 而授田之法叞矣。由百畧租二石, 本極輕微, 及授田之法廢, 無田而納租如故 斯為重矣。貧民不堪, 相率藏避, 而富者兼仼租不益增, 故政府之財計日絀。及 安史乳後, 户籍更減而財用日繁科劒百出而無濟國用, 於是久與實際情形脱 10 節之租庸調制不得不毅然廢亲而以兩税制代之。雨税之制始於德宗建中

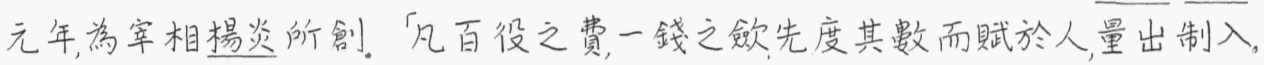
户無主客, 以見居為簿人無丁中, 以只富為差; 不居處而行商者, 在所州縣税三 十之一, 度所取與居者均。居人之税夏秋兩入之。此制大意在政府量出制 入按人民資産多少而均税之。此種以資産学標準之賦税制雖推行上不無 15 困難, 但原則上實無可㫮誐; 後世襲此原則, 無多更張良有以也。又安史㖟後,

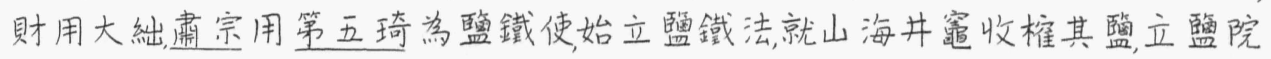
官吏以收其利。此丁田之外别開財源也, 史稱民不益税而國用以䉇。又中 葉以後飲茶之風極盛, 於是又有茶税。唐中葉以後政治上迄未安定軍旅時 興支度浩繁丁田賦税之不足均為盬茶是頼訖唐之末, 監茶之利溥於丁由, 至 20 以首相兼領之; 政府財計所頼於此可見, 監茶之利代丁田之税, 此又財政史上 之一進步也。

四兵制有㡺一代之兵制, 先之以府兵濟之以彍騎終之以禁 兵及鎮兵; 每下愈况國事遂不可為。府兵制制自西魏北周, 成於隋唐。於天 下諸州置折衝府五六百數關中約居其半, 選較殷惯之農户以隸之, 服兵役, 給 25 宿衛, 三季耕耘, 一冬講武, 有事命将率領出征, 事解輯罷, 兵散於府, 將歸於朝既 免軍人專擅之弊, 亦無耗財養兵之苦。此制視漢代窝兵於震, 全國人民皆服 兵役之制較有彈性, 而效能則一, 或且過之。唐初重府兵制, 民以㯟籍為榮。 武后以降, 承平既久, 不重武事, 人賤府兵率相逃避番衙且缺更無論武備矣。於

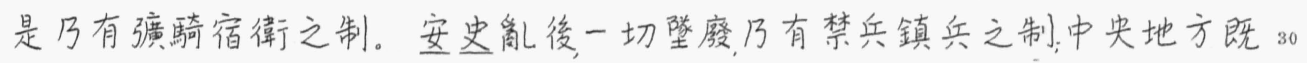
離為雨制, 且為宦官强藩所綰控, 朝廷遂失其權。且宦官盤拵强藩峙立, 競張

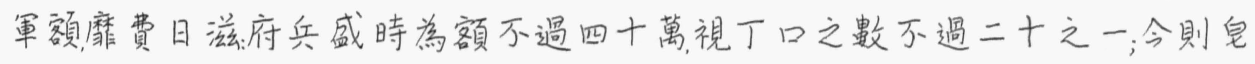
衣滿道, 至以雨三户而養一兵, 國計既絀民生尤困國事不可为矣。

五法律唐律上集秦漠魏䁌之大成而加以改進者。後世承 
之, 損益甚微即现行之法律雖規摹西洋法律, 固亦未能全脱唐律範圍, 蓄唐律 審慎精密, 誠有足取者。又就暧刑一端而言, 答不過二百, 流不過三千里, 役不 過四年, 死不過絞斬, 無終身四禁凌革碟鋸之刑, 緣坐限於父子, 亦無族誅之制。 凡此皆與现代法律學説学近, 明清之律反較搌酷, 非所語於進步矣。論者謂 唐律舆羅馬法甚多相類之處, 惟唐律以禮教為中心, 羅馬法以權利差中心, 此 東西雨大法系根本觀念之不同也。

\section{三。宗教哲學之光大}

四、文笨㙯街之鼎盛

唐代為中國文繁㢣術之極盛時期尤以詩與畫畫不特超前抑且 絕後。李延壽諭南北朝之文學云江左宫商發越, 貴於清綺; 河朔詞義卓㣚, 重

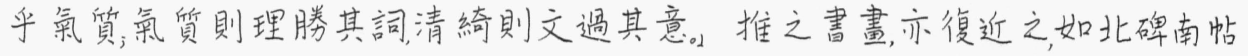
尤其表徵、及隋唐統一盛運, 南北文化交流觀摩砥礌蔚然鼎盛, 誠有副乎李

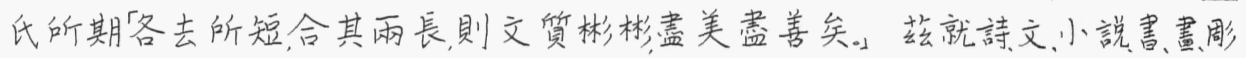
15 塑諸端分別畧述之。就中惟小説畫塑颇参印度西亞之風其餘皆中國傅統 文㙯㶌長成熟者。

一 詩唐人於詩造詣獨深, 此三尺童子所已飫聞。明人高棟 約論之為四期日: 詩自三百篇以降, 漢魏質過於文, 六朝莱浮於實, 得二者之中, 備風人之體惟唐詩学然。然以世次不同, 故其所作亦異……畧而言之, 則有

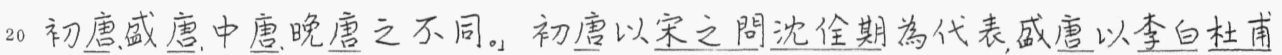

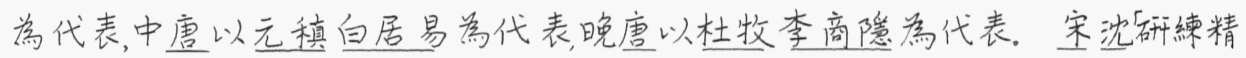

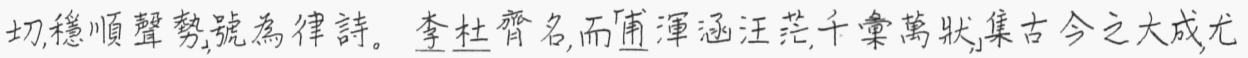
為中國詩史上不祧之大宗。元稹論之云歷世能者之文互出……然而莫不 好古者遺近, 務莱者去寞……律切則骨格不存, 閑暇則繊糟莫備; 至於子美, 盖 25 所謂上薄風騷, 下該沈宋言奞蕉李氣呑曹劉掩顔謝之孤高, 雜徐庭之流䨖, 盡 得古今之體勢, 而兼人人之所獨專, ……則詩人已來未有如子美者。後之論 者謂為信然。至元白淺易相尚詩格為之一受。前此詩之取材率多廟堂酬 酷, 感興偒懷山水田園, 風花雪月而已, 此純貴族士大夫之文字也。杜甫善陳 時事, 於政治社畣之黑暗面揭之不暲, 故有詩史之稱。白居易尤以揭發民隐 30 刺諷時政爱職志。以淺易之體富麗之詞, 歌政治社會之不平千言百韻極力 狀摩, 實為中國史上富有社會性的平民文學之稱首, 是以京都江湖數千里間, 傳題於榔校佛寺逆旅行舟之中, 諷誦於士庶僧道婦孺妓娼之口, 可不成哉! 且也前此之詩為士大夫所專享腺作欣賞皆無與於平民。有唐詩教大興蔚 為風尚, 不但詩人佳作得誦一時至於販夫走卒妓娼婦嚅不惟能誦詩篇, 且亦 
時有侴吟。舊傅詩歌中本不乏其例, 而敦煌發现之寫本卷子中, 多民間雜曲, 敍事長詩, 尤為佳例, 是又唐人文學平民化之又一例也。綜上以觀唐人之詩, 不惟文學技術之造詣集古今之大成, 而題材新鮮, 内容豐富, 自士大夫至於平 民莫不醉心於此。故詩學之盛莫過於总而由貴族文學推廣為平民文學此 又顯著進步之表徵也。

二文唐代文章分駢文古文雨大派。唐初承六朝之後文尚

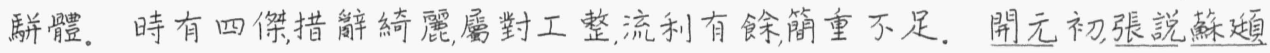
以雍容華貴雄渾凝重見稱, 馬并作風為之一䃞。當陳末唐初駢文極感之時, 姚察父子撰梁書, 敍事傅論皆以散體古文行之, 峌氮鋭筆, 曲折明暢, 一洗六朝 無见之習, 出時拔俗殊雷難能惯為文章復古之先鋒。武后時陳子昂富嘉謨10 等亦力主淿浮㦄, 反雅正。大曆真元之間, 文字多尚古學, 效揚雄董仲舒之述作,

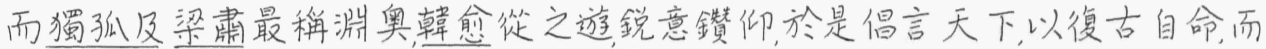
其才足以副之同時柳宗元、皇甫湜、李的李篗等恽起相尚; 古文派之基礎始立。 然终量之世, 駢文風行, 得柳古文有不敵之勢, 此觀全唐文中中唐以後之作品 仍駢多散少, 足為明微。至宋之歐㯖曾王繼起, 宗尚韓柳古文之勢始大振, 支15 配文壇約近千年。由駢體蒈為散文, 亦文學史上一解放進步也。

三小説漠至六朝之小説類屬神仙鬼怪或宫闇情話, 且光到 簡記, 殊乏風味蓋作者傅錄故事, 無意造設。至唐人乃設奇畫幻, 有意㓱作, 故

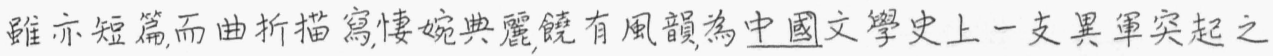
怔旅。近人就其體裁分為雨大類, 一曰傳奇, 二曰亳文俗文。傅奇小説實亦2 0 散文運動之一支, 以附庸而蔚為大國, 其别又可約為三類因宗教信仰之風犘 而有神仙鬼怪之傅奇, 如柳毅傳抌中記南柯太守傳等是也; 因婦女生活之解

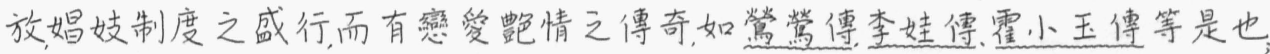

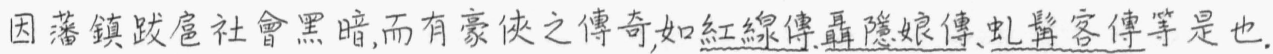

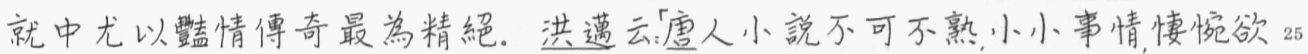
綛, 間有神遇而不自知者, 與詩律可稱一代之奇。此蓝指傳奇而言, 其推崇可 謂備至。蓋唐世文學不外駢文古文詩歌小説唐人之詩空前絕後前已言之, 駢文承六朝之餘風, 多用於詔誥碑誌在文學史上之地位本不甚高; 榦柳古文 踓為後世所稻, 然文以載道, 亦未能遇越馬班, 並肩莊左; 惟傳奇小説雖古文 運動之附庸然以解放之文體反映社會上種種現赛生活舆思想且致於成熟30 之境在中國文學史上亦屬空前之創獲。前人以其小道鄖而不論洪氏生當 宋世, 以與詩律恶稱, 洵為卓識。近人有謂傅奇小説在文學史上之地位反較 韓枊散文為重要, 蓋就洪説引而申之耳。次論受文與俗文, 印度文學常以 散文與詩歌聯緅成文, 佛教文學自不例外, 中國傅統文等則䇼無此例。自佛 
教大行以來, 其徒為欲使平民大象易於瞭解佛經計, 乃答照印度文字之體式 寫為宣傅文字, 於是有嚄文與俗文。此類小説多已失傳, 幸賴敦煌石室保存 不少。大抵一篇之中有詩歌, 有散文, 且有駢文, 以詩引文, 以文引詩, 弗詩夾文, 相映成趣。惟無論詩文駢散率多俚俗口語易於通曉。此種小説蓋初磨感

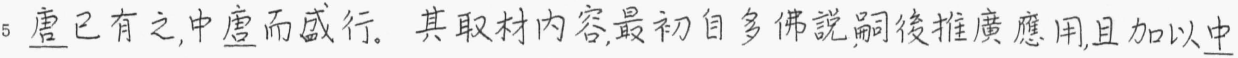

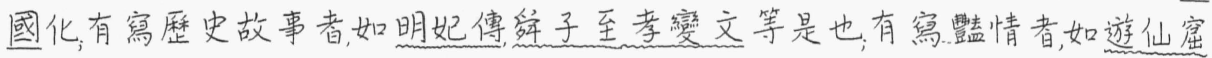
是也。就中如遊仙窟寓中國生活化之察實内容於變文體式極爰成功論者

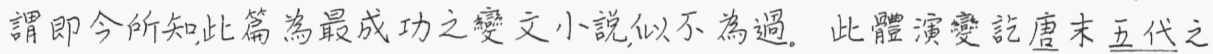
頃, 有烈國故事、太宗入冥記等, 純散文, 無韻語, 文體轉䔻, 遂開宗代話本元明演 10 義之先聲。總上以觀徱奇小説之等育舆成長皆在本國, 而文義較深, 流行於 士大夫間, 一般平民未必皆能欣賞。至於變文俗文淵源於國外, 而語雜俚俗, 易於通曉蓋純乎平民文學矣, 是又文㙯普及之一端也。

四書法南北朝之世, 南北書法風尚不同。北書方嚴遒跏, 長 於碑榜, 應用於貴族社會富有傳統的宗教攻味。南書疏放奸妙, 長於簡札踓 15 亦應用於貴族社會, 但較有日常生活氣味。隋磨一統, 書法作風亦赹融和如 虞世南、歐陽詢袸遂良皆南人而學羲之者, 乃傅世諸碑皆兼寓北風是可知矣。 太宗玄宗提倡書法, 承隋置書學, 要學大與風犘一代行草隸策, 各盡其妙。及

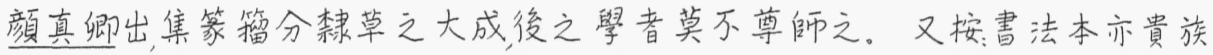
性之㢣術唐世士大夫無不善畫, 原無足奇; 乃觀近世敦煌發現之管人富經則 20 寻常抄手所腺之字亦頗雅健深厚, 非後世一般人所能及。是書學㢣術示由 士大夫貴族之㙯術普及舀平民藝術矣。

五畫與彫塑畫在南朝已極盛行畐時謝赫制六法為繪畫批 評之標準。其説頗有客觀之科學精神, 蓋治中國德統畫法與印度西亞畫法 於一爈者。隋唐君主多好繪事, 為之提倡, 故其時畫法與書法並稱精絕。當 25 時甚多外國畫家寄寓長安擅譽朝野, 中國畫家亦復受其影軴。蓋中國傳統 之畫固尚骨法, 印度西亞之畫重凹凹, 唐人畫中亦多凹凸之法, 大約即受當時 外國畫家之影響也。大抵人物畫所受之影響最深山水則稍浅耳。盛唐時, 畫之精者有李思剖尚工震, 善傅彩遂開後世北宗一派; 有王維, 唯意所適, 妙得 神韻, 遂開後世南宗一派而吴道子尤稱獨步, 號稻畫聖云。與吴道子同師而 30 以塑像舆道子之畫同様騰譽士林者, 則有楊惠之。南北朝之世, 中國彫刻因 佛教盛行而大盛, 其作風亦深受印度彫刻之影響, 雲岡龍門諸刻莊嚴雄偉, 而 極生動, 足学表式。唐時石刻圖像視南北朝似未能有以過之, 而塑像之風大 行, 是亦一進步也。 


\section{五史學舆地學}

唐代經學雖調和南北但無所發揮, 反不如史學地理學之有進步。 一史學唐人對於史學颇有真獻。唐初官修晋梁、陳北齊、周

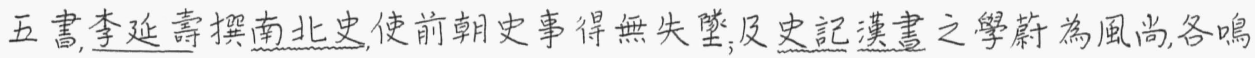
其家固無論矣。而劉知幾之史通與杜佑之通典尤堪推重。前此史家惟有5 史事之撰述, 無就史學方法作綜合之研究者。劉代史通為中國史學方法 論之始祖, 而訾議中肯, 議論精核, 千餘年來不能有以過之, 其在中國史學史上 地位之崇高可以想見。前此史書類䋀通史断代史, 其體裁或紀傅, 或編年; 而 杜代通典分門别類, 專講制度, 是為政書之始, 而博大有條貫, 亦為累世所所法, 至今十通與二十五史並稻而杜書為之首其偉大示可想見。惟其發凡起例10 出於劉秩之政典, 則仍知幾之家學也劉化精研史學宜其有此創見矣。

二地理學南北朝時代地理學已甚發達, 䇬道元水經注尤堪 稱為千古奇書。隋唐承之, 地理罍益見興盛。隋世編輯嵒宇圖志一千二百 卷規模之大誠屬可驚。唐初, 䰤王泰编輯括地志五百五十五卷, 記述細詳, 雚

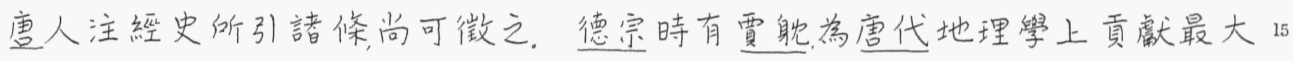
之學者, 曾撰古今郡國影道四夷述四十卷, 並作海内莱夷圖, 廣三丈縱三丈三 尺率以一寸折成百里。是入圖者, 東西三萬里, 南北三萬三千里, 當東包旦本, 西逾大食, 北逾大漠, 南嗇南洋諸國。皇昌時代菳夷圖跋云, 贾圖所載, 凡數百 餘國其範圍之廣, 圖繪之詳可知。且古郡國題以墨,今州縣題以朱, 後世地圖 以朱墨分古今, 惯始於此誠一劃時代之偉著也。賈氏又有皇䔄四達記十卷, 20

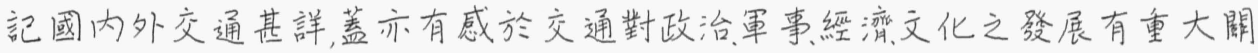
係耳。惜此諸書皆不傅, 惟新唐畫玨理志轉載賈氏所記中國通四夷有七道, 今世中外學人研究唐代對外交通仍惟此是頼。稍痋李吉甫撰元和郡邀志 四十卷, 記載詳䀰有法度, 今存地志之書當推此质最早矣。此外隋唐學者對 於四裔諸民族之記載特多。尤其注意西域。唐人著作之有名者如云奖之2 2 太唐西域記十二卷王玄策之中天䇥行記十卷許敬宗之西域圖志六十卷. 玄装域記為中國中古時代旅行記中範園最廣内容最富之巨著, 為研究六 七世紀印度西域史之極重要参考書。其序論云, 日月所照有四大洲皆在大 海中。東昆提訶洲, 南瞻部洲, 西㫿陀尼洲, 北拘盧洲。南瞻部洲有四主, 南為

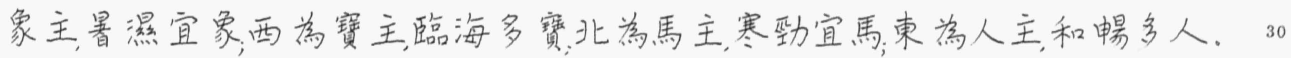
按象主蓋指印度南洋諸國, 䆩主蓋指波斯大食諸國馬主當指中亞細亞至蒙 古諸國, 人主謂中國也。是南䝩部洲即相當於今亞洲則當時外人已知北束 西尚各有一洲。此種新的世界地理知識蓋即此時德入中國者。西域圖志 离高宗敕撰, 多至六十卷蓋既遣専使採訪風俗, 又合番書以成之, 不惟空前之 
巨製, 即其後亦無可比肩者, 惜示不德!

討論問題:

一, 考試制度對政體取士有何益處?

二試述中國考試取士制度之桃源及論唐代之取士制度。

三討論中国所用之賦税制度, 漓何並每所得税:

四、當時重要之文學有那些。為何没有長篇小説?

五. 唐代史學地繁有何成就? 


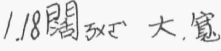

宏閭篦大

19 姿卬謂人之状犬榴舉動

態动動作的状犬㹸

姿態行動態度

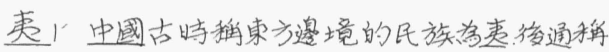

邊境非漢人的民族学夷

四夷四方名處的奏人

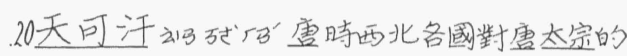

尊號

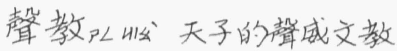

向化仰慕

向萗仰莫

竭誠山世”䛃”謂十分誠懇

.22集結41 4 6 r 聚合在一起

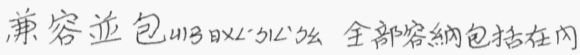

達量宏忍度量通连䰟宏容忍

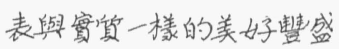

1.26盎尤盛貎

生氣盘然充满着青春與活力的樣子

鼎盛加到正當牡盛。

28 楷 35 s $^{2}$ 法式

楷模淩代, 弯後代之模釷

29草爾斯×代儿公 Wells, Herbert George (1866-1946)

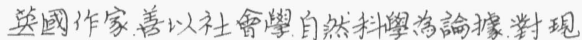

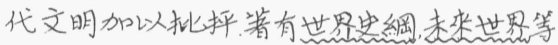

30䲧、小碉堡

塢壁土等的碉堡，以防定盗

桎出刑具名用以㢣犯人足者

梏《刑具名。用以慗犯人手者

桍梏 刑具名、表示限制局禁之意

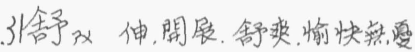

般分掩避

自慗自己將缺點隐筬起来

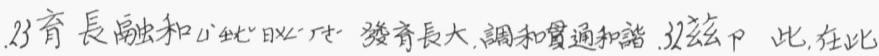

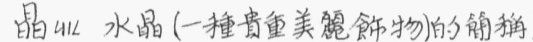

結晶礦物整名商风有化整成分之物算由
2.2赔叭闽雅聲音相和

餘韵食鉒下来的䖝味

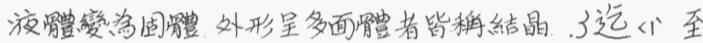

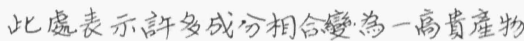

以迄以至

醇洤了一堆、濃厚的酒

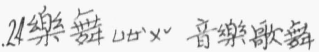

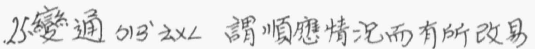

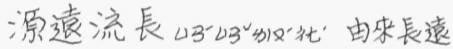

.26洪下远大, 水流

醇化特博穿隹的智識分数而成立系統。

曺和 $3^{2}$ 高, 極

嶄新極新

4 淤湖深、深水

洪流㕍合形容故多来源不同的合而高一

学昛“女性動物生産小動物後所流的一崜液

體, 用来給小動物阣, 使之長大

销源本源

痕殁跡

痕跡事物經過所留下来的跡象

乳融轉化形容瞭解吸收後而成巻一種

有用的功效。

蒇呟盛，美

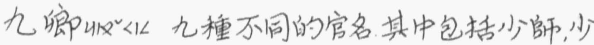

傅等。

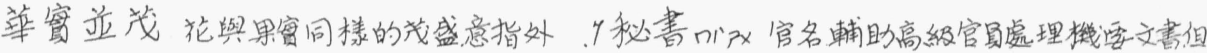


本身汥有舜佈命令的權力

2.7 加官 414 《 3 謂兼職

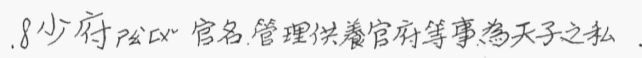
府。

預山济與

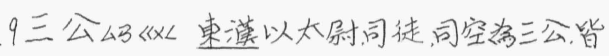

学官名，又稱三司。

.10塚云个同锥

雜塚即象多的粶子

紜US 猺

紛㬎多而滛

體系云、开由許多要素形成有秩序之系統

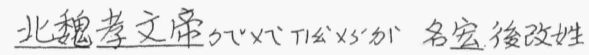

元大興文治均民田制户籍禁胡服楜語，並 悉都洛陽、以期改彎国俗在位甘九年(4) -

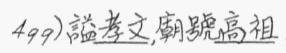

督多一治理

箵整治理整顿

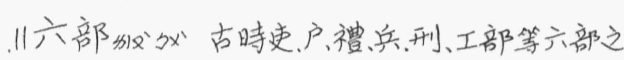

總稱皆官署名

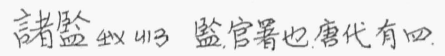

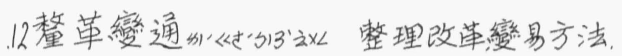

得以應用

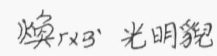

焕然—新全部一新.新得明亮

臭得不佳之氣味香文反

化臭腐学神奇使腐壤䍃用的一變而成 新鮮奇妙

.14制衡出厂毫制平衡

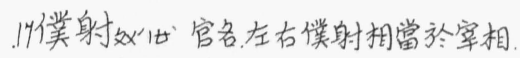

崇彻高, 貴重

高宗《似 即害高宗太宗第九子立武則天学

后, 在位三十四年( 650 - 683 )

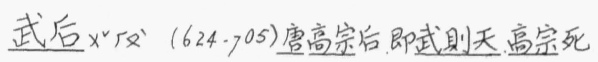

自立为皇帝(684.704)國躆围、晚年被迫旗政

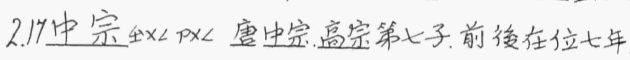

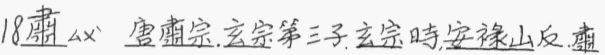
宗即位平安袮山，在位七年(756-762)

代加害代宗建宗子在位十七年( 763 - 779 )

.19米且5 5 略, 不精。

粗浅觀之简略的看来

20些議 批評議論

.21制命出的 法度君命

橎厂去考核

審覈審察考核

.22撰出× 3 言敦

擬31 起草

詔出幍皇帝之命令。

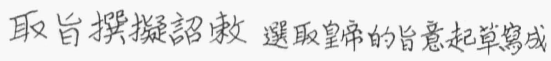
命令

.23密心託, 含有、居所

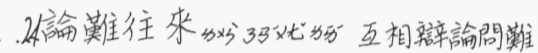

遈彻放縦

各遈意氣各人都任性行事, 万顧一切。

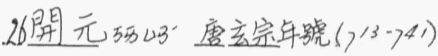

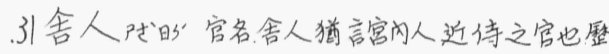
代以告人名官者很多，如中書告人。太子告人，起 居管人、通事舍人等。

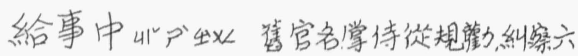

部之整誤

.33掣忧捉取

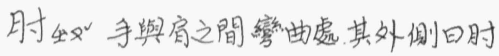

掣时形容阻㩖他人作事

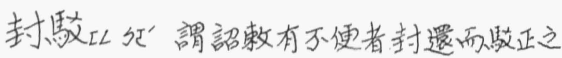

隆穧的高出。大

3.3 太常动”能官名九卿之一, 掌宗廟禮俄

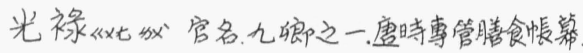




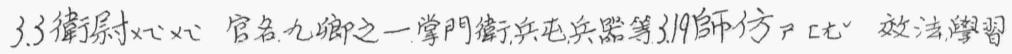

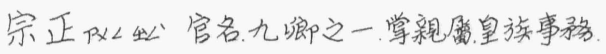
太㒒动如一官名, 九艮之一一掌養馬牧畜之事 大理汃办官名, 九㫰印一掌刑法之事。

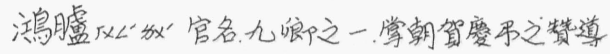
相澧

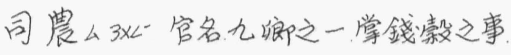

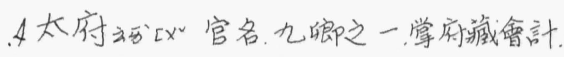

國子《x古”時謂公很大夫之子弟。

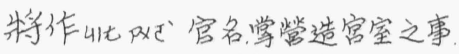
都水汃阬化官名掌水道灌溉等事。

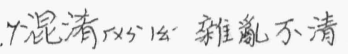

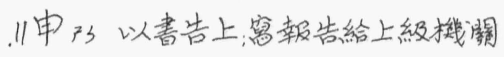

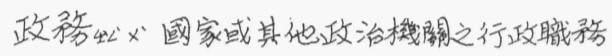

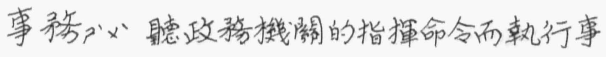
務

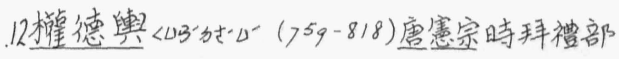
尚畫同平章事, 箸有權交公焦。

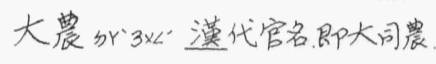
13唒原常久。

恒规猶言常规

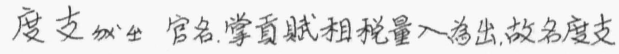

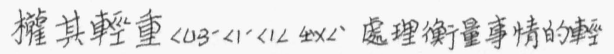

重緩急。

特引”依賴

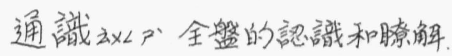
.19銓 $\angle U B$ - 選官

銓選審查资格, 授以官娥

真舉《必《屾”古時諸候每年真土於天子又有良 真舉。 .18刑獄下以心閣於刑罢坐篮等事

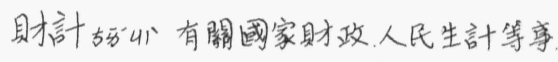

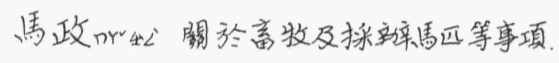

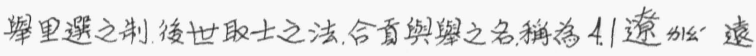

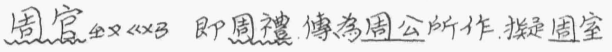
之官制

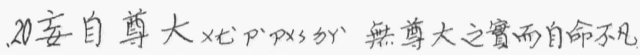
比附外地”以進似者相比。 .21諦加詳審

諦考深思詳細的蜜查深深的思考 龐昽大

龐大很大

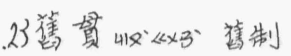
.26紊×5 熖

紊不堪言乳得不能榄。

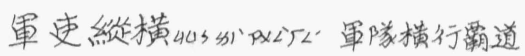
疊吅一重複

州郡畕架州郡政府的層層組䋨常有重 複

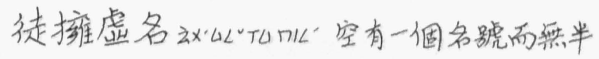
點赛算

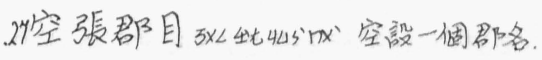

.29牧伯叭的”買州之長官。

轍待”車輪走過的印子

同出一轍自一保路出來，形容其相似 30才敫介徵召通告之文書

檄外朝廷文告所万及的地方, 猶言政府管 害區以外之地

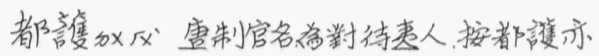
突影铻國主之橉

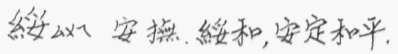
33 大漠加哦指外嗦古大沙漠。

遼闊 共大宽閵 .4廷导动准古官名、掌刑狱

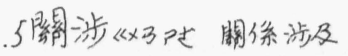
.6振㞣整 
4.6 振絸整理大網

挈《优提, 带頜

挈领提要

振網挈領整理大细使之简單明瞭

8 暂澈《活”忧算通澈底

疏閣防政”不精密

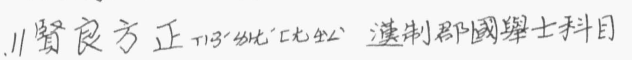

之一魏熋度宝皆沿之

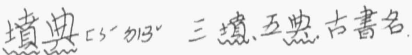

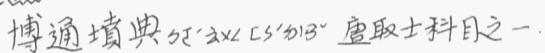

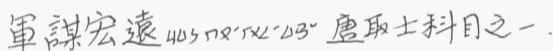

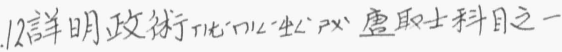

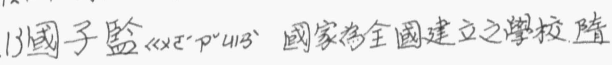

\section{至清稱國子篮。}

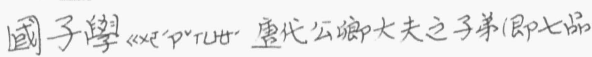

以上官员之子弟所進之桼校殿国子篮之一種

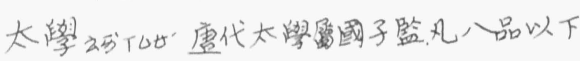

官员之子弟及庶民之俊秀者得入太整

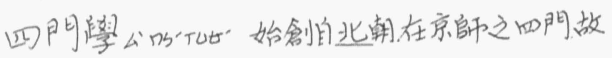

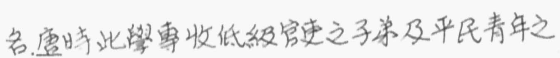

绶季节

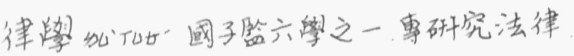

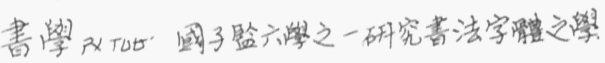

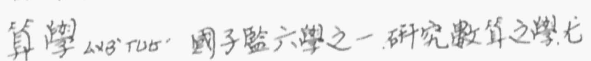

以推华糜日的其主要科目

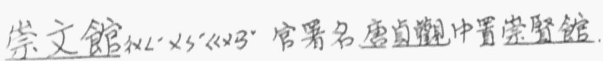

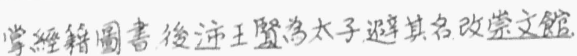
14 仲呿其次策二者

仲冬冬季文第二月即夏磨十一月

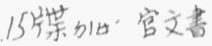

滾铩、碲有官方文書

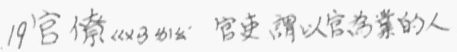

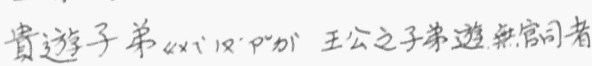

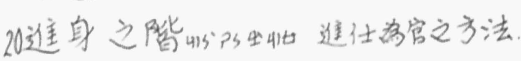

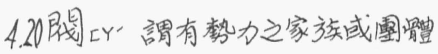

阿栰家世

.22䚺舉私4 40 皇帝下令而舉乵䛨考試。

23察舉行 4 山 考察選舉

孝伀子女對父母應有之態度行学

孝廉下公办污由各郡推舉出品德高超的人才。

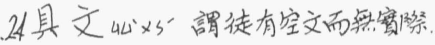

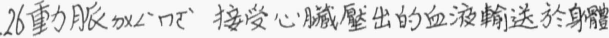

各部之血管。此透表示原動力的意思。

24泯除心行”消除

售く閏没

誘必教道

䧄誘開唉教道

凝312.成聚一液體漸結济固體

凝成相聚而成

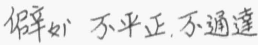

壤昽地域

诏辛㖶偏僻地方

向心力化似引向中心之力

.28我《妱不相合

有霡我有時有效，有時然效

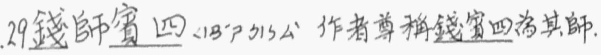

金富四即金穆、第一課註解及第十五課。

康为用

無庿不用

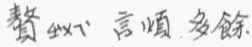

熬言名言之謂

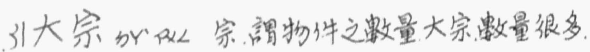

34 不加为中重量之笨位为十斗合103.55公升

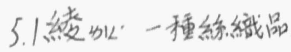

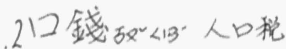

力役か门颜用民力以供営役

.3憧憬往 412 想念

憧憬稻道想念错掦 
5.6 勢《蓝

.9日絀日”代、日溸团蜼

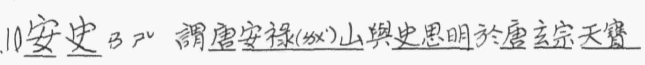

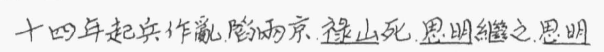

死, 其子朝義繼之, 歷三代, 凡九年此難始平史搯 安史之㩱

科敛㱜办召敛同钴、凑集钱物

毅门果決

毅燃決然
5.20 溥奴

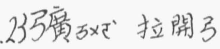

彍騎遭代宿得兵

禁4 15 古時喟天子所在

禁兵䊈帝王之衖兵。

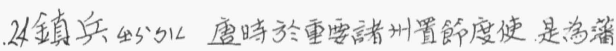
( C B ) 鎮, 鎮兵济籍鎮之軍隊

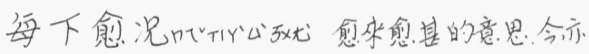

作每况愈下

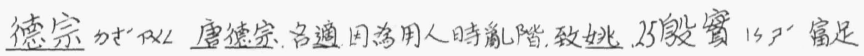

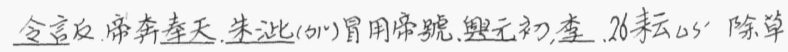

是收復京師帝乃遗, 在位二十五年( 780 - 804 )

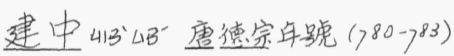

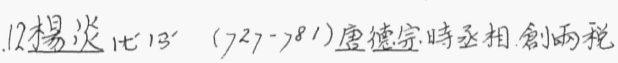

法以代租電調制

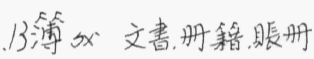

以見居等簿以居住的人, 列入名册按册 納税

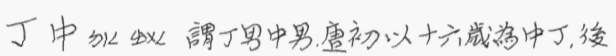

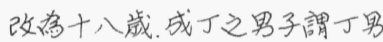

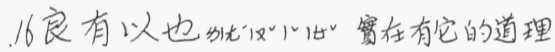

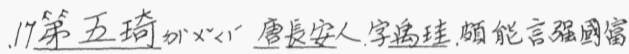

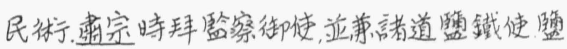

鐵名使自琦始。

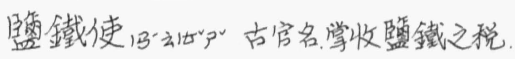

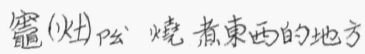

推《征税

收推其篮征收辟税

18 益税八奴增加税

饝昡”曹富

19訖く舆选通至也

訖未安定始终波有安定

200浩伀大, 多

支度浩繁用费极多。
耕耘 耕田與除算

輯耻社”則

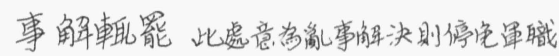

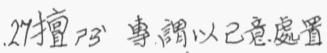

専擅不請命而行

. 28 柰隶籍出山服兵役、柰隶㩯軍籍也

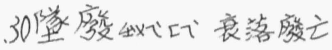

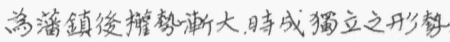

綰勿”联絡

綰控 聯絡控制

峙出直立不動貌

峙立数立

.32㿝訟槶吏

息衣瀮道形容满街都是兵土表示兵士之多

6.1 摹吧”與摸通掉仿也

规摹獏仿

2 答名鹪刑之一以竹片杖打

流为售刑之一遣送犯人到遠方

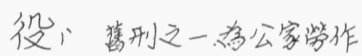

了绞山售死刑之一用繩使繁而死

斬生3”售死刑之一, 以力断頭而死 
6.3 四《關禁。因禁, 閶進監獄。 凌外侵犯

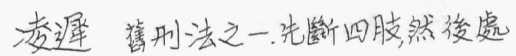
死。

磔坐さ”分裂肢體

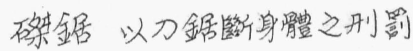

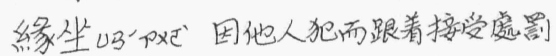
族言朱F出部一人有罪而殺及新戚族人 4 嚴酷13“5”嚴格而䁈情。

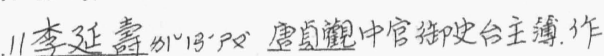

南北史一百八十篇, 颇有佟理。

云山救言, 謂, 説

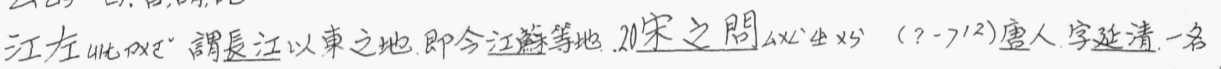
宫商《顾宫商皆为五音之一宫商在此指

詞曲。

㻐越巨Y山だ㡎掦，指音韻

綺《1, 美䨳

貴於清綺以清潔策烈浮有灀值 朔煺”北方

河朔愄河之北

桌私正

真佣正直捯强

１2氧算《出一性情、天生之情態

碑引刻有文字以便倦守或作紀念之石

北碑北朝的碑

帖云化作書於紙上曰帖

南帖通朝的帖

仍表徽夘“出人摽記證明

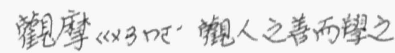

砥方磨石之細者

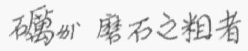

砥䃇磨鍊之意

14 林多以文算具偖貌

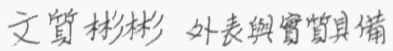

6.14 周”加么用刀在木石或金㳟上刻字或花紋

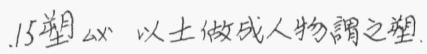

彫塑彫水或塑土制偶像之謂

197 詣!謂所至之境 造詣如言塄桠深入日造詣 飫心飽

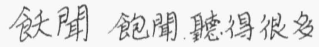

高様《幺 $3 K^{v}(1350-1423)$ 明福建人、工詩为 蛙中十才子之人。

.18浮地, 虚而不䆵, 在液體之表面而不下沉。

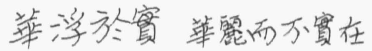
.19風人CL 日 5 猶言詩人

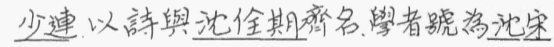

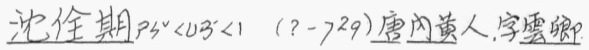
魏建安後、詩律属㡎、至沈宋二人皆菜麗如

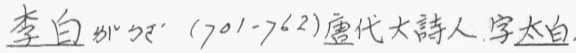

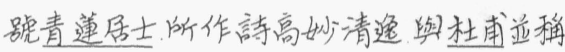
詩宗

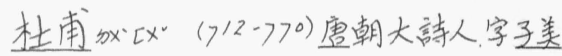

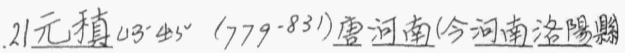

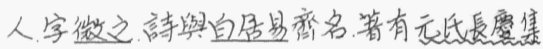

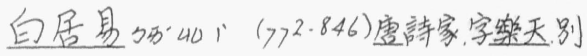
䠎香山居士，其言寺深愿密霞、而平易近人、與 語體颇相似箸有血芯長聪焦。

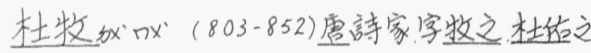
孫箸有禁( $(23)$ 焦

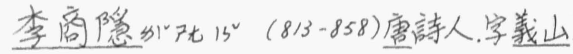

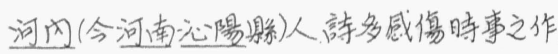
22 律言寺恥?近體言寺之一種、分五言、七言二種。

有一定格式 渾化文、多 涵的包容。 錦鏞, 为初需名家 
6.22汪忧深腐、液體物停聚一處日一汪

汽咙廣大, 万可知, 水貌

甫渾涵汪洼千角萬特甫指杜甫, 形

容术土甫之詩用詞题才之精两富。

.23祧云幺遠糜学祧, 意遠祖之朝世數遠而特透

不祧之大宗不透之大祖廟，意即石可更 改的大始祖

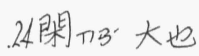

夙暇本謂唖事之時在本課中意指文章疏

䧄

瀻个13 細微，小

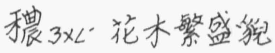

瀻穠(或曰槽繊) 謂細小與繁密。

.25簿万逼近迫。

騷么幺指詩文之事

風騷指铣垒之風雅, 及離騷

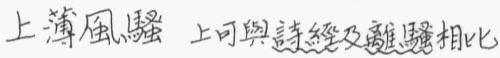
該《历，兼偖

䔡李李加 指穌武與李陵以五言詩箸名

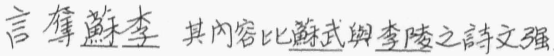
者动包含湮没

曹劉弦“加”曹氏父子(曹操, 曹歪、曹植均善文

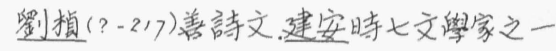

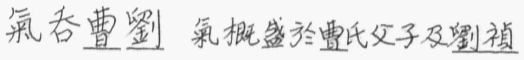

掩污䈉㣰藏

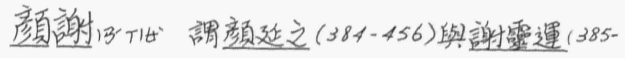

433) 皆南朝有名的文人

孤《x特出幼年無父、弧高、謂性情超出流俗、

徐鹰仙山徐陵(507-583)庭信(513-581) 二人

文章皆綺麗, 有名

流麗加外流惕美篦

.27信然 $155^{\circ}$ 炚。謂果真如是

相尚化陇互重

廟堂吆礼, 宗廟, 朝廷
627 西州得勸酒、報答

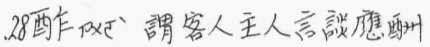

酬酢朋友交往應對

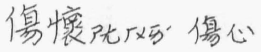

善陳P分後喜好述説

.29揭4 4 世高舉,表露

民㣰n1 152 民間不能上迹的痛䇢

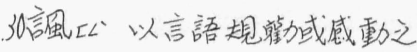

本諷以言語譏笑或規勸

職志出出志願

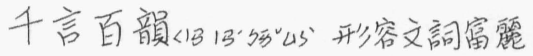

了壮犬摩的她叭哔畫形容

江湖山必仪表示曲方之意

没寺公和尚住的地方。

佛寺佛㾰

道旅引如”客店旅舍

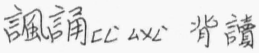

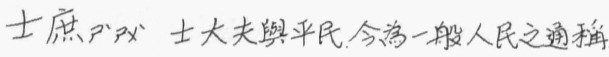

僧心信奉佛教的和尚

僧道僧徒與道士

獳旴兒童

娼彶妓女

妓娼妓女, 歌女。

34風尚洦优風氮

椇圪置党货物

販夫置責货物之人 走卒阳跳供奔走的下人

7.1口今心 背誦朗讀

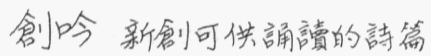

敦煌的炬忧”甘肃省夥名、因藏有唐及五代人

手富的書甚多而出名

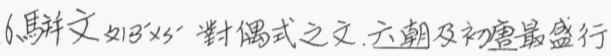

古文《x x s 文體文, 本相数於騂文而言, 故沿

用有散體文这専粍 


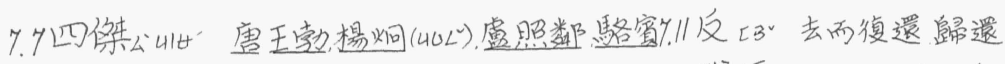

王四人文章弯名踇初需四傑。

措地置

措㣪謂敦話作文時運用的詞向

䨓出义聡結編輯

笝對謂认雨語聒接成對

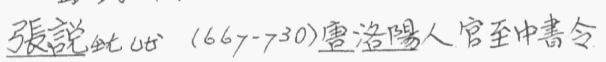
封燕國公朝廷大作，多出自其手

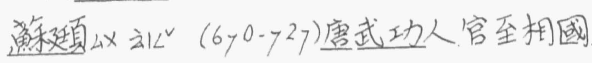

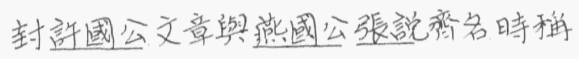

歪許大手筆。

8㢈山和

雍容有威儀也

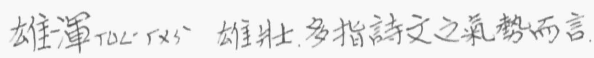

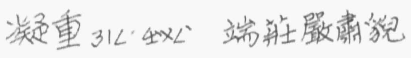

陳行南朝之一篮三世, 凡五主共三十三年

$$
\left(557^{-58 q)}\right.
$$

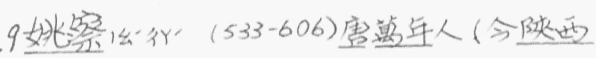

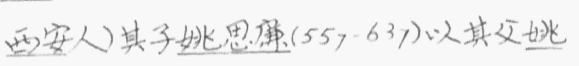

察之盖稿成染書陣書

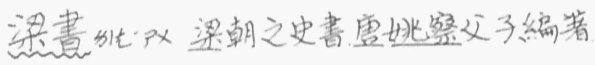

凡五十广卷

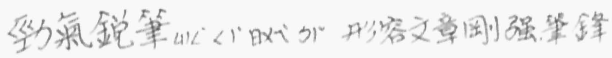

尖锐

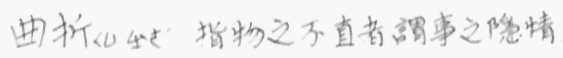

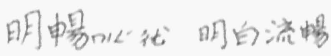

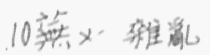

篦见新消多食余

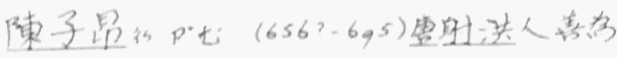

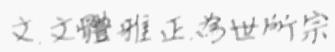

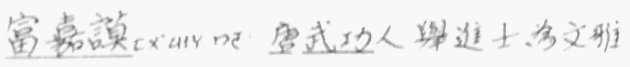

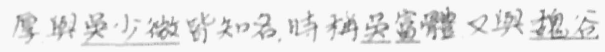

因同䊈北京三保

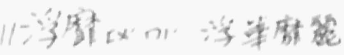

雅正1 Y 的公文雅正直

大曆汃的唐代宗年躆( 766 . 779 )

真元幽吗。善德宗年號( 75 - 804 )

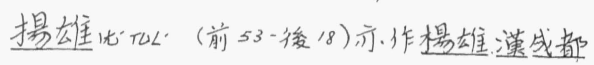

人字子雲, 博懔深思, 以文章箸名, 者有法言

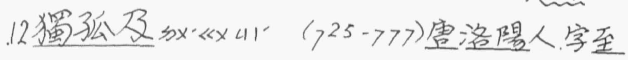

之, 性孝友、为文表明善惡長於言義論, 有毗陵焦

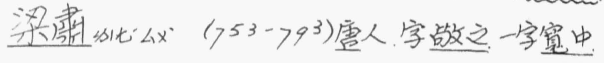
建中初中文鲜清震科，多次作皇太子諸王侍 敦

奥公精深。

暲愈5 3公( 768 -824)磨昌黎人, 或日南陽人字 退之通六經百家, 崇懦乎佛, 文章自成一家, 为佼 世治古文者所效法。

鋭意时们立志堅決, 一一意

鍇P以3 籍究義理

瓚仰深求其理而信仰这。

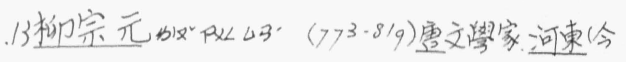

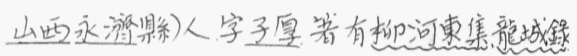

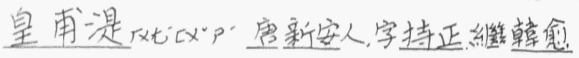

而倡古文箬有皇甫持正焦

李毁为“玄 $\left(77^{2-841}\right.$ ) 字望之趙郡( 今河北趙夥

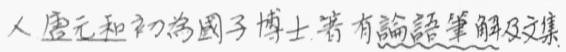

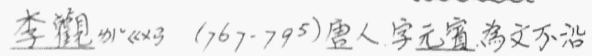

謷前人时謂舆韓愈相上下，有李元愎文編

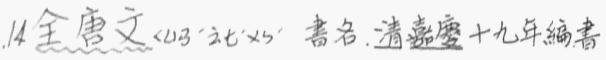

中有需一代之文九一䉓八千四百八十八篇三

千四大

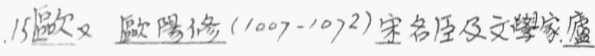

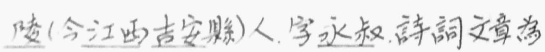

世所重

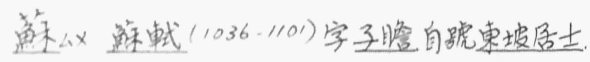

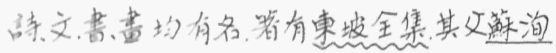




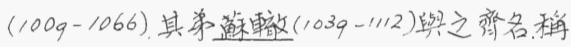
逼代父子或三䝵

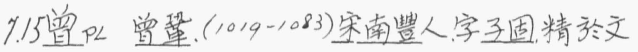

章箸有元慧類稿

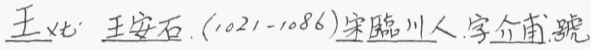

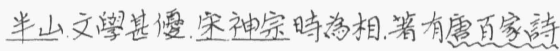
選等。

. 16 增云3 . 拜天地祖先時所用的台, 古時有大事多

設增如朝雷、盟䈍、及封拜大特皆用之

\section{文增文残界}

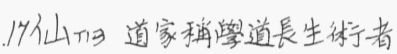

神仙道家稳得道之士能落化不测者。

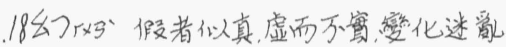

設奇墨幻設計一些奇㤏的事情、且極畵 彎化

.19悽 1 悲鹪

婉奶”美、和㮌随和。

悽婉謂啨音悲哀而婉轉

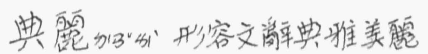

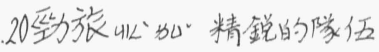

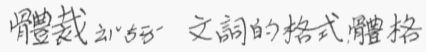

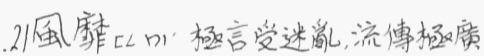

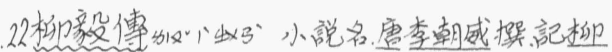

毅遇女言是龍女为其夫所县，託媇带信與

其父洞庭君後毅妻死, 再娶則济龍女

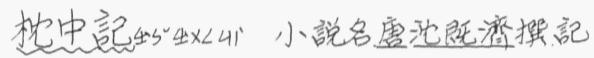

虚生遇道者号公、授以枕、枕之入夢、爱中歷

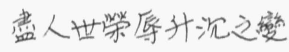

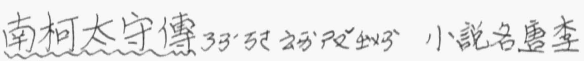

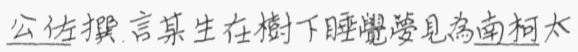

守之事, 立意與枕中楌同。

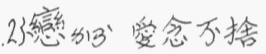

愈系接男女相愛

豊色口豊色之俗窎, 幍事之有閣受情者。
豊色情 指美麗動人的愛情

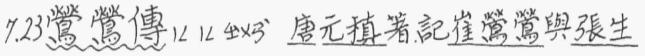

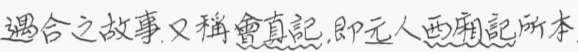

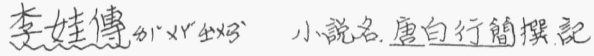
各妓李娃與常州刺史榮陽公子離合事

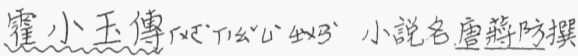
記名妓霍小王與李十郎有約，两李员約不往霍 皘思致病, 一日有黄衫客强摤学至、霍既胃查。 一㔖而死

估跋外・言行路之莫住

扈不强撗

跋扈强霸之意

俠TY扶弱抑强者

豪俠有勢力而行善之義俠

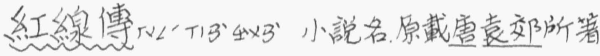

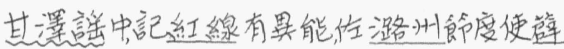

禽治事之故事

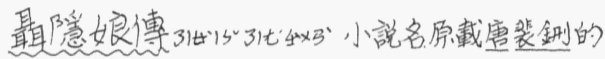

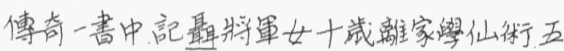

年後回家所作神具之事靕

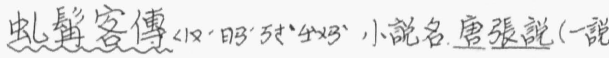

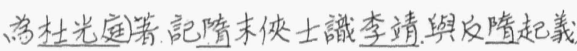

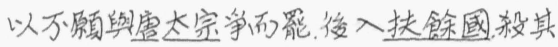
主而自立

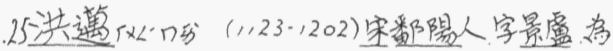

留極精博、䈐有夷堅志等書。

.28詰告《出下之文。

誌出記事文之一種

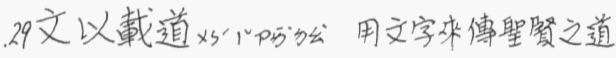
遇萬䟚超過

遇越超越

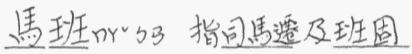

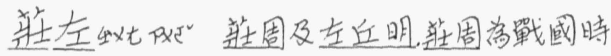
蒙人其人生管是在随順自然, 舆老子並浮道家 


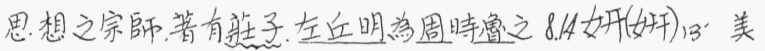

太史、依春愁而作傳, 名日在芯春愁亦名态

悪

7.29 並肩痤左舆邀左相等

.30臻到至、及

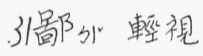

32泊化一信, 真

消学卓誡窗在具有高超的見解

外経秋地連, 結合。

聫等叒連結, 連合。

8.4 相映成趣化心行《互为参炤更学有趣。

俚加鄙俗

俚俗 粗俗

５翤司公繼續，謂子孫

觡後以後继續

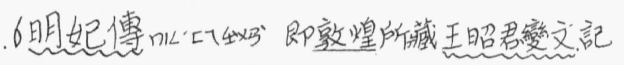

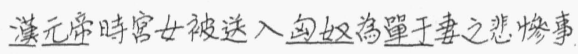

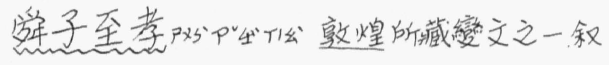
古帝舜之孝行。

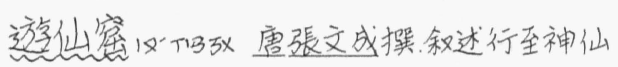

窟遇雨年青女子的故事

. 9 真《 $<2$ 短時間

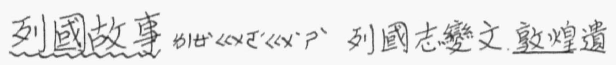

青之一叙述伍子蛋避楚逃吴事吴伐楚後被

耓事。

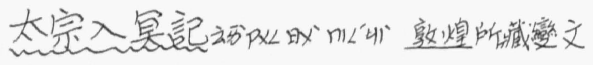

之一, 述層太宗生魂到除間事

韻語心心䫓文即有赔之文。

10 尔4 5 懹胎。

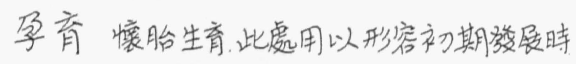
. 13 遒仅健

迺丛力筆意老練

方嚴远峌方正箃整，筆意老練 . 14 榜然揭示, 又専指揭示考試名次之榜。

疏放娥妙, 大方不拘束, 美麗而神妙。 札此古代富字之小水它、今多指書信。

薢札書信

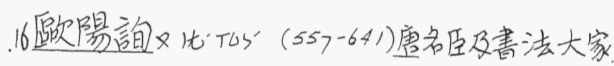

遥湘( 今楜南長沙㲘) 人

羲之川出王载之

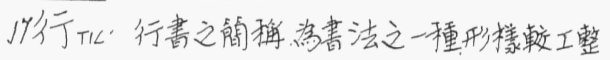
端正。

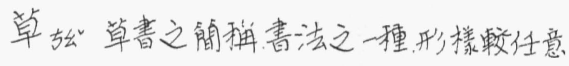
流利。

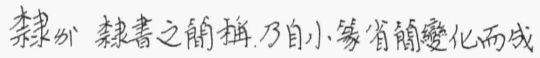

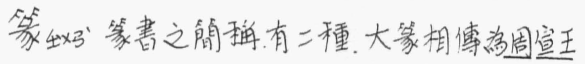

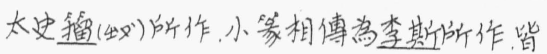
古體文字。

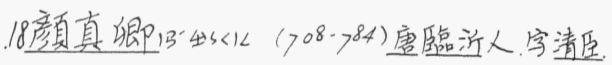
玄宗時为平原太守, 博學工詞章, 善法筆力强 勡有力

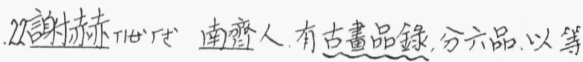
差畫家偠劣

.24盩如一起火, 存火之工具

一烣表示融化吸收之意

緒们謂作畫

縚事腐幍作畫之事 . 25 朝野後“涹”指朝廷與民間

㐭監朝野北得到全國的稻諧和尊故

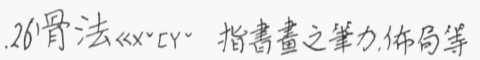

凹幺邊高中低之形粶如“巴”

当议邊低中高之形粶如“沐”

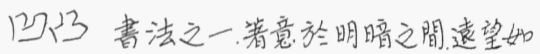
立顝近看有平面之花紋。

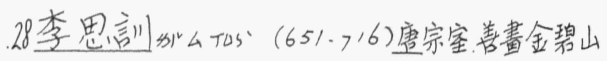
水为北宗畫法之祖、封彭威公漓左武衛大 將軍，世稱李将軍。 
8.28 傅坛“附箸附加。

傅彩, 猶言箸色

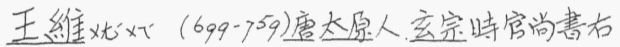

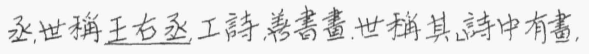

書中有詩”畫瓷南宗之祖

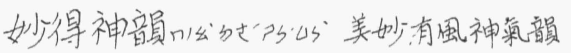

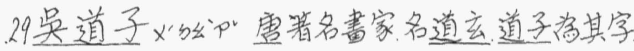

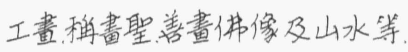

.30騰云上上升, 奔跑跳起

騰譽 督名極盛

士林户”此”謂文士所聚集

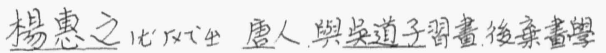

塑致成精絕, 世稱聖手

.31雲圈US'《t在山西太同夥西武周山, 以北魏

石佛箸名

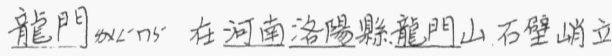

刻塑石佛甚多, 大半造成方气北委鬼

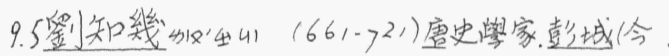

江䉏銅山夥人，字子玄，著史通，深具史䧕

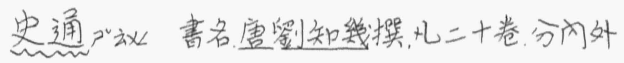

篇内篇諞史家體例、外篇述史籍源流、类我

國最初之史翼理諞書, 清浦起龍有史通通釋。 極敦明

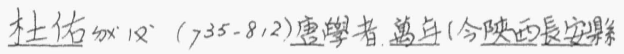
地人字君榔。官至同徒, 撰通榓

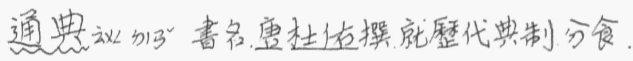

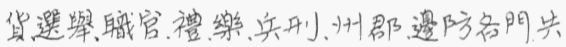

二百卷

.4中肯的心 万謂議論得其要點

核代詳察果子闪之硬算以保護其中之揰子者,

精核精解而得其中精要而缓過仔細考察

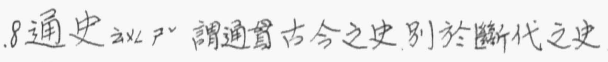

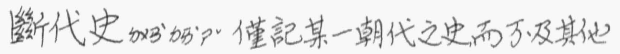

者

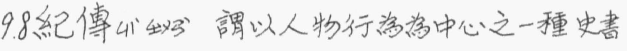

體裁

編年313313 史之一體、依年代学序将事踶於年下,

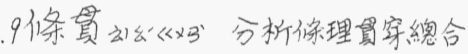

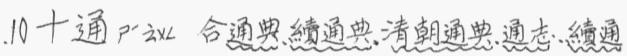

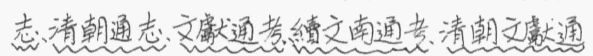

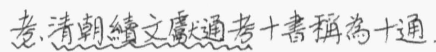

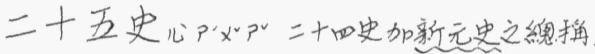

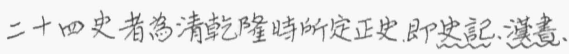

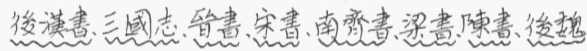

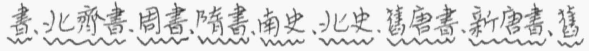

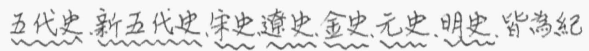
傳髏

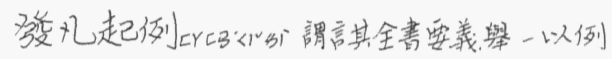

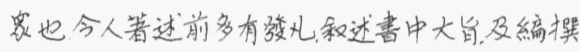
體例、亦稱九例

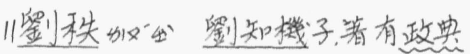

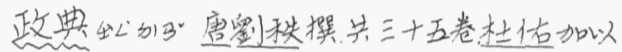

肼元禮樂啅曰通榓

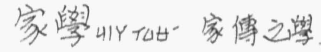

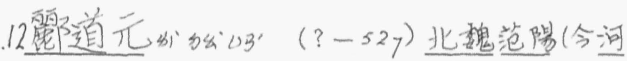

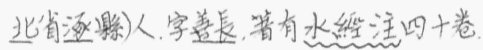

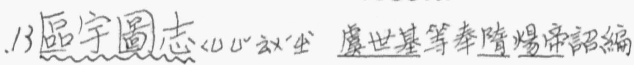

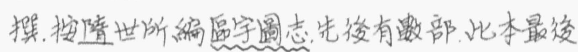
出, 规模示最大, 共一千二百卷

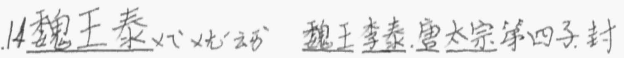

魏王。

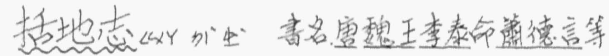
捛风五百五十卷，序略五卷。

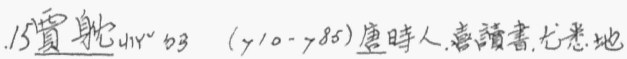
理, 九四方文人或出使责狄者, 必詳間各地现俗。

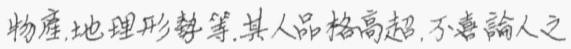

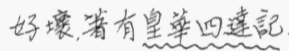




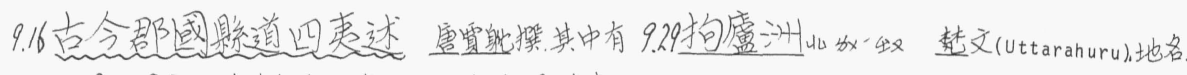

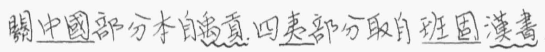

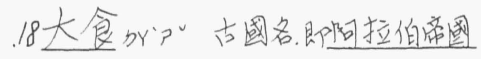

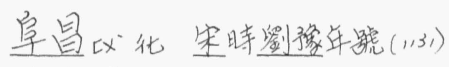

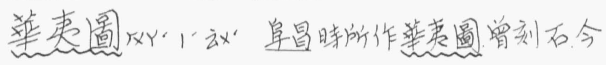

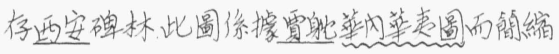

者。但作者石詳。

19 墨吸黑色

朱政色

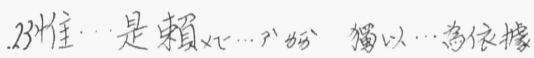

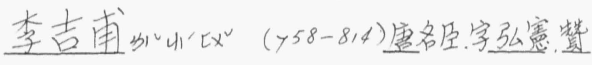

皇人㥶宗時学相。

元和郡縣志透李吉甫撰地志存於今者此

学最古, 已遗失七卷半及圆、今本四十卷。

.24具詹P3 秘富

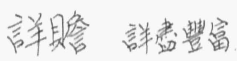

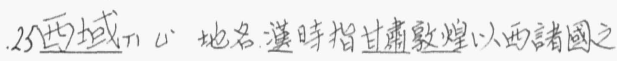

總稳

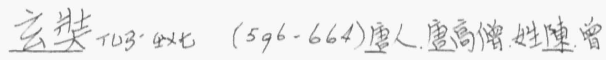

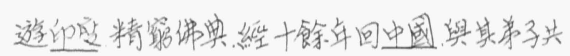

碩佛䍃

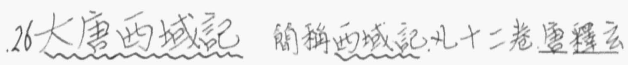

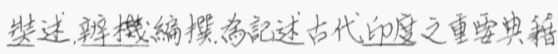

英、运等國皆有罣本。

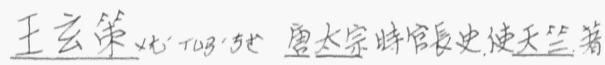

有中无督行憝

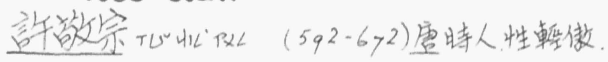

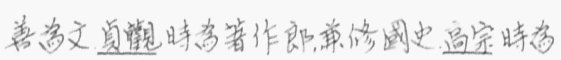

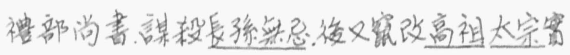

録箸有西域圆志

.29思提髚洲奴云化生楚文( Videha) 地名

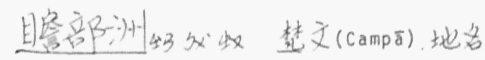

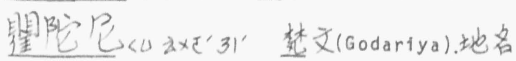




\section{第八課部曲沿革寒放}

楊中一

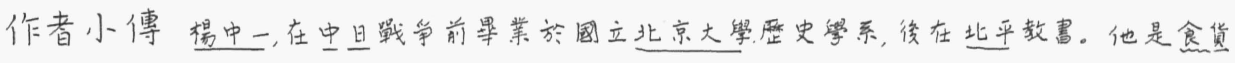
半月刊撰富端文較多之一人。

本課簡介本課取自㛫中一在食货半月刊第一卷第三期中墢表的部曲沿革略放。全文分十三

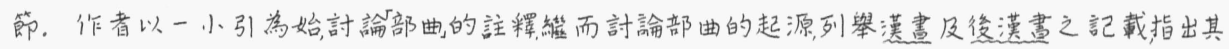

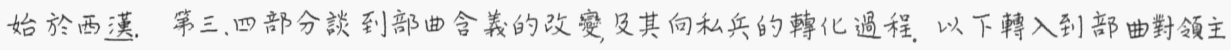
的義務, 包括從牫及服納租役的義弱; 领主對部曲有加以保護及供給耕地的義務。再討論到由10

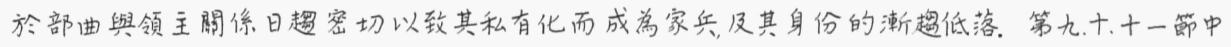

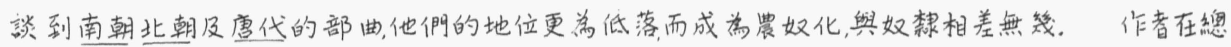
括全文之前, 提到部曲二字另外的用法, 以免譡者誤會其用於别勮之意義。

\section{一 小引}

在中國的史籍上, 我們常常看到部曲二字的連文。注疏者在這 二字下面都是這樣的註著:

後漢書息官志将軍領軍皆有部曲。大将軍營五部部校尉一人, 部有曲, 曲有軍候一人。

這種註釋, 不能夠包括了部曲的含義, 那是不用説的更進一步, 毁部曲考的作 20 者何士驥君研究的結論—

一部曲二字連文之本義, 即軍制上士卒隊任之義。

二部曲在唐代為供象之義。(國鼠論丵部曲放)

也是不能使我們了然於部曲的沿革。對於部曲最好的解説據我所見到的, 是:

後漢末及三國時代有所謂部曲的身份師由後漢時期家臣的身 分轉化而束。唐代法制部曲是半自由的身分。在後漢三國, 這 大約是私家將士而已。……束漠的大私有土地便是橿後的荘, 私

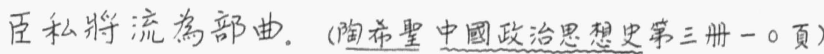

在這幾向話裹, 陶先生很簡括的給了我們一個部曲沿革的輪廊。但只是一 30 個輪廍, 於詳確的了解部曲的沿革, 還是不呴的。

因此, 對於部曲沿革的考究仍然不是無意義的事。本文毁想作 進一步的考察但為舉力及時間所限搜集的材料太少, 依舊不能有充分的述 説。好在是一個賞試後日有得, 當更加補充和改正。尤盼有識學者, 不苔賜 
教, 使區區此文得成引玉之磧那就非常榮幸了。

$$
\text { 二部曲的起源 }
$$

部曲起源於西漠, 為行軍時軍隊编制的制度。淩漢畫息官志: 将軍不常置。本註日: 掌征伐背叛……事訖即罷……其領軍皆有 部曲。大将軍營五部、部校尉一人, 比二千石, 軍司馬一人, 比千石。 部下有曲, 曲有軍候一人, 比六百石, 曲下有屯, 屯長一人, 比二百石。” 其鉒将軍, 置以征伐, 無員職, 亦有部曲司馬軍候以領兵。

從這段記载裹, 我們可以看出, 所謂部所謂曲, 俱是軍隊的編制猶 如现在的軍、師、旅围虔軍隊中的編制是一様的, 這由在西邁時凡稱部曲, 都是 10 指著軍隊的編制説的, 亦可證明。如:

及出揧胡, 而廣行唖部曲。(史記作伍伍亦軍隊中的一種編制.) 行 陣, 就水草屯舍人人自便不擊刀斗自衛莫府省文書……程不誡正

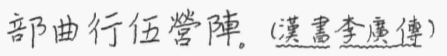

顔師古註日:

15

20

傮尚於簡易, 故行道之中而不立部曲也。

很明智的這是關於署置部曲的例子, 部曲是軍隊中編制的制度, 如果認為這例子不算充分的説明, 那㦄, 我們再看看趙充國的話。趙充圈説: 今歸步卒萬人屯田, 地勢平易, 多高山遠望之便。部曲相保為整羁 木樵校聯不絕, 便弓努, 飾阴具烽火幸通, 勢及辩力。以逻待勞, 兵 之利者也。(藻書趙充圈德)

在屯邊的時候部曲須繁及䧧力的相保可胃部曲是軍制了。

\section{三部曲含義的轉熟}

大概因济部曲二字常常被連結在一起, 運用習惯了, 於是, 本凮軍 隊編制的部曲一轉而成了代表軍隊意義的代名詞了。這種部曲含義的擴 25 大䧺在新莽大乳的時候, 因為軍事旁午, 部曲二字總會不離人們之口的。部 曲有了卒隊伍之義就是這㧽緣故罷。

東漢之初部曲多為士率隊伍之義, 如某某的隊伍、即稻為某某 的部曲:

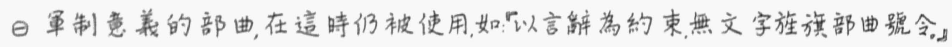

(知金子德)就是一個例子。

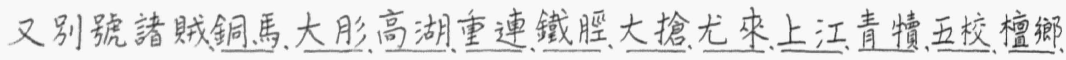

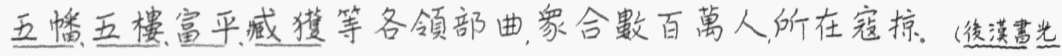
武㱔)

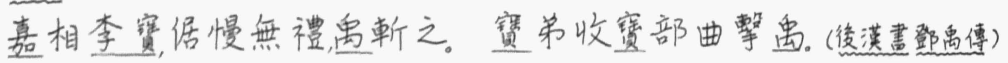


這時部曲成学軍隊意義的普通名詞了。

四部曲向私兵的轉化

部曲身分的轉签, 是在漢末三國時期。我們知道, 三國是中國歷 史上的一個重要轉舜時代——奴隸制轉向農奴制的時代。與二世紀以 後之羅馬很相似。部曲在這個時期裹由隊伍的意義轉化為私兵。

部曲向私兵的轉化約有下述载點, 可以作爱原因看:

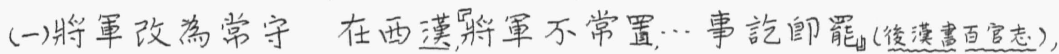
所以將帥與部曲不易發生惯切的關係。到了東漢明帝時,將軍改為常守。 明帝初, 置度遼校尉, 以衙南單于象新降有二心者。後數有不安, 遂 諞常守。( 後漠畫百官志)

將軍由整置改為常守, 遂與部曲有發生特别閵係的機會。因此主帥與部曲 不僅有從屬的閎係, 而且形成君臣的職分。

(二)郡國守相得自置吏東漢時太守的僚尿, 視太守為主人。屬吏 對於主官的關係, 㨡趙翼的研究是:

後漢畫: 盛洪為太守張超所置功曹, 超遣詣幽州, 中途症袁紹所留, 15 以洪局東郡太守。會曹操困超洪乞師於紹以救超紹不許超竟被 滅。洪乃與紹絶紹興兵圍之城破以死殉。太守歐陽歈欲舉督郵 颜延為主簿郡吏郅惲起而言日:延资性荟邪, 明府以恶為善, 主簿以 曲学直, 此既無君, 亦復無臣。公孫譛初為劉太守郡吏, 太守坐事徙 日南, 譛祭先人塚日: 昔為人子, 今為人臣、當詣日南, 今舆先人梓於此, 20 遂随太守往。則並㙷然有君臣之稱也。劉表遣從事暲蓠詣許, 欲 以觀虚惯。嵩日: 若至京師天子假一職, 則為天子之臣、将軍之故吏 耳, 不能復為将軍死也。可見未仕於朝者, 猶為私臣也。甚至有為

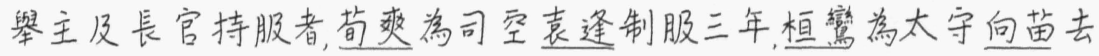
官奔奕終三年, 此虞舉主持服者也。王允為劉瓉終三年, 此為長官 25 持服者也。(陔稌暴考郡圈守相得自置吏條)

由此可見郡國屬吏對於長官不但有君臣之分應為長官死而且, 發生了似乎

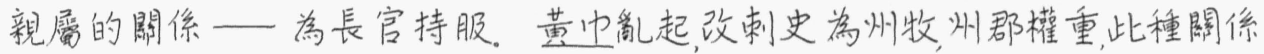
更学發展了。

(三)屯田制的惯行屯田制度本不始於三國但牠却於此時發達3 0 起來。自曹操用囊祇韓浩議建置屯田, 積款許都, 以制四方, 收了效果之後屯 田就大大地與盛。其屯佃的情形, 可於下引記載見之:

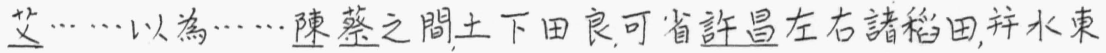

下。令淮北二萬人淮南三萬人, 分休且佃且守。……遂北臨淮水, 自 
鍾離而南, 横石以西, 唒沘水四百餘里, 五里置一營營六十人, 且佃且 守。(㗂畫食货志)

建置屯田的登艾的將士。稻部曲。魏志鄧艾傳:

會已死艾本營將士追出艾檻車, 迎還。

5 在至畫段灼德中，却説:

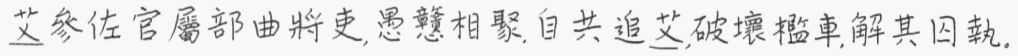
由此可見屯田將士與主帥發生的密切閏係了。

(四)豪族屯聚随著土地的兼併而發生了豪族, 趙魏豪古, 往往屯 聚。黄中槞起电聚更学發達。

依故河間太宇陳延璧。陳溤二姓舊族官冕。張掦利其媂女, 貪其 鮆剘。㷊率其宗族学之策畫, 圈六十食日, 卒全堡壁。(魏志常林傅) 張揚以數萬之象, 不能攻下故河間太守陳延壁, 可見當時豪族屯聚堡疁之 堅及其守衛之冡。

時袁紹盛於河北而汝南紹之本郡。門生宾客, 布在諸郡, 擁兵拒守,

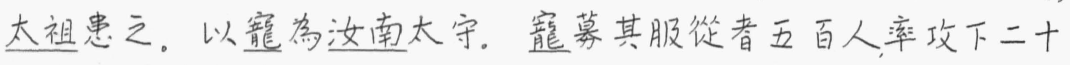
餘壁。誘其未降渠帥, 於坐上殺十餘人, 一時皆平。得户二萬兵二 千人, 令就田業。(魏志满憿德)

這更是豪族養私兵以资守衙的事暧, 所謂豪族, 是與官僚分不開的。

由於上述䉝點, 我們可以看出部曲向私兵的轉誉的痕跡來; 部曲 20 與主官相虎日久發生了特别密切的閆係漸漸地轉学私屬遂為盡守衛之责, 因而形成與西洋騎士(knight)相似的私兵。

\section{五部曲對領主的義務}

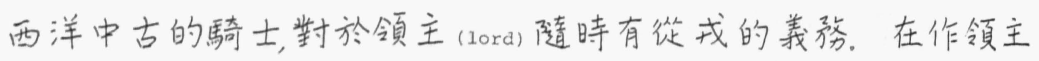
的騎士的時候, 騎士須要宣誓, 以示忠茓。部曲也是需要向主將聽誓, 周禮大 25 司馬:

郡吏以旗物鐸鏡, 各帥其民而致質明弊旗誅後至者……韋吏聽誓。 賈公彦在下段疏云:

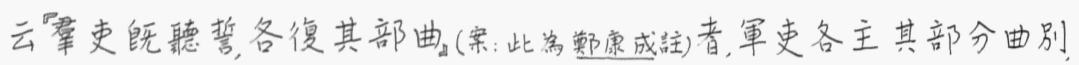
謂若伍長主五人, 雨司馬主二十五人卒長主百人等, 皆是部曲。至 於誓之時, 出向象前。璤誓訖, 各復其部曲本處, 故云復其部曲也。

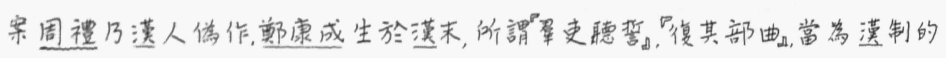

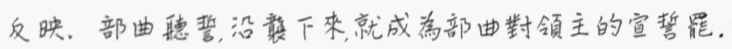

部曲對於領主有随時筀我的義務。

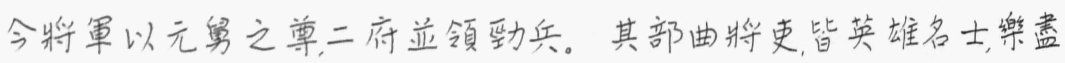


死力……(九州春秋, 魏志袁紹湮註引)

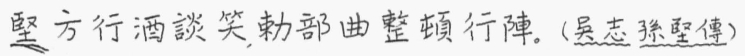

以部曲随先主入蜀, 數有戰功。(罳志魏延傅)

除了從或之外, 部曲對於领主還有服納租役的義務。晋畫武帝

紀:

泰始元年, 詔復缺役, 罷部曲将吏長以下貿任。

感䔰三年, 大䞑, 降除部曲督以下啠任。

梁啓超糬留任云:

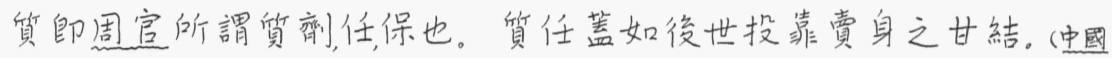

文化史諽義)

10

疑梁説非是。因為所謂“罷, 所謂降除, 不宜指著甘結説, 蓋前覞言 罷其後就用不着再降除了。且“降除義為减除師减低之意, 甘結何能减低? 因此, 頗疑貿任為部曲對於領主的貢役, 如此, 則所謂“罷所謂”降除方總可通。

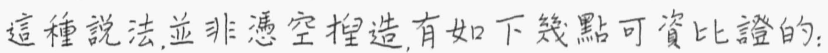

( ) 質舆貲通, 貲是臣下見君上時所執的禮物。孟子:

庶人不以傳質為臣。(萬音)

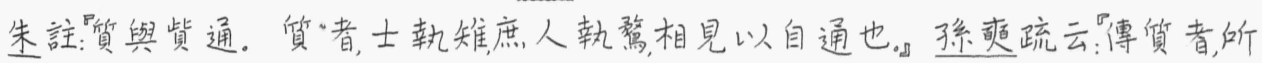
執其物以見君也。如公執桓圭, 候執信圭……是所以䈪䞇也。又管子:

令諸侯之子將委筫者, 皆以隻武之皮, 很大夫豹飾, 列大夫豹幨。

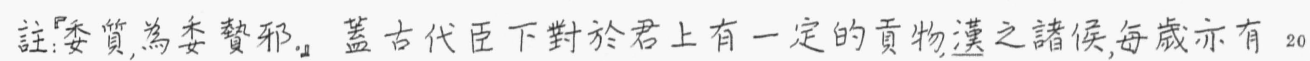
酎金的獻納。這種獻納就是部曲對於領主真役的前身, 因此部曲對於領主

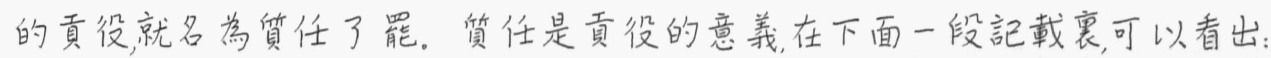

然山數未集, 糧仗不多。宜錄州郡大姓子弟, 以禹留任, 㚹附廣漠, 付

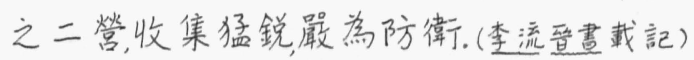

算任不是甘結, 應為多“糧仗的真役吧。

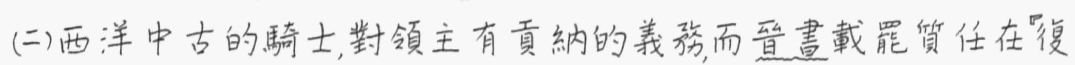
徭役之下, 可供對比。

(三)部曲向領主有租税的責納。圎睃李雄載記:

加范長生天地太師, 封西山候, 復其部曲, 不豫軍征, 租税一入其家。

這樣看來, 貿任似應作梖役解, 那末, 部曲對於領主除了宣誓從或 30 之外, 還有服納賁役的義務了。

六領主對部曲的責任

部曲對於領主既有如許的義饬, 領主對於部曲有什麼责任呢? 這, 可以分做雨點, 一是保萑部曲, 一是給部曲土地去耕種。 
部曲之受領主保護乃是一句空話。因有領主本身師須部曲來 保衛, 又怎能保萑部曲呢? 不過領主有許多部曲, 成学一個集團, 比起孤立的 人来, 不受兵匪的騷擾, 所以所謂保護部曲, 惯是部曲自己保護自己, 領主只是

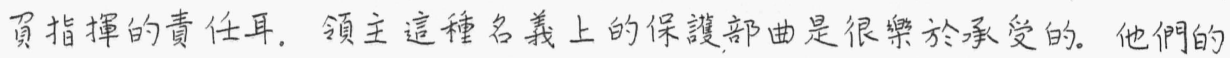
5安危, 是以領主的安危為準, 所以有時他們還對領主進些意見。

通親威部曲流涕日: 今孤危獨守, 以失大援亡可立而待也, 不如亟從, (鬿志圼通德)

在政治上, 有時為覊摩領主, 先安其部曲。魏略:

(孟)達以延康元年率部曲四千餘家歸魏。……若沜欲來相見, 且當先 安部曲, 有所保固。

領主與部曲, 茓在是有相保的關係的。至於部曲䉽種領主的土 地到南北朝時最顯著, 但在魏至時期亦有䇝條例證:

習以别部司馬領主文州刺史。時, 承高幹荒临之餘胡狄在界張雄跋 扈, 吏民亡叛入其部落。兵家擁象, 作為寇害, ……單于恭順名王揞 首, 部曲服事供職。同於編户。(魏志梁垍傳)

加范長生天地太師……復其部曲, 不豫軍征租税一入其家。(曋書李 雄戴記)

所謂”同於編户口, 租税一入其家, 皆是耕種地主土地之證, 部曲赖耕 領主的土地以生存, 因此, 部曲與領主的䦞係越發密切起来。

部曲轉化学私兵, 前已述及。這種轉化使部曲與朝廷的䦣係䞶 於微末的地位, 而與領主有了深切的依頼闢係。州牧的部曲, 就是州牧的私 兵不過在名義上屬於朝廷罷了。蜀志黄權傅:

左将軍(劉備)素有驍名, 今請到, 欲以部曲遇之, 則不满其心; 欲以富客 䄚待則一國不容二君。

從這衰透漏出州牧就是邊疆天子, 他的部屬, 與朝廷的關係極学 軗微了。這時部曲, 實即家兵但名稱不同而已。部曲與家兵的區别, 不是與 領主關你的相異, 而是在有無註册(師是否經朝廷承認遇) 朝廷承認過的叫做 部曲, 否則為家兵。

諸将……又競表拜諸營壁民㴜部曲。(槐略)

部曲就是表拜過的家兵。部曲與家兵的分别因為部曲的私有

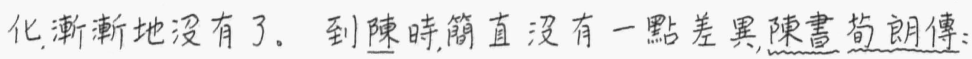

時京師大䬻百姓皆於江外求食。朗更招集部曲推食解衣, 以相眽 瞻, 象至數萬人。……幸部曲萬餘家, 濟江入宣城界立屯。……高祖崩, 


\section{……祕不弡喪……朗弟曉微知之……謀率其家兵襲台。}

前稱部曲, 後稻家兵蓋部曲與家兵㪄一了。

部曲即轉化為私兵(即家兵) 完全依頼耕種領主的土地以生存, 而 領主亦以部曲的貢役虞生活资料的來源於是部曲與領主的闘係愈益深切 化。部曲愈多, 則領主的勢力愈大, 生活也就越益高贵起来, 所以領主多招懷。 部曲:

時四方大有, 摆居閶中, 諸將多引為部曲,……歸者無以自業諸將各

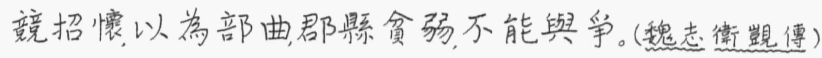

領主的部曲多了, 自己不能管轄過來, 則派人統領著。統領部曲 的有部曲将及部曲督:

將軍郝昭, ……少入軍为部曲督。(䊝略)

諸葛誕剣造凶嫍, 主薄宣隆部曲督秦絜……(魏志炎四)

(何)進部曲將素恕苗……(菼雄记)

今追赐整像䦣中候, 如部曲將死事科。(魏志卷四)

領主学保存實力, 對部曲也㿿力不使其受損失。這於曹仁之努15 力救其部曲, 可以看出:

仁登城望之, 乃募得三百人遣部曲將牛金逆與挑戰。賊多, 金兵少, 遂為所圈、……在城上望見金等重沒……位……遂披甲上、馬…… 直衝入賊圊, 金等乃得解。餘息未盡出, 仁復直還突之, 拔出金兵, 亡其數人。(鬿志曹仁傅)

因桨部曲與領主的關係這樣深切化部曲便與領主的宗族家屬 親戚有了相似的關係:

典宗族部曲三千餘家居乘氏, 自請願徙詣魏郡。( 槐志李典傅)

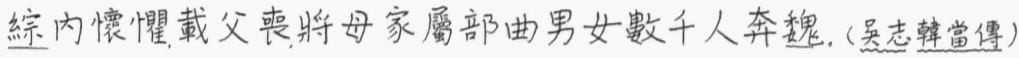

通親威家部曲流涕曰……(魏志桂通德)

不唯此也, 而且常常父去子領:

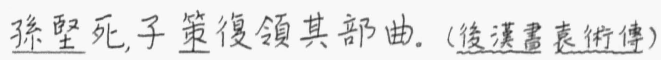

後(馬騰入為衛尉子超領其部曲。

在魏晋時部曲已赹於私有化了。

八部曲身分的低落

部曲的私有化將其原有的身分降低了。在古代兵士由贵族来 充當, 現在他們的身分降低到平民以下去了。他們的地位, 仍較奴㲡為高, 叫 做軍户。宋書沈文秀傳:

㶯獨何人, 而能自立。便可速率部曲, 同列軍門。 
不能自立而須受人保護則列於軍門列軍門, 就是所謂軍户了。 定孝武帝大明元年詔:

軍戶免為平民。(案畫武帝紀)

這是部曲比平民地位低的證據。部曲的身分低在三國時亦可 5 找一旁證。諸葛恪園合肥城中遣士劉整鄭像出傅消息被擒不屈而死。詔 日:

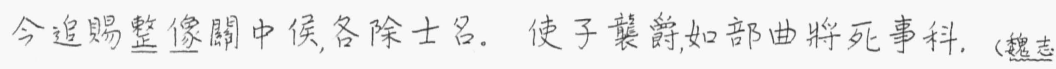
卷四)

這裹所謂士想即部曲, 除士名, 郎去其部曲之籍也。部曲的地位 10 大概與唐代之官反很相似。因為部曲地位。的低落, 在早的部曲的編制到了

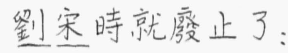

参軍督護江左置, 本皆領營, 有部曲, 今則無矣。( 察書直官志上)

可是在北朝部曲仍桨置官, 至隋尚有部曲督部曲将服制的规定。 ( 凡隋書儀褿志)

15

部曲本学行軍時的軍隊的編制, 後轉為軍隊之義。至其形成一 個階層, 惯由於屯田, 部曲在魏厽時的任務, 多為且细且守。的佃兵。由佃兵慢 慢地成為主㸹的私镯, 由官而轉為私, 至唐就成了類似蕽奴的半自由民了。

九南朝的部曲

部曲轉袋為私屬對於領主的關係自然更形深密起爽。南朝自 20 宋以後部曲節完全屬於私人:

促鿷不受( 不受朝廷之賞也) 部曲千餘人並私加賞整。( 梁書羊促傅)

朝廷賞賜不受而私加赏麥, 可見部曲與政府沒有什麼關係了。 部曲郎完全成為私属所以常舆妻兒家累並提。陳畫高祖紀下:

沈泰反復無行……其部曲妻兒, 各令復業。

25 陳書世祖紀:

世祖鎾收其部曲家累。

陳畫沈象德:

象表於梁武帝, 稻家代所隸故義部曲, 並在吴興。

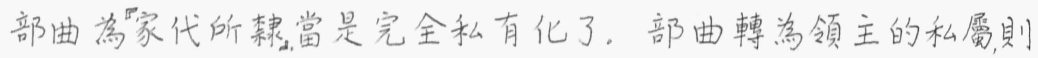
30 部曲節為領主的勢力了。無部曲剔無勢力之可言所以—

琰素無部曲, 無以自立。(南史殷孝祖僡)

部曲與領主地位的闢係既有如此之重要, 自然領主願多多招募 了, 私家部曲之招募舆形成, 可以蕉峻学例。

永嘉之乳百姓流亡, 所在屯聚。峻約合得數千家……推峻為主… 
峻懼, 率其所部數百家, 汎海南渡……至是有鋭卒萬人。……潕納亡 命得罪之人。有逃死者, 峻輙匿避之, 象力日多……遂下優詔徵峻 為大司農……以弟逸代領部曲。( (㩊畫蕉峻德)

這段記載, 是领主的部曲之來原與形成的寫真。領主招集了這 許多的部曲, 在戰㩊時用以保衛或從戎。

定泰始以來, 内外频有戰愎, 将伯中以下, 各募部曲, 屯聚京師。( 南黹書李安 民德)

新吴洞主余孝顷舉兵助勃……孝顷子公颭……領五百人偽降… 文育因之, 送于京師, 以其部曲分隸象軍。( 陳畫周文畜德)

案: 余孝頃曾為豫章太守, 及侯瑱鎮豫章, 孝顷於新吴影别立城栅, 與琪相拒, 摸 10 悉象以攻孝顷, 自夏组冬弗能克( 見陳書侯德傳) 。㫜部曲固员從戎之责矣。

而於無事的時候則用以耕田:

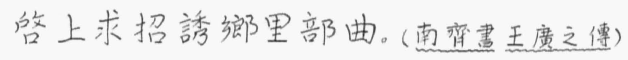

遂去職歸山, 居於東林寺, 有田數十頃, 部曲數百人, 率以力用, 盎供山 象。遠近歸慕從之如市。( 梁畫张孝秀傳)

鄉里部曲, 就是力田的部曲, 部曲在此時的主要任務就是耕田了。 大概領主對部曲的真役誅求甚奇, 惜未能考究出來! )不然張孝秀為什麼一 蛊供山家就遠近歸慕, 赴之如市。呢?

部曲因為耕田, 就附著於土地漸漸地震奴化了。

- 0 北朝的部曲 
這種需要。鄉人部曲, 在北朝就因此形成了。

及武帝置部曲, ……聽慎以本鄉部曲數千人自随……昂自領鄉人

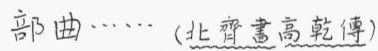

這鄉人部曲, 就是在鄉間種地的。貴族需要大量的鄉人部曲, 常 5 有侵害平民的事。

乃詐為書, 言爾朱北将以六鎮人配契胡為部曲, 象皆愁。(北史蛮杰紀)

這種詐書, 是因貴族常掠良民学部曲縔能發生作用的。贵族所

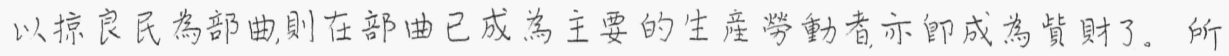
以运種佔奎部曲, 與漢代掠良人学奴婢的事, 有同樣的意義。

部曲不惟因离耕地而漸赹農奴化, 而且, 同奴隸勞動制下的奴婢 一樣, 常常成离賜與品了。

寻除徐州刺史, 給廣宗部曲三百, 清河部曲千人。(北娈書崔浚傳)

賜馬三百匹部曲八千户遣之。(悲史靁淢德)

放免奴婢的時候, 也㯖領主留為部曲及客女:

詔: 自永熙三年七月以来去年十月已前, 陳土之民被抄略在化内 离奴婢者, 及平江陵之役良人没為奴婢者, 並宜放免。所在附籍, 一 同民伍、若舊主人猶須共居㯖留為部曲没客女。(周畫武帝紀)

農奴化的部曲, 耕種土地, 如募代的奴隸一樣, 對國家須納税課。 這種税課, 到隋煬帝時總免除的:

煬帝毁位, 户口益多, 府庫盈溢。乃除婦人及奴婢部曲之課( 通放 田賦放)

至唐代部曲成為私家的佃奴, 對國家没有課税之可言了。

$$
\text { - - 唐代的部曲 }
$$

到唐代部曲的地位更為低落, 他們完全尿於領主:

州影没有户籍, 随主矚贯:

自幼無歸投身衣飯其主以奴畜之。及其長成因娶妻。此等之人,

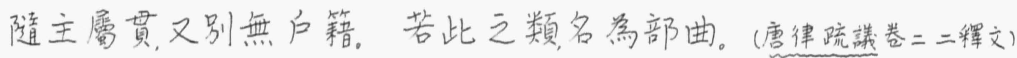

不向國家納税:

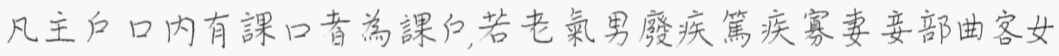
及視九品以上官不課。( 新唐畫食货志)

因学部曲受領主的券養, 所謂"其主以奴畜之所以, 他們事主須存 敬謹甚至妻女也得交給領主, 任其茹淫:

茹他人部曲妻, 明茹已家部曲妻及客女各不坐。唐律疏諼卷二六葉徒一年半條) 
客女就是部曲之女, 意律疏議卷十二以妻扁娈條,

客女謂部曲之女, 或有於他處轉得, 或放婢為之。

這棣看來領主茹淫部曲的妻女之權, 在法律上是有保障的部曲 的身分, 简直和奴婢没有什麼分别了。不過部曲和奴婢尚了完全相同, 他們 還有一些差異。大體上説部曲可以轉事他人, 唐律疏議卷十八賊盗二造畜5 蟲毒條答問云:

部曲䚁許轉事, 奴婢比之資財。

部曲不同資財, 與律比畜産。由主人自由處分的奴婢, 總算高一些換句話説部 曲是較奴婢解放一些的。閣於部曲與奴婢的異同何士龭君在他的部曲放

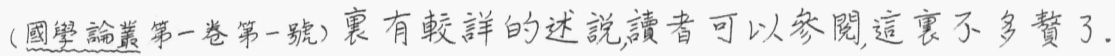

根握何君的考證, 唐時社會上由良民至奴粶, 其間有四級:

一良民二雜户三番后四奴婢。

部曲的身分同於官后, 唐律疏議卷二十二鬥訟二;

官后與部曲同。

而官后於番户, 唐覦要卷六:

有言官后者, 是番仁之總躆非謂别有一色。

那末部曲的地位較奴婢高一級師處於第三級了。不過部曲與 奴䍮相異的這種概念我們雖不可不知但決不應當把這黑點者重了。這個 黑點, 只是個人解放程度上的差黑不是理解他們的重要所在。我們應當知 道部曲同奴婢一様, 都是社畣的主要勞動生産者, 都是受领主盤剥與役使的, 20 他們在階級隸屬的闢係上, 有同様重要的作用!

由部曲可以轉事他人, 較奴隸稍䒚解放一些看來, 部曲正合於農 奴的身分。惟現在尚未能確證部曲就是農奴, 不便惯指; 但敢徼言, 部曲至少 是近於農奴的。這種説法, 並不是全無根據的武邀, 而是有下面兩個理由可 為旁證:

(一)在唐以前, 有鄉人部曲, 從事於耕種土地。他們有流入農奴的 可能。

(二)唐後有所謂部曲吅, 有似農奴:

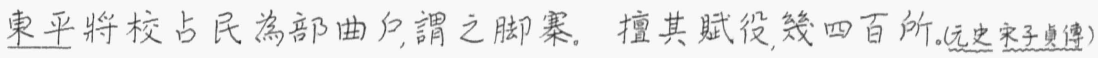

這椂, 部曲近於農奴我想不是随意的安造罷。

$$
\text { 一二部曲二字之另一用法 }
$$

關於部曲的沿革, 在前面已大體的述説了。但還有一點我㑚應 該注意。在史籍上部曲二字的使用, 即在同一時代其含義往往不同。例如:

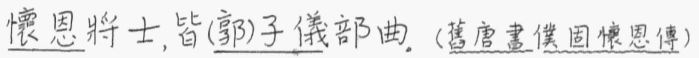


泚死, 休走鳳翔学其部曲所殺。(鹪唐畫源休德)

此處所謂部曲, 自是指著部下士卒而言, 與—

部曲是学家僕事主須存敬謹。(慶律鬥訟二)

的部曲, 迥不相同。這是什麼原因呢?

我以离部曲在轉化质私兵之後, 仍有隨時從戎的義務。在每事 的時候, 有一部分任保衛之責, 仍不湴的受軍事剖練, 同時, 也有一部分從事耕 種土地, 即成為所謂鄉人部曲, 因為耕田的閩係, 對於軍事就生疏起來。這椂, 時間長了, 任保衛的部曲和鄉人部曲就漸漸分離一方仍為家兵, 一方則超於 曹奴化。因為習惯上的關係耕田者雖低落到曹奴的地位, 依舊稻之脈部曲。 10 亦即因此, 部曲的含義存了不同私兵和曹奴化的耕地人, 都被稱蔒部曲了。

自唐以後部曲二字逐漸少見, 這大概部曲轉為佃蕽, 因之部曲向。 為佃所所代替了罷? 至士卒隊伍之義的部曲, 至時尚被沿用:

太祖已取涂乃遣人説均用曰: 大王窮迫時郭公開門沿納……旗 細人之言, 自前犽翼失豪傑心。竊為大王不取也。且其部曲猶象

貌高所将, 多孛羅部曲。( 明史撗廊帖木自德)

太祖朁擒陳禁先釋之, 令招其部曲。( 明史溤勝德)

龍興守将胡美遣子通款請刎散其部曲。(明史路基愽)

這都是取部曲的初義, 不是震奴化的部曲了。但這部曲似尃用 20 於起事未成或敵人方面師非朝廷所有的非正式的軍隊上去的。

\section{一三 結語}

由於上面的述説我們對於部曲的沿革, 可得如下的結語:

( ) 部曲起於西漢, 虞當時軍制——此制至劉宋始無。

(二)束漢之初, 部曲成离士卒隊任之義。

(三)束漢三國為部曲向私兵轉化時期。

(四)魏厽時部曲轉為私兵, 且有種地者。此時部曲, 為綵過朝廷承 認的家兵。

(五)到了南朝部曲完全㪣為私有的家兵大半從事種田。在北朝 因着蓕園的形成部曲成為鄉人部曲, 逐漸附著於土地了。

(六) 唐時種地部曲淪於曹奴的地位, 但軍隊亦有稻部曲者。

(七)唐以後所用部曲含義多從古義—士卒隊伍。但多用於非

正式的隊伍。 
討論問題:

一, 奴隷制度在中國經濟上是否有歴史性的重要影锌?

二部曲, 是否即为奴隷?

三試舉漠代滅亡之原因。

四試比較漠代減亡淩之中國及羅馬帝國衰亡之後的歐洲。

五試述唐代大一統思想復興之原因。 
1.1部曲秘《軍隊編制的制度 沿革列《”事物之變遥日沿革 致弦同考

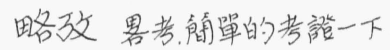

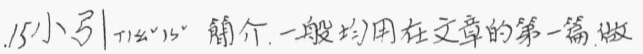

一大概的介紹

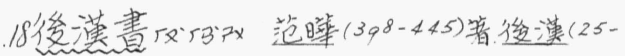

2.1䃌的灲用火燒成長方形的硬土塊

引玉之磹謂以自己粗郘的文章引出大

象精美而有意義的詩文, 俗云扰碍引玉

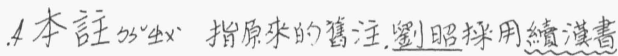

中之志時録其舊注, 㛵之有本註。

罷汃去職, 完星

事訖即罷事情一結束就除去其職位

220)史書, 有十二帝后紀十二卷, 十志三十卷, 列傅, 5比外相當於

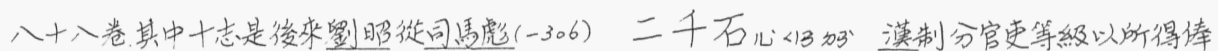

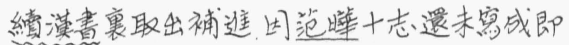

被媇死

禄多少为準、有二千石, 平石、百石等各稱。

. 7 員職 43 “出”部下和職位。

尉双古官名、今陸、海軍官制、有上尉，中尉

少尉。

校尉古軍官名

. 19 染候4 05 仅古官名, 於行軍時, 探軍情者。

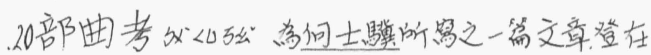

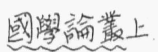

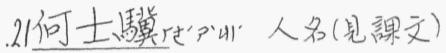

.23 嵄双供役使者

㒒奥表示許多供勞役者

.24 然加明明眭

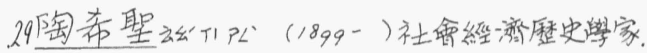

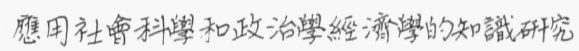

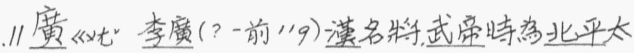

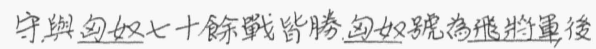

自殺而死。

行下移動

行陣移動軍隊, 行軍。

12 万幼狡部

刀斗古行軍用具白天用作者飯之工具夜 揧以警象報時。

莫府 $n \times\left[x^{2}\right.$ 莫府者以軍幕学義, 古肎通, 軍隊行

旅、無一定含地, 故以帳幕酱居。

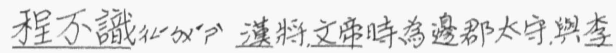

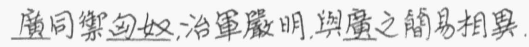

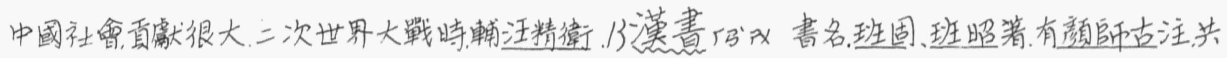

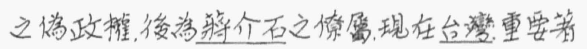

作有中或社霄的分析，中國封建社艒史等 中國政治思想史陶希聖著, 一九五四年台

北全民出版社出版。

30 部㱙”大、空

輪虽物之外部、大概的情形。

. 烟分妱, 希望想望

各加惜

不各具易教客氣的表示請人多指教的意思

2.1 區區《仙小脃客氣的表示小小的

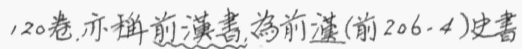

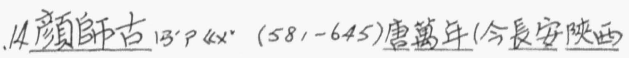
夥人，博管臂書，曾受部考訂五經文字多所校

正、注班固漢素。

.16署置砤出設置, 布置

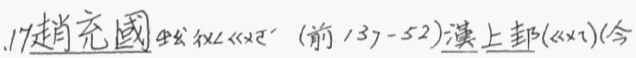

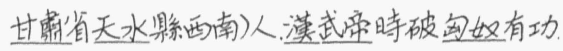

䔶宣帝時, 其言屯田十二便窝兵於震, 有世所

推重

18 㝳田䇋云沼”以兵士從事曹耕。 
2.18塹《圆圍城之水或坑。

.19樵《同譙高樓

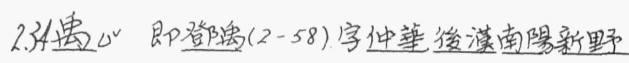
人光武時学特軍. 功高

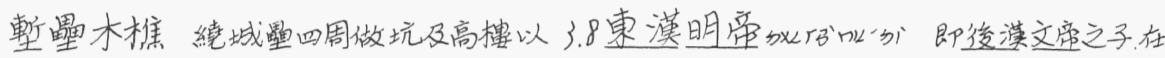

望㪣

校出公润

校聯相速, 如攔

飾》”飾門具, 兵器加以彩飾。

烽 $C L$ 古時邀防储盗罒, 作高上台, 上置柴学, 盗

至、则燃火報警謂之烽

.21㷏外合

势及拜力按情形可以合作

19逸! 安樂

以逸待勞謂在戰街上稳居工作以待 敲人之速攻

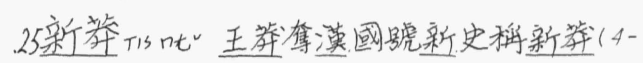

25)

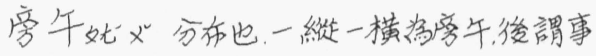

物多而乳日旁年。

.29束㳇用带子將物圈緊

約束限制之使就軼園

旅4 12 旗之一種

旌旗旗之通释

踫令伀汃傳呼之命令

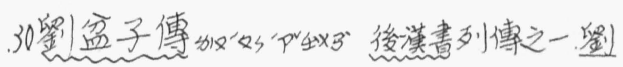

盆子河太山式夥人，城陽景王童之後

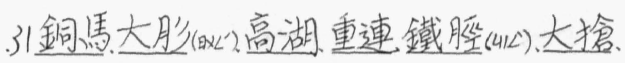

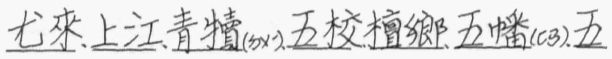

樓富平減獲後漢光武常政滴時, 各路人馬起

兵、每隊伍各有之名字。

.32完敌、唅奪、盗非。

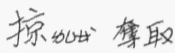

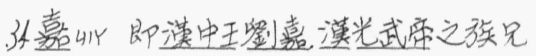

佸心自大且不恭敞。

倨慢、驕傲且万客潘
位十三年 $(227-239)$

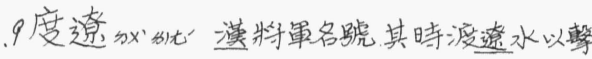

匈奴故名、明帝时置度遼赏。

單于径“”古匈奴對其君長之稳

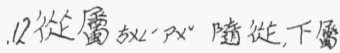

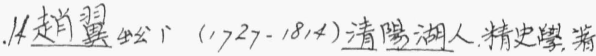

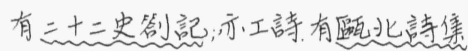

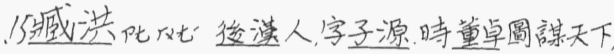
洪説服太守張超誅卓超然其言, 後浮袁紹

圍攻、城䧟被乾而死

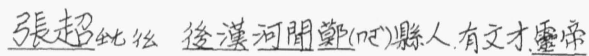

時從車騎特軍朱售(405)征黄中, 曾为别部司馬。

著作九十九篇, 又羓於草毒, 妙絕一時, 人世共傳

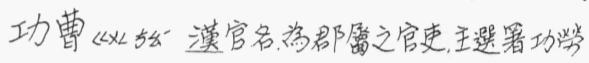

詣卜至往候

幽州、和古代州名、即今河北遼䆬一带

袁紹吸”陇( ? - 202)東漢汝陽( 今河南商水夥

西北)人, 曾起兵討董卓㩚河北、後被曹操所欺, 病㻐而死。

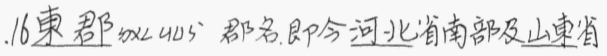

西北部地

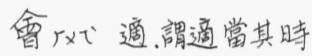

气《 1 求

气帛市求人出兵相助

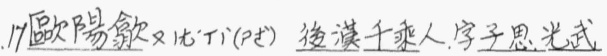

時拜汝南太守, 怯以禽污罪下狺文, 死獄中。

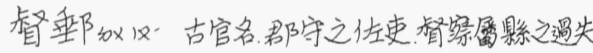

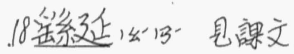

主簿出”叭焦官名、主管文書簿籍

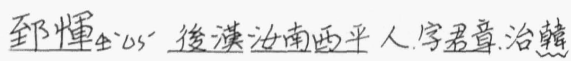

熟㩔低春愁明天文曆數。 
3.18 资口天生的本性

资性本性，天性

邪㤌 不正

拿邪不知足上石正

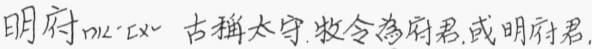

简皏明府

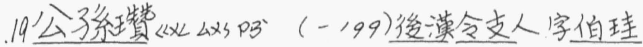

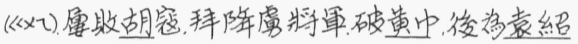

所欺卒酱紹兵所䐨。

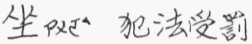

太守坐事徙目南太守因事犯法而往

日南

20日南日”3 3 古郡名、漢置今安南順化等地。 塚到汇高大之填墓

漈先人塚在祖先㣁前拜漈

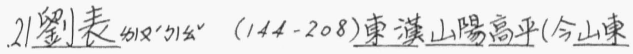

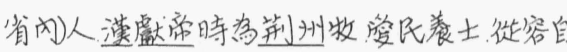

保、死後其子致琮降曹操。

從事故一个古官名青刺史之传吏

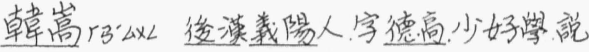

路表附曹操，並謂操威德表大怒欲耓之, 繼

知蒿娂他意乃止

許で 即誯昌, 在今河南省。

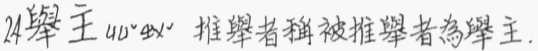

持服行欧因長輩死而在家服衰三年謂持服。

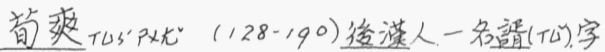

慈(5)明年十二通春秋論語, 箽卓起用之, 九十五

日而位至三公、繁王允等欲共圖卓、万人病死，有

䄚易詩傳, 公羊閔、漠語等九有稌篇。

司空么政古官各, 周六卿之一即大同空, 後世

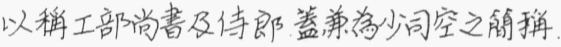

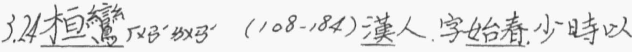

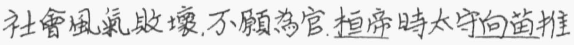
舉變变孝廉。始到官而皆卒、即去職奔变, 人高 其義

向苗份吆漢人，桓帝時曾为太守（是上）

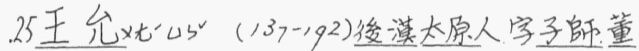

卓迸乳，允扶助王室，又結号布刺耓卓

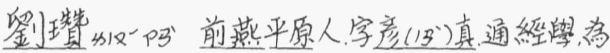
世大儒弟子從之受業者常數百人。

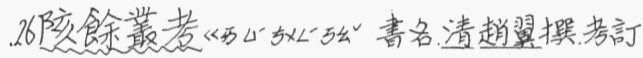
䌊史甚学詳细。

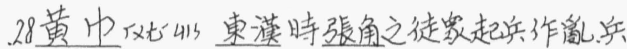

皆以黄中包頭，稻黄中之媳，黄中，即指張解之 徒象

州牧的呼古官名、領治一州

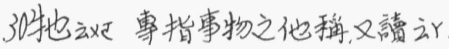

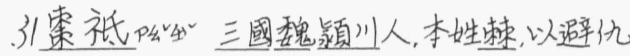
家而改姓軎, 官随留太守、時紫旱, 軍食万足, 祗募民廸田。軍國因而富足。

暲浩以了公三國魏河内人字元嗣( 八) 聰明而

有才略，曾领兵拒重卓於叠津，後湓曹操媇任。

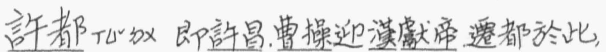
故而稻言午都

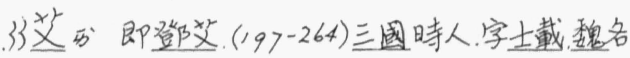

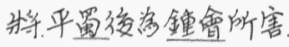

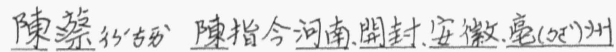
一带、蔡指今河南上蔡, 新蔡、汝南一带。

稻加植於水田之踒類

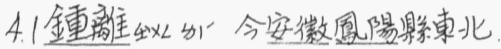

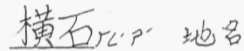

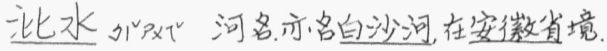

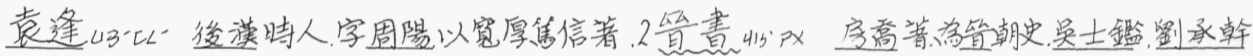
稱於時靈帝時青司空, 死後被封稻宣文。

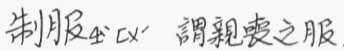

同注

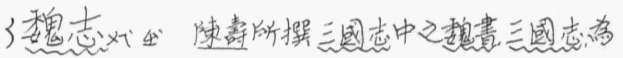




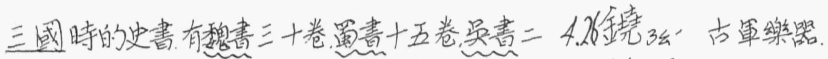

十卷.

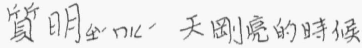

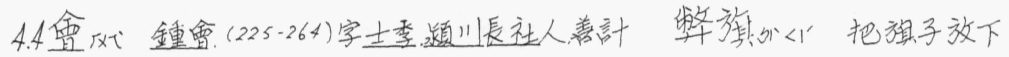

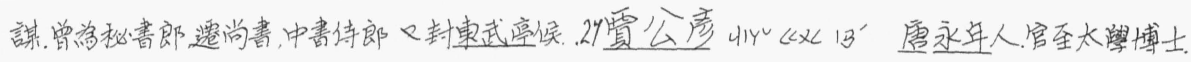

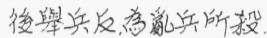

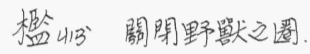

檻車风禁犯人之車。

.6意意妼 愚而䣓直

因執《汉和篮禁

. 8 豪右忶必謂一方之霸。

.10河間地山沼今河北省境内

冕几 $13^{2}$ 古時大夫以上之福冠皇冠

㝴莬謂領袖謂做官。

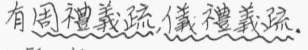

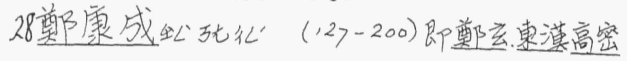

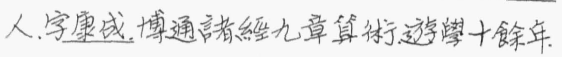

因賞錭福、被禁十四年、成書甚多、特人皆敬之

. 什舅拨 母元并

元舅天子之舅

二府几地指何進及其弟向道

致兵坏引堅强有力之道隊。

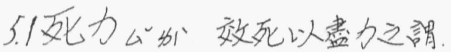

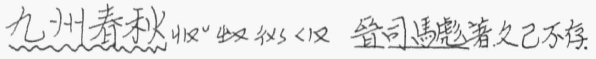

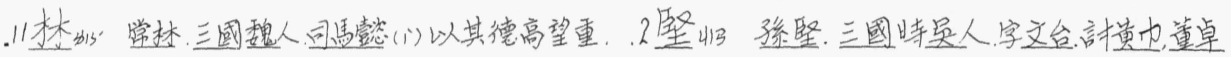

常拜之。

策畫战反計畫

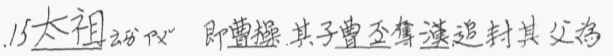

武带, 朝踫太祖

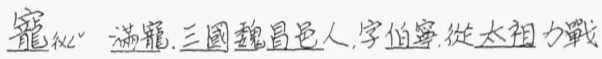

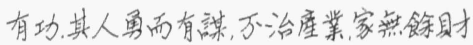

簒偊招集

16 渠《正大. 他人

官中被軍中主特統率

渠占中销盗完之大磌目也。

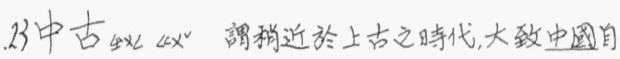

秦道以至富宋

從我, 晒“㷡”從軍, 當兵

.24誓”、約束、自表不食言之細

宣誓謂依法令之规定或宗教之形式, 對大 农灰䈔守約束之謷言。

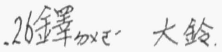

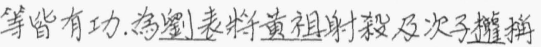

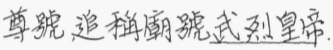

行酒不怩倒酒以敬客。

勅分同敕、命令的意思

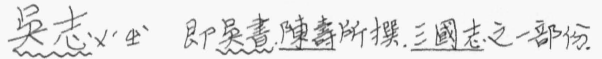

共二十卷

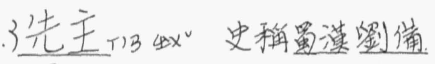

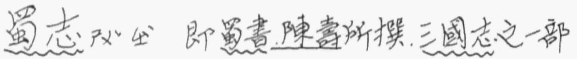
份共十五卷。

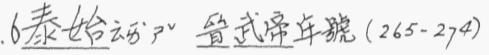

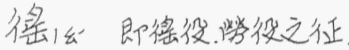

詔復得役下命令重新再征学役。

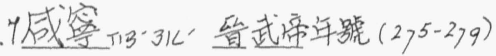

赦捄釋效, 免罪。

大赦對全國罪犯釋放或减刑之謂。

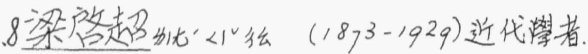

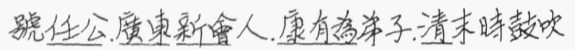




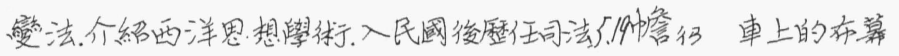

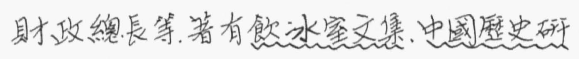

豹憺用的皮所製进上用之篡。

究法等

5.9 算弯刂

.20邪他同耶”，助詞。

.2酎敌”重製遇之懐原的酒。

甘吗自願，自認

西主金謂漠時諸候真金以助祭。

甘結 凡将县才物唭事主領回時, 均命本人 2 )遭交 $\Delta 8^{2}$ 算野

作一情硕道命之㨜、謂之甘結。

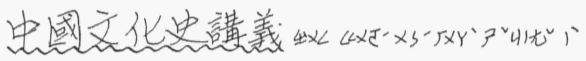

梁登超所編

14 揘31 世毫合附會

控造虚造

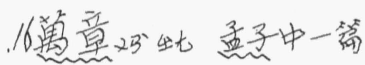

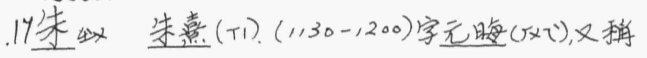

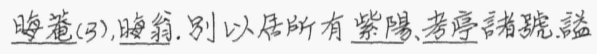

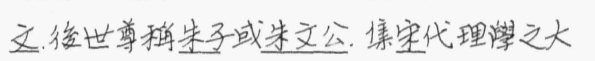

成。所言主回畫, 明清科举奉学標準。

雉出動物, 形狀似第、雄者尾甚長、羽毛美麗,

俗檤野鴙

揫入即鸭。

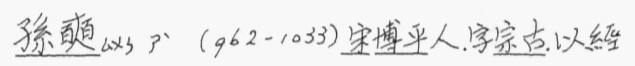

山遭夜山野之意

糧仗化的此糧食和兵仗( (兵器的總稃)

漠咋・北方雨量㴍少, 算水不生, 形成流動之細 砂(掹小之石塊)所成的一塊大旒地。

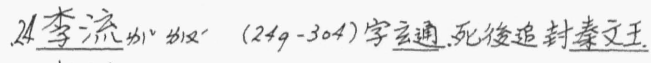

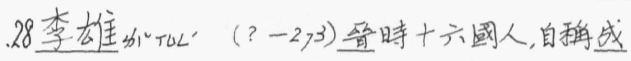

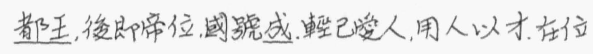
三十年

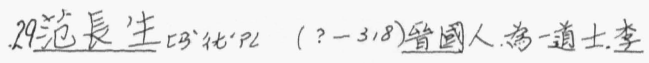

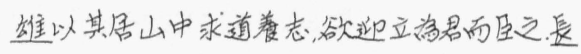
生固拒, 雄拜之济录相、雄既即帝位, 加長生天地 太的、封西山侯。

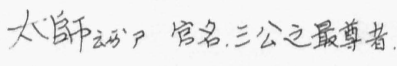

豫心湓加。

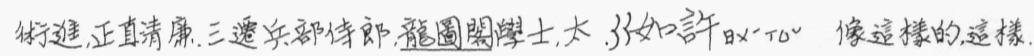

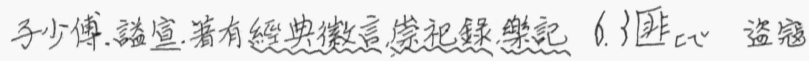

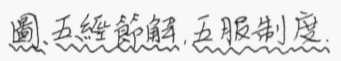

18 圭《姃上尖下方之王器。古日寺王候朝科祭祀

所用之物、五等諸侯, 各勃一種圭。

桓圭長九寸端公所勃

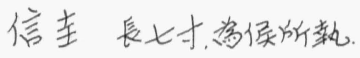

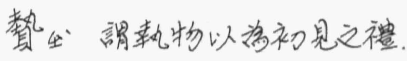

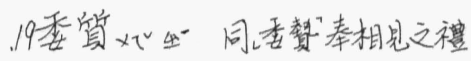

隻武之皮訛对出奴以隻虎的皮整成

的外套。

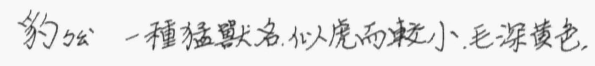

背有黑圆點。

豹飾用豹皮製成的飾物。
涉虽么 婹動

騷嗄㩕溦使人不安。

6洋云、眼实

流涕流渡、意指哭泣、

援U马一救助, 禁助。

亟山急切

8覃傌山1 約束

摩的一慗

覊摩雾制、万使脱離、

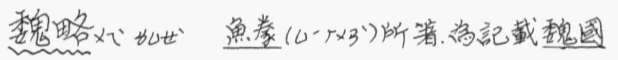

重要人物及大事之青, 共38或39卷。

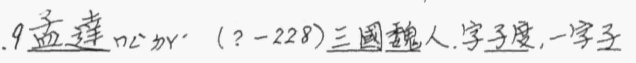




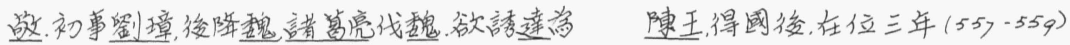

援、魏人疑蓬達燿遂反。不久欺减。

6.93 延康13.5 漠獻帝最後一年的年號(220)

元吗 始

元年第一年

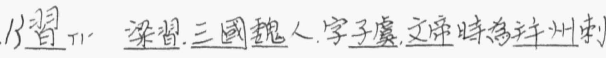
戈, 政治上有大功。

年州引秋漠以今山西省及陕西之售延安、

榆林等府地学科州, 北朝至磨以今山西售太

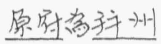

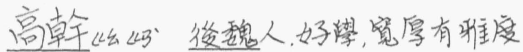

張堆跋扈開展武力, 暴横。

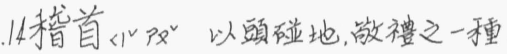

15编户引135x编入户口册之人家、意謂平民。

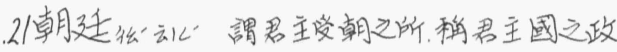

府。

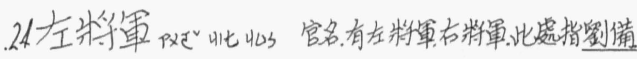
20透云通透，影真露。

漏收水透下

透雨 表示, 㩆露

30竞竟山次学逐

表拜㭃垴上奏章

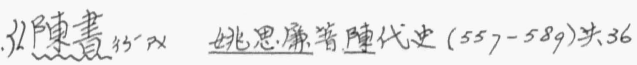

卷。

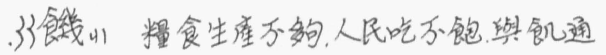

大餧大荒年。

具辰出了。給、救湔。

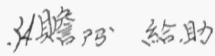

具辰期客以盰物糧食相助。

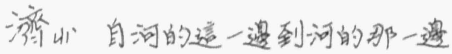

湾江遇河。

宣城TU红合安徽省网。

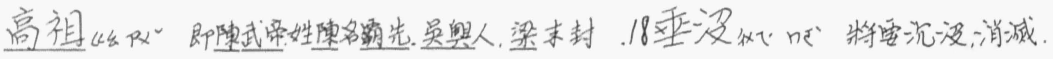

6.34 岁亩引 皇帝死謂崩

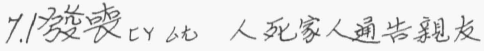

襲厂，攻其万偖。

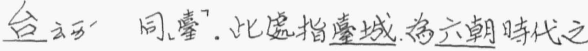

宫城。在今南京城北、玄武湖亭。

招裹生幺场一招之来敫、

.7大有汃飞軖年

降圆中《秋人会陕两省。

赤阳召幻出幺三國魏太原人，学伯道，鎮守河 西十餘年, 諸葛亮園陳含, 相攻拒十稌日，亮引 退

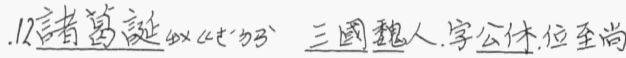

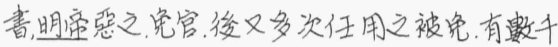

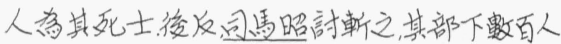
坐石降而被斬, 皆曰, 為諸賞公死万一恨。

莣TUL 惡

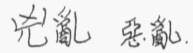

溥汃此滤舆簿通即悵缚文書也

主溥即主簿

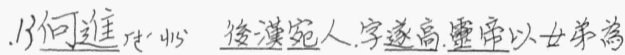

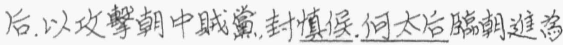

太傅，後以謀昩中官，反需所害。

通吆”種族名、今湖南、四川雲南、贵州諸省有之。

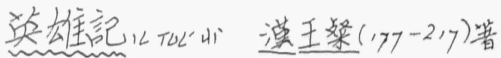

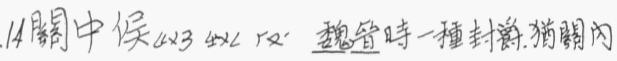

侯

科顽法律之條文，或官事之分曹。

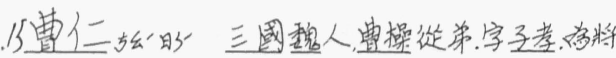

嚴整奉法令。封嘎候，死後助名忠。

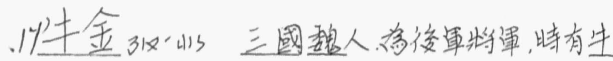

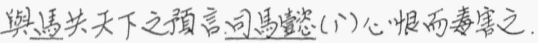

道引迎㖟。 


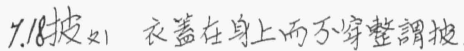

披用甲是一種古戰上所穿之護身衣, 披用即 穿甲之意。

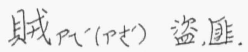

.13典加”李典，三國魏人、字是成，事曹操，以功升

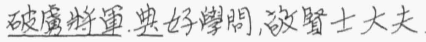

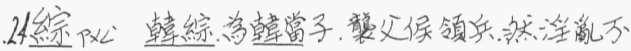
正、後死於惠舆之役。

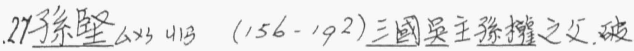

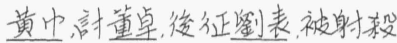

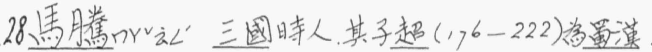
之名将。

衛尉入代同謢衙之官

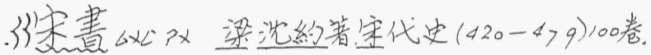

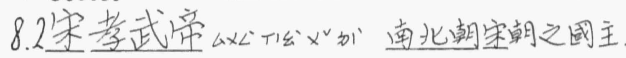

$(454-464)$

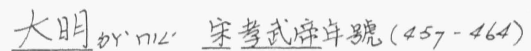

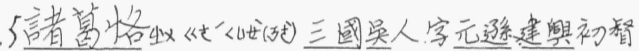

8.22 梖的分易易給。

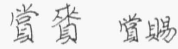

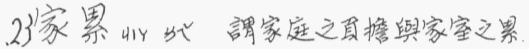

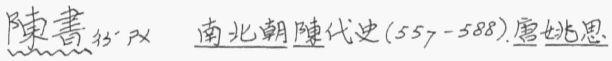

策撰、凡三十天卷, 为二十四进之一。

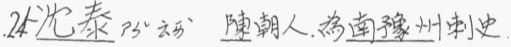

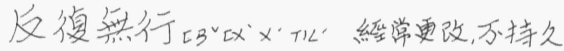

28染武帝纰“加”( $664-549$ ) 南北朝梁開圆主,

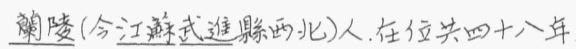

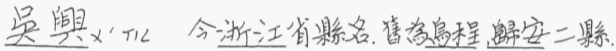

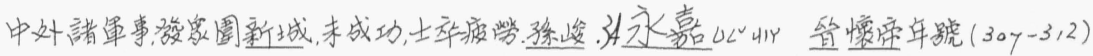

团民怒舆其主亮铩䄫之

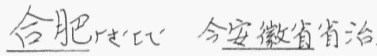

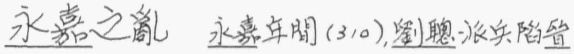
都城洛隑, 透帝於平淂, 以帝瓷左光祿大夫。

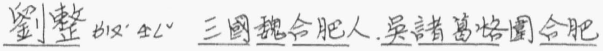

後二年, 艒。亚窝群哣, 使帝著青衣行酒

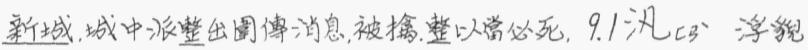

终羔他緇

鄭像癿卵化三國魏人, 是課文

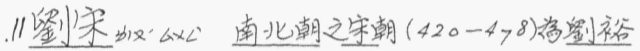

所建，故云烃案

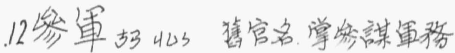

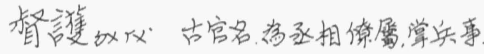

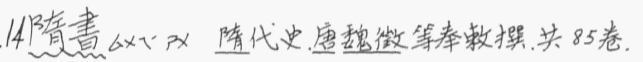

学二十四史之一

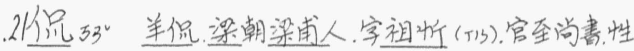

豪侈

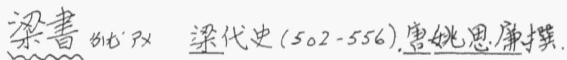

氿海南渡乘船向南方遥移。

撫 $匚$ ×

撫㬎保護收留

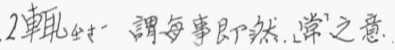

医引藏避

峻䡛医避之婇峻常收藏隐避他們

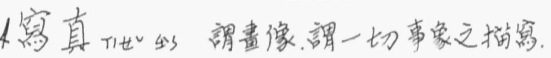

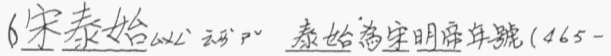
$4 y^{\prime}$ )

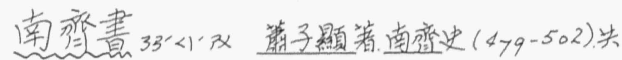
59 卷. 


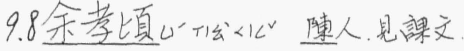

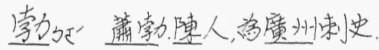

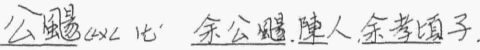

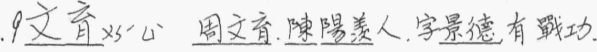

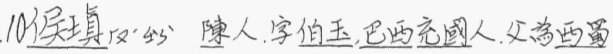

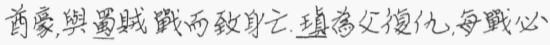
浮先㖓, 遂減䍖賊。

棚出以以竹木編成之城凿 川1徂故至

自夏徂冬從夏天至冬天 弗的不 .21日再曼日゙ル㕫德國人
乃詐学書於是假造一封信

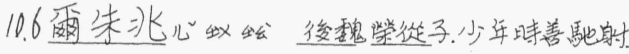

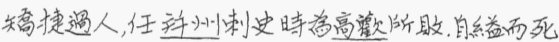

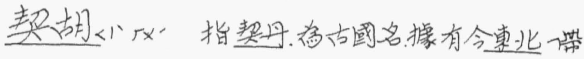
地, 徍学金所減

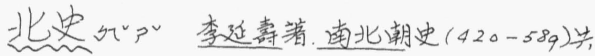
100 卷.

12最T 万人, 万人。

除㣗 拜官

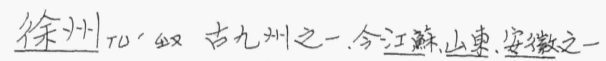
部份

.14客女㔚3 3 如言他處来的女子。

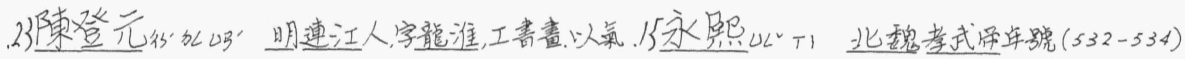

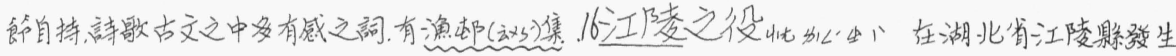

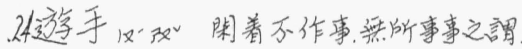
的戰事。

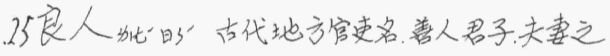
互稳 26 夫欧百㪟有夫。 30 攀妈企求拉上閣係

攀龍点依附貴顆以求登進

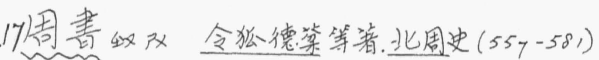
共50卷.

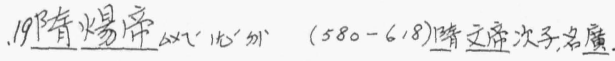

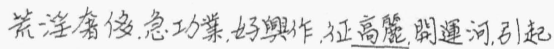
民繁、被殺、

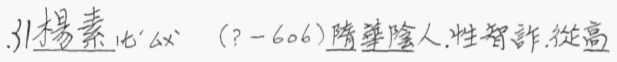
祖定天下，特功䮓横。

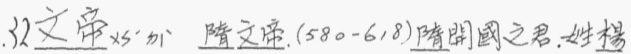

名堅等除人, 統一南北, 在位二十四年

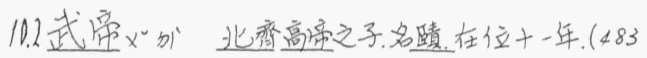

$$
\left.-493^{3}\right)
$$

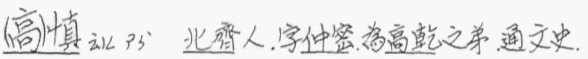

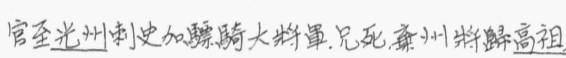
後又降画臹，終学高祖所破

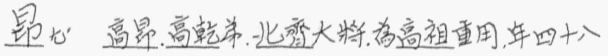

因戴欺被耖。

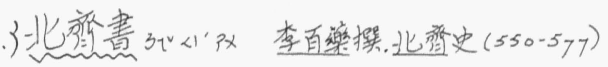

共十卷

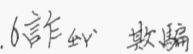

20通政动弦”即文蒸通考。

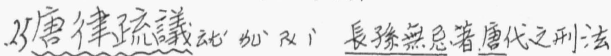
量.

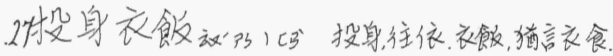

謂生計所赖者。

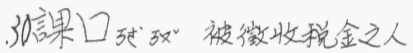

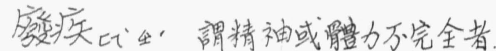

黛疾敂“出”病重, 不能治之病。

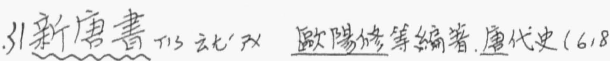

- 907 ) 共250卷.

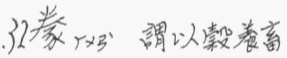

弮養畜䖭

.3 信董4 152 慎

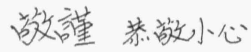




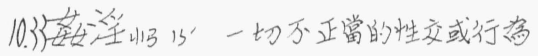

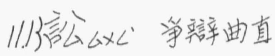

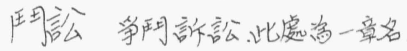

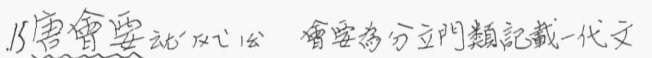

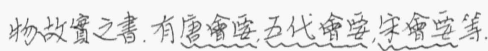

.20盤如”查究

盤剥想辩法剥取之

. 29 東平汃奻元置重平路，即今山東重平影。

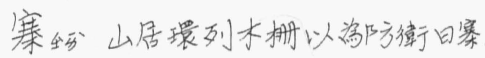

脚寨山下的㩟

元史U3 宁宋溓等編箸。元代史(12801368), 共210卷

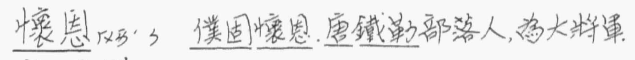

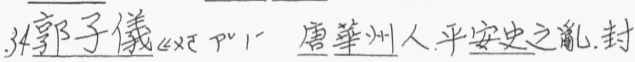
汾陽王，世䊈郭汾淂示稻郭令公、永泰初又 大破吐䈏。

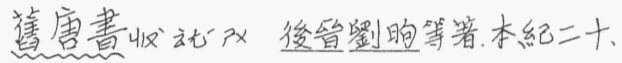
志三十、列傅一百五十、凡200卷。

12.1 此与 来泚, 兽昌平人, 德宗時, 姚令言兵碳, 帝出

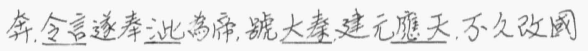

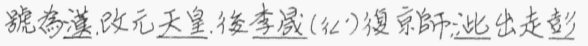
原省其部特乎所䓵。

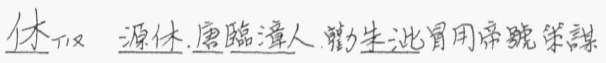

内外國事，後泚欺死，休走国淂帉其部曲所殺

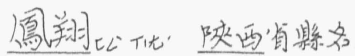

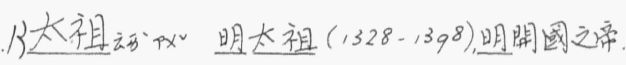

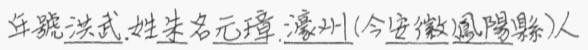

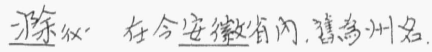

均用岓心趙均用。元末起兵者之一。

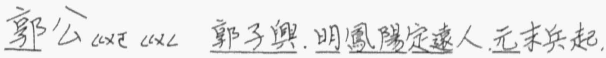

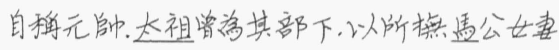

太祖.

.14細人介明器小之人或方善之人。

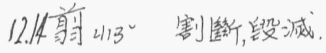

自翦羽翼自己毁减自己的教力。

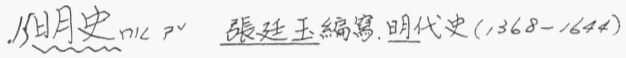

共332卷。

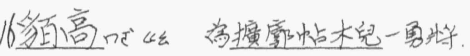

粰山龙即以其学特、意指带领。

貌高所㸱学徝高所带領的部蒙。

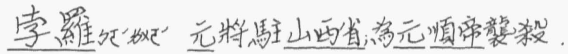

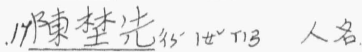

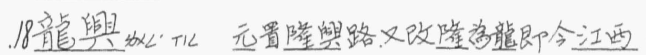
南昌影。

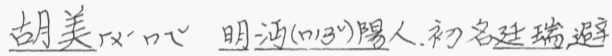
太祖字易名。仕整友諒，降太祖後伐張士副。 通款礼和引 



\section{第九課論成吉思汗}

曈儒林

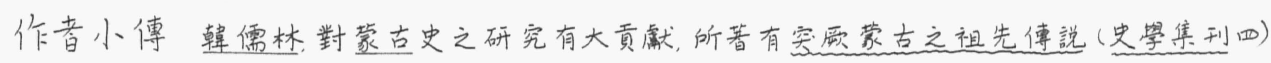
成吉思汗十三翼考(藮西大學中國文化研究所焦刊，一，等。

本課簡介本篇為作者在摩史研究一九六二年第三期中所發表的全文。全篇共分三部分, 為 作者以三個万同的角度去看成吉思汗在歷史上所占的地位及其影響; 一在蒙古民族歴史 上: 當時社會狀况, 成吉思汗統一中國之出發點, 及成功的原因、䌊過及後果。二, 在中國糜史

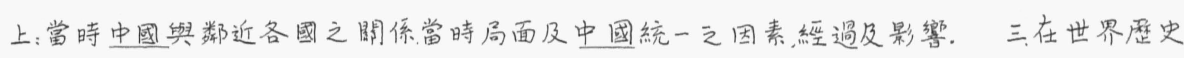
上: 蒙古與花刺子模及倽察二國在當時之關係, 各國被統一淩所受之影瑤, 及統一於束西方各10 國多方面之影䈉。

过去有些历史家完全否定了成吉思汗。他們强調蒙古人在战 采中的屠杀和破坏, 看不見成吉思汗在历史上所起的进步作用。对成吉思 汗有好評的人, 例如十三世紀末期亲身到过中国的意大利人馬可波罗法国 15 历史家茹安維尔(1224-13/7) 以及小阿美尼亚的海敦和谷儿只的历史家等, 他們 的評論也各有所偏。因此我們今天就成吉思汗在蒙古民族历史上中国历 史上, 世界历史上所起的作用継䋶加以考察, 看来是有必要的。本文不过是 作者个人研究之一得把它发表在这里, 旨在提供討論希望得到批評和指教。

\section{$(-)$}

$\begin{array}{ll}\text { 有星的天 } & \text { 有草皮的地 } \\ \text { 旋轉著 } & \text { 翻轉著 } \\ \text { 众百姓反了 } & \text { 全部百姓反了 } \\ \text { 不进自己的卧内 } & \text { 不卧自己被儿里 } \\ \text { 互相搶掠財物 } & \text { 互相攻打 }\end{array}$

《元朝秘史第2 54 节这首詩歌真实地説明了十二世紀末蒙古高 原上社会混乱的情况。这种混乱情况是当日各部落間的复仇和掠夺战爭 造成的。十三世紀波斯的历史家也説: 在成吉思汗出現以前, 他們没有首領 或君长。每一个或两个部落分散地居住着, 他們不互相联合, 他們之間进行 着不断的战爭和敌对行动。其中有的人把搭掠和暴行, 不道德和放蕩视为3 0 英勇和美德的行为。金朝皇帝經常强索或掠取他們的椇富。蒙古广大人 民处在这种无休止的战争中, 遭受了很大的災难和死亡。当时誰能統一各 部落制止唅掠和殘杀誰就会受到人民的拥戴和歌頌, 誰就推动了历史向前 发展。成吉思汗就是完成这一偉大历史任务的人物。 
当时蒙古高原上的部落很多, 大体説来, 以成吉思汗为首, 以克鲁 倫鄂嫩土拉三河发源处为根据地的蒙古諸部落是一个集团。它的东方呼 倫县尔两湖及额尔古納河一带十几个部落是一个集团, 其中以塔塔儿为最 大。此外, 土拉河流域有克烈集团, 色椤格河下游有笺儿气集团, 这两个集团 5 的西方是阿尔泰山地区的级蛮国。这几个集团进行的长期复仇战和掠夺 战, 使蒙古陷于分裂和混乱。最后成吉思汗把他們都打敗了, 把蒙古統一了, 人民才得到了安定。当然成吉思汗和其他几个集团的首領一样主观上不 是为了人民的安定, 而是为了霂足“恶劣的情欲—荟欲和权势欲”而进行战 采的。成吉思汗以歼灭仇敌乘其駿馬納其妻女为人生最大乐事就是最好 10 的证明。

那么为什么成吉思汗独能完成蒙古統一的历史使命, 其他部落 的首領都失敗了呢? 这就不能孤立地只从蒙古的内在因素寻求答案, 而必 須进一步看看它南方的强大邻人一金国在蒙古統一过程中所起的作用 了。

在女真統治者的心目中, 最大的敌人, 除南宋外, 便是北边的蒙古 族了。辽代在今鳥兰巴托东西大道上建立了許多边防城。现在根河满洲里一綫的界壕遗址若为金初泰州婆卢火所浚的話, 金初边境亦和辽代 差不多。在这样情况下, 蒙古族几乎完全处在他們的掌握之中, 金世宗以 后, 国力㰾衰, 边界后撤到今由蒙古呼偷具尔盟莫力达瓦旗—河套西曲一 20 綫的新边墙。距金国最近的塔塔儿集团, 逐漸强大, 成了金国背后的威胁。 成吉思汗建国前, 金国于1195, 1196.1198 三年速緢出兵栲栳㴪( 今呼倫泊濣里 札河( 今苏联境内鳥尔杂河) 移米河( 今伊敏河) 等地进行策韵借以减輘北方的 压力。其中 1196 年翰里札河一役, 成吉思汗为了报复血仇, 曾协助金国丞相 完顔衰攻击塔塔儿。金国前后几次进兵, 直接地削弱了东部集团的势力, 間 25 接地却帮助了成吉思汗完成蒙古統一的大业。

塔塔儿集团对于成吉思汗协助金国打敗同族人, 当然十分痛恨。 从1 200 年起, 东方集团十一个部落便联合起来篦击他。1 201 年更在根河結 成联盟推机㭘为首領, 对他举兵进行报复。可是一方面由于这些部落連 年遭受打击, 内部不能团結, 一方面也由于成吉思汗接受了金朝的官职和支 30 援, 在蒙古族中增加了威望和力量, 战学一接触东方集团便溃敗了。

1202 年成吉思汗灭掉了塔塔儿, 从此蒙古水草丰美的呼偏具尔 著名牧場落入成吉思汗手中了。成吉思汗控制了两个集团的富镜草原, 真 是如虎生翼新占領的呼倫具尔草原給成吉思汗提供了大量的战馬和牛羊, 物质力量成倍的增加了, 多年来蒙古高原上各集团間势力均衡的局势維持 
不住了。于是一向侷促在三河发源地的铁木真竟能于1203 年灭克烈, 204 年灭际蛮1 206 年自豪地宣告“七載之中成大业”而称成吉思汗了。

十二世紀末居住在蒙古高原上的部落依统朝秘史及波斯拉施 德使集》所著录的統計, 差不多近一百个。这些部落不仅强弱大小不一, 就是 語言, 宗教民族、文化水平也不完全相同。統一之后統統在蒙古这个共同名 称下結成一个强大的共同体。从前各个部落各有自己的名称和首領, 有时 为了战爭的需要也成立部落联盟, 推举一个共同首領, 不过战爭一結束, 联盟 就解散了。有时一个部落首領死了, 所轄的牧民逃散这个部落便若存若亡。 自从成吉思汗統一各部落后, 有不少非蒙古族的人民也被吸收进去。于是 蒙古顿时成为一个势力强大人民众多的共同体的名称。我們当然不能説 10 有了成吉思汗才有了蒙古族, 但成吉思汗的統一事业对蒙古族的形成是一 个很大真献却是不能否认的。至少我們也应該説, 偉大的蒙古族在世界历 史舞台上起重要作用, 是从成吉思汗开始的。

对于以成吉思汗为首的貴族讲掠夺所得比劳动所得还要光荣。 因此蒙古統一之后, 社会秩序虽然安定了, 可是他們并不从事畜牧业的发展, 15 却䮠迫蒙古牧民远离蒙古高原深入邻国进行大规模的掠夺战爭。在这些 战争中, 死的牧民当然回不到本土活着的也多半戍守在初征服的土地从事 镇压和监視。因而蒙古本土的劳动力严重缺之生产就迅速下降。僙妧史 本紀蒙古各部連年饥餙的紀載可以推知在貴族阶級穷奢极欲的同时, 牧民 已陷于讱寒交迫的地步。

北中国自安史乱后就陷于割据状态。自契丹族占据燕云十六 州, 白沟河便成了契丹、北穼两国不可逾越的深淵。十二世紀初女真南下, 更 把中国从淮河中流拦腰切断分成两个天下。此外, 西夏据河西西辽也建国 于新疆及其以西的地区。成吉思汗兴起时, 中国正处在这样四分五裂的衰 25 落局面。西夏、金国和西辽东部所割据的地方, 都是府代的州县, 所統轄的人 民除西辽外絶大多数是汉人。这时不仅淮河以南的南宋过着委麻不振偷 生苟活“河而幸安”的生活就是进入中原的女真党项峌旅, 也早已变成游手 好䦐的腐朽地主了。这些国家在战孚时期所駘迫的兵士, 多数是汉族农民, 少数是北方各族的牧民或农民, 差不多等于驅迫汉族农民自相殘杀。和平 30 时期各国各有疆界和禁令經济文化不能互相交流互相学习。居統治地位 的地主知識分子更竭力鼓吹忠于本国君主的封建思想以愚弄本国人民加 深各国間的敌对和隔閶。这就严重地阻止了各族社会經济的发展和文化 的进步。 
成吉思汗摧毁了或开始摧毀这几个处在衰朽阶段的王朝扫除 了各族間的疆界消灭了分割汉族的墙壁, 使汉唐以来我們多民族的大国又 恢复了原状。因而各族人民的精神状态顿时改观。以前各国所关心的如 何防御如何隔綛的問題不存在了。如何称伯称侄用大量岁币䝧买一年苟 5 延殘喘的和平問題不存在了。西夏亡后, 元代历史家説: “下下会于一, 驛道往 来, 視为东西州矣”。这种論調不正可以代表当时人对中国恢复統一, 結束分 裂的心情么?

在我国历史上北族有許多杰出的首領匈奴的冒頓突厥的土阳, 室点密兄弟回紀的怀仁可汗都是一世之雄。可是何以他們都不能进入中 10 原, 成吉思汗及其后人独能成功呢? 看来不是成吉思汗比冒㮌等人特別有 才干或武力特别强大, 而是当时北中国特别衰朽和以上諸人所面对的汉腐 时代形势大不相同。

当时西夏最小; 它“抗衡辽金宋三国偭乡无常, 視三国之强弱以为 異同。”可是成吉思汗对这样一个小国一生却攻打了四次, 临死还没得亲見 15 其灭亡。可見他的武力不是什么无敌的.

蒙古和金国的战爭最久战祜也最惨酷, 有人把“河朔生灵尽”白骨 纵横乱似麻”的責任都归給成吉思汗, 是不是公平呢? 我們詳細分析一下金 国内部的情况认为結論不能是那样的簡单。

处在衰朽阶段的金国, 蒙古兵一踏进国境, 所有矛盾都暴露出来 203 . 女真政权从中都( 今北京) 逃避到开封后, 黄河以北的統治力量削弱农民 起义遍地爆发了。这些起义綛大多数是自发的无組織的。有領导有組織 的农民队伍只有㛫安儿領导的紅袄軍, 活动在蒙古金国和南宋三种势力接 触的山东地区。各地武装地主既然不能再依靠金国政权来鎮压农民軍, 便 各自“据險自守”, 对其邻近的农民軍进行鎮压。这些地主为了控制劳动力, 便 25 劫持其佃客, 乡邻、亲族結集在山砦或水枫里, 組織成他們自己的反动武装. 如果地方州县官被农民杀掉或逃走这些武装地主也就入县摄事”, 作威作福 起来.

武装地主的势力大小强弱颇不相同, 弱小的为强大的所吞并, 或 自动地加入强大的組織, 借以保存自己的力量继續对农民軍进行鎮压。元 30 初刘因《靜修文集》卷十七郭弘敬墓銘云: “金点祐主南渡, 而元軍北还, 是时河朔 为墟蕩然无統强焉弱凌众焉客暴孰得而控制之? 故其遗民自相吞噬殆尽”。 足見当时地主武装之間, 互相殘杀的惨酷。

武装地主的政治路綫不是固定的要看怎样最符合他們的利益。 金世宗説这些人“辽兵至則从辽定人至則从宋本朝至則从本朝”。正足以説 
明他們只注意保持自己的統治地位, 不管皇帝是那一族的人。金末河北苗 道潤, 武仙之流继續为女真皇帝效劳, 参加反对蒙古軍的战争。張柔、張荣之 流則降附蒙古加入反对金国的行列。在蒙古、女真南宋三种势力接触的山 东地区, 更有些混入农民軍的投机分子李全之流、在叛金降宋之后, 具蒙古势 力强大便又投降了蒙古。他們不管背叛誰拥护誰目的只有一个就是想任 借一个政权扩大自己的势力, 猎取更高的地位。在这一点上, 所有的武装地 主們都是一致的。

成吉思汗西征时把灭金的任务完全交給木华黎。李华黎接受 的軍队除汪古契丹、真兵外蒙古兵仅仅只有一万三千人。他所轄的汉軍 尽是新降的武装地主的軍队蒙古灭金的长期殘酷战采, 实际上主要是这些 投降蒙古可汗和继績支持女直皇帝的两种地主, 在扩大蒙古政权或保护女 真政权的条件下, 在两个政权統治者的指揮下进行的战爭, 双方所残杀的几 乎全部是汉人蒙古和女真統治集团虽也参加战爭, 但更大的任务是組織监 督这些惨酷的战采。

金国内部的民族矛盾也是尖锐的, 元朝多承用金制, 元朝把国人 15 分为四等, 大概也是学习金朝的, 因为金朝在兵权財权上, 用人已有“先女真次 渤海次契丹次汉儿”的次序。渤海人数不多, 又与女真为同族, 矛盾不很突出, 河北汉族对女真猛安謀克人户强夺土地結怨最深所以女真政权迁洨后, 河 北农民便乘机起来进行报复。契丹族的地主不甘心失去政权蒙古兴起时 也紛紛起来为他們作响导当謀士, 有的且糾众独立, 建立政权.

可見成吉思汗兴起时, 金朝已处在瓦解的前夕。除了南察与金 国、西夏与金国蒙古与金国契丹与金国的战爭外, 金国内部还充满了农民反 抗地主的阶級矛盾, 汉族契丹族反对女真政权的民族予后, 也充滿着继續效 忠女真皇帝和降附蒙古可汗的地主阶級間的矛盾。在遍地战火的北中国, 死亡了无数人荒葭了很多良田沃土农业生产受到了严重的破坏因而金国 25 山东河北山西河南到处缺粮, 普遍陷于饥餙状态有的地方竟达到人吃人的 地步。文因描述当日的情况道“河朔大乱几二十余年, 数千里間, 人民杀翏戈几 尽, 其存者, 以户口計千百不一余”那么我假若把所有这一切焂难完全推到成 吉思汗身上, 显然是不符合事实的。

可是这种岑难, 一部分究竟是成吉思汗造成的。盛吉思汗初入 30 中原目的只在唅掠財物, 不在占有土地金国大河以北虽説只有十一个州县 没有打下, 可是接受金国降款后, 他就退出居庸关了。蒙古以畜牧为业不需 要大量劳动力, 因而屠杀人民, 毫不顾惜。常用屠城等殘酷手段对待英勇抗 战的人。人死多了, 劳动力就减少了, 这不仅和武装地主的利益相矛盾, 而且 
对蒙古軍的作战, 也很不利。所以当时史天倪王棫刘世英塔本等都相继向 蒙古統帅木华黎、索秃等建議改变屠杀政策。嗣后大規模屠杀虽稍稍停止 可是各族将领却大量俘虏人民, 作为自己的农奴这对于破坏农业生产, 差不 多是一样的。

金哀宗説，北兵所以常取金胜者、恃北方之馬力, 就中国之技巧耳”。 金衣宗完全用唯武器論的眼光看蒙古的胜利和金国的敗亡, 当然是不正确 的。蒙古受地理条件的限制除了为畜牧狩猎服务的简婳手工业外当时其 他技术工人, 不仅极端缺之, 甚至根本没有。成吉思汗为了軍事的需要竭力 輸入当日世界上各种最先进的軍事紅驗和技术。他从中原搜罗了大批手 10 工业技术人員——造弓的, 造甲的造鳴鏑的造攻战之具的造火炮的, 以及造 金汁炮的等等, 直接地改进了他們的武器, 間接地也提高了他㑚手工业的技 巧。他又从中原輸入造桥技术, 符牌与驛站制度, 来改善他們的交通条件, 重 用中原医生来改善蒙古的医疗和卫生, 更迁移大量农民到漠北来发展蒙古 的农业。成吉思汗的主观意图虽然是用这些农民技术人員和手工业工人 15 来加强武力进行掠夺战爭, 但同时也改进了蒙古的物质生活条件, 发展了生 产力, 对蒙古人民是起积极作用的。不过这一点积极作用是建立在广大中 原人民的痛苦和死亡上的。成吉思汗向漠北迁移的农民和工人不仅沿途 缺乏食物, 大批死亡, 就是到了漠北, 由于地理条件突变, 寒冷不支, 以后也有大 批再迁回中原的利害得失衡量起来代价显然是太大了。 的世界讲, 中国是經济文化最发展的地区之一。就中国讲中原的經济文化 发展的水平又最高。大批外族进入中国大批少数民族移居内地后他們在 經济上, 文化上都得到了发揮才能的机会, 特别是进入内地的少数民族在祖 国的散文詩歌书法繪画上, 在医葯和农业科学上, 都真献出卓越的成就。 发展了呢? 还是衰退了呢? 有些大漠族主义历史家心中横着少数民族做 中国皇帝的时代必为黑暗时代的偏見抓住一些符合自己需要的史料, 加以 夸張和普及就把那个时代渲染成了人間地獄。例如有人爱用“異极江南, 富 称塞北“两句話来描写元代的社会, 难道“每一年有收二三十万石租子的, 占着 30 二三千佃向”的江南大地主, 也是穷到极点䈪儿卖女的蒙古人也是富得堪称 么? 若认为汉唐有文景之治开元盛世是理所当然在少数民族做皇帝的元 代阶級矛盾就一定不能緩和, 不可能出现“治世”这是什么邏輯呢? 任何封建 王朝都是民族的监獄, 在一定的时間或一定的条件下, 民族予盾都会变得突 出, 要説蒙古王朝没有一线光明, 是不符合历史事实的。 
从成吉思汗到元順帝总的看来, 这个王朝可分两个阶段, 忽必烈 以前, 政权是統一的政治中心在和林經济文化高度发展的汉族地区, 只是这 个国家的一部分, 蒙古貴族仅遣人搜刮, 需索却沒把全部力量投到这里。忽 必烈以后, 西北藩屬独立, 政权分裂他仅仅占有东方, 差不多只做了中国的皇 帝。到了这时, 政权的䋑济基础几乎全部建立在汉族地区, 要想进行长期統 治和剥削, 必須加强汉地的統治力量, 在这方面, 蒙古統治集团采取的办法很 多, 我們在这里只談他們的屯田和馬政。

蒙古統治者在綵济落后的边疆地区实行屯田政策是十分成功 的, 这种电田政策, 成吉思汗已經开始实行了。他迁移大批汉族农民到漠 北委任鎮海管理进行星殖。以后他的子孙继續执行这种政策, 元史》《兵志 10

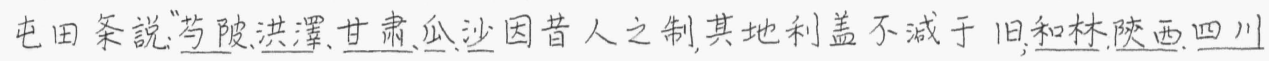
等地則因地之宜而筆为之。”蒙古的鄂尔渾河流域到西南的云南諸省, 开 辟了汉唐两代所未曾开辟过的土地。

蒙古統治者为了养馬把牧地也扩大了。东越耽罗( 今朝鮮济州) 島) 北踰火里秃馬(今苏联县加尔湖东, 西至甘肃, 南至云南等地都有他們的牧 15 馬場所。

蒙古皇帝加强屯田和馬政的目的, 在于鎮压国内各族人民解決 粮嗆和交通工具的問題但耕地面积和牧地范囯扩大了, 农产品和牲畜的数 量增加了, 对社会經济的发展是有利的, 这不正是所謂“祜合福所倚”？

元代地方官的升降往往由其对农业增产有无成績来决定。这20 当然只是具文。但就偶然遗留下的生产数字来看, 至少在一定时期内, 生产 力确实年年有所增加的。依《元史》《世祖本紀》, 至元25年耕曠地35 70 頃, 28

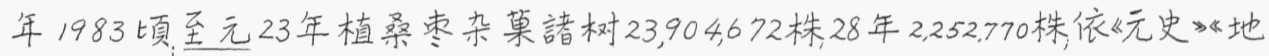
理志狛記載, 至元27年全国人口达到5 $8,834,711$ 人超过历史家歌頌的“开元全 盛日”一千多万人( 《旧唐书》《地理志焉元2 8 年全国人口48,443.609人。若説 25 元代由于蒙古人做皇帝, 社会經济趋于萎縮, 显然也是不符合历史事实的。

\section{(三)}

关于成吉思汗西征的記載我們今天能讀到的, 主要是回教地主 知識分子紀录下来的。蒙古人信仰珊蛮教, 对于回教的風俗习惯自然不会 尊重, 这些回教历史家咒詛成吉思汗是不难想像的。因此, 我們今天就应該30 用批判的眼光来对待这些記載。

蒙古草原上自古就有中亚商人颠卖东西双方的商品。1214 年 成吉思汗在北京近郊接受金国求和的时候, 中亚花刺子模国王摩訶末遗派 赛夷・宝合丁・刺昔到北京見成吉思汗借以偵察蒙古的虚实。当时成吉 
思汗即要求蒙古和花刺子模双方經常派遣使臣、商人、商队往来, 交換两国精 良商品維持永久的和好。成吉思汗对待花刺子模商队也是友好的。可是 舍婪的花刺子模边将由于重涎蒙古商队的珍貴商品, 竟干起杀人越货的勾 当来。及成吉思汗再派使节去质問, 又遭到使臣被杀使团成員被割去影澎 5 的侮辱。摩訶末統一中亚和成吉思汗統一蒙古高原以后, 双方貴族继續向 外掠夺邻人的剘富, 那是必然的。可是在西夏和金国灭亡之前, 若不是花刺 子模对蒙古实行进攻成吉思汗是否便揮戈西向, 实在很难説。花刺子模的 欺真, 对素重复仇而又处在无往不胜时期的蒙古貴族, 是不能忍受的, 所以成 吉思汗决心进行的复仇战爭, 就会鼓舞起来他們的敌悴心。

成吉思汗西征时, 花刺子模的算端也才哃剖拉吞了波斯和河中 (錫尔河与阿姆河間地)。在这些新征服的領域中, 政权还很不稳定, 統治力量 也很薄弱。就軍队讲, 軍人是康里人不仅軍权掌握在康里軍官手中, 地方政 治也由他們操纵。宗教呢? 派别很多, 算端屬阿里派, 与伊斯兰教名义上的 首领哈里发处于对立地位。特别是花刺子模的人民对康里軍队的暴横, 厌 15 苦莫名。这就是花刺子模当日国内的情况。在統治集团中, 算端与康里将 領地方首領报达的哈里发他的母族之間, 各有各的打算。战絆由可恥的边 将杀人越貨引起, 叭不容易鼓舞。因而便提不出一个作战部署的整体 計划, 也組織不成全国一致的抗战力量, 只有步步退却, 着着潰敗进行一城一 地的守御战了。

成吉思汗西征的对象, 除花刺子模外, 还有一个里海北部的欽察。 成吉思汗何故遗速不台、者别二将越过高加索山, 进击欽察, 絖道里海以北, 返 回蒙古呢? 这仍是为了复仇和掠夺。

从蒙古的土拉河到里海北的优尔加河, 这个无边无际的大草原 上都是突劂族人, 虽有部族間的分界却无語言上的隔閶。这个草原的最西 25 端住的是突厥族的欽察部人。成吉思汗的世仇戥儿乞部破灭后, 首領逃入 意及亚蛮敗亡, 又逃入欽察。成吉思汗遣速不台等进击优尔加河和鳥拉 河之間玉理伯里山的欽察部就是因为它藏喏了他的“負箭之糜”。

欽察各部落或逃或战意見很不一致他們向邻人斡罗思人請求 援助, 斡罗思各封建主又各顾自己的利益, 行动也不能統一, 所以他們的联軍, 30 遇到成吉思汗的这一支偏师就被击敗了。看来这次战争, 是乘机复仇是偶 然的若説成吉思汗在蒙古大本营早就制定了进軍克里米亚半島的作战計 划似乎是不大可能的。

历史家説成吉思汗一生曾“灭国四十”, 他所减的西域各国当然也 在这个数目之内。这些国家的奴录主或封建主为了巩固自己的統治和剥 
削, 把自己的国家看成禁区, 封閉本国人民的耳目, 和外国隔絕起来。他們只 希望所轄的人民渾渾哥哥愚昧忠順千秋万代供他們一家一姓任情压迫和 剥削。如今”一代天驕成吉思汗”出現了, 他的战馬冲破了大大小小“四十”个国 家封禁人民的銅墙铁壁使他們的人民看見了更大的世界可以活动, 看見了 更高的文化可以学习, 从历史发展的趋势看, 盛吉思汗难道是該否定的么? 5 灭国四十是不会没有流血和破坏的可是我們拥护各国大小奴隶主、封建主 的封鎖禁閉呢? 还是贊成成吉思汗打破封閉, 給各族人民在緛济文化上釗 造互相交流互相学习的条件呢? 对社会发展起推动作用的, 是封閉呢? 还 是冲破封閉呢? 当然不会是前者。

当然盛吉思汗在西域的破坏究竟是巨大的。以畜牧业为生的10 蒙古人对于农业和城市的摧毁毫不各惜。花刺子模首府王龙杰变成澤国 馬魯綠洲成了荒無之区, 都是成吉思汗灌城决堤的結果。血族复仇在当日 蒙古人生活中还占重要位置, 成吉思汗的一个孙子战死在范延城下, 这个城 堡在成吉思汗的愤怒之中, 也全部毁灭了。

成吉思汗从动身西征起便采用中原的交通制度, 在通往西域的15 大道上, 开辟“驛路”設置“驛騎”鋪牛“和”邮人”, 把中原旧有驛站系統延伸到西域。 这一艰巨事业一直到他的子孙时代还继䋶进行改善和发展。西征时带去 大批汉族技术人員沿途辟山开路修筑桥梁, 改善东西交通条件, 为了維持道 路上的安全, 他还特别在交通大道上設置护路卫士頒布保护往来商人安全 的扎撒( 法令)。突厥世系墸者花刺子模的阿不勒・噶齐(1605-1664)説: 在伊20 朗和突兰今中亚之間的一切地方享有这样一种安宁, 头頂金盘, 自东组西, 不 会遭受任何人的侵犯。这样东西暢通无阻的时代, 古代史上曾出现过几次? 成吉思汗把东西交通大道上的此疆彼界扫除了, 把阻碍綵济文 化交流的堡垒削平了, 于是东西方的交往开始頻繁距离開始縮短了。中国 的创造发明如火药紙币驛站制度等輸出到西方, 西方的药物織造品天文历 25 法等也輸入了中国。泉州和波斯的忽里謨子之間有大量的商船定期往返, 中国和东南亚各国(真腊、暹、佳唧度等等)的使节和商人, 在一定时期内几乎 相望于道。由于海上交通頻繁捎工航海經驗的积累无代中国航海家除了 凭針路定向行船外, 潮訊風信气象的规律也能初步掌握了。明初郑和西使, 正可 看作元代海外交通事业的继緢和发展。

討論問題：

一, 中国及警古的生活方式中有什磨特出的文化石同點?

二萬里長城的意義虚何：是防止遊牧民族入侵抑或阻止中萃民族與外族之接触? 
三。試述造成成吉思汗成功的屡史原因。

四成吉思汗如何印镫了歷史慗上的“傽人説”?

五蒙古王朝衰亡的原因何在? 


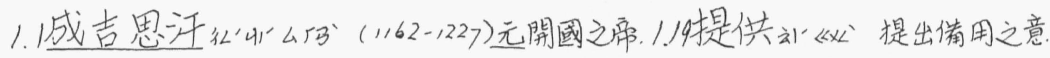

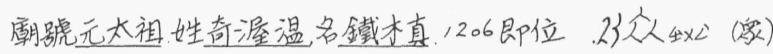

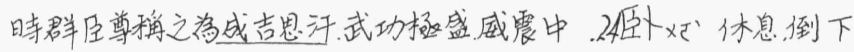

外、在位二十二年(1206-1227)

优《婂)

历为 歴)

战忪 (戰)

.14屠动赤

屠杀 残耓

杂䦿(耚)

场仅分(培)

进 415 (進)

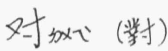

13亲《( 彩)

国《㳊”（國)

罗 此 (羅)

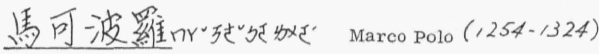

意大利人元世祖時曾到中國並漛官二十食余年。
有歐人熟悉中國情形之第一人

卧内睡房

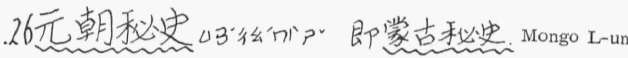
ni'uca tobci'an (The Secret History of the Mongols) 1240 b⿵ 青撰者佚名, 370 譯為邁文, 又由 Palladius 譯有 俄文、第一至六章 P. Pelliot 曾譯为法文。

节山瑯)

实户（惯）

.24会代( 覥)

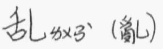

种敌“(種)

当阮( 當)

部洛秋“外代人民聚居在一起, 而末成國家之

民族

复圪(復, 複, 覆)

复仇 颕仇

夺敂”(㸝)

28诐斯的么國各。Persia

.16尔心(雨)

29 长赫( 長)

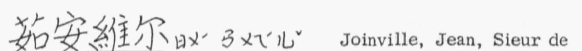
$(1224 ?-1319$ ? $)$

君长君主, 首領

亚 $1 \gamma^{\circ}$ (幖)

两为化 (雨)

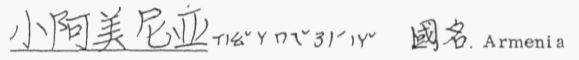

联出13 (联)

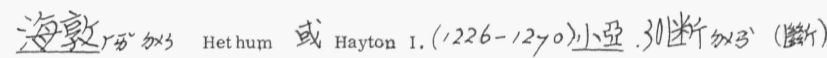

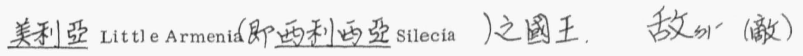

儿心 (完)

动勿心動)

谷儿只《的儿壮”國名, Georgia，在亞美尼亞之北 .18 继41 (繼)

来加 (来)

.19个《优)

发 $2 r($ 煞)

这甜（追）

里出( 裡裹)
湯犹不受約束

放湯不受约束，任所欲為

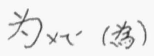

.31金朝4 13 弦其先学女真族, 世居公花江之串 1115 年㛵帝, 國䟽金, 佔有今東三省及黄河流 域及江落安徽之淮北等地, 歷五世九主( (1) - 1234 ) 有棠古所减 


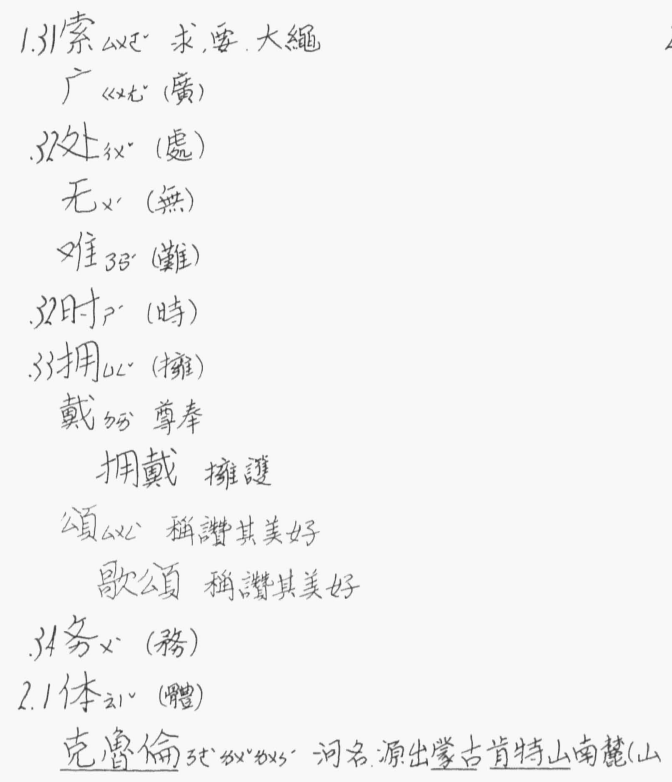

足)

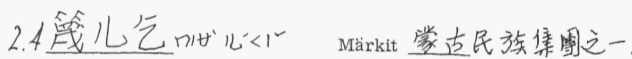

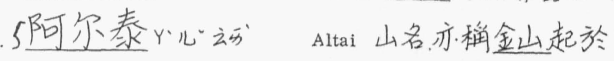

天山之北在掌古之西部

区 $<($ 傴)

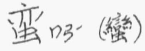

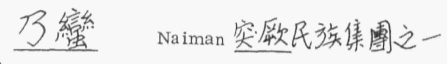

６陷们落入, 满之反

后仪( 後)

忉羊尤(樣)

观 $x \times 3$ (觀)

8恶ざ (惡)

欲心 (愍)希望, 願望

情欲人情所䝠望的一具才富與權势

权《 3 . (旅)

势? ( 勢)

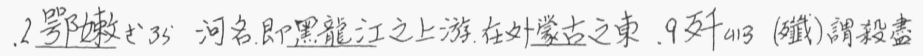

北部

土拉动”加河名，亦搯圆拉，源出外蒙古首持山

西麓

据岎(據)

武动了（圈）

东汃 (東)

呼偷以秘湖名, 在今黑龍江省。

了具尔心湖名在今黑龍江少
天芯(减)

歼灭殺监隇絶

駿405 良馬

釤馬良馬

乐蝶)

。证积(話)

.11 台. П (.nY) (磨)

独分（猫）

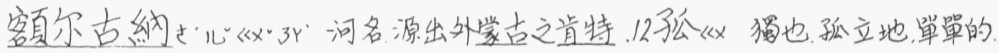

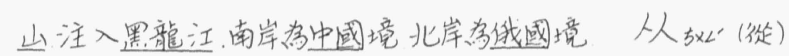
带的分带)
寻ros. (变)
几41 (幾)
. 13 令邻多, (粼)

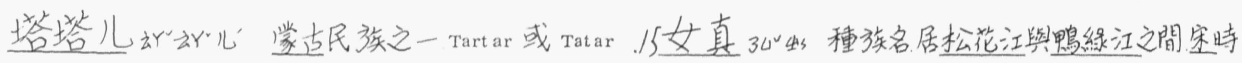

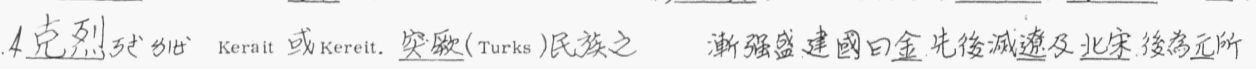
集嘈。 隇渶清即其後代

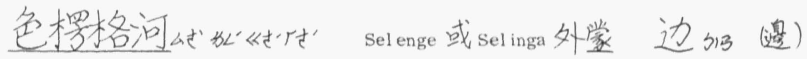
古沙漠以北之最大河東北流注入具加尔。16辽加( 遼)

湖(Baikal Lake)

辽代朝代名其先学契丹、互代丝時始改國 


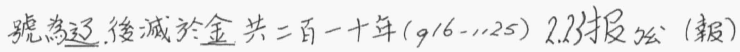
2.16 三兰办策)

$$
\text { 协化( 協) }
$$

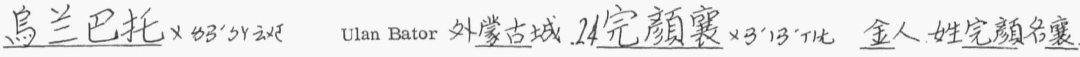
根河《优河名, 在黑龍江省呼倫影水 击 4 , (慗)

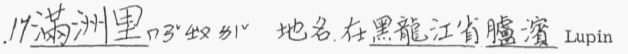

縣之西北角, 舆廯聯交界

綫仍即線。

壕厂城下人工造的风下的清道

界壕在邊界上作㳑壕用以自得。

址到基地

遺址留下来的陳跡

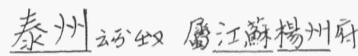

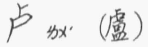

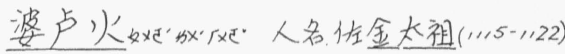
伐遼曾学泰州都統

浚405疏通。治河使之深
25.11

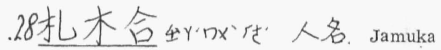
举4 (舉)

.29职出( 職)

30 触㣗( 解)

31 丰CL (豐)

33 占积 (佔)

34 质出 (算)

3.1 侷 $4 \omega^{\prime}$ 不安適貎

倘促量小而顯得不安的栐子 铁乡世 (鐵)

铁木真元太祖之名

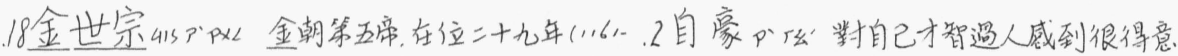

1189 )

.19撤忧退

称径( 稻)

了拉施德外了的名 Fadl Altah Rasid al-Din

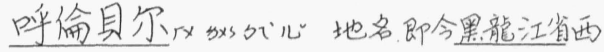

角, 境内北有呼倫池甜月) 南有具尔池( 湖)，故名。

达外 (達)

旗《1 学古行政區名如傫

波斯人, 303 年奉命編撰史總或史集Jāmi al一

tawārih 初述学古諸部落歷史, 次述㒸古帝國

歷史

4 录的( 錄)

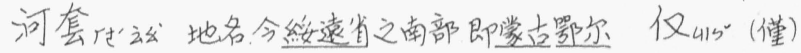

多斯

20 墙《沙）

胁个䱢)

.21栲栳泊自弦”幼㕱”地名。

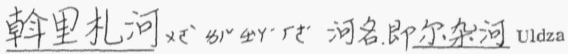

22苏公 ( 蘇)

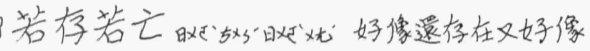

$$
\text { 已減亡 }
$$

.10槙時立刻。

12 献 113 (獻)

认的( 認)

应儿(應)

杂PY.(離)

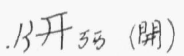

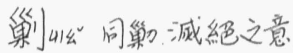

策襲点佔他人所有为已有

23厌i (檿)
.14井阰(譜)

劳力学労)

还励 (還) 


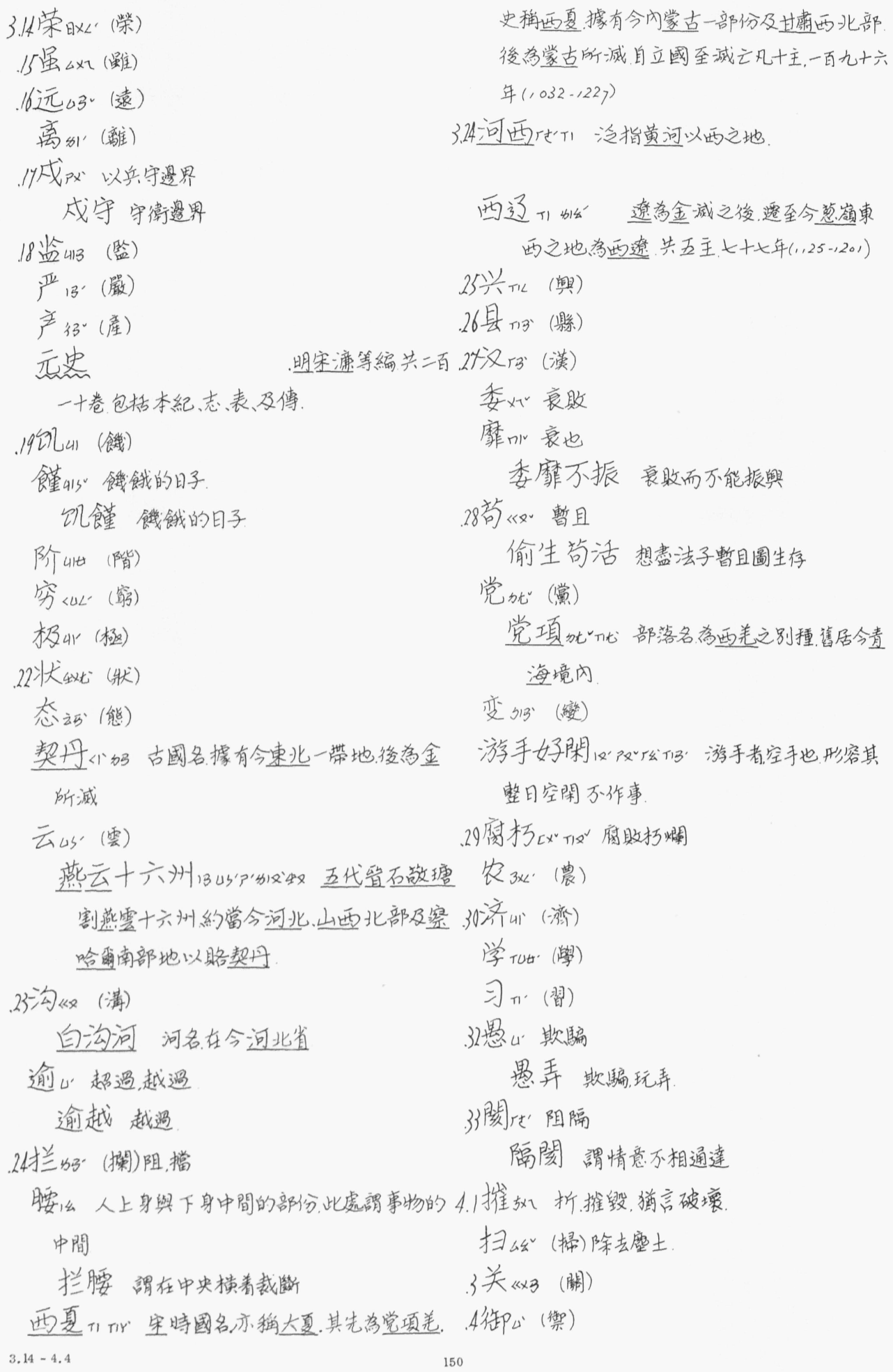$$
\text { 2)愚心欺騙 }
$$$$
\text { 愚弄欺騙玩素 }
$$$$
\text { 33閶陵阻隔 }
$$

委的哀敗

犘口，衰也 .28苟《檕且

$$
\text { 偷生笴活 想患法子暫且圖生存 }
$$

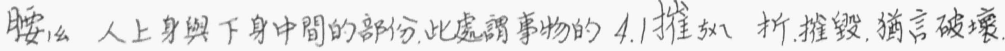
中間

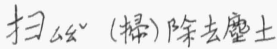
拦腰嗃在中央横着裁铉 . 关《好(關)

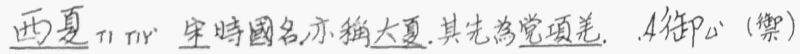


4.4 防御防借抵抗

伯吧“對父之兄或尊長之敬稱

侄出”稻兄弟之子日侄、對尊長自焰侄。

稱伯稱侄意指與别人别或拉關係。

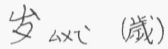

币夕（幣)

岁中，小國或管成每年進真之剘物

购《泪軎)

实鸣”(算)

.5喘䎮”呼吸繁促

苛延残喘意謂暫時延長已弱的生命

驛、古時送官文書信的使者沿途暫息易馬、或

止窃之所。

騂道, 古時通向各重要都市的道路通常建 造得較好

8杰4 世傑)謂才督過人者

杰出謂才能高出象人之上

冒顿呵”名, 漢初匈奴之單于, 大拱其疆 土曾南下葍高祖於白登、恵常時又送信㩐品

后，漢不得已與之和新並納紫幣

突厑动一比一種族各、分東西二部今上耳其人

Turks 学突㰮别族

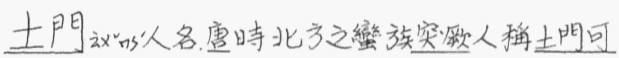

汗.

9 点办 ( 點)

室点密西突㷧之可汗，士归可汗之弟

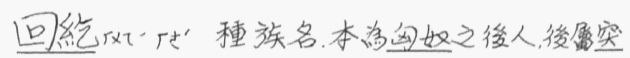

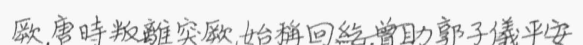

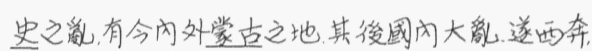

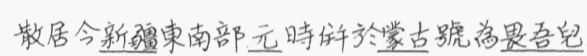
颀不叹名, 懷

怀仁可汗唐朝時回紀之尊長

. 11 质《幹)

13偭吸背
4.13多忙( 良

偭乡无常即面向無常, 有時為敵, 有時为友 好管为卧）

.164参5 3 - 惨) 稘痛

惨酷值痛残, 忍。

灾加 (露)

生灵猶言生民即活人。

尽415 (盡)

向骨加《指死人

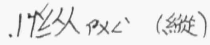

床木喟喻甚多而畄之意

河朔生灵尽向骨纵横乱似麻黄河 以北活人都没有了, 遍地都是死人

犸《xて (毁帚)

18 年加(單)

19踏动以足著地

踏进走進入

矛吆長柄有刀鋒之古兵器

盾汃分践寽時用以防兵力之武器。

矛盾語是㫢非子; 喻人行为互相前街衝 突.

暴公急速

暴露㩆现出来

20 开封抲化河南省榡名。

21义卜(義)

起义革命仗義舉兵

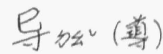

.22队力口代( 榢)

队伍即軍隊

㛫安儿比的金宣宗南䢮後，山東區震民起

義領袖之一

袄么”(被)指上衣

红袄軍豚任皆穿紅色上衣以相識, 故名。 .23装的必(裝) 
4.25去力41世”强取

劫持强力捉拿起来不效

砦地同寨

山呰山上的要寨

行常設置於河上或㮕个

26摄試(攝)代理

.28答动吃下去。

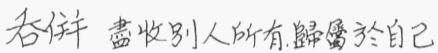

. 30 刘加澱)

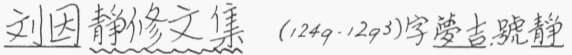

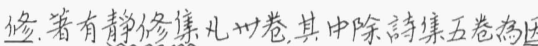
自定外、餘皆桨阴人故友所集。

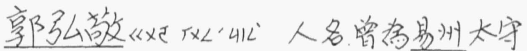

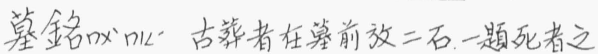

姓名, 一刻鉻、叙述或槄揚死者事迹。

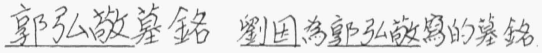

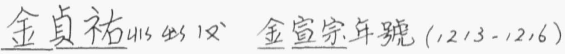

河前为墟㵣然无统黄河以北成为旒地,

繁人管理

３１强焉弱凌众焉塞暴强者欺弱者人多的

對人少的不客氮

遺民1'n'指易代後万願在新朝為官或为民者。

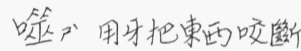

自相各险殆尽彼此相咬吃、幾乎都不.20响下儿 存在了 . 护化

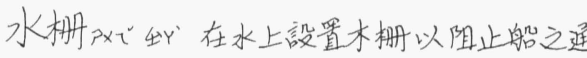

摄事代人管理其娥弱

太祖攻伐有功，卒年八十三

5.4 机41 (機)

投机分子善於迎合時機，以取得利益者

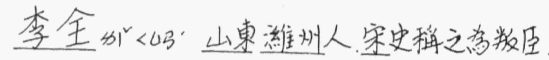

凭如 (憑) 靠 凭借靠着籍

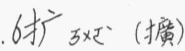

猎为( 幍)

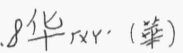

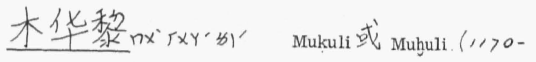
1223)成吉思汗手下一部特。

.9汪古炕《河套北邉的一族, 原学金國展部之一

万人䔽)

.10际山1 (際)

.12条动（條）

双杹(雙)

.13 参战 (参)

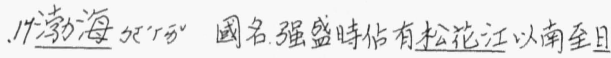
本海之地, 五代時腐遼所隇。

与喓

18 猛安、謀克叫“3叹方式金官名、金初啫部民牡

皆兵, 千人之長学猛安, 百人之長青謀克

迁<13 (倦)

泣帉河南省之别稻

响导引路之人。

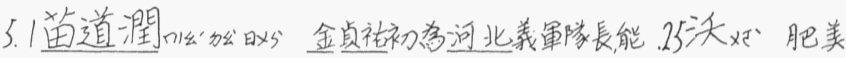

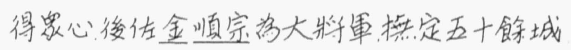

决土肥美的土地

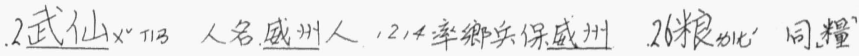

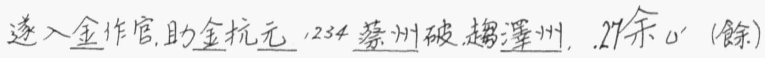

为濐之戍兵所殺。

29 显 130 (影)

張柔乱炚，人名金宣宗時曾为高官。

.32居揵关阰《好

閣，名，在河北省昌平夥西

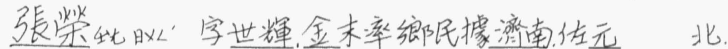




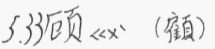

顾惜爱情關心

6.1 史天倪, ”动31.

不能相處, 1225 年学武仙所媇

與武仙俱治直定, 二人
6.13 医、(監) 疗幼(療)治病。

卫妨( 衙)

漠北吧引沉沙漠之北、即外掌古.

14图动 (圖)

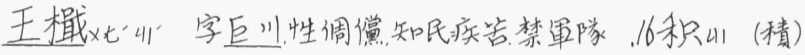

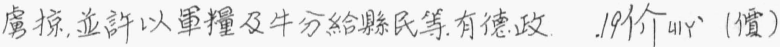

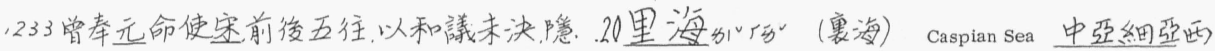

䨓致疾, 卒于南京。

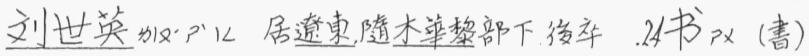

於師

塔本动”夘”伊吾盧人, 從元太祖攻伐、平时

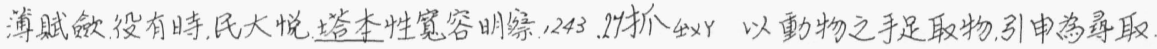

年卒.謚忠武。

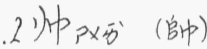

抓任 拿住、認清楚

索悉吠”动善騎射, 元太祖以皇妹妻之, 聁又

以皇女妻之

了将优（㸹）

虏加以(虜)

5 金衰宗4 13 万账金席在位十年( $1224-1233)$

胜訟(勝)

. 6 确《山甘(確)

狩㫟冬天打獵

狩猎以猊具或鹰犬捕捉鳥獸

婳加”狭小, 不精类

簡婳解單低級

.8术际( 術)

. 9 罗加只捕鳥之網

搜罗搜求而招致之

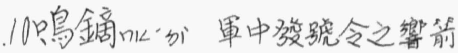

.11炮始軍用火器, 即。砲; 元時有火炮, 金汁炮。

12 桥《(橸)

28 夸 $5 \times 4$

渲TU畫家以水墨塗在紙上青渲。

染炚”在白布上加颜色, 使等色。

渲染形容過份擴大的描述

爱为( 渗)

29 写仙 (察)

.30数心責

卖㕫(赏)

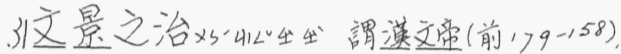

漢景帝(前, 56-143) 時的太平盛世

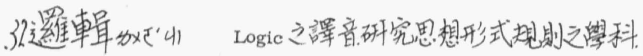

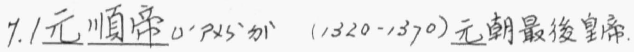

在位三十天年(1333-1368) 到明軍北伐，顺席

乃奔上都(即元世祖建都地，在今察哈尔省）

元朝即之。

总P迎 (總)

忽必烈仅が如 Khubilai $(1,2,5,294)$ 成

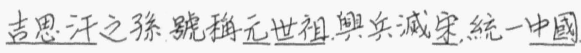
領土包括丝洲及臨洲東部、疆域之腐、前古未 有、在位三十五年。

在右雨半、雨方各拿一半, 有事時用之以言正真鹤。

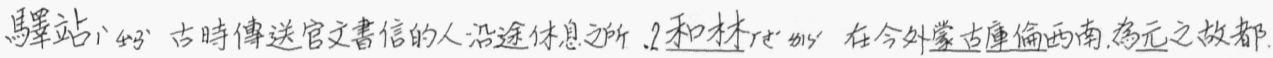




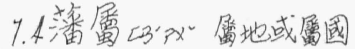

.5础㣗礎

.6乎弦

办吗( 就)

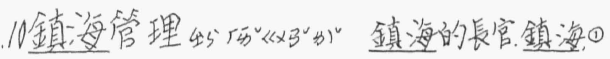

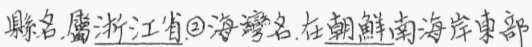

垦强 (饗)

孙么吗(孫)

执正( 執)

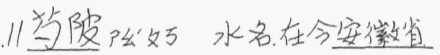

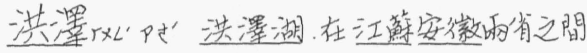

肃公(肃)

后《xy即公州、在今甘肃省冈

沙尼即沙州, 在合甘肃省风

盖《沼(篮)

目收(舊)

12 筆生開始

因地之宜而集为之看當地的情形及 所適宜的開始墾殖

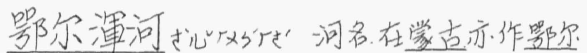

地長約千餘里

1)㞋辛㚧（䦣）

開辟開答弡展

.14养氿 (羪)

耽罗加物“即湾州息, 朝鮮南海中之大岛古之

耵罗国

１５踰心過，越過，超過

北踰北方遠至

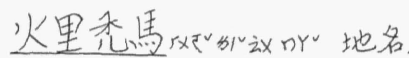

具加尔湖汃U1Y“湖名 Baikal Lake

.18餉化”稳軍用之銀米。

范印諥

.19倚, 依, 靠
719 福兮福所倚福兮福所伏語思史記指 禍福交相依倚

.22至元的山元世祖年躆、至元二十五年即 1288

2)苯阴

树劝（樹）

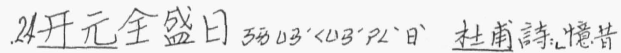

開元全盛日, 小邑猶藏䔽家室”言唐玄宗開元 時( $73-741)$ 之盛

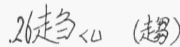

䎹妇 2 草水有病目篓

委管宿 衰退

.29瑟册蛮教3 3 吗山公 Shamanism蒙古人所信之散 .30 呪积求神加福於人。

詛辟求神加禂於人。

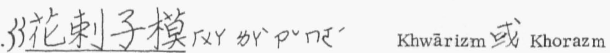

國名、中严一信奉回教的突㷧族所建的帝國。

後螖元太祖所减, 元史又棦之有回回國

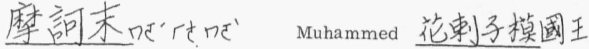

.34 宝吆”(琶)

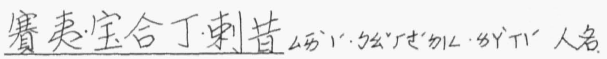
8. 漤加 貪爱食

夏婪燰剘噯食

涎13. 口液, 口水

重涎口水下流、俗用学羡甞之意

越呭跳過。過份代人作事。

杀人越货殺人並唅去其貨物

勾當《妨尤县不得人的事情

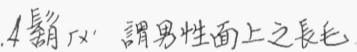

䯳仙影

，戈《古兵器，似長力

揮戈表示向前進攻的意思

.9媃柺怒恨

敌嵲禦所恨怒者 


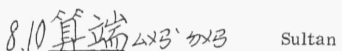

川稳凶澺)

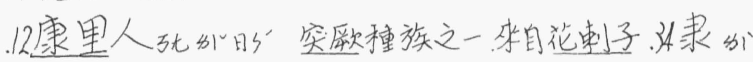

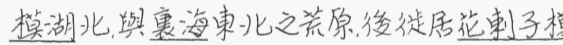

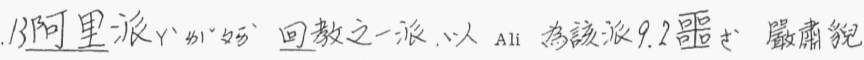

之祖

伊斯兰散、公别岎 Islamism 即回教。

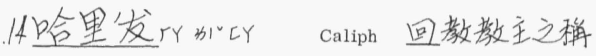

厌必(㟲)

. 16 报达弦加地名, 巴格達Bagdad之别罣。

19 气 11 (汽)

署的布置

部署布置

.18划厂原澅)

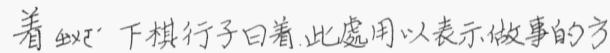

策。

着着每一個方策

20 倽察く行突缼之道牧部落

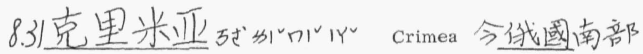

之半跒

(隸)

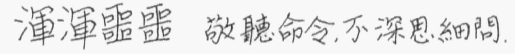

\section{昧叭不明}

愚昧不智不明

了冲㧐衝)

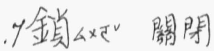

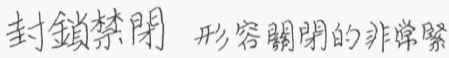

龙物么（龍）

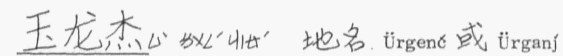

花刺子模首都

澤捄水聚集之彪

澤國謂多水之地

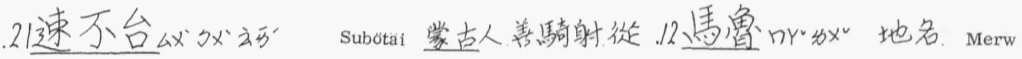

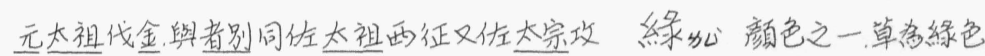

伐有功, 卒年年十三

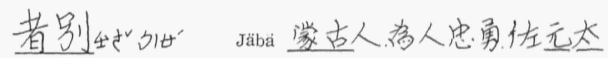

祖攻伐，嘗轓前锋。

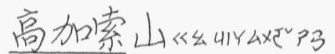

丝二洲之分界

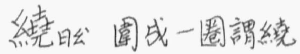

続道謂有所躲避而号選較逗之路而行。 27糜莱石卒爛

员箭之糜受了箭偒。

. 28 斡罗思地加公么 Oros 即俄羅思

30 )服(師)革隊

偏师一部份軍隊

营以

(営)
緑洲一沙漠中有水可生植物的地方

羔化未墾之团

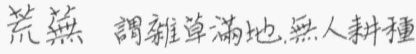

旗《注水

堤云”防水之建箱物。

旗城决堤破壤河堤使河水流入城裹。

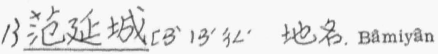

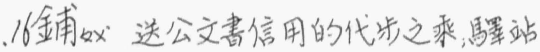

鋪牛各站偖有牛馬

由限激)謂傅送書信

由人指傳送畫信的尃人

$$
\begin{aligned}
& \text {.198艮山䀶) } \\
& 18 \text { 领地（算） } \\
& \text { 梁必( 樑) 橋 }
\end{aligned}
$$


9.20 扎撒出 4 Y 突㷧語、Yâsåk, 法令。

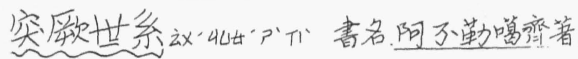

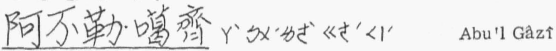

(1605-1664) 花刺子模人, 箸有突厰世系, 有迲

文翻譯(Histoire des Mongols et des Tartares)

伊朗! 犹國名。Iran

. 21 突兰动“加”國名、Touran

宁31 ' (䆬) 安

安宁安全

头动 (頭)

盘如”盤)

. 24 垒加 (埾)

25紙功和多用紙作成代替硬幣而流行於社霄

之一㮔錢

历办潪)

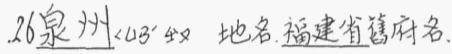

忽里謨子的“ne”p 地名, Ormuz 或 Hormuz

在 Persian Guf 内。

. 27 真腊私加”古國名今年埔塞Cambodia 之地。

暹㳩進羅、Siam 古國名、今泰國、Thailand

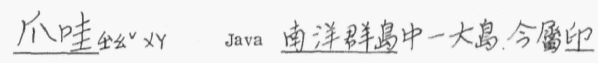

尼.

28 捎忶船拕之尾

捎工掌舵之人今一般指船夫

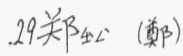

郑和私任”明雲南人、本姓馬小字三保、明

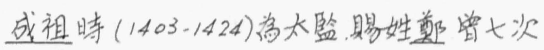
到南洋宣揚國威, 世撚三保太監。 


\section{第十課論元末蕽民起義的發展蜕㸺及 其在歷史上所起的進步作用}

\section{王崇武}

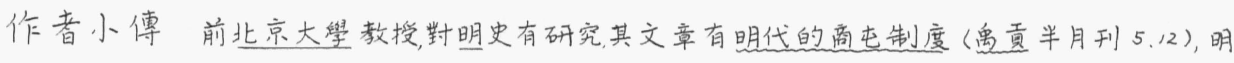

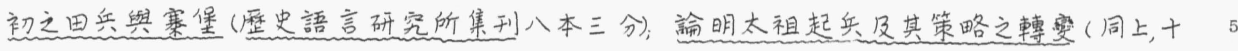
本一分) , 論元未農民起義的社會背景( 䳸史研究, 一九五四年)

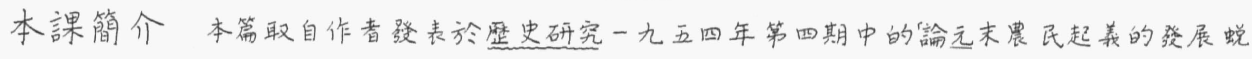

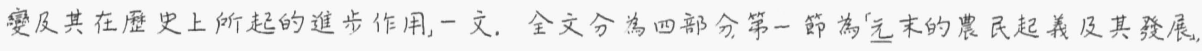

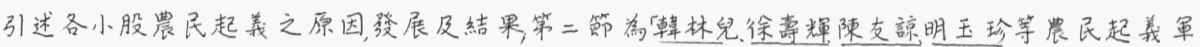
失敗的原因。本篇則是全文中的第三四雨節。

本篇首先介紹朱无噇之出身, 其思想及影每其思想的因素。尤为重要者為考證其 蜕变之經過。其後之一節則討論整㧽罢民起義所引致淩来的進步情形, 其中大略包括五點:

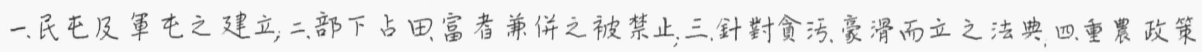
之建立; 五仁宣之治。

\section{三朱元璋的蜕化轉荄}

朱无璋生於安徽唒陽的一個盆農家一三四四年, 安徽河南一带 普遍荒旱, 同時又流行着可怕的傅染病, 那年他只有十七歲他的父册和大哥 都得病死了, 穹困無依才跑到附近的一個廟裹做和尚可是㾰裹的存糧也不 多, 所以他出家不到雨個月又被師父挷出去气討。

他四方游走, 在光固汝㒸等處叫化了三年, 而這些地方正是20 當時白運教最盛、曹民軍最多的地方。他耳濡目染藉此不但熟悉了農民起 義的組織者—白革教同時也結識了一些農民起義的個别人這和他後来 被邀参加紅巾軍, 並在相當時期之内為這個起義奮門有關係。

可是由於朱元璋曾有過三年的流浪生活, 使他久歷艱辛, 也使他 既更世故, 因此他的一切行動都十分深沈機警, 所以傈管他是贫農出身, 可是2 5 他参加農民起義却是綵遇再三考虑才投軍的。

還有, 郭子興這支農民隊伍也是略有問题的。郭子興是濠州地 主, 鑒於各地曹民紛紛起義, 遂散家財, 陰結蜜客, 參加了農民的隊伍。但果竟 由於他本人是地主, 和其他同事的幾位農民領袖意見不相同。據明朝的官 書記俞鲁孫潘等人出於曹, 其性粗直、又説他們的智識皆出子興下, 子興易3 0 視之, 每議事, 㯰與四人異。這是説郭子興和其他農民出身的領袖在思想意 儎上有距離因此造成了他們之間下能密切的合作。

朱元璋在郭子興部下, 最初是很受蔫信的, 郭子興以義女許配他, 人稱元噇為朱公子。他和郭子興的關係非常密。 
郭子興的思想意識皖然如此, 朱郭之間的闢係又很密, 那麼朱元 璋對於農民起義的態度, 看法, 自然也就很容易受到郭子興的影響。

所以在一三五三年, 彭大趙均用調朱元璋把守盯眙和泗州, 朱元 璋㫜因 ${ }^{\mathrm{B}}$ 二人粗暴淺謀, 不可與共事没有去, 他獨自在定遠一带, 招兵買馬收編 5 了一些地主階級的軍隊, 並攻佔和州為以後渡江在南京建立根據地打下基 礎。

随着農民軍的散漫自流使他們在軍事上政治上造成了很大損 失, 而由於地主階級的頑强抵抗更使他們的勢力日漸縮小。因此在一三五 五年, 朱元璋渡江以後的態度便大改繇, 他竭力拉攏地主階級的讀書人, 如攻 10 下太平, 便以著名的學者李習做知府, 請陶安做幕客。一三五六年, 克南京起 用夏煜孫炎楊害等十數人, 佔镇江後徵聘秦從龍和陳遇他對於秦陳雨人出 而做官, 非常高舆甚至把他們比做古代的名相。一三五八年, 請范祖幹葉儀 許元等十三人講論經史。一三六。年, 又把代表浙東營派的大地主劉基定 㵂葉琛章溢等人禮聘到南京。在明朝開國的前幾年, 劉基對於朱元噇的影 15 響非常大, 而劉基本人則是元朝的官僚地主, 他曾組織地主階級的武裝堅決 反對蕽民起義。

自然這並不是説, 朱元璋已被地主階級的知識分子所完全同化,

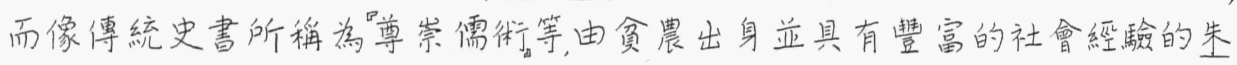
元璋, 他不會和地主階級的知識分子如何投契用中國歷史的舊術語説, 他倒 20 是王霸雜用。儒釋道兼施的。他起用逭些江南浙東的文人, 正是想通過他們 收買地主階級藉以减轅在統一全國的道路上所遇到的阻力。舉例説, 這時 他收編了很多地主階級的“寨堡軍隊而這些軍隊在打撃元朝和削平其他的 農民軍是起了很大作用的。

朱元璋從此由暲林兒所領導的農民軍中蜕化出来他後來深以 25 曾參加過這支軍隊為可恥極力迥護, 並站在地主立埸呪駡他們是妖人説自 己起義時, 只是匹馬單戈, 而没有参加過白運教所領導的蕽民軍隊。

在朱元璋和他的䜌承者的尃制高涯下, 明朝人對於朱元璋参加 紅中軍和後來蜕綮的歷史是不敢説也不敢寫的。所以後人對於朱无璋曾 否参加暲林兒所領導的曹民起義已綵不清楚, 至於他什麼時候才轉莎態度, 30 歴史上更没有明文記載, 但是這段轉礔的歷史是非常重要的, 我們必須做一 番役細的考察。

朱元璋雖然矢口否認和白運教號召的震民起義有關係, 但是在 皇陵碑中, 他描寫一三五二年, 无兵撤㩝州之圍他奉郭子興之命到定遠一带 召募新兵時, 有這樣的幾向話: 
巴而解去(指元兵解濠州之圍)亲戈與梒予脱旅隊, 馭馬控䩴, 出

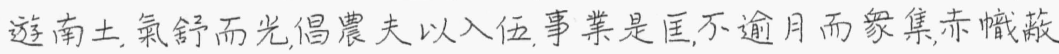
野而盈岡。

白逢教領導之下的農民軍是以紅布包頭和以紅旗為號的, 這和 反抗蕽民的地主階級以青布包頭和以青旗或黄旗為號的軍隊是截然不同5 的。朱元璋带領的軍隊洎然是用紅旗( 赫掝) , 可見他在出遊南土召募軍隊

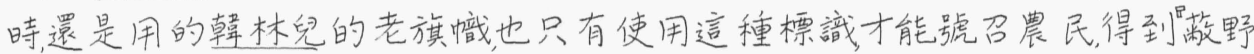
盈岡的捈象擁護。

這可以充分證明在一三五二年時, 朱元璋還是在白運教領導之 下組織農民軍, 他朁不是孤軍作戰的匹馬翚戈, 也没有脱離農民軍的隊伍。1 0

一三五五年二月, 朱元璋攻克和州, 樭總軍元帥, 三郭子興死, 韓 林兒封郭子興的兒子郭天敍繼任為都元帥, 而以郭子興部下的雨員大將張

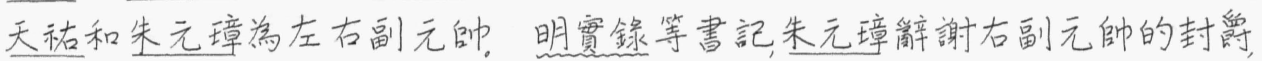
説甚麼大丈夫不受制於人!

這是説, 明朝官書記朱元璋這時已經脱離了農民軍。

可是鐵一般的事實證明這種記載是後來偽造的。在同一書裹 記載這年進攻和州很困䧼, 因度守城的无兵勢力非常大, 朱元璋自度兵力單 弱, 攻下下, 因而命三千名先鋒部隊換上地主階級的青色軍服偘装做幫助元 兵守城的隊伍混進城然後以他們自己以紅中包頭的部隊尾其後結果裹應 外合才把元兵打垮。他們敗然搹装做地主階級的士兵, 可見朱元璋還没有20

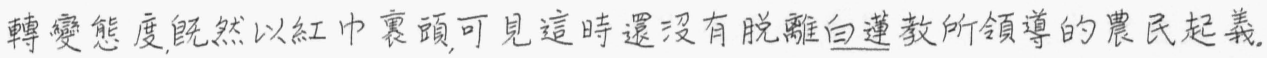

這年五月, 朱元璋由和州渡江, 攻下了采石南京, 因此被暲林兒提

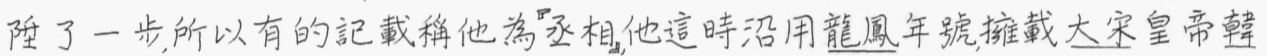
林兒, 是毫無問題的。但就在這時, 他已紅改用黄旗做標儎而不再用農民軍 的紅旗。黄旗雖不是以青旗為標誡的地主階級軍隊的旗徽但果竟是灰色 25 的態度, 它已不像紅旗那樣有鮮明的反封建色彩。我疑心從這時起, 朱元璋 和以暲林兒㼜首的贯民起義便逐漸脱離。

這個裂痕伴随著朱元璋的勢力日益發展而漸漸擴大, 後來在消 减了陳友諒, 而同時在劉福通被害, 韓宋勢力衰微時, 更把它表面化。朱元璋 在一三六六年進攻張士誠時發布了一道平周榜榜文雖然還沿用龍隊年號, 30 但他已改熟了以前的語調説:

近覩有元之末, 主居深宫臣操威福, 官以具有求, 罪以情免, 缶害舉 親而劾仇, 有司差異而優富㾰堂以為虑方添见官, 又改鈔法, 役數 十萬民湮塞黄河, 死者枕籍於道途哀苦聲聞於天下。不幸小民 
誤中妖術, 不解其言之妄誕酷信嬭勒之真有冀其治世以蘇困苦,

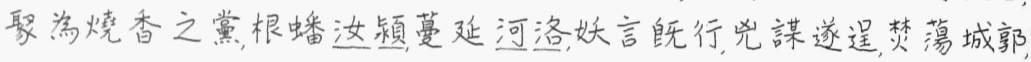
䄫翏戈士夫茶毒生露, 無端萬狀。元以天下兵馬錢糧大勢而討之, 略無功効愈見猖欯然事終不能濟世安民。是以有志之士, 旁萑 熟虑乘勢而起或假元氏為名, 或託香軍為號, 或以孤兵自立, 皆欲 自酱闫是天下土崩瓦解。予本濠梁之民, 初列行伍, 激至提兵, 灼 見妖言不能成事, 又度胡運難以立功, 遂引兵渡江。

可見這時朱无璋一方面要打倒皊污腐化的蒙古統治者, 一方面又反對聚血

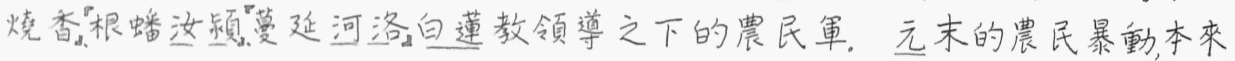
10 是由於民族舆階級的㻺迫引起的, 因而他們苞阴的目標, 一方面要打倒蒙古 贵族, 一方面又仅對豪紳地主這時朱元璋只提到反對蒙古的民族口號, 而不 再談贫富的階級衝突, 這是説他只是繼, 承以往農民起義鬥爭的一面而放杗 其另一面, 因此緩和了地主階級的反抗大大地促進了自己勢力的發展。後 來把无朝統治者趕出長城他更把這個陝義的民族口號也抛掉主張萃夷無 15 間, 他説: 蒙古色目, 皆吾赤子, 又説“姓代雖異體字如一⿻上使一般蒙古色目的 震民安心耕種, 不受歧视所以他能順利地統一全國並使社會日漸安定。

總之, 朱元璋後來踓然脱離了農民革命的隊伍但推倒了元朝解 放了生産力, 在推進社會向前發展上, 是起了重要作用的。

四、元末農民起義在歷史上所起的進步作用 白流在歷史上却起了很大的進步作用。

首先随著蒙古贵族的打倒他們覇佔著的牧場和荰田都交了出

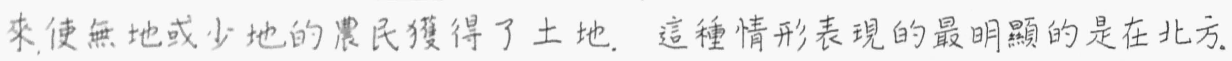

在京载河北一带, 無論在元末曹民戰爭期間, 或後來徐達常遇春 25 等攻佔大都時都没有打過激烈仗照理人口的死亡或逃徙率不很大不應該 有甚麼空䦕荒地。可是明初這一带是土曠人稀的“蒐榔原因是蒙古貴族逃 走後有大量的土地空出來.

明初對於䋑營北京一带是非常注意的。在很多書裹都可以看 到由山西或塞外(長城以北向這一带移民的事苗。明政府對迷移的農民很

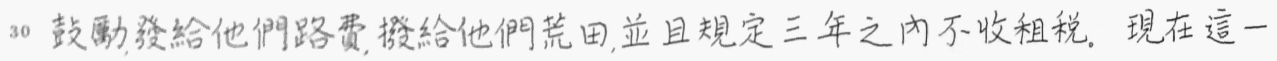
带的農民数於他們的祖先籍贯還有雨個最流行的傅説: 一説是由山西洪洞

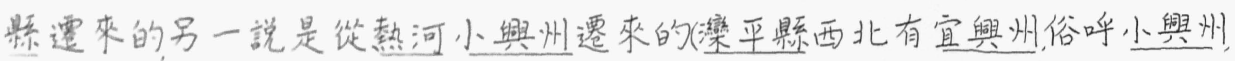
永楽初㩔, 正是由於明初這些要民事惯造成的。

在河南山東以迄淮水流域經過十幾年的曹民起義戰寽, 把大部 
分的地主打垮了, 消隇了, 他們所佔有的大量土地也同椂交與無地少地的曹 民。 這可由一三七。年鄭州知府蘇琦和湿南知府陳修所上的條陳中看出

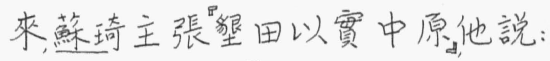

“自辛印(一三五一)河南兵起天下騷然兼以元政衰微将帥凌暴, 十年之間耕桑之地澹為草莽。方今命将出枊廊清天下, 若不設。 法招徠耕種, 以䨢中原深慮日久國用虚竭。為今之計, 莫若計復 業之民墾田, 其餘荒無土田, 宜责之守令, 召誘流移未入籍之民, 官 給牛與種,及時播種。

陳修説:

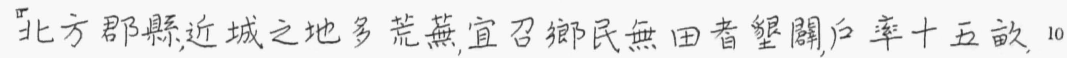
又給地二敨舆之種蔬有餘力者, 不限頃鲛皆免三年租税, 大約在近城一带, 多是地主, 土豪霸佔的土地經過農民起義戰寽, 把他們打垮 了, 因而空出來很多土地使震民有地可種。

一三七一年, 明政府下詔”、古者井田之法計口而授故民無不授田

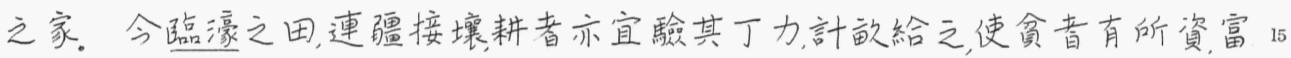
者不得兼併若兼併之徒多占田為已業而轉令貧民佃種者罪之。經過農民 戰学, 在安徽一带, 已是百里無笺家, 但見風起虚。可見地主階级遭受嚴重打

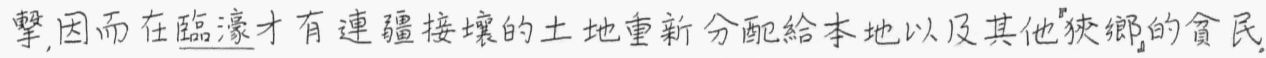

在江南最富庶的薑松一带, 把以張士誠离首的地主階級打倒後 將他們要調到别處去種田, 而把他們所佔的廣大土地没收了, 於是無田少地20 的蕽民得到土地耕種。據一四二三年的統計蘇州一府包括太含州及長州 等七影缴纳的秋糧共二百七十九萬九千石, 其中民糧只有十五萬三千一百 七十石, 官田則有二百六十二萬五千九百三十石, 也就是説, 那裹没收踟公因 而使農民得到耕種的土地佔全府總糧數的十五分之十四, 這個數字可能誇 大一些, 但没收地主的土地必定是很多的!

明初以貧民䓳荒就是使他們耕種以前地主丢荒的土地叫做民

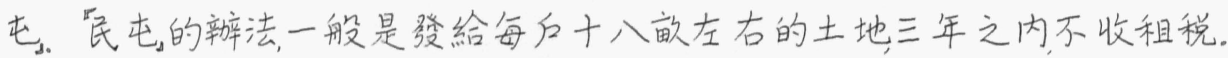
有時在初種之時, 還發給耕牛、曹具和種子。每年分配的土地是很多的, 在盟 寬録衰有一些零碎的記載, 有便於比較我把它歸納起桃, 如下表:

\begin{tabular}{|c|c|c|}
\hline 年 代 & 分配答盒民的土地數(以顷為單位) & 附 \\
\hline 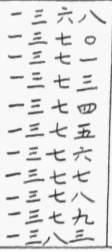 & 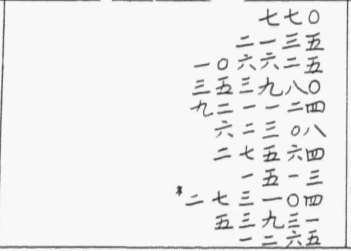 & 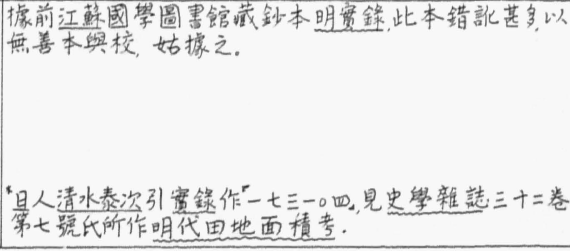 \\
\hline
\end{tabular}


必須指出: 這裹的“荒田。大半是指的内地尤其是指的綵過農民戰 采的地方。如一三七。年的開荒僅限於山東河南和江西三省一三七五年, 僅限於䆬國及江西浙江等地一三八三年, 僅限於鎮江太平等四府及山西平 陽府。由於根據的史料不完全, 我們雖不能肯定自一三七五年以後内地的 5 荒田便大量减少, 但相對地可以説, 自一三六八至一三七四年, 開墾的顷數逐 年增加, 而自一三七五年以後則逐漸减少, 自一三八三年以後, 在明寅錄上便 不特别標明内地增㗽的土地頃數可以想像這時地主丢荒的土地已大致分 配完了。

民屯墾荒在朱元璋的大力推動下, 收到了很好的效果盟詩綜記 10 陶安知饒州, 由於栍極倡導民屯, 很受老百姓的爱戴, 後来他因事調往南京民

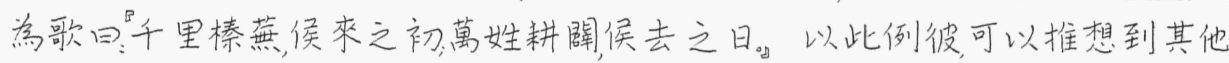
的地域。

自然在㧽别地方如蘇松一带明政府把一些没收的土地仍然照 元末地主以高额私租率分配給農民對於農民説來好像是換湯不換藥。其 15 實不然至少在明初吏治清明的時期明政府只向分得土地的老百姓要固定 的租額, 而且時常益䍖减並不像舊地主時代有很多的额外勒索, 故在剥削方面 比較暧。又明朝初年, 以一部分没收的官田做官吏的俸淥因而减少國庫的 開支對於農民也有間接的利益。

由於農民戰爭把嚄地主打垮, 也解决了明朝的軍餉問題。

朱元璋自從攻佔南京後便利用地主丢荒的土地, 惯行軍隊屯種, 叫做軍屯。兵士無事便屯田, 有警則打仗這種且耕且戰的辦法, 在江陰龍江 一带施行得很有效後來更推廣到其他的地方。

在明初, 軍隊屯㙟並不像後来僅限於邊遠地方, 而是在河南山束 北平傸西淮安等地主階級打垮了的腹地。

每個兵士開勆田地的數目不一定一般地説每人約得五十畧左 右, 在個別地多人少的處所可以儘量多種所以每人有分到七十畧八十副甚

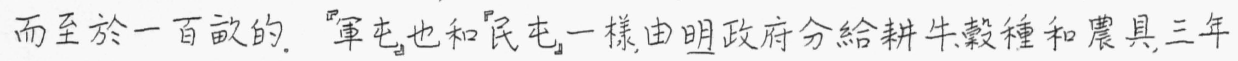
以後才收租税而且收得很少, 每畧只要一斗糧而已。

明政府定出種種優待褒掦和處罰的辦法來鼓厝兵士屯田, 在“軍 30 屯, 方面收到很好的成績。朱棣靖難。而後把國都䇥南京遷到北京, 同時把重 兵駐絷北方以抵抗蒙古, 他統有四十八萬大兵, 其中除十二萬人選入所謂禁 衛營團, 由明政府供給口糧外, 其餘三十六萬人都分配在順天府内設置衛所, 讓他們屯田種地。内地墾完漸及邊遠, 這時盟史記邑束自遼左北抵宣大, 西至 甘肃, 南㿿滇蜀極於交阯, 中原則大河南北, 在在興屯矣! 
據一三八入年的統計數字, 全國”軍屯的收穫量為五百多萬石, 單 只北平一地軍兵收模的米多就有入十多萬石, 全國”軍幽的總收入足敷所有 軍隊的開支, 所以朱无璋很自豪地説他養兵百萬, 不费百姓一粒米!

軍隊在内地屯田, 最初是且耕且戰的, 後來由於無仗可打, 於是熟 成了一般種田的老百姓。他們本來是被地主剥削, 失了土地的震民现在又。 分回被兼併的土地, 這正是由於震民戰爭造成的結果。

第二, 朱无璋雖然建立了地主階級的政權, 但他却没收了蒙古贵 族和反抗過他們的大地主的全部土地。為了緩和階級矛盾, 對於一般地主 也加以限制。所以朱明王朝和以前地主階級所支持的蒙古政府果竟是有 些區別的。

最初, 朱元璋還提出相當强硬的反抗蒙古貴族的口號, 一三六七 年, 他追撃元兵, 德檄北方曹民强調“中国居内以制夷狄夷狄居外以奉中國。 並痛斥那些投靠元朝認賊作父的大地主(指元將王保保及張思道李思丳等， 這表明他可以和漢人地主階級合作, 但不能向蒙古貴族讓步, 也不同漠茹地 主妥協, 而蒙古贵族和漢茹地主雉有廣大的土地及財富, 他們和漢人的衝突, 15 正是當時社會矛盾主要的方面。

後束朱元璋踓然不再做反階級壓迫的宣傳(所謂明王出世, 但對 待曾反抗遇他的地主是十分嚴属的。以蘇州鸽例張士誠的部下都是大地 主, 他没收了這些人的土地恶把他們罚往臨壕去種田。同時又没收了䕎州 大地主沈萬三的家産,把他充軍到雲南。

至於對待一般地主, 朱无噇也加以限制, 他不准富者。”莱併, 又禁止 部下佔田。他遥移浙江等九布政司和應天等十八府的地主四千三百余会 於南京永祭時, 他的兒子朱棣復僄移應天及浙江地主三千向到北京。很明 顯, 地主不能離開他原籍的土地, 一離開便大大削弱, 不成為地主。而朱元璋 父子這種策略却給他們很大的打揧。

明政府何以要這樣做? 不待説, 它知道這栐才霂足震民的要求, 平息震民的忿怒恶瓦解震民所發動的反抗地主的戰爭。换句話説這些措 施乃是農民起義促成的。

第三, 朱元噇深刻地了解到: 農民起義是封建統治王朝最有力

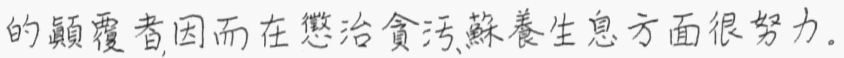

他手訂了三本愍處荟污豪猾的法典—盟大誥續編及三編頒 行天下, 使家喻后曉, 恶令榔村學校以此作教本, 當時硧讀太誥而到南京朝見 的師生就有十九萬多人。

這三本法典愍處的對象是贜官地主, 據明史刑法志記, 依太墪條 
文檢查, 當時犯凌挐處斬的瀻官地主有载千人犯死罪的有䇝萬人。其中以 後來太誥三編所訂的愍處條例比較宽大然所列進士監生等不法地主自初 犯到四犯還有二百六十多人這是朱元璋緩和階級矛盾政策的一方面。

另一方面, 是朱无璋的重農政策, 表现在他的暧征薄歛和曻種桑 5 雵上, 一三九四年, 他更派大批國子監生督道各豦興修水利, 共開塘堰四萬 九百八十七虎開等河渠四千一百六十二條修理陂渠隄岸五千四十八處對 於震業生産量的提高起了很大的作用。

後來歷史上有名的仁宣之治。便是由於愍治不法地主和積極推 動重農主義的結果, 而這種政策的採取, 正是曹民十幾年的戰爭换來的。

討論問題

一、試論秘密社圈在反非遗族皇朝運動中所占之地位。

二試將朱元璋起義過程分段討椧.

三。試論軍屯, 的好虔, 在别的文化裹曾否有過軍电。

15 四, 中国歷史上中央政府税收的来源是什磨? 学何如此?

五. 為什磨中国的京城一向都在北方? 


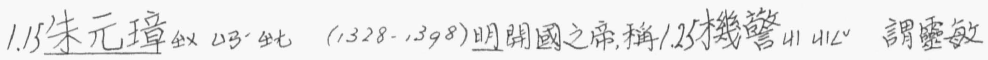

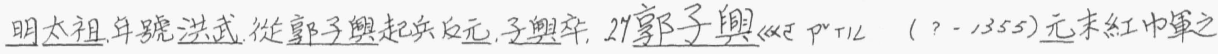

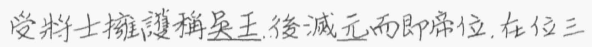

領袖

十一年(1368-1398)

蜕际謂蟲類所脱之皮

蜕化、繁化

.16 安徽鳥陽了欧化比安徽省縣名

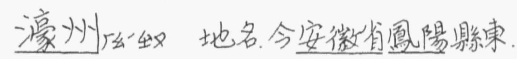

28 䆩313 客

陰結䆩客暗中文結算客

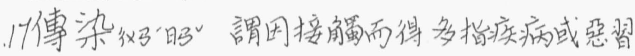

而言

傳染病能傳給他人之病

.19舶父? 比和尚的敬搯

替 313 驅逐

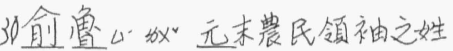

孫潘4以奶元未曹民領袖之姓。

3)義、假、有其各而非媇非真者。

義女非自己所生, 且非一家, 而諰作父女或

母女之閣係者, 在本語中, 指馬公女, 兵起,

就郭撫飬, 後馬死, 郭以女部配䢌。

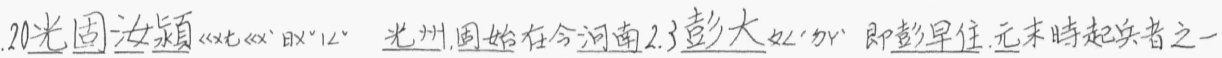

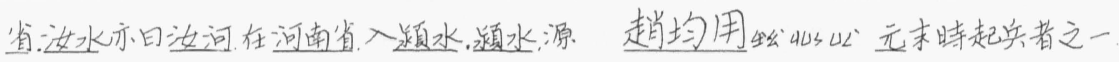

出河南、入安徽省入淮水

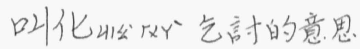

.21自婵教偊办了“出一秘密教派源出於佛教 目于眙仙地名, 在安徽省息陽縣束 泗州公”地地名, 在安徽省。

的白道宗。

耳儿人及動物的㯖㷵器官

耳濡目染謂受了聞見之影響

悉们知

熟悉 敦知

.23巾山頭上戴的或镇上圈的布製物

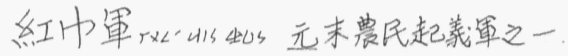
奮鬥多不屈服於環境努力杬爭

项浪线水面上大的起状

流浪形容一個人在社雷上,或不同的地方

過着不安定的生活。

. 25 飽忽弦。满足之意

更《( 收有其語音) 縚歷

飽更世故即飽綵世故意为数人世上的

事情有很多然驗

沈行 深切

深沈石浮浅, 不影露

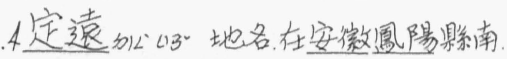

与和州起生又地名、在安徽省。

. 7 “漫吗 不加检制

散漫謂整偖, 不嚴㯵

. 8 元真 $\times 3$. 强硬不改

徝强等强固執

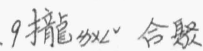

拉接能联络, 旁合。

10 太平动如”地名、在安徽省、

李垍加“仃”元未明初人, 治党書, 旁通諸縚明太 祖攻取太平時翼與陶安出迎太祖，時已八十

餘瓷授太平知府, 死於任期

知府出的“瑟官名，一府之長官

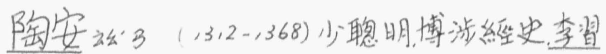

之門人, 明太祖取太平後留渗幕府。

幕客的“䧕即幕友、軍中或官署所請治文晴者

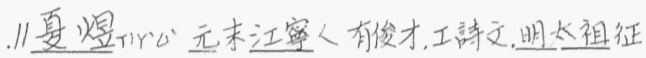

陳友颜時之儒臣、 


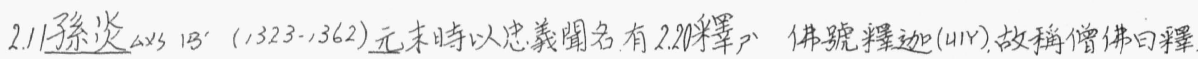

詩名、軍亂時者賊婂所殺

㛫罳沈'仍明陽曲人字希式。洪武初年官至御

史中买

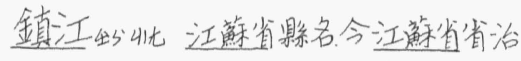

聘妙請

徵聘征求請用

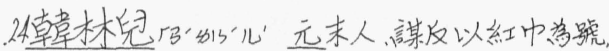

人㛵紅軍, 亦挣香軍淩自稻皇帝, 建国日宋。

25迴可以兄同回

㢠謢猶言雇貢忌庇護

哾政同。兄

呪第以不好之語唯人。

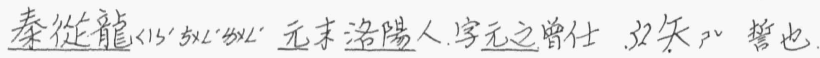

元，因兵㖟避居金真江明太祖到他家去請他，與

他討論政事。

陳遇行心(1313-1384) 明上元人, 字中行留太

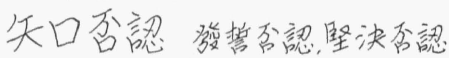

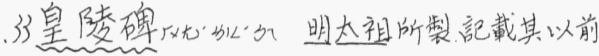

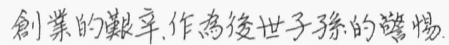

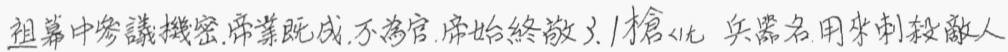

信繁者稍青争誠先生

予山我

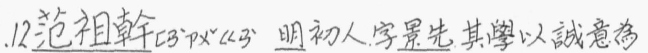

主事新孝。

葉儀她字景翰、明初繁者

駆穴控制車馬

韁怕同繮”繫馬之繩

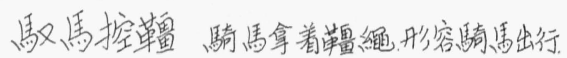

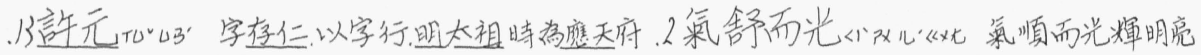

教授、捘以甤反帝命入獄死

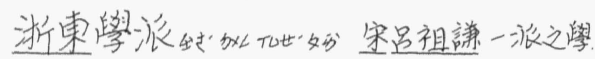

兼取朱意陸九牒之長而致力於史學考古今

成股、祖謙浙東人，故名。

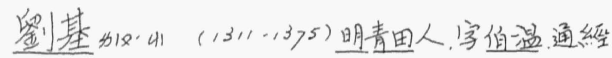

史、工詩文，尤精天文兵法、作太祖成帝業、

追耂正

事業是匡事業得以修正，新辛好。

赤分紅色

了圈《灭背

赤幟旅野而盈圈整個山野都充满了 紅旗

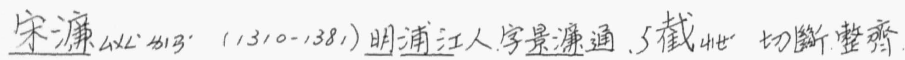

五䌊、工詩文，俢元史

截然分明貌

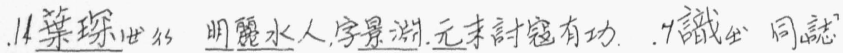

章溢圠! ( $314-369)$ 明浙江龍泉人字三益

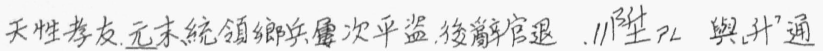

隐, 旦太祖以重金請之

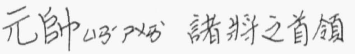

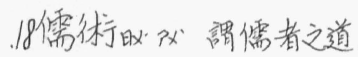

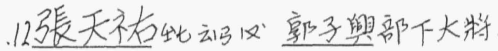

.19投契动《情意相合

. 20 王忧此處指王道, 謂王者所行之正道

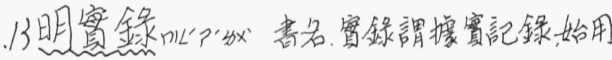

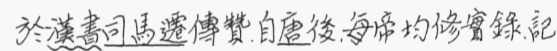

霸外蒙强, 在本課中指霸道而言, 意即䡜仁義

而尚權術之政，别於王道而言。

載各帝之言行, 此地指盟态祖窑金录。

.201夸3 0 Y 倒。 
3.20 打垮打欺

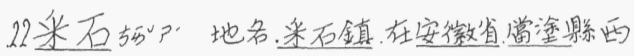

北㐫演江要地

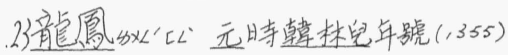

. 25 徽「飞 摽䧕

旗徽旗㩆

灰队㛵浅黑色

灰色此䖖謂態度不明朗

29 陳友諒行-120多优(1320-1363)元末人自立

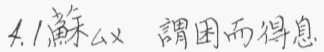

冀其治世以旗团苦希望佛把世界

治好、因而减除他僻的困䏽

.2蟠奶”曲屈, 伏

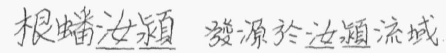

河洛代”如”謂黄河洛水之雨流域

萝延河洛淁展到黄河及洛水的流域

光T化舆凶通, 惡之意

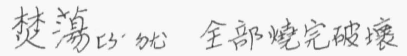

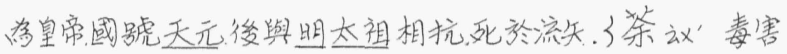

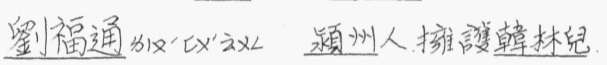

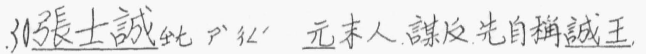

號大周、又改稻吴王、與明太祖相抗拒降自

殺而死

乎周榜奴“生又优”一篇宣言, 目的想打股

周, 指張士誠。

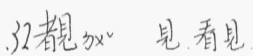

薹害动“仍即御史官各司紤察之素

33刻不攻整他人的罪状

薹害舉親而劾仇辜㥶推舉他的親戚

朋友而攻謷他的仇人。

有司1 2 “公粍官吏。

有司差蚠而夏富官吏對宊人不好而偠

待富人。

鈔弦紙幣錢

鈔法由國家制定之钱慗法。

枓湮以不流通

塞幼填充空間

湮塞充满使石通

枕秒以物置於磌下而卧。

枕籍(山心) 絽撗相蒀而卧

4. 酒告列甚

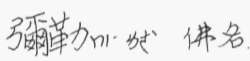

冀山希望望。
荼毒生露、毒害生命、

無端・加了謂無来由，不合道理

無端萬状不正當的行学很多; 偠法- 的形容

. 4 揾忧狂妾

獗山狂妄

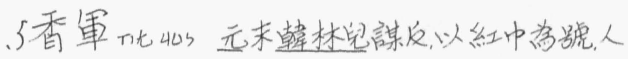

稻紅中，亦㛵香軍，因其先世以自婵會焼香感禹

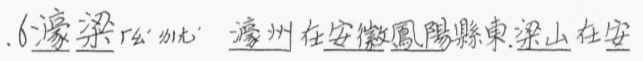

徽省

行伍比猶言軍隊

初列行伍起初就是軍隊中一兵。

提兵动以筫兵带兵。

灼时明

灼見很明白的看是, 知道

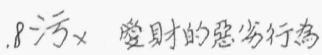

盆污賈圖钱时的恶少行为

１１＼cjkstart紳队猶言官族，包括職官及退職官员

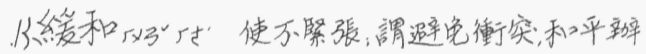

理

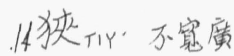

犷義価就事物之一方面而言者。

拋吆亲

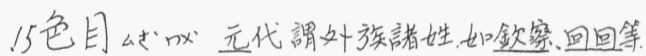




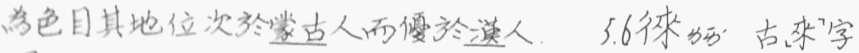
4.15 赤子儌

慮奻、臱疑, 謀思

16 止支《1 謂旁出之路或敦风事物之錯出者

歧祝不同等的待遇

24幾山謂近國都之地

京畿近成都之地

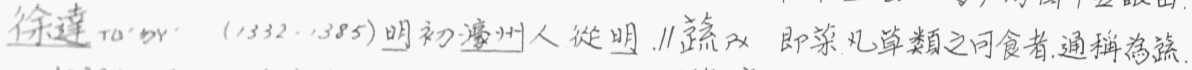

太祖征略以方受命为大特軍、克元都

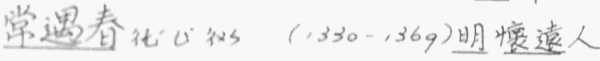

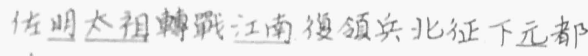
25大都加加地名元時捎今之北京曰大都 .26謶5 比空圆

土䐔人稀士地空大人少

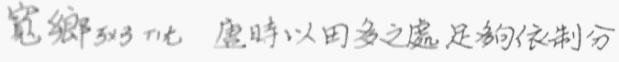

配給人民者多曾鄉

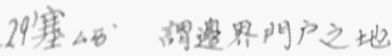

塞外喟透塞以外之地

30 復秋效給

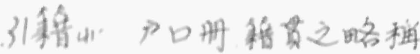

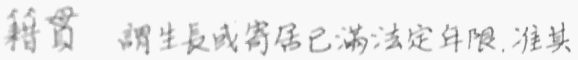
入镍之地

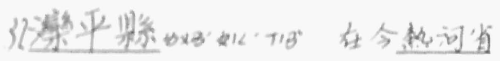

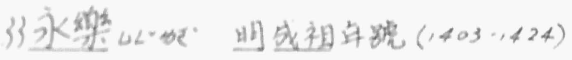

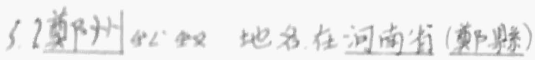

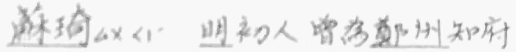

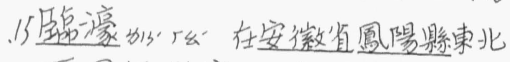

１７百里無幾家，但見闽起虐意人家很少。

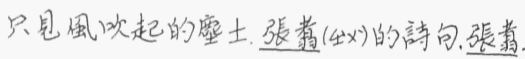

$(1287$ - - 368) 元言寺人、箸有蜕港焦。

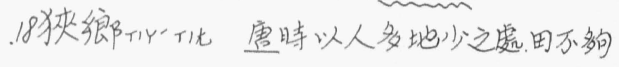

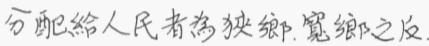

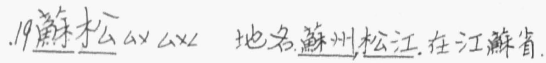

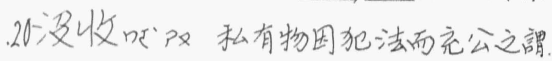

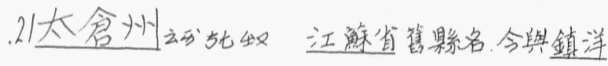

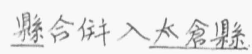

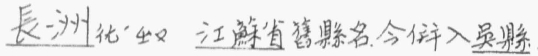

.3/言化产差錯

善本P分引 指精印精鈔或䌊遇精密校正而

難得的書籍

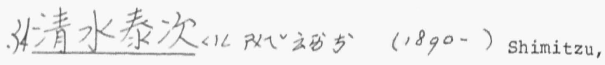

Taiji 日本歷史家数中国明朝社涻及縚㴒史特

有研究

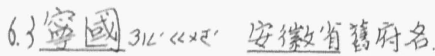

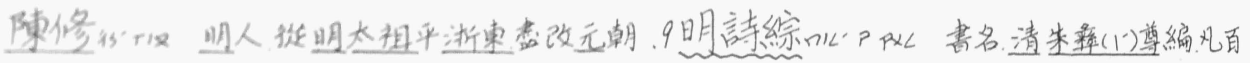

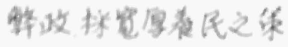

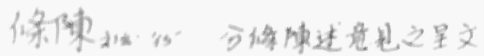

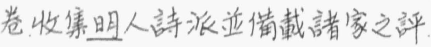

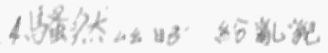

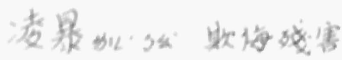

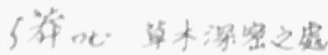

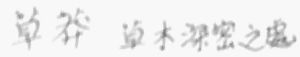

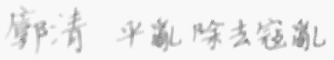

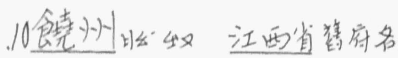

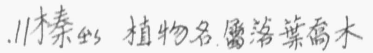

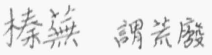

.16盜置4 03 除免

益置减减免

勒战”强迫, 强制

勒索强取时物 


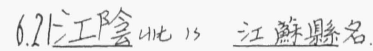

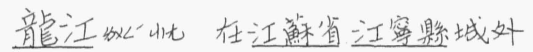
.24腹的猶内也

腹地, 内地

. 29 㑑待风方分特别好的待遇

褒吆貲美

褒掦兟美表掦

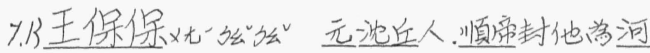
南王、明減元後, 监席北走, 太子立, 任以國事

大歇明特徐连於和林

張思道癿么咍元未人起兵作㖟者之一, 勢

力在今陝西一带

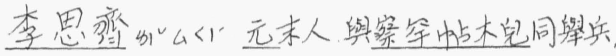

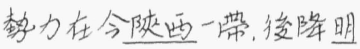

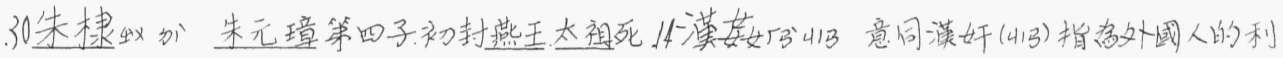

後起兵、搅靖難兵、成功淩即帝位、有明成祖。

年踋永樂、在位二十二年 $(1403-1424)$

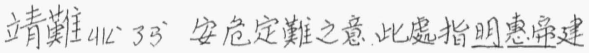

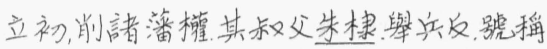

靖㐨住、攻戰三年遂隐京師

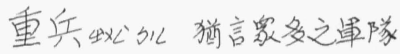

.)絷䚺 止

溤絷連隊必營

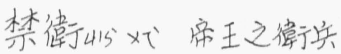

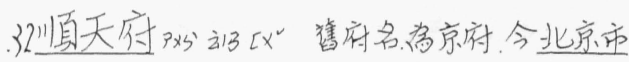

有其墔治

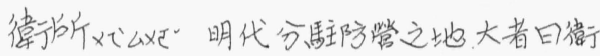

小者目所

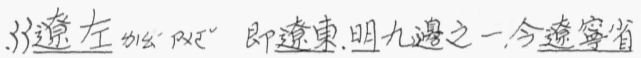

境

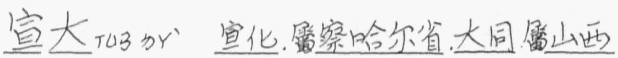
省.

. 34 滇的雲南省别稻

交阵州出。指安南北部之速京州

在在哈场猶㨿處

Y.2墼议足多句

足等交定夠

. 3 米立加算米的调數叫粒, 如一粒米

.12追到由後面趕上。

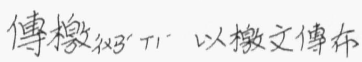

江痛质动优極力指责
益而泟害本國的人

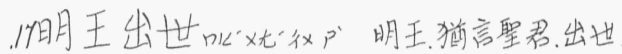

佛家語謂如来( 佛名, 表示救世主)出现於世間

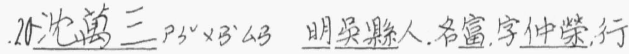

三。人因以萬三秀呼之, 很有錢, 後哈太祖所殺

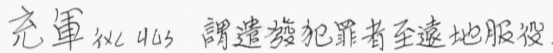

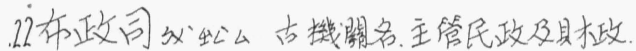
. 3 應天心动了明代府名即今南京 .27忿沙怒生氣

忿怒很生军

措施故”猶言施行

.30真真加了從高處往下落。

真真覆化跌, 推翻

嶶化青罩

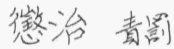

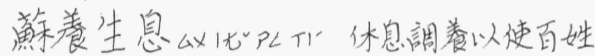
能生長繁殖, 意指使老百姓能平静的生活。

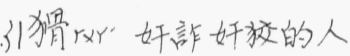

明大言告n加加《公明太祖撰, 385 年成書次

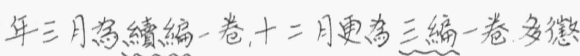
治窗官污速之詞。

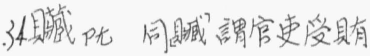

具藏官良污受賄之官吏

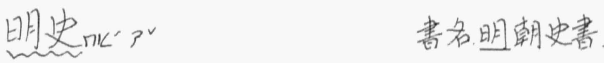

共336卷, 有本紀24卷, 志75, 表13, 列傳220, 目錄

4 、清康熙18 年 1679 ) 開始編治, 到乾隆四年 
(1739) 才完成。型法志为其志之一。

8.2 進士4 45 ’ 科舉時代之科目通過此特殊之考

試者謂進士。

監生4 13 队謂進入國子篮就慧者

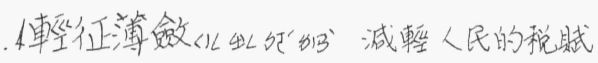

.5堌却方形的池。

堐沐篦水之土堤

. 6 渠《水停棈䝵

河渠謂水流棈聚之地, 以便水利, 有助農

耕

陂如篦水埸

陂渠紫水場

隄云同堤. 防水之建等物

隄岸防水之整列建箱物

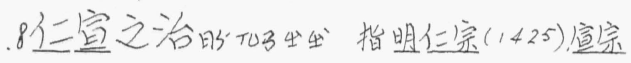

(1426-1435) 時代的政治。 
第十一課略論宋代地方官學和私學的消長

噼子健

作者小傅劉子健, 一九一九年生, 又名J a mes T.C.Liu 是健字的借音, 原籍黄州贵陽, 在上海和韭 京上舊式私熟和中學。一九三六年疑桠清萃大學抗戰期轉入燕京大學果業, 曾被旦軍逮捕。 勝利後回燕大任課。不久, 去東京國際法庭, 收集檔案、控訴東條等日本高級戰犯。同時替大5 公報寫通訊。又找到偊政府送目本天皇的翠玉屏風等件交回中國。

一九五0年在閔此堡大學University of Pittsburgh 得到歷史博士學位, 後本又回去教書。 一九六。到六五在史丹福大學Stanford University。此後在上林士屯大學 Princeton University 做東亞系 和糜史系的教授、主要的研究範圈是宋史和歷代制度沿革。短文有中文的, 旦文的, 但莫文的居多。 有些在旁人編的合集衰。自著的有 Reform in Sung China (1959); 嘼陽修的治學與從政(香港, 1963) , Ou-yang Hsiu : 1967); 主編的有 Change in Sung China (1969) 和 Traditional China (1970).

本課簡介本篇取自作者發表於食货第三期中一文, 全篇首先介紹定代興祭之原因, 然後分六 點分析官學和私學的消長, 最後總結全文大意並附私學之演䯭及分類。第一點中作者考証

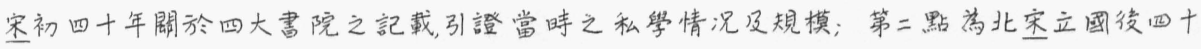
到八十年間半官性或官立學校初辩及優待私祭之緣由; 第三點則為磨曆改革, 政府令地方

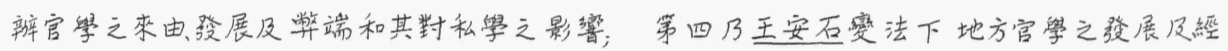

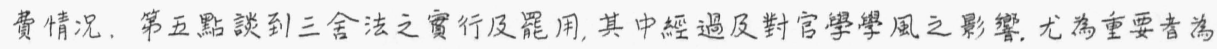
蔡京於此期間所扮演的角色; 及由於官學消沈引到私學之再度弡展; 第六點討論南宝之 官學學風, 各種筹措經费的方法, 及其對私睴的影響。

宋代興學, 奠定了中國文化近千年來廣大和深厚的基礎。配合 的因素很多, 舉其大者而言: 技術上有印刷衍的進步和傅播經渓上有都市和 商業繁榮的支持, 政治上有政府的注意社會上有士大夫階層在官在鄉在家 族團體中的倡導, 甚至窮榔僻壤, 也逐漸出現了三家村的教書匠。這種發展 是劃時代的, 真有深遠的决定性的。高階層文化的準繩經過地方的各種教 25

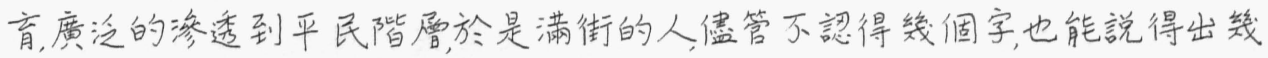
句聖人的話。就這廣泛深遠的渗透而言, 地方上的官學, 尤其是私學, 比起國 子監太祭重要得多。就文化延續而論也是如此, 蒙古入侵鄙視儒生。首 先挽救這厄運的是地方軍人。一面向蒙古人妥協一面培植地方勢力, 維持 社會秩序, 在他們統治的地區内招士興學。後来才有元朝的新政策重開科3 0 舉獎敫儒學。明清兩代文風更盛這文化的傅統更根深蒂固甚至弄到連改 革都困難了。

這個大題目, 以往已有不少論著。許多周知的史實, 無需再重複。 可是多數作品, 侧重中央。以中國地區之大, 今後的研究惯在應該對於地方 
性的題目, 多多努力。有些論者, 已往注意到宣代的地方教育, 並且指出若干 的成就弊端和困難。本文再提出一些補充修正和分析。其中更著重一個 中心問題就是私學和官學兩方面的前後消長。

第一點, 北宋最初的四十年, 地方上很少有正式學校。所謂四大 5 書院之稱言過其實。文獻通考首先承認“是時未有州影之學, 先有鄉黨之叟”。 接下去却列舉疽山白鹿洞徐州石鼓書院應天府書院和潭州获麓書院, 説“宋 興之初, 天下四書院……此外則又有……禽陽茅山後來無聞。獨四書院之 名著。”豆海也提到四大書院, 而列舉不同, 以為是白鹿洞获麓, 應天和禽陽。

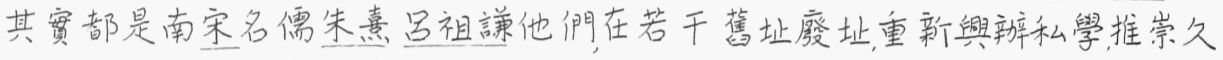

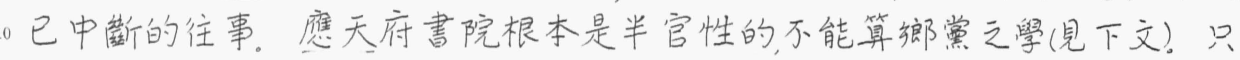
因名臣范伸淹在那裹讀過書, 有文公掦, 所以也在推崇之列。但根據有關五 代的史料宋會要輯稿和緢資治通鑑長編, 一類的史料, 可以看出宋初少數書 院规模很有限, 對於這些學院政府綵過地方官的申請, 只是稍予奖贈而已。 無非是賜額貝易國子監書, 賜九經任長書院者為小官, 或賜官衔仍舊回去教書, 15 或加賜赴阙召見再回去教書的旅费這時還没有賜田的。

至於白鹿洞在南宋最有名, 而就北宋初期而言, 簡直是反證太平 興國二年( 977 ) , “气具易九經。三年後, 洞主”自己請求认其田入官”, 换了個小差使到 别地方去任職這書院根本㽻了。䋶長篇值得詳引; 以江州白鹿洞主明起為

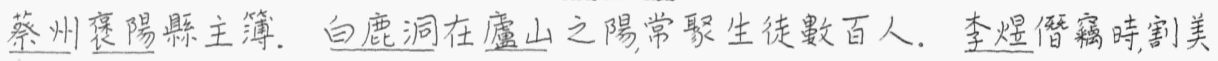
20 田數十頃歲取其租庰給之, 選太學之通經者, 授以他官, 俾領洞事, 日禹諸生 講誦。至是起建議以其田入官故爵之。白鹿洞由是漸廢矣”。可見這書院 本就不是鄉黨之學。既是南唐官方支持, 而北宋以文字自詡何以反倒要收 其美田, 聽其荒廢呢? 逭有大小雨套原因, 大原因是北察初平天下, 吸取江南 文物, 恶不重用, 更不想培養江南人才, 例如: “平諸國, 䁇收其圆籍。惟蜀江南多, 25 得罢書—萬江南書一萬餘卷。又下詔開獻書之路”。而當初南唐興辩的書 院還要向新朝“气貝易九䋑”。相形之之下, 可見中央集權之强, 地方教育之弱。小 原因是這類書院本身的缺點。五代時許多文人避隐山地讀書授徒。在盧 山一带的比較最多。但自鹿洞並非純粹儒家作風洞主這名稱, 就能體會到 一些駁雜的意味。至於聚的生徒有的是本地人有的是避䧧的, 也有的是亡

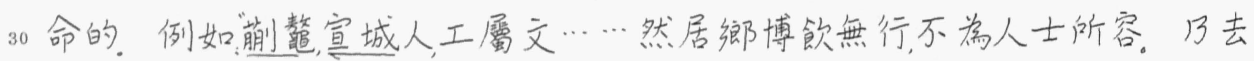
入盧山國學亡頼尤甚。晚乃動風操……至後主末, 始登仕版。迨國亡,銓授 未及遂不復謀仕……埾隐居盧山數年卒”。和他同稱虎山三害的另一人更 不好學。“盧絳……讀曋稍通大旨……每以博奕角觝离事。舉進士不中, 遂

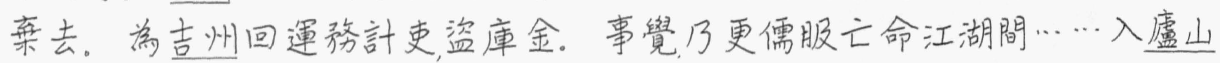


自鹿洞書院。猶亡頼, 以屠販学事, 多脅取同舍生金, 又特椎貨掗賈於山中, 將

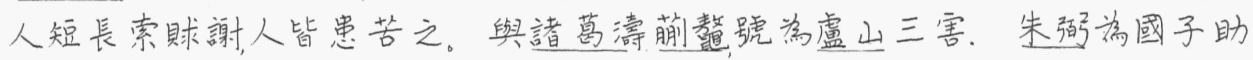
教將捕治其罪, 復亡去”。宋朝政府對於可能潛伏前朝舊臣、窝藏不法文泿的 書院當然聽其停㩔。

第二點, 北宋立國以後四十年到八十年間, 還並沒有積極的鼓殿5 地方教育。只是經過官員申請對於少數私等予以優待, 或准許開辦少數的 半官性或官立的學校。幾件事情在感平四年(1001)配合起来産生一個新政 策。首先因嵒知州請求，以國子監紅籍賜潭州岳麓山書院。”同年, 邢是等校 訂周禮䕏禮公差嗀梁德正義……命模印頒行……於是九經疏義悉具矣”。 這才“詔諸路州影, 有聚徒講誦之所, 並賜九綵”, 宗論説“成平四年, 詔賜九經於 10 聚徒講誦之所與州縣學校等, 此畫院之始也”。這考語很正破。“與州縣學校 等“應該是解釋為等於也算有了州縣學校這才是書院的開始。通考王海等 説定初就有書院不確。

在這時期隽天府書院最大。由私人捐款發起, 却董為半官性的 學校。應天府是宋朝的南京離京城不遠, 不像江南那樣地方, 會讓政府不放 15 心。五代戚同文在那裹教書有名。他有七個弟子, 雨個兒子都在宋朝任官。 大中祥符二年( 1009 ) “府民曹誠以貲募工就威同文所居, 造舍百五十間, 聚書千 餘卷博延生徒講習甚盛。府奏其事。上嘉之詔賜額日應天府書院命奉禮 郎威舜賓主之, 仍令本府幕職官提舉。又署誠助教。舜宾, 同文孫“對於這半

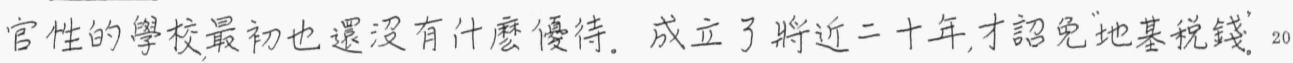

政府具易田給學校是仁宗初, 天聖无年二年間(1023-1024)才開的例。 賜江甯府茅山書院由三顷, 並以供學生飲食。這書院後無聞, 恐怕是管理不 善, 經費缺乏, 慢慢衰廢了。最著名的是亮州, 知州孫蔓建立學舍四十食間, 又 以”已俸瞻養”在離任的時候請正式撥給該州“職田十頃。這先例成功, 才産生 更進一步的新政策。地方長官願意興學, 可以申請, 經中央批准撥田作經费。2 “命藩輔皆得立學。其後諸傍郡多願立學者詔悉可之。稍增賜之田, 如䆓州”, 這裹可以看出先由士大夫階層提倡, 政府才慢慢放棄對地方聚徒的警戒心, 而用財力來補助。士大夫提倡願意立學也並不全是济了當地居民其中也 有的是為了他㑚自己随任子弟的需要。例如西安, 寄往官員颇多子, 弟輩不 務肯構, 唯咨嘲謔軖薄, 閊諜詞訟……到任後奏乞建置府學……現有本府及30 諸州修業進士一百三十七人……風俗稍晸”,

第三點, 政府積極的命令地方辦官等, 是慶曆四年(1044)㢇曆改革 時的新政策。那時士大夫階層的發言權已經提高很多, 對於宋初國策能略 加改铰。雖然磨曆改革, 因為官僚間朋黨之間的爭執不久就結束了。但有 


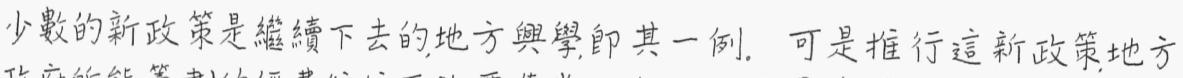
政府所能䈔劃的經費, 往往不夠, 要靠當地私人的力量來捐助。而另一方面, 官辩學校已經産生一些壞影響。

這项新政策的來歴, 宋會要輯稿説得最清楚: “自明道景裉間累詔

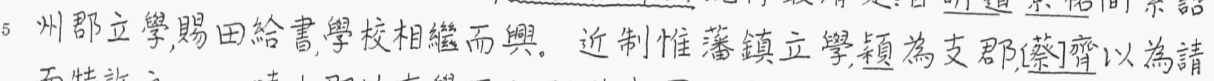
而特許之……時大郡始有學, 而小郡猶未置也。慶曆詔諸路府軍監各令立學, 學者二百人以上許更置縣學”。各書上䦔於這個詔書, 常常用“慨然”二字, 這可 能有䇝層含義。一是仁宗学改革派言論所感動, 二是仁宗下決心放荎以往 消極需要呈請而經特准的政策, 積極的創立前所未有的新制度, 責成地方政 10 府興學; 三是慷慨的用國家財力來供給。但是賜田十頃, 實際上是不夠發展 維持的。有的地方將就的把孔廟擴充一下。就是那梯, 也還靠當地士大夫 地主階層“率其私錢一百五十萬以助。有的地方是把犯法的寺院財産充公 改設學校或撥用其他涉訟的土地。例如酬州所需經費相當大: “有美田…… 訟不解……師为奏請得田二千五百畧有奇, 與民耕作, 歲輸錢百萬, 是為新田 15 ……惯三倍於其舊”。离什麼要這樣多的經费呢? 主要是供給學生生活沒 有這新田的時候“新學成, 顧苦在後。有田磽瘦, 食不能百生。游翼之士或自 罷去”游學之中也有瞥端, 而官廳興建往往是良污機會。慨然新定的政策, 在第二年就另下詔書查弊”今後有學州縣, 得輙容非本土人居止聽習。若

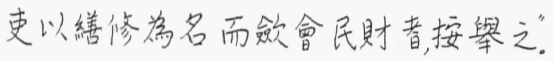

在這時期, 地方官祭初興弊端逻不大而對於各地教育的禆益很 多。宋代文化的提高擴展與漸漸的深入民間, 實在是這時期才開始的。万 過官學興間接的對於私學的發展並不完全有利。一般而論私學就不免相 形見絀停留或退居於準備學校性的小规模, 不容易再有發展。例如這時期 三位最有名的私學教授石守道孫復, 胡瑗, 孫胡雨人都去太學任教對於太學 25 固然好, 而他們自己原有的學校就衰落了。胡瑗的例證尤其重要, “下湖州 取先生之法, 以有太學法至今著為令。後十餘年, 按: 是1056 年了先生始來居太

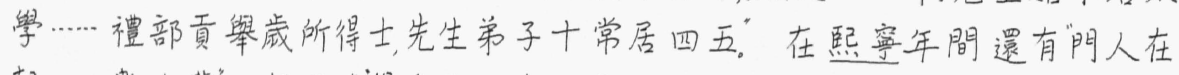
朝……數十暃”。但同時, 學者非王氏不宗, 而先生之學不絕於緀”。到了南察 初年, 已經是要費力搜求, 才能找到胡瑗的遗書和往事。到朱喜時, 他説: 問安 30 定平日所講論今有愽否? 日並無, ……如當初取湖州學法, 以虞太學法, 今此 法無、今日法乃蔡京之法。官鼍易受政治影響而引起弊端下文再説。這 裹是證明最有名的地方私學從這時期起到南宋初年, 反倒有退步的現象。 這並不是説全都如此, 北定後半期洛學蜀學很有名。這是因为兩澏都有 其特殊背景, 洛陽是歷代以來的文化中心致仕的權貴往往聚合一些名士。 
四川少大乳經濟又很繁榮。洛蜀而外就是閩學, 官祭較少, 而沿海大地方民 間的經渓條件優厚因此到了南宋, 傅播浙束和江西極一時之盛。

第四點, 王安石莜法, 如奥周知, 目標更大, 想用各級學校經常考驗 彪升到太學, 來根本代替舊有的科舉制度。本文只補充载點, 充實地方官 學的主張不限新法一派。而在新法之下, 學校經費仍舊不呴。元袸也並没5

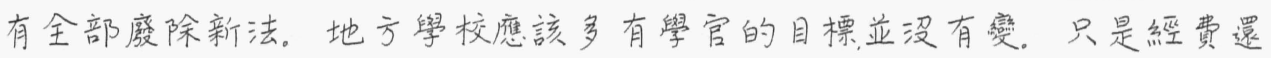
是没有方法增加。而對於新法時的行政弊端却注意改善。換言之, 若千基

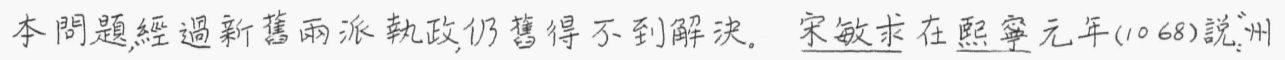
縣有學舍而無學官。四方之士輘去鄉里者, 以求枊也。諸州置學官三歲一 下, 務得士三百人”。蘇軾在翌年説地方學校“唯空名僅存”。所以熙蜜四年1 0 (1071)命令各路轉運司選差學官, 州軍一律發學田十頃, 有田不及者益之, 多者 聽如故”到元䇺元年(1078)各州有警官者共五十三處。更可見要辦得有规模, 十頃舊額多半不多句的。舊派領袖司馬光也説“諸州……祭校大抵多取丁憂 及停闌官員, 以茇師長……游戲其間未嘗講習”。而元豐年間“諸州學或不置

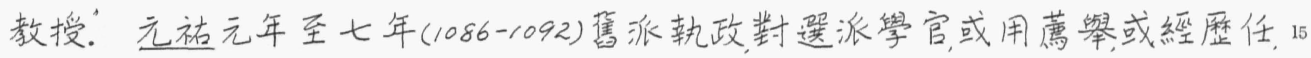
或循资考績, 多所規定, 這裹不必詳説。但結果到了紹聖年間(1094-1097) 還有 人説: 今州郡未有學官處, 可量士人多塞而增置之。或要長官擇郡官之有學 問者兼領”。根本困難是地方官學絰費少, 待遇低一般官僚風氧“重内轅外“在 中央做官就不肯去外地, 更不肯去做清苦的學官。學官不太充害, 官學的弊 端也少人監督。元祐八年(1093)詔諸州元無影學處䡛创修, 及蕉學舍損壤許令20

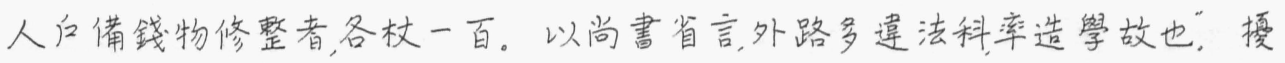
民取財, 當然不對, 但䊺費和維持費, 没有完善的剘政和行政管理的制度, 也是 事霓。

第五點, 北定末期從繁京假恢復新法之名, 而行擅權任私之赛起, 到他下臺, 已無從挽救直到亡國为止, 這段演化最為混商。地方官學的情形, 25 也是這混傐的縮影。從崇䆬元年(1102)起, 大舉擴充州學縣學行三舍法, 並增 加經費。比新法當初的規模大得多, 但從政和元年( 1111$)$ 前後起反又缩减一 些費用, 挪去供應君主的浪費因此大失士人之心。宣和三年( 1121$)$, 又取消三 舍法。而在擴充和增加經費的過程中, 弊端大起。官學裹的風紀, 也非常差。 蔡京最初的目的就不正當。他要利用學校來收買人心同時限制言論。立30 黨禁, 在官學衰設立“自訟盾”令人“洗腦”放烡批評性的學説, 這是周知的, 不必多 説。州學縣學裹作文, 有“時忌”更可以看出普通的不自由的束縛。“州縣學考 試, 未校文字精弱, 先問時忌有無。語涉時忌雖其工不敢取, 時忌如曰休兵 以息民, 節用以整財, 罷不急之務, 清入仕之流。諸如此語熙整紹聖間侒: 師新 
法時及復行新法的初期試者共用不忌, 今悉絀之。”這種教育政策的結果決 不畣好的。

祭京的魄力相當大, 令“天下皆置學”至少“二三州共置一學”、因 病“有司病費腐難瞻”。就決定一個大的新政策, 除原有祭田外, 以常平欵项補

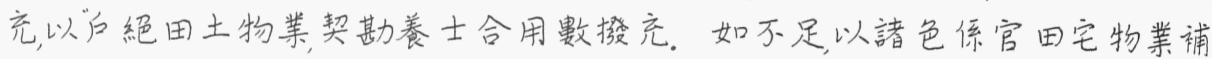

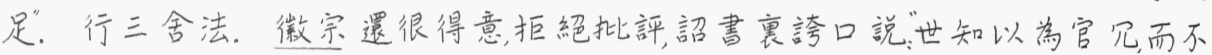
知多士以䁇之美”。崇察二年(1103) 又增置縣學和州縣小學, 並規定州縣學校 敕令格式。以經费規模制度而論真是前所難望的充備。但慢慢的也鱟得

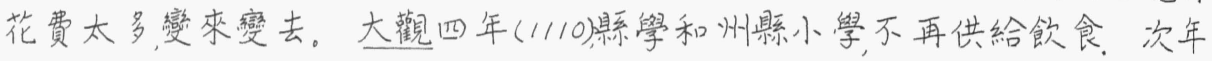
10 修正細節, 縣學的教諭等, 是州學選差派去的學生, 還是算州學的人, “依條給食” 或“月給食钱”。政和二年, (1/ / 2 ) 有詔書説“今學校之興……浸失本旨。至參以 科舉罷廢影學給食之法, 害令惑象者非—”。又過了兩年, 再令一部份學校“罷 支食錢, 最初擴充, 撥用常平欵項。後来别的開支增加, 常平又感缺乏。“詔

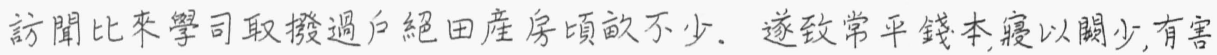
15 歛散。可令諸路學事司, 取大觀四年前詔諸州以前三年瞊學支费過惯數内,

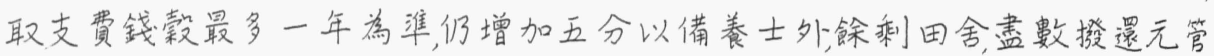
係官司。政和三年( 1113$)$, 又詔諸路已掕良田譻學提舉學事司更不撥還常平 價鐵。”只是限制不得再另外撥田了。朝令夕改尚不止此。宣和三年(1121) ,

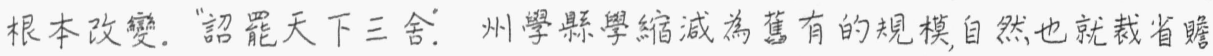
20 學之费, 只保留三舍法前原有的田産。凡是在實行三舍法這些年内所“添置”

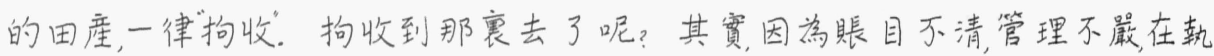

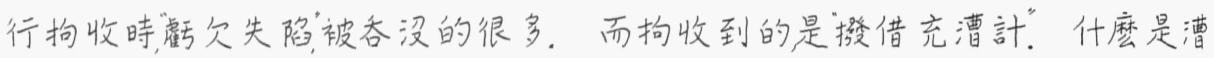
計呢? 原來是君主的浪费奢侈。“神宗皇帝修講常平之政, 置提舉官。錢穀

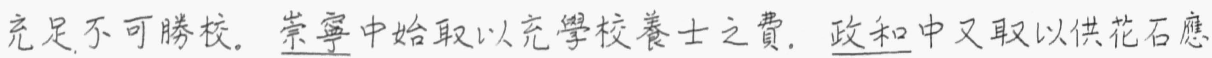
25 奉之资。僅費三十年, 所有無㹡。這段記載可以看神宗的英明, 微宗真是個 敗家子! 同時也看到王安石的新法財政相當成功, 南宝以来的評論往往有 偏見功則歸諸神宗, 遇則算在王安石與新黨小人頭上。㯰有各種記載中, 特

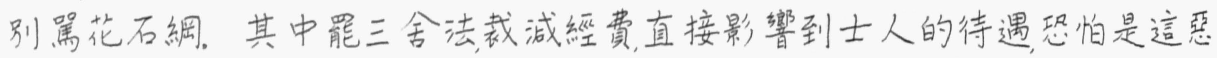
評的小原因之一。

地方官學在經費充足的時候, 也並没有辦好。經費增加行政弊 端也增加。大觀二年(1108)有詔”養士之類舍宇之數費, 用之多寡田業之頃畧,

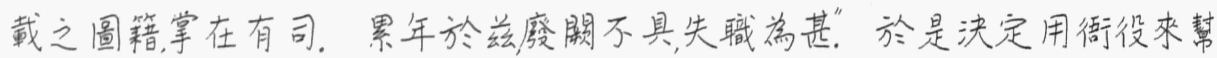
管。“諸路學费房廊, 止是科差剩員一名收掠其間侵欺盗用, 失陷官錢……許 依州縣法召募庫子一名, 専行收納。其或少處亦气權令本州庫子兼管。”其 
蒀, 庫子又何嘗一定可靠? 至於田産, 蓗頭就有弊端, 有勢力的大家, 有時“請託

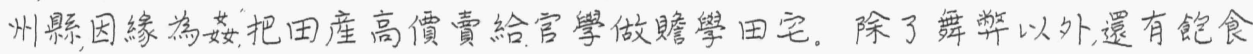
終日的浪費。州官燕犒破瞊學錢, 乃無限定之數往往腐有支用。對於學生, 也務婆嗸腆领食。”

在這種情形下, 學風怎樣畣好? 諸州教授有或多務出入罕在學5 校……有未嘗升堂者, 往往止託逐經學諭, 撰成口義, 愽之諸糹, 抄錄上簿而已, 未嘗親措一詞於其間。”有的是忙着在校外活動, 具占補收入“為人撰答簡牘語 之類。教授如此學生更糟。其中有“富家子弟, 初不知書, 第捐數百綋錢, 求人 試補入學, 遂免身役“有近似“官居”的優待。政和三年( 1113)訂定學规。但風氧

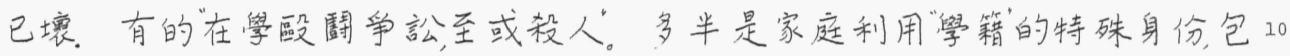

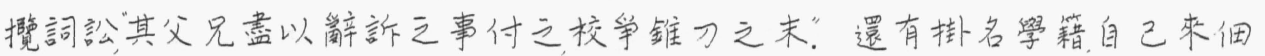

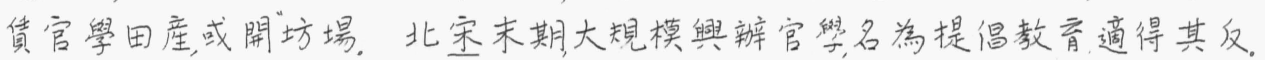
因此秀才之稱, 已被人軠視。但人事消長往往有一種補償律(Law of Compensation)。

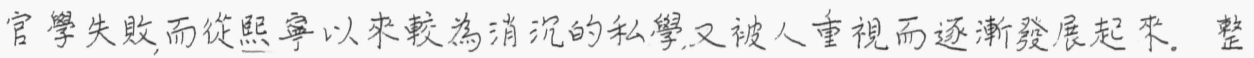
個教育的德播還是在推廣。

第六點南宋的官學, 也是没有解决北宋學制所遭逢的若干問題, 學官的品啠, 學生的風氣, 學産的被侵和經费的困難。另一方面, 私人辩的學 校却大量增加踓然經費也困䧼可是教和繁的水準一般説来都比較好, 甚至 比北定的程度還高。南宗初, 急於軍事, 教育被認為“不急之務”州學縣舅多半 停辯。建炎二年( 1128 ) 规定設置教授的有四十三州。繼而又罷“任满更不差2 0 人将就由科舉出身的行政官吏兼任。後來又再設教官, 並且可以和太祭的 官員互轉。簡而言之, 一般不受重視陷入简徆停滞的状況, 舒璘, 是奉化人, 朱熹陳溥良的朋友。在他給其他朋友的载封信中, 説明了學官地位之低和

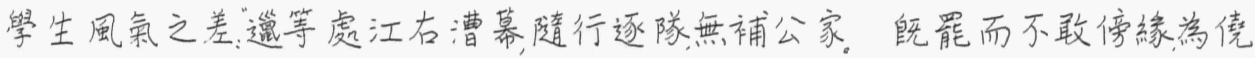
倖圆, 遂分教於此。始至士 士子循習敝婳。舖哆之餘渙然而散。不惟祭不知2 5 講, 而廉恥亦㲋。”以下载封信, 常常提到努力教授雨年, 不見成效。還有一信,

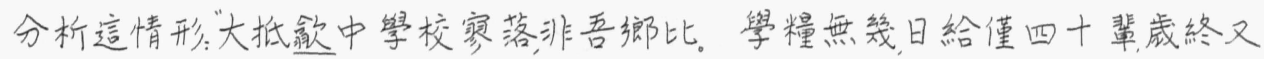

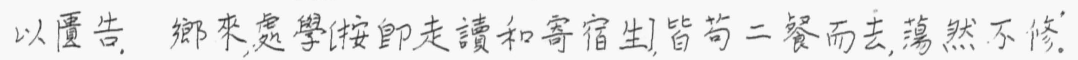

經費少在紹興甘一年(1151)時, 曾經討論過, 北宗將亡國時學田

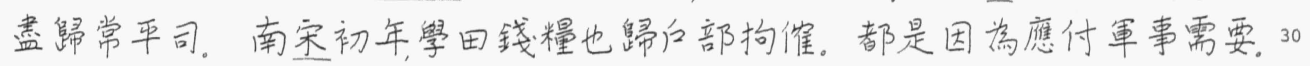

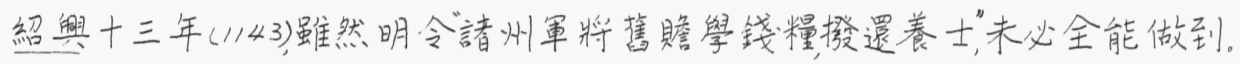

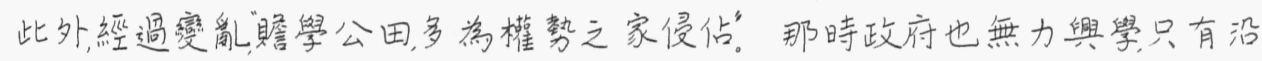
襲老辩法, 把買了僧道度牒而後來成為綛産的和僧道違法擅置, 並無敕額的

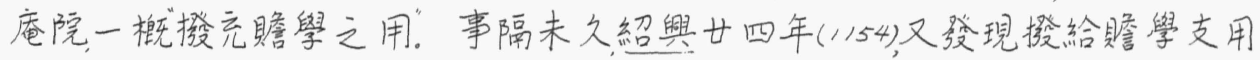


的又被地方政府撥入别項“侵移总用”, 據趙鐵寒兄的研究, 州學的經费不夠,

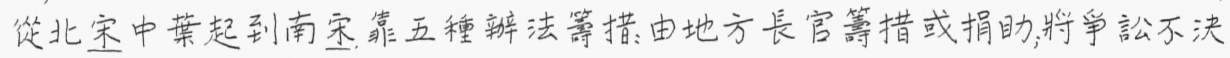

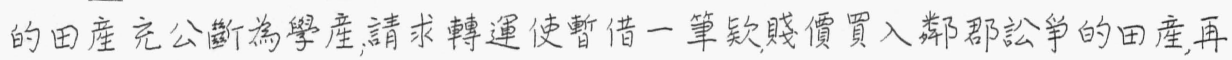
以收租償還借欵刻書販賣來補充䋑費, 自給自足; 曾在無法, 請鄉黨父老供給 5 伙食, 等於為他㑚自己的親友設立羘费奖學金。這裹再補充很小的裁點。 有時, 是學生集體自己捐欵買地, 但這不過是三五個特例。許多官學舊房, 久

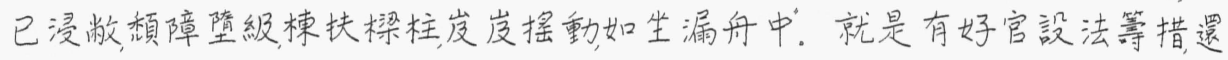
得靠本地士紳捐助。有時, 計劃新建學址, 要絰過前後十五年, 三任縣令的繾

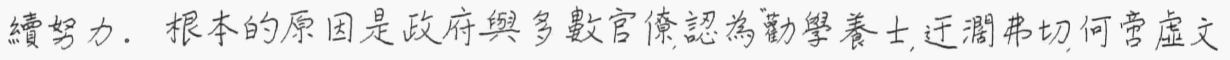
10 ? ”。官學情形如此不好, 但是許多道學大儒自辦私學”, 名竪戻止士大夫講習 之所, 自為建置”在理宗一朝(1225-1264)尤其多。此外還有親族社围的組織辩 族學鄉學, 義學。文風之威, 主要不是靠官學, 而是靠私學。

最後略作結語。北宋初期地方上没有官學而有規模的私學也

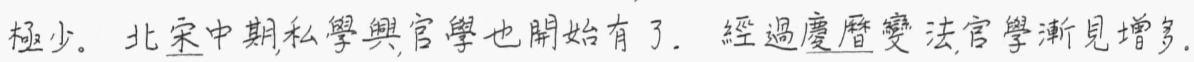
15 䋑過王安石的新政更見擴展, 凌駕私學之上。但主要限制, 官學的經費還是 不呴, 繁京大事興學撥用常平欵項, 官學極盛。但後來一面減費, 一面有弊端, 又告不支。最大的失敗還是把學風弄壤, 一羱不振。南宗政府也没有恢復 之道, 官㦛根本没有中興。教育的重擔, 還靠優秀的學者, 私人桃領道。

附带鳌上私學的演䃞和分類。富貴之家, 延請家館, 這不必説。

20 可是清寒子第而有社會關係的, 有時也可以去附讀沾光。唐人常在佛教寺 院讀書, 這途洏在宋代已漸衰微, 政府官員甚至會對於和尚讀書發生懷 疑。“洪擬……聞有僧聚書數千卷誦讀晨夜不休, 擬識其茹日: 是非釋子所

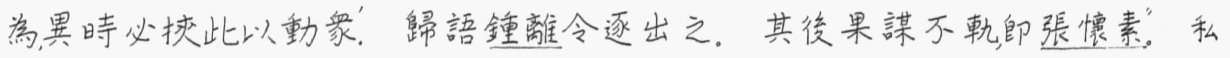
人書院源起五代, 是代佛寺而興的。范仲淹就是一個好例。先在長白山醴 25 泉寺詯畵, 每天雨升米, 十幾根監菜, 半孟醋, 一點監。後來就改入應天府書 院生活好得多。北宋中葉這類清寒出身的名臣出守地方, 往往興辩學校, 還有許多㹂士, 職位不高, 却自辦私學。這些人之中, 還有更進一步辦族學榔 學義學的。這都是起於北宋中葉, 而盛於南宋在世界社會教育史上放一異 彩, 而對於近千年來中國文化的渗透平民階層, 真獻最大。

討論問題

一, 試論為何在中国社會地位之高低是以知識程度為依據而不是以出身之尊华虔準。

二, 教育的最終目的為何:

三試敦論以科舆制度為進身之階。 
四、印刷術的發明對察代教育有何影響?

五、試列舉篃措學校經费之困難處。 

1.1消長化的“猶言盛衰

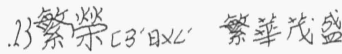

.24 三家村 $434145 \times 3$ 謂榔間人少之透

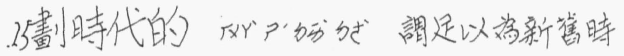

代剖分之標瀻者，如言劃時代的作品

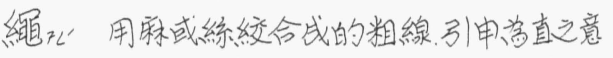

集絶、猶言水平、摽準

26 6 渗 35 , 水慢慢的流下.

渗透 形容透過

儘415 璤任

價管雖然就是

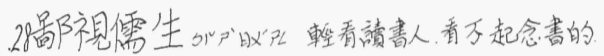

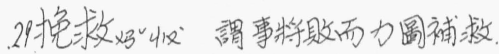

厄竾蜼

厄運不好的連氣

妥云义安穆。

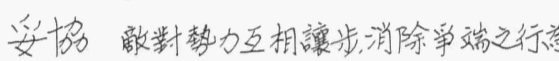
培妃補養

培植謂湌育人才

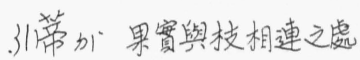

根深常固形容堅固

.34側重战乱化唒言看重一邊

2.2整端的好了不好之事件, 毛病

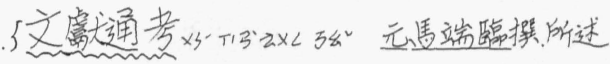

典制, 共三百四十八卷

鄉虽、㤝㕱猶鄉里

狼黨之學在人口較夥城少的地方所建 立的掔校

6 盧山为“93 山名, 在今江西省。

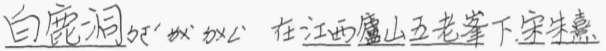

嘗譜㶅於此。

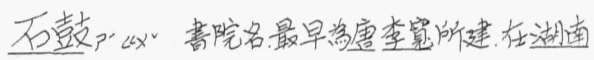

省衡陽縣北文石鼓山、故名、实代徐州有一畫院。10 亦用此名。

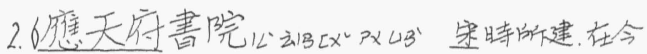
河南省商近影城内。

潭州动生又湖南長沙。

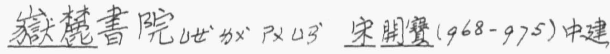

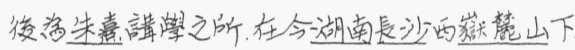

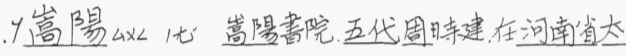
室山南篦、初名太室書院、宋時始改有蓠陽、因 院址在蓠山(即太窑山)之陽。

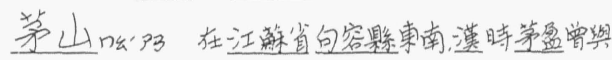
弟居此, 故名、有書院

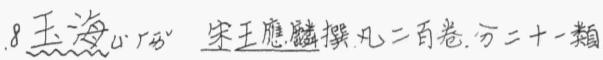

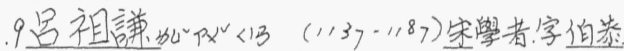

金等人、所箸日香蒸焦

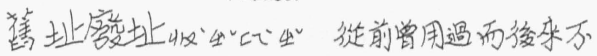

用的地方。

推崇动秋“尊敬之意。

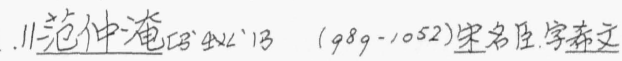
学秀才時即以天下病已任，过宗時官至涉知 政事，死後謚文正。

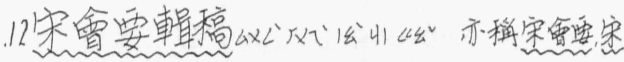

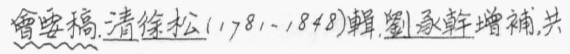
460 卷

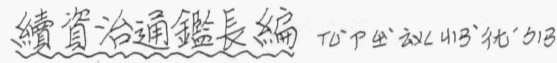

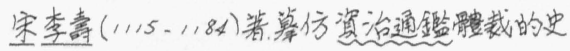
書, 共520卷, 目䥻二卷

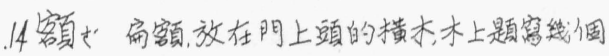
大字

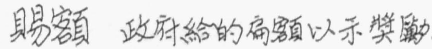

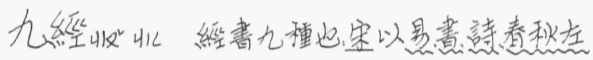

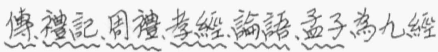

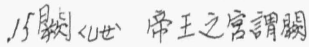
赴閶召見到京都去拜見皇。

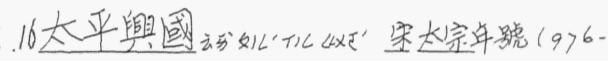
983) 


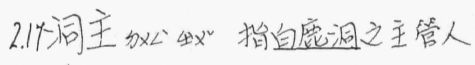

差得奉命辫理之事弱

差使, 示作差事謂官中蹦时委使之職弱。

18 日月起n L $^{\prime} \angle 1^{2}$ 人名曾桨自鹿洞書院的主持人。

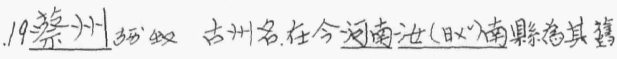

治。

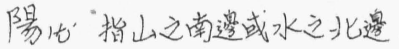

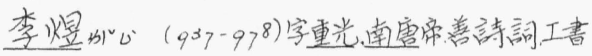

畫後降察史桷後主。

晔哂越分謂在下位者私擬其上

偕䆚視冒用名位

.20俾引使

.22南唐3 动五代土國之一 $\left(937-97^{5}\right)$ 婹有今

江箵安徵之淮南及福建，江西等地。

詡机火言也。

自詡自套

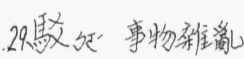

歌离雅雅㖟

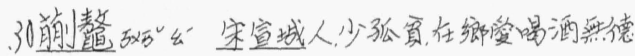

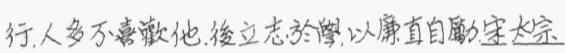

時進士，徒隐佸盧山，华

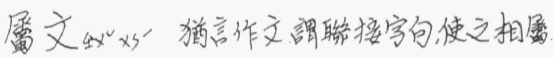

工廨文很霄作文

引赖的善

亡束直 即無賴指石良之行学

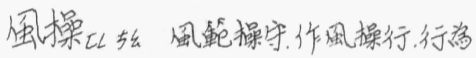

後主仅生”即南雷最後带李显。

仕版”“吗”謂官吏之册籍

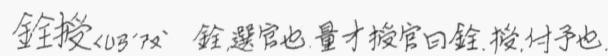

授職, 选官授職
博亦博局戰，下掑謂云博舆堛棋

2.33觝公以触也

角觝, 亦做角抵, 古校力之战即今之摔交。

34 吉州州的即今江西吉安夥

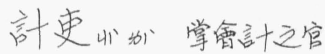

回連務言十更管運輸暑言十的官

盜妐偷或管

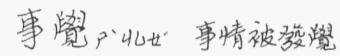

了. 1 屠动”宰教牲畜

屠敗等殺及骐喜牲畜

椎く凶世”謂専啬

椎货専喜物品

㖶以强給人車西。

贾《存货待蕒

咝䨘人不願置而强責給他。

米寽沎拿、持、取

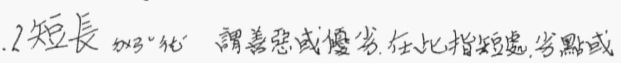

㖕行。

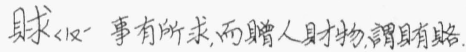

县求謝以具才物報答

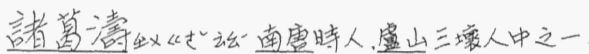

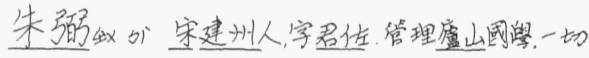

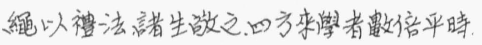

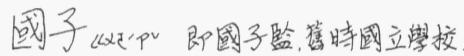

了捕的提。

窝岖藏医

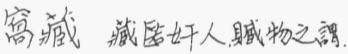

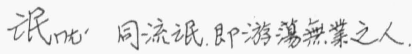

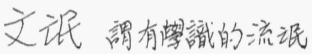

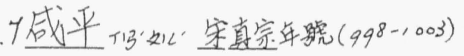

8知州生嘋售官名一州之長官

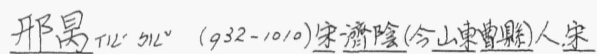

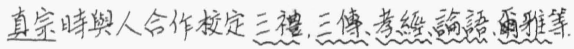

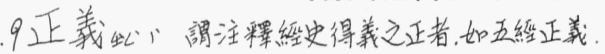


3.9疏義阦门註釋請解

悉门皆都

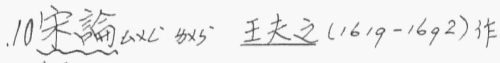

.14 媢沎了謂以助物助人

指款拿出諓具才来助成一件事。

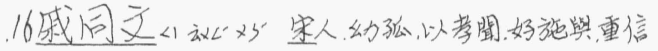

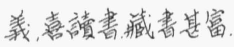

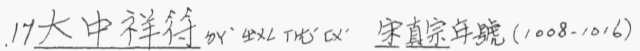

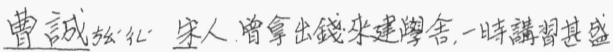
.18奉禮郎化办”㕱”官名、掌管執義行事。

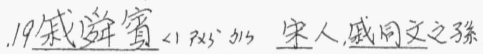

幕娥的生在幕府任職。

幕娥官在幕讨任職的官吏

20地基加山造房屋之地盤

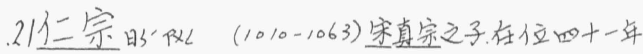

(1023-1063) 为宋朝第一仁主

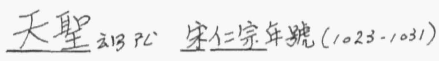

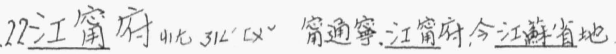

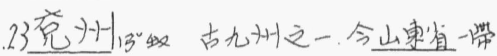

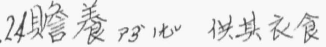

认已俸貝詹湌用自己为官所得之錢供其衣食

吃住费用。

娥田企动”古時数官更所給之公田

26 輔顺 就城时近之地

澅輔指地方而言非中央直轄之地

27 戒山世防偖

警戒因畏危險而有所防偖

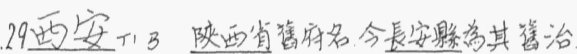

.30務、専力

構《架等建設

肯拱部父创業而子能继成功業者

咨口铩

嘲生部以言相調年

謔30世戯言。

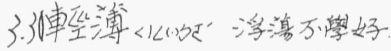

唯咨嘲言虐車㜽溥只想取笑他人, 説此敛

言而万紫好。

謀加、話多得敦倜不停

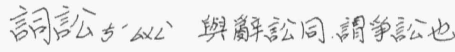

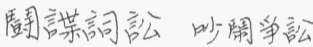

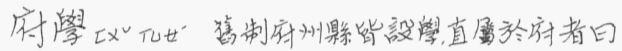
府踭。

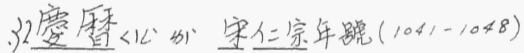

.34月月如 黨類

月月黨、結滛派排斥他黨者

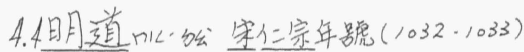

景鿆山长安仁宗年跣(1034-1038)

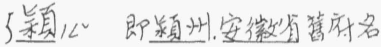

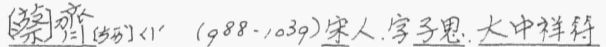

間進士。曾出知鉡州

.6路的宋時行政區域分各路，猶合之分省、

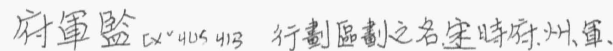

篮皆愿於路

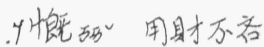

慨然用是才而然可惜之意。

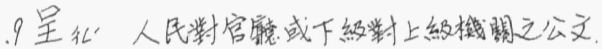

星請人民對官署成下级数上级請求之用語。

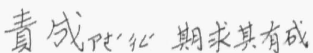

.10慊㔚意同慨

慷悢要喑用县才万各

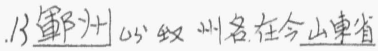

14 奇山謂單数或零撔。

有奇有零䰙之意如言二千五百畧有奇, 竟省二 千五有多畋

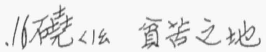

瘠山地地肥

磷瘦形容土地石肥

18 女莫石覓 
女得 不可以

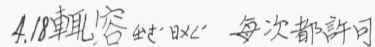

.19䉴防補也, 治也

縉俢 修治

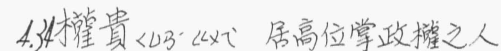

了. 1 盟口13 福建省别稱

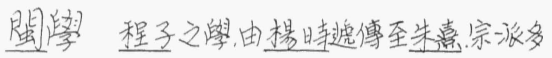
在呩中故日閩慗

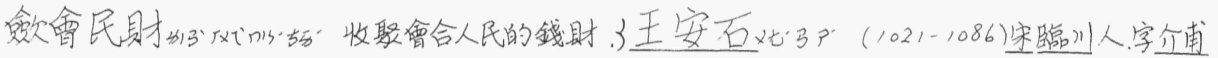
按分舉出, 攻撃他人之罪状

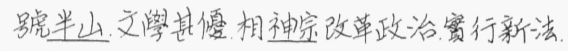

按燢 敛舉

20 裨方益

襖益益迶心好虎

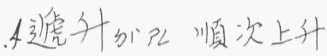

５元社有吸成定哲宗年號(1086-1093)

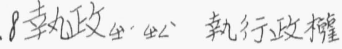

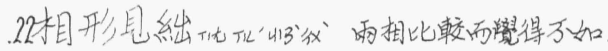

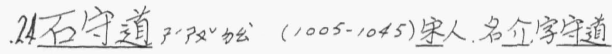

天狸進士，好蛽有志尚。

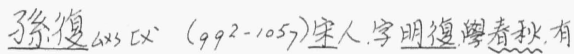

結術

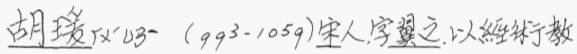

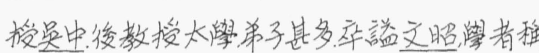

安定先生

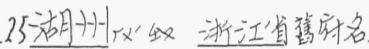

26 著秘標舉尊舉

者等令標舉以漓律法

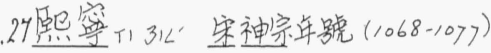

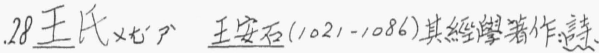

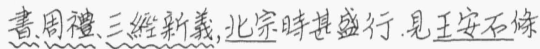

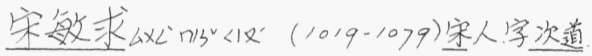

嘗预修需書熟於朝廷典故, 家富藏青甚多

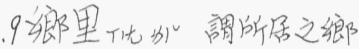

輊去鄉里随便的離開家鄉。

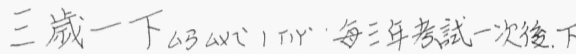

指下考埸。

10翌! 次

翌年明年，次年。

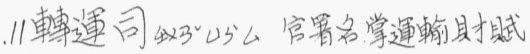

.12元豐US'CL宋神宗年躆(1078-1085)

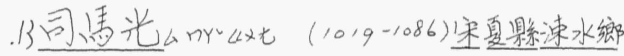

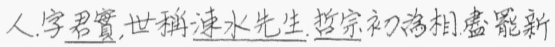

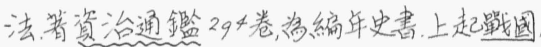

下到五代

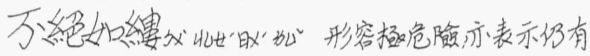

一线連慗

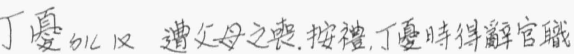

回家

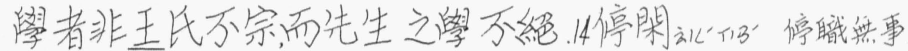

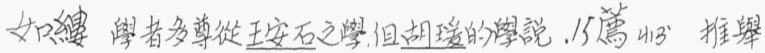

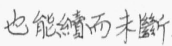

䉓舉 推䁷出的人才。

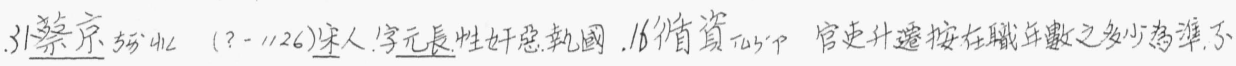

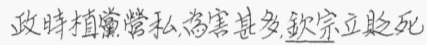

可越級

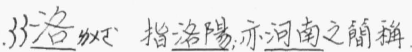

考綪弦山考核官吏之成績

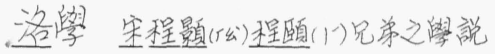

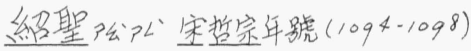

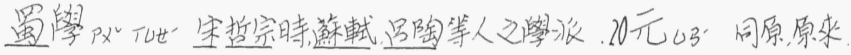

因皆置(四川) 人, 故名

.21杖的舊制五刑之一, 用木杖打罪人 
5.25下蒙似动”謂去除職够

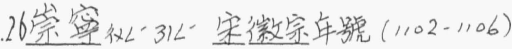

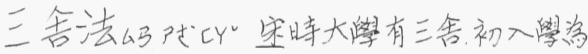

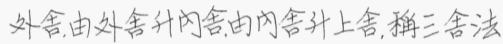

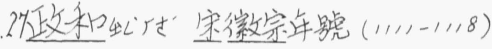

28 挪3 30 - 移

浪费㱛比無益的消费

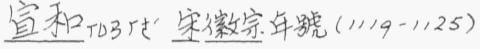

.29風紀UL4 闽俗教化與细常

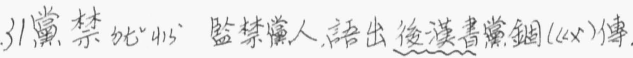

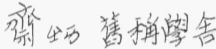

自訟亱䠋繁名

洗个”用水去万潔言胃洗

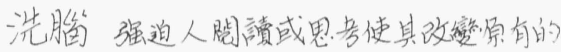
想法

弲忌4i 禁止某些事情。

時忌敦當時所禁止的事

縛似用絕束起来

束䋠 受約束

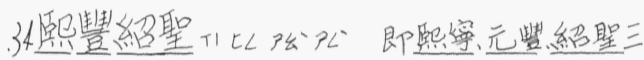

调年踉

6 . 3 自鬼妢”指精神

魄力猶言毅力

4 病㚭虑患

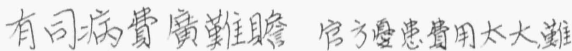
认供給。

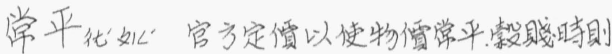

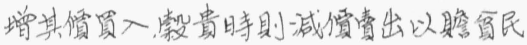

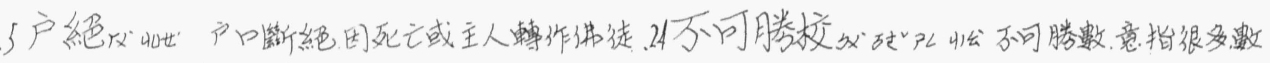
户絶团土物業絶了户口的所有的不動

\section{珄及動虽}

契勘《沙”調查

契勘善士合用數授充裯查供湌士

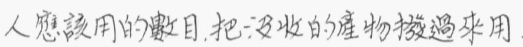

6.5諸色色係官团宅物業各種政驸自有的産業

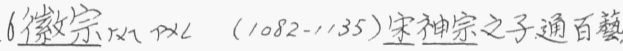

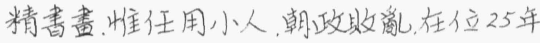

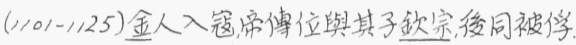

9 大觀思外《宋徽宗年踥(1107-1110)

.11教言前忪心官名、管縣激所教的整生

.11浸4 15 漸

浸失本旨澌激失掉了原来的目的。

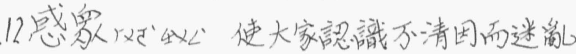

. 化比来外加猶言近来

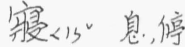

閶《世與缺通

寝以閭少停顿两缺少

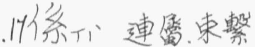

管係管理

18多六夜, 晚上

朝令文改指政令常常改率

晌拘捕

拘收没收

22 各没代人管理目才物而私下佔有

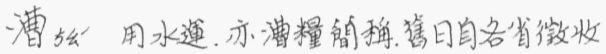

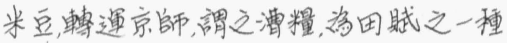

漕言十漕運的填目之下，地方篮常用水路 運給中央政驸的物資。

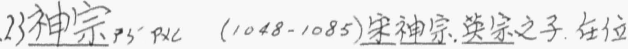

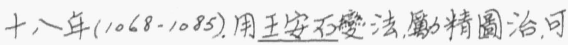
惜求之滑急而失敗 万完。

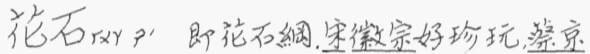

使朱冲及其子密取浙中珍異水運至京城( 汗,

今開封，跮花石紸

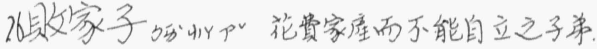




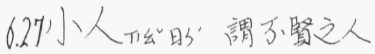

.31宇心屡也

告宇访舎屋宇

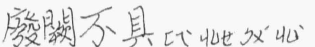

告或紀錄下来。

.32 语宁以官署

衙役官箸之差役。

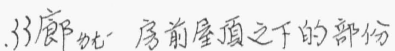

房嫏泛指绫等。

收掠阠虬进收取

科差剩冒一名收掠

一倜没事作的人員去收取。

.34庫子攻 P 管庫之人。

7. 大家外㛧世家大族。

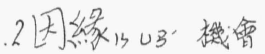

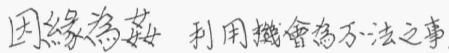

爱䔩义”作整

了楛落飲酒

搞弦以酒食学償連隊

藻搞领酒吃美食

4䐬云3。豐富

豐胑豐䔰

.5出入㣗㳀支出與发入,

罕厂万稀少, 很少。

6 升 36 澄進、数降下而言

升堂喻繁問已稍入阴

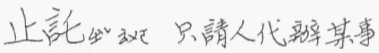

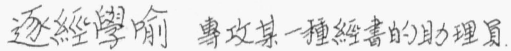

口義敌》; 口述紅義, 即今所謂傅義

抄弦同、鈔”, 依㨾不改的再窝一遍。

抄錄同敛録、鈔腺文字

惧斯補万足。

具占補補方足。

贘放一文書

$6.27-7.24$

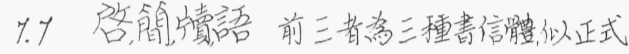
信, 短信, 非正式信, 語即幾向話。如賀詷, 家 剖等。

. 8 米曹䋇謂其事之髙至不可收拾。

緍n'絲

涽錢以綡特钱穿在一起, 成一挐位如一䡒 錢，十艒錢，

.10毆又擊打

盈虚寻相打

包攬言司言公包辩别人的咅莗以圖利

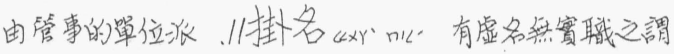

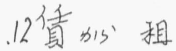

佃蓓租田

坊場比“忧”作買賞的地方

.13 个賞珑抵當，如得石僧失。

補償補救抵遗損失。

16 逢 Ú, 遇

遭逢遇到

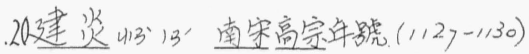

. 22 滞出职在一起而不流動

停滞停留方動。

舒璘P 圳

徽州教授、日寺稻第一教官。

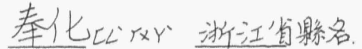

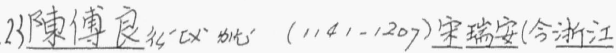

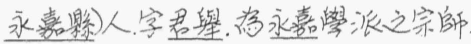

. 24 鼠加一作事不細心

锫等自謙言司

江右性必指江西

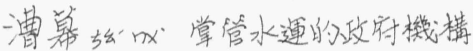

邆等虎江右漕幕舒㜆在信中説他

這调筷才能的人在江右漕官的部下作事

傍綵妈“吗”依附相随

僥骀”謂獲得意外之利益。 


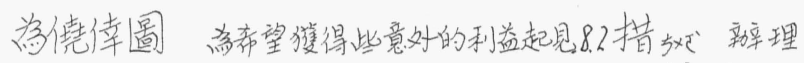

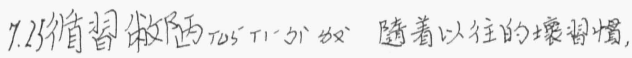
照常按着壞習惯作 舖奴應作餔, 食也 啜社”飲

喆甫啜之食余吃喝之後 渙 $\times 23$ 流散

渙然分散貌。如水之流散 .26震泷失

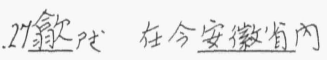
察加空虚

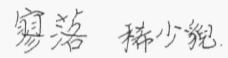
輩加道類人。

四十䍵四十调透類的人。 .28蛽列公之, 缺

以遗告報告“不夠了”。

皆皆二餐而去㳻然不修都尚且吃雨顿 飯即走, 完全篦意念書。

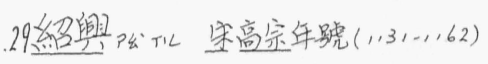

甘活同甘二十。 ３０倠４０，應作槛，專利，專賞

拘倠専收取

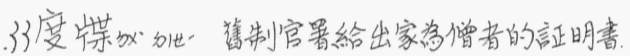

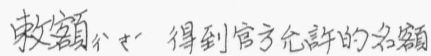
.34庵子奉佛的小屋 愿院和淌和女僧所住的地方 8.1 党牙椟易

侵移总用侵佔而移作他用。

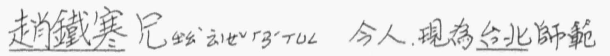

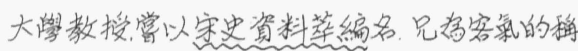
呼

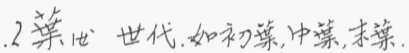

中䈎中期時代 䇾得预先打算言十劃。

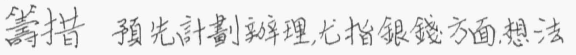
子箁集金錢。

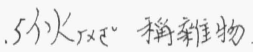
伙食稍每日的银食。 膳P马，飯食。

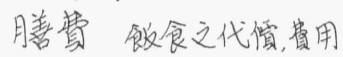
Y浸415 污點。

浸做污染敗哄。

障此济防䖝或阻隔视线之用具

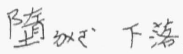
級山階次也, 階之一層曰一級。

颓障陸级障子破售, 上下用之階级也倒 3

楝汃屋中主要的架在柱子上之屋材。

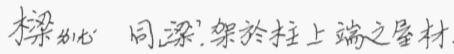

楝扶樑柱大祭靠在墚柱上。

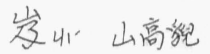

岁苃危险媱 . 9 过閭山5 岖”猶过遠也。

迁盟用切謂不切於事情。

营分僅。不旁，通用有相等之意。

何兽虚文万是如同虚文嗎? 跟虚文有什 麼万同呢?

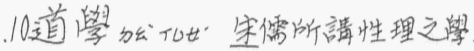

实加至安, 止。

实上来躁。

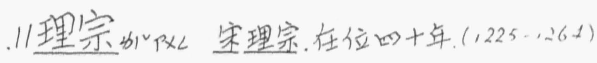

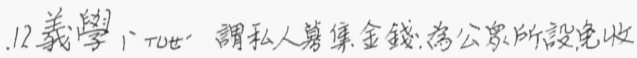
残费之殂校。 15 凌㿝, 踰越 驾U I Y 踦。加於其上。

凌唯超越, 出人之上, 亦作凌架。 .11蹋4 4 世不小心而無法站立。 
一距政不振謂失斯後不能振作恢復。

8.18 中舆期《 TL謂既衰而又復舆

擔加以以杖员物, 效於肩上者

重擔重大的责任

20 清寒《儿江南窮

放軩猶言分利益。

沾光有所依靠而猚些利益。

21 膲 4 小路

途征猶阿路、事情之初步方法或秘法。

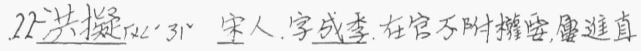

言, 有淨智先生集、杜甫敦注。

䆁子 P P P 僧徒之颜。

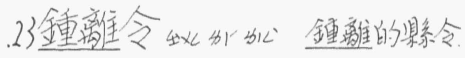

車九《事車雨輸間之距離, 法則。

果謀不軌果然意圆謀谣, 或行不法之事

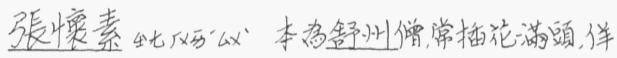

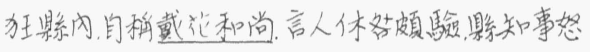

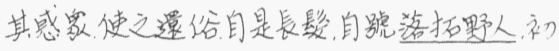

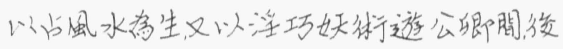

竞謀石軌事欺被捕媇死。

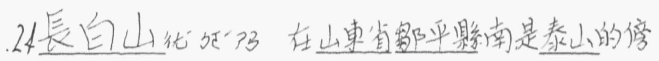

支

. 25 千十 P L 容量虽位名, 容皘等於31.6立方寸

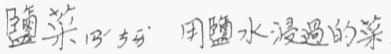

秀山盛飲食之器

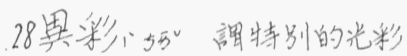




\section{第十二課宋代南方的虚市 \\ 全漢昇}

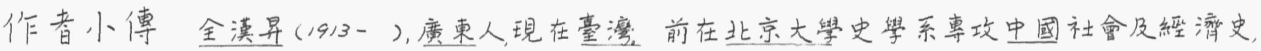
又研究中古時代佛教束漸引起的種種社會现象。1936 在中央研究院摩史語言研究所專研究 宗代都市现任看港新亞畫院研究所教弱長, 曾在食货半月刊及麼史語言研究所集刊發表文章很5

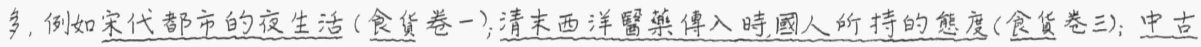

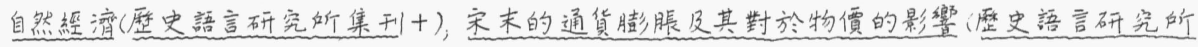
焦刊十)等, 並著有中國行畣制度史, 唐宋帝國舆運河。

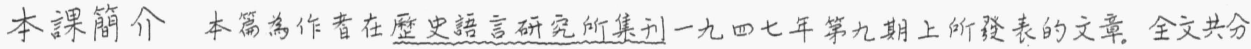

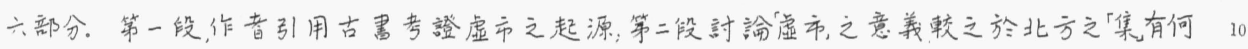

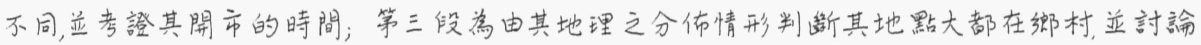
造成此现象的原因, 第四段談到其中留易的方式, 貫黄商品的内容, 由而推测其规模之大小, 及 往來客商留易的情况。第五為虚市舆城镇起源之因果及閏係, 恶以歐洲城鎮較之, 第六為 全篇之總結。

\section{(一)宋以前的虚市}

中國經營商業的市, 起源甚早。易慗鿷説:

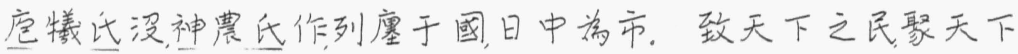
之貨。交易而退, 各得其所。

這固然是一種愽説神農代之有無其人尚不敢必但由此我們亦可推知從事2 0 貿易的市發生之早。至于虚市, 㨡至沈懷遠南越志所説亦可上溯至至代:

越之市為虚多在村場。先期招集各商或歌舞以来之。荆南 嶺表皆然。

到了唐代, 虚市更学登连。見何格恩唐代額南的虚市(食货半月刊第五卷第 二期)茲不鳌。

(二)虚市的意義及開市時間

䦣於虚市的意義, 吴處厚青箱雜記卷三云:

嶺南謂村市学虚……葢市之所在, 有人則霂, 無人則虚。而嶺 南村市, 满時少, 虚時多。謂之虞虚不易宜乎。

由此可知南方“虚市。一名之取得, 是因為閉市以後人貨星散市中空虚的原故。30 這與北方的集之取名正相反雖然二者只是同惯而異名。清屈大均腐東新 語卷二云:

葉石洞云: 昔者聖人日中为市, 聚則盈散則虚。今北名集, 丵聚 也; 南名虚丵散也。 
上引青箱雜記説虚市之所以得名, 由于满時少, 虚時多, 可知虚市 䧧不是時時都做買賣只是一種定期市。其開市做買賣大約隔三數日舉行 一次。宗畣要食货一七載淳熙二年九月二十二日,

臣僚言, 瑯落有號㪄虚市者, 止是三數日一次市合。……

5 又参察子詩集卷一歸宗道中云:

數辰競一虚。

其中有规定每逢寅西雨日開市的。趙汝适諸蕃志卷下海南云:

距(昌化)城五七里許外, 毁生黎所居。不旁數百峒, 時有侵損之

害。周候遣熟黎峒首諭之, 約定寅西二日為虚市。率皆肩擔

背負或乘桴而來與民留易。黎人和悦民獲安息。

有规定三日開市一次的。錢易南部新書卷辛:

端州以南, 三曰一市, 謂之趁虚。

此外又有规定雨日開市一次的。案異要食货一七及六七載至和三年七月,

二十八日, 上封者言。嶺南村虚聚落間日聚集裨販謂之虚市。

在規定開市的日期内虚市也很少整天做買党, 其買的熱閙時 間多半是在早上。所以范成大的詩每將虚市與早晨連在一起。如石湖詩 焦卷六曉出克城山云:

落月墮眇莽, 残星澹微茫。……墟(當師是虚。字, 想是後來才加士 旁的。) 市稍來集, 笉籠轉山忙, ……

又同書卷七清逸江云:

晨興遇墟市, 喜有魚蝦賣。

又同書卷一九馬當汱阻風。居人云, 非五日或七日風不止謂之重陽信云:

趁墟漁子晨爭渡賽廟商人晚醉蹛。

${ }^{25}$ 自然虚市也有整天做買䔬的。如周去非领外代答卷二説在暞州與黎人交 易的虚市到日暮才散云:

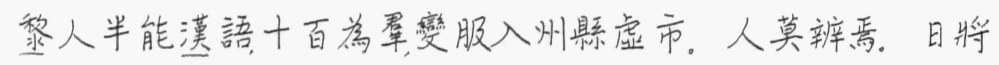

晚, 或吹牛角病聲, 則紛紛聚俞結隊而蹛。始知其為黎也。

這些虚市所以隔日或隔三數日才開市一次開市後也不整天做

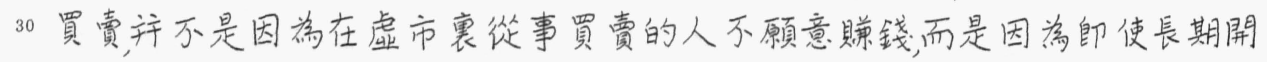
市, 也找不到主顧結果買䝴做不成, 反要虧本。虚市的主顧多半病居住于牠 的附近的農民(由于下一節説虚市地點在鄉村, 可以推知。) 他們人數既少又 非富有購買力實在很小, 同時在虚市裹出䝴貨物的人多半是附近鄉村的 生産者, 他們的生産技街非常低下, 從而所生産的物品不多, 故示不足以應長 
期開市作買壹的需要。所以虚市的買䝴只好隔三數日或隔日才舉行一次。

自然在規定開市以外的時間, 虚市也䧧不是絶對没有買䝴的行 学因為虚市中也有固定的商店。例如洪遇费堅两志卷五説永嘉的虚市有 米肆云:

永嘉徐秉鈞縣丞有女曰土七娘慧解過人將箝而死。母溤氏5 悼念不能釋, 忽夢女坐庭中, 弄博具。記其已死呼謂之日”, 自

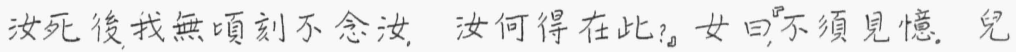
已復生為男子矣。取骰子示母日,此菜子格也蓋是我受生處。 他日至黄土山前米铺之粼訪我, 彼家亦且作官人。言訖而舅, 以語徐。徐所居在安溪村不知黄土山為何地。或日”仍南郭1 0 外一虚市, 去城才五里。節往寻跡, 正得一米肆。……

又夷堅支登卷九説池州的虚市有酒店云:

池州東流影村墟當有少年數輩, 相聚於酒店賭博…… 不過在開市的時候, 虚市的買員規模較大于閉市的時候卻是可以推知的事。 (三)虚市的地理分佈 15

定代的虚市多分佈在南方各地並没有在北方的(因羞在北方的

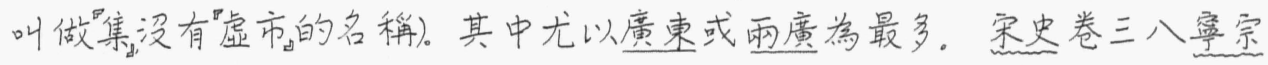
站説:

(開禧元年) 六月戍子, 罷廣束税場八十一墟。 其中最多見于記載的為欽州(那時屬廣南西路現屬廣東。的虚市。领外代 20 答卷一○云:

余觀深廣之女, 何其多且盛也! 男子身形卑小, 颜色黯惨。婦 人則黑理充肥少疾多力。城郭虚市, 页販逐利率婦人也。而 欽之小民皆一夫而數妻。妻各自解骐逐市, 以瞻一夫。 又鬼董(撰人秩)卷一云:

嘉定戊寅冬廣西諸司奏知欽州林千之食人事。始千之得末 疾, 有道人教以童男女肉强人筋骨。遂捕境内男子十二三歲 者腹而食之。…… 又以厚賄使卒掠人虚市間。”

又范成大桂海虞衡志説廣西的虚市云:

古辣本富横間墟名。以墟中泉釀酒䚁熟不著埋之地中, 日足3 0 取出。

其次江西也有不少的虚市。夷堅支丁卷五云:

浮梁民程發為人庸力, 屢往江浙間。淳熙十四年九月……所 居五里外有虚市日腐平距邑十五里。程一日往…… 
又夷堅支成卷一云:

閩僧宗達住持羅源山寺。連江林行者之叔某, 以沙彌受業, 其 後游方江泪間與蓬相遇于南昌村墟.......

又荑堅两志卷一三云:

鄉人李富王利用紹興二年知新淦縣。以宣撫使入境躬至村 墟督賦。……

此外浙江, 安徽湖南等地也有虚市。上節曾引夷堅五志卷五説浙江永嘉有 虚市。關於安徽的虚市, 范成大入蜀記卷三説繁昌影有虚市云:

10 又荑堅支癸卷四説湖南醴陵有虚市云:

二十一日遇繁昌影……晚泊荻港.......荻港蓋繁昌小墟市也。

吉水縣人張誠以乾道元年八月往潭州省親故次醴陵界投宿 村墟客店。

在定代南方的虚市中, 又有偏于與文化較低的民族交易的虚市。 在婹州( 師海南島)及湖南都有這一類的虚市。第二節引的諸蕃志卷下及嶺 15 外代答卷二説瑷州有與黎人交易的虚市。至於在湖南與苗人交易的虚市,

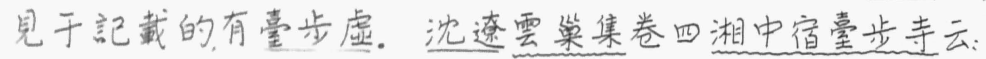

湘源初甚微屡捏不满缸。比至薹步虚泛泛為長江。虚頭市

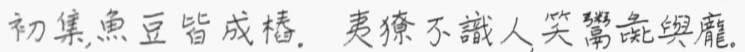

虚市的地點大都在鄉村, 由于上面所引的夷堅志多記有“村墟(宋 20 全要食货一七及六七作村虚) 可以知道。這可説是虚市的一種特色。我 們知道, 通常交易的市埸都是在城市的多, 所以货物的集散多以城市作中心。 如今虚市的地點卻在榔村, 這是什麼道理呢? 很明顯的這完全是從鄉村的 消费者及生産者的便利上着想。因为有好些鄉村距離城市很遠, 如果什麼 物品都要老遠的運往城市才能出賞或老遠的跑到城市才能買到是很不經 25 湾的一回事。況且鄉村的物座在城市裹固然可以找到主顧在鄉村裹也不 是完全没有人買的; 因為榔村的農民固然贫窮購買力低但事惯上每一農家 都不能閐著阴惯行絕對的自給自足政策(就是反對分工, 主張與民恶耕而食 的言行也不能自製鐵器, 而以粟易之。而要以其所有, 易其所無。所以峦便 於鄉村的消费者與生産者的原故虚市也就在鄉村中應運而生了。

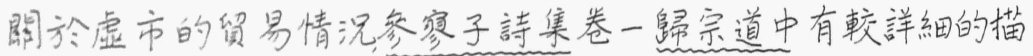
安

朝日未出海, 杖黎適松門。老樹暗絕壁萧條聞哀猿。迤遥轉 谷口, 悠悠見前村。農夫爭道來聒聒更笑喧。數辰競一虚邸 
店如雲屯。或摧布與楮, 或驅鷄與㹠。縱横箕篣材, 瑣細難具 論。老翁主留易, 俯仰象所尊。區區較寻尺, 一一手自翻。得 無筋力疲雨髸理霜根。

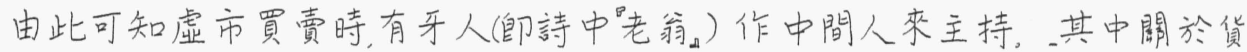

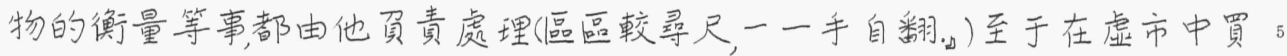
員的商品, 則有鷄猪( 㹠) 等食料, 及布、紙(楮) , 筫第等手工業製品。此外, 上節

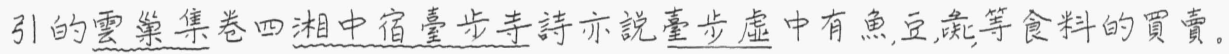
其中關於魚的買賣, 上引石湖詩集卷七清逸江亦説, 晨興過墟市, 喜有魚蝦 責】同書卷一九馬當汱阻風……説趁墟漁子晨爭渡。此外夷堅己志卷二 ○亦説韶州村虚責䰻云:

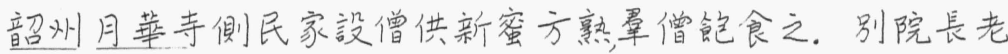

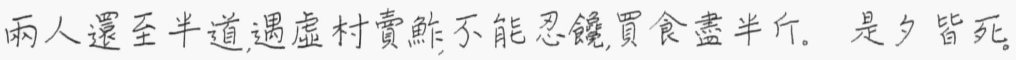
至於猪的買賞夷堅三志壬卷九亦云:

餘干古步有墟市數百家為商賈往本通道, 屠宰者甚悉。王 生擅其利數世。每將除一豕必先注水沃灌使若充肥因可剩15 獲利。

復次, 柴及蔬菜也是虚市中的主要商品。陸游劍南詩稿卷一溪行云:

逢人問墟市計日買新蔬。

此外虚市中又有茶的買党入罢記卷三説:

二十一日過繁昌.……晚泊荻港......有趙先生荻港市中人, 父 20 賣茗。荻港蓋繁昌小墟市也。

又第二節曾引夷堅志説虚市中有米肆及酒店, 可見虚市中又有米及酒的買 赏。

就以上所列的商品加以考察可知在虚市中買䝴的無論是食料 或是手工業製品, 大都是日常生活的必需品。復次, 由上引答家子詩集卷 25

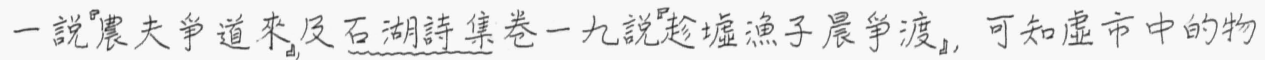
品多半由生産者直接出党, 不用商人作媒介。同時, 由於上引等堅己志卷二

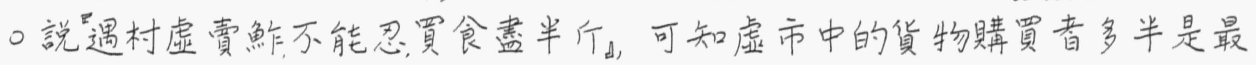
後消費者, 而不是把所買物轉骐他處的商人。

根據上面的論邀, 我們可以推論: 當時虚市留易的规模是很小的; 30 因为無論從其中留易的商品或参加貿易的人(購買者與出䝴者)本看, 虚市的 留易都带有很濃厚的地方色彩。所以, 隔篺日才開市一次開市以後熱閶不 了多久, 也就完了( 見第二節)。完了以後虚市的徖寞或冷落的情況, 有如需监 集卷四湘中宿臺步寺所説: 


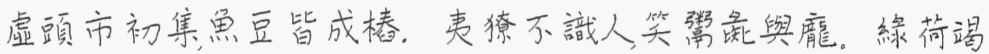
苞苜, 人散誰復撞? 鷗鳥亦来下, 酒斾停空杜. ……

復次, 由於虚市每年商税收入之小, 亦可知其貿易不大, 空畣要食货—七商 税项下列舉廣東英州各虚市年收商税的數目云。

5

10

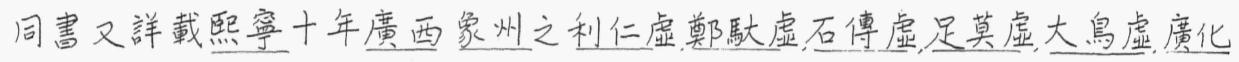
虚, 張峒虚連在虚的商税收入, 數量也是一㥞的微小茲從略。

我們如果把同時代的大都鿖, 如洨梁杭州等每一交易, 動以萬計。 15 不單白天買䝴, 且䌡以夜市, 以及商税收入數量之大的情形見拙著北密泣梁 的輸出入留易及南宋杭州的消費舆外地商品之輸入二文與虚市的微量貿 易比較一下, 一定會感到虚市留易之小得可憐!

虚市的留易固然微小, 而且富有地方色彩, 可是同時也有超越地 方性質的地方。閶於此點由於當時虚市之有客店及邸店等設備, 可以知道。 20 上引费堅支癸卷四云:

吉水縣人張誠以乾道元年八月往潭州省親故次醴陵界投宿 村墟客店。主人一見如素交延接加禮。

又参寡子詩集卷一䠛宗道中云:

數辰競一虚邸店如雲屯。

25 邸店在察代是各城市替外來客商的方便著想的一種設備。客商販運貨物 至某一城市時, 一方面可在氏店住宿他方面又可将他們貶運的货物堆存在 邸店内。故邸店一方面是旅館同時又是堆栈。(見拙著察代官吏之私篦商 業, 中央研究院歷史語言研究所集刑第七本第二分。) 虚市所以有此設備自 然是因有外地的旅客及商人常到虚市, 可以做他們的買䔬的原故否則客店 30 及邸店便没有主顧從而支持不住了。這種客商常到虚市的事實, 可以鉒干 古步的虚市為例。上引夷堅三志壬卷九云:

餘干古步有墟市, 數百家為商賈往桃通道。

門於外來商賈對于虚市貿易的地方性的破壤我們可以從雨方

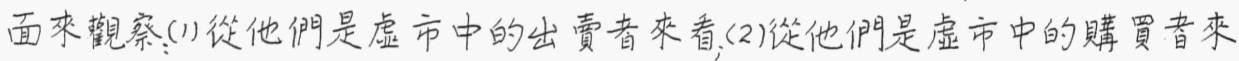




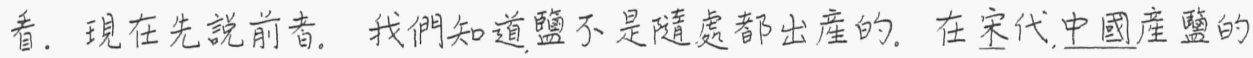

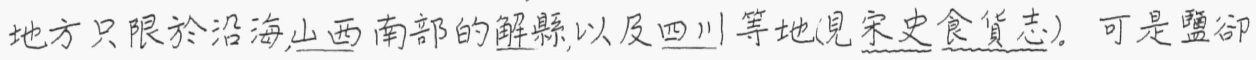
是人民日常生活的主要必需品雍也缺少不了牠。所以, 在虚市中留易的商 品雖然大半限於本地的物産, 在外地出産的監卻也老遠的被運到虚市來責, 以满足鄉村消費者的需求了。例如案畣要食货二六説客商欺監到湖南的 虚市出党云:

(紹興三年) 五月十五日, 荆湖南路提舉茶醖显謙之言: 吃今後鎮

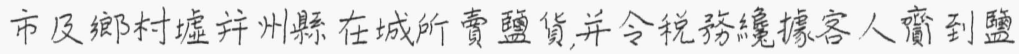
引气驗封引住赏, 並師時于引上用雕造大字印子, 稱已于某年 月日驗引驗封于某處住䝴官親押字……

又上述在虚市買䝴的货物中有布紙筫第等手工業製品。這些物品固然大 部份是鄉村副業的産物但其中一小部份也有由城市手工莱者製造, 從那裹

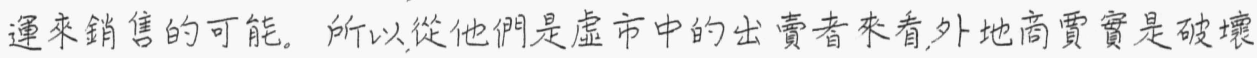
虚市留易之地方性的因素。

復次從他們是虚市中的購買者本看, 外地商人也是破壞虚市留 15 易的地方性的因素, 商人一尤其行商——的職物是販運貨物, 使各地的 物産互相流通。所以外地商人到虚市購買的貨物絶不是自己消費, 而是轉 販往另外一些地方—尤其城市—出党。閣於此點, 一時踓然找不到直 接的證據, 但由下面的事惯也可以推論出來。夷堅支景卷一説江陵商人攜 款到榔間買猪云:

江陵民某氏, 世以圈猪為業, ……民長子嘗㩲银券, 其直百千, 䧧 一僕出鄉間留易……

又夷堅緢志卷二説虚陵屠后到鄉間買猪云:

虚陵城西有彭屠, 常以五更初往士里㾰下買猪。暗中忽望見 正丙岡趙宅师子。㩲尖刀以行, 更十余步忽聞田中叫聲。……2 5 這襄踓然没有説明土黑廟是怎麼樣的一個地方, 但由其附近有田一點束看, 可斷定其在鄉村間。這些到鄉村購買食料(例如猪) 的城市商人是在什麼 地方和食料的生産者交易呢? 上面引文雖然没有明説是在鄉村中的虚市 購買, 但虚市既是榔村中的買賞地方, 他們貿有到那襄購買的可能。他們在 那衰購買後當然是運到城裹自己開設的商店出党, 而不是由自己完全消费30 的.

(五)虚市與城鎮起源的闑係

歐洲城鎮的起源, 有種種的不同。其中有一種城市起源于定期 市; fair) 舉行所在的堡壘或寺院的四週。我們现在討論的宋代南方的虚市, 
也是定期市的一種所以我們很有趣的墢見到虚市與城鎮起源的關係。

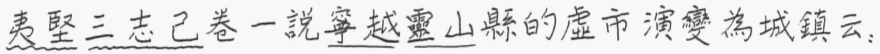

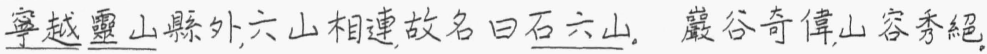
舊萹墟市。居民益廣商旅交會至於成邑。

5 又王存等元䇺九域志卷五説泰州的柴墟擴充成鎮云:

(泰)州東南七十三,四鄉柴墟永豊二镇。

又李心傅建炎以來繋年要錄卷三一及三九和穼畣要方域一三市鎮雜錄都

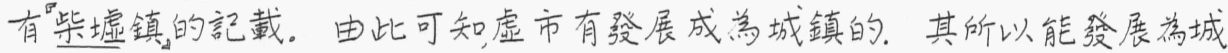
鎮約有雨種原因（１）交通方便便于商品的集散故能發展為城鎮，上文説，商 10 旅交畣當然是交通方便的原故。(2)居民多了(上文説居民益廣。虚市的主 倠也從而增多。以前虚市因為主顧少, 只好隔幾天才開一次市做買賣; 如今 則因主顧加多, 天天開市也有人来購買故虚市便由满時少, 虚時多。的市場蓆 学天天做買眚的城鎮了。

\section{(六)結論}

15

總括上述可知宋代南方的虚市是在當時鄉村自足經濟下發生 的交換形態。在其中買䝴的商品多半為日常生活必需品産于附近的榔村。 有其中從事買䔬的人多半为附近榔村的消費者及生産者。因此這種買賞 極富有地方色彩。同時, 因為鄉村居民的生産力與購買力都不大所以這種 買賞非常微小隔裁天才開市一次。

不過虚市留易也有打破地方色彩的地方。在虚市中聳事買賣 的除附近鄉村的居民外, 又有外来的商人。他們一方面將外地的商品監及 手工業製品) 骐入虚市, 他方面又在虚市收買商品(食料)轉販入城市出䝴。可 是我㑚不應把這種情形鋪張太過因㪄虚市的留易究竟是以鄉村的消费者 與生産者存主體外来的商人只居於次要地位而已。自然其中也有些虚市, 25 因為交通方便留易增大發展為城鎮的。

\section{民國二十七年四月于廣西陽朔中山紀念堂}

討論問題

一般述宋時南方虚市的性留,

30

二虚市上赏些什麼束西?

三榔村及小镇上人民的生活如何?

四整的運要與普通日用品有何不同?

五, 虚市如何發展成城鎮? 


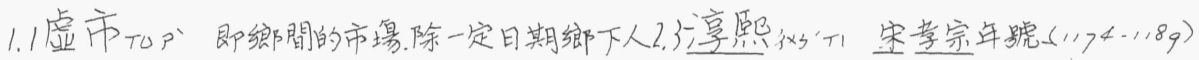
来作買党外、即無人, 故云虚市

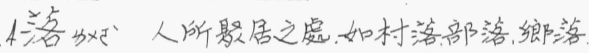

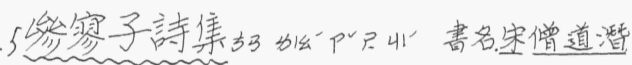

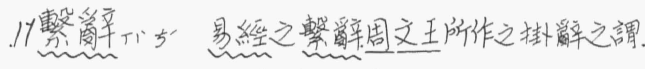

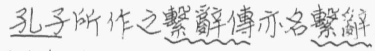

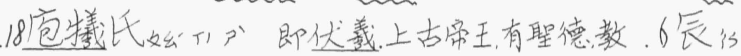

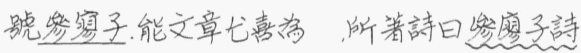
焦

人民提漁及畜牧, 在位一百五十年。

没地死

作煺起

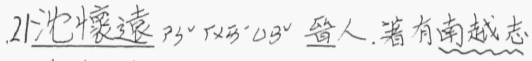

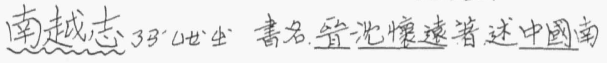

方雨簧一带地情

溯么八追記往事, 回想以前的事。

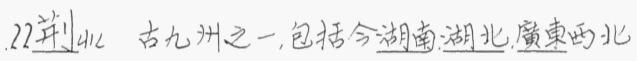

角及愿两省全夥等等地方, 朔南指此等地方之 南。

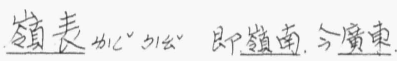

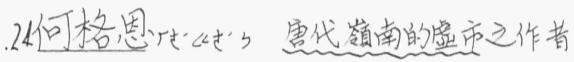

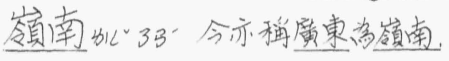

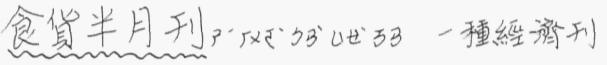

物名每半月出版一期。

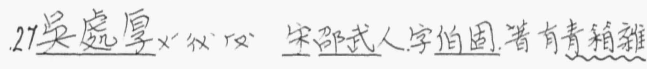
熟

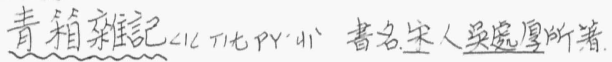
九十卷, 所記多當代思闻, 亦多敦言寺之話。

.30星散秈公即分散。

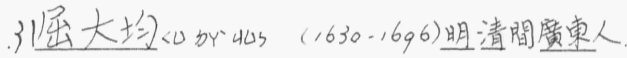

字翁山、好遊、以詩文著名

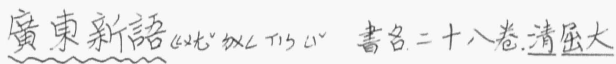

均撰大旨採慮整通志略其琶两詳其新故名, 凡天

地, 山、水、神、人、䖵、算等共二十八語, 每語有一卷。

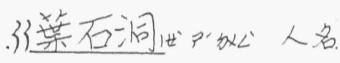

聖人到旷指古時帝王或品格極高之人 2.2 隔《さ間，離

數辰競一虚幾個鍾頭之肉大家競争䨘 置完㣪即散去

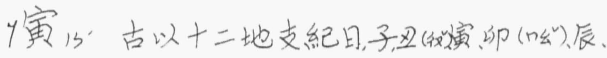

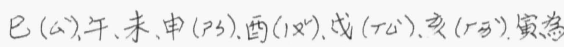
地支之第三位。

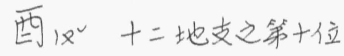

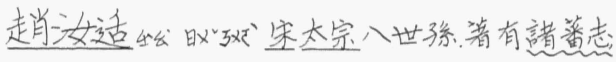
叙述甚詳。

言者蕃志的巧出書名趙汝适著, 雨卷述十二,

十三世紀時中国與外族文易事情

海南个的3 3 ”地名, 即海南捣, 在廣東省南海中岛

中有五指山，沿海近山为高地，向为黎族所居

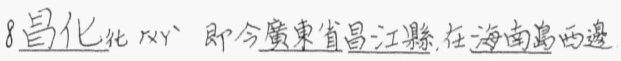

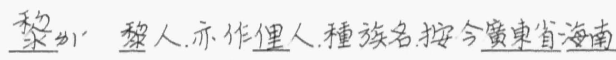
遇上即黎人所居，生整居五指山中，就黎居五 指山外。

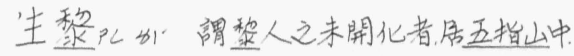
山同动通洞，山穴地

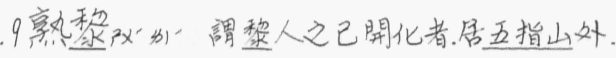

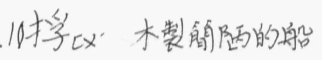

悦心世楽, 愉快。

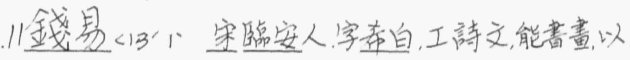

才澡知名, 箸南部新責。

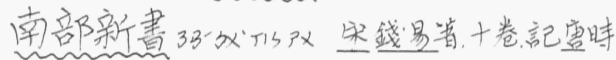

故事, 亦雅载朝章淢典因革损益

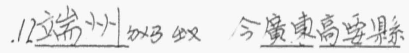

趁虚的“仙猶趕集, 在一定的目期到市䶍上去

買高 


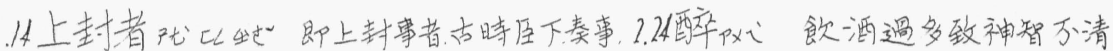

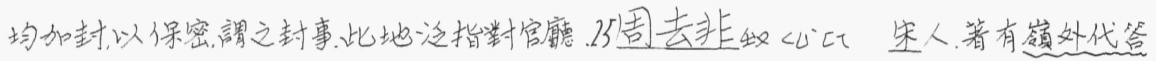

远報告者

間4 43 分隔

間上隔日也

螝女，小也

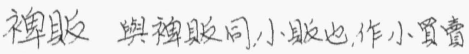

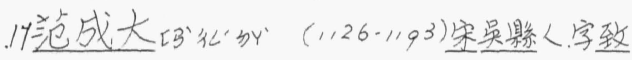

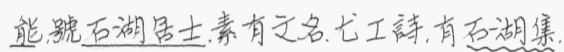

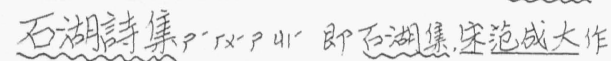
.18日琴伀。灭明

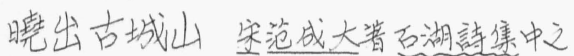

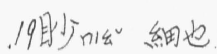

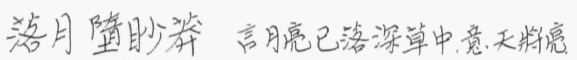

澹加，安静幽間

残星澹微法言天上星星也不多了。四发安 静、亦窉天快眖時的情形

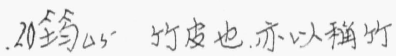

龍意加盛物的器具用竹做成

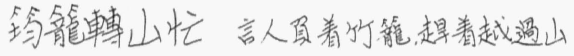
頭爽作置黄

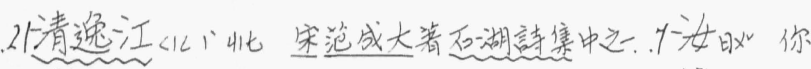

. 22 蝦个Y水中動物, 第節足類, 長尾, 分頭腹尾三

部、有解角雨数，甚長，偅類皮真多，均可食。

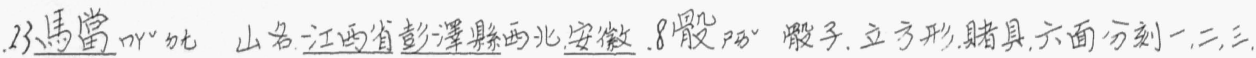

省速流縣两南北臨長江，形勢雄䧗。

垘地回流也。

馬當沃阻風在馬當坐船遇虽

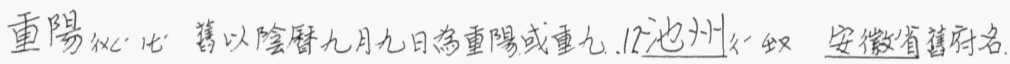

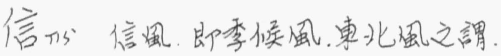

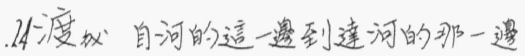

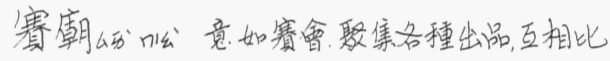
$2.13-3.17$

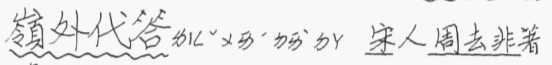

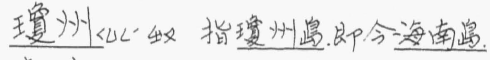

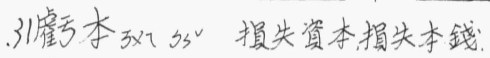

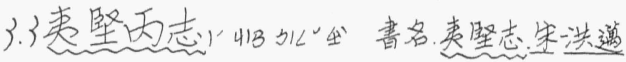

(1123-1202)翼、所記皆神怪之説, 原書420卷。

现只疜甲乙丙丁志各二十卷, 支甲至支成五十卷,

三志洛千卷。

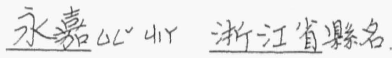

左肆公陣售华物之虎，今意为商店。

米镸聿啬米的商店。

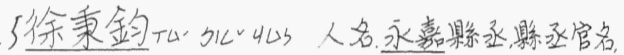

蚌助縣長者。

慧「们智, 敏

解山世明㛺

慧解聰明暁事

年年山古女子磌䯭上的一㮔用品, 女子成年( 十五

歳)始用之, 故示用以喻女子成年。

6 悼枟悲傹

悼念賏念( 多用在人死淩悲鹪而想念)

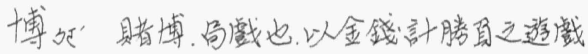

憶, 思念。記得

不徝見憶不必想念我

四、五、少點

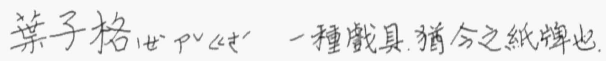
儿語心告, 告訴。

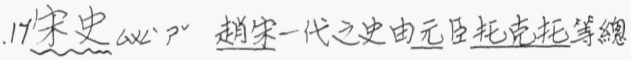
裁監修, 共四百九十六卷, 有本紀、志、表、列得为 二十几史之一。 


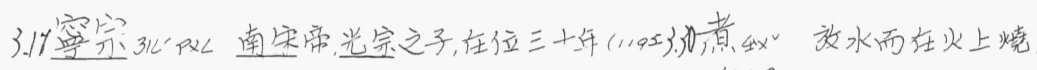
1224) 䆟宗紀, 宾史本紀之一。

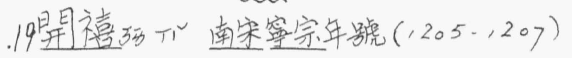

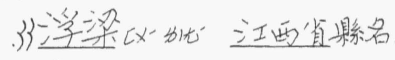
庸比與傭通, 即为人工作

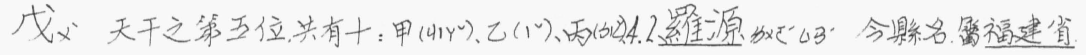

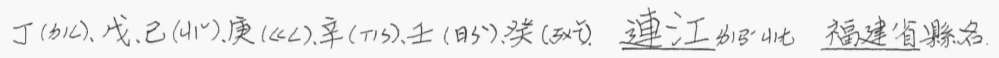
亦糐十千.

子 p v 地支中之第一位。 叔改稻父親的弟弟

伐子古時以干支相配稻甲子，如甲子，已击;

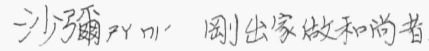
甲戍、乙亥等, 以紀年、日、日、時。

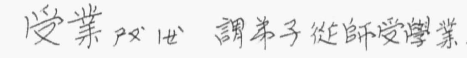
游方 12 .

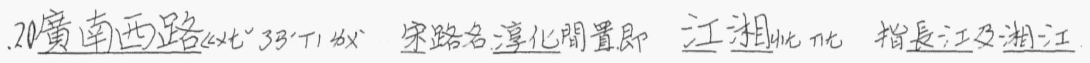

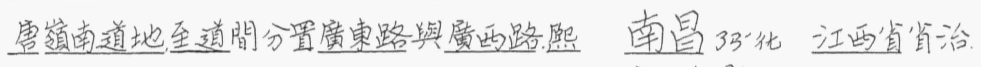

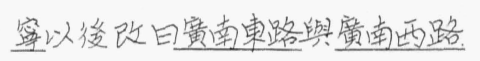
22黑音分深黑。光明貌

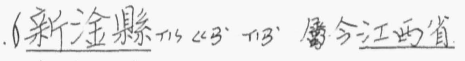
宣撫使 $1430 x^{v}$ P 惨强 色暗之意

黑音怡除暗貌 .23理か活上之紋路。

黑理充肥意皮色黑而肥胖。 疾山病之䡜微者。

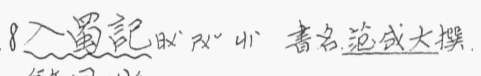
繁昌縣圻“彻仍安徽省夥名。

暏地謂船停靠河遇。

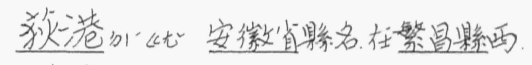
10 西遭陵加加湖南省紫名。

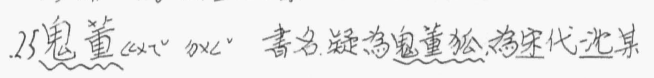
省，多述鬼故事。 侁门舆遗”通。 撰人佚作者已不可考

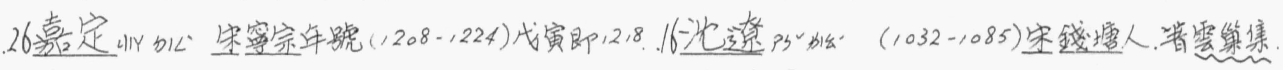
末疾叭收謂病在四肢。

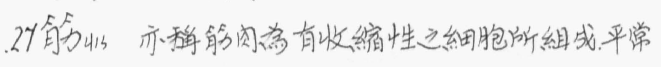
指滑骨各会另, 可陵意動。

鸽骨謂骨幹

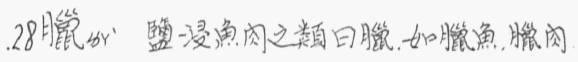

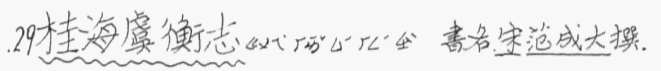
記悅南之山川物虽。

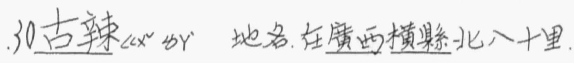

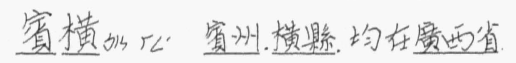
醇震沋製酒。 醇慗酒製酒。

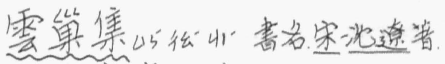

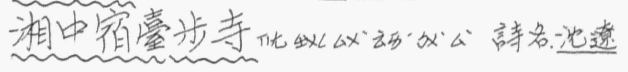
作, 在具零笨集中。 䔶门引水入器。

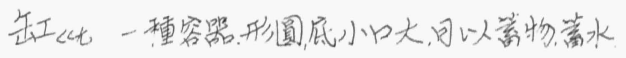

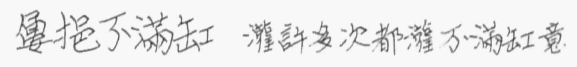
水甚少。

比引近

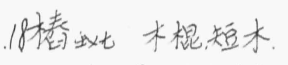
魚豆皆成椿魥豆類皆央成偆。 獏妅两南夷人。 
4.18 竞出猪。

鹰昽通尤”, 多毛之边

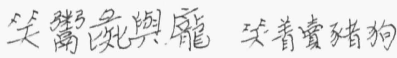

.23着想圵化”即想贵心想。

. 28 言午行心゙化践國時楚人, 主張君民证耕。

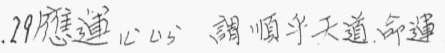

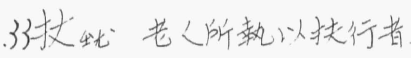

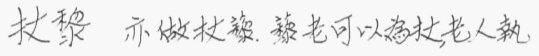
以扶行, 諳这扰籍

適》往、至

松的好長青榼这一種

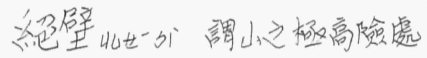

萧仏感恩空虚冷清。

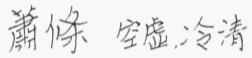

京两悲稘

猿山月, 動物名, 形状犬似人、能立能坐

迤, 科行也。

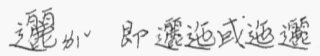

这透露行速延也, 一路行去由析相速的 漛子

.34忿风安静平稳的漛子

$$
\text { 悠悠安間的栐子 }
$$

聒《 XY 语鳌少雜、

聒聒多言乳人之意

喧TU3大短言語

5. 惟㩦小拿, 提带着

楮讻紙

㹠动与同、豚”(动 5 ”小猪

箕山掦米去槺之具受應土之㽞。

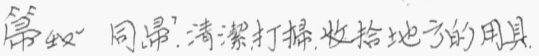

璔栿”細，小。

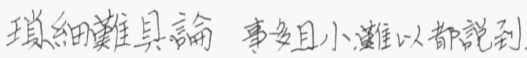
２俯的。向下，仰之放

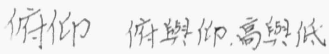

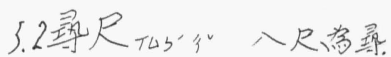

㟫䧟較臂尺为一點小或少的東西也要 用尺来量量

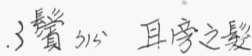

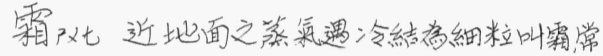
用来形容自了色

雨謷理霜根整理耳旁已漸白六髮毛。

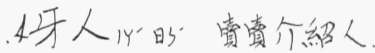

.5 衡量以“姚测物之輊重。

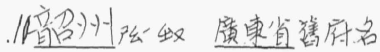

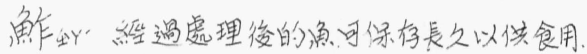

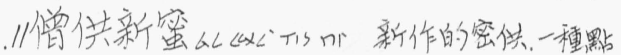

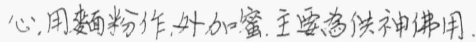

長老此“幼”棓僧之年德皆高者

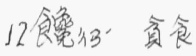

14 食余千 4 《3 江西省夥名

古当《”我地名

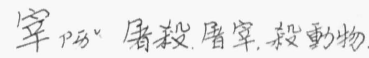

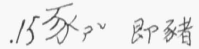

沃欢”引水注入田内

㴌《注水

沃㵀湤水使其肥美。

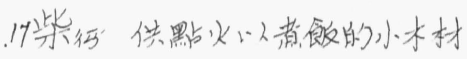

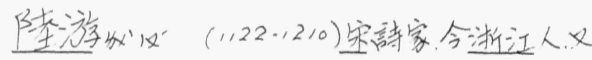

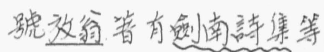

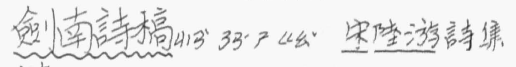

18 新似柴也

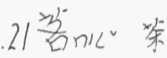

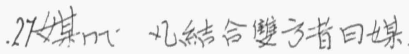

媒介謂介紹人。

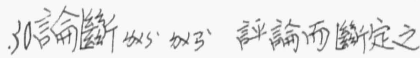

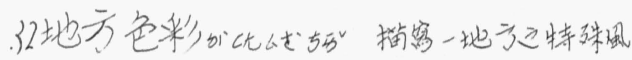

份舆景物稻漛地方色彩

. 3 综4 1 静, 安。 
5.33篹吓・冷静, 冷清

宗窝冷静

6.1简比一種在水中生長植物, 夏時開紅或向花, 箱大

圆形, 可用本包束西

. 2 笣等弜吣謂包裹也

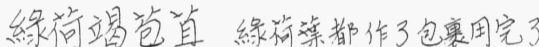

撞紅擊碰

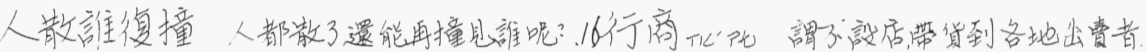

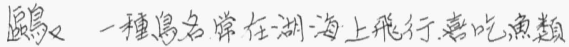

斾娰旗的通稳

杠《掛旗的長竹

酒斾停空杠酒甜的旗子空空的掛在

秙上

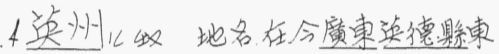

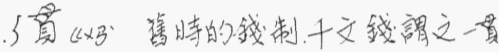

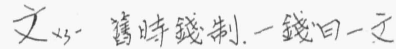

12 象州不化的地名，在今类画象影

14 都拿的化人民及货物聚集之大都色。

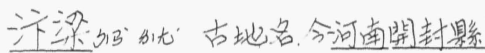

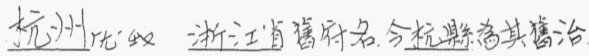

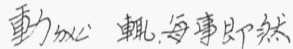

動外萬言十每一次就計算到盂钱

.22素交的骀老朋友

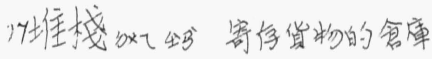

30 從而…秋“因此就.

從而支持了住了因此而不能维持了

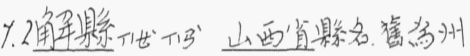

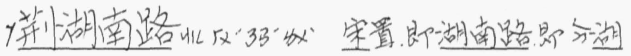

南润廷湖以南

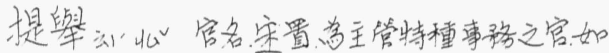

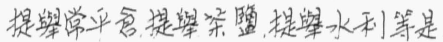

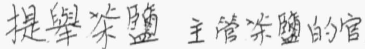

是謙之後《1出实澶州人, 字巷道

.8灗山謂持物與人

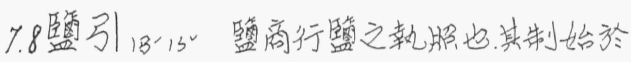

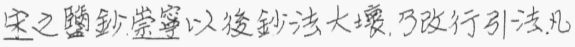

商人通壿限以㭙日, 视地遠近各給以引。

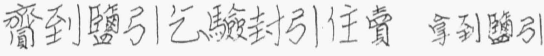

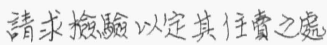

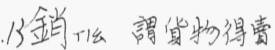

銷售謂没賞货物
.21圈北3 收住, 閣住

圈猪養腊, 把猪關起来養

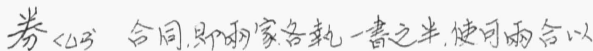

学信

銀券合同可當银钱使用, 故謂之银券。

直出”舆值”通

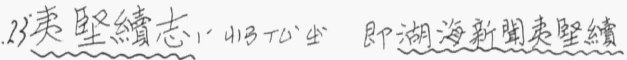

志五卷。元某人捛, 記載故事軼事预言

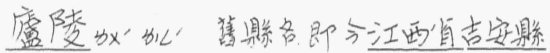

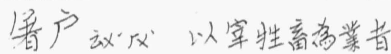

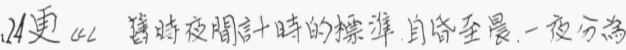

一, 三、三、四、五更、五更即天快竟時

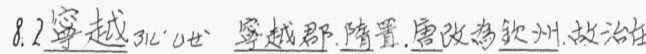

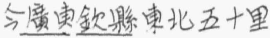

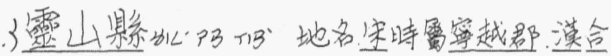

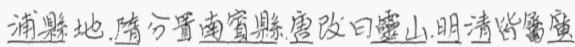

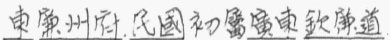

澱河, 山之高直者。

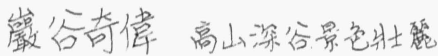

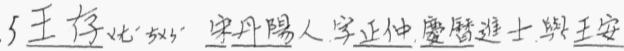

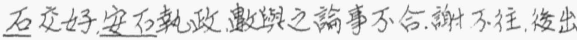

知珫州。

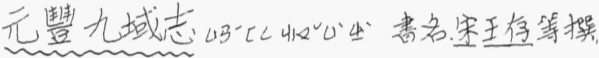

共十卷, 記宋神宗時良鎮名,人口出虐等颇敾細

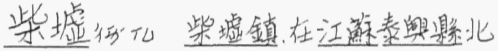




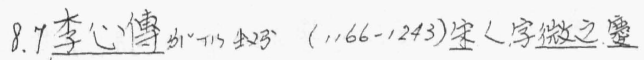
元初考試未取、閉户箸書, 晚年当史館校勘, 具易

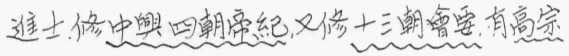

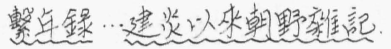

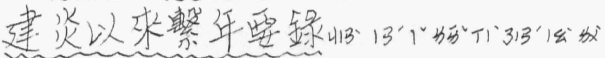

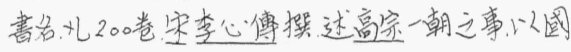

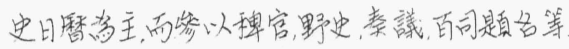
瓷定人諎野史最足瓷若言正者。

. 3 鋪奴陳設、张布

鋪張涻大其事。

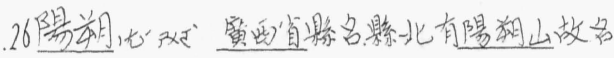




\section{第十三課 毛澤东思想开辟了中国历史科學发展的道路}

\section{邓拓}

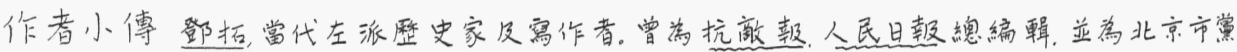
委会之賞刊物煎線之主等, 1966 年文化大革命時被北評攻聚澞反動, 反社會主義者。 本課簡介本篇為作者發表於摩史研究一九六一年第一期之全文全篇共分三部分, 第一部

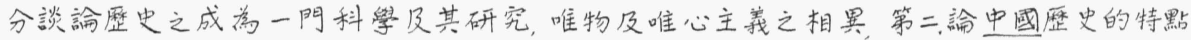

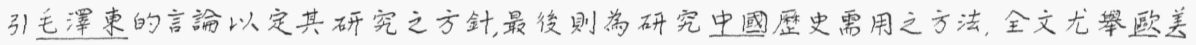
各國作多方面之比校。

\section{$(\rightarrow-$ 一閳革命的科學}

历史学在中国具有悠久的历史和优良的德統。如果从三千七 百年前孔子作春秋的时候算起中国历史学的发展比欧洲人所称道的世界 历史学的鼻祖希腊的历史家希罗多德还要早三百多年。中国历代有許多 杰出的历史家对于历史学的发展做出了重大的真献。但是从人类历史发 展的复杂过程中找出客观的規律性把历史的研究工作第一次变成为一門 15 科學, 这却是从馬克思恩格斯开始的。

馬克思和恩格斯非常重视历史的研究他們在德意志意識形态 一书中説“我們仅仅知道一閏唯一的科学即历史科学。历史可以从两方面 来考察可以把它划分为自然史和人类史……我們所需要研究的是人类史 因为几乎整个意誡形态不是曲解人类史就是完全做开人类史。”馬克思恩 20 格斯的学説就是对人类社会的发展史做了深刻的研究而产生的。馬克思 主义理論的每一步发展它的列宁主义阶段它在中国革命中形成的毛罣东 思想都是对于新的历史情况进行科学的研究和新的概括的結果。因此馬 克思主义向前发展一步, 历史科学也随着向前发展一步。

当人們越来越明确地认儎和掌握了历史发展的规律, 钎且越来 25 越自觉的运用这个规律以指导社会变革的实踐的时候, 历史科学的重要性 也越来越明显了。这鬥科学的任务, 总的来説, 不但要能够正确地説明社会, 而且要帮助人們去改造社会。这正如馬克思所説哲学家的任务不仅在于 説明世界, 而且要改造世界“是一样的。在这里, 我們应該肯定历史科学是实 踐的科学是革命的科学、因此历史科学的研究工作必須符合于革命的需30 要。馬克思在資本主义上升时期就看到了資本主义必然走向灭亡,他找到 了社会发展的客观规律, 从而建立了科学社会主义理論。禹克思主义者对 社会历史的研究态度和一切旧的历史学家的态度完全不同。旧的历史学 家常常宣称他們的研究工作仅仅是对历史材料的記录和整理, 仿佛他們是 
“公正的”, “不偏不倚的”实际上, 无非拿这种好听的話做标榜, 来对人民群众灌 輸反动历史观而已。这样的历史研究工作当然只符合于剥削阶級維护他 們自己統治的目的。这是他們的阶級利益所决定的。事实证明历史科学 和其他社会科学一样具有鮮明的阶級性和党派性。它是一門政治性很强 的科学研究历史的人如果阶級立埸、观点和方法不同研究的結果就决不相 同。

毛澤东同志在实踐論中説过: 在很长的历史时期内, 大家对于社 会的历史只能限于片面的3 解, 这一方面是由于剥削阶級的偏見縉常歪曲 社会的历史另方面, 埧由于生产規模的狭小; 限制了人們的眼界。人們能夠 10 对于社会历史的发展作全面的历史的3 解把对于社会的认識变成了科学 这只是到了伴随巨大生产力一大工业而出现近代无产阶級的时候这就 是馬克思主义的科学。

由于剥削阶級立場的限制，旧的历史学家对历史的看法就不能 不带有它面性。他們对历史的研究不能不在統治阶級所許可的范園内进 15 行。至于现代资产阶級的历史学就更明显地淪为犝断資本家的文化奴候 它已走向极端反动和阷落的道路根本不能称为科学了。这样説, 是不是对 于现代资产阶级历史学的过分暧藏呢? 完全不是。这是根据事实做出的 判断.

以资本主义世界的第一大国美国的例子为证: 959 年1 月出版 20 的美国历史評埨季刊, 在第一篇的地位上, 刊登了美国历史学会主席瓦・普 韦勃在美国历史学会第七十三妌年会上的演説, 題目是作为高級冒險事 业的历史学”, 这个资本主义世界历史学家的代表现身説法介紹了他如何 进行历史研究以及如何爬上了美国历史学会主席“这样高的地位”。他説他 原来“想当作家没有成功”, 但是后来为了生活“受倔”于得薩州油矿公司壟断 25 资本家为他們編写得薩州一个浪人集团的历史。进一步他就編写得薩州 的历史了。他説他“呆在得薩州乃是投機投得对“也是”一个巨大的冒險”。他 认为这种冒险生意“好像一个人和别人签訂了合同, 要赶三千只羊走过一百 五十英里的荒野一样。但是这种冒㭘生意却使他賺了不少錢竍且获得了 博士学位派拉蒙公司还把他的著作拍成了电影。他夸耀这种冒険使他能 30 筍解決經济的困难”追求个人的兴趣”, “賺了不少钱”。这个高級冒險家的讲 演充分地暴露了美国资产阶级历史学界以及整个資本主义世界的资产阶

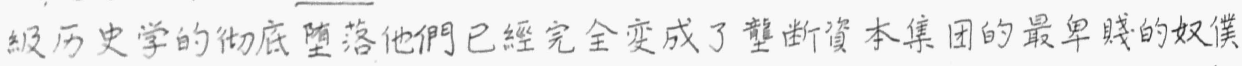
和据客。現代资产阶級历史学的这种高級冒險事业”的形成如同现代修正 主义的出现一样, 它們都是帝国主义政策的产物, 都是帝国主义走向死亡的 
反映。帝国主义一方面驅使它的学术文化事业伴随壟断資本从事投机和 冒險另一方面驅使現代修正主义者披著馬克思主义的外衣販卖美国的世 界主义和欧洲中心論等等貨色。

显然在現代历史学領域中存在着两个根本对立的理論陣綫一 个是正确地反映人类社会历史发展規律的馬克思主义的历史科学淒綫另 一个是没落的現代资产阶級以投机冒險为能事的历史学輎綫。这两个陣 綫的尖锐的思想斗爭, 是世界范图内的阶級斗爭的一部分。历史学是随着 阶級斗爭的发展而发展的, 离开阶級斗学就不能了解历史同样也不能了解 历史学。毛䍘东同志在“丢掉幻想准备斗学”一文中説“阶級斗争, 一些阶級胜 利了, 一些阶級消灭了。这就是历史这就是几千年的文明史。拿这个观点10 解釋历史的就叫做历史的唯物主义站在这个观点的反面的是历史的唯心 主义。

不管資产阶級历史学家站在历史唯心主义的立場上, 如何强詞 夺理力图掩盖阶級斗采及其在历史学領域中的反映历史学領域内的斗采, 实际上是同各个阶級的政治斗学密切联系在一起的。中国历史学界过去 15 的斗采完全证明了这一点。每当革命的轉折时期历史学領域内就必然引 起激烈的斗爭。第一次国内革命战寽时期和以前，中国历史学論坛上就展 开了唯物主义历史观同唯心主义历史观的大論战。胡适之梁潄溟等人当 时大讲什么“东方文化”、“精神文明”、“玌子精神”、“好人政治”等等, 胡适之又在 “整理国故”、“少談主义”的幌子下搬弄美国资产阶級的实用主义哲学, 而恶毒20 地攻击馬克思主义説馬克思主义“是很危險的”、“是没有用处的”。当时李大 釗、㲘秋白蔡和森等同志有力地批駁了实用主义唯心史观的反动理論特别 是毛澤东同志在”中国社会各阶級的分析一文中, 深刻地分析了中国各阶級 的历史特点粉碎了各种反馬克思主义的謬論为我們党的民主主义革命路 綫方針和政策提供了馬克思列宁主义的科学論据。大革命失敗以后一方 25 面是革命更加深入另一方面是反革命的“葍䅇”更加猖狂。在这种形势下就 出现了中国社会性稹問題的論战。托派分子严灵峰之流硬説中国已經是 資本主义社会, 这样就抹繁了中国人民反帝反封建的民主革命的任务, 其目 的是反对中国共产党的民主主义革命綱領。瓷产阶級反动历史学家如陶 希圣之流則把中国社会称为“帝国主义侵略下的封建社会”、“前资本主义社3 0 会”、“商业资本主义社会”等等他把明朝以来和中国通商的外国商人一概叫 做帝国主义他还説中国沒有封建制度和地主阶級只有所謂“士大夫阶級”才 是封建势力。这些人的一切胡言乱語目的都是为了反对中国无产阶級領 导的反帝反封建的民主革命。这一埸論战継縜发展扩大后来又成为中国 
社会史閭題的論战。当时一批反动的历史学家有的竟然否认中国历史上 奴隶制度的存在有人还认为中国封建社会在周朝就已瓦解了。德国人民 的叛徒魏特伏格尔和目本法西斯的历史学家秋澤修二之流更公开地为帝 国主义侵略中国辯抑説什么帝国主义侵略竬不阻碍中国的发展甚至于説 5 只有外来的力量才能推动中国社会的进步。这許多中外反动历史学家的 奇談怪論实际上都是企图抹杂中国历史发展的规律, 否认中国革命的必然 性。我們在各个历史时期都要注意揭发和批判这类反动理論的任何表现 在革命和建設的各个時期坚持历史科学的革命陣地都有重大的意义。在 今天以正确的观点来研究历史同样可以对我們的革命和建設事业发生很 10 大的促进作用。我們今天的历史学家当然应該正确地解答为什么我国会 出現社会主义建設的大跃进? 中国的一穷二白的历史根源何在? 这些問 題只有按照历史发展的脉絡給以科学的解釋才能使人㑚认儎清楚。

1938 年1 0 月毛澤东同志在党的六届六中全会扩大会議上的投 告中指出: 一般地説, 一切有相当研究能力的共产党員都要研究馬克思恩格 15 斯列宁斯大林的理論都要研究我們民族的历史都要研究当前运动的情况 和趋势; 螎䋎过他們去教育那些文化水准較低的党員。特殊地説干部应当 着重的研究这些, 中央委員和高級干部尤其应当加紧研究。指导一个偉大 的革命运动的政党如果没有革命理論没有历史知識没有对于实际运动的 深刻的了解, 要取得胜利是不可能的。”毛澤东同志后来又再三指示我們必 20 須认真研究馬克思列宁主义理論研究中国的历史和現状。毛澤东同志的 許多著作都是馬克思列宁主义的理論武庫中的重要武器同时也是中国历 史科学的无价之宝, 是对于中国历史科学的偉大真献。我們的历史科学工 作者应当从毛䍘东同志的著作中学习到研究历史的理論和方法找到解决 中国历史問題的鎖钥。

毛罣东同志对中国历史科学的发展做出了偉大的真献。他根 据中国革命的需要指出必須研究中国历史的特点把握中国历史发展的特 殊规律, 这就給我們打开了中国历史科学之門的一把钥题。毛䍘东同志在 “新民主主义論”, 一开始就提出了“中国向何處去”的問題; 他回答这个問題説: 30 “我們要建立一个新中国”。接著, 毛罣东同志就詳尽地系統地分析了中国的 历史特点。他指出“自周秦以来，中国是一个封建社会，其政治是封建的政治， 其經济是封建的經济。而为这种政治和經济之反映的占統治地位的文化, 則是封建的文化”而在“外国資本主义侵略中国，中国社会又逐漸地生长了 资本主义因素”以后, 中国又“逐渐地变成了一个殖民地半殖民地半封建的社 
会。”他分析当时的中国“在日本占領区是殖民地社会, 在国民党統治区, 基 本上也还是一个半殖民地社会, 而不論在日本占領区和国民党統治区, 都是 封建半封建制度占优势的社会”。由此毛澤东同志得出結論説，中国革命的 历史过程必須分为两步, 其第一步是民主主义的革命其第二步是社会主义 的革命, 这是性质不同的两个革命过程。”毛澤东同志在对中国历史作了。 全面的深刻的概括之后説”这就是现时中国革命的历史特点。在中国从事 革命的一切党派, 一切人假誰不懂得这个历史特点誰就不能指导这个革命 和进行这个革命到胜利誰就会被人民扰亲变为向隅而泣的可怜虫。

掌握了中国历史的特点才能有的放矢地运用馬克思列宁主义, 解决中国革命的实际閔题。否則即便口口声声夸奖馬克思列宁主义这支10 好箭却不能用它桃射中国革命之的那又有什么用处呢? 毛䍘东同志所以 能夠成为偉大的馬克思列宁主义者, 就因为他抓住了中国的历史特点使馬 克思列宁主义的普遍真理和具体的革命实践紧紧地結合起来, 从这一点 出发毛罣东同志正确地制定了中国革命的路䋐方䣄和策略。在中国革命 的战略閫题等著作中, 毛濖东同志按照中国的历史特点指出中国是人口众15 多的大国、經济发展不平衡几个帝国主义統治中国矛盾很多, 封建势力割据 造成长期的不統一状态有利于革命力量以弱敌强走向胜利。毛罣东同志 具体地分析了中国革命战采的特点由此产生了中国革命战爭的一整套战 略战术, 胜利地建立了农村的革命根据地, 以农村包围城市, 最后占領城市。 事实证明抓住了中国的历史特点革命中的部多閔題就都迎刃而解。

中国革命的敌人极力抹繁和昰曲中国历史发展的規律, 他們根 本否认中国革命的必然性借口“中国国情特殊”向馬克斯列宁主义进攻向中 国共产党进攻向中国革命进攻那是不足为怪的。奇怪的是在革命队伍中, 也有人因为不懂得中国的历史特点而机械地搬用外国的縚騟使中国革命 遭受了重大的損失。第一次国内革命战采时期, 右傾机会主义者陈独秀等 25 人根本不懂得中国的历史特点对西欧十八十九世紀的资产阶級民主主义 革命也只是一知半解, 就货他們的主观武断认为中国民主革命只能由资产 阶級領导不能由无产阶級领导, 因而他們完全放亲了对革命的领导权变成 了投降主义者。后来我們党内出现的三次“左”倾机会主义同样是由于那些 同志不㙹得中国的历史特点照抄外国綵驗, 只知城市起义, 看不起几亿农民30 的偉大力量, 甚至反对农村根据地反对游击战爭㟇菒革命的游击战学为流 寇主义”。归根結底“左“䓃”傾机会主义者都是根本不懂得馬克思主义的历史 科学的。他們把馬克思主义关于人类社会发展规律的学説当做抽象的敖 条, 以代替关于中国历史的具体分析因此, 他㑚只空談一般的革命理論和各 国的共同规律, 竬不了解这些共同的规律是从許多国家和民族的历史发展 35 
的許多特殊規律中概括出来的。他們离开了自己祖国的历史发展的特殊 規律, 不从实际出发, 对具体情况不进行具体分析, 因此, 他們即便知道一些抽 象的一般的理論原則, 也是没有用处的。何况离开了具体的特殊的規律, 实 际上也就没有什么抽象的一般規律之可言了。

反过来説, 我們紧紧地抓住中国历史的特点, 正确地掌握中国历 史发展的特殊規律, 恰恰能夠更好地认識人类发展的共同規律。因为任何 特殊的規律, 都是共同規律的具体表现。馬克思主义关于社会发展的共同 规律的学説是从人类无数具体的历史实践中抽取出来的, 我們用它来指导 革命就应該让它回到具体的实践中去。这个从具体到抽象再从抽象到具 10 体的过程, 对于我們革命和建設的实际工作是必需的。毛摆东同志抓住了 中国历史的特点就抓住了全部問題的关鍵这无論对于我国革命和建設事 业或是对于历史科学以及其他学术的研究来説都是“踏破铁鞋无筧处的无 价之宝。已經被人认識的客观真理説起来辀不希罕, 但是要发现它和掌握 它却很不容易。經过中国长期革命实践的考騟人們完全应該懂得中国历 15 史的特点是决不可忽視的, 由此也应該更清楚地认識毛䍘东思想的偉大和 正确。

在我們党的六属六中全会扩大会議的报告中, 毛澤东同志著重 地説: 我們这个民族有数千年的历史有它的特点, 有它的許多珍貴品。对于 这些, 我們还是小学生。今天的中国是历史的中国的一个发展我們是馬克 20 思主义的历史主义者, 我們不应当割断历史。从玌夫子到孙中山我們应当 給以总結, 承継这一份珍貴的遗产。这对于指导当前的偉大的运动, 是有重 要的帮助的。共产党員是国际主义的馬克思主义者, 但是馬克思主义必須 和我国的具体特点相結合辀通过一定的民族形式才能实现。馬克思列宁 主义的偉大力量就在于它是和各个国家具体的革命实践相联系的。对于 25 中国共产党説来就是要学会把馬克思列宁主义的理論应用于中国的具体 的环境成为偉大中华民族的一部分。而和这个民族血肉相联的共产党員, 离开中国特点来談馬克思主义, 只是抽象的空洞的馬克思主义。因此, 使馬 克思主义在中国具体化使之在其每一表現中带著必䩄有的中国的特性, 即 是説按照中国的特点去应用它, 成为全党亟待了解辀亟須解决的問題。洋 30 八股必須廢止, 空洞抽象的調头必須少唱, 教条主义必須休息, 而代之以新鮮 活潑的为中国老百姓所喜聞乐見的中国作風和中国气派”。毛澤东同志这 一段話是十分精辟的内容是十分丰富的其中有几点特别重要:

$$
\text { 第一, 中国几千年的历史留下了极其珍贵的遺产, 而且具有显著 }
$$

的特点; 
第二, 中国的現状是在长期历史发展中形成的, 要了解现状必須 从中国历史的发展中来考察,

第三，反对空洞抽象的教条主义和八股公式要把馬克思列宁主 义的普遍真理同中国的具体实践相結合使馬克思列宁主义中国化;

第四、对于中国的历史德統必須运用馬克思列宁主义加以批判5 和总結只有在这样的基础上寸可能有新的创造。

这几个論点对于历史科学的研究具有特别重大的指导意义。 从这里, 我們不但知道应該善于抓住中国历史的特点而且可以知道应該怎 样去抓住中国历史的特点。

但是必須指出, 我們説要抓住中国历史的特点这和“特殊国情論”毫 无共同之处。“特殊国情論”者实际上恰恰是抹㙰了中国的历史特点他們离开了 共同的规律来談特殊性, 其結果就是抹繁了一切客观规律, 变成純粹的主观 臆断。他們有时非常勉强地从洁如烟海的史料中找到个别的例子来证实他 們的主观臆断例如有人从史料中找到元明清以来許多达官貴人各有家僮 若干的記載, 便断定中国奴隶制度长期存在。这正如列宁在“帝国主义論”序 文中所説“在社会生活现象极端复杂的情形下, 随时都可以找到任何数量的 例子或单个事实来证实任何一种意見。”其实这样做又有什么用处呢? 不 过是枉費心机而已! 我們进行历史科学的研究必須从大量的普遍的事实 出发决不能尼面地抓住一两个例子濫加臆断。我們所説的中国历史的特 点, 是从分析大量普遍的事实中得出的結論, 它符合于人类社会发展的共同20 规律, 但又不是抽象地刻板地与共同規律相一致也不是完全离开共同规律 終于毫无規律可循的所謂“特殊国情論”。

我們承认作为共同规律的具体表现形式来把握的中国历史的 特点就是, 承认历史发展的内在予盾的普遍性和特殊性的关系。資产阶級 历史学家从来不懂得这种关系, 他椚言必称希腊罗馬, 除此以外, 都无足道。2 5 你説奴隶制度, 他就只, 承认希腊罗馬是典型, 至于中国和其他国家历史上的 奴录制度都被説成是“变態”或者是“亚种”。其实中国的奴录制度也是一种典 型是中国的典型。典型可以有各种各样的, 应該説, 中国的奴隶制度是很典 型的辩非只有希腊罗馬的奴隶制度才是典型。这些人言必称希腊, 又好为 人师而我們有的同志也竟然受其蒙騙, 甚至受了傳染。其实他們对于外国30 历史的知識也是不多的。毛罣东同志在“改造我們的学习”中已綵指出”不論 是近百年的和古代的中国史在許多党員的心目中还是漆黑一团。許多馬 克思列宁主义的学者也是言必称希腊, 对于自己的祖宗, 則对不住, 忘記了… …有人对于自己的历史一点不懂或懂得甚少不以为恥反以为萦。…正有些 人对于自己的东西覞无知識于是剩下了希腊和外国故事, 也是可怜得很, 从 35 
外国故紙堆中零星地㭘来的。”这是一种极坏的作風, 这种人是不能研究历 史的。

总之我們要在肯定人类社会发展的共同规律的前提之下, 来研 究作为这种共同规律的一个具体表现形式的中国社会发展的特殊规律。 5 这是馬克斯列宁主义的根本方法。毛澤东同志説过“对于物质的每一种运 动形式必須注意它和其他各种运动形式的共同点。但是, 尤其重要的成为 我們认識事物的基础的东西, 則是必須注意它的特殊点, 就是説, 注意它和其 他运动形式的盾的区别。只有注意了这一点才有可能区別事物。任何运 动形式, 其内部都包含着本身特殊的矛盾。这种特殊的矛盾就构成一事物 10 区别于他事物的特殊本质。这就是世界上諸种事物所以有千差万别的内 在原因或者叫做“根据”毛罣东同志的这段話教导我們, 研究中国历史, 必須 在研究中国历史的特点方面下功夫, 无論研究中国的原始社会史奴隶社会史, 封 建社会史等等都要弄清楚中国的原始社会、奴隶社会、封建社会等等和其他国家 的不同点无論研究中国那一个民族的历史, 也都要搞清楚这个民族和别的 15 民族有什么不同的特点, 同样, 无論研究中国的工业史农业史商业史等等, 也 都应該抓住本国本行业的特点。只有抓住特点, 才能表現一般只有找出特 殊规律才能更好地説明共同规律。把一般与特殊結合起来, 㲔且着重地通 过特殊来看一般这应該成为我們的历史科学研究的基本原則。

特殊规律决不可以凭空臆造, 它必須是深入分析全部历史事实, 找出特殊的予盾, 即透过现象揭发其本质而后达到的結果。毛䍘东同志在 “予盾論”中説过:不但要研究每一个大系統的物质运动形式的特殊的矛盾性 及其所規定的本质, 而且要研究每一个物质运动形式在其发展长途中的每 一个过程的特殊的矛盾及其本质。一切运动形式的每一个实在的非臆 25 造的发展过程内, 都是不同质的。我們的研究工作必須著重这一点, 而且必須从这一点开始。”現在我們大家就从这一点开始去努力从 事中国历史科学的研究工作吧! 中国历史中需要研究的問题多 得很, 在大家面前展现着非常广䦣的天地人人可为英雄, 人人都大有用武之 地。目前我国历史学界采論的許多問題, 如中国历代衣民战学的性质、作用 30 和規律性的問題，中国封建土地所有制的形式閣題，中国社会史分期問題等 等, 它們的一些基本内容曾經是爭論了二三十年而没有解决的現在我們在 新的条件下对这些問题重新加以研究是有实际意义的。当然认真的研究 还只是开始許多問題从根本上来説都还没有得到真正的解決。但是只要 以毛澤东思想为指导, 努力抓住中国的历史特点, 那末，中国历史上的各种問 
題都不难得到比較完善的解决。

\section{(三)我們需要大立大破}

从研究中国历史的特点下手我們的历史科学研究工作必然会 有迅速的发展。我們必須在理論上大立大破先立后破。我們要大立以毛 罣东思想为指导的革命的历史科学理論大破资产阶級的反动历史学理論。 和现代修正主义的反馬克思主义的荒謬理論。

现代资产阶級历史学中流行着“欧洲中心論”的荒諗观点这是必 須首先打破的。我們在中国历史科学研究領域中, 一定要树立起民族的自尊 心。毛罣东同志在“唯心历史观的破产”一文中説“自从中国人学会了馬克思 列宁主义以后中国人在精神上就由被动轉入主动。从这时起近代世界历10 史上那种看不起中国人看不起中国文化的时代应当完結了。长期以来, 我 国一部分历史学家受了“欧洲中心論”的影响抬不起头来, 不敢大讲中国历史 的特点实际上就是看不起中国这是奴性的一种表现。中国民族的輝煌的 文化成就是不可磨灭的。近百年来尽管許多帝国主义不断地侵略中国但 是没有任何一个帝国主义能呴把中国最后变为它直接統治的殖民地, 这也 15 证明了中国这个具有几千年优秀文化傅統的民族在世界历史上应当有它 的地位。

誰都知道“欧洲中心論”是西方資产阶級征服世界的帝国主义侵 略政策在历史学領域中的反映它的实质就是殖民主义, 当着西欧的资 产阶級要建立一个統一的资本主义的世界市埸的时候, 他們需要“欧洲中心20 端为他㑚効劳。但是现在形势大大不同了。东方革命的突起特别是中国 革命的偉大胜利对于亚非拉丁美洲发生强烈的深远的影响。亚、非拉丁美 洲各国的革命浪潮空前高涨这就充分地説明了“欧洲中心論”是非垮台不可 的。大破“欧洲中心論在历史科学中还是一个艰巨的战斗任务, 在这方面我 們还要准备好好地打几个回合。

还有一些人力图证明中国历史和欧洲历史是完全相同的。为 了这个目的他們不惜对中国历史采取削足适履的办法。例如尚鋮看到欧 洲封建社会比中国的短就把中国封建社会砍头去尾看到欧洲資本主义发 生就认为中国资本主义也发生了。这完全是公式主义。他們它面强調社 会发展的共同性, 不顾历史事实不敢讲出中国的历史特点。他們别有用心3 0 地硬套公式, 以欧洲历史的具体情况为标准来“改造”中国的历史。他們甚至 于无中生有牵强附会去迎合外国的历史公式。他們看到欧洲有宗教改革、 文艺復兴就认为中国也应該有, 看到欧洲有百科全书派就赶紧到中国历史 上去找。这决不是研究科学的态度而是一种奴性的表现它是已經死亡 
的半殖民地半封建的旧中国的殘余影响在人們思想中的一种反映。

恩格斯在1890年三月給康・施米特的信中説过这样的話“全部 历史都应該开始重新研究首先必須詳細研究各种社会形态的生存条件, 然 后才可試图从这些条件中找出相应的政治私法美学、哲学宗教等等的观点” 5 現在是我們开始重新研究和編写中国历史以及世界历史的时候了。中国 历史需要我倗重新編写, 世界历史也需要我們加强研究。但是首先必須把 中国历史研究好。

关于公式主义还需要着重讲一讲。我朊要彻底打垮公式主义 需要彻底破除迷信。公式主义是历史科学发展的严重障碍。公式主义的 10 研究方法是离开中国历史发展的具体特点只在中国史料上加进馬克思主 义的詞句理論和史料没有内在的联系; 或者先引用一段馬克思主义的理論 然后找一两个例子去证明它, 表面上看来也没有什么大錯誤, 但这种风气对 历史科学水平的提高却是很大的障碍。我們特别要提倡对具体問題进行 具体分析。

恩格斯在給爱因斯特論易十生的信中談到了这个問題。爱因 斯特描写挪威小市民却把他和德国小市民混同起来了, 恩格斯在信中説挪 感小市民是不同于德国小市民的他們没有当过农奴而德国小市民却是农 奴出身的。恩格斯写道“我应当説明不把唯物主义的方法当作研究历史的 指导綫索而把它当作现成的公式将历史事实宰割和剪裁得适合于它那么 20 唯物主义的方法就适得其反了。”因格斯在給康・施米特的信中也説过在 許多年青一代的德国人那里他們只用历史唯物主义的套語(一切都可能变 成套語)，来把自己相当盆乏的历史知瀻尽速构成系統而后自豪地欣賞自 己的功业。”恩格斯在这里虽然説的是德国的事但是我們也无妨㭘查一下, 有没有像恩格斯所批評的德国青年人的这种表現呢?

为了不把历史唯物主义变成套語或公式, 而是真正掌握历史的 特点説明中国历史发展的特殊规律, 我們必䩄深入历史科学的领域掌握全 部史料加以科学的分析和认真的研究。我們有了毛罣东思想为措导, 就掌 握了打开历史科学大門的钥题。只要我們钻进去就会发現許多問題。研 究工业史农业史的就要钻研工业史和农业史的史料。高等学校的历史教 30 师应該引导学生认真钻研史料, 大胆提出問題有些年軖的同志反映説抓 不到閣題这就説明他没有钻进去任何工作只要你钻进去总是会发現問題 的。

掌握大量史料是很重要的。毛澤东同志在”改造我們的学习”中 告訴我們要找出客观事物的規律性就須不凭主观想像不㶵一时的热情, 不 
凭死的书本而凭客观存在的事实詳細地占有材料, 在馬克思列宁主义一般 原理的指导下, 从这些材料中引出正确的結論。有了大量材料财能进行去 粗取精去伪存真由表及里, 由此及彼的研究。不掌握大量材料就不可能得 出正确的結䛺。

我㑚提倡掌握史料决不是像资产阶级历史学家那样以史料学 代替历史学。在馬克思列宁主义者看来, 史料学只是历史科学的一門戟助 的学科。如果执亲历史唯物主义理論, 只是史料堆砌就不成为历史科学了。 中国资产阶級反动历史学的代表人陶希圣曾經叫喊“亲公式而取籿料”的口 号, 他的目的是要反对馬克思主义的革命理論就和现代修正主义以反对教 条主义为名而反对馬克思列宁主义一样。我㑚所説的反对公式主义, 是和 他㑚截然不同的。我們强調必須在毛澤东思想的指导下来掌握史料。从 这个意义上来説我們掌握的史料不是太多而是太少了。考古发掘的材料 很多, 也还沟有进行深入的研究近代史更需要继縜进行多方面的調查研究 工作。中国过去没有严格的国家档案制度許多档案都保存在私人家里。 我們应該大力搜集、整理这些档案村料。近代史上許多問題都可以进行調查, 就是 明末清初的历史也可以进行調查, 把調查材料和历史記載結合起来, 可以説明許多 問題我們必須掌握中国近代史和現代史的半富的第一手材料, 包括人民公社的材料, 在 这方面，我們党在长期工作中所创造的优良得统是永远应当加以保持和发掦的。

史料和馬克思主义理論必須結合起来, 成为有机的统一体。在 处理史料和理論的关系方面我們要防止簡单的“加减法”。“加减法”是把史料 20 和理論硬凑在一起没有融合和消化, 这样也就不可能有真正的馬克思列宁 主义的中国化。在利用史料方面, 必須紅过严格的审查和批判。恩格斯在 “論馬克思的政治經济学批判”一文中説过“唯物主义认識的发展, 那怕是单单 对一个历史实例都是一种科学工作要求多年的冷静钻研。因为这是很明 白的, 单靠几句空話是做不出什么来的, 只有大量的批判地审查过的透彻地 25 掌握住了的历史材料, 才能解决这样的任务。在这方面毛罣东同志是我們 学习的典范。毛澤东同志的每一篇文章都是根据对大量材料的深入的分 析研究然后概括出来的。无批判地堆砌史料是没有用的。我們即便研究 古代历史, 也决不是为了好古, 而是为了解决现实的問題。中国革命胜利了, 如果我們把中国革命的历史和經驗很生动地写出来对于正在进行革命斗 30 争的其他各国人民都将是莫大的鼓舞。毛澤东同志在新民主主义論一书 中説过“我們必須尊重自己的历史, 决不能割断历史。但是这种尊重, 是給历 史以一定的科学的地位是尊重历史的辯证法的发展而不是公面古非今, 不是 贊揚任何封建的毒素。”同样地馬克思在“路易・波拿巴特政变記”中也説过: 
使死人复生, 是为了贊美新的斗采, 而不是为了勉强模仿旧的斗学, 是为了提 高某一任务在想像中的意义, 而不是为了迴避在现实中解决这个任务。 是为了再度找到革命的精神, 而不是为了让革命的亡灵重新游蕩起来”。当 然我們为了现实的目的而研究历史决不是要用今天的标准去衡量古人, 决 5 不能把古人写成現代人的面貌不能率强附会。我們是要从过去人物的活 动中吸取緸驗教剖、来教育人民群众。要多写劳动人民的创造, 写他們的生 产斗争和革命斗争, 而不是主要写帝王将相的活动和王朝的更替。

在历史科学研究中必須反对思想的它面性。毛罣东同志对这 个問題有过許多重要的論述。他在批嚲五四运动时期的领导人物时曾䌐 10 指出他們缺乏馬克思主义的历史唯物主义态度, 好就是好, 一切皆好, 坏就是 坏一切皆坏。这种它面性对以后的革命起了很坏的影响。现在已不是五 四运动的时代但不能説这种影响已絰没有了。只有克服了沿面性才能提 高历史科学研究的水平。

因此, 我們在历史科学領域中, 必須开展两条道路无产阶伋同资 15 产阶級) 和两条战綫(“左”的和“右”的偏向)的斗学。历史科学方面的修正主 义观点还有一定的市場我們必須进一步加以彻底批判。我們要从正面树 立正确的观点先立后破。

我們的方針还是百花齐放百家爭鳴。学术上不同的意胃应硋 暢所欲言, 不要有任何顾虑。根据毛澤东同志提出的六条标准就可以辩别 20 香花和毒草就可以暢所欲言。学术問题和政治問題是可以区别开来的。 即使有些問題可能和某些政治观点相联系, 也还是可以討論的。要做到百 家爭鳴还必須結合各人的专长, 不要乱出题目做文章。同时要提倡言必由 衰的实事求是的作風。除了政治上的六条标准以外, 要鉴别学术水平的高 低历史学界还可以有自己的标准。此外, 还要給所有的研究人員以充㭲的 25 时間，这样，才能充实自己，才能不断提高。历史科学的队伍必須在战斗中壮 大起来，在科学的实践中壮大起来。树立一个正确的观点是不容易的需要 反复辩論一直到别人䮎不倒的时候才能成立。研究的过程同时是一个斗 爭的过程。我們相信馬克思列宁主义的中国历史科学, 在毛摆东思想指导 下, 依靠大家共同的努力, 一定能呴得到重大的成就。

30

討論問題:

一雷克思主義者對研究展史的盟度如何。

二, 毛洋束怎楼分析中国的屡史特贴?

三何神欧洲中心端? 
四、毛罣東對歷史科學研究有何貢獻?

五作者認為如何才能把中國歷史研究好? 


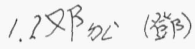

儿否必之, 遠長

悠久長之之意

优风(傮)

.12区欧e（歐）

称道稻瓚

.13鼻引始

鼻祖始祖

腊加（滥）

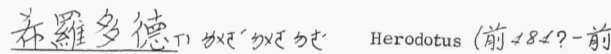

424)世稻史學之祖。

.14类加(類)

. 15 复的(複)

. 16 国克思口Y゙万ざム Marx, Karl (1818-1883)

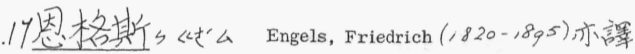

为恩格尔

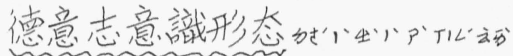

Die Deutsche Ideologie (The German Ideology) 馬克思恩格

斯合箸

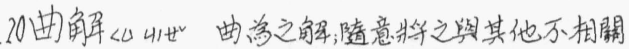

者聯掯一談

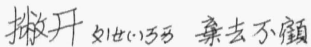

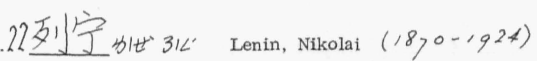

.2)根括《分《活×C”) 包括大概

24 随 $2 \times T^{\prime}$ (随)

26 觉吡, (整)

运叭( 運)

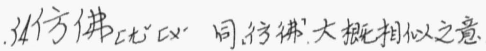

2.1倚、偏，側

听云化㯖)

标夘(標)

标榜表掦稱諧

灌輸《奶P 邓 注入
2.2万史观引 ア 《妈謂就历史説明世界中種種事 物, 学物理瓶之数搯。

4 鮮仍明好也

鮮明明㙷清新

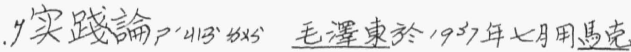
思主義的觀點及認識論去約正共虐賞, 内的教條 主義和經驗主義而富此文。並在延安的抗日簐 事政治大整作過兂演。

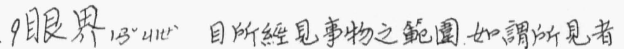
展日眼界筧, 目所能胃之界限

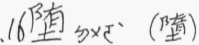

隋洛謂䧟於惡道, 惡事

1总战出小也

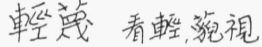

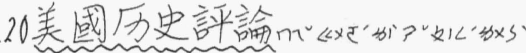

The American Historical Review 者一季利

.21韦吼

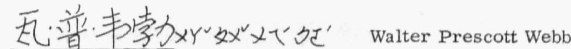
(1888-1963) 執教於德克薩斯大繁箸有 The Great Plains, The Texas Rangers ( 1936 拍成 電影)，Divided We Stand, The Great Frontier 等韦

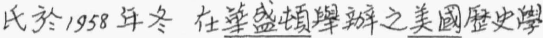
霄第七十三屡年禽上演譒History as High Adventure 冒吸謂勇往無所虏忌

冒险不避危险而勇往直前之意

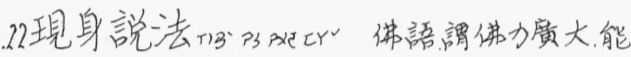
现種種身，向人颜法後引申省以已身㬼喻而 告人

23)爬如以手足着地而行由下攀緣而上。

.24崔《同㩁”

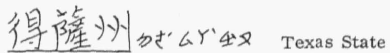

矿敌㕱(硔)

.25浪牲放縱

浪人行蹤唋定的人。 
2.26 呆加停留

.27签《13 (签)題署, 签訂, 签名訂定

赶《况 (趕)

.28具羊坐始”獲得

获汹、(獲)

299派拉掌妢战口L Paramount

电加（電）

耀公向外涻大

夸耀自我表掦

.31暴奴 影露

暴露 顯出

.32 彻代(澈)

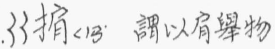

掮客 代人買曋货物者

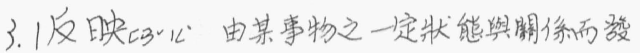

生舆之相待之副象曰级映, 如言文祭是時代之

反映瓶念是留际生活的反映

了欧洲中心論以歐洲为世界中心之詢

货色的“式即偊货物

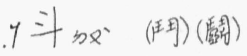

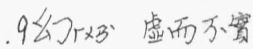

幻想謂虚而万富之思想

准秋如“準)

备汃(偖)

丢掉幻想准备斗学

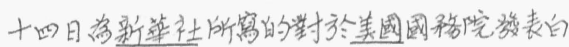

皮軎的辞論

15系个i (慗)

.19坛动 (增)

論坛討論的埸所

.18适”(嗃)

大使(1938-1942).中央研究院院長

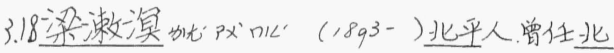
京大學教授。1 927 - 1937 学贯村重建運動領道

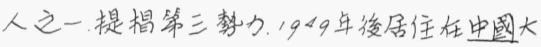

除, 拒絕接受违克思一列宇主義。

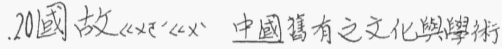

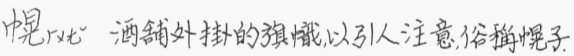

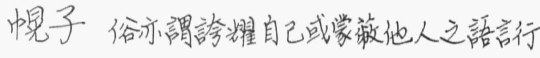
为等需㹸子。

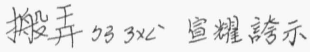

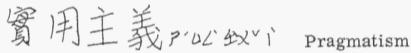

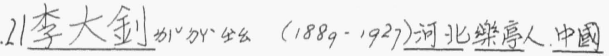

共雇償制始人之一, 五由運動的组䋐者和合直道

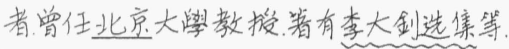

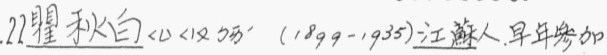

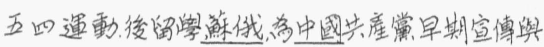

領導人之一, 後在福建被捕處死, 箸有翼秋自文焦

等.

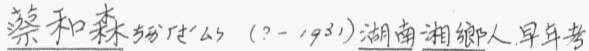

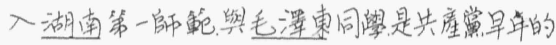

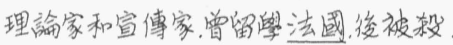

.23中国社会各阶級的分析毛罣東於

1926 年三月因反数當時共㦃賞肉存在着的雨種

倾向，左，右倾機艒主義而富此文。

.24粉碎的“妋破碎如粉㭊

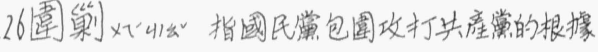
地而言

托派动欢分 Trotsky yites, 追随Loon Trotsky (1879-1990) 者

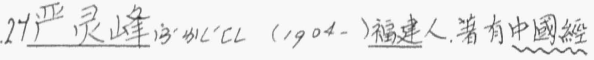

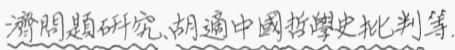

.28筫PY 减

抹繁 淿减

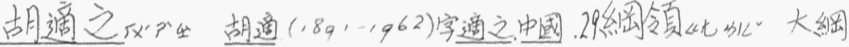

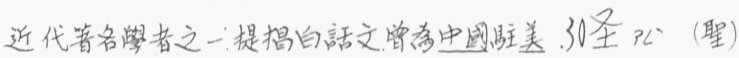


間題

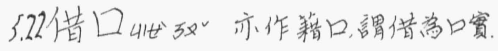

.25右化真机会主义指共虐償内、以陣独秀感代

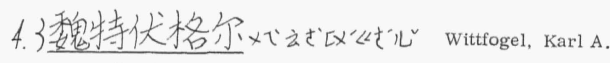

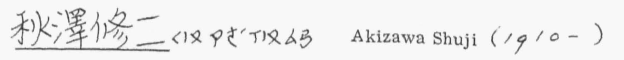
日本一法西斯的歷史整家, 原名秋津督二Akitsu Keriichi

㤑昌分(礙)

8 坚4 8 (埾)

.11跃咁 (躍)跳

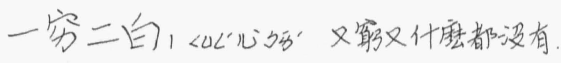
12 月永戊 (脈)

脉㬎各物相連屬而有佟理

.15斯大林么多“的” stalin, Josif(1879-1953)

钥《世(公) (铪)開銷之具

金党钥解決閔題的工具

.28是七. ? 即鏳匙

钥是比䦔之具 .29新民主主义論毛罣東於, 940 年一月为如何

建立一個新中國而窝此文。

3.8 立<1 無贅的哭

向隅而泣對辐而哭形容一個人孤單絶

望和悲鹪

怜的沼, (憐)

虫秋”(蟲)動物之總稻、昆蟲、節足動物之一類。

可怜虫颉陷於团韄的人。

9 的方射整目標之中心

有的放矢有中心目摽而效箭, 形容並非

雜滔两罂目的的做事

10 奖 $41 \iota^{2}$ (奖)

紧415 (祭)

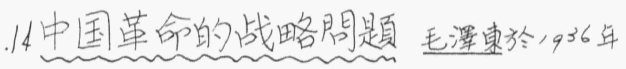

十二月總結過去共産革命的縟驗而窝, 本書共分五

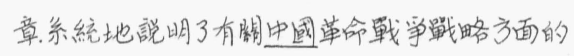

表，只注意同國民當合作而态記了震民的這種傾向。

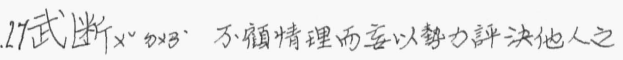

由直; 今亦謂僅恣已思强断事理日武断。 .29投降动“化”謂降順㪣人

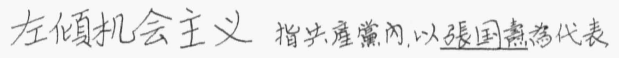

只注意工人運動，而忘記了贯民的遥揰倾向。

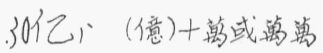

.3笺的 欺

誣䉝謂造言以污人之名䈨。

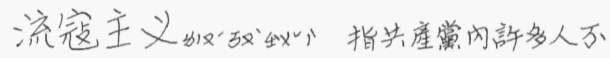

䝠做鞎苦工作建立根據地, 只想用流動方法

招兵買馬搌大紅軍、希望跑到大城市去吃喝玩

然。

3 打由象㣔优謂由各種事物中, 抽取其象之共同

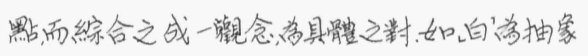

的，两泊、馬之泊”洛具體的

教条必公云令人道守这规則或保文。

教条主義 Dogmatism

让㕱(讓)

6.12 踏破铁鞋无䚁处喻很少, 很䧽找着。

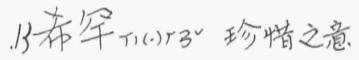

.26王不 $5 \times 3$ (環)

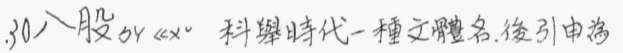

所有因謷做舊, 有一定格式而万注重冈容之文章

言唃。

.31 气派似妢猶氣概。謂人之態度與舉動。

7.1)臆门同意”

臆䉼以一己文私意决定一切

觔吸”盔力

免力强笛力之意又力不及而强行。

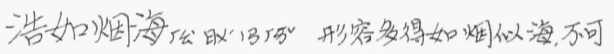


腾數

7.13 僮动男偻人

家僮家闭使用的男㒒人

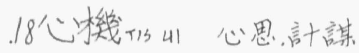

枉費心机白费心思意即没用

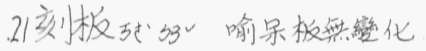

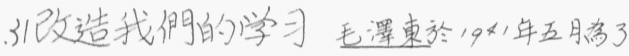

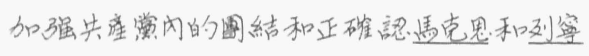

主義, 在延安幹部暑議上所作的報告。

红渿稻物之黑色者

漆黑甚黑甚暗

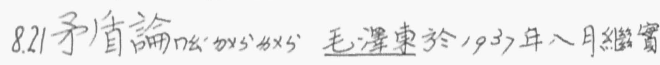

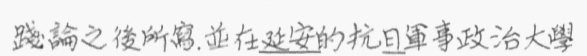

㮔過

9.9唯心厉史观的破产

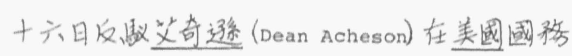

院編好白皮書後於1949年×月三十日富給迲鮊阳

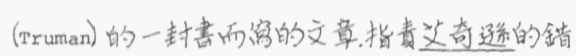

敦短點

及煌rut 光明

煇煌光彩擢目独

14 磨梿

磨尔消减

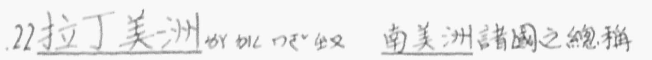
25 合教兵交释日合

回合兵交鉖之次數

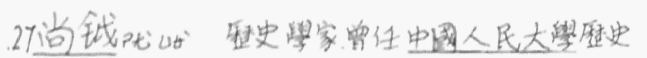

系主任其主張中成明末清初已有瓷本主義之旨筑

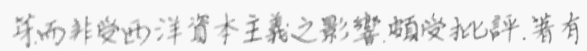

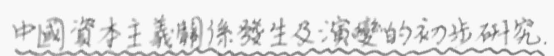

28砍强以力用力奻之能砍

30 号有用心号有别的目的

缃套泣槙仿

套公式使噢合公式

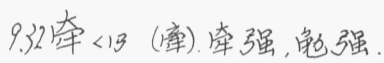

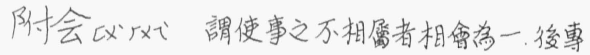
用病旁强凑合之意。

.3) 31

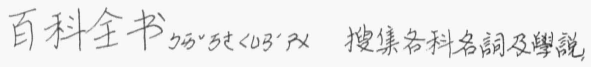
分類編成。用简明文字説明, 謂之百科全書。會集

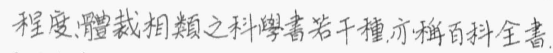

百科全书派接受 the Encyclopedists 法國百科 全書(1 5 51-1) $\left.7^{2}\right)$ 之編者之影響者。

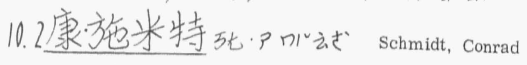

4 私法么 E Y 规定私人間權利義務之法律, 如民 法等,㡤公法而言。

１噯因斯特方以动人名原名不群。

易十生i 秋陑 Ibsen, Henrik

.16挪威3 3 队”7 Norway

.19剪4 $13^{\circ}$ 黹断

剪裁除其繁尣, 疗其精要

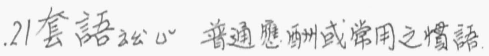

.22构《構)

.28年占陬3 (镍)

.30月旦的 (浐)

11 . 7 乱切《一臂臂堆起来

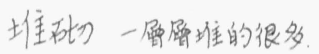

12 掘406，穿，如掘地、掘牛。

14 珰咙(擋)档案、各機關所保存之記錄文件。

.19有机风“山謂有生命者

22 审 $33^{2}$ (審)

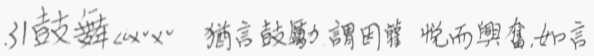

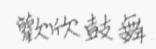

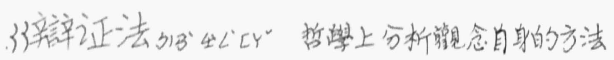

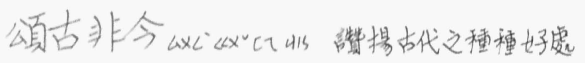
而哾曾代不好

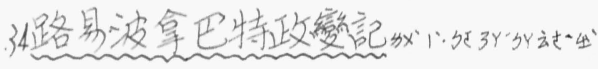

引I3'41" "The Eighteenth Brumaire of Louis Bonaparte" 蓝 
克思1851年舅

12.18 齐《1 (孪)

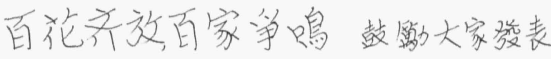

意見如息叫花開之不受任何限制拘限。

.19点如(虑)

.22专嘈 (専)

表秋中心或心中

言必由束所敦的必是徒内心儛出的言

敦

.23 鉴43”(鉒)

.24裾山多、富。

充裾充足, 姠多。 



\section{第十四課 清廷辦理外交之機閣與手緢}

\section{張忠紘}

作者小傳張忠馛、前北京大祭政治系教授、靶中国行政制度有研究。著有中萎民国外交

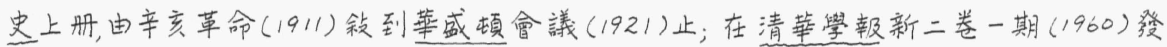
表有孔等與民主思想要點的比䡬.

本課簡介本篇乃作者發表於文史雜誌制刑㖃一九四一年一月版之全文。全篇共分三部 分, 計端三段不同的時期清廷的外交措施, 缮細情形, 及改蜜的因素等, 第一部分説

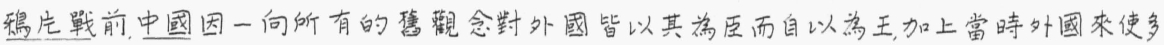

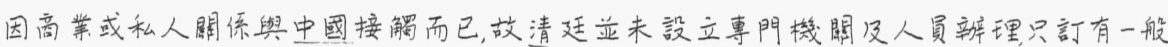

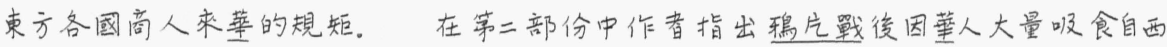
洋輸入之稂它引致清廷派尃员前往查辨海口事件而與英人交涉決裂引起戰采, 從而签

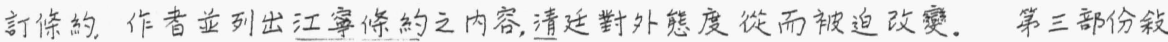
及因商業交往而再度引起之戰学, 天津條約之签訂, 其内容, 及引起之誖果。此之為總理 各圈事務衙阴建立之總起。

二十四年冬作者服務於北京大等, 曾利用外交部駐平辩事處、即駐平擋案保管 䖖)中之檔案, 擬草作中国外交部之沿革及其組織一書。惜嗣因平津局势不稳, 外部將留 平之一部份檔案掃數南要, 致作者之計割不克完成。本文為當日業已脱稿之一部, 曾 散見外交用款中。來逾以捘時有友人與其他作者索閲此稿, 故重新加以整理, 併庐一 文, 以就教於譡者。

(甲)鴉光戰前

鴉层戰前, 中國與西洋各國迄未發生近代外交關係鴉汽戰後, 中 國始與西洋各國發生條約上的關係。英法聠軍北犯北京條約訂立淩中國 25 與各國間的關係始漸赹近代化。

鴉片戰前中國與西洋各國雖然没有發生近代外交關係, 但除各 國商民在邊地留易, 或私人來華不計外, 各國政府亦曾常有使臣來華或傳遮 文書等事。各國既曾有使臣來藮或傅遞文書等事, 则清廷自不能無接待此

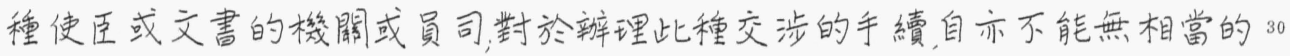
規定。這就是本文中所要討論的目標。

鴉汽戰前, 清廷向無派使西洋各國之舉貽書例由西洋各國使臣 或來人带回。但俄羅斯與中國接壤數干里, 雨國間之交涉較繁清廷間亦有 行文俄羅斯之必要, 此種公文例由中國理藩院咨行俄羅斯薩那特衙門。鴉 
光戰前, 清廷踓無派使西洋各國之舉但西洋各國因希冀獾得通商留易等利

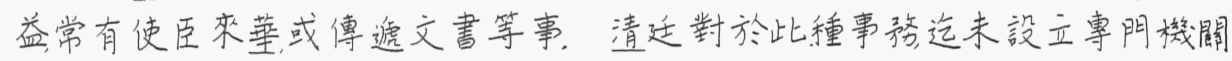
或員司辩理。

鸦片戰前, 西洋各國如有事陳請, 其“奏疏不得交遣往使臣带本, 俱 5 令尃差陪臣、交各該督撫轉奏。外國一應事宜, 㛜文申報各部, 俱由禮部轉發, 不得擅自徭申, 或直陳奏御前。各省督撫提鎮官與各外國王, 非有公事不得 擅自移交, 私相往桃。惟俄羅斯一國因與中國陸地接壤數千里: ‘我羅斯行中 國之公文用俄羅斯薩那特衙門及托博勒城( Tobol sk) 守尉印信咨行中國理䚀

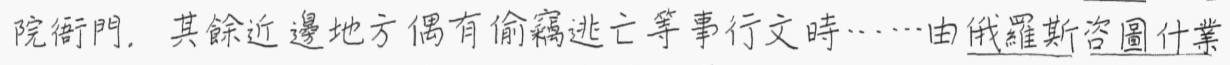
10 圆汗王(師土糗圖汗)。此種行文之手續與儀注極為簡便無甚可述。但西洋 各國如差遣使臣來中國則清廷接待此種使臣之手續與儀注均較為繁雜。 此時之清廷根本不承認近代國際公法中, 國與國平等之原則, 亦不知有所謂 近代外交或近代國際閖係仍本中國傅統之普天之下, 莫非王土率土之演莫 非王臣、之嚄觀念認外使之来為傾心向化一切外國使臣悉為梖使。是以此 15 時清廷對於西洋各國使臣之待遇悉本此義。接待西洋使臣之機關往往即 為接待朝鮮琉球緬甸等國賁使之機關, 其儀文與手續, 與接待朝鮮, 琉球頖甸 等屬國貢使之儀文與手䋶亦無大黑。

鸦片戰前, 西洋諸國曾遣使來中國者, 有荷藏、鄂羅斯(即俄羅斯?

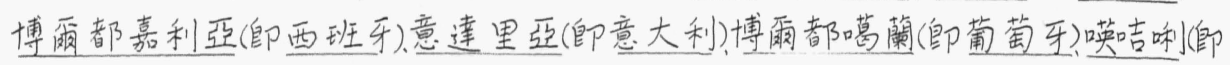
20 英吉利)等团, 其中除荷蘭與俄羅斯二國外, 其他各國本使均先至懬東澳阴, 由 雨廣督撫代題栜禮部議准後行該督撗填給勘合, 於該省文武員弁中捒派二 三員伴送入京, 以资沿途彈厤。经過各省仍豫派幹員護送伴行按省更遞各 營沉遁遗官兵防護。使臣入京均由澳門水路達京仰。使臣入京之船不得 過三隻每船不得過百人, 正副使及從人來京者不得過二十人餘俱留邊㯖赏。 25 貢使至京行崇文朋監督, 踰明行李照入免税。次日具摺奏聞。使臣入京後, 寄居四摆馆中, 由館中官員招待, 各國入京使臣及随從人等應行照料事宜, 俱由内務府經理。禮部派委司官二員, 幫同照應, 外國表文使臣到館後赴 禮部進呈。如表文係外國字體由邊省督德摆出漢字副本。儀制司接表送

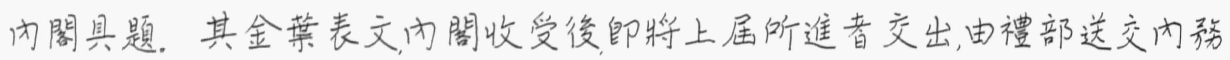
30 府。如使臣受國王命, 必親怗表文方物, 由禮部奏明請旨, 行钦天監選擇吉日, 带領該使臣敬謹豫備。其應於何處召見屈期均候特旨遵行。使臣在京如 遇三大節, 没凡传殿日期應與朝贺。如遇皇帝巡幸木蘭, 由禮部堂官一員带 领赴行在䀐仰。如遇萬寻聖節, 带入同臬園㯖戲如遇筵宴带使官入座。使 臣在京如已與朝贺, 由禮部奏明停其召見。有未與朝贺者, 於使臣回國時, 將 
應否召見奏請剑定。有已舆朝賀, 應停其召見, 而硋使臣援例請見者均據呈

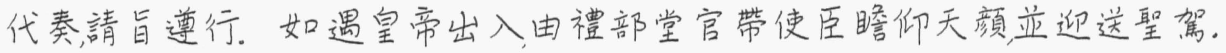
使臣在館時, 有請出寺㡿遊䜿等事, 由禮部先行奏聞将所行街道, 知會步軍統 領, 不許收買史書兵器及一應違禁物品。不得與舖行人等私相交易。使 臣回國時, 於午門領賞行都察院派御使四貣, 行鴻墟寺, 派鳴贊四員序班二員; 5 行護軍統領彈壓, 行工部舖設桌張, 知照后部工科、陝西道, 及各督䅉, 並該國王。 頒赏無定額, 屈期将上次賞賜物件, 開單具題請旨赏給。如軍機處先期奏准 交出正赏加賞清單, 将賞賜國王物件, 開送内閣撰入栜内, 交本使㵝回。外國 使臣附載方物售於邊境者, 㯖。如願自出夫力, 携至京城留易可於頒赏後在 畣同館開市三日至五日。使臣往返所带货物俱免收税。使臣還國時題明1 0 在禮部筵宴三次, 在四罣館筳宴一次, 付知精羘司辩理, 回至原来省分筵宴一

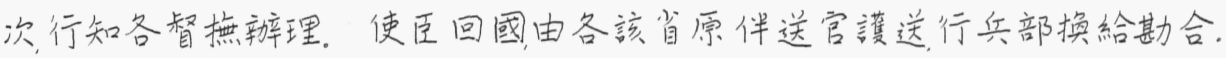
䋑過各省, 仍遴委幹員, 更哌護送。禮部将起程日期知照各該處督撫。仍令 各該處督挴将使臣出境日期题明報部。使臣回國時,留邊人役同送出境。

\section{(乙)鴉先戰後}

鴉它戰前清廷辩理外交之機閏與手續已如上述。各國商民在 邊地留易者例由各省大吏監督總轄。遇有大故則由邊省大吏畣衔奏聞, 候

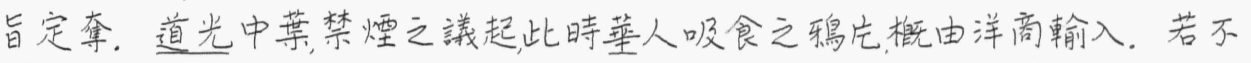

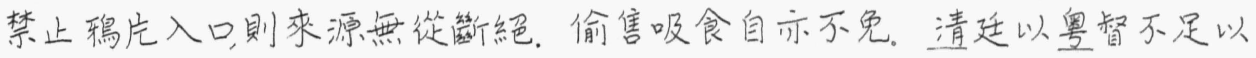
當此重任污於道光十八年十一月十五日(一八三八年)諭湖腐總督兼兵部尚2 書街林則徐, 带欽差大臣關防, 馳驛前往懬東, 查辩海口事件, 所有該省水師, 兼 蹛節制。是為以欽差大臣辦理邊省由海道来藮各國夷務之始, 林既带有 欽差大臣關防, 其權自較普通邊省大吏之權病重, 得便宜行事, 但遇事鲾重大 時, 林仍請旨裁奪。

林至粤後以嚴㕍禁煙故, 致與英人交涉決裂。英人北犯, 舟山定 ${ }^{25}$ 海失守。清廷不得已, 乃於道光二十年七月, 一方詔令雨江總督伊里布為敛

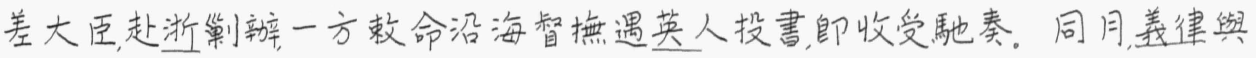

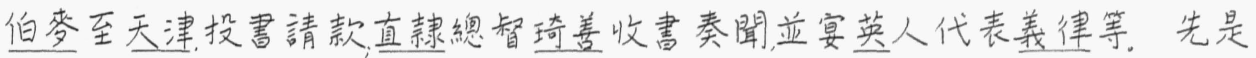

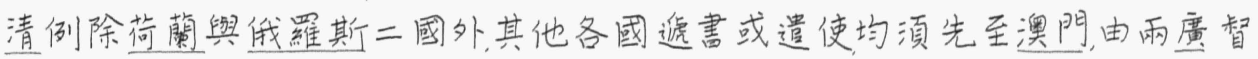

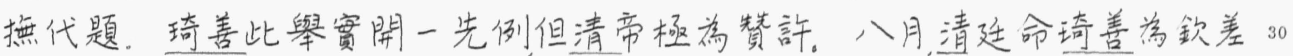

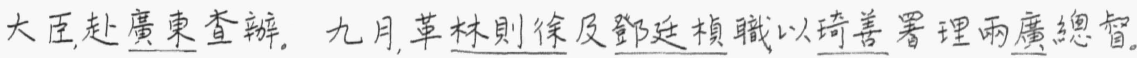

此後則中英間時戰時和, 沿海諸省曾數次與英人成立暫時之局 部協定或休戰條约。此種協定或條约均由倽差大臣舆英人商訂, 其後雖多 為清廷否認但均以此中所訂款项過於奇刻清廷不欲承認。而敛差大臣有 
權與英人訂約, 固清帝所允許。師此已開由海道桃堡各國與廷命剑差大臣 訂約之先例。其後清師霬败, 英軍連陷沿海沿江各地, 進迫南京清廷不得已,

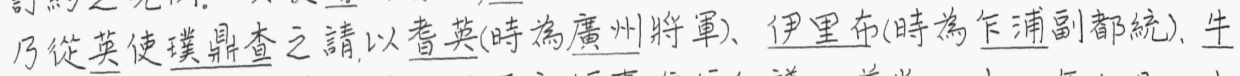

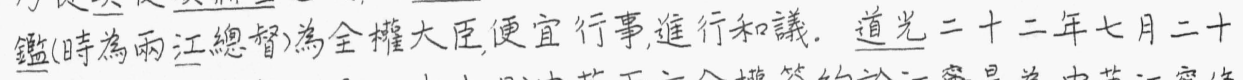
5 四日(一八四二年八月二十九日) 中英雨方全權签約於江斉, 是禹中英江玨條 絇。为中國與由海道本茥各國正式訂立條約之始。在中國外交史上開一 新紀元。

觀乎上述吾人已可見自鴉片戰爭起後清廷對外交涉之楼閔與

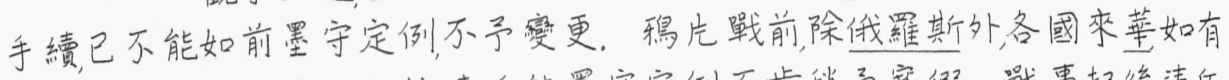
10 所求概以和平方法出之故清廷能墨守定例不肯稍予寬假, 嘠事起後清兵

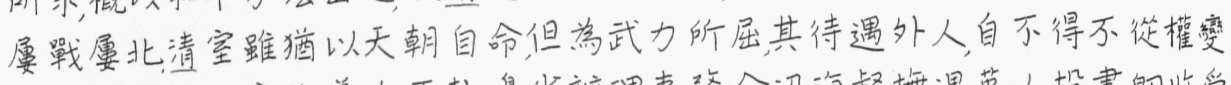
更定例、諸如命剑差大臣赴邊省辩理夷弱, 令沿海督挴遇英人投書, 即收受 馳奏終至以耆英伊里布等存全權大臣便宜行事, 進行和議。凡此皆已開前

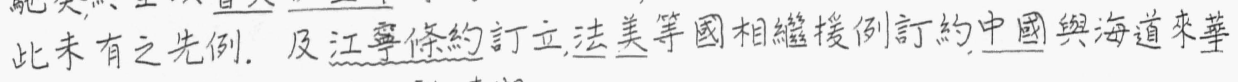
15 各國間之閶係, 乃入於一新時期.

柾片戰前中國與各國迄未墢生近代外交關係已如前述。其各 國商民在邊地留易者, 且不得與大吏直接交涉, 道光二十二年清廷既被迫 舆英人訂立江富條約英人除獲得他種權利外, 並於约中规定:

一唡後大清大皇帝大英國君主……所雷蕉英人民……各往他

$$
\text { 國者, 必受䠹國保劶身家安全。 }
$$

二自今以後大皇帝恩准英國人民带同所層家眷寄居沿海之廈 州、湢州、厦門、害波、上海等五處港口, 貿易通商無礙, 英国君主 派設领事管事等官, 住硋五處城邑, 尃理商賈事宜, 與各該地方 官公文往桃。 大皇帝准其嗣後不必仍照向例, 凡有英商等赴各該口留易者, 勿論舆何行商交易, 均聽其便。

四、英國往中国之總管大员, 與中國大臣無論京内京外者, 有文竜

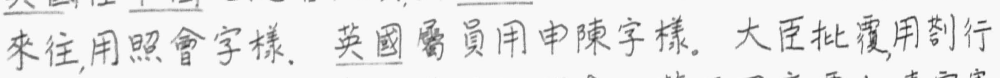

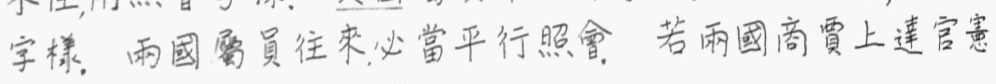
不在議内仍用奏明字檬。

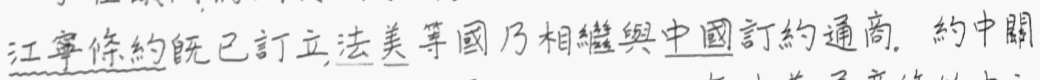
於舆中國交涉往束均有類似上述之规定。一八四四年中美通商條约中之 规定且有為江蜜條約中所未載者: 
一如地方官有欺䅐领事各官等情, 准該領事等㸹委曲中訴中國 大畫秉公查辦。但該領事等官亦不得率意任性, 致與中國官 民動多牴牾。

二, 雨國均不得互相徵索禮物。

三合息國日後若有國書遞達中國朝廷者應由中國辦理外國事。 弱之领差大臣、或雨盧閩浙雨江總督等大臣将原書代奏。

四嗣後合悉國如有兵船巡查留易至中國各港口者, 其兵船之水 㑡提督及水師大員與中國該處港口之文武大害均以平行之 禮相待。

同年中法通商條約中, 除有類似上述二約中之規定外, 並规定有: 10 一中國地方官於該領事等均應以禮相待……淌有不平之事, 該 領事等官遥赴總理五口大臣虎控訴, 如無總理五口大臣、師申 訴省垣大害為之詳細查明秉公辦理。

二將來佛蘭西若有國書送達朝廷該駐口領事官應将國書送與 辦理五口及外國事饬大臣。如無五口大臣師送與總督代為15 進呈。其有國書復轉, 亦一體照行。

鴉光戰後英美法等國條約覞已相繸訂立, 清廷遂不復能如昔日, 視一切外國使臣悉為真使或拒絕接待。各約中䠶有明文規定開放沿海之 懬州福州、厦鹏、蜜波上海五口, 准許外人通商, 並許設立領事管事等官往該五 處城邑, 與各該地方官公文往來。且約中對於中外官更文移住來等事亦有20 明文規定。故自鴉片戰後迄英法暃軍亳起期中, 中國與海道来菜各國間之 關係較之戰前已大䃞更, 在此期中, 各國根據條約中付舆之權利, 派領事往通 商口岸與各省大吏或地方官直接交涉。中國方面亦遵照約文以禮相待。 清廷並颁給雨廣總督欽差大臣關防辩理各省海口通商事㢦。惟鴉汽戰後 英法美等國舆中國訂立之條约中, 並未规定交換駐使。美法雨國之條約中 25 亦只规定有「日後若有國書遞達中國朝廷應由中國辩理外國事務之欽差大 臣、或雨廣閩浙兩江總督大臣將原害代奏。其有國畫復轉, 亦一體照行。職

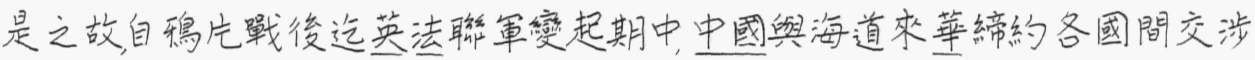
往來之狀況雖已較前改善, 但去近世外交關係尚遠。

在上述期中, 清廷除遵約命各省大吏或地方官以䄚接待締約各30 國之代表或領事等, 並以番督学欽差大臣辦理各省海口通商事務外, 並未依 照近代歐美國家惯例設立任何機閣専辩外交。對外一切交涉, 概由通商口 岸所在各省瓣理, 而以奥督總其成。蓋鴉光戰後諸條約, 係威迫之結果清廷 實無意完全放育其鹤日閉開自守之政策, 亦無意與西洋各國㓎生近代外交 
閣係對近代外交惯例, 亦無意接受或竟慒無所知。條約中之規定係戰敗之 結果清廷不得不遵守。但清廷之所願遵守者最高限度亦止於此, 故各國 之代表或領事, 若赴無通商口岸之沿海各省, 清廷必命各該省大吏暟諭折回, 諸凡交涉必䩄就地協商或统由奥督辦理。各國若有國書或文移送達清廷

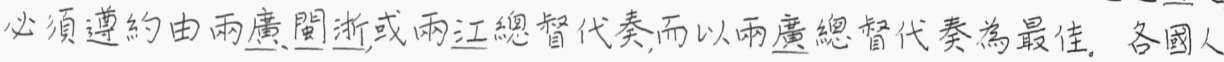
民不得入居内地。若欲派使臣入京則仍遭峻拒如必欲入京則必須僄中國 體制。俄國為陸路通商之國家, 在此期中, 與中國交涉往来仍照向例, 不得與 海道來蕉各國受同一待遇。俄國商民亦不得由海道至通商口。

(两)總理各國事務衙門之緣起

10

鴉光戰後英美法等國條約訂立, 各國對菜通商雖較前便利但為 條約所限制, 仍不得满其慾望。清廷復堅守成約, 對外交涉, 不肯越過約中所 規定稍事讓步。及葉名琛主政畺東哃愎自用甚至拒絕接見有約各國代表

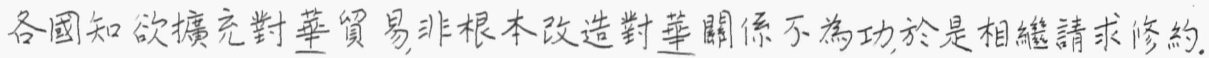

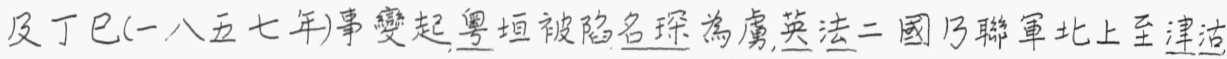
15 俄美二國遣使随之。清廷不得已终之乑通成例, 先之以直隷總督譚廷衰收 受各國投遞公文, 進呈軍機大臣拆閲, 並與之交涉, 檤之以允准各國設或日後 廣東有不辩之事, 則福建雨江總督, 折江巡撫皆可請為代奏终之命大學士桂 良吏部尚畫花沙納赴津「查辩, 並頒給欽差大臣關防, 進行和議。

同年, 美俄英、法四國天津條約成立，中國與西洋各國間之關係於 20 焉大熟, 天津條约惯樹立中國近代外交關係之基礎, 中英天津條約中, 除增 開口岸給與英人以通商等便利外, 並规定有:

一约定照各大卧和好常規亦可任意交派秉權大冒分詣……雨 國京即。

二大英剑差各等大員及各眷層可在京師或長行居住, 或能随時 往来總候本國諭旨遭行。英國自主之邦, 與中國平等。大英 欽差大臣作离代國秉權大員, 唓大清皇上時, 遇有礙於國體之 禮, 是不可行。惟大英君主每有派員前往泰西各與國拜國主 之䄚示拜大清皇上……至在京師租㶵地基或房屋作病大 臣等員公飡, 大清官員亦宜協同乵辩。僱筧夫役, 亦體其意毫 無阻攔。

三大英敛差大臣並各隨員等皆可任便往來收發文件行装、囊箱 不得有人擅行㫃拆由沿海無論何處皆可送文専差…… 凡有 大英欽差大臣各式费用皆由英國支理舆中國無涉。總之泰 西各國於此等大臣、离合宜例准有優待之處, 皆一律行辦。 
四大清皇上特簡内閣大學士尚畫中一貣與大英欽差大臣文移 會晤各等事務。商辦儀式, 皆照平儀相待。

五、今茲約定, 以上所開應有大清優待各節, 日後特派大臣秉權出 使, 前來大英, 亦允優待, 視此均同。

六大英……設立领事官, 與中國官員於相待諸國領事官最優者, 英國一律無異領事官署領事官與道缶同品副領事官署副領 事及翻䍘官與知府同品。視公務應需衙署相見, 會晤文移, 均 用平禮。

七。英國民人准聽持照前往内地各處遊歷通商。

八英國民人在各口並各地方意欲租地蓋屋, 設立棧房, 禮拜堂、醫 院埙墓, 均按民價照給, 公平定議不得互相勒掯。

九嗣後英國文書俱用英字害富, 暫時仍以漢文配送, 候中國選派 學生學習英文英語熟悉師不用配送漢文自今以後遇有文詞 辯論之處總以英文作為正義。

十、嗣後各式公文無論京外内敍大英國官民, 自不得提書夷字。15 法美雨國天津條約中, 均有類似之規定。俄國原為陸路通商之 國家與中國交涉往來向有定例原異於由海道來華諸國, 已如前述。今随英 法聯軍至津, 獲得海口通商利益, 並訂有杰津條約約中對於此後中俄雨國交 涉往本有明文規定一如海道來萃諸國與後者享同等待遇。故天津條约訂

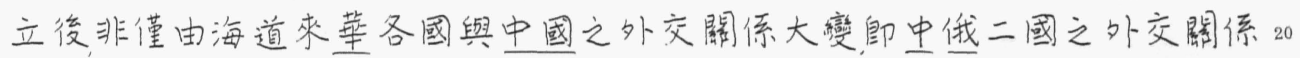
亦大誉易。自茲以後海陸雨道来莱各國, 在待遇上殊無差異。

清廷之承認天津條約原為被迫之結果。當中英雨國代表在天 津交涉時, 清廷反對最力者, 厥為中英天津條约第三款中之規定。該款中之

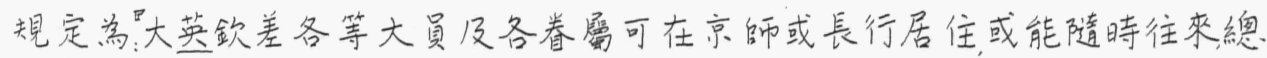
候本國諭旨遭行。及天津條约已緸簽訂, 清廷仍思設法補救。適中英天津 25 條約第二十六款中曾規定中英雨國應派代表至上海會議通商章程。 五八年十月十二日中英雨國代表會於上海清代表乃藉此機會請求英國暫 不派使駐京英方允諾, 英使整駐他處, 遇有事故時, 再行赴京。天津條約, 上海

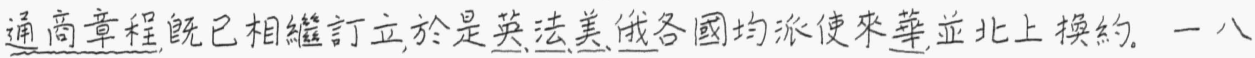
六。年六月英法美各國使臣至大沽。美使於七月二十日由北塘赴京二十 八日抵京復折返北塘於八月十六日在該地換約。俄使已先於五月間至京, 在京換約。惟英法兩使不肯由北塘赴京因之中國與英法二國復發生衝突。 雨國聯軍於八月一日由北椨上岸, 陷大活據天津, 入北京, 焚圆明圈感豐帝出 走。清廷不得已復與英法兩國分訂北京條約互換天津條約。中英北京條 
約中, 除规定他项權利外, 並规定關於大英欽差駐变大臣嗣在何處居住一節, 在遍會商所定之議茲特聲明作為罷論。將來大英欽差大員應否在京長住 抑或随時往来仍照原約(指天津條約) 第三款明文總候本國諭旨遵行。北 京條約哤已訂立, 各國派使駐京之議乃定。中國與各國間之關係此後遂入 5 於一新時期。

先是, 天津條约訂立後, 中國與英法雨國在上海綪議通商章程清

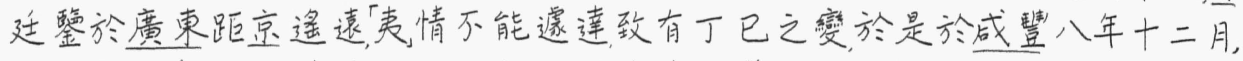
援雨鷹總督之例, 改授雨江總督何桂清為欽差大臣辦理各國通商事宜。成

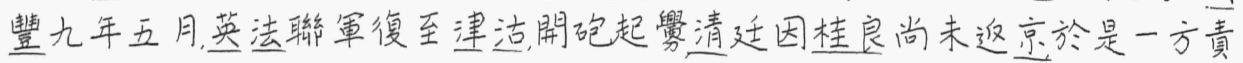
10 令僧格林沁嚴防海口, 一方責令恒福、文暗辩理撫局。翌年夏英法復增師北 上至天津海口, 清帝仍命恒福辦理侮局。及僧格林沁兵敗, 天津砲喜失陷清 廷乃命(或整十年七月)大學士桂良馳赴天津, 會同直隷總督恒福辩理夷弱均

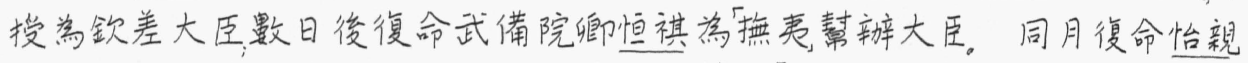

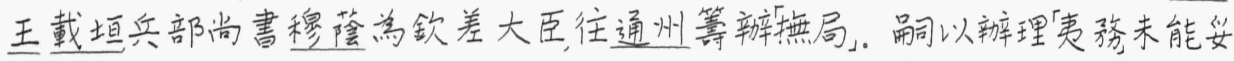

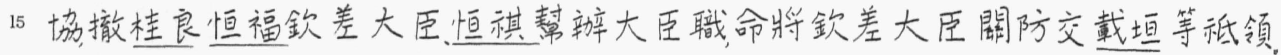

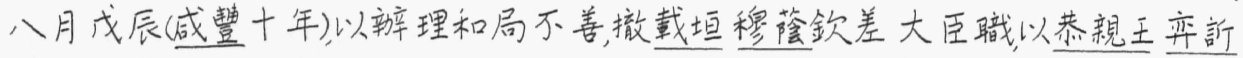
症欽差便宜行事全權大臣辦理和局。翌日, 文宗北狩熱河。自是以後和局

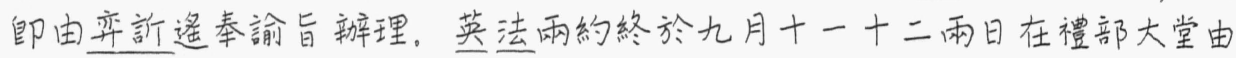

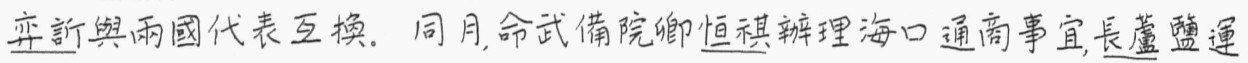
20 使崇厚以三四品京堂候補, 敉同辩理。

和議踓已成立, 但一切外交通商善淩事宜均待辩理。且各國事

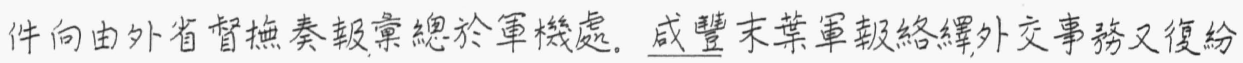
繁。外使駐京之後若不尃一其事, 必致辦理延緩不能悉協樴宜。加以新增 口岸甚多, 南北相去數千里, 若仍令其歸五口钦差大臣辦理不獨呼應不電尤 25 恐諸多窑礙, 因上述種種原因, 故奕新等於感整十年十二月初一日奏䶮辩 理通商善後章程六條, 其有閶本題之要旨如下:

一京師請設立總理各國事弱衙門以専責成也查各國事件, 向由 外省督撫奏報重總於軍機處。近年各路軍款絡繹外國事務 頭緒紛繁。駐京之後若不悉心經理, 専一其事, 必致辩理延緩 未能悉協樴宜。請設總理各國事務衙門以王大臣領之。軍 機大臣、承諭旨非兼領其事, 恐有跂誤請一併兼管。並請另給 公所, 以便辩公, 兼備與各國接見。其應設司員擬於内阔部院 軍機處各司員章京内, 满漢各挑取八員, 輪班入值。一切均倣 照軍椪虎辩理以符舊制。 
二, 南北口岸請分設大臣以期易顧也: 查道光年間通商之初秖有 廣州福州厦門空波上海五口, 設立欽差大臣一員。現在新立 條約北則奉天之牛独直隷之天津, 山束之登州南則鷹束之围

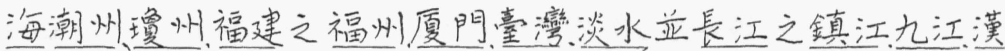
口。地方遼润南北相去七八千里。若仍令俱歸五口欽差大 臣辦理不獨呼應不靈各國亦不願從。且天津一口距京甚近 各國在津通商若無大員駐絷商辦, 尤恐諸多窒礙。擬請於生 荘天津、登州三口設立辦理通商大臣駐禁天津專管三口事務。 直隷為戴輔重鎮督臣控制地方, 不能專駐天津, 而藩臬雨司各 有専素亦未便兼理其事擬倣照雨淮等處之例將長嘘監政裁 10 撤歸直隷總督管理。所有利弊, 另行具光陳明外, 其監政衙署 養廉師撥給通商大臣下必另議添設以節經費。嚄管官税一 併歸通商大臣羊管分晰造報並請分夏給辦理三口通商大臣 閶防一顆無庸加欽差字樣仍准酌带司員, 以資裹辦遇有要事, 准其會同三省督撫府尹商同辦理庶於呼應較露，其萑有五15 口欽差大臣一貣以雨廣總督領之, 咸䇺九年, 改隷雨江總督。 查現在新增内江三口, 並廣東之潮州璮州福建之囔灣淡水口 岸較多, 事務更繁。誠恐該督曾國藩兼司其事非特鞭長莫及, 並虑未能諳悉夷情。應仍責令署理欽差大臣巡撫薜煥妥為 辦理。至天津, 上海雨處所辦一切事件, 應倣照各省分别奏咨20 之例, 由該大臣随時知照總理衙門以免歧誤。至吉林, 黑龍江, 俄人從前越界侵佔歷任将軍隐匿不報以致日久無從禁阻應 請飭令該特軍等於中外邊界據宽奏報不准稍有粉飾。其中 外交涉事件一併按月咨照總理處察核。現察天津一口将辦 理通商䃼有進口货物, 並無出口大宗如果日久留易不旺彼必 25 㩔然思返。擬仍臨時酌量情形或將通商大臣裁撤以省圥員。 奏入經由内閣惠親王等會議後請照原議辦理。於是上諭:

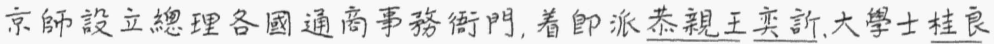
白部左侍郎文祥管理, 並着禮部頒給倽命總理各國通商事務關防, 應

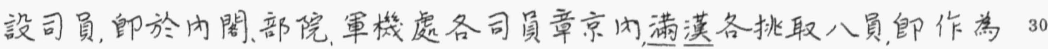

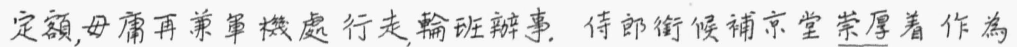
辩理三口通商大臣、駐紫天津, 管理牛鞋天津、登州三口通商事務, 會同各

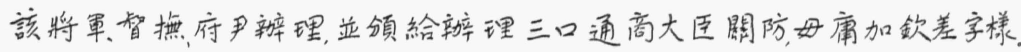

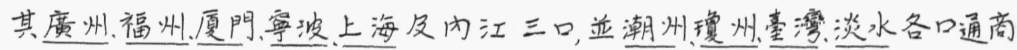




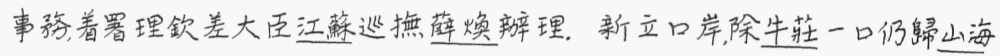

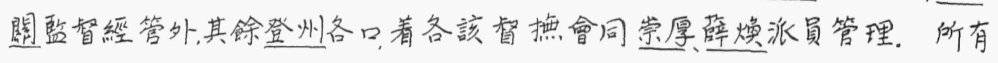

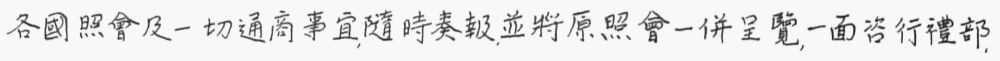
轉咨總理各國通商事務衙門。亚着各該特軍督援互相知照。遇有交卸, 專案移交後任。其吉林、黑龍江中外邊界事件, 並着該特軍等橡實奏報一 面知照禮部, 軧咨總理衙阴, 不准稍有援饰。

設立總理各國通商事務衙門既見上諭, 巷親王奕訢, 大學士桂良。 质部左侍郎文祥復奉命管理奕訢等於是積極筹備, 一面通知各國一面建設 衙署, 考司員。翌年(感䇺十一年)二月初一日, 恭親王奕訢等正式整用總理各

10 國通商事務衙門關防, 並繳還舊有之倽差大臣䦥防。

(錄自「文史雜誌创刑號, 民國三十年元月重度出版)

討論問題:

一, 正式辩理外交之機關成立前, 有何種西洋人到中國来?

二鴉片戰爭前清廷對外國使臣的態度及待遇如何?

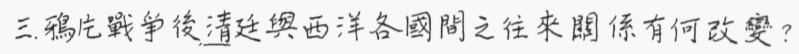

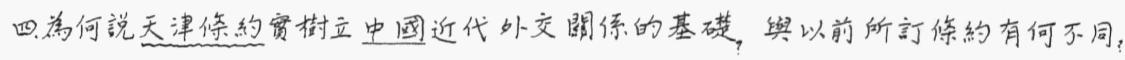
五總理各國通商事務衙門何時成立的? 有何職责? 
1.19 擬3 12 起草, 先作一個槁子。

津山天津

平津 北平跟天津

.20担么的都拿起来

不克处起不能

脱稿动《公謂箸作完成

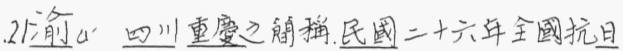

時國民政府倦都於此

.22京尤山为即(如即位)近。

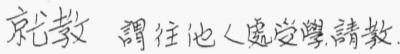

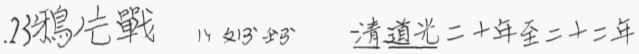

(1810-1812)因英人射運扸它(opium) 於我国而

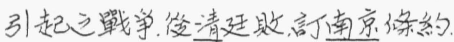

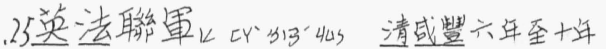

探數指全部的數目而言

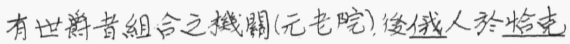

圖設官署, 置将軍管之, 即中国所謂之盖那特语阳

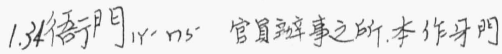

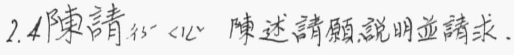

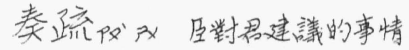

.5陪妇。随從着

陪厔古時諎侯之大夫数天子皏陪厔，又大夫 之厓示稳陪厔。

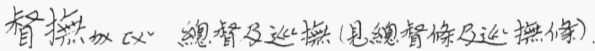

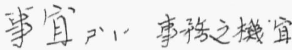

一應事宜一场的事情。

6 僬此直接行事

㣞申直接申赫。

御前心《1 諳皇帝所在

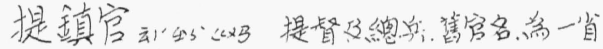

之高級武官。

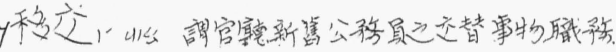

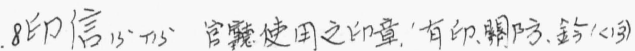
記之别) 有各崜去同之数别。

京條約

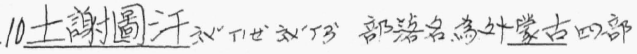

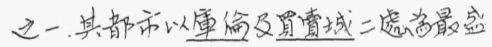

京徒和議由中國補償雨國軍费各銀八有荡雨。

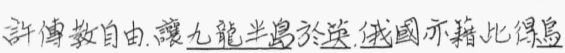

邀里江以㝵地諳之北京條约。

.28选多傅送

30 冒同U B'; 謂官员。

３2目台，䁬遗

眙書送信, 整送文書。

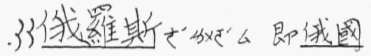

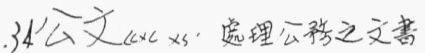

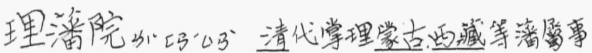

移之官署, 清末改省理潘部

咨甲公文晴之一種同级機钽互用之

咨行公文通知

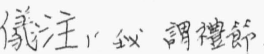

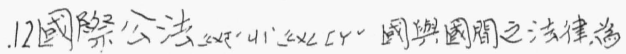

各國所承諰昔。

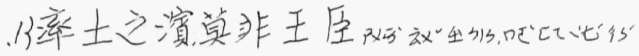

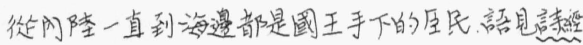

的唯紧出。

14仙直《向往

傎心一心向往

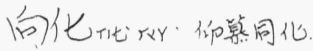

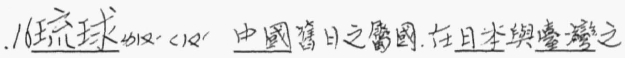

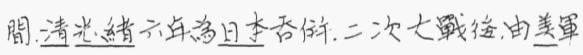
佔領。

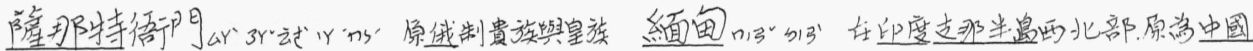


2.17 儀丈|×3'䄚節制度

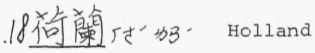

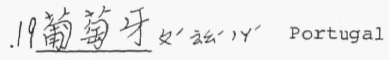

笑咭唎《顺加 England

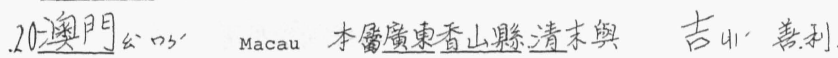

策菊身訂约許其永遠管理
上陆上次.

2.30方物比义各地之物鷹

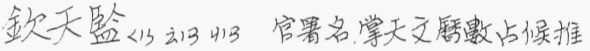

步之事。

吉日好日子

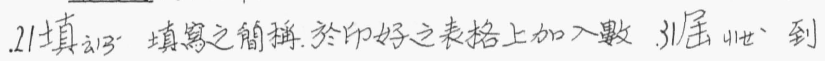

目、年月日等文字、謂之填窝

陆期到時候。

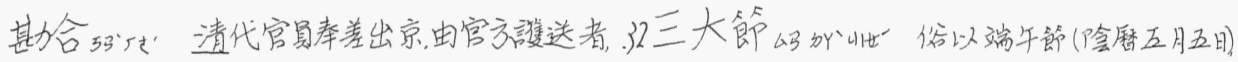

皆驗身份証明等文件、謂之勘合。

手引我官

.22伴炽陪同，陪着。

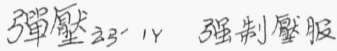

豫心同预”

幹《3、才能, 主體

幹冒新事能幹之官员; 主要之官员。

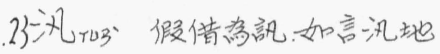

凩地清代緣営兵制, 凡干總, 把總, 好委

所屡者皆日氿。其駐地謂之沉地, 乃查問

往来行人戛也

25 崇文門社“始”吗”北平内城城阴南之左日

崇文. 俗稱哈德明。

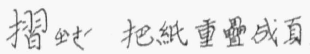

奏㨡清時有特别要祭的事件時用之。

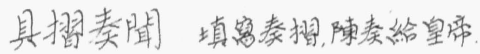

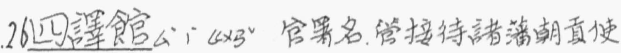

人及通譯等事。

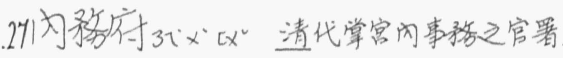

表文引糸”奏章

28儀制同1坐么管理儀式制度之官署

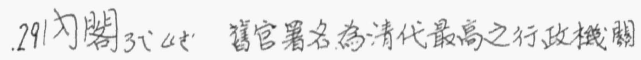

金葉收以金製成之搡溥光。

金菜表文表文用的纸上有溥金它表示正重。 陆山次數
中秋節( 入月十五日)及年節福三䬣。

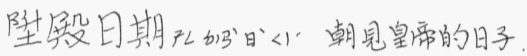

贺厂只以禮物相奉磨。祝公真。

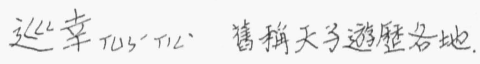

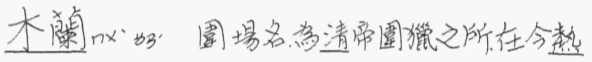

河省圄場縣、清帝常於每年八月與王公等承比

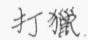

.33 行在伅防冾搯帝王巡幸所居之地。

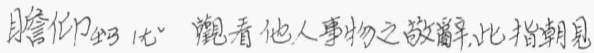

皇帝

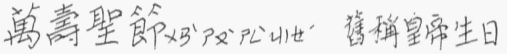

趛污酒席

还宴以酒食請客。

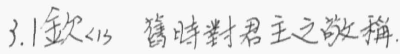

颌运由皇帝決定。

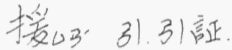

援例引用先例

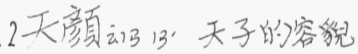

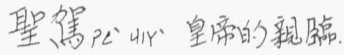

矤䧈众下代猶言通知。

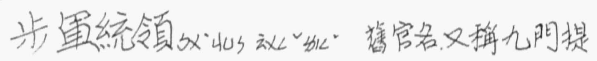

督主管原城治安等事

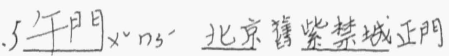

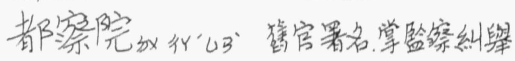

御史心(.)鹪官各、掌約察。 


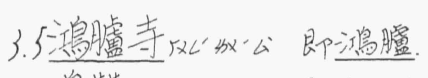

軍民之事的官。

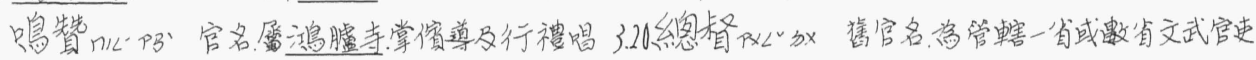

貲远事.

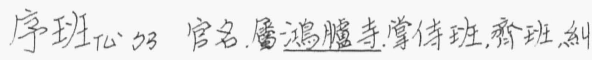

儀等事.

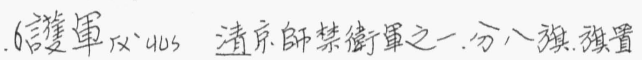
統領、咳領等娥。

\section{之最高長官}

湖廣總督清初置湖廣省, 㢈正初分置 湖南湖北三省, 准雨湖總督尚有湖鷹總督 之䊈

兵部引分篦時天部之一, 似今之軍政部

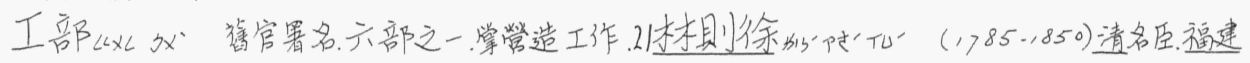
这事.

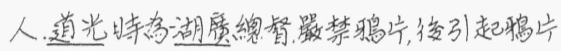
知胑出出猶知雪。公文用語。知悉之意多用 於下行文, 如、令行知照”之類。

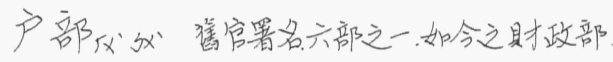
工科《弦官署名, 六科之一指察工程, 註銷工 部文卷。

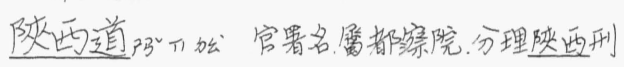
名、梌驗在京工程事務。

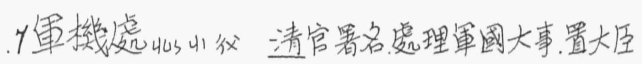

數员、由大學士，尚昰等兼任。 . 8 清單《加项目清楚詳細之挐子。

.9携1, 同熣, 带

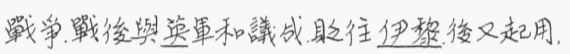

官雲貴總督, 謚文忠 倽差大厔《徆名以行”整時由皇帝特命出外 辩事之長官。

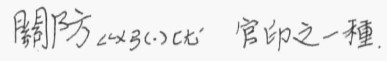
溤公, 快跑。

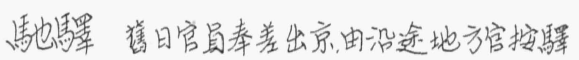
供給其夫馬糧等, 謂之馳驛。

.22食含制山他一出指揮管轄。

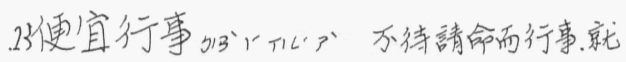
事势之便宜(合宜) 不及請命而相機施行也。

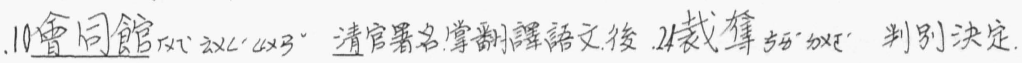

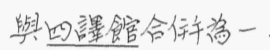
.11精熹司桃防么掌管储宴者。 .13 遴为, 慎遙

遴委小心的委任

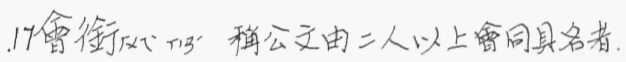
.18定集的“的”謂決定可否或去取。

候旨定奪等候皇帝的意思再作決定

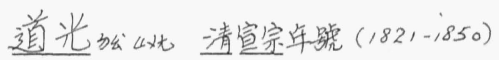

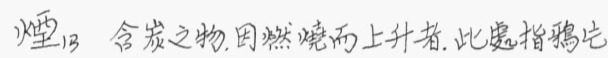
煙。

禁煙禁止吸食鸦论。 概《分一概、同等, 一律、

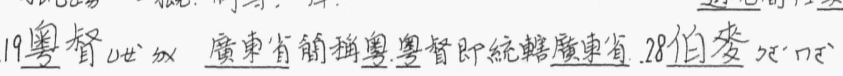

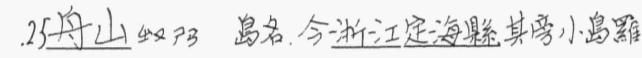
列、称舟山群遇。

定海汃汤浙江省夥名。

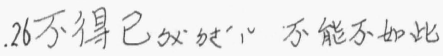

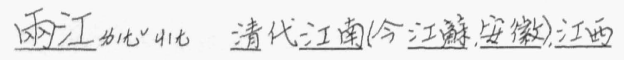
雨省之繌稳

伊里布1 汃外( ? - 1 842 清宗室官至雨江總督

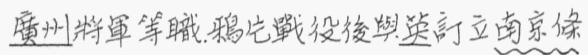
約。

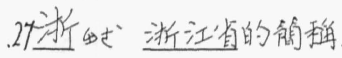

義律”加 E11iot， Sir Charles(18011875)筷人。

道光間任资國註奥留易事務長官。 
英軍官統海軍

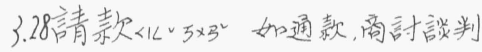

直柰隶出”的河北省舊名

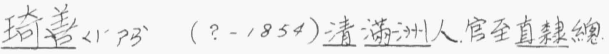

督。淩代林剘徐督奥。
4.10 筧5 5 3 䝠諒。

窗假窗容原諒

11 北3 斯

權〈UB, 篮通, 衡量

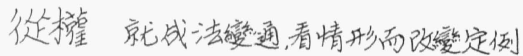

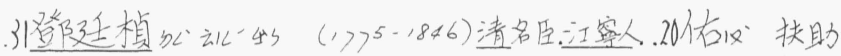

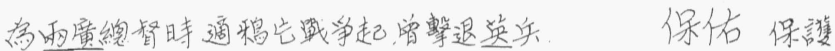

署改代

身家3 4 以 夺身及其家庭

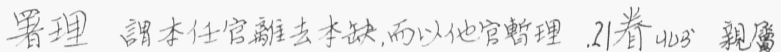

其事

家眷家屬

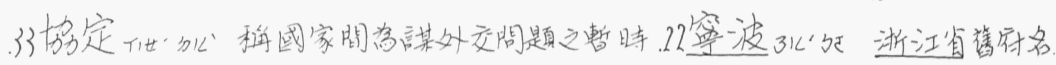

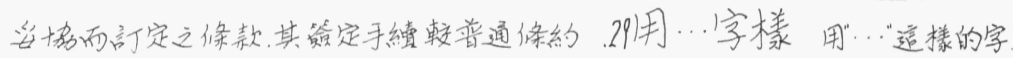

青解單

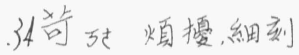

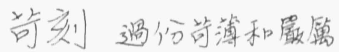

炤金讼代公文書名、今國祭往来之文書用之

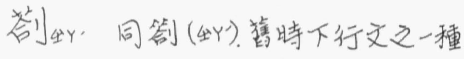

茖行同莿。

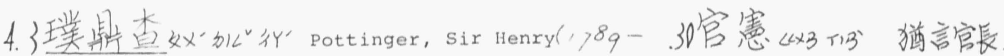

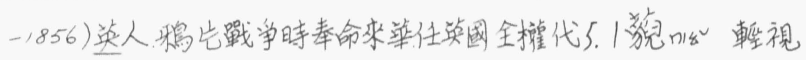

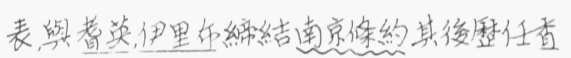

港印度及瑟德拉斯總督

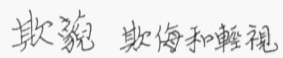

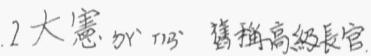

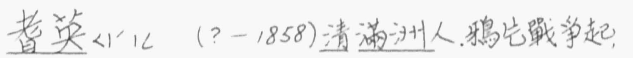

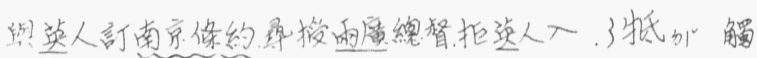

城然睗自盤

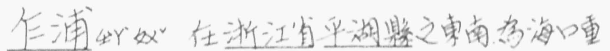

牾道

抵掊抵解，衝突

地

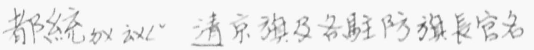

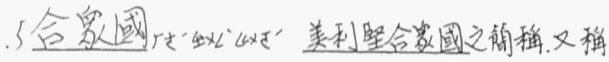
美國

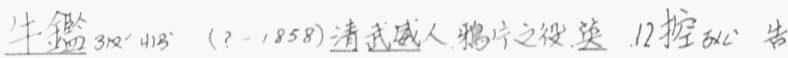

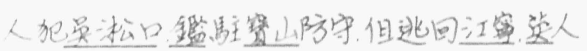

遂入長江僌革娥治罪。

控言斥人民向司一法譏阔告培或起培之謂。

法律各郭。

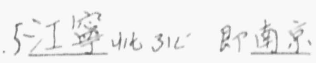

江窝條約 即南京條约咩是淉文

.13坦吸。低，小的㙛

省暏即省城省治所在

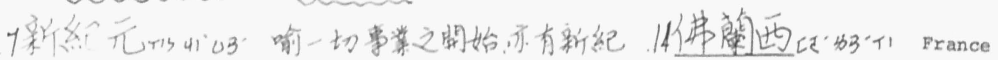

镜之竞

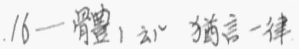

9墨梿指黑子

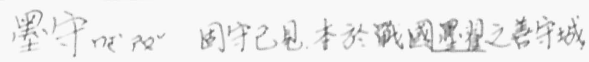

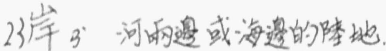

口岸江海之港口。 
5.28 締方結合不解

綗等訂立像約

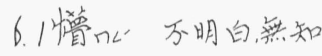

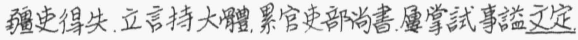

6.20 焉13 代名詞。之, 此

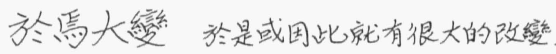

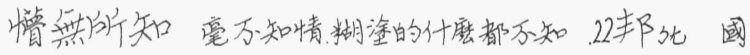

道。

大邦大國

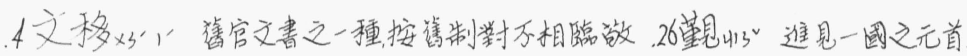

之官署用之, 徒假瓷公文之一體。

.27泰动栖也。

S佳Uir 好，美

最佳最好。

6 峻 403 高. 嚴刻

峻拒㩔简拒縃

. 9 慈息理各國事務俉行日

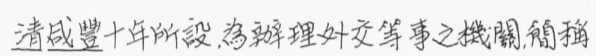

總理衙門，光緒康子之役後、改設外䅂部、

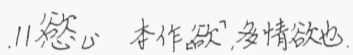

慾望謂方足之感念舆欲满此感念之願望。

泰西俗指歐美日泰西猫言雨两之遂

舆其國山《相交好之國

29 襄力下化相力

襄方乵辛幫助乵辛理

僱《䇳買学力

䚁口寻求

.31 行装㬝行李

囊3九。盛物之具

楯化盛物之具常焰稙子。

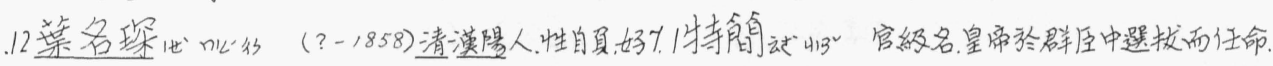

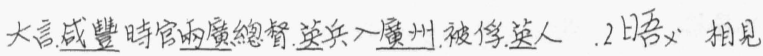

挟之至香港, 淩徒入印变, 卒於斯。

愎か。意氧用事不揌人言。

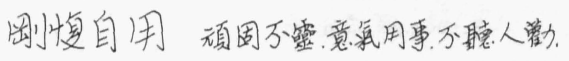

一意孤行

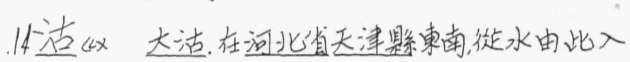

海, 亦搯大沽口, 鎮在口内之南岸, 與北岸之墟沽 相数。

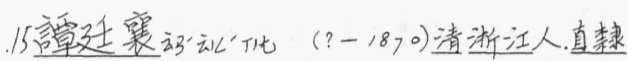

檑晤霄見

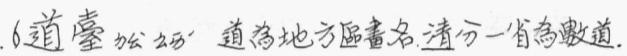

道堂癌舊官名，一道之長

10 篮《分建篗

栈尽卯地，堆猜货物及留客住宿之所。

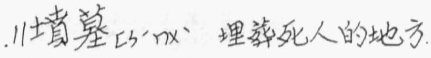

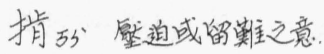

勒指逼取剘物

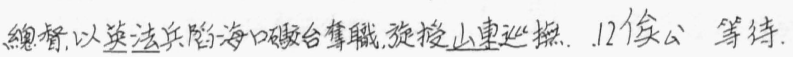

官奎刑部尚書。

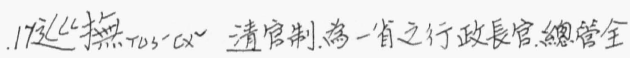

省民政軍政。

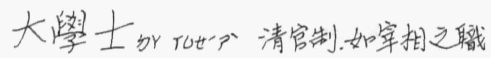

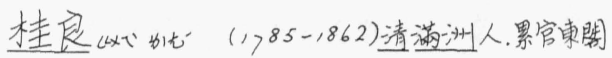

大學士。单譏大臣、

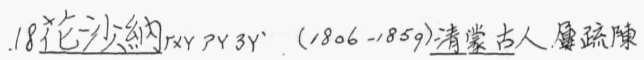

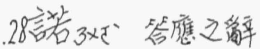

允諾答㷳認需可以

事故ア”《唒事情。准多就意外福患言

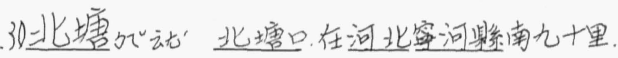

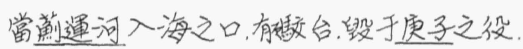

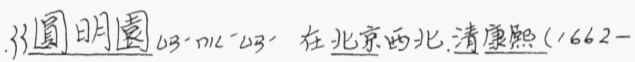

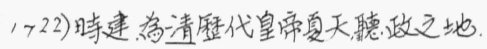


7.33感豐T及一CL清文宗年號(1851-1861)

8 . 2 槴闰上海的简粍

. 6 先是仍队在遥個之前

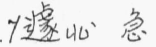

遂達很玦的達到

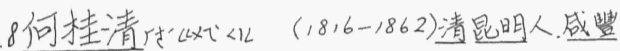

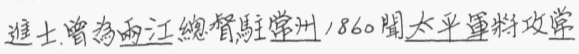

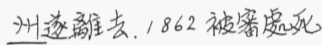

.9舆似謂意見不合感情有裂痕。

起鼠弦生德突

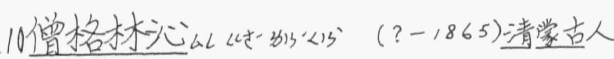

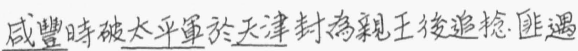

状死

怕福原的

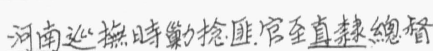

文煜妙心清消洲人，平捻匪有功任山㝵巡

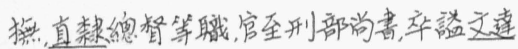

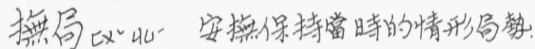

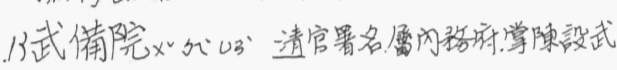

偖給县易徽收等事, 長官曰武偖院莭。

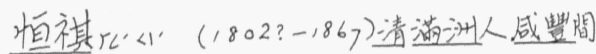

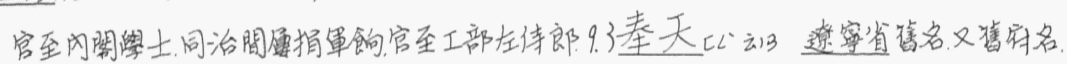

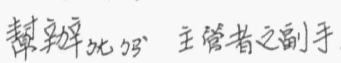

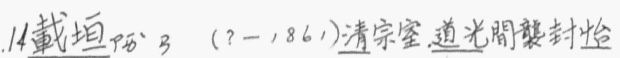

魏王。1860被派到通州孯美迲人交涉談判

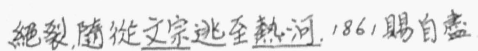

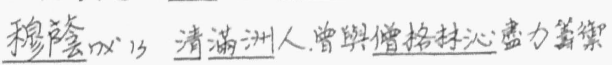

洪㛫軍官至兵部尚書

通州动纡在今河北省北京市之車。

.15撤㣖除去

撤…娥取消其娥位。

祗出放

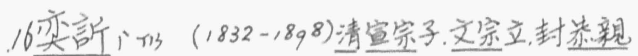

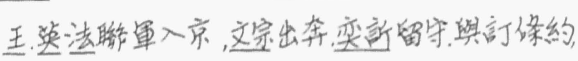

络繹繼繒不縃貌。

.24 年應以心彼此消息相通。
25 窒到阻塞

窑礙 妨礙

.29悉丁詳㙉

$$
\text { 悉心盡其心力 }
$$

31歧誤《”错誤

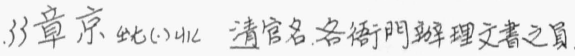

挑北選挥

挑取邀擇取用

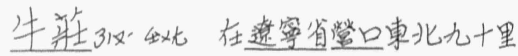

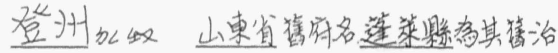

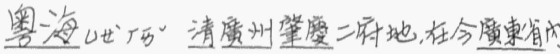

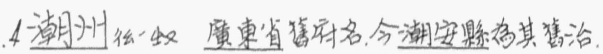

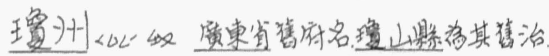

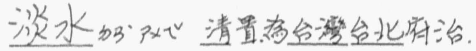

9 畿輔山秋“近都城之地。

民政兼目才政的械阔
後官軍機大臣、

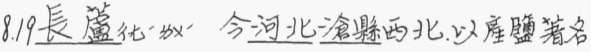

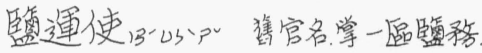

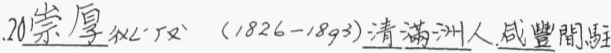

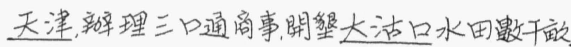
京堂4 1 动舊時京官較尊者之一偅稻謂, 有三

畞、五品京堂等。

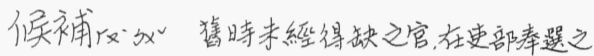

後, 到官署報到, 身罒候補缺授官, 謂之候補。

.21善後8 3 的謂事後謀收拾整顿之法。

九江山恢“江西省夥名、篦名德化，九江府治

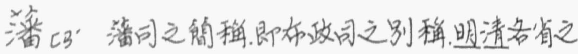

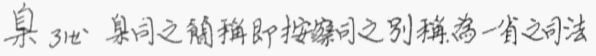


機關

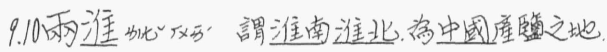

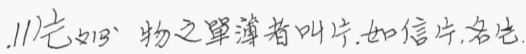

号行具它陣明号在一張紙上窝明白。

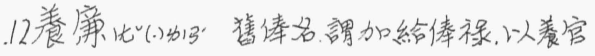

吏廉潔之心。

.13日析个1明白。

分时析分解清楚。

造報訟㕬造具表册報告。

14顆万圆开少物。一倜日一顆。

酌此员商量

裹襄伛相助

襄新辛相助辦理

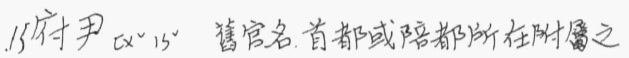

長官。

庶於㫟山希望之詞猶言或可。

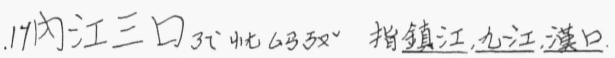

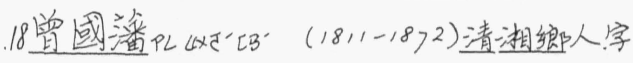

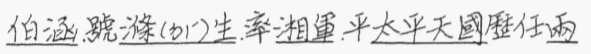

江直隸總督，文草示佳，有曾文正公焦。

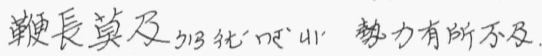

19 諳乃知, 熟悉。

諳悉完全瞭解。

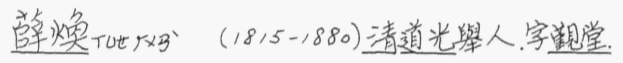

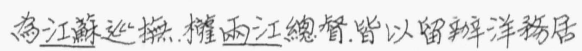

上海.

.21吉林山多以，省名，在中國㝵北部。

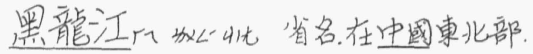

.23飭行命令

放令即命令。

粉放物算之成細末者

粉飾装飾表面, 有隐藏宒情之意。

.25日王忧舆盛。

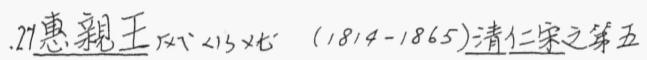

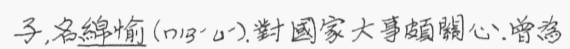

奉命大㸹隼與僧格林沁同撃洪秀全軍。

9.28 着出幺命令䍃

.29 亿寺郎户”加官名、各部置左右侍郎二人以佐 各部之大臣。

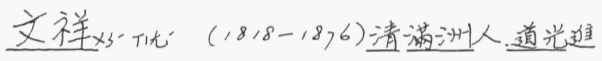

士，工部侍郎，軍譏大臣、制立樂理衙明。

10.4卸他解除娥務

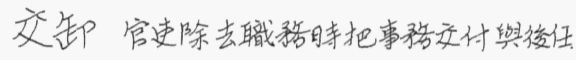





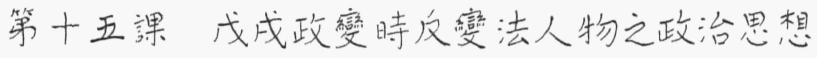

陠整

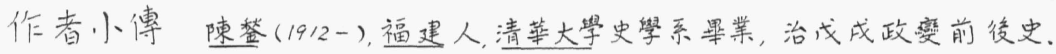

本課简介本篇乃錄自作者在燕京學報第二十五期, 一九三九年六月所發表一文。作者把 5

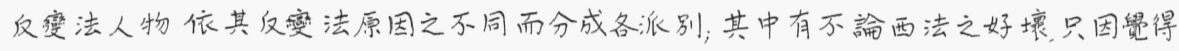

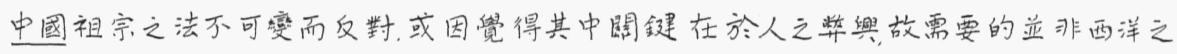
法治, 而是歸根究底的人治問题, 另一派别是在比較中西二法後一部份認为中法優於 西法故滺法为不正確之舉, 另一部份人留得西法踓亦有可取用之處, 但只能用之為副, 而

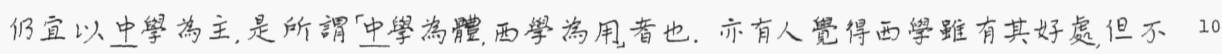

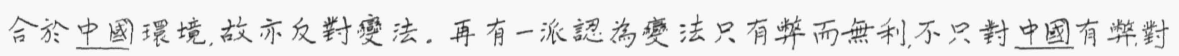
外國亦然, 進而討論到民權與君權之利㢣是非。

反變法者之政治思想可分為兩大類一為比較保守者之思想— 師為無條件之反誉法, 所謂無條件者, 乃根本不承認有誉法之一詞。其中又 15 可分雨層: 一則認為治國當用人治或德治, 不應言法治, 法治, 既不存在自無所

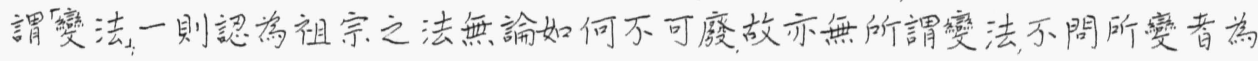
中法抑西法也。所謂祖宗之法者, 究其內容兴则仍為傅統之德治, 故與上者 實殊途而同歸。復次有條件之反誉法論者, 亦有二種: 一為從比較中西之法

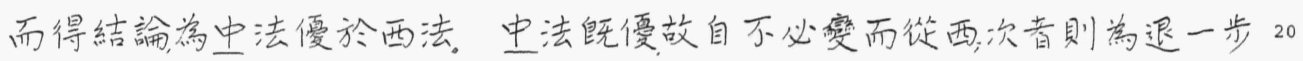
承認西法亦有所優但以一與中國國情不合不能全部採用, 二必以中㸓制體, 西學為用, 不能反客為主, 故西法非必不可取新政非必不可用但如康等之察 法則不可。從之則有弊而無利最大者尤在於壞人心。所謂中法之優仍在 以德治、以人治師王道。而西法则為富强為法治, 虞霸政。由此觀之, 成成時 此雨種政治思想之爭辩其意義仍为二千年爽, 政治思想史之舊問题師德治, 25 及法治之奚, 而此篇紀載亦無異漢代監鐵論大夫與文學之詰難之重演也。

(一)無條件反褰法者

甲. 以人治反法治

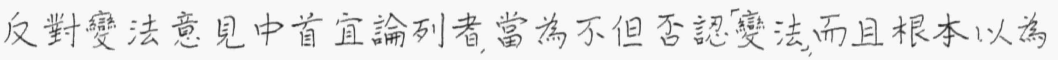
治國之道不必有法之一字者。法苟不足治國則妻法問題不攻自破此則以 30 人治(舁德治)駁法治者之主要論點也.

倡人治者其持論大抵不出於孟皆有治人無治法及徒法不足以

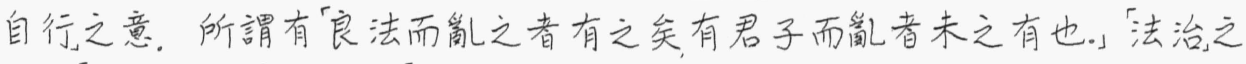
失與人治之得, 曾廉有言後世人不知治天下不可無精意而但求之於法度。 
夫法度笱可以治天下, 則是一胥吏, 可以佐天子理萬邦, 不必用賢能之人。同 是周官之法度, 周公存, 則法度舉, 周公之, 則法度紊, 國之治否關係于人者为何 如乎! 如王文成行保甲之法于赣南, 而赣南大治今之門牌連坐之法, 仍王文 成之遗法然行之而不見其效者何則, 大吏任守更而不得其人守吏任紳士而 5 不得其人耳。足見治天下而徒言法不足以治天下求之於法而不求之於人 欲國能治不可得也。此輩反繁法者對於時政之窟敗亦深致不满但認為其 原因在于人之万良而非法之問題, 如徐致祥論當時官方吏治士習之壤, 甚為

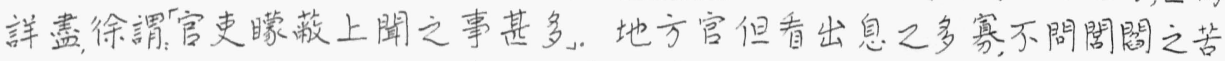
率惟體上司之愛憎不察地方之利病。蓋因入仕途者多由捐納保舉而來! 10 捐納者, 但問其资, 不能復問其人保舉者, 則半由競營而来、至報效一項惯是

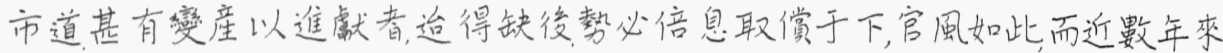

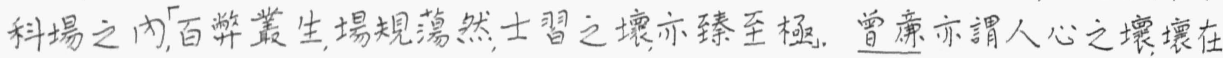
以做官為營財之心理與徐代之意相同。曾因此謂中國一切皆非煮制度之 不良, 而但為人心之敗壤而已。譬如科舉之制病戀法諸人挀病最深認為習 15 非所用, 用非所習, 一如今人之論學校教育與社會脱節, 者。曾謂科舉之本身 無弊習科舉之士，並非不足用所以至如是者，由于在上者不能用經街。科舉 之士所習者為經術而居官之後所行者為法令不用經術非紅術不足用。經

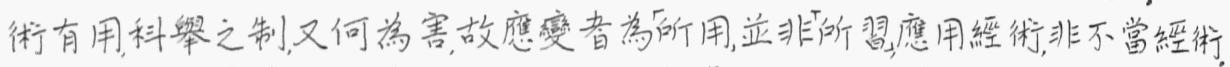
取士之法尤莫善于制義, 其文章有儒者笉象之人必為博通而正大篤槚而遠

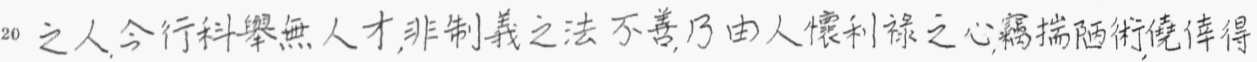
科名欲正其失仍先正制義制義正則心術端心術端則人才興矣。不但科舉 之情形如此就當時之兵制之壤繁法者所最欲改革者, 曾謂亦純屬于人之問 题蓋用兵以得将浮先以能謀為勝, 而火器非用兵之要。伸國之敗于日本由 於中国軍隊不明兵略非兵士不足用何必行围練武额兵效西人民兵之制? 25 必勇不畏死之人方能當兵, 非任何人皆可為兵也。由召募而來者, 必皆勇不 畏死之人故募兵者, 教化之良法也。曾國潘名為娄練其穦則召募, 胡林翼始

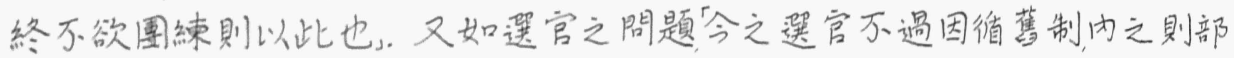
院之考察外之在督撫之驗核則是任人而非任法今部院考察之不察督撫騟。 核之不公, 㔀是人之失而非法之失奈何以人之失而䠋朝廷大法乎?

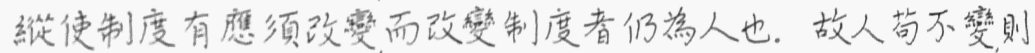
制度踓蜜示無用而空言更為無用如王先謙所謂:

中國祭人大病在一空字理繁興則舍程朱而趨陳王, 以程朱務留

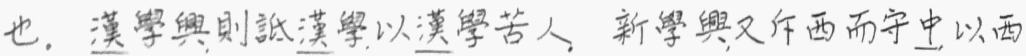
繁尤繁重也, 至如究心新學者, 能人所難宜無病矣, 然日本維新從 
製造入, 中國求新從講論入所務者名, 所圖者私言满天下, 而無實 以繾之, 县仍然一空終古周濟而已。

葉德輝因之有言, 中國之壤既由於人而非由於法, 則與其言筱法

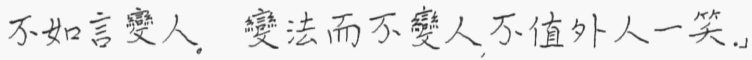

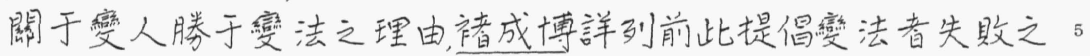

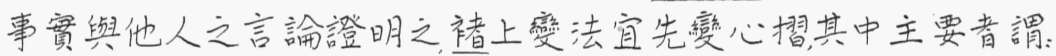

行法之本, 首重得人致治之謨, 必期實践, 請以人维法, 以身取人,... …當今之世, 非無治法之患惯無人心之患。欲求嚄法, 先宜察心。 ……自同治初元, 曾國藩左宗棠沈葆福李鴻章諸人, 因外患日深, 力崇西學……所以步武泰西随時立法惯已万遗餘力。當其經 10 營伊始, 一切章程規制勘酌蔷善, 思議周詳。威謂始踓效彼所長,

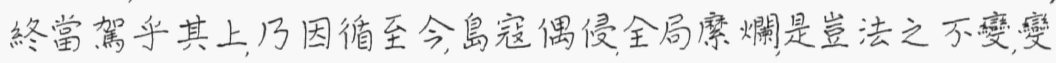
之不善哉, 亦誤于, 行法之不得其人耳。......船械諸工, 果能符宗掌 原議悉由萊廠自辩乎，……李鸿童所派學生果有一二造詣精䋓

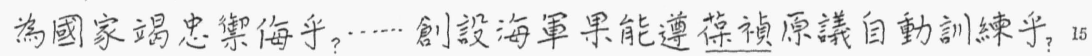
推之他事, 莫不皆然……率有初而無終言多而行少……遗韵 敗於粉飾, 患氧优于荟私……所虑者上以惯求、下以名雇……欲 得真才, 而用乃峑污閣茸之流。欲所舉者皆㹂必先擧人者之無

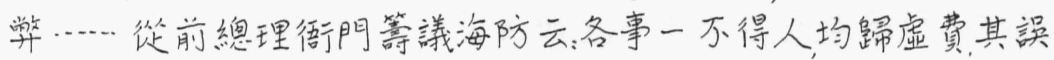
在用非其人不在法之不善。彼時丁日昌之議曰, 除船械一切, 必2 0 須效法西人外, 其稌人心周俗察吏、安民當循我规模加以賽意度 以我之正氧靖被之戻攻, ……李宗義言日練兵製器, 㿿壤立法之

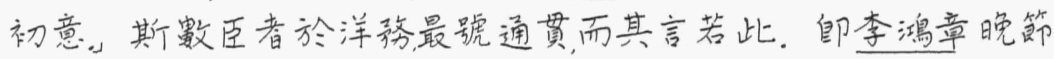
全墮沈迷夷俗而……奏云……泌謂䡜危為安轉弱為强之道全 在于仿習機器, 臣亦不能有此方隅之見。由是擎之, 足徵惯理唯 25 㟇初心不昧, 致治㦲㩊之本, 在此不在彼。 與褚之言説相輔翼者, 則病庚子時外人認為罪鬼之一之山串巡 挴李秉衡奏言:

有治法無治人, 雖得泰西之法而效之亦徒使其闕利營私之計, 試 觀近數十年, 凡尃辩交涉之事, 侈言洋務之利者無不家貲千百萬, 30 昭昭在人耳目, 究之其利在公乎? 在私乎? ……臣賦性迁拙洋弱 非所素習, 而默察治㩊之權, 㮩以正人心培國脈為本補救偏䌘可 也因䓨廢食不可也。

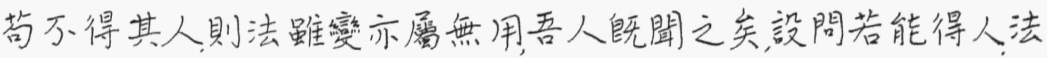


亦可以变乎? 以曾廉之意見埧警法而能得人盖近于不可能曾謂中虫人之孚 西學, 万過滛通西人語言, 文字諸藝術, 借以刺取外國之國情, 拿其利權而制之,

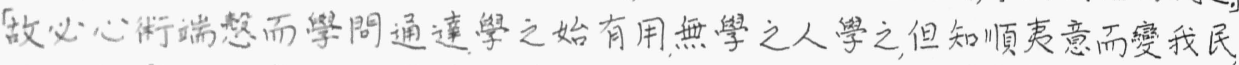
使人相率入于夷狄然苟其人离學問通连, 万一定能學外國語言文字, 故西學 “害無提倡之必要。曾代作此雨難之論(Dilemma) 或有自命學閤通達而有下能 繁外國铻言文字之苦舆?

問题既在人而非法, 故捄時治國之良法郎為人之改造, 然则如何 方能墏人? 黄仁渻有言

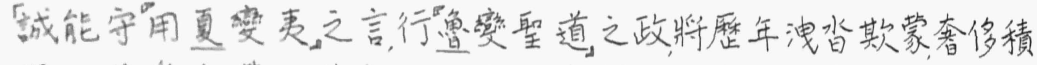
習之甚悉去蕉而作新之。大臣盎钭錯之忠小臣守敬復之義。

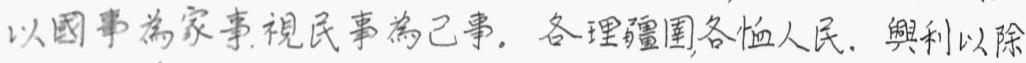
其害舉善而教不能。暧心惯力, 以行惯政, 而收宽效。各州縣得 人则一省治各省得人則天下治, 較之栾鹤謀新效夷礐法難易

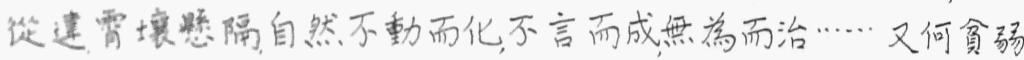
之虑惟洋務高談時務是圆哉?

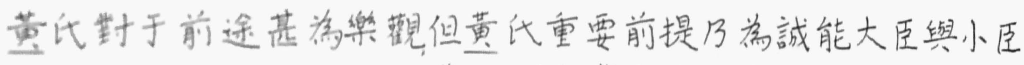
如此如此至于如之何方能如此如此, 黄代則未赏言之, 亦未言其困蜼或容易。 按以往言人治者之主張若求政治昌明不外由学君上者以身作則修胃平治、

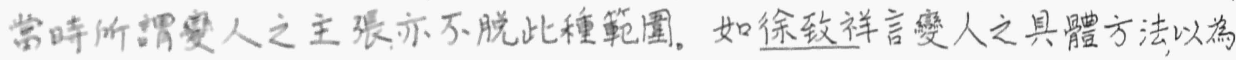

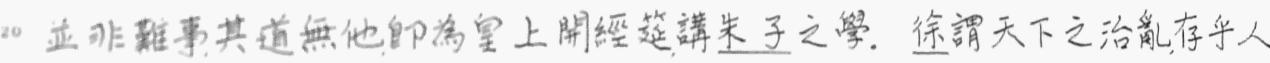

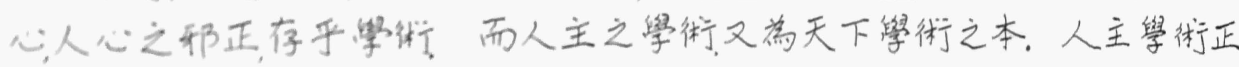
于上而淩天下學街正于下，未有繁街正而人心不正人心正而天下不治者。

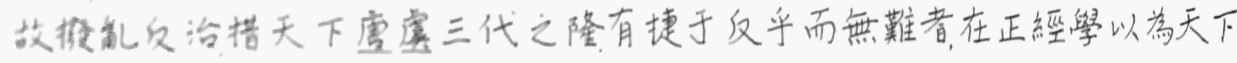
倡耳.

堡氏甈引孟子一正君而國治, 乃孟子正心以正朝廷正朝廷以正

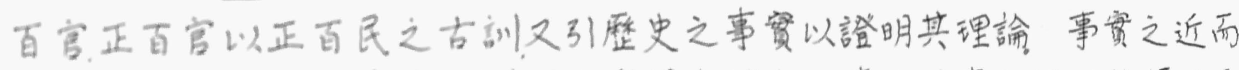

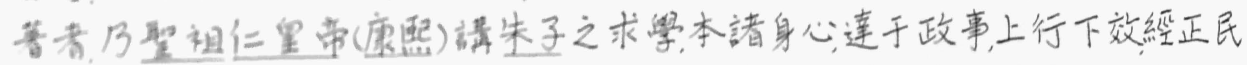

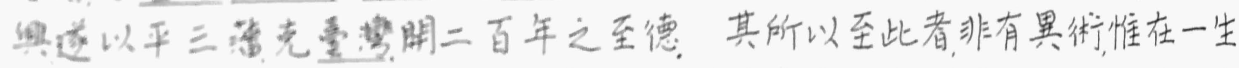

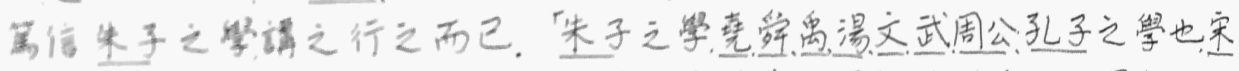

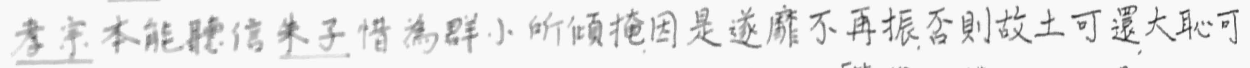

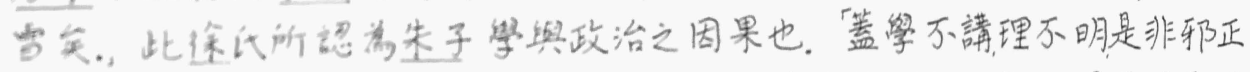
万人能粗因全士奸倿得以桇而入用人行政不得其當顺媇立鄰不得其道, 整否

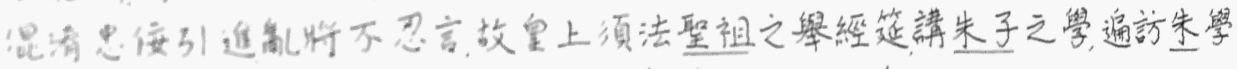

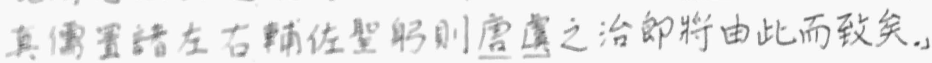


夫法治人治之問題非片言所可決要之, 二者寛蜼以偏廢惟此辈 持人治以攻法治者, 但由持皎法者之法字就字面以解釋之, 以彼言法也, 我言

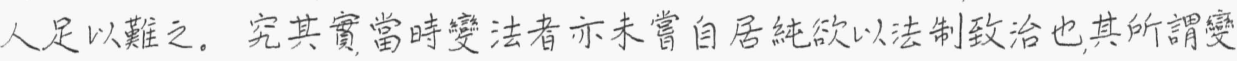

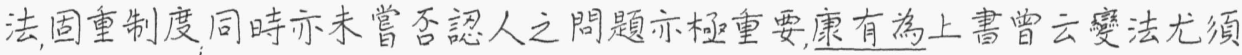
亳人。其消極者則為去頑固守舊之大医栍極者則皇上定國是以為表率于。

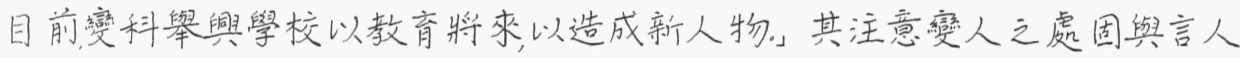
治者同特其熟人之工具與目標有不同而已。

\section{乙祖宗之法不可㙰}

漠以前用太禹謨中人心惟危, 四句有帝王之心愽謂之十六字心 傅, 又約之為危微精一。四字, 㡺以後歸納至敬天法祖勤政受民八字, 至明大備。10 及有清一代對于祖宗之成规益認為神聖不可侵犯其忌暲之特多, 即惟恐其 有損其祖宗之威嚴, 而歷朝之聖諭聖訓, 無異後世之成文害法, 自世祖至穆宗 無不以敬天法祖為垂誡者。前此帝王之舉措, 廷臣言路引經據典力爭而不

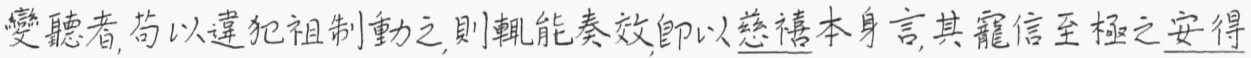
海以太監出京有違祖制有山束巡撫丁赛禎就地正法, 而莫可如何。神武門 15 護軍與太監互毆本科護軍于重典而言官以祖制太監不能私自出入为言, 亦 悟而加传故光緒之毅然数法、后師责以九列重臣非有大故不可亲, 今以遠

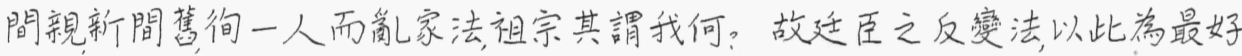
理論根據。㓮毅每遇設施新政必痛哭列祖列宗, 而縈祿與康有鳸會于罣署, 亦以祖宗之法不可落亦為足以難康而有餘者, 可以見祖制觀念入人心之深 20

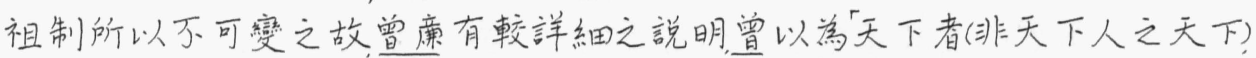

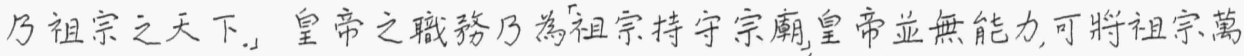
世不落之法加以更改。細事必歷就而後行, 可以更改而祖宗之宏綱, 則決不 能放。其意以為政治理論之實行, 非若其他事務, 可以任意試驗, 皇帝因極尊 噘, 而與祖宗相較則膛乎其後, 箵一代開基之祖宗縃非後世守成之子孫所能 25 及尔孫而欲革先人之法, 其禍乳必甚于未革之世故一世之法必與一代相終

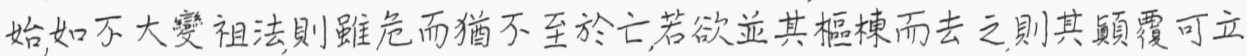

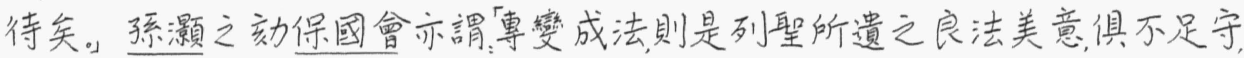

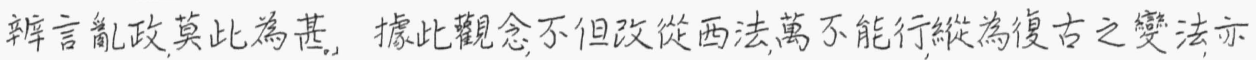
有不可, 故治國之法乃虑黄仁㴚所謂害章列祖列宗聖訓詔諭就已著之成就 30 之事, 究自强不息之道也。

夫天下無一成不綮之法若遭持祖制者之言, 則是法之㹂否, 不以 時宜地宜為微, 而專視其為祖制否德宗對太后之言日; 祖宗而在今日, 其法示 必不若是! 兒窅忍壤祖宗之法不忍亲祖宗之民失祖宗之地, 康有為之對 
榮祿則日”祖宗之地不能守, 何有于祖之法? 持祖宗之法者於此亦無以難之 也。究之清代祖宗之法亦非祖宗之發明, 本由渾洲草昧之法淮而學中國之 文教也, 吾人觀聖諭聖訓之内容則祖宗之法, 惯師承授傳統之儒家德治思想 則挟祖制而仅咳法者, 亦仍為擁護德治而反法治者也。

\section{(二)由中西法之比較反誉法者}

主人治者不言法而言人, 守祖制者但問法之为祖制否而不閔中 西法。其由此比較中西法之優劣而得反䃞法之結論者, 則認為中法優不可

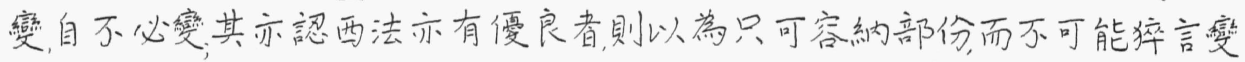
法。

\section{甲.中法優於西法}

謂中法優於西法者, 其由隶固為傅統自尊之心理, 亦因當時崇拜 西法者言之過甚成第時病洋迷, 以近年名詞言, 埧所謂缺乏民族自信力, 者, 故 引起一切守萑者之更加反感而益認為中國並非不如西洋。極倡維新之張 之洞于此點則痛心疾首言之日:

近日風氯甚替, 普西學者, 自视中國朝政民風無一是處殆不足以 比於人, 自視其高曾祖父, 無不可鄙賤者, 甚且將謂數千年以来歷 代帝王無一善政歴代將相師儒無一人才, 不知雨千年以上, 西國 有何叟, 西國有何政? 。

張認為，中國雖不富强然天下之人, 無富貴貧賤皆得俯仰蒐然有

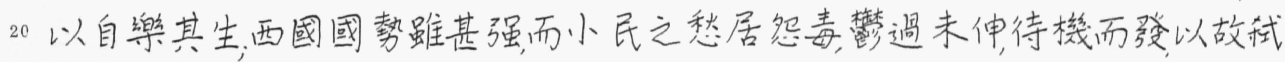
君刺相之事, 則知其政事有不如我中國矣。

西政所以不及中国之根本原因黄仁濟用形而上, 形而下為之解 釋, 黄之言曰:

技㙯微長富强謀術師総能精, 於齊家治國平天下之道又何所取 耶。若謂天地人物, 皆可以算學得之似此則外洋宜有治而無睬 有舆而無衰有生而無死有存而無之, 有强而無弱有富而無異。 何以治螕興衰生死存亡富貧之故外洋亦又得而握之。蓋此算 數之中又有一天理之主害焉外洋但知一時一事之推测而中重 早悉百世千載之推测斯師我中國有聖人而外洋不能企及者。 此種有數與理之差别, 而産生之政治高下, 盖郎中國之優於外國

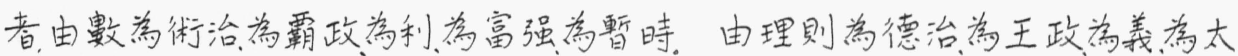
平茇永久。黄又言日:

外洋専重利, 並行一信字, 上下同心, 有君臣一體之意其國踓富强 終不能群情一統我中菜共重義, 兼行一仁字, 因少同心, 反形衰弱。 
惟修身、齊家治國平天下之道, 惯由此而推引。外洋專從數, 並行一 術者, 凡事皆有數定故並君臣父子夫婦兄第善惡真淫吉凶禍福 之理全然不講, 中菜則於數中桇説一理字, 百事聖紅聖傳皆有理 以穹其間。为

故朱一新痛斥西人之説至謬其國不能久存師由於西人知有㙯5 而不知有理, 朱以㙯括西學是更甚于黄之以數矣。

彼我狄者無君臣、無父子、無兄弟無夫婦, 是乃義理之噋。将以我

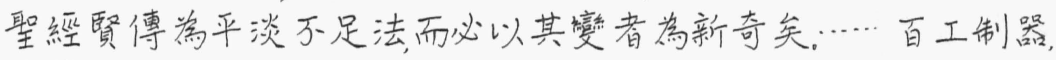
是㙯也, 非理也, 人心日伪機巧日生, 風氧堭開, 有莫之為而為者, 夫 何萝其㙯之不精? 今以㙯之未精, 而欲變吾制度以徇之, 且誉吾10 義理以循之。何異救刖而率其足拯溺而入于淵? 是亦又可以 已乎，……治國之道以正人心原風俗学先。法制之明抑又其次、 況(中國)法制本自明借。初無候借資于異俗詎可以未流之失各 其初祖而遂以巧利之説導之哉? 』

朱氏以為中國因義理而有制度故萬不可以㙯不如西人!篎而15 學之, 而黄仁濟更認為将来中國必能統一世界, 非由于武力之能征服, 郎以中 國之德治王道高出于外洋之故。吾人再觀黄代之説:

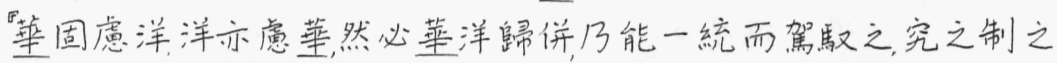
之道仍是彼以長, 我以正彼以巧, 我以拙彼以伪我以誠被以力, 我 以德彼以暴我以仁彼以街, 我以權彼以數我以理彼重利, 我重義, 20 彼重武, 我重文彼重商, 我重農彼重戰我重言。

黄代此種自信心理之根據則庶孟子之言, 黄謂外洋重利, 然孟子 言上下交征利而國危，外人言富强而孟子言孝悌忠信可以撻堅甲利兵，中西

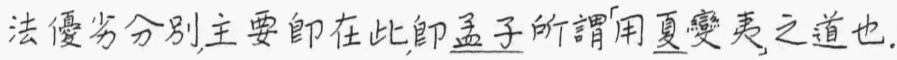

更有進一步甚将西人數㙯富强之術示認為不及中國者, 如屠仁 25 守謂西人所擅長之天算, 皆中國之固有, 大戴禮尚畫、考露曜及張子正蒙地圖、 地行地轉之説師西洋之天文地理, 六藝中之數師今日之西學宋儒之格致師 西洋格致之學, 中土伊古教法體用賅寅初無威遗、葉德輝謂西洋曹工育兵 之法亦不足效。蕽事在地利尤在天時西人遇天奖亦束手無策技藝雖巧, 第 工製商運一商兼運百工, 不如中國之各商其業, 英德兵制雖善, 但不能引于中 30 原之地以外則西文亦不及中文, 西教更不及中教也、李東衡亦言中国聖經 賢傅大而網常倫紀之重小而名物象數之微無不備具推而百家九流之書凡

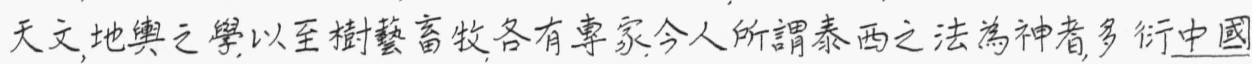
之緒餘以為絕諎特中國不以此専長耳。 


\section{乙西法可用而不宜篎法}

中法瞢於西法, 已如上述其有言西法可用者程度雖有差別, 亦相 去不遠師認為西法学技㙯富强種種長處可無妨採用, 惟須在雨種條件之下:

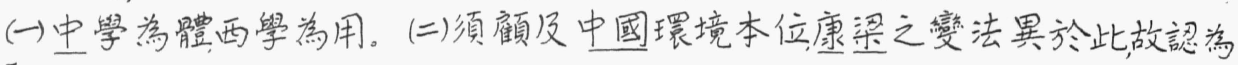
5 毃法而反對之。

\section{(a)中學虞體西學為用}

中體西用, 一語, 禹吾人所常聞, 而數年前時賢尚加以爭訟者。若 以政治思想觀黑言之刞此語之逐義, 乃為德治為主, 而药以法治, 師於王道之 中参以霸政也。盖所謂目的與方法之不同蓼用西法為應時勢之需要暫時

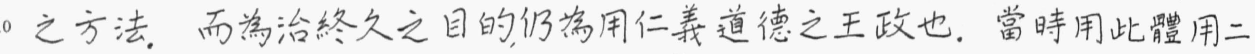
字之意義未必其心中有如今人所評論某物之體方有某物之用之意所謂體 用之分, 可謂主輔之分, 本標之分, 久暫之分也。

以中學浮體西學為用之辦法, 最著者為張之洞所言:

“先通經以明我中國先聖先師之精意, 考史以識中國歷代之盛衰

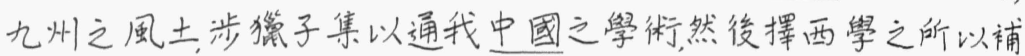
吾關者用之, 西政之可以起吾病者取之斯其無害而有益, 如食生 者有毫氣而淩可以飫庶盖, 先番臟腑而後可施薬石, 西學先由中 學, 亦猶是也。

文悌参保國會, 亦謂, 欲得西法之益必先修孔孟程朱之學植病根 20 柢使人熟知孝悌忠信禮義, 廉恥名教笉節以明禮然後始可習外國文字言語

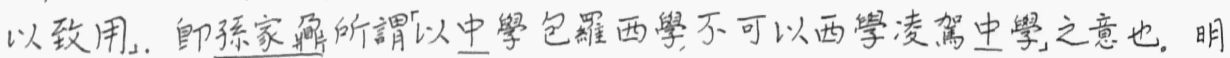
乎有此體用之分。故一方面用倎可蔡，一方面體則不能臂。中法之本網等

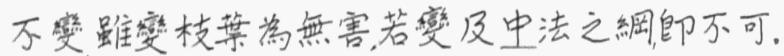

25 計哼而不榎。

王仁俊曰

一時可蜜與萬世不变之分, 張之洞曾詳析之:

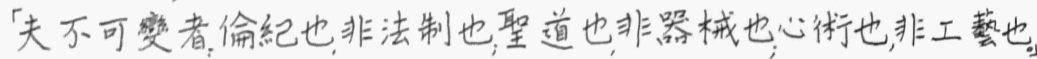

又日

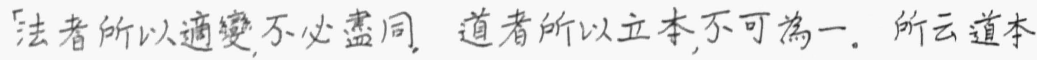
者,即主細四维也若並此㐬之, 未行而大乳作矣。

所謂百世不蜜之缃倫紀聖道孝弟忠信師中翼。而法制器械工

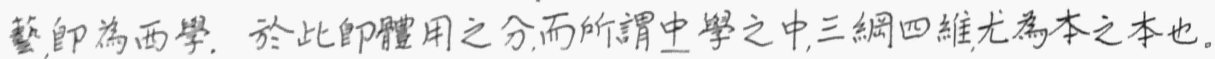
初視此颣名詞皆学道德倫理之範瞦, 似與政治無涉然在德治者之眼光則除 道德外無所謂政街道德即政治之工具也。治國方法毁為上引下效自己及 
人之教化方法故三綢之説乃治術之基礎所以百世不變者也。德治為萬世

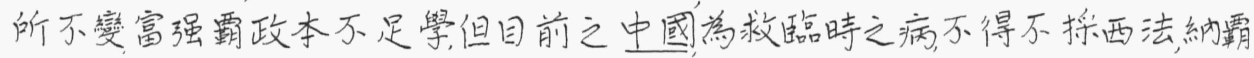
術於德治之中, 至富强追及外人之時中國有德治而西人但止于富强不能再 進, 是永久之勝利自屬於中國也。

此種説法, 初視之與康梁似非大相遥庭。姑不論康梁後日之思5 想, 世人舅為守舊師當時之康梁亦末嘗抹叔中國之一切政教其尊萗孔教示

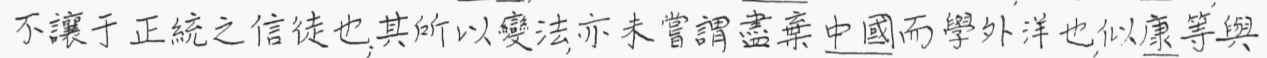

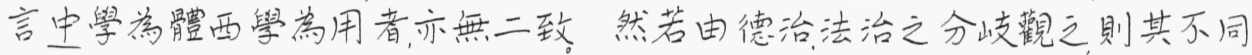
之處自明。

(1)内容上康之雖尊孔子而藉孔子改制倡民權平等之説此為10 其思想中最重要之部分。民權平等與三綱五常之説, 有根本之衝突而網常 倫紀師中孪為體者德治主義之基礎。故不同一。

(2)在方法上康梁主從革行一切制度著手雖未賞抹殺人治但 倾向于制度改革, 具體設施者多, 而不再高言道德教化之論。由德治者之觀 點視之則其治國之方, 但知有法尤离西法而非重德化之人心。故不同二。1 5

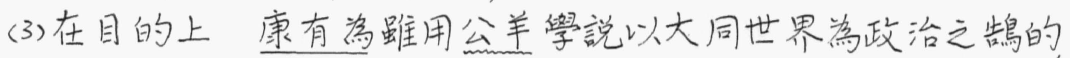
但康自言眼前之中國不能談王道惟須講富强故在主德治者認為康之目的 只在富强而富强者初非治國之最後目的。此不同三。

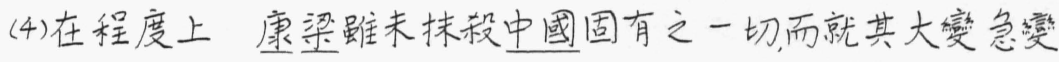
之態度刞载于将西法為主以中法為輔師法治為主德治為輔, 與中體西用又2 0 相反。此不同四。

$$
\text { (b)中國國情 }
$$

主西法雖長而不可亳法者, 又以离政治須顧及國情, 西法之採用 當以適合中國環境点標準, 易以今人之詞語師所謂中國本位文化也。就主

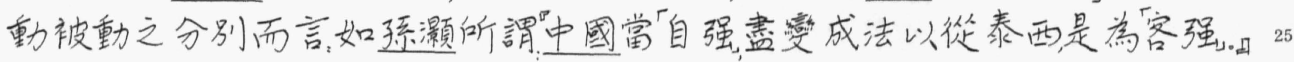
客强自强之分別蓋取彼之長補我之短則主動者為我嗇荎所學, 則俯仰随人 葉德輝所謂。自彼通之, 謂用夏敦夷自我通之, 則为開后揖盗, 此中界限不可逾 越。

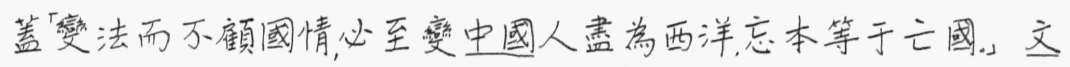
悌所以云学是又何必塾法者也。李束衡謂師令富强埒于泰西而人心之陷3 0 溺已不可救恐患不在夷狄而在奸民不在㞣弱, 而在㖟臣賊子。今人言國情 本位所以重要者謂一國環境不必同于他國故其翼説試之此國而收效者, 未 必亦同于他國所謂地宜者也, 當時示有此種論調。上引張之洞之言讀史以 儎中國歷代之盛衰, 九州之風土。即著重于㼜治者當認識本國國情之重要, 
知國情之所長所短知已知彼方知所以取法。葉德輝亦謂: 立國各有其政而 不可强同。褚成博則謂中國文物制度迥置外洋, 自有其致治䄮之法不必定 罍外洋行之西洋而治者, 未必行之中國而亦治。所謂國情不同之由來師文 化背景與社會緸㴒背景之不同。文化背景之不同曾康謂:

天下强弱之勢, 在于明已之短而用其所長, 中國之所長在人倫明 于上子, 親于下。仁義行乎天下, 飲食有其式, 衣服有其章, 所恃 師在此。

文化之背景主要者為德治之背景, 至于社會之背景則為徐致祥 所謂中國自古以農立國工商富强之途未必適用者也。

如民權一事, 反對者最認為有弊不可行者, 其所列弊點, 將述之於 下節, 於此先述其自國情立場説明民權不合于中國環境之故。

第一以歷史上之民族性言, 埧有王先謙之説由于西人民族性重 公中國則重私之不同王之説法及態度頗類乎近人之據中國民族性, 而論中 國絕不能行社會主義者。王之言日:

夫所謂自治云者, 以前西國本無政教百姓困苦不能相忍自上摩 下，以此成局。中國數千年聖帝明王殠其作君作師之力, 皘累經

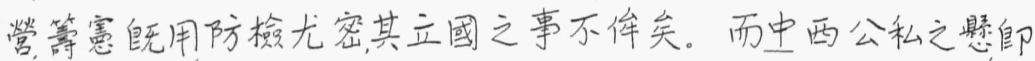
由此而生。西人各摤一自治之權鳩合大朋互相抑制坐而謀者 公益出而議者公言, 政令公之土地公之。为印度取之公司, 而歸

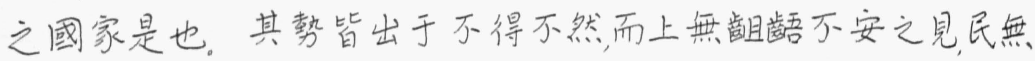
推諉坐視之心習成故也。中國之民, 自黄帝堯舜以来戴君若天 望君为神, 又的其宽然有餘也, 而欣欣焉以自私撃壤之歌是也。 自夏后氏家天下、民亦以為吾君之子也而相與私之, 君與民各據 其私而私之局成。其在詩日雨我公田遂及我私, 昌言之而無 所暲其由本桷矣。今以中國自私之心而引西人自治之政其不 能相合決矣。日本以専制之國改㪄立害嗄乙未和俄之事交閧

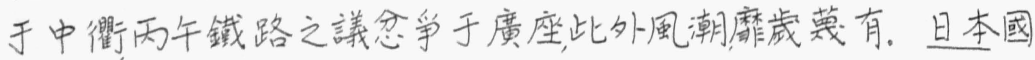
勢隆感尚猶如此若制度流濶奸究潛滋起而與官府相持殆有不 可問者也。 第二就國内當時情況而立論則有張之洞之四無益説其主要者 為人民程度不足以行民主, 甚似近年高論四萬萬阿斗不宜行害政而民主及 中産階級之政治, 者。張日, 將言立議院乎?中國士民尚安於固婳者多。環

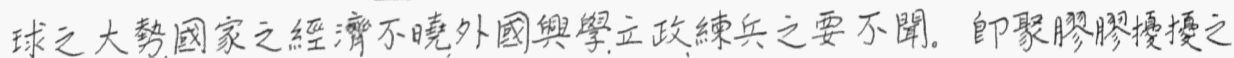

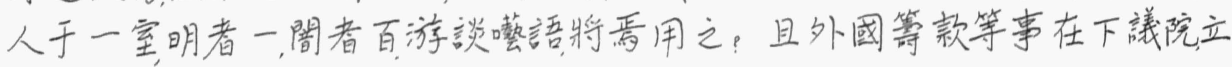


法等事在上議院故必知家中有貲者乃得舉議員。今菜商鮮鉅資、荤民又無 遠志議及大舉等铂必皆推諉默息議與万議等耳。此無益一。

其次則中國本有許多民權不必提倡尚有其餘之權則下可提倡。

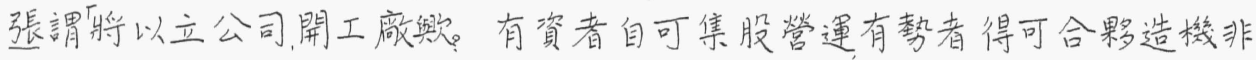
官法可禁。何必有權: 且变商徆習常有藉招股行騙之事, 若無官權為之愍。 罚, 則公司资本無存者矣, 機器造货廠無官㩲為之彈壓, 則一家獲利, 百家行引,

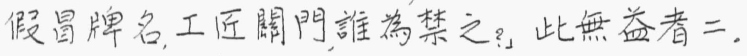

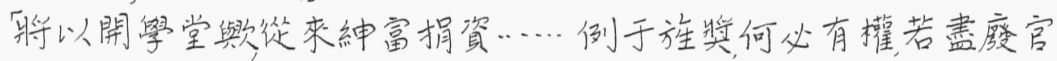

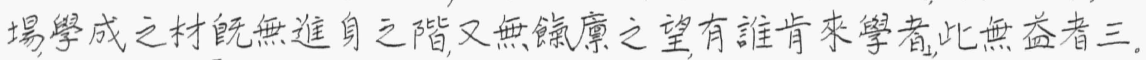

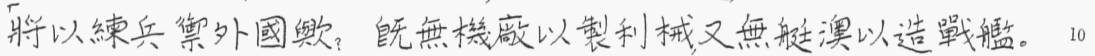
即欲購之外洋非官物亦不能進口, 徒手鳥合, 豈能一戰: 況兵必需飭無國法 豈能抽鳌捐? 非國家擔保豈能借洋倩?, 此無益者四。

就中國國情稇不能學西法再進一步由國情而論若口口聲聲言 西法, 所㸺仿者果為何國之法。譬如今人常質問主全盤西化者, 所化者俄之 蘇维埃乎德意之法西斯乎? 抑英美之德謨克拉西乎? 則不能泛泛言西化 15 也。黄仁濟在當時已有如此之詰難語外洋各國又有各國之法制政令各有 優劣短長尚難合為一致。非因時制宜取長補短擇其合于我國情而用之, 又 何所取法哉?

變法不但以中國空間為本位, 而且時間問題亦甚重要, 如梁鼎芬 謂'中國不宜变法只可取法制之, 壤者修之, 不足者採西法補之, 尤要行之以漸, 20 而又可續進突飛; 此又針對康有茇之迫不及待之態度也。因之反嚄法者 有康祭病一事西學又為一事之分析如王先謙所謂; 康梁今日所以惑人自為 一教並非西教。

康學師﨎法舆西學不相同除此點外尚因康所用方法或方式之

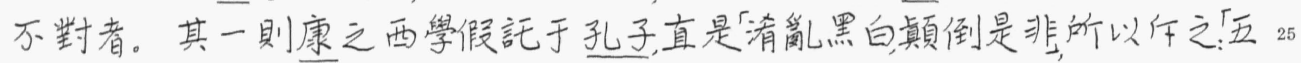
經之掻賊古今之巨虽。其二則河所謂皇上奉慈宫行者治天下, 臣民效之謂 之順。康梁假託新政以亂天下, 臣民和之謂之逆如此則界限明晰。彼等所 病乃逆也, 非新也, 離間雨宫何謂保皇, 妾希民主何謂保國哉?

討論問題

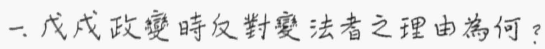

二反對綮法者主張㦄如何改良政治以抵抗洋人?

三試論黄仁滦所锶: ‘外洋専重利, 并行一信字, 中萃共重義, 兼行一仁字。

四、試論張之洞之四無益説。 
五, 戊戍政熟失敗之原因何在? 


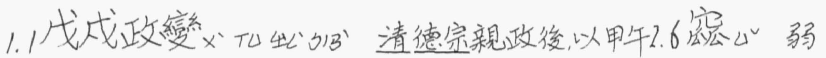

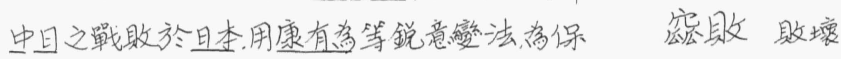

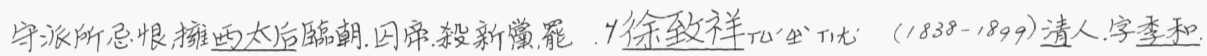

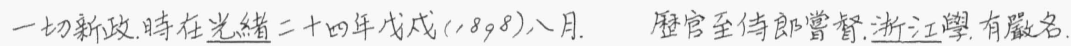

世稱戍戍政戀

.8矇芜 欺騙

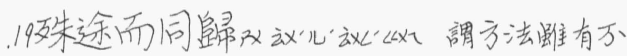

矇蔽欺騙隐瞒

同，而結果卻是一粶的

息怕利息以青金所獲之子金

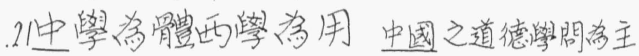

體、两洋之技㙯窝用

出息生座之利益

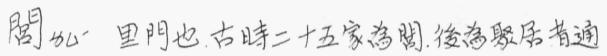

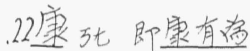

.26言吉416 青間。

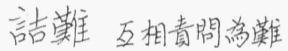

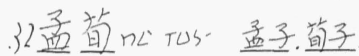

皏

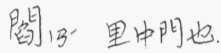

䦓閻謂民間

.9憎P L 瑟受之反

徒法不足以自行謂只有法本身示不能曾行。

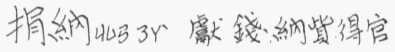

其意有必得靠人来推行。

保舉吆皈 因人推第而得官。

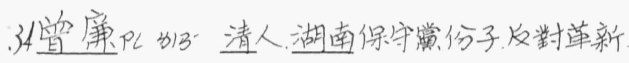

法度 $Y^{\prime}$ 名 $x^{\prime}$ 法制

2 . 1 胥化古官名、即㫣吏

岝吏舊時穹廳掌理公文案件的小官吏。

10 䅎心謀治

竞竟營競相言某求

報效弦伀報思效力。

１/市道队吆市場交易之道, 意即專從利益上着眼

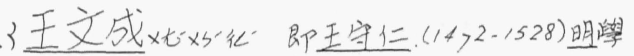

者, 字伯安世稱陽明先生! 官至兵部尚青, 曾巡復

14 言后《恥

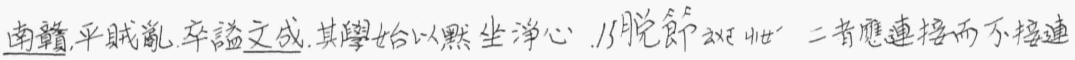

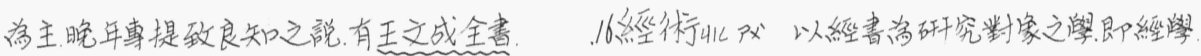

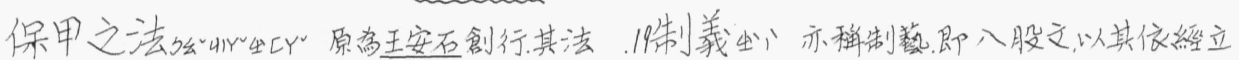

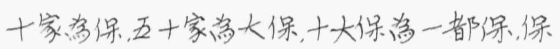
義故名

與大保各有長家雨丁以上選一人济保丁。

贛《引”江西省别名。

贑南江西省南部

挀病引以学恥

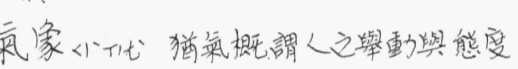

售加 意志純一

篤窝誠管忠鼻

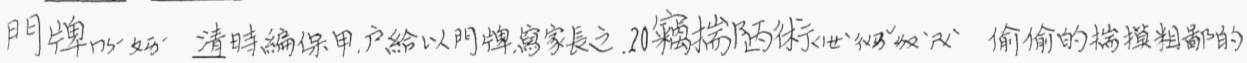

名與男丁數, 揭於阴上曰阴牌。每年更换之, 十法術。

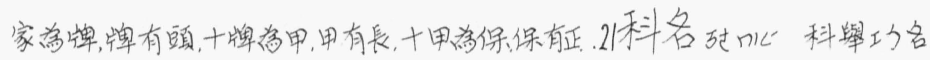

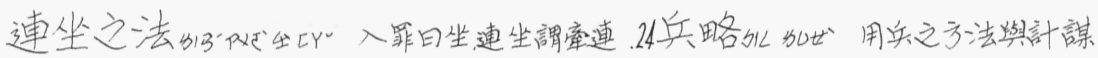

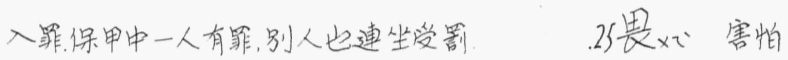

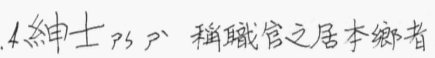

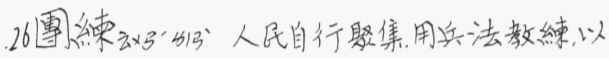


保衛地方者

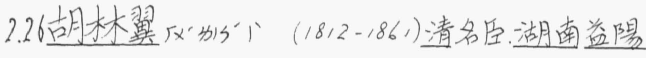

人, 字季高, 为減太平天國功臣之一, 後学㑊甘

總督官至㝵閣大繁士軍機大臣。

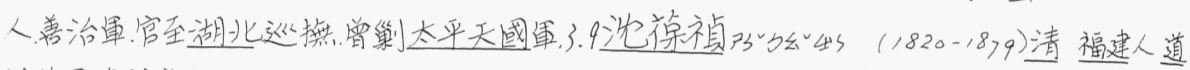
與曾成濇等莋各

24 因循以似守舊盟而不改。

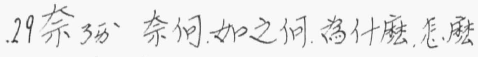

31王先謙忧仍《仍(1842-1917)湖南長沙人。

字益吾同治進士。官至内閣整士銜工古文部。

箸有漠書補注。後漠書集解

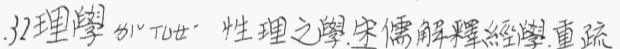

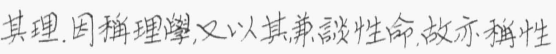

理然

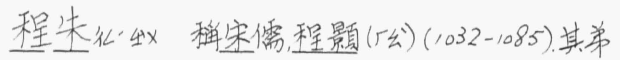

程監(1 $)(1033-1107)$ 及朱喜(1130-1200)皆以主敬

存誠消主

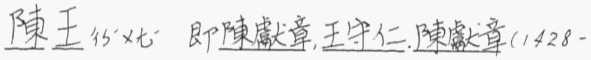

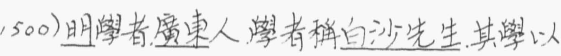

青争学主，有自沙焦。

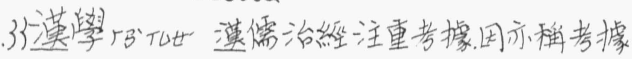

之攀。

3.2㬎的桃點

怒各古韻久遠, 長久

图炕。然

㬎古国湾终久總是采用

3 䈎德輝は犹化(1863-1927) 楜南長沙人清 光進士。太平軍興以守城功至江西巡挴光 緒初官至兩江總督。

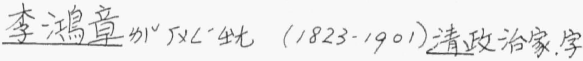
少全合肥人, 平太平天國有功官至直隸總督。

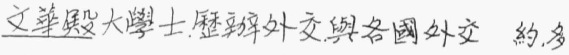
其手訂

10 武足䟢。

步武謂追随人後而涾之。

㞸平、猶是, 語助詞。

伊始謂事之開端。

甚斗能商量

甚斗酌度量其可态而去或取之

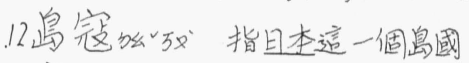

摩n, 應作犘

燈闌加物腐欺, 欺壤

縻爛壞到不可收拾。

.13械厂謂器物, 兵器

15 侮欺厴

16 䙴汉, 謀

遠酷段於粉飾忠氣伏於狊私因遮 瞒過錯, 使遠大的言㽪失欺。因领及自私而 失掉原有的忠心。

光緒進士。清末滩新運動盛於湖南曾力持, 18 間动才能下等者

反数立部箸有書林清話等

4 不值一笑外出1 公喻毫簧僄值

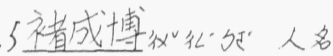

7 謨叭謀畫

践山富行

察践窝行

9 同治动出清穆宗年躆(1862-18 4 )

等明細密之毛

閭算才能下等者

20 J上昌加日”征(1823-1882)清人字雨生, 官至

江邀巡撗，所歷皆有名綪，佐曾國藩仿造两洋

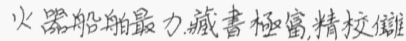

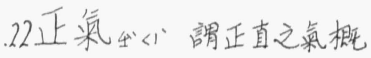

靖4

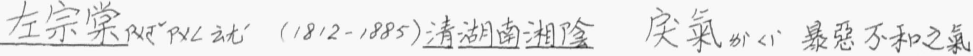




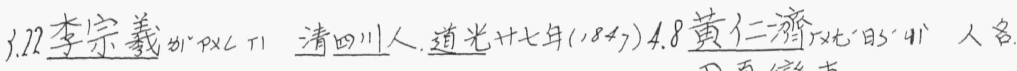

進士

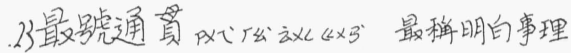

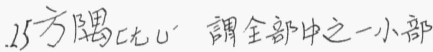

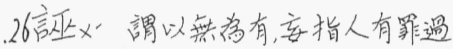

昧们暗藏起来, 不明

甚阷克勝

甚戈爱 平定㖟事

27 翼; 輔助

輔翼㜂助

实子時《ャvア”指康子之役, 清光緒二十六年

(1900)義和團起而排洋, 笑、美德法、奥、意、且、

俄入威䨿軍入北京之事件。

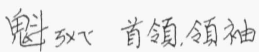

罪鬼斗罪犯之首領

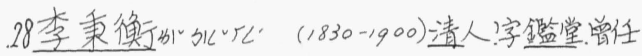

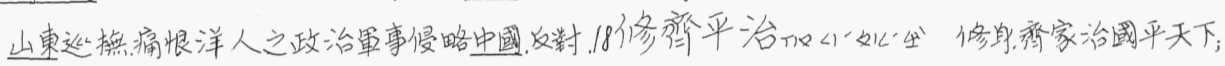

一切新建設。

.30侈行過份，大

侈言大言

31賦顺承受

賦性人所天生承受之性情

迂拙心的“过闇等拙

32默可方語

黑犬察静静的觀察

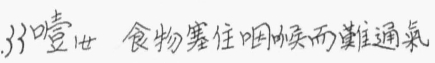

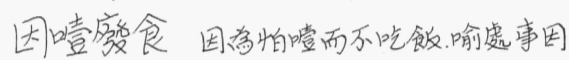
偶雨两改其常。

4.2刺占探察粙取。

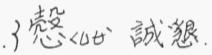

端菢空端正而誠懇

.6舆敢山”語末助言司, 表疑問, 如“吧”

.7捄报同, 救

捄時挽救時世

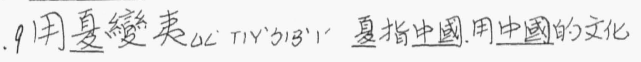
改餐外邦人。

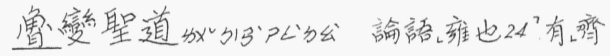

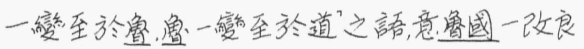
即可有聖人之道

洩他同泄、泄、多貌

沓却多

洩沓甚多

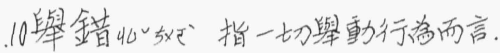

敬復山“地”券敬的受命行事。

. 園心邊界

疆園疆界

恤心可粼,爱惜

.14留下謂天空

霄壤懸隔猶天地相離甚遠 此为儒家所提出的政治哲整即先由调人做 起, 純而搌及家庭國家, 終至使天下太平。

20 莛金13 席㬝

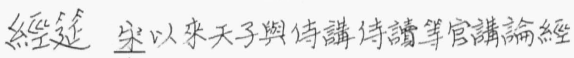
史, 本無定時, 明始定於仲春( 春李之中) 伸秋舉 行雨次, 清因之。

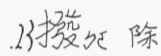

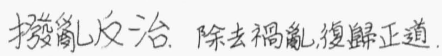
揵奻”快

有捷于反乎而整䧼者能返到治而 没有团雖的最快的法子

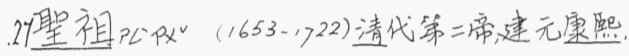

守成两兼，開制，奠定清代之局，在位六十一年。

28 三潘 4353 清初明之三丨降将, 虽三桂, 耿《精

忠, 尚可鼓三人反, 後被减, 世稻三渚之乳

.29文妙”圈主王

武”周武王 


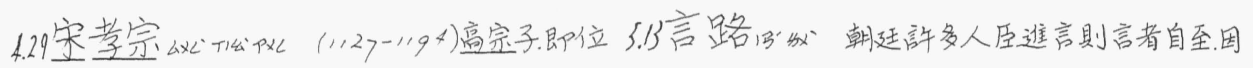
後力圖恢復而伐金、屡错功, 在位二十又年(1, 6 3 -

謂言之由以進者曰言路。

1189 )

.30群羊擘) $<S^{\prime}$

群小謂象小人

. 31 雪 r $^{\circ}$ 洗除

大恥可雪大恥学可以洗刷乾淨了。

.32领《13 象人, 皆

壬明㙰人

会壬謂小人

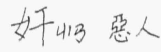

奸倿有叺的㙰人

苔如惡

賢歪好人, 壤人

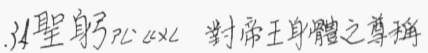

5.1 它始半

它言半句話, 即很短的談言古

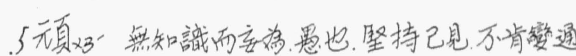

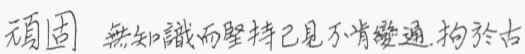

制而方知㣞通。
.14奏效㹣伀事之進行而有效者，如言某事现

已秦效

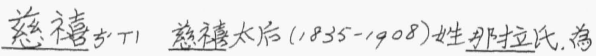

清文宗妃、㖟宗母, 穆宗德宗雨朝先後䠛朝㯖 政, 共四十七年、晚年耽逸樂寵倿臣、國事遂大 䍃

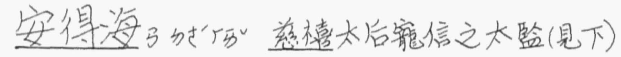

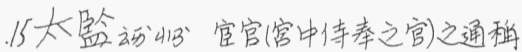

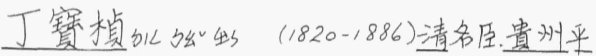

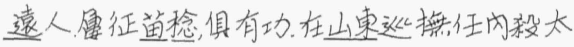

監安得海尤箸名。官至四川總督

正法乱E Y 治其罪

就地正法謂即在犯罪之虎執行死刑 神武門的“的”北京售皇城之一北阴

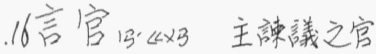

.19宥18 留赦

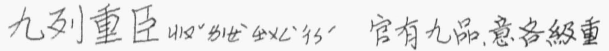
要的官

.18㿟TCS 順也

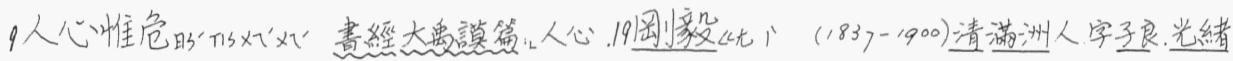

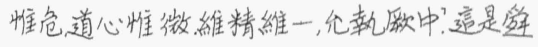
間官至兵部尚書, 軍機大厔、反新政, 康子役起

剖遇的話: 人心是不安定的, 道心是細微純蟹

的, 故必䩄時時注意尃修, 以保持中庸?

必傅原秋马”锶傅受之秘密方法

10約U世簓約, 約略, 大略

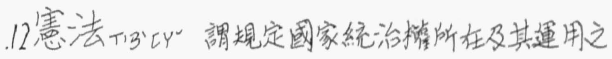

根本大法

聒軍入京随慈禧画行, 死於途中。

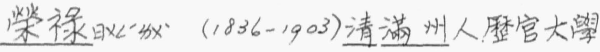

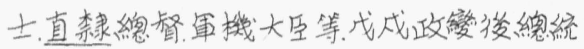

武衛策, 義和圈之役, 往西安, 事定回京, 仍居

要位

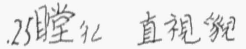

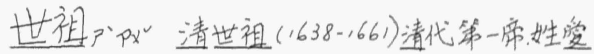

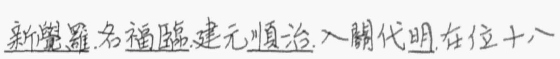

年 $(1644-166)$

瞠乎其後相差太多, 趕不上之意

盟基抲4 1 创立事丵之根基

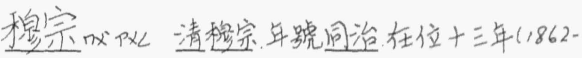

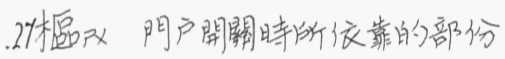

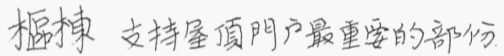

$\left.187^{4}\right)$

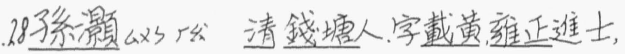


官至左副都御史

族病狄

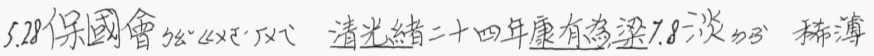

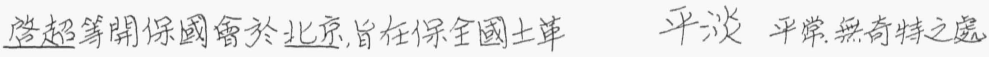

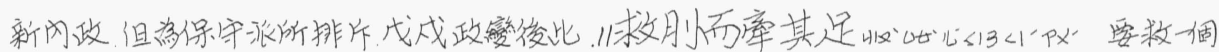
禽示消减

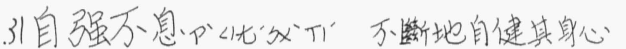

也易熟: 君子以自强不息。按此指個人浐

食而言, 又九立國之道示须先務自强。

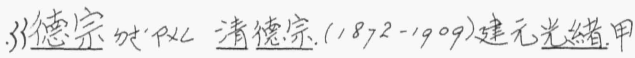

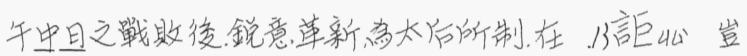

位三十四年。

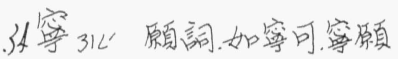

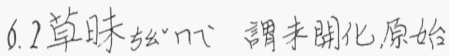

. 8 猝战急速

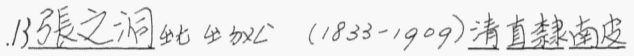

人, 任督悲達三十年, 在楜遮總督任网最久

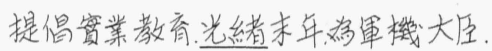

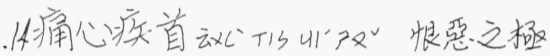

.15替动哀

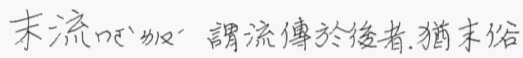

末流之失後人的過失過錯。

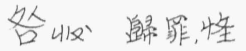

. 33 征秋 取

上下交征利在上的舆在下的被此互相 取利

悌云”謂善事兄長，或兄弟友受之意

捇动、打撃

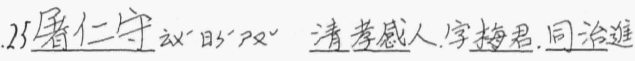

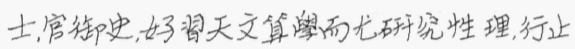

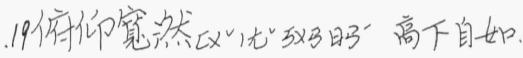

必端人多畏之。

.20怨毒吸放 恨㤎

㷊楼心謂思皘於心中而不问解

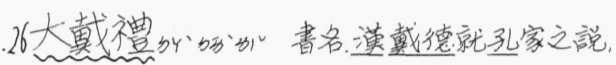

輯古禮而成共入十五篇, 现只存四十篇。

.22开分而上化儿陇謂超乎形顝之外者:如精

神思想等。

形分下下似儿似背具體而有形的物筧。

.28案际制治，主

主宰對于事物具有制裁力者

7 . 2 直出指女子不失飨者由真

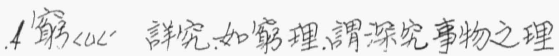

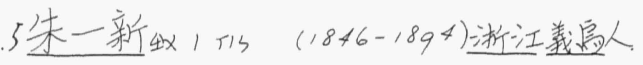

字鼎甫。關心當時國情數次進言, 曾任噟雅

書院傅席。

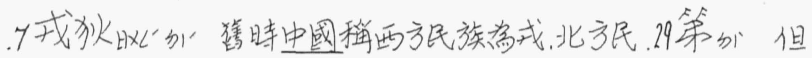

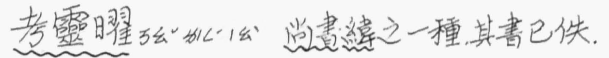

\section{克阮畫有輯本}

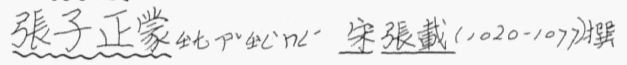

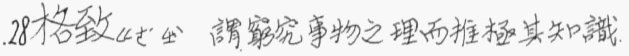

西洋格致之祭即指令之物理學。

中士知动即中國。

中土伊古教法中国古時的教法。

賅《偖, 兼

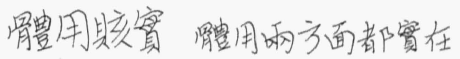




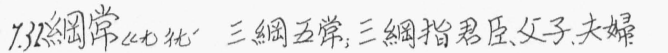
五常指君臣、父子、兄弟、大婦、明友、又請仁、㐿、 禋督、信。
宗的傅, 德宗行新政, 命開辦京師学堂, 後任 大楽士。

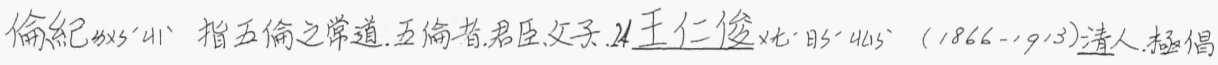

兄兼夫媂、明友。

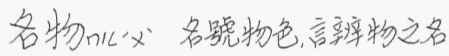

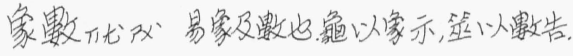

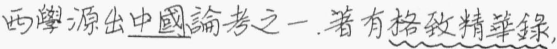

及整致克微，把古青中所載材料之舆西学

有閣者都提出来以證西残之所本。

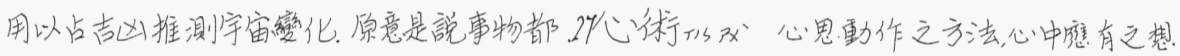

有一定形象及數量。

33 輿心謂地

地筫具 今锶大地。

.34 䋓言旨收世”造言精絶

8 . 12 標夘表现於外者

本標根本及外表

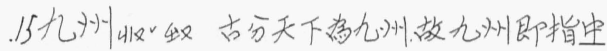

國

周土化动”謂其地之風氣與土産之物。

涉㢳捄为世涉水獵獸, 喻看很多書。

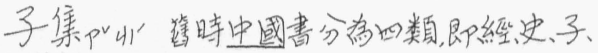

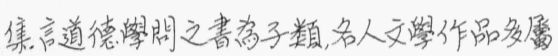
集類.

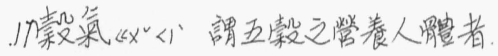

羞似謂有滋味之食物

庶羞察味

臟肬胸腹内各器官之總稳

腑的“肚内部之哭官。

臟腑胸腹冈各器官之總船

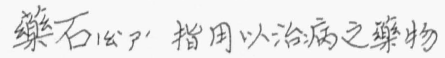

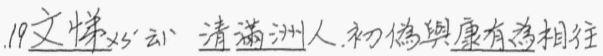

返，得斥有学任意妄为

.20柢外豆之根

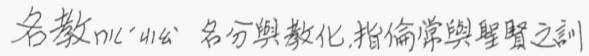

氣食令《4 世謂人之志氧與情操

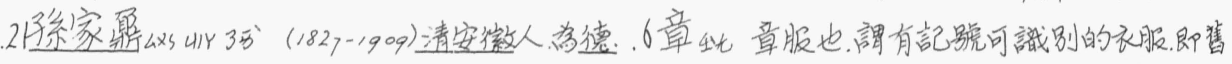

法, 如正義感誠富、仁慈等。

㭁維对，絪也

四维謂禮、義、莱、恥、四者学治國之四網也 31弟云同悌

.3)嵭得田地

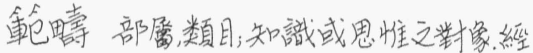

分析後所鲜之各大類, 且可依之以成系統者

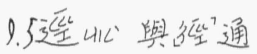

暹庭即些庭謂不同

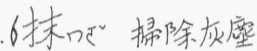

抹殺探减之意

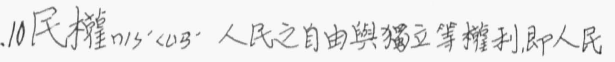
對政治上之權利。

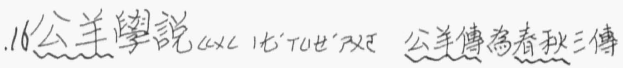
之一, 為今文, 其要旨在碐揮孔子作春愁之大義 微言, 最要者学三世説, 即毃世, 升平世及太平 世埭有学引伸之为人類社會弡展的三階段 公美祭邁朝曾受重视, 至清朝又復興起。

告鳥《即告鳥的,習射者之目標

.2 捍、中國的一種古禮男人見面時多用之, 此

處表示讓請的意思

捍盗敦請强盗進爽

.30即令U1 如即便, 縱使

埃我相等

10.5 人倫的“多如”謂人類之偷常颜五偏條 
時召臣法定之服。

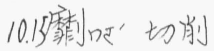

.16殚加竭責

.17亿年叹, 奠等之意

.18㮩恢聚集

杂島合大朋集合成大賞

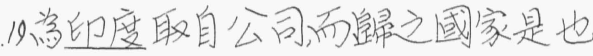

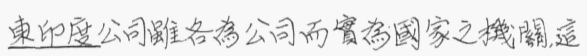
是一好例子。

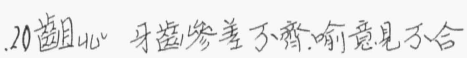

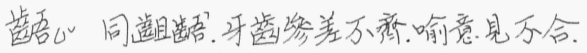

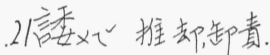

推諉推托，不真責任。

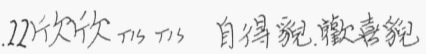

撃壤山1 日尤”壤、古時玩具, 用木作二壤, 前展後 鋭, 如鞋将犬。先置一壤於地, 再從三四十步, 外, 以 手中壇擊之, 中者峦上, 謂揧壤。

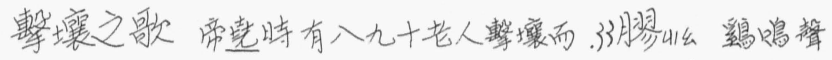

歌日: ‘日出而作, 日入而息。数井而飲, 耕田 而食, 帝力於我何有哉, 意天下太平百姓無 学, 安居樂業

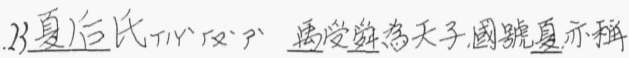

夏后化

24雨心下雨降雨

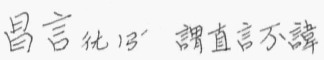

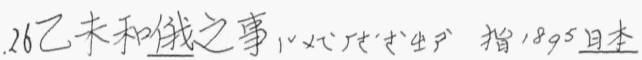
涌也

营咬没有, 洪

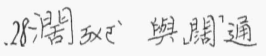

奸究掼盗賊。 之人.

固必腒婳

.34腊分思帏

嚾门葰中語

焉乃安、何,怎樣 什麼呢?

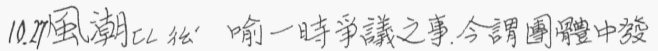

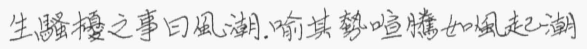

磨紫总有没有一年沿有; 年年皆有。

流澅布散開，流行

究奸; 外病盗肉青宛

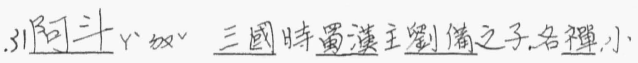

字阿斗，性胆小軟弱。此處用以形分容才能低下

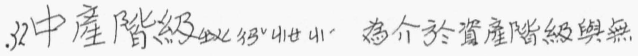
犀皆級間之小商人小自耕農，猲立手工業者等。

直屋两謂是聞波少

玨球泍”叫猶言全地球，全世界

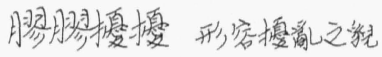

我采焉用之要怎㨾用他倗呢? 用他倗作

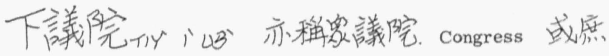
民院 House of Commons. 出人民公選之議員組織。

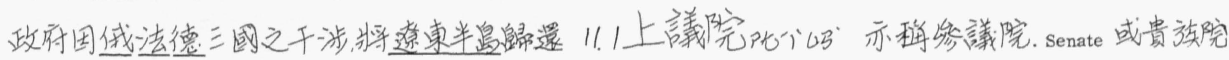

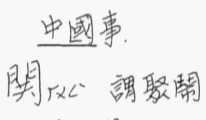

文珰璔言互爭

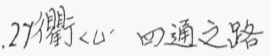

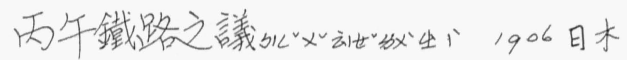

公佈鐵路国有法，並收置京金鐵道

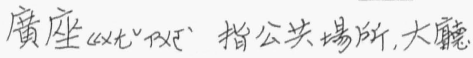

\author{
House of Lords \\ 鉅岓與这通 \\ . 4 股《事物之一部份, 在此指股分而言, 即特營
} 業资本分端若千部分, 謂其各部分日一股。

果多以合垬

合果多謂二人以上互訂契約，共同出资，共作 同一目的之事業。 
11.8 方焦4 謂表彰

11.28 妄希非分之希望絶不能䆩现者。

旌獎表掦嘉桨

. 9 食氣升所受的報酬。

亲犾所受供給

䭒㡴公家供給之日用

10艇阭”小而長之船

澳公 海船可停泊之退

艇澳 指造船故

艦山分䟠船

. 11 島又即岛鸦、一㮔黑色的島

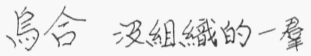

.12 抽㪀謂自全部中取出一部分

整捐加４００３清朝所创的一種行商通貨之税

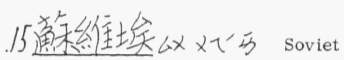

法西斯CY”川

德謨克拉画施们さが多厂D Democracy

泛坋不切窗

泛泛浅簙, 万深刻

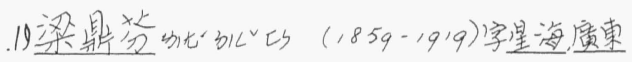

人, 陖與張之洞幕府事, 深隹豪梁民㩲之説

.21金十敉、細長絴物之具

舒對正對

. 25 直出竟

直是竟是, 铇直是

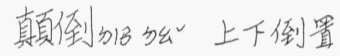

. 26 掻虫吆, 専食稳根之害蟲

掻墭、喻小人之存害者

莕茧汃”蟲名

巨虽蟲稳奸盗之巨鬼斗

.24 和代鳌相碓，如附和。

.28离倠間为“情使人万和

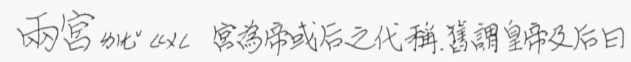

雨宫，此戛指德宗與慈禧

妄忧篎誔不筧。 


\section{第十六課 道統與治統}

\section{錢穆}

作者小傅銭穆( 1895 - ) , 未進大學譡書, 曾任北京大學、西南㖒大等校教授、又為香港新

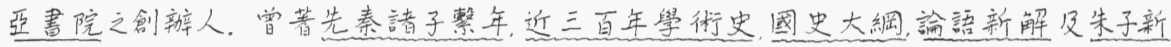
學塞政熋私言等書。

木課简介本文睩自作者著作政瑟私言一書, 全書分上下二卷, 共十五篇, 如作者於自序中云:

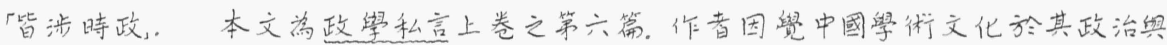
他國情形相異, 其原因絶非偶然, 因而在本篇介紹各朝代之政教關係, 詳列政教 合一之要義, 道埨其中得失。

中國德統政治尚有一端義當関述師政治與祭街之緊密相融洽 是也。中國古代政治之轉换點, 乃在春秋戰國之際其時自由學者興起, 百家 爭鳴並多握得各國政治之實㩲由此而貴族政治解體士人政治代興。孔子

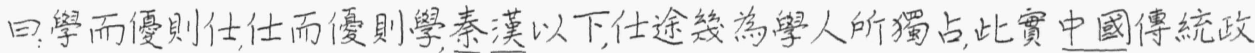
治一至堪注意之大特點也。然本篇所欲論則不在此。本篇所謂政治吠街 15 緊密相融洽者, 乃指於政治機構中, 有不少専屬學衍文化事桠之部門不僅為 學人占仕途乃謂於政途幹等業, 政府中多設専官, 不閣政事, 而主持一切祭衎 文化事業之保存擴大與流愽此等垂在史册國人認為固然不復警怪然若與 並世各國以往史迹相互對比則必知此非偶然殊值大書特書, 一表彰之也。

中國傳統政治中之學術譏䦣歷代演繁紛雜大抵學人入仕途多20 有不問政事, 而仍以尃修學業病官職者, 此皆仕途清選非才優學卓不得充任。

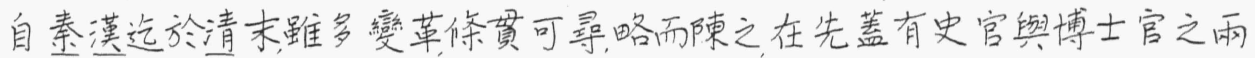

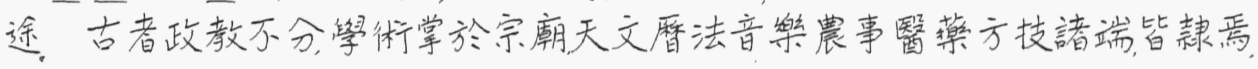
總其任者勋史官也。此為封建時代之覐職。漢書㢣文志所謂王官之學大 率屬之。戰國以下, 百家風起, 其勢上掝政府各國皆爭養士, 有授以大權責之2 5 重任者亦有飬以厚禄奉以敬禮而不煩以事, 僅備顧閣, 不治而議論者, 而齊之 稷下先生為尤者, 演熟而為秦漢之博士。此乃代表社會下層平民學者新興

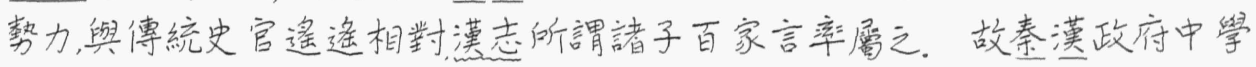
職流别、以史官與博士官捣雨大類史官上, 承官學而博士多屬家言, 然二者同 屬於太常此仍古者, 㩓街統於宗教之遺意也。

史官承舊統然太史公自謂文史卜祝星屠之間, 主上以倡僈畜之, 較之春秋衛史萃龍滑與䄚孔日, 我太史也實掌其祭不先國不可得, 地位迥殊, 蓋史官權望之墮落, 正足徵政治意識之上進舆宗教露威之衰替, 然史公上追 春秋而為太史公畫, 不僅卓然脱出宗教氛圄抑且底貶諷諭, 文無避忌然言論 
之自由樹後世正史之典範。此後歷代對於國史, 皆知鄭重赛護覞妙選人才, 又尊其權任不加侵犯故國史館雖屬政府一機閣修史雖為政府一要業, 然並 不因此有損於史官秉筆之猡立與尊嚴直文不隐奉为史職。建州入主, 欲牢 籍明代遗臣、万以修史相號召, 官修二十四史踓不能畫满人意要之治乳竪奸, 開卷朗然猶十得其七八也。

至秦”漢博士官, 尤為䫛職踓秩僅比六百石, 然得頚朝廷大議備左 右顧間, 漠武以後又掌教弟子, 並多出使循行, 或視水旱災荒或行風俗流民, 或錄冤獄或宣諭告, 名臣碩學多於此出。然䰠査而下, 博士議政之事渐稀大 率專掌教育, 至隋别設國子監博士始不隸太常, 此学學術正式脱離宗教之最 10 後一步。然自唐以下, 國子監僅一冷署博士徒素餐不聞於國家教育有所建 白, 此若中國傳統政治於教育颇不酉職不知此正中國傅統政治一優點赤漢

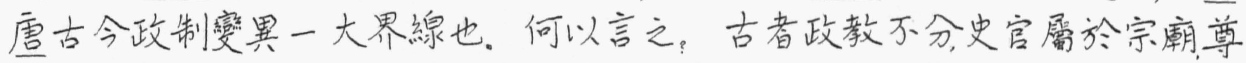
嚴無上, 列國之史, 皆由周天子分出諸候不能自有其史此古制也, 自戰國鲁

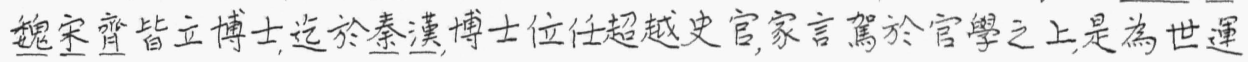
15 之一進, 漢武表章六藝専設五經博士掌教弟子, 皆予出身, 乃復由家言轉官 學。然哀平以下, 即有古學流行社會, 與朝廷博士爭衡, 東京博士弟子威至三 萬人, 然博士多倚席不講, 其時經等之流得則古禜伸而今學絀師亦家言 感而官學衰之一微也。所謂家言盛而官學衰此師祭街自由統於下不統於 上。自孔子迄於鄭玄, 皆以民間私學同靡一世, 樹範千古, 然政府轉加尊禮不 20 復壓制。馬鄭所講, 皆今古雜采, 不遵循朝廷官皇, 而朝廷予以寬容此正猶孔

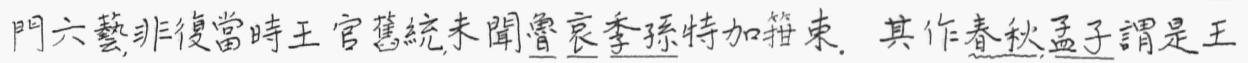

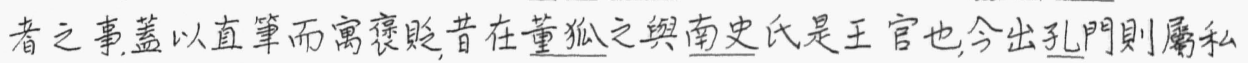
家王官統於上, 春秋則為家言統於下。此後歷代政史論其官職踓仍上統而 其精神則皆家言, 皆下統也。若諞教育、玌师七十二弟子, 墨徒三百, 其他諸子

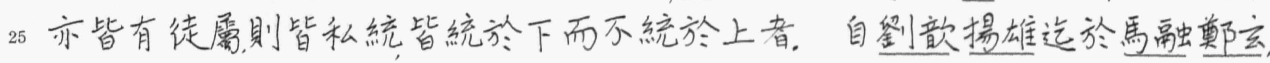
皆私言, 皆下統也。古者所謂政教不分, 乃宗教非教育、漢武五綬博士掌教 弟子, 則已非宗教異於古昔然政教合一终不可久教育之㩲終亦下移。教育 重家言不重官學循下統不循上統, 此正中國傳統文化一絕大特點, 而政府亦

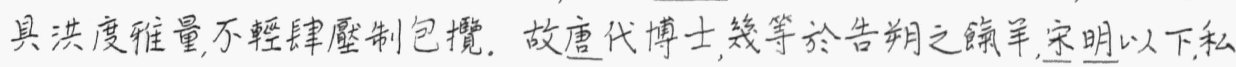

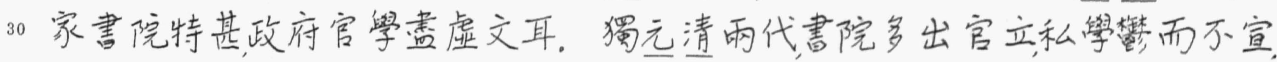
然此固非中國之正統, 故知中國傳統政制雖稻政學緊密相融洽, 政府於文化 事業踓保護宣揚, 不遗餘力, 然於教育大權则讓之社會私家之手, 史官以多涉 政事, 又非私家財力能腾故歷代皆由政府操持然仍不失私家自由精神。此

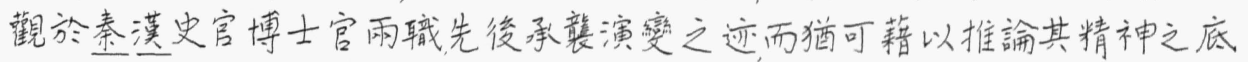


裹者也。

中國歷代政府, 又以收藏圆籍為首先注重之一事。張荅為秦主 柱下方書萧何入咸陽, 先收其圖書簿籍藏之。此或猶多闢於政事者。至史 官有金遗石室之藏則專屬文獻其王室藏書尤著者, 前漢有天禄閣, 後漠有東 觀, 鬿至以下有崇文觀總明館, 士林館, 文林館, 麟趾殿諸稱。及唐遂有三館, 定 又增祕閣而学四。及清代遂有四庫七閣蔚為政府藏書之大筧。此等藏書, 皆有典司尃官, 校傕簿錄始自劉向歆父子七七略中經任昉四部、篇目鳌然源流 明備, 試閲八史經籍志下及清代四庫總目, 中國傅統政制, 注意文獻網羅散佚, 保藏整輯之功, 殆舉世莫與京, 而秘閣藏書, 又使學者得恣意漁獾其中, 如掦子 雲校書天禄閣, 下逮東京, 碩學名儒, 皆藉束觀為著作之地, 如延䇫以博士徵拜10

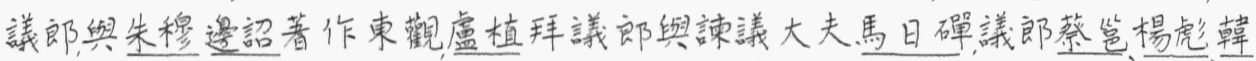
説等, 並在東觀䋶漢纪、馬融拜校書郎中, 諎束觀典校秘書, 蔡䇼召拜郎中, 校 書束觀之類。此皆無政事職守, 専典校書著作。及槐晋遂以著作郎名官。 齊梁以下, 著作為令丵子起家之選。下及定代館閣尤清菜, 必號稱天下英俊

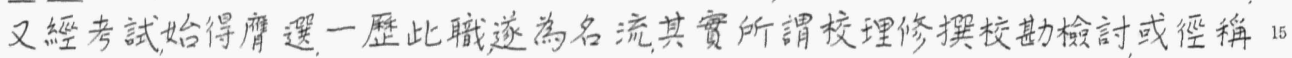

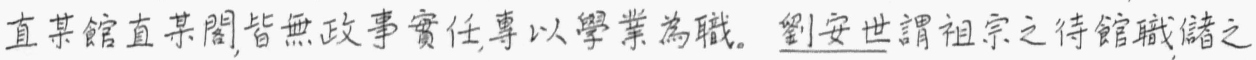
英傑之地, 以飾其名節, 觀以古今之書, 而開益其㮩明稍偠其庰而不責以吏事,

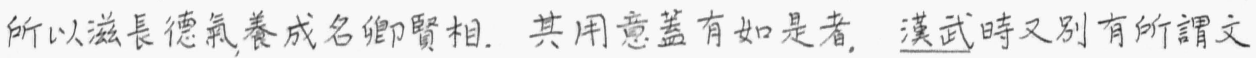

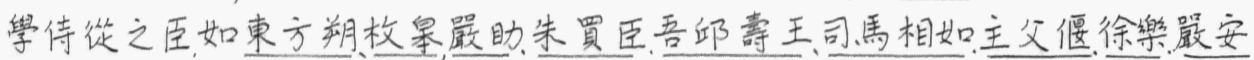

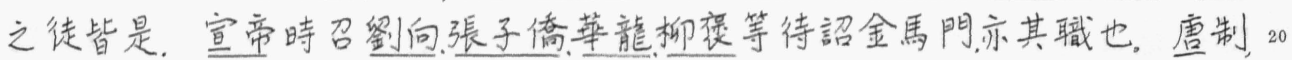

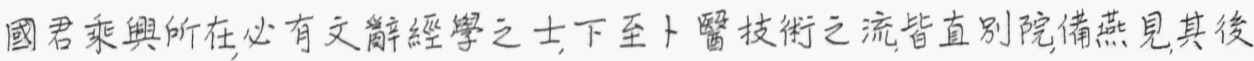
翰林學士遂掌内命, 至號内相、權重䄚遇甚至。及明代専設翰林院畫移前 代祕書著作之職䠋之, 而制誥别屬内閣則翰林仍閑職, 其地位極清高, 除浮講

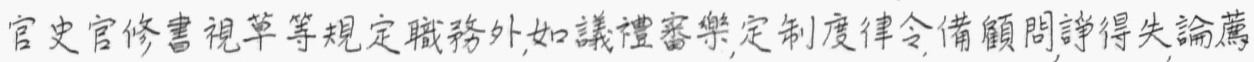
人才, 指斥茹位, 以常獲從幸, 尤胃親密, 故於政事多厓救將順之益。明代又有 25 庶吉士之制, 以新進士未諳更事, 俾先觀政其先進學於内閣後則隸之翰林, 此 等亦無政事害责, 翰林皖望縈地密, 從容中祕於古今典章沿革, 制度得失可以 恣情探討以備一旦之大用, 而庶吉士以英俊後起, 亦得侍從䔡灾, 並許建言白 事, 储才養望学政府培植後補人才, 至有深意。故當時以翰林為玉堂仙以庶 吉士為半路修行其為時瞥羡如是。清代亦沿明制中國近五六百年来政府30 大僚於政事有所建樹者大率由是中出踓流弊亦不免然其崇文尚學之用心,

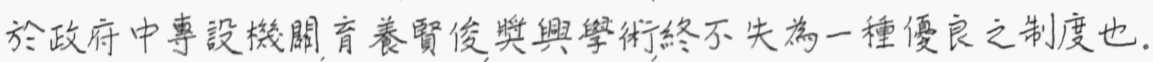

今就中國傅統政制與掔術文化事業相聯慗相融洽之要義再扼 要言之。一者在有考試制度, 専为拢取學人使之從政故其政府僚吏乃全為 
學者。此種政制可名為學人政治或簡稱等治, 以示别於貴人政治或富人政

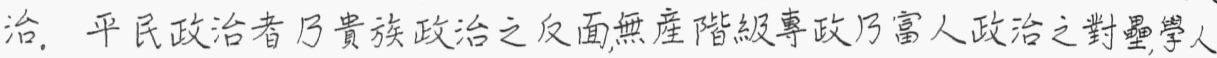

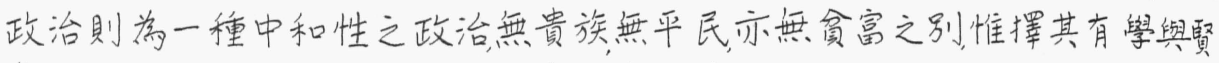
者。然覞使從政古人云, 一行作吏此事便休, 政府究非學校官吏亦非覐者,

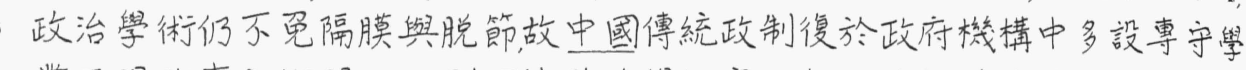
業不問政事之衙阳如此則可使政治學街密切相融洽相渗透, 抑且社會文化 事業之保護舆推動, 有非政府之力不克蛊其圆霂之功能者。言中國已往成 绩則歷史紀錄团史館)與圆書保存(袐書監)尤為其最著之雨事。然此非政治 干预學街或支配學街之謂, 學治之精義, 在能以學街指道政治, 運用政治, 以连

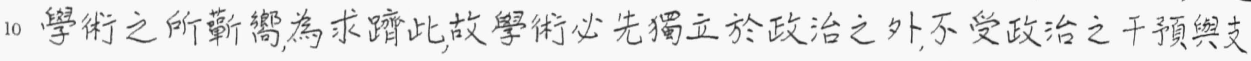
配。學街有自由而後政治有挒導。學街者乃政治之露瑰而非其工具惟其 如此, 乃有當於學治之精義。故中國傮統政制, 一面雖注重政脬之密切相 融洽, 而另一面則尤注重於政學之各褞厥職。所謂作之君, 作之師, 君主政師 主教。孔子以前其道統於君, 所濖王官學是也, 孔子以下, 其道統於下所謂百 15 家言是也。玌子為其轉捩之楅紐。孔子賢於堯舜此则師統尊於王統也。 漠代設博士, 其意踓欲復古者王官掌祭之舊統, 然六籍皆出孔門, 又㜾子素 王為漢制法則雨漢絰師論學仍重下統道統於假不統於君, 盖自孔子以下而 其局已定矣。故政府當受學術之指蒋帝王亦當有師傅治權上行, 教權下行。 晏相必用學者, 此自西漢已然。天子必當尊師向學其風自束漢而著, 後代遂 20 有經筵日講之官, 而東漢太學生之議政其兆端亦遠有由來矣。及於隋唐政 府遂尃掌考試不主教育, 唐之國子七學僅成虚設。客明而下, 莫能革也。其 有反此道而行者必為象誹所萃。王荆公身居宰相而頒三經新義, 大為時㹂

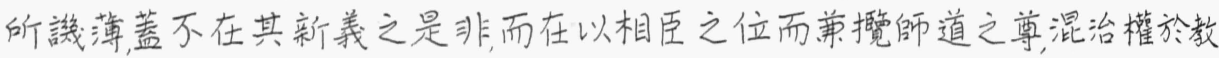

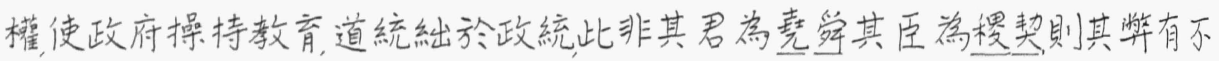
25 可勝言者。張居正當明之晚季振衰起弊, 功不可没然其彈壓害院講學, 首相

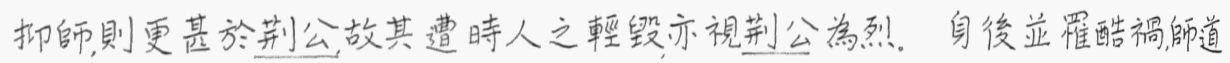
之失其統, 而上統於政府, 此自清代部族専制乃始然耳, 明代以前下爾也。故 中國德統政治於學街文化事業踓畫力保萑而扶翼之, 然於教育則一任社會 自由抑且尊師萗道王統自絀於道統未賞以政府而專擅教育之大權。 然今日國人觀點則颇若教育乃政府之天職若教權即統於治權 此亦有其來歷, 一則承㢣清代三百年以治權侵越教權之皘習而視为固然一 則模倣西方制度而不復詳譬彼我之異同。西方自中世以来宗教政治本屡 分行, 教堂之尊嚴踓王候亦俯首屈滕如庶民, 是彼教權亦在下不在上, 抑且教 權尊於治權亦與我約略相彷彿也。惟彼方宗教朁主出世而復多預俗事流 
弊息无甚, 反動亦烈。自北歐宗教革命、以及現代國家新政權興起教權逐步退 讓治權逐步進迫政府遂代教堂操握教育之權然此所謂教育權者, 亦僅其一 部分而已。舉要言之, 則國民教育與職業教育是也。欧洲近世大學興起若 溯其淵源則亦一種職業教育也。自科學感興近代教育益䞶新型然彼中大 學教育、既多保有自由精神抑且祭校教育亦終未全㚜宗教之權威。昔唐儒 韓愈著師説, 分師為傳道授業解惑三者。言近代西方等校教育, 特偏於授業 解惑而傳道之即則仍在教堂授丵解惑之教施之青年傳道則不分老幼人之 有生莫不當受此西方今日依然政教分行, 不以教專屬於政也。中國古代政 教合一, 自春秋戰國之際而始戀, 百家繼起自由講學代握教權偶墨開宗, 皆趨

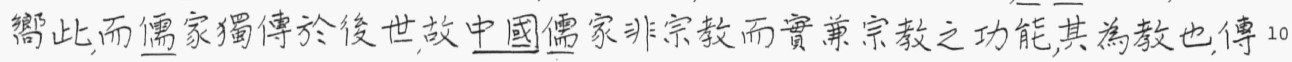
道之師猶崇於授丵與解惑。東漠以下嬬學衰, 而佛教束流先則沙門不拜王 者, 明教權之不能屈抑於治㩲也。其次則君相之尊皆頂禮膜拜於佛寺, 此無 論南北朝皆然至隋唐亦無不然時則奉僧人以國師之尊。直至察明儒學又 與佛教為代興。王荆公程伊川皆为絰筵講官, 爭坐講不立, 此又一沙門不拜 王者之意也。蓋惟如此, 乃使人知政府不為舉世之至貴猶有尊於從政者, 15 道之大端乃在師統非君統。故中國近世踓無宗教, 而猶得使政府不踞獨尊 之位也。元清雨代, 皆不尊儒, 元人不知尊, 清人不欲尊然皆奉事喇嘛或多立

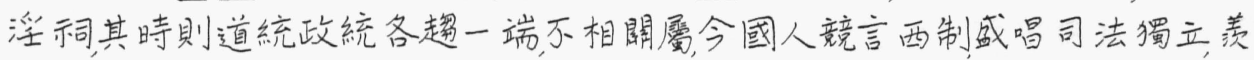
法治之不可攀不知人事国不以不犯法為極则, 西方於法堂外尚有教堂, 官吏 犯法固當俯首於法官警吏之前, 然犯法者亦僅耳。使無宗教尊嚴,人生一出20 青年期, 暴業大學校移身社會, 即已為一無所受教之人, 苟其身踞高位, 則誠舉 世莫能屈非然者則富贵雨行經商或益愈於從政人竸於財貨而㶌不平激而 禹無産階級専政亦其宜也。凡今西國所以不盖然者, 宗教之為功。蓋如菲 周所謂無用之用, 固未可輕漠視之。中國誠模効西制或更超而出焉考試監 察司法諸權盖得獨立, 使不兼受其基督上帝之教, 則富貴而外人生不復有尊2 5

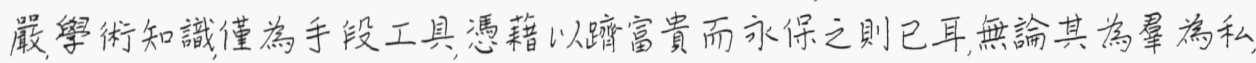
要之將止於我之所謂覇, 非所語於内埾外王之域也。抑且近代政治率常操 於政黨之手, 又濟之以所謂宣傳者, 恣政府在上之力, 㸹無微而不至, 使政府與 商人相狼犋教育與宣愽相配合, 政治之力㭩莫與競踓日言端出版集會自由, 而三者皆本之教育若教育無自由, 則人之真得自由者幾希耳。故真求民主3 0 精神之惯现必使人道大統下行而不上湊必使教權尊於治㩲道統尊於治統,

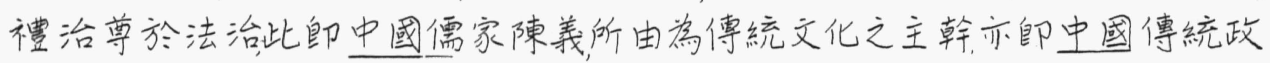
制精意所在。降一級而求之若西方之政教分行, 尚猶不失其衡平之勢, 若僅 以選舉言民權, 而教育大政默而㯖之於政府, 則未其不病者。然則政府凿 
不閔學校教育事乎? 日非此之謂。初級國民教育當讓之地方自治, 上篇已 論之, 若高中大學, 各級學校雖可由政府籌辦然政府當自居為護法不當自居 為主教學校尊嚴, 當超然於政治之上惟各級職業教育, 可視政府需要而創革, 其他則政府當畫量尊重學校之自由, 又當嗇量提倡社會私立學校自由講學 5 不依政府意見為意見, 不隨政府轉動而轉動, 教育之權應在家言不在官學。 抑更有進者, 在西方有宗教在中國有儒禮, 尊師崇道踓昔之帝王不敢背, 遑論 於今日, 必使從政者於束身奉公不犯法律之外, 於人道猶知有所尊於已體猶 知有所屈。内心外貌猶有所敬禮, 則不奉耶佛諸教必推䦐儒禮使教育精神 與德統文化相得益彰, 此則中國德統政制本已有此趨㗽抑已有其確然可考 10 之成績此亦堪為今後新政制所取法之一端也。

今考五五蜜草特定教育一章, 甚為重視教育之意至顯其第一百 三十六條注重全國各回域高等教育之平衡發展, 一百三十七條規定之教育 經費之最低限度, 應佔中央預算總額百分之十五, 其異㾑省回之教育經费, 應 由國庫補助第一百三十八條又规定國家對於列舉之事丵及人民應予以䄄

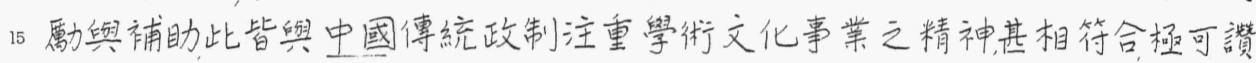
許。惟第一百三十六條謂全國公私立之教育機䦕, 一律受國家之監督拉推

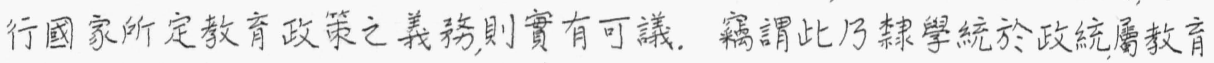
於政治覞舆中國德統文化傳統政制相背, 乃亦非西方政制所有。教言乃百 年樹人大計, 國家政策則贵乎因勢推移, 二者不當辀為一談。且教育乃人生 20 真理之切實践履與切實探究根本無政策可言。若以政策辦教育、未賞不可 收目前一日之速効然終將貽後來無穹之鄑祜。近世德國属行國民教育, 一 時謂其功効勝於毛奇特軍之兵榢然推演之極今日德國之雨度敗覆亦未始 非此種以治權決定教權之虞害有以使之然也。昔中國春秋戰國之際越王 勾践與范掻深謀, 十年生聚, 十年教訓, 卒减强吴報夙仇然越祚亦不長越王勾 25 践之與范掻, 正猶德王威廉之與俾斯荅也。然則以國家目前政策定全國教 育方針, 其茇得失斷可見矣。又草案第一百三十一條中莱民國之教育宗㫖, 在弡揚民族精神, 培養國民道德訓練自治能力, 增進生活智能, 以造成健全國 民。窲謂此種列舉亦有可商, 人類教育宗㫖猶有超於造成健全國民之上者。 若尃以造成健全國民為目的此亦尊治權於教權重政統於道統流弊較淺將 30 㪄塽義之國家主義此必有損於文化教育之大全。若流弊較深, 自必随國家 政策而定教育方針。然所謂國家政策者, 究極底裹則國家不得不以政府為

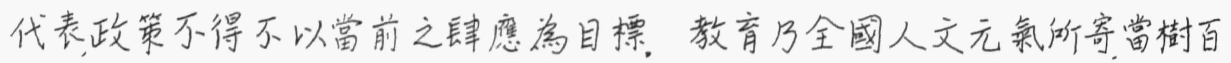
年不拢之基豈能追随政府當前政策為轉移乎? 故本條所列舉若以定為地 方國民教育之條目, 而使全國各地域得本此宗㫖, 各自谌酌本地方實際情况 
以虞受通則猶之可也。若以全國職業學校應視國家需要, 随政府政策而创 建或改革, 亦猶可也若籠統包舉全國各級教育, 如今㥶草所云, 埧流弊將不勝 言。椣謂将来中國新害法必有雨事首當注意，者當明白規定立法司法監 察考試四院之獨立性使其超然於政黨之外, 一則教育必㖹量自由, 不随政府 政策為措施。若能達此雨目的則政局已可小康民主精神自得逐步實现惟

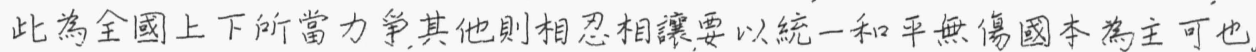
抑復有一小節當復論者。今國民黨人尊推孫中山先生稳為國 父此由模効美國以菜感頓為國父也。盖美国十三州之獨立, 由萃盛顿所率 領中華民國政府之創建由中山先生所倡尊崇之以國父之畄宜無不當。然此僅 言政統非言道統也。近代美國之共和政體固為莱代所首念然美國人之人10 道文化則遠有束歷故美人言教統仍歸耶穌不屬莱代。中華民或之政府固 学中山先生所手涂然中菜民族之人道文化則亦遠有本源非亦由中山先生 制之此在中山先生之民族主義之講演中, 關發已至潂切。故言中等民國之 政統必推中山先生為不䄻之祖若言中華民族之道統與教統則中山先生亦 一孝子順孫耳, 豈得同椂奉為不䄻之祖乎! 今全國大小各級學校若逢中山15 先生敦辰與其逝世紀念日及國慶大節, 㿼崇仰追思之䄚此亦理之宜然若今 每七日有紀念週每逢學校有典禮必先對中山先生遺像行禮致敬是以尊中 山先生於政統者而一體尊之於道統。若細䉪中山先生民族主義之遗教此 等崇拜恐亦非中山先生所集受。此亦今日學統絀於治統之一例也故連带 而論及之。

討論問題:

一等術機關在中國傅統政制中佔有何地位?

二二十四史之萹著有何特點?

三試述各朝收藏圆籍對當時及後世之梖獻。

四試埨中国䇛代考試制度之利整。

五作者對今世中国之教育有何批評及建議? 

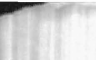
1.11合TY合和。

融洽彼此间之感情和好

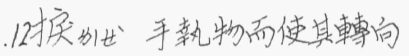

轉掞黑占轉方向之退

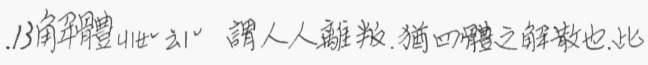

遗喻貴族政治之崩溃解散特天。

.18重彻傅布於後世。

19 些世3心敦同時。

迹山同跡

史还唩史上的事情

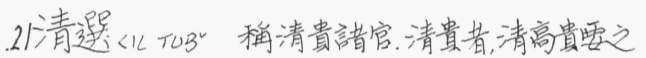

意後世則稻翰林院为清贵衙門, 因之, 清遙

亦即諸翰林也, 翰林, 自本課翰林佟。

.23方技比4 謂監十星相各偅之技能

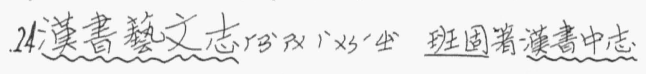

之一記載党時書籍目錄。

.25撼厂3 摇動

.24㖟下先生山田仍队見第三課

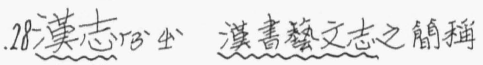

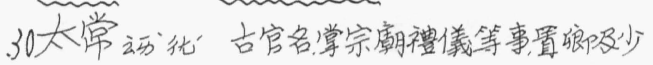

很各一。

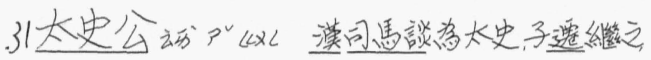

皆稳太史公、此地指司馬透。

畜心着。

文史…畜之見司馬震給㶵安的信，信

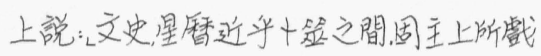

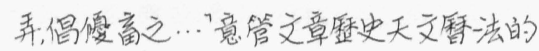
和管十筮视禧的人相近, 本是召主所战素 和养些女祭戲子一樣

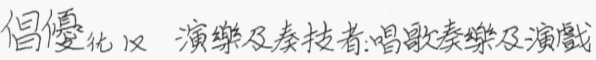
的人。

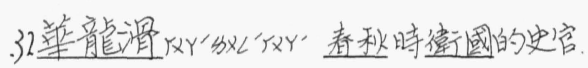

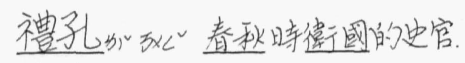

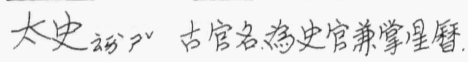

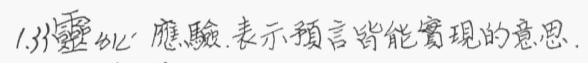

霘威應驗與神威。

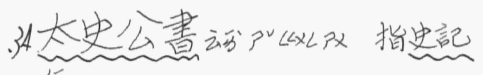

斧化氣; 氛圆即四周的氯息。

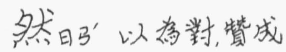

2.1鄭秘重

鄭重慎重

了建州岎纡指清帝愿熙因其祖先以建州衛 叛明.

空幼等固、铜篚犯的地方

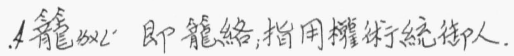

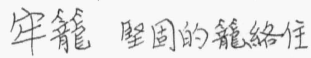

二十匹史心ア公ア 即明史與以前各朝代

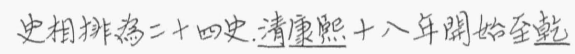

隆四年完成㗍時示十年。

浪用的清也明也。

朗然 形容清楚

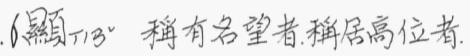

晾械高級重要娥位

秩出禄，官俸

8硕”'大

石直紫望街精深之士。

10冷加清闻

冷署清㳉之宫署

素餐仪5 3 謂無功而空食禄

狛加”随述

建自4 13 . 的謂就公共事情有所淒述及建議

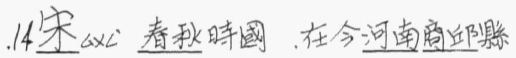

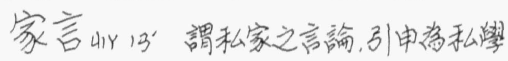

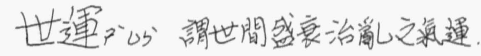

15 表章幻纯同表彰”;顯掦。

出身秋的謂入仕之途科舉時代有進士出身

等類.此需入仕之階級。

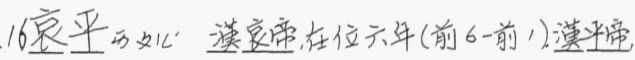


在位玉年 $(1-5)$.

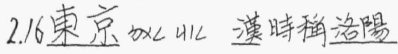

17倚、特

倚席不諿特有席位但万請學

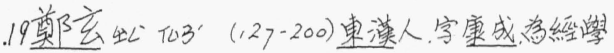

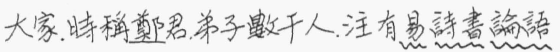

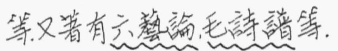

千古《沐《喻時代久遠

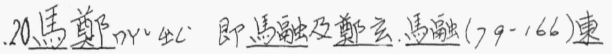

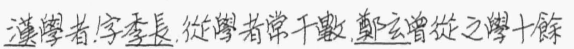

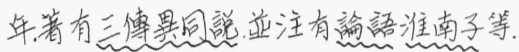

来柿”彩色

今古䨂采现代的與古代的色彩混雅皆

有.

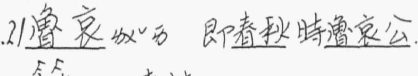

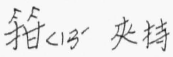

箝束以鳌夹持約束。

.22重狐够地春秋丝國之良史官

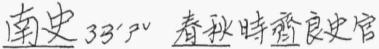

29 雅量1 $Y^{2}$ 优從容之氧度

朔捄謂㓌曆每月初一日

告《即告朔

告前古者天子季冬够来藏十二月之翊於言者侯

諸侯受而藏远祖嘲。每月朔日則以特羊告 瘚請而行之, 謂之告拼。

飨门生牲

飧兼生羊

告稝之食送羊喻僅存之福節

. 30 㷊管心停滞

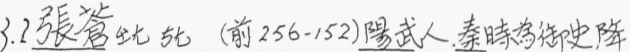

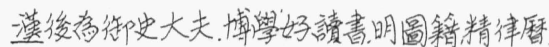

. 标下星似周官名、即御史

主柱下方書为御史, 主四方文書。

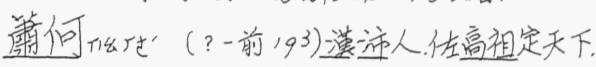

論功第一, 法令多出其手。

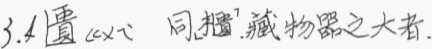

金遭石空以金为掼，以石学室以藏物主

示保慎之意, 亦國家收藏書籍之透

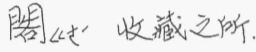

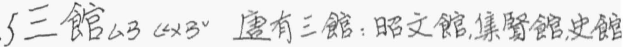

掌俢史藏書校住碓之娥。

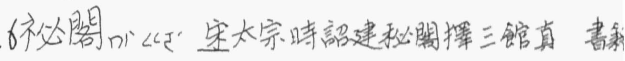

蕾食余卷及古畫墨跡藏其中

大觀是》《劝形容类盛。

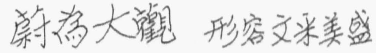

兴典加守。主其事。

典司主事的官员

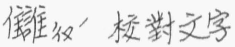

校隹准校對文字

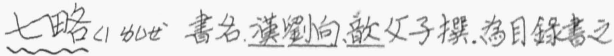

始、分示藝略、兵書略等, 夹入卷

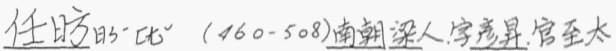

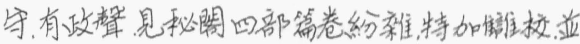

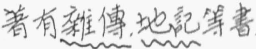

教然加明, 整然有序

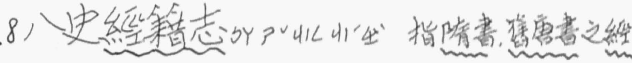

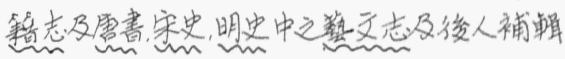
之補遼金元篡文志補三史警文志補元史期 忘志

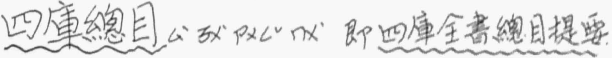

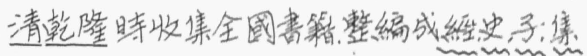

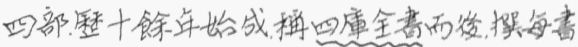

提要, 二百卷, 條舉得失, 甚便於祭者。

. 京顿比

哈舉世奠與京全世界没有能根它比的 恣p 效任

恣意任意陡意

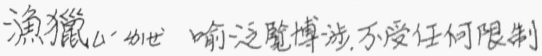




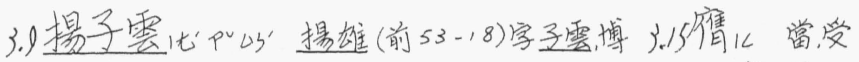

學深思以文章名世, 著有态玄法言等畫。

膺選當選

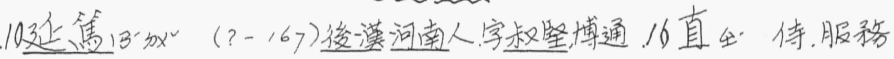

然傅白家之言, 以文章知名於世。

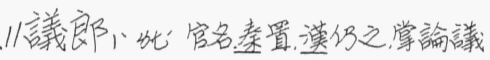

朱F㣎的吚( $100-163)$ 後漢人字公叔，幼以孝

稻授侍御史, 後拜尚貫、禄仕數十年, 家無餘資, 及

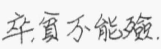

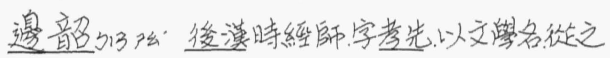

者數百人。

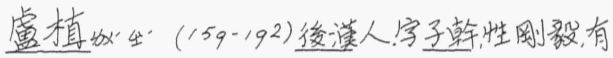

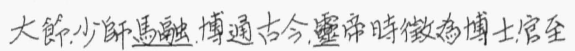

尚㶳

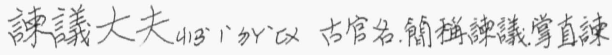
與議㴜.

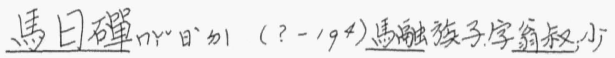

傅融業、以才凛進。

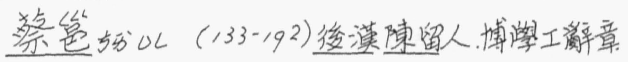

善音律, 着有繁中郎焦。

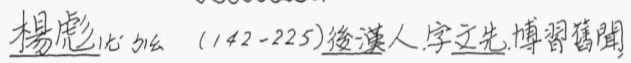

但整文集傅世。

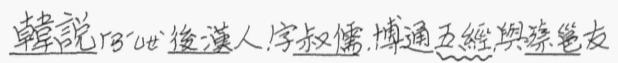

好。

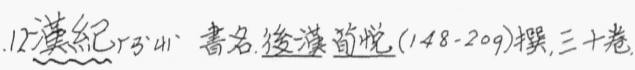

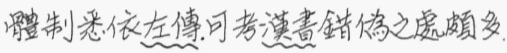

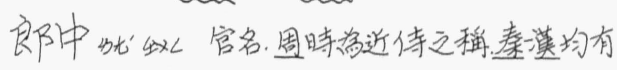

郎中之官。隋雷至清各部皆設之济同官之位最 高者。

.14令㒒出心如”謂尚書令舆嵄射

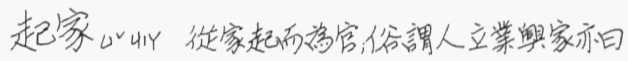
起家.

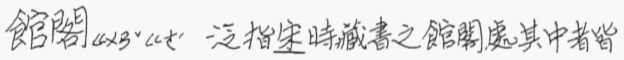
文等儒臣、

清等《ルイメ請清高貴重之士。

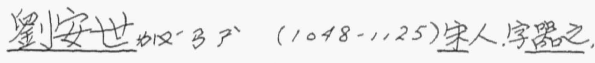

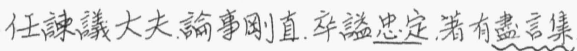
館職《弓゙出”案制, 凡直史館、昭文食官, 集算院者

謂之館職。

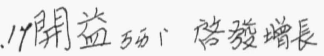

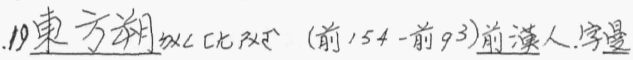

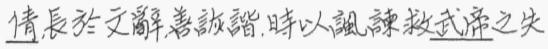

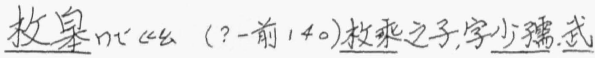

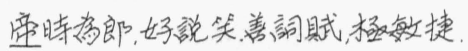

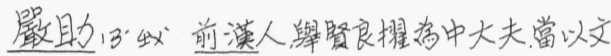
辤侍武帝左右、特思任用、後以事見铢

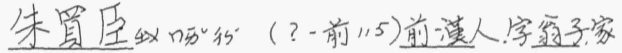

貝好淘官至函相長史、後被武常所耓。

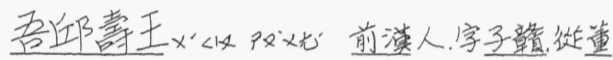
仲卸受春愁武常時学侍中, 累官光祿大夫。

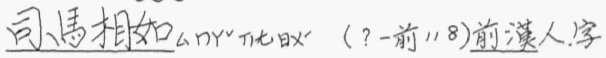

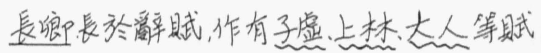

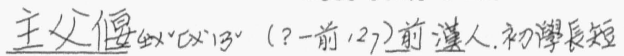

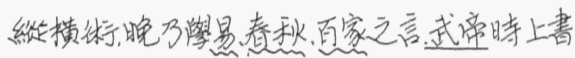

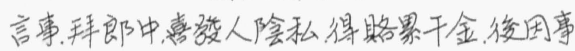
被较。

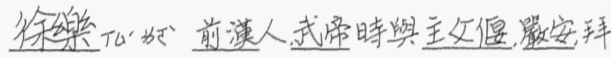
为郎中曾上亳言世務。

嚴安污引前漢人, 武帝時上書言整匈奴之非 利、拜郎中。

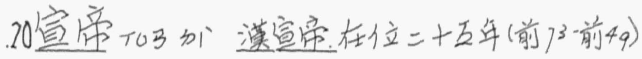

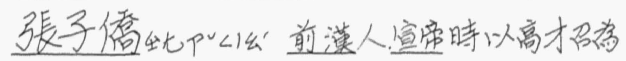
奇材之一。

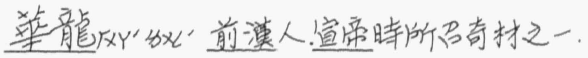

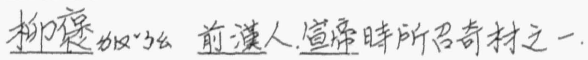

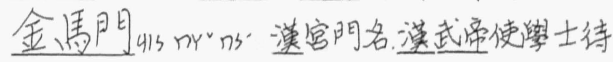




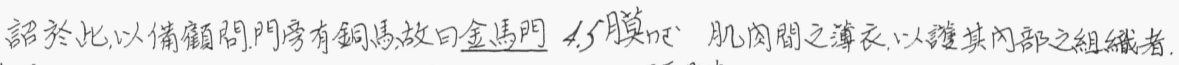

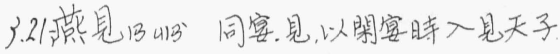

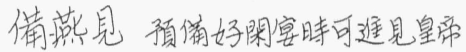
隔膜有所間隔

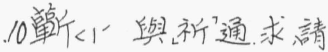

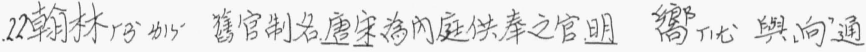

清兩朝, 则有進土朝考後得庶吉士之皏號

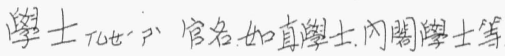

辝很心中希望速到目的。

內命3で吅君命万、經外朝者。

入相3元不翰林之别稱

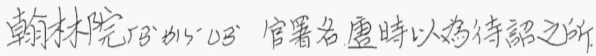

明時掌袐畫箸作

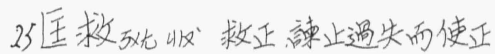

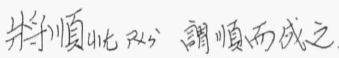

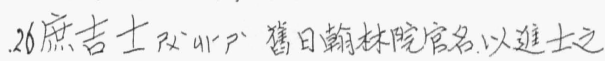

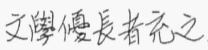

更事《常事、䍃歷世事。

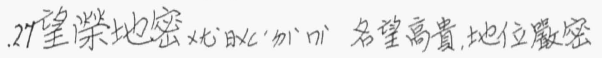

中秘的叭中秘著, 宫禁网所藏之書
䠔很山登，上升達。

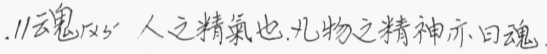

孁魂指精神或心意之露體, 對物筫或肉 體言。

15紐31 器物之提執部份。

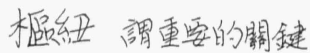

. 16 素王的“炕”颜有王者之道而無王者之位者，世

稱孔子为素王。

.20兆丝事件末碳時之预徽

北端事件未袂之预徽和其用端

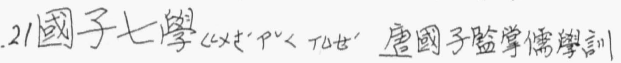

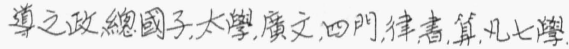

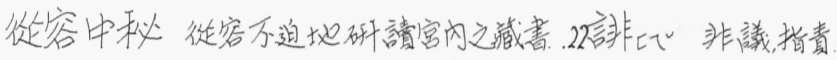

.28蕒T心使热汽包圈四周

卒故们聚集

食出用火烤㥜染

董会喻培飬感染

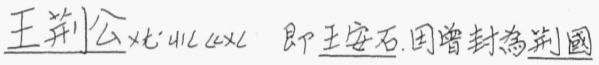
公故皏

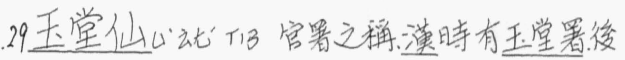

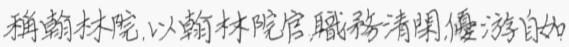

世嗙之王堂仙。

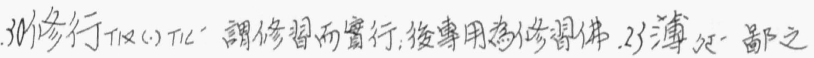

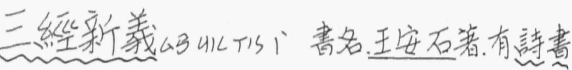

周䄚三聯新義, 北宋時曾盛行於望校, 到南宋

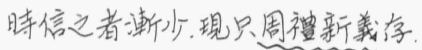

法或整道之意。

半路修行䇎非自始病比者

蔧色污心所受慕

羡仍、真欲爱慕

豐色羡 心所爱慕

.3扼主捉，持握。

把要尤扼撢要領, 如㡎言行文能中肯, 或 行策佔㨡要衝皆稱扼要。

. 34 拔加, 提拉。舉之使任事也
譏薄譏諷嘲㔀。

治權出《UB'謂政府治理國家之㩲。

24 稷山曹官

契挝舜臣，商之祖

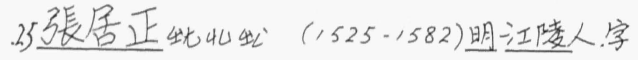

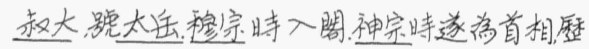

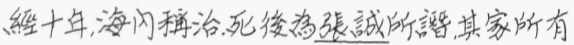

被没收、箸有太岳焦等

.2霖心如此 


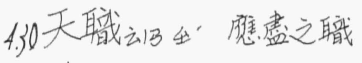

, 33 月粶门謂人體大小腿相接派, 可以屈伸。

屈䐐雨滕箸地而直其身。

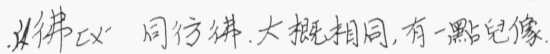

5. 9 開宗的阷開始

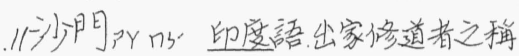

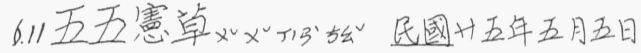

國民政拊宣佈中筮民國㥶法学案。

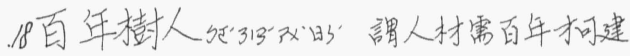

立起来。

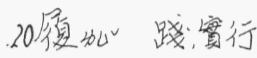

践復謂瓷行

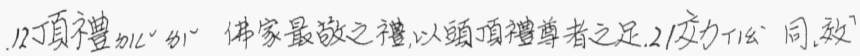

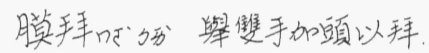

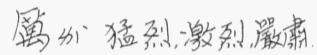

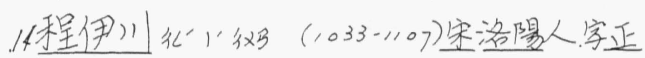

䝵行嚴格急切的管行

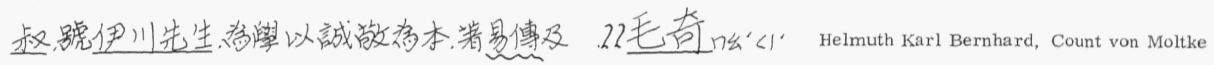

春秋傅。

16 踞岓謂坐其上

不踞罣尃不佔唯我猫尊的位置。

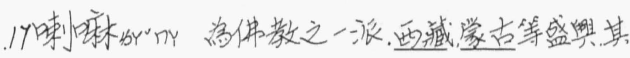

僧徒幍喇啉

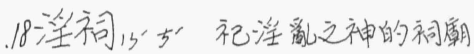

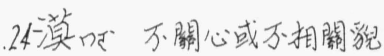

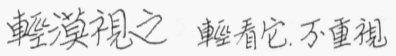

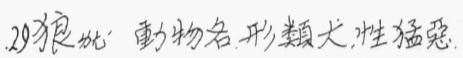

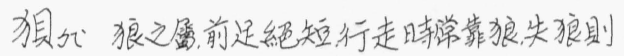

不能動

狼犋相需而不可離者(通常指酱㙰方面) . 0 幾山相去万幥

幾希没有多少了，很少了。

31 凑凑) 战靠近

上湊附和在上者，

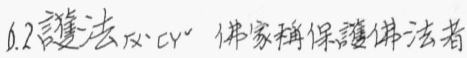

了主教纠岎天主教中、稻奉教皇使派分掌世

界各地教務之人。

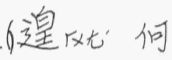

遑商於今日何端於今日意即现在通不.16言延加生日

必説了。

8 蟹行開㫃。

推閳 推崇没掦
(1800-1891)德國名将

. 4 勾践《4 13 ”春秋越王嘗为吴王所欺, 万用文 種范掻染相, 失志復仇率減吴。

范虽虽印加”春秋時楚人, 仕越與越王共减

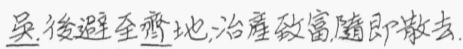

祚防藏、命

越祚越國的举命

25或廉风土

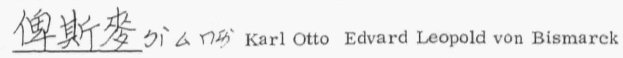

$(1815 \cdot 1898)$ 德國政治家

.26 方金十无出謂計劃進行之一定走苟向。

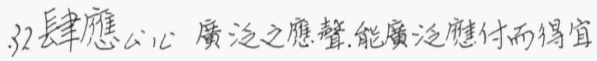

人文矂如颣之文化

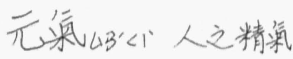

34 宗旨P X 4 的主要之目的

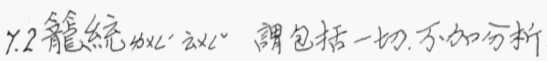

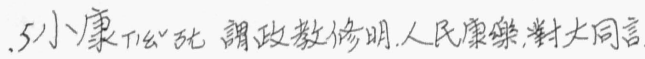

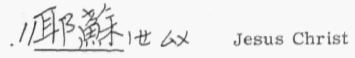

.13㓢敌即㓢切

㠒切謂行事得中事理。 
注音符號表

符號音如：讀如：例如：

\begin{tabular}{|c|c|c|c|c|c|c|}
\hline ל & $b$ & bwo & 白 & 施 & 邊 & 31 \\
\hline 文 & $P$ & pwo & 皮 & 女 $1^{\prime}$ & 平 & 文 \\
\hline 7 & $m$ & mwo & 摸 & nd & 母 & $n x^{2}$ \\
\hline$\tau$ & $f$ & fwo & 分 & $=n$ & 飛 & El \\
\hline 万 & $d$ & de & 得 & D放 & 都 & 勿又 \\
\hline 士 & $t$ & te & 他 & $\hbar Y$ & 天 & 413 \\
\hline 3 & $n$ & ne & 拿 & $3 Y^{\prime}$ & 年 & 319 \\
\hline 为 & 1 & le & 李 & s 10 & 樓 & 蚁 \\
\hline « & $g$ & ge & 跟 & $\ll n$ & 敢 & 《३ \\
\hline 5 & k & ke & 看 & ろ引 & 哭 & $3 x$ \\
\hline$\Gamma$ & h & he & 好 & 厂幺 & 花 & $r \times y$ \\
\hline 4 & $j(i)$ & je & 幾 & $41^{2}$ & 見 & 413 \\
\hline$<$ & $\operatorname{ch}(i)$ & chi & $t$ & $<1$ & 秋 & $\langle 1 又$ \\
\hline$T$ & $\operatorname{sh}(i)$ & syi & 喜 & $T 1^{\circ}$ & 笑 & 714 \\
\hline 出 & $j(y)$ & $j r$ & 真 & 㝳 & 張 & $\Psi t$ \\
\hline 彳 & $\operatorname{ch}(y)$ & $c h r$ & 吃 & 彳 & 差 & $\{Y$ \\
\hline P & $\operatorname{sh}(y)$ & shr & 事 & $\vec{p}^{\prime}$ & 神 & アク' \\
\hline 日 & $r(y)$ & $r$ & 肉 & ब $x^{\prime}$ & 日 & . ब' \\
\hline p & $t z(y)$ & $t z(y)$ & 早 & $p \hbar^{v}$ & 字 & $p^{\prime}$ \\
\hline ち & $\operatorname{ts}(y)$ & $t s(y)$ & 草 & 与幻 & 次 & 市 \\
\hline 厶 & $S(y)$ & $s(y)$ & 四 & 公 & 三 & 43 \\
\hline
\end{tabular}




\begin{tabular}{|c|c|c|c|c|c|c|}
\hline 符號 & 音如: & 讀如: & & 列如: & & \\
\hline$Y$ & $a$ & a & 大 & D & 把 & $\partial Y^{\prime}$ \\
\hline ट & 0 & (w) 0 & 多 & $b \times d$ & 博 & $s z^{\prime}$ \\
\hline さ & $e$ & $e$ & 特 & 去 & 餓 & さ \\
\hline 世 & e & ye & 夜 & - せ & 别 & らせ' \\
\hline 万 & ai & ai & 愛 & 历 & 太 & ム方 \\
\hline 2 & ei & ei & 為 & $\times 7^{\prime}$ & 睡 & $=x$ \\
\hline 幺 & $a u$ & $a u$ & 高 & « & 好 & $r \check{\mu}$ \\
\hline 又 & ou & ou & 就 & $41 x^{\prime}$ & 區欠 & 又 \\
\hline 3 & an & an & 飯 & $=3$ & 安 & 3 \\
\hline ५ & en & en & 很 & $T 4^{2}$ & 音 & in \\
\hline 九 & ang & ang & 王 & $\times \pi$ & 張 & 出九 \\
\hline 2 & eng & eng & 冷 & $B E$ & 紅 & \\
\hline 儿 & el & er & 兒 & $u^{\prime}$ & & \\
\hline-1 & i & $i$ & 地 & Sו & 應 & 12 \\
\hline$x$ & u & u & 五 & $x^{2}$ & 土 & 㕕 $x^{2}$ \\
\hline 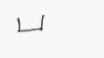 & $f_{u}$ & yu & 需 & $T u$ & 雨 & 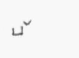 \\
\hline
\end{tabular}


从简体查繁体

\begin{tabular}{|c|c|c|c|c|}
\hline (2笔) & 斗阴㯺 & 辽遼 & 后 後 & 极 \\
\hline 儿兒 & 认認 & 边 邊 & 会 樰 & 两 \\
\hline 几 幾 & 队隊 & 发 㻐 & 杀 殺 & 医 \\
\hline [3 笔 & 办 辩 & 圣 聖 & 众 象 & 还 \\
\hline 干 幹 & 邓 & 对 對 & 杂 雜 & 歼 \\
\hline 万莴 & 双隻 & 16芼 & 冲衝 & 来 \\
\hline 与 與 & 书畫 & 动 動 & 刘劉 & 坚 \\
\hline 亿億 & 15笔 & 执 執 & 齐 孪 & 时 \\
\hline 个個 & 击 撃 & 巩 种 & 产珄 & 县 \\
\hline 么 麼 & 节䬦 & 扩擴 & 关關 & 里 \\
\hline 广廣 & 术 術 & 扫淿 & 兴興 & 邮 \\
\hline 义 義 & 灭 减 & 亚 亞 & 讲講 & 听 \\
\hline 卫 衛 & 委整 & 机 機 & 农 農 & 采 \\
\hline 习習 & 占佔 & 权 權 & 寻 寻 & 乱 \\
\hline 乡 鄉 & 卢盧 & 过過 & 尽 盡 & 体 \\
\hline 秋笔 & 业 業 & 协 協 & 导 導 & 彻 \\
\hline 丰 喑 & 旧嚿 & 左馛 & 孙 孫 & 余 \\
\hline 开開 & 帅狛 & 庈嬮 & 阶階 & 邻 \\
\hline 无 無 & 归歸 & 夸 誇 & 观觀 & 条 \\
\hline 韦 草 & 电 電 & 夺 奞 & 买 買 & 系 \\
\hline 专 専 & 尔 䨒 & 达達 & 【7笔 & 状 \\
\hline 云雲 & 乐 樂 & 划 剖 & 进進 & 疗 \\
\hline 艺私 & 处虎 & 师 師 & 远 遠 & 应 \\
\hline 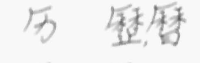 & 务 務 & 当當 & 运運 & 这 \\
\hline 区區 & 饥 饑 & 虫蟲 & 坛壇 & 沟 \\
\hline 气实 & 兰简 & 团團 & 坏壞 & 怀 \\
\hline 长 長 & 头頭 & 发 歳 & 护護 & 穷 \\
\hline 巾 幣 & 汉 漢 & 迁 遭 & 报 報 & 证 \\
\hline 从從 & 宁察 & 优 傻 & 严祳 & 灵 \\
\hline 仅僅 & 写寫 & 价價 & 劳 勞 & 际 \\
\hline 为 & 让讓 & 华 辣 & 苏畄 & 纵 \\
\hline
\end{tabular}




\begin{tabular}{|c|c|c|c|}
\hline 18笔 & 录 錄 & 垒 置 & 盖蓝 \\
\hline 杰 傺 & 参 骖 & 以笔 & 断 薪 \\
\hline 环環 & 艰 歎 & 赶 趕 & 惨 \\
\hline 拥 擁 & 19笔 & 获獲 & 随 \\
\hline 势 勢 & 带带 & 恶 惡 & 随随 \\
\hline 拦攔 & 荣 & 档 檔 & 《12笔 \\
\hline 范軼 & 药 樂 & 桥 橋 & 趋 走岛 \\
\hline 构 構 & 标 & 样 樣 & 联 \\
\hline 画 畫 & 树 樹 & 础 礎 & 确 確 \\
\hline 患 輁 & 战 戰 & 顾 顧 & 领 筑 \\
\hline 卖 賣 & 临 臨 & 虑 慮 & 御 䋣 \\
\hline 矿礦 & 显 顯 & 监 監 & 腊 篦 \\
\hline 态 態 & 虽 & 紧＼cjkstart緊 & 装 装 \\
\hline 欧區 & 响 響哴 & 党 黨 & 蛮 喘 \\
\hline 虏 虜 & 脉 脈 & 钻 鍇 & (3笔 \\
\hline 国 國 & 钥 錀 & 铁 鐵 & 摄 攝 \\
\hline 罗 羅 & 适 適 & 敌㪣 & 碍 礙 \\
\hline 图圆 & 种種 & 积 皘 & 鉴 鑒 \\
\hline 购 購 & 复 & 称 稱 & 签 簽 \\
\hline 凭 憑 & 胆膽 & 爱 愛 & 触 觸 \\
\hline 质 啠 & 胜 勝 & 准 凖 & 献 獻 \\
\hline 胁 妿 & 独獨 & 离 離 & 辟臂亲 \\
\hline 备 備 & 将 㸹 & 难 䧼 & [14笔] \\
\hline 变 篮 & 奖 獎 & 继 繼 & 墙 檣 \\
\hline 郑鄭 & 亲 & 以笔 & 稳 楥 \\
\hline 單 & 养 & 据 握 & \\
\hline 怜 擞 & 类 & 职 職 & \\
\hline 稗 & 总 & 营 營 & \\
\hline 寶 & 济 湾 & 跃 躍 & \\
\hline 审 & 举 舉 & 欲 慾 & \\
\hline 实 䆩 & 觉 & 盘 盤 & \\
\hline 肃 萧 & 袄 襖 & 猎 熘 & \\
\hline 隶 䉿 & 陙 墾 & 浲 樑 & \\
\hline
\end{tabular}




\section{中國歷代朝代表}

唐堯公元前2356-公元前2258南北朝公元420-588

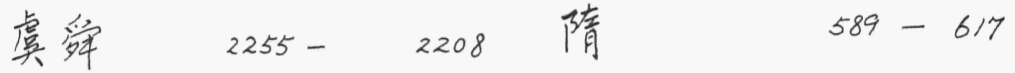
夏 $2205-1766 \quad$ 唐 $618-906$ 商 $\quad 1765-1122$ 五代 $907-959$

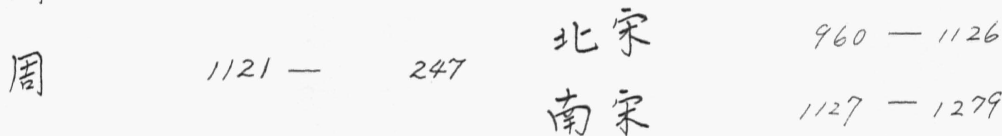
奉 $246-207$ 元 $1280-1367$

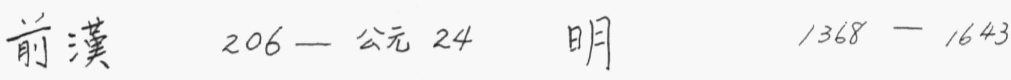

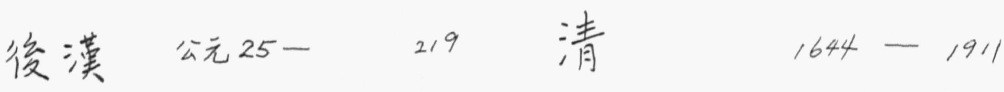
魏2 20 - 264 中策民國 1912 至265-419中萃人民共和國1949- 


\section{Index}

(Numbers after each item indicate the lesson, page and line in which it occurred.)

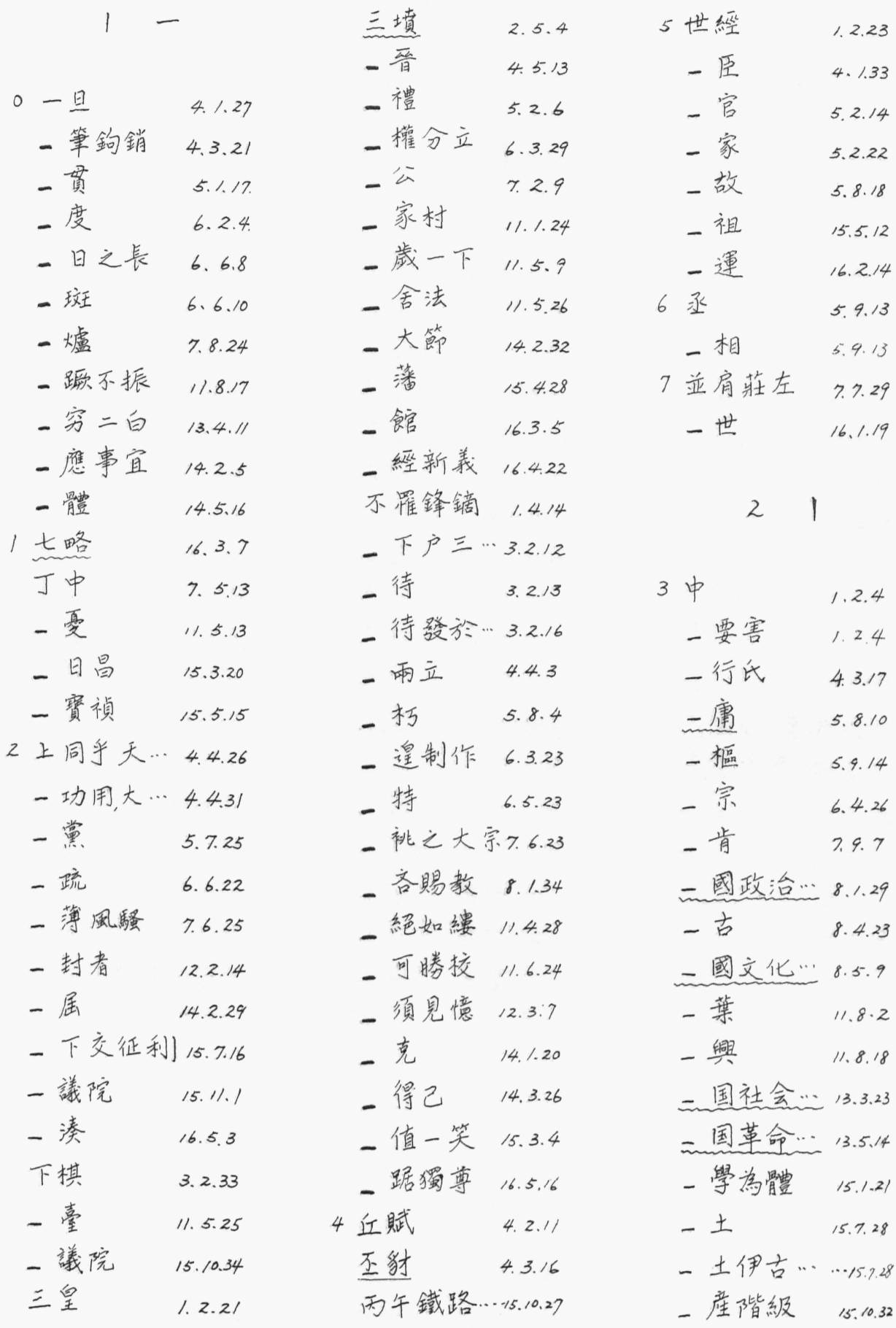




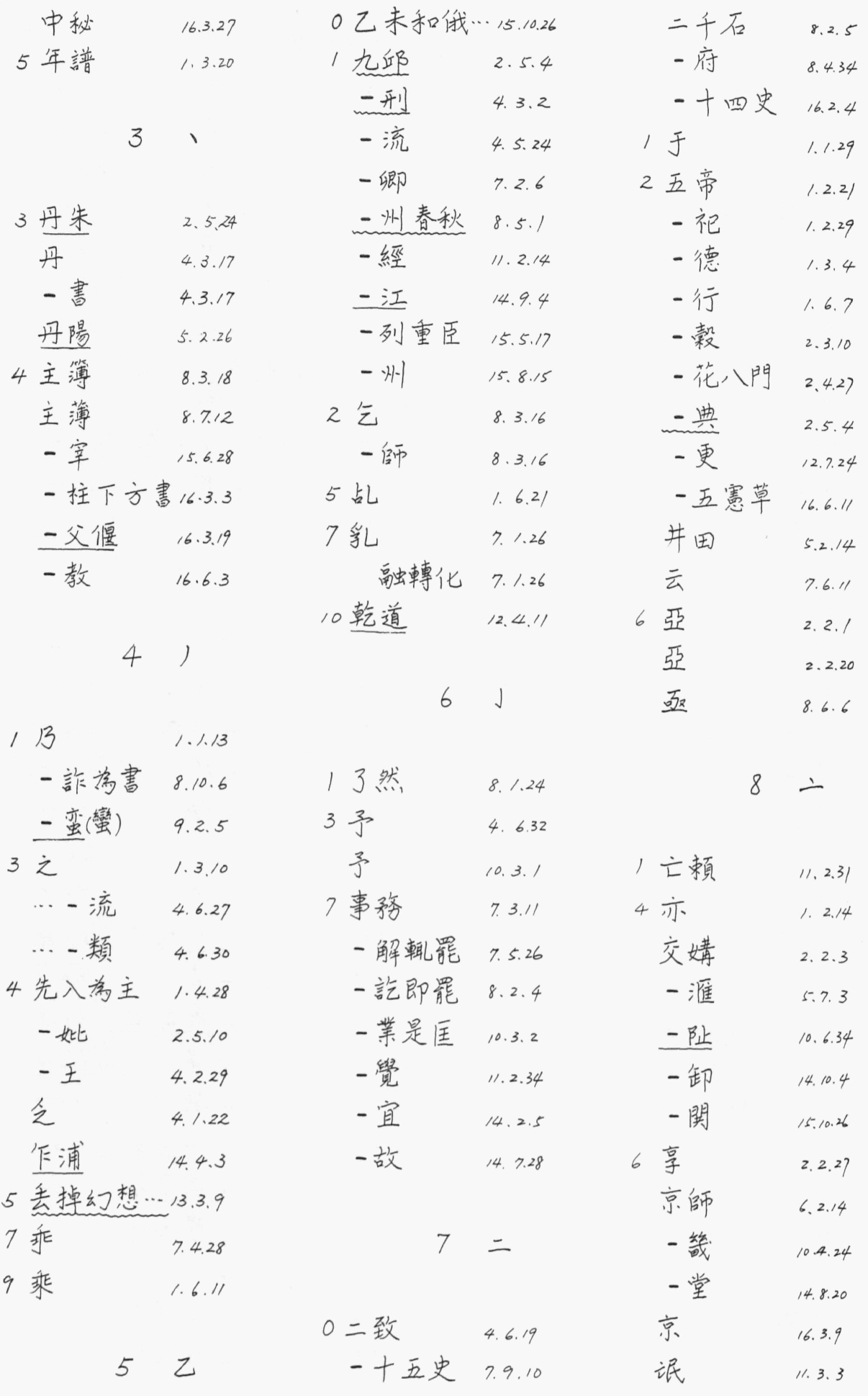




\begin{tabular}{|c|c|c|c|c|c|}
\hline \multirow{3}{*}{$9 \frac{\text { 商均 }}{\text { 一鞅 }}$} & 2.5 .24 & 仰 & 1.3 .11 & 作 & 12.1 .18 \\
\hline & 4.3 .20 & 伍 & 1.7 .14 & 佚 & 4.6 .18 \\
\hline & & 企 & 6.2 .1 & 佚 & 12.3 .25 \\
\hline 9 & 个 & - 圖 & 6.2.1 & 伸縮性 & 4.6 .26 \\
\hline & & 伐 & 6.6 .26 & 佛郎克 & 3.3 .26 \\
\hline 0人䋰 & 2.1 .15 & 仲 & 7.4 .14 & 一寺 & 7.6.32 \\
\hline - 肩摩 & 3.2 .15 & 一冬 & 7.4 .14 & 一藷西 & .4 .5 .14 \\
\hline - 主所惑… & $5: 8.23$ & 休 & 8.12 .1 & 位 & 6. 5.34 \\
\hline 一散誰復撞 & 12.6 .2 & 伊藏 & 5.3 .7 & 一臣 & 6.5 .34 \\
\hline －心惟危 & 15.5 .9 & 伊斯兰(藏侾 & 文 11.8 .13 & 佑 & 14.4 .20 \\
\hline 一倫 & 15.10 .5 & 一朗 & 9.9 .20 & 伴 & 14.2 .22 \\
\hline - 文 & 16.6 .32 & 一里布 & 14.3 .26 & 6 来歷 & 1.6 .1 \\
\hline 2 今古學考 & 1.5 .8 & 伊 & 15.3 .11 & 佩 & 4. 3.24 \\
\hline 一古雜采 & 16.2 .20 & 一始 & 15.3 .11 & 一六國相印 & P. 4.24 \\
\hline 介 & 4.4 .1 & 仿佛 & 13.1 .34 & 侍 年 & 6. 2.31 \\
\hline 仇 & 4.4 .4 & 任昉 & 16. 3. 7 & 一衛 & 6.2 .31 \\
\hline 仁宣之治 & 10.8 .8 & 伙 & 11.8 .5 & 一郎 & 14.9 .29 \\
\hline - 宗 & 11.3 .21 & - 食 & 11.8 .5 & 侈 & 6.7 .3 \\
\hline 代數 & 1.7 .9 & 5 伯 & 9.4 .4 & 侈 & $15,3.30$ \\
\hline 代 & 7. 2.18 & 一麥 & 14.3 .28 & - 言 & .5 .3 .30 \\
\hline 3 以 & 4.2 .15 & 何以 & 1.3 .15 & 供頓煩勞 & 6. 7.6 \\
\hline ‥ - 起 & 4.2 .15 & －業之守 & 4.3 .14 & 㑆 & 8.8 .21 \\
\hline 以迄 & 7.2 .3 & -士驥 & 8.1 .21 & 侄 & 9.4 .4 \\
\hline - 見居為䈯 & 7.5 .13 & 一進 & 8.7 .13 & 佯 & 15.10 .17 \\
\hline - 逸待勞 & 8.2 .19 & - 旁虚文 & 11.8 .9 & 佳 & 14.6 .5 \\
\hline 一己俸譻善 & 11.3 .24 & 一桂清 & 14.7 .8 & 7 信奉 & 1.1 .14 \\
\hline 一賈告 & 11.7 .28 & 似乎 & 6.2 .7 & 一仰 & 1.3 .11 \\
\hline 仕 & 6.6 .11 & 佐 & 2.6 .12 & 一如是也 & 4.5 .29 \\
\hline 一進 & 6.6 .11 & 伷 & 5.5 .2 & 一然 & 7.6 .27 \\
\hline 一版 & 11.2 .31 & 一農 & 5.5 .2 & 一圭 & 8.5 .18 \\
\hline 仙 & 7.7 .17 & 一貨 & 11.7 .12 & 一風 & 12.2 .23 \\
\hline 令嵄 & 16.3 .14 & 余 & 2. 5.12 & 促 & 2.3 .5 \\
\hline 4 伏羲 & 1.2 .20 & 一孝頃 & $8 \cdot 9.8$ & 保障 & 3.1 .18 \\
\hline 伏 & 5.7 .10 & 作坊 & 3.2 .25 & 一劶 & 14.4 .20 \\
\hline
\end{tabular}




\begin{tabular}{|c|c|c|c|c|c|}
\hline 保甲之法 & 15.2 .3 & 倚 & 9.7 .19 & 傍 & 6. 6.16 \\
\hline 一舉 & 15.2 .9 & 倚 & 13. 2. 1 & 一晚 & 6.6 .16 \\
\hline - 國會 & 15.5 .28 & 倚 & 16.2 .17 & 一緣 & 11.7 .24 \\
\hline 俊 & 4.3 .25 & 一席万講 & 16.2 .17 & 傕 & 11.7 .30 \\
\hline 俘 & 5.5 .5 & 候旨定奪 & 14.3 .18 & 備燕見 & 16.3 .21 \\
\hline - 虜 & 5.5 .5 & 一補 & 14.8 .20 & / 傾 & 4.2 .18 \\
\hline 仗 & 7.7 .24 & 俯 & 12.5 .2 & 傾 & 14.2 .14 \\
\hline 俚 & 7.8 .4 & 一仰 & 12.5 .2 & - 心 & 14.2 .14 \\
\hline 一俗 & 7.8 .4 & 一仰蒬然 & 15.6 .19 & 僈 & $4 \cdot 4 \cdot 31$ \\
\hline 候 & 2.3 .26 & 修睬治平 & 15.4 .18 & 傳播 & 5.1 .32 \\
\hline 一瑱 & 8.9 .10 & - 行 & 16.3 .30 & - 聞 & 5.2 .22 \\
\hline 侷 & 9.3 .1 & 倡傻 & 16.1 .31 & - 染 & 10.1 .17 \\
\hline 一促 & 9.3 .1 & 借口 & 13.5 .22 & 一染病 & 10.1 .17 \\
\hline 便宜行事 & 14.3 .23 & 條陳 & 10.5. 2 & 一檄 & $10.7,12$ \\
\hline 俄羅斯 & 14.1 .33 & 9 偶 & 1.1 .24 & 傷懐 & 7.6 .28 \\
\hline 係 & 11.6 .17 & 假使 & 1.3 .28 & 鿖 & 15.4 .32 \\
\hline 侵移兑用 & 11.8 .1 & 偶 & 2.2 .3 & - \pm & 15.4 .32 \\
\hline 候 & 14.7 .12 & 偶 & 13.7 .9 & 12 僚屬 & 6.2 .12 \\
\hline 侮 & 15.3 .15 & 偉大 & 5.2 .19 & 㒒射 & 7.2 .17 \\
\hline 倫 & 1.1 .18 & 侧 & 6.2 .31 & 㒒 & $8 \cdot 1.23$ \\
\hline 一理 & 1.1 .18 & - 重 & 11.1 .34 & 一奥 & 8.1 .23 \\
\hline 一紀 & 15.7 .32 & 偷生苟活 & 9.3 .28 & 僧 & 7.6 .32 \\
\hline 食 & 3.3 .20 & 偭 & 9.4 .13 & 一道 & 7.6 .32 \\
\hline - 㡺 & 3.3 .20 & 一乡无常 & 9.4 .13 & 一供新蜜 & 2.5.11 \\
\hline 侜 & 4.1 .28 & 偏师(師) & 9.8 .30 & 一格林心 & 14.8 .10 \\
\hline 倖 & 1.4 .15 & 停閶 & 11.5 .14 & 堯 & 11.7 .24 \\
\hline 倣 & 4.3 .22 & 一滞 & 11.7 .22 & 僮 & 13.7 .14 \\
\hline 一效 & 4.3 .22 & 脾斯券 & $16 \cdot 6.25$ & 僱 & 14.6 .29 \\
\hline 俸 & 4.3 .30 & 10 傺 & 6.2 .8 & 13 儉 & 4.2 .16 \\
\hline 倍死不貞 & 4.6 .17 & 杰(傑)出 & 9.4 .8 & 儀 & 1.6 .22 \\
\hline 倒行逆施 & 5.8 .13 & 倡導 & 1.3 .15 & - 式 & 1.6 .22 \\
\hline 值宿 & 6.6 .15 & 傅 & 2.3 .30 & 一禮 & 4.6 .21 \\
\hline 倨 & 8.2 .34 & 傅 & 7.8 .28 & －注 & 14.2 .10 \\
\hline 一慢 & 8.2 .34 & - 彩 & 7.8 .28 & 一文 & $14,2.17$ \\
\hline
\end{tabular}




\begin{tabular}{|c|c|c|c|c|c|}
\hline 儀制司 & 14.2 .28 & 元整 & 11.5 .12 & \multirow{2}{*}{\multicolumn{2}{|c|}{ 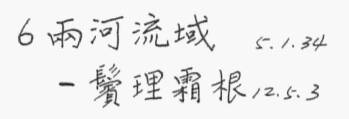 }} \\
\hline 儌 & 4.3 .1 & 元 & 11.5 .20 & & \\
\hline 僻 & 7.4 .27 & \multicolumn{2}{|c|}{ 一曹九域志 12.8.5 } & 一江 & 14.3 .26 \\
\hline 一壤 & 7.4 .27 & 一氮 & 16.6 .32 & 一淮 & 14.99 .10 \\
\hline 14 儒家 & 4.1 .1 & 4 光武 & 5.9 .23 & 一宫 & 15.11 .28 \\
\hline 一家之法. & 4.5 .12 & 一祿 & 7.3 .3 & 7 㓱魯孫潘 & 10.1 .30 \\
\hline 一術 & 10.2 .18 & 一固汝潁 & 10.1 .20 & & \\
\hline 儕 & 2.2 .5 & 先主 & 8.5 .3 & \multirow[t]{2}{*}{12} & 准 \\
\hline 一輩 & 2.2 .5 & - 是 & 14.8 .6 & & \\
\hline 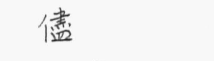 & 11.1 .26 & 労 & 10.4 .2 & 0八索 & 2.5 .4 \\
\hline 一管 & 111.26 & 兆 & 16.4 .20 & 一股 & 13.6 .30 \\
\hline 15 信者 & 4.2 .17 & －端 & 16.4 .20 & \multicolumn{2}{|c|}{ 一史經籍志 16.3 .8} \\
\hline 一蓄 & 4.2 .17 & 充軍 & 10.7 .20 & 2 六㙯 & 1.2 .17 \\
\hline 優待 & 10.6 .29 & 一裕 & 13.12 .24 & 一畜 & 2.3 .10 \\
\hline 償 & 11.7 .13 & 5 克 & 4.3 .15 & 一博 & 3.2 .14 \\
\hline $2 /$ 䡌 & 5.6 .33 & 一魯倫 & 9.2 .1 & 一國 & 4.1 .19 \\
\hline 一然 & 5.6 .33 & 一烈 & 9.2 .4 & - 家 & 4.5 .24 \\
\hline & & \multicolumn{2}{|c|}{ 一里米亚(亞) 9.8 .31} & 一部 & 7.2 .11 \\
\hline \multirow[t]{2}{*}{10} & 儿 & 总 & 11.8 .1 & 公羊傳 & 1.2 .28 \\
\hline & & 6 兔 & 4.4 .6 & 一孫弘 & 4.6 .29 \\
\hline 2 允 & 6.6 .7 & 一獲狗烹 & 4.4 .6 & －賣 & 5. 4.15 \\
\hline 一諾 & 14.7 .28 & 7 竟州 & 11.3 .23 & 一孫譛 & 8.3 .19 \\
\hline 元載 & 3.4 .19 & & & 一風易 & $8 \cdot 9.8$ \\
\hline 一稹 & 7.6 .21 & 11 & $\lambda$ & 一文 & 14.1 .34 \\
\hline 一和郡縣 & -7.9 .23 & & & 一羊學説 & 15.9 .16 \\
\hline 一舅 & 8.4 .34 & O入蜀記 & 12.4 .8 & 5 兵曹 & 6. 4.34 \\
\hline 元 & 8.6 .9 & 2 肉經 & 2.5 .3 & 一部 & 14.3 .20 \\
\hline 一年 & 8.6 .9 & 一寵之娈… & 3.1 .25 & 一略 & 15.2 .24 \\
\hline 一史 & 8.11 .29 & 一務府 & 14.2 .27 & 6 具體而微 & 3.2 .19 \\
\hline 一朝秘史 & $9 \cdot 1.26$ & 一閤 & 14.2 .29 & - 文 & 7.4 .24 \\
\hline 一史本紀 & $9 \cdot 3 \cdot 18$ & 一江三口 & 14.9 .17 & 一摺奏聞 & 14.2 .25 \\
\hline 一順帝 & 9.7 .1 & 一命 & 16.3 .22 & 其 & 4.3 .7 \\
\hline 一帥 & 10.3 .11 & 一相 & 16.3 .22 & 7 典型 & 2.2 .23 \\
\hline 一楉 & 11.5 .5 & 4 全唐文 & 7.7 .14 & 一墳 & 4.6 .8 \\
\hline
\end{tabular}



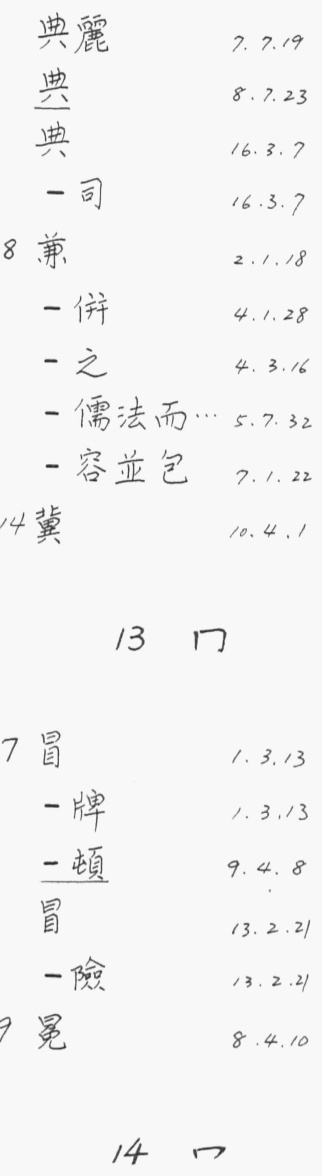

2 见

6.6 .31

一員

7 冠

一冤

$$
15
$$

6. 6. 31

6. 6.25

$8 \cdot 4 \cdot 10$

5 治

一金術

冷

一署

8 凍

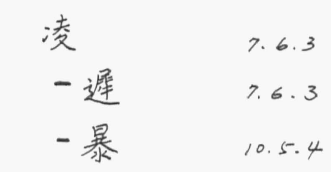

凌

- 駕

9 凑

14 凝

一成

一重

7.4 .27

7. 7.8

\section{U}

2 凶

一筃

8. 7.12

3 出土

8. 7.12

- 勤駇

5. 3.14

- 身

6.5. 4

6.5 .22

一納惟允6.6.?

-入

11.7 .5

- 息

15.2 .8

- 身

4 凸

16.2 .15

7. 8.26

[ن]

- 3

10 與國

7. 8.26

7.8.26

$14 \cdot 6.27$

$$
18 \text { 15 }
$$

$$
\text { 1 刃 }
$$

ᄀ

- 斗

2 分析

一晰

$2 \cdot 2 \cdot 19$

切磋
4 刖

3.1 .22

刑

3. 1.22

一辟

4. 2.29

一尠

4.3. 9

一狺犬

7. 3,18

列㣛寇

自惑故事 7.8 .9

- 宁(㸘)

5 别苑

13.1 .22

一有用心

3. 3.11

册!

13.9 .30

6 制

4. 6.22

一矣辟

1. 2.23

- 衡

$4 \cdot 3.3$

- 命

7. 2.14

一服

7. 2.21

一義

8.3 .24

美

15. 2.19

刺戟

- 史

1. 3.33

一諷

6.4 .9

刺

7.6 .30

券

刻畵

15.4 .2

12. 7.21

一板

4. 3.29

7 削

13.7 .21

削

一足適履 3.4 .28

- 刀

5. 4.2

一平

5. 4.3

前提

…則已否埧4.6.8

8 剔

2.1 .32

剝

3.1 .19

一消门

3. 1.19 


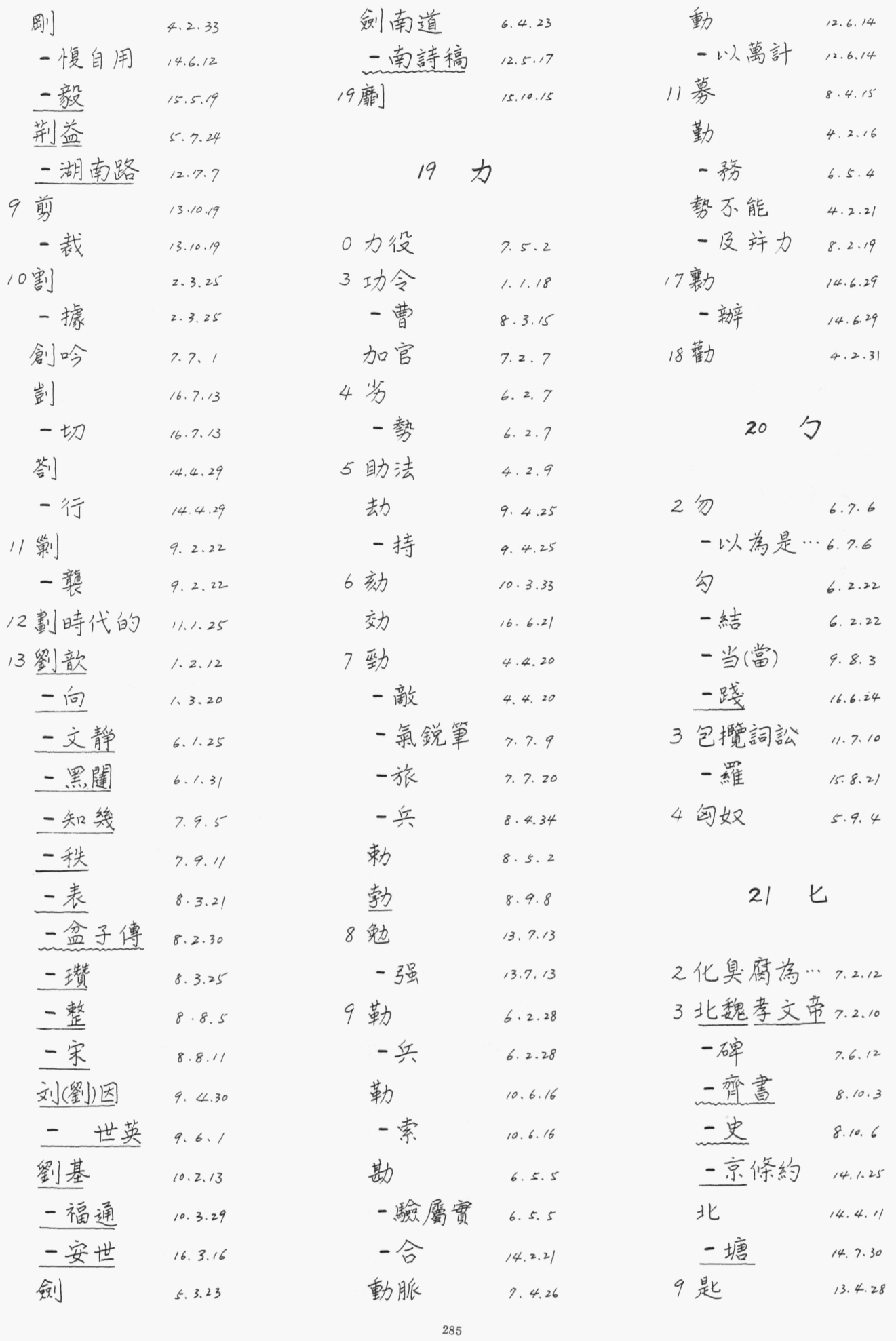




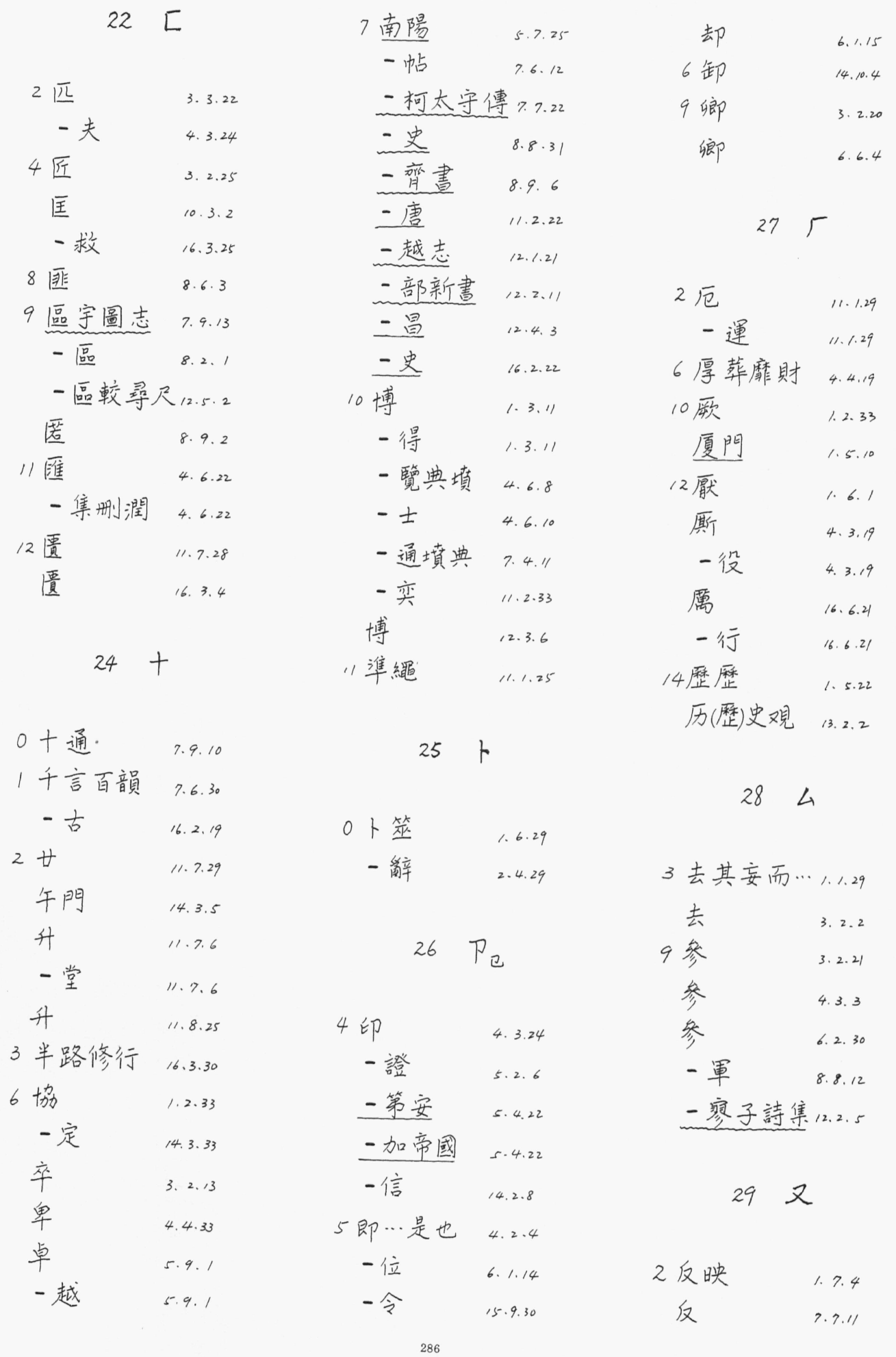


反復無行 8.8 .24

一映

13. 3. 1

6 叔魚

一向

3. 1.28

一世

4.2.27

一孫通

4. 3. 2

叔

4. 6.23

取㫖撰擬…72.22

受業

12.4 .2

7 敍

$$
\text { 一述 }
$$

2. 4.10

叛

一容

30

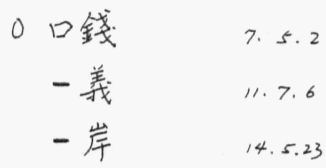

2 古誼

$$
4.6 .8
$$

一文

7.6

一今郡國…7 7.9.16

一辣

12. 3.30

一步

史記

12.5 .14

一通

1. $2 \cdot 32$

一天倪

7. 9.5

一迹

9. 6.1

司馬談

16.1 .9

一馬遷

4. 2.24

一農

5. 2.21

- 空

7. 3.3

一馬光

8. 3.24

一馬相如

11.5 .13

16.3 .19
台管海岪5.6.7

台

8. 7.1

叫化

10. 1.20

右傾机会…3. 3. 5 . 25

可怜虫

13.5 .8

号行具生…12.9.11

3 同盟

2. 2.33

一知國政 6.6 .3

一出一敨7.3.29

一治

15.3 .9

4. 5. 25

一物

15.7. 32

- 教

15.8 .20

吏

5. 5.33

一部

6. 3.34

各不相下

5. 7.22

一造意氧

7. 2.24

向

7. 1.20

- 慕

7. 1.20

一心力

7. 4.27

一笛

8.3 .24

一隅而泣 13.5 .8

- 化

14. 2.14

合肥

8. 8.5

合

13. 9.25

一息國

14.5 .5

一夥

15.11 .4

吉州

11.2 .34

一水縣

12. 4.11

吉

14.2 .30

- 日

14.2 .30

一林

14.9 .21

4 吹笔鼓瑟…3.2.14

呈

4. 1.18
呈

吾

11.4 .9

4. 2.13

一邱䜭王 16.3 .19

吕代春秋2.1.22

一留

一相

5. 6.23

5.7. 7

一不章

5. 7.31

一世衡

6. 3.3

一祖謙

11.2 .9

君權

5. 2.14

一守, 任數…5 5.8.21-

- 长

9.1 .29

吴越

5. 6.7

一起

5. 6.34

一道子 7.8 .29

- 志

8.5. 2

一興

8. 8.28

一處厚

12.1 .27

告冴

6. 2.27

告

16.2 .29

一前

$16.2,29$

一前之食氧16.2.29 吞

吞

7. 6.25

一年

9. 4.28

- 没

9. 4.28

吟

11.6 .22

交

7. 7,

否

8. 1.34

5 和諧

15.4 .32

一林

4. 7.2

一州

10.2 .5

和

15.11 .27

周 


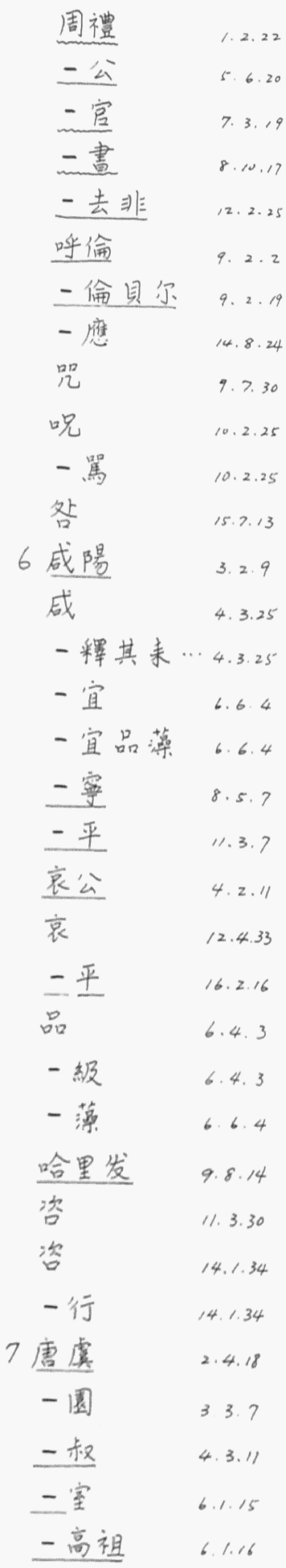

一玄宗

- 會要

哲

一學

哲

員额

一職

8 啓

啓

一誘

一, 簡, 獍語

唱

售

啣

一接

唯咨嘲謔…

一心厉史…13.9.9

啜

9 喚

單調

一于

喝采

啼

一飢號寒

喻

䠆

惠

喘

善陳

一後

喇嘛

喧

旁
8.10 .25

3. 3.7

3. 3. 7

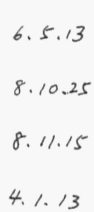

4.1 .13

4.2 .33

$5 \cdot 8.31$

8. 2.?

2.5 .25

7. 4.27

7. 4.27

11. 7.7

$4.6 \cdot 2$

5.4 .8

4. 1.22

4.1.22

11.3 .30

11.7 .25

1. 6.14

1.5 .33

8.3 .9

3. 2.33

3.3. 7

4.2 .26

4.5 .11

$11.7,26$

9.4 .5

7. 6.28

14.8 .21

16.5 .17

12.4 .34

11.8 .9 $\begin{array}{ll}\text { 暎咭唎 } & 14.2 .19 \\ 10 \text { 嗜 } & 1.6 .23\end{array}$

一汸品

跼

一後

1/嘗

嘔

嗼

嘉

一定

12 嘻

嘲

13 噬

哥

16 㗽

1.6 .23

7.8 .5

7. 8.5

2. 1.23

6.2. 1

6.6 .24

4.2 .34

12.3 .26

15.3 .33

11.3 .30

9.4.31

9.9 .2

16.4 .10

17 嚴刑罰以…4 4.2.31

一道

一酷

5.2 .26

7. 6.4

严(嚴)灵峰

13.3 .27

嚴助

16. 3.19

一安

$16 \cdot 3.19$

18 颚

3.1 .23

19 輬

14.6 .31

㙯

$15 \cdot 10 \cdot 34$

$21 \mathrm{r} / \mathrm{S}_{\mathrm{g}}$

2.1 .29

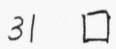

2 四鹏留 7.4 .13

一傑

7. 7. ?

一夷

7. 1.19

一十輩

11. 7.27

一譯館

14.2 .26

一倠

15. 8.30 
一庫總目

因

一禁

16.3 .8

7. 6.3

一執

7. 6.3

3 回紀

$8 \cdot 4.6$

一連務計吏11.2.34

- 合

13.9 .25

因緣

11.7 .2

一緗酱媒 11.7 .2

- 循年 15.27

一噎黁食 15.3 .33

5 估

- 唡

15.10 .32

國子

15.10 .32

一子監

1. 3. 4

-子學

7. 4.13

- 子

7. 4.13

一故

11.3 .2

一際公法

13. 3.20

一子七祭

$14.2 \cdot 12$

洷

16. 4.21

圍

4. 3.19

園

15.4 .11

糬

12.7 .21

一猪

12.7 .21

10 圆明園年年. 33 圍剩

13.3 .26

$1 /$ 圖樣

3.2 .17

一安

5.2 .9

湦

6.1 .33

雪練

15. 2.26

32 土土 $_{\text {土 }}$

0 土拉

$9 \cdot 2 \cdot 2$
-間

9. 4.8

一曠人稀 10.4 .26

一謝圖汗 14.2 .10

2 在在

3 地域

一盤

一理志

- 基

一方色彩

$10 \cdot 6.34$

一輿

圭

4 均

一用

一場

坑

一儒

坐

址

5 坦

重

一詢

一汥

一涎

重

6 型

垣

垮

7 埃及

埋

$$
\text { 一伏 }
$$

埒

8 堆

一栈
$2 \cdot 3 \cdot 30$

5. 3.32

5.4 .15

11. 3.20

12.5 .32

15. 7.33

8. 5.18

2. 2.26

8. 12.13

3. 2.25

11. 7.12

4. 6.17

4. 6.17

8. 3.19

9. 2.17

$5 \cdot 5 \cdot 19$

6. 6.20

6. 6.20

8. 7.18

9. 8.3

16. 1.18

2.2 .23

14.5 .13

10.3. 20

5.1 .33

6. 2.25

6. 2.25

15.9 .30

1.6 .15

12. 6.27
基礎

域

堅蜮

堅

一强

堅

執

- 行

一政

2.1 .15

2. 3.30

培

一植

9 侁

堡

一涅

6. 2.19

堪

一稱

$8 \cdot 5 \cdot 2$

5.8 .19

6. 3.28

11.5 .8

堤

报(報) 达9.8.16 報效

$15 \cdot 2 \cdot 10$

堰

10 塗

10.8 .5

叙

1. 7.8

3.2 .14

塏

3. 2.18

塑

䲧

一壁

7.6 .15

7. 1.30

塚

7.1. 30

塔塔儿( (兒)

8. 3.20

一本

塞

$9 \cdot 2 \cdot 3$

塞

10.3.34

10. 4.29

- 外

10. 4.29

塘

$10.8 \cdot 5$ 


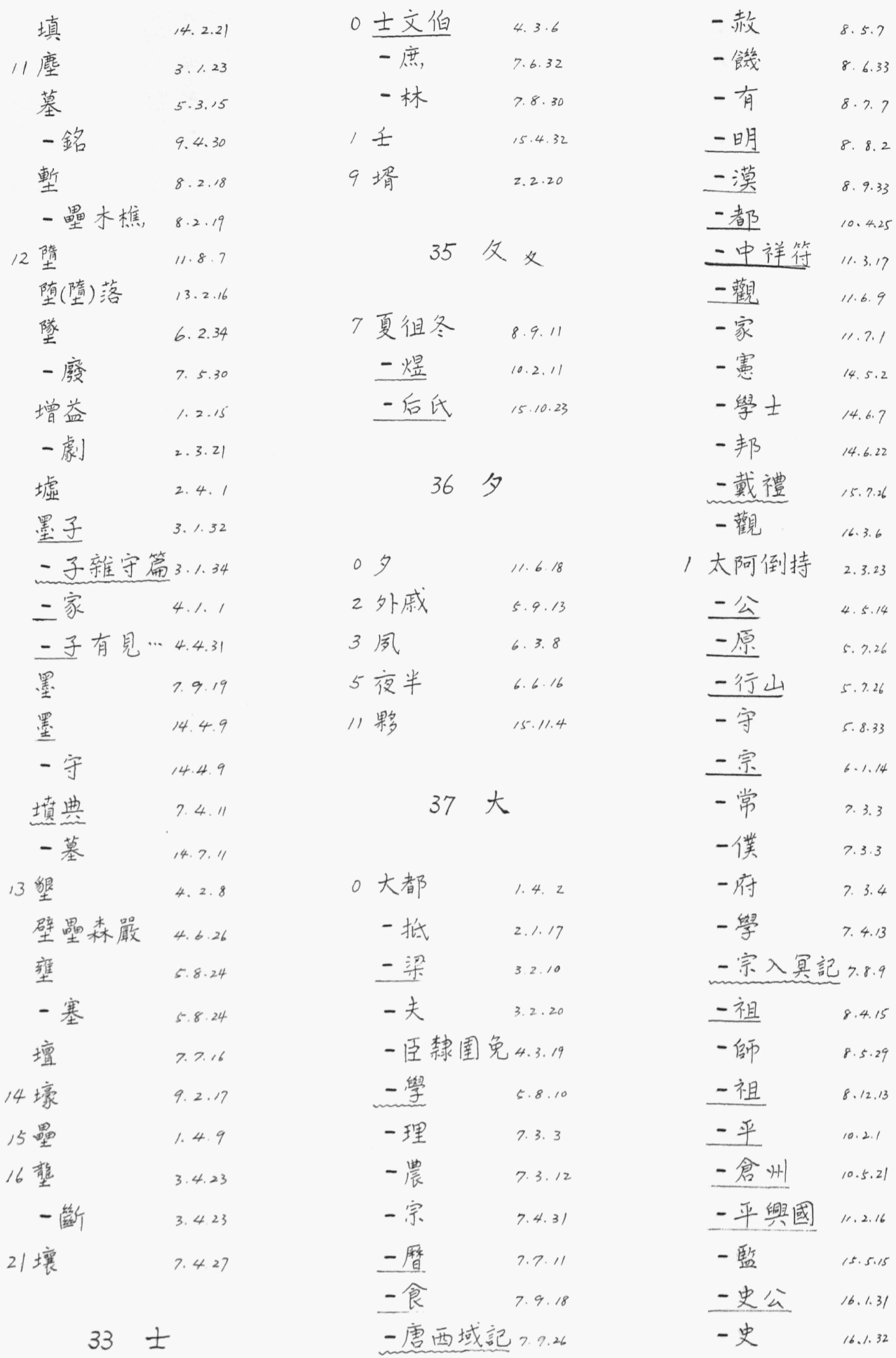




\begin{tabular}{|c|c|c|c|c|c|}
\hline 太史公書 & 16.1 .34 & 契 & 16.4 .24 & 5 始 & 1.4 .34 \\
\hline 天之倖民 & 1.4 .15 & 7 套 & 13.9 .31 & 岈 & 2.2 .6 \\
\hline - 問篇 & 2.5 .21 & 一語 & 13.9 .31 & 妾 & 3.1 .24 \\
\hline -子 & 2.6 .9 & 8 奠 & 6.3 .20 & 委筫 & 8.5 .19 \\
\hline - 皇 & 5.6 .30 & 奢 & 6.7 .3 & 委 & 9.3 .27 \\
\hline - 可汗 & 7.1 .20 & 一侈 & 6.7 .3 & 一靡不振 & 9.3 .27 \\
\hline 一 聖 & 11.3 .21 & 10 奥 & 7.7 .12 & 6 威㔛 & 6.1 .28 \\
\hline 一顔 & 14.3 .2 & 13 奞 & 4.3 .23 & 姻 & 2.2 .1 \\
\hline 一職 & $16 \cdot 4 \cdot 30$ & 一垭 & 10.1 .23 & 㚣 & 5.8 .20 \\
\hline 夫 & $4 \cdot 2.7$ & & & 一淫 & 8.10 .33 \\
\hline 夫 & 8.9 .26 & 38 女 & & 姚思廉 & 6.6 .15 \\
\hline 3 夷子 & 4.4 .22 & & & - 察 & 7.7 .9 \\
\hline 荑 & 7.1 .19 & 0 女真 & 9.2 .15 & & 7.1 .19 \\
\hline 一堅丙志 & 12.3 .3 & 2 奴 & 2.3 .12 & - 態 & 7.1 .19 \\
\hline 一堅䋶志 & 12.7 .23 & - 柰隶 & 2.3 .12 & 妍(奸于) & $7 \cdot 8.14$ \\
\hline 4 大 & 6.2 .34 & 3 妃 & 6.1 .29 & 7 娱 & 3.2 .31 \\
\hline 5 奇 & 11.4 .14 & 一頞 & 6.1 .29 & 一樂場 & 3.2 .31 \\
\hline 奉禮郎 & 11.3 .18 & 好學 & 6.5 .23 & 8 婚姻 & 2.2 .1 \\
\hline 一化 & 11.7 .22 & 妄自尊大 & 7.3 .20 & 婕妤 & 6.1 .30 \\
\hline- 天 & $14 \cdot 9 \cdot 3$ & - 希 & 15.11 .28 & 婆卢火 & 9.2 .17 \\
\hline 奈何 & 15.2 .29 & 如許 & 8.5 .33 & 娼 & 7.6 .32 \\
\hline 6 奔 & 1.2 .24 & 奸 & 15.4 .32 & 婉 & 7.7 .19 \\
\hline 一走 & 1.2 .24 & 一位 & 15.4 .32 & 婪 & $9 \cdot 8 \cdot 3$ \\
\hline 奏 & 6.2 .23 & - 宄 & 15.10 .28 & 9 媒 & 12.5 .27 \\
\hline 一疏 & 14.2 .4 & 4 妙 & 1.1 .14 & 一介 & 12.5 .27 \\
\hline 一摺 & 14.2 .25 & 一得神韻 & 7.8 .28 & 10 媾 & 2.2 .3 \\
\hline 一效 & 15.5 .14 & 妖 & 1.4 .27 & 嫂 & 2.5 .21 \\
\hline 奕 & 11.2 .33 & 一妄 & 1.4 .27 & 嫌 & 6.5 .34 \\
\hline 一訢 & 14.8 .16 & 妣 & 2.5 .10 & 㜍 & 6.6 .8 \\
\hline 契 & 6.5 .5 & 妓 & 3.2 .30 & 11 嫡 & 6.2 .12 \\
\hline 一胡 & 8.10 .6 & 一院 & 3.2 .30 & 一長 & 6. 2.12 \\
\hline - 丹 & 9.3 .22 & 一娼 & 7.6 .32 & 13 赢奉 & 4. 6.10 \\
\hline 一勘 & 11.6 .5 & 妥 & 11.1 .29 & 14嬪 & 6.1 .29 \\
\hline 一勘羪士 & 11.6 .5 & 一㔹 & 11.1 .29 & & \\
\hline
\end{tabular}




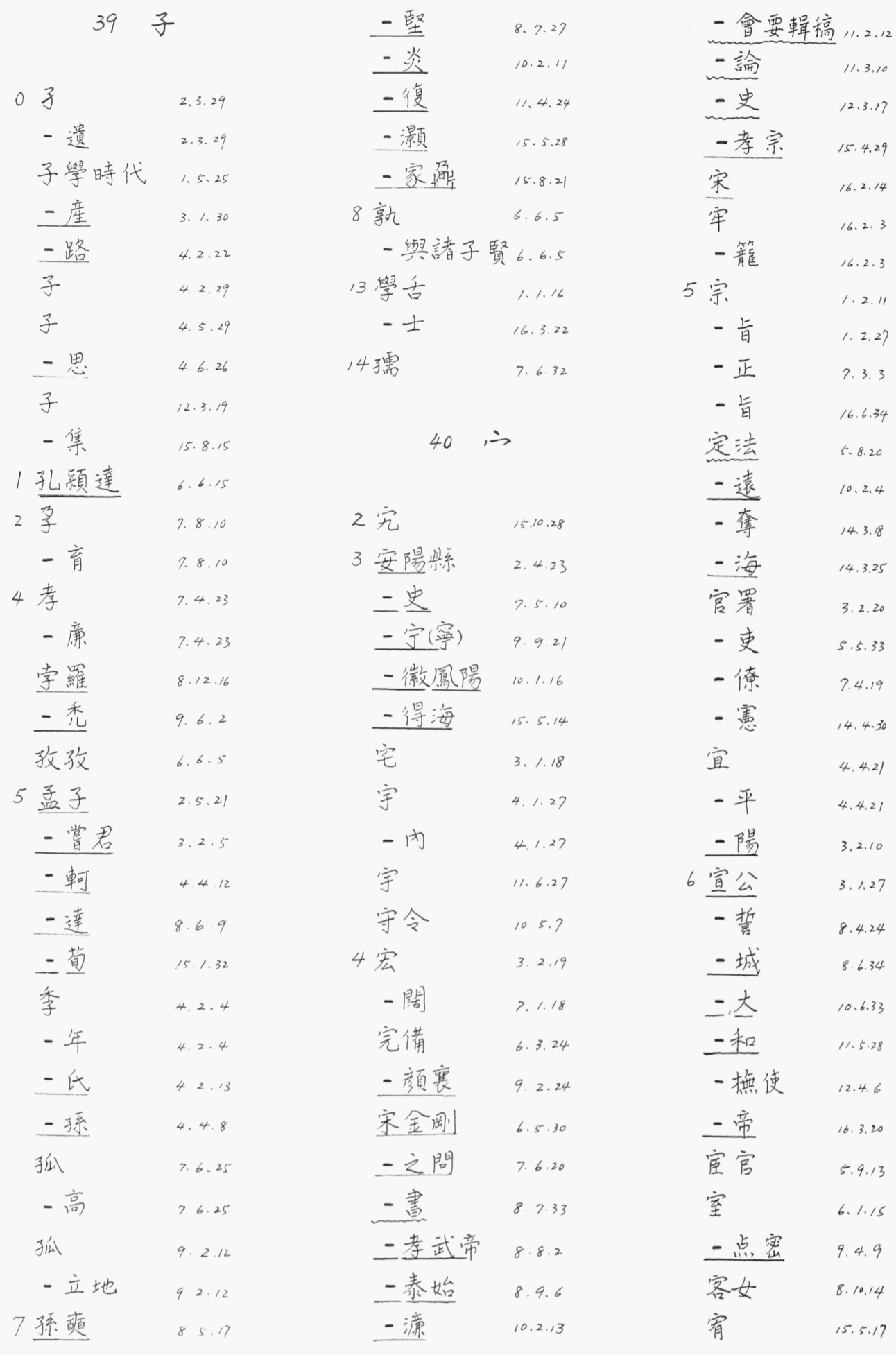




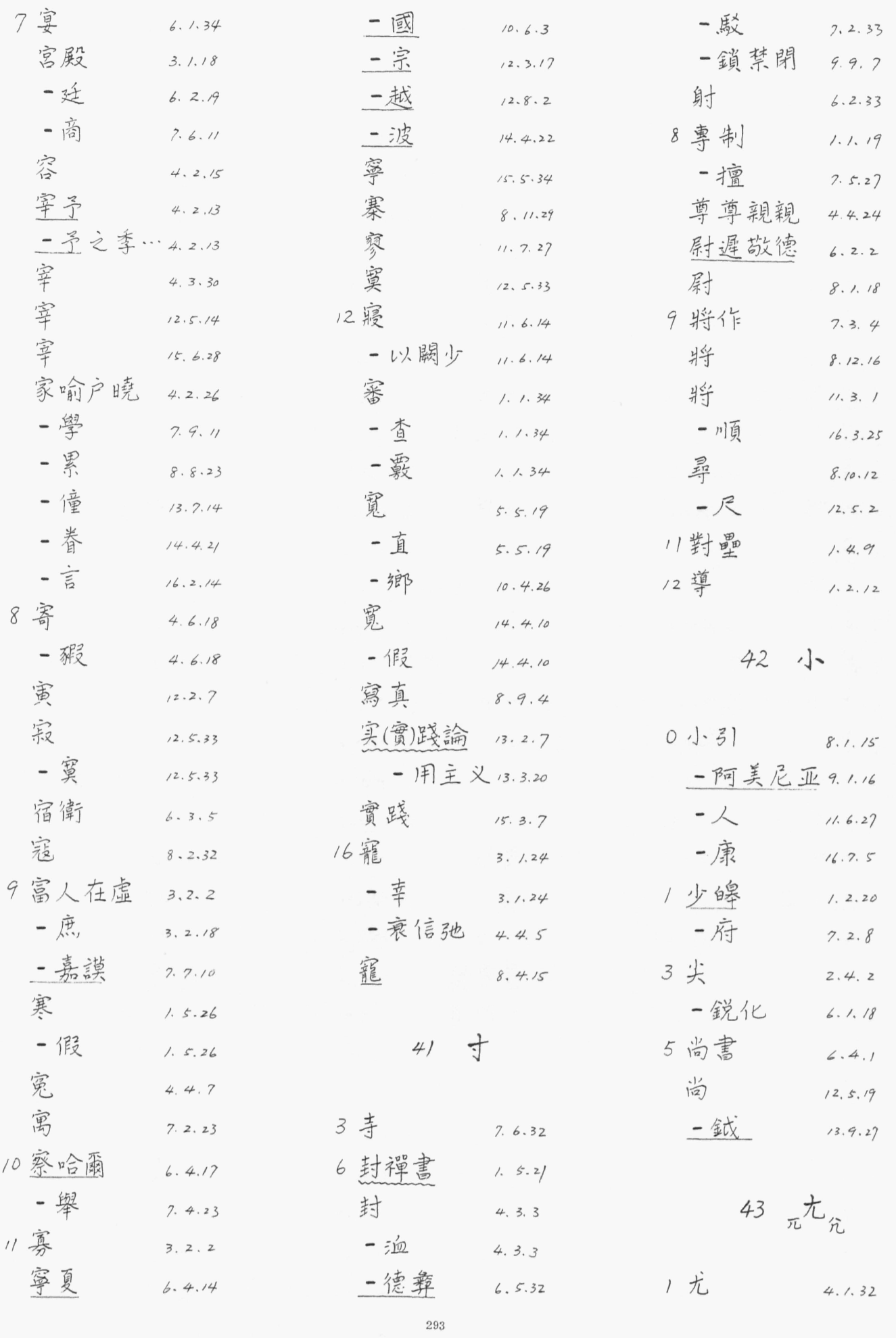




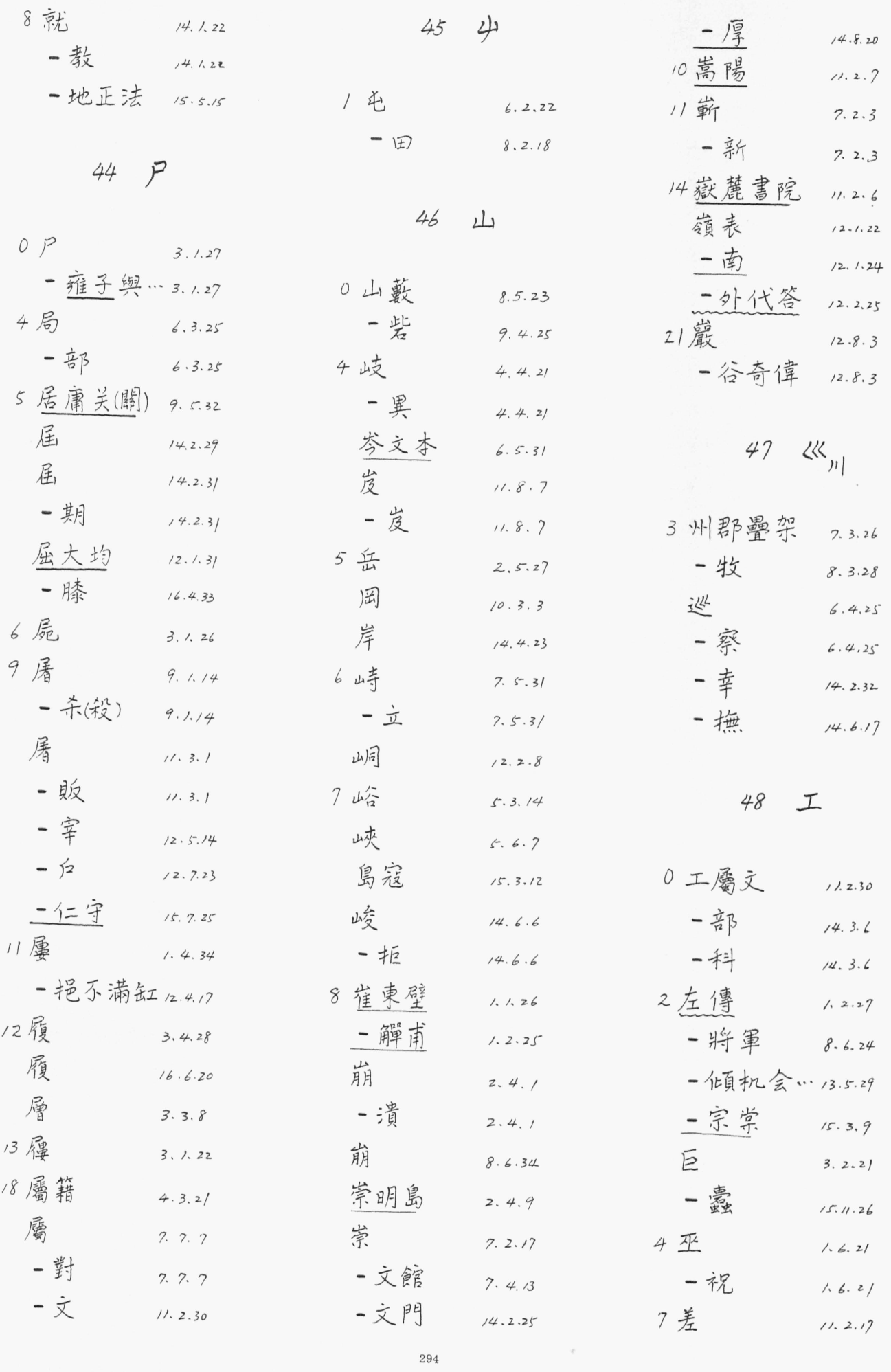




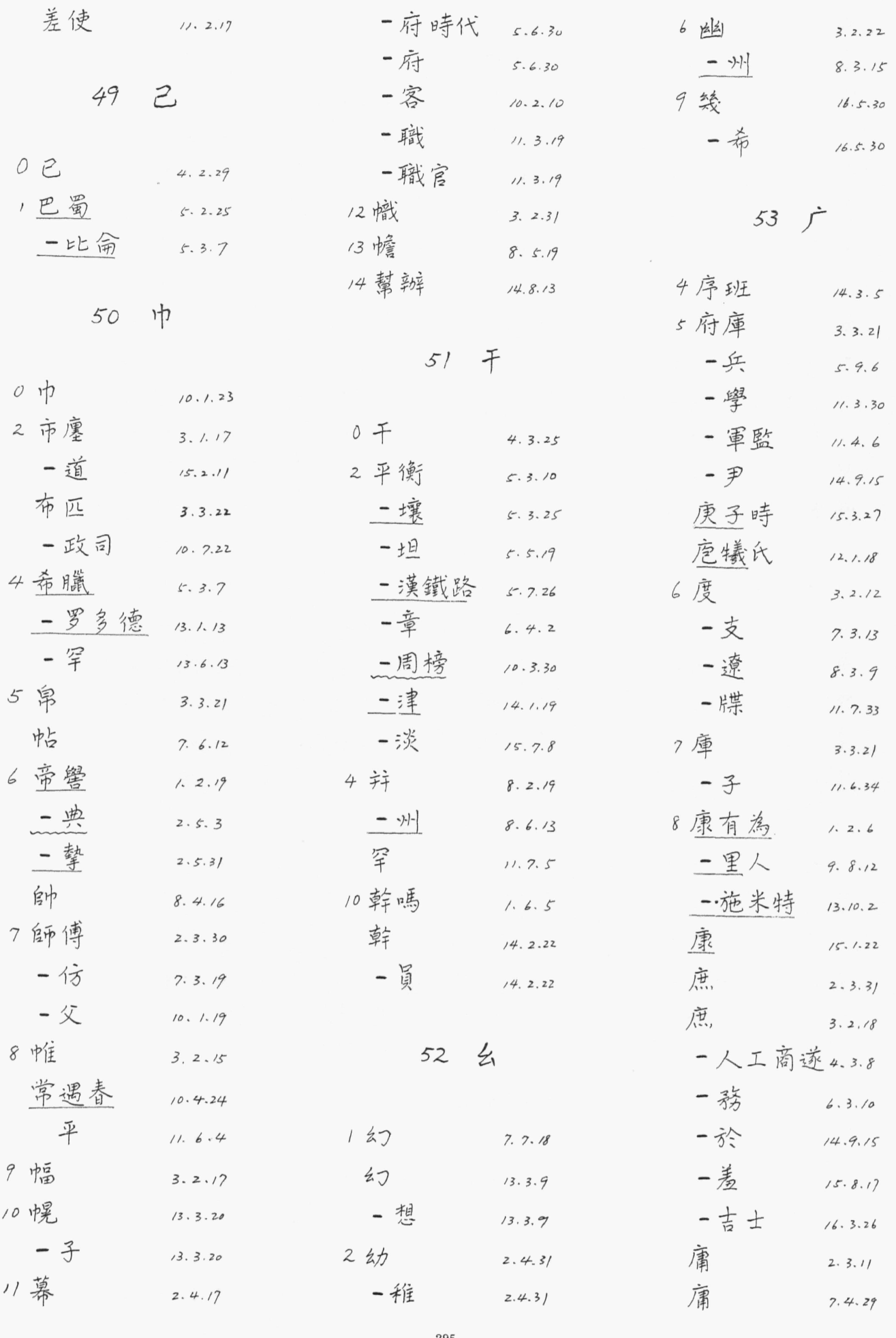




\begin{tabular}{|c|c|c|c|c|c|}
\hline 庸 & 12.3 .33 & 延 & 4.3 .23 & 5 䋈 & 5.9 .26 \\
\hline 廊 & 11.6 .33 & 一攬 & 4.3 .23 & 8 張本 & 1.5 .21 \\
\hline 虐 & 11.7 .34 & 一康 & 8.6 .9 & 一湯 & 4.6 .29 \\
\hline - 院 & 11.7 .34 & 一篤 & 16.3 .10 & 一説 & 7.7 .7 \\
\hline 10 争 & 4.4 .30 & 廷 & 6.2 .19 & 一超 & 8.3 .15 \\
\hline 11廊 & 8.1 .30 & 一尉 & 7.4 .4 & 一雄跋扈 & 8.6 .13 \\
\hline 一清 & 10.5 .5 & 6 㢠 & 10.2 .25 & 一荣 & 9.5 .2 \\
\hline 12廣泛 & S.3.24 & 一護 & 10.2 .25 & 一柔 & 9.5 .2 \\
\hline 㢆 & 8.2 .11 & 建中 & 7.5 .11 & 一天祐 & 10.3 .12 \\
\hline 一束新語 & .2 .1 .31 & - 炎 & 11.7 .20 & 一士誠 & 10.3 .30 \\
\hline 一南西路 & 12.3 .20 & 一炎以來 & $=12.8 .7$ & 一思道 & 10.7 .13 \\
\hline 一座 & 15.10 .27 & 一州 & 16.2 .3 & 一懷素 & 11.8 .23 \\
\hline 㾝 & 3.17 & 一白 & 16.2 .11 & 一之洞 & 15.6 .13 \\
\hline 度妄 & 4.119 & & & 一子正蒙 & 15.7 .26 \\
\hline 一疾 & 8.10 .30 & $55-$ & H & 一蒼 & 16.3 .2 \\
\hline 一閶万具 & 12.6 .31 & & & 一子僑 & 16.3 .20 \\
\hline 㾰堂 & 7.6 .27 & 2 弁 & 14.2 .21 & - 居正 & 16.4 .25 \\
\hline 屡居 & 11.3 .32 & 12 䔩 & 6.3 .30 & 9 强公室而… & 5.7 .17 \\
\hline 13 糜 & 3.3 .20 & 一旗 & 8.4 .26 & 一焉弱凌,... & 9.4 .31 \\
\hline 康 & 15.11 .9 & 一端 & 11.2 .2 & 10 敫 & 1.4 .17 \\
\hline 14息天 & 10.7 .23 & & & 12 彈 & 3.2 .14 \\
\hline \multicolumn{2}{|c|}{ 一天府畫院11.2.6 } & \multirow{2}{*}{\multicolumn{2}{|c|}{56 t }} & 壓 & 14.2 .22 \\
\hline 一建 & 12.4 .29 & & & 13彊 & 4.2 .33 \\
\hline 腐 & 16.315 & \multirow[t]{2}{*}{10 斌 } & \multirow[t]{2}{*}{4.4 .8} & 14 䨎勒 & 10.4.1 \\
\hline 一选 & 16.3 .15 & & & 15 彍 & 7.5 .23 \\
\hline 16虚山 & 11.2 .6 & 57 & $弓$ & 一騎 & 7.5 .23 \\
\hline \multirow{5}{*}{$\begin{array}{c}\text { 麻 } \\
\text { - 大 } \\
\text { 麻 }\end{array}$} & \multirow{4}{*}{$\begin{array}{l}7.3 .21 \\
7.3 .21 \\
12.4 .18\end{array}$} & $0 弓$ & 2.3 .9 & \multirow{2}{*}{\multicolumn{2}{|c|}{$58 \Rightarrow y$}} \\
\hline & & |引玉之磗 & 8.2 .1 & & \\
\hline & & 2 弗 & 4.3.1 & $9 \frac{\text { 知 }}{4}$ & $12,4.18$ \\
\hline & & 弘文館 & 6.6 .17 & & \\
\hline & \multirow[t]{2}{*}{ 又 } & 一濟荅生 & 6.7 .7 & \multirow[t]{2}{*}{59} & \\
\hline \multirow{2}{*}{54} & & 3 弛 & 4.4 .5 & & \\
\hline & 1.2 .3 & 4 弟 & 15.8 .31 & 4 形而上 & 15.6 .22 \\
\hline
\end{tabular}




$\begin{array}{cc}\text { 一而下 } & 15.6 .22 \\ 8 \text { 梤, } & 7.6 .14 \\ \text { 翢, } & 7.6 .14 \\ \text { 一塑 } & 7.6 .14 \\ 9 \text { 彭大 } & 10.2 .3 \\ \text { 彰 } & 3.1 .26\end{array}$

$60 \%$

4 役

一龄

6.5 .2

役

5 往常

彼

一此

征

一服

征

征

一 耳又

征

徂

彿

6 待

後勤

- 宫

漢書 8.1 .18

- 主

律

一祭

一詩

㿟。

7 徒

- 勞

1.2 .16

2.2 .5

2.2 .5

2. 3.16

2. 3.16

2.3 .22

$4 \cdot 2.12$

14.7 .23

$15 \cdot 7.16$

8.9.11

16.4 .34

3. 2.13

5.5 .34

6.2 .23

11.2 .31

6.6 .32

7. 4.13

7. 6.22

15. 5.18

1. 6.8

1.6 .8
一擁虚名7.3.26

徐

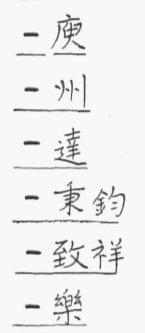

5. 7.4

7. 6.25

$8 \cdot 10.12$

10.4 .24

12. 3.5

15.2 .7

16.3 .19

侳

11.8 .21

徍

一 申

14.2 .6

徒法不足…15.1.32 8 従

一屬

2. 2.11

$$
\begin{array}{ll}
\text { - 事 } & 8.3 .21 \\
\text { - 我 } & 8.4 .23 \\
\text { - 而 … } & 12.6 .30 \\
\text { - 權 } & 14.4 .11
\end{array}
$$$$
\text { 8. } 3.12
$$$$
\text { 一容中祕 }
$$

御

一用

3.3 .23

$$
\text { 一前 }
$$

徙

16.3 .27

3. 3.23

14.2 .6

一都

5. 7.11

得士者昌…4. 3.22

一薩州

13.2 .24

徠

9 循

10.5.6

- 行

5.5 .33

- 吏

5.5 .33

一資

5.9 .1

一習敞徆

11.5 .16

星敵徆11.7.25

10 復

复(復)仇
4. 2.12

9. 1.27
得

8.5.6

12 徵

3. 3.22

徵

4.3 .1

一兵制

$5 \cdot 9 \cdot 6$

一聘

10.2.11

德宗

7. 5.11

- 意志意…13.1.17

一宗

15.5 .33

一謨克拉西15.11.15 14 徽

10.3 .25

一宗

11.6 .6

$$
61 \text { 心忯 }
$$

○公機

13.7 .18

一傅

15.5 .9

一彷

15.8 .27

3 忌

4.2 .34

忌

11.5 .32

4 忠

4.2.32

忽必怒9.7.1

一里锝子9.9.26

忿

10. 7.27

- 怒

10.7.27

5 怨

6.7 .8

一毒

6 恢

15. 6.20

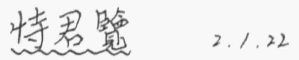

恃

态

7.3 .13

一格斯

4. 6.16

恥

13.1 .16

6.6 .6

一右不及…6.6.6

恒

7.3 .13 


\begin{tabular}{|c|c|c|c|c|c|}
\hline 6 恒规 & 7.3 .13 & 9 愛因斯特 & 13.10 .15 & 12 害 & 5.8 .19 \\
\hline 烅 & 15.4 .11 & 崰 & 5.5 .21 & 一令箸於 & 5.8 .19 \\
\hline 息 & 15.2 .8 & 曷 & 9.3 .32 & 一法 & 15.5 .12 \\
\hline 恣 & 16.3 .9 & 一幸 & 9.3 .32 & 憎 & $15: 2.9$ \\
\hline －意 & 16.3 .9 & 一昧 & 9.9 .2 & 読(恣) & 9.5 .5 \\
\hline 恒福 & 14.8 .10 & 愕 & 6.3 .6 & 一借 & 9.5 .5 \\
\hline 一祺 & 14.8 .13 & 嗄 & 14.6 .12 & 13 應 & 4.5 .2 \\
\hline 7 患 & 4.4 .18 & 10慎 & 5.8 .20 & 一侯 & 4.3 .24 \\
\hline 悉 & 10.1 .21 & 一到 & 3.3 .4 & 憶 & 12.3 .7 \\
\hline 悉 & 11.3 .9 & 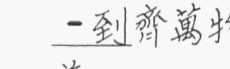 & 4.4 .15 & 15 懲 & 10.7 .30 \\
\hline 悉 & 14.8 .29 & 慈 & 4.2 .33 & 一治 & 10.7. 30 \\
\hline - 心 & 14.8 .29 & 一禧 & 15.5 .14 & 16懷 & 1.1 .14 \\
\hline 悌 & 15.7 .23 & 愧 & 6.7 .8 & 一疑 & 1.1 .14 \\
\hline 悠 & 12.4 .34 & 懊 & 9.8 .9 & 懷 & 6.6 .9 \\
\hline & 12.4 .34 & $1 /$ 慕 & 4.5 .18 & 一片某 & 7.4 .15 \\
\hline 悠 & 13.1 .11 & 慟 & 6.3 .9 & - 恩 & 8.11 .34 \\
\hline & 13.1 .1 & 磨州 & 6.1 .33 & 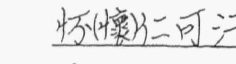 & I9.4.9 \\
\hline 悦 & 12.2 .10 & 実 & 11.4 .10 & 䢸 & 2.3 .28 \\
\hline 8 悴 & 1.3 .23 & 一慨 & 11.4 .10 & 一殊 & 2.3 .28 \\
\hline 悶 & 1.5 .33 & 慨 & 114.7 & 憎 & 14.6 .1 \\
\hline 惠 & 4.2 .33 & 一然 & 11.4 .7 & 一無所知 & 14.6 .1 \\
\hline 一親壬 & $14 \cdot 9 \cdot 27$ & 蓂 & 15.4 .3 & 17戀 & 7.7 .23 \\
\hline 惑 & 5.8 .23 & 欲倊 & 9.2 .8 & 一愛 & 7.7 .25 \\
\hline 一囱 & 11.6 .12 & 慾 & 14.6 .11 & 意蔐 & 8.4 .6 \\
\hline 惟…是赖 & 7.9 .23 & 一望 & 14.6 .11 & 18懼 & 4.2 .29 \\
\hline 悽 & 7.7 .19 & 惨 & 12.3 .22 & & \\
\hline 一婉 & 7.7 .19 & 惨(惨) & 9.4 .16 & 62 & i \\
\hline 情欲 & 9.2 .8 & 一酷 & 9.4 .16 & & \\
\hline 悼 & 12.3 .6 & 虑 & 10.5 .6 & 文 & 9.8 .7 \\
\hline - 念 & 12.3 .6 & 慧 & 12.3 .5 & /戌 & 12.3 .19 \\
\hline 9 意旨 &, 2.16 & 一解 & 12.3 .5 & -3 & 2.3 .19 \\
\hline 愈 & 2.3 .11 & 12 憔悴 & 1.3 .23 & 一戊政綬 & 15.1 .1 \\
\hline 一見 & $\begin{array}{l}2.311 \\
4.4 .1\end{array}$ & $\begin{array}{l}\text { 憧憬 } \\
\text { 一憬稱道 }\end{array}$ & $\begin{array}{l}7.5 .3 \\
7.5 .3\end{array}$ & $\begin{array}{l}2 \text { 成績 } \\
\text { - 古思汗 }\end{array}$ & $\begin{array}{l}1.4 .17 \\
9.1 .1\end{array}$ \\
\hline
\end{tabular}




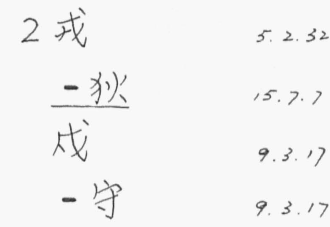

3 形

4 或邀一時…4.5.26 5 武断邀川

13.5.27

一傽院

14.8 .13

武

武

威廉

感豐

7 慼同文

15. 3.10

一舜䆩

8 裁奪

9 戟

㦲

一龍

15.4 .29

載垣

10 截

$$
\text { 一然 }
$$

11 绒

13 戴胄

戴

16.6 .25

14.7 .33

11.3 .16

11.3 .19

14.3 .24

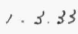

15. 3.20

5.3 .26

14. 8.14

10.3. 5

10.3 .5

4. 4.6

6. 5.30

9. 1.33

$63 户$

○户率十五副10.5.10

- 縃

11.6 .5

一䋓田土…11.6.5

一部

14.3.6

4 实

4. 6.16

实

一止

11. 8.10

11.8 .10
4 实氣

15.3.22

客玄龄

一廊

6.2 .3

7 扈

11.6 .33

7.7 .24

$$
64 \text { 手才 }
$$

1 扎撒

2 打垮

3 托派

4 抑

一制

抑

一依此制 4.2.15

批馼

扶

- 乩

一持

一蘚

抗頍

一衡

折獄

一衝

承襲

抓

一住

投身

一契

一降

抄

一錄

扼

一要

拋

1. 6.8

1. 6.21

6. 6.21

2.2 .28

5.8 .13

4.4 .12

4.5 .3

4. 6.29

6.4 .29

6. 3.22

9.6.27

9.6.27

8.10 .27

10. 2.19

13.5 .29

11.7 .6

11.7 .6

16.3 .33

16.3.33

10. 4.14
5 拆

一散

担

抬

一䫓

拙

抵

一押

押

拔

拔

拒

拒

披

一甲

拉施德

一能

拍盧洲

拘

一收

一倠

招懷

抽象

抽

抹鴊

抹

一殺

6 拳

括

括 指揮

拼凑

$8 \cdot 7 \cdot 18$

一丁美洲

16.3.34

5.10 .2

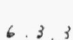

11.). 30

8. 7.5

13.5.33

15.11 .12

13. 3.28

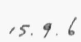

一地志 7.9 .14

5. 2.22 


\begin{tabular}{|c|c|c|c|c|c|}
\hline 6持服 & 8.3 .24 & 8 排斥 & 1.4 .21 & 9 搜罗( & \\
\hline 䠋 & 7.4 .6 & 接子 & 3.3 .4 & 揮 & 969 \\
\hline 一领 & 7.4 .6 & 控 & 3.3 .28 & 一霔 & 148 \\
\hline 按 & 11.4 .19 & 一制 & 3.5 .28 & & $x<6$ \\
\hline 一舉 & 11.4 .19 & 一訴 & $1, \cdot r .12$ & 椯 &, 8 \\
\hline 拯 & s.7." & 哖 & $4 \cdot 5 \cdot 26$ & 一測 & $2 / \alpha$ \\
\hline 一溺而入 & $\cdot 9.71$ & 掣 & 7.2 .33 & 插 & $6 / 2$ \\
\hline 挑 & 11.8 .33 & 一时 & 7.2 .33 & 提解 & 1.6 \\
\hline 一取 & 11.8 .33 & 掩 & 7.6 .25 & 一供 & 861 \\
\hline 挨 & 3.2 .29 & 措 & $7 \cdot 7 \cdot 7$ & 一兵 & 9,9 \\
\hline 7捄 & 9.8 .7 & 一鳏 & $7 \cdot 7 \cdot 7$ & 一舉 & 1046 \\
\hline 一時 & 15.4 .7 & 一施 & 10.7 .27 & 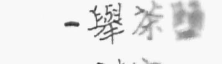 & 477 \\
\hline 挾 & 4.6 .10 & 措 & 11.8 .2 & & 127 \\
\hline 一寒之令 & 4.6 .10 & 掠 & 8.2 .32 & $-\nmid$ & \\
\hline 一天子以。 & 8.6 .29 & 推崇 & 11.2 .9 & 援 & 83.34 \\
\hline 捉 & r.8.w & 一諉 & 15.10 .21 & 援 & 86 \\
\hline 媢 & 6.5 .34 & - 幦 & 16.6 .8 & -例 & 4.1 \\
\hline 一杗前嫌 & 6.5 .34 & 挽 & $4 \cdot 3 \cdot 5$ & & \\
\hline 捐 & 11.3 .14 & 一制 & $4.3 \cdot 5$ & 一造 & 104 \\
\hline 一款 & 11.5 .14 & 一救 & 11.1 .29 & 揭 & 7629 \\
\hline 一納 & 15.2 .9 & 捷 & 15.4 .23 & 㨁 & 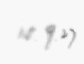 \\
\hline 振 & 7.4 .6 & 挨 & 16.1 .12 & & $(99)$ \\
\hline 一絸 & 7.4 .6 & 掯 & 14.7 .11 & 10拪 &, $7^{10}$ \\
\hline 一絧挈領 & 7.4 .6 & 釈 & 14.1 .20 & 括 & $n * 1$ \\
\hline 指 & 9.9 .28 & 一數 & 14.1 .20 & & 0.1 \\
\hline - I & 9.9 .28 & 扫(接) & 9.4 .1 & & 1320 \\
\hline 挪 & 11.5 .28 & - 除 & 9.4 .1 & 1/摰 & 2.51 \\
\hline 一戌 & 13.10 .16 & 掘 & 13.11 .12 & 糜 & 1215 \\
\hline 悑 & 11.3 .3 & 据 & 13.2 .33 & 一搷放政 & 4420 \\
\hline 挹 & 12.4 .17 & 一客 & 13.2 .33 & 一擦 & 6.1 .8 \\
\hline 採 & 5.5 .10 & 9掦 & 1.4 .6 & 一部本 & 97.33 \\
\hline 一鐵 & r. 5.10 & 一雄 & $7 \cdot 7 \cdot 11$ & 摹 & 76.7 \\
\hline 一用 & 6. 3.34 & 一子䨐 & 16.3 .9 & 㩔 & \\
\hline 8 掛各 & $11.7 \cdot 11$ & 搜 & 1.6 .23 & 一妵 & \\
\hline
\end{tabular}




\begin{tabular}{|c|c|c|c|c|c|}
\hline / 猚 & 9.4 .1 & 14 擬笪 & 14.1 .19 & 7 敕 & 6.3 .9 \\
\hline 一毁 & 9.4 .1 & 15 擲 & 3.2 .33 & 一宛真 & 11.7 .33 \\
\hline 携 & 14.3 .9 & 攀 & 8.9 .30 & 教之认務 & 4.2 .32 \\
\hline 摺 & 14.2 .28 & 一龍虐 & 8.9 .30 & 一部前 & 11.6 .10 \\
\hline 12 懒 & 1.2 .27 & 㮮 & 10.1 .19 & 一禿(佟) & 13.5 .33 \\
\hline - 开(艮型) & 13.1 .20 & 16 接总 & 10.2 .9 & 一条主義 & 13.5 .33 \\
\hline 撮 & 2.1 .54 & 拦(攔) & 9.3 .24 & 斯家子 & 11.6 .26 \\
\hline 挜 & 2.4 .17 & 一腰 & 9.3 .24 & 救刖而率 & 15.7 .11 \\
\hline 播 & $\sqrt{.} 1.32$ & 17 渟 & 3.2 .26 & 8 敦 & $7.7 \cdot 1$ \\
\hline 一種 & 10.5 .8 & 慗 & 15.10 .22 & 教漫 & 10.2 .7 \\
\hline 撰 & 7.2 .22 & 一壤之歌 & 15.10 .22 & 故 & 4.2 .22 \\
\hline 一人伕 & 12.3 .25 & 18携 & $12 . r .1$ & 9 放 & 4.2 .32 \\
\hline 撫 & 8.9 .1 & 摄攝 & 9.4 .26 & 一者弘 & 6.3 .3 \\
\hline 一糸 & 8.9 .1 & 一事 & 9.4 .26 & 一䔆 & 8.10 .33 \\
\hline 一局 & 14. 8.10 & 20攬 & 4.5 .23 & 一復 & 15.4 .10 \\
\hline 撤 & 9.2 .19 & & & 10 题辰競一意 & in 12.2 .6 \\
\hline 撤 & 14.8 .5 & 65 & & /1敌儌㯖 & 9.8 .9 \\
\hline 一職 & 14.8 .15 & & & 旉文 & 6.6.) \\
\hline 捂 & 10.4 .30 & ○支度浩繁 & 7.5 .20 & 一奏铎明 & 6.6 .7 \\
\hline 撥 & 15.4 .23 & & & 敷 & 10.7 .2 \\
\hline 一䍃反㳊 & 15.4 .23 & 66 & 攴 & & \\
\hline & 12.6 .2 & & & 67 & \\
\hline 13拥擁戴 & 9.1 .33 & 2 收椎其監 & $7: \sqrt{.17}$ & & \\
\hline 據 & 2.3 .25 & 一掠 & 11.6 .33 & ○文献 & 2.2 .20 \\
\hline 擒 & 3.1 .28 & 敃 & 8.1 .1 & 一治 & 6.3 .18 \\
\hline - 猚 & 3.1 .28 & 3改元 & 6.3 .16 & 一筫枌莏 & 7.6 .14 \\
\hline 擋 & 5.6 .5 & 一造我們。 & 13.7 .3 & 一增 & 7.7 .16 \\
\hline 操生棅之板 & 为, 8.19 & 4 放湯 & 9.1 .30 & 一以載道 & 7.7 .29 \\
\hline 擅 & 7.5 .27 & 5 政 & 4.2.30 & $\frac{\text { - 充 }}{\text { 不 }}$ & 8.9 .9 \\
\hline 撻 & $1,7.23$ & 一枒 & 7.3 .11 & 一带 & 8. 9.32 \\
\hline 㤅 & 16.1 .25 & 一典 & $7 \cdot 9 \cdot 11$ & 一景之治 & 9.6 .31 \\
\hline 擔 & 11.8 .18 & 一和 & 11.5 .27 & 一鬳犬通考 & 11.2 .5 \\
\hline $\begin{array}{l}14 \text { 擦 } \\
\text { 比3 }\end{array}$ & 6.1 .18 & 6 效死 & 4.3 .16 & 一讯 & 11.3 .3 \\
\hline & $7 \cdot 2.22$ & - 忠 & 5.7 .19 & 丈 & 12.6 .5 \\
\hline
\end{tabular}




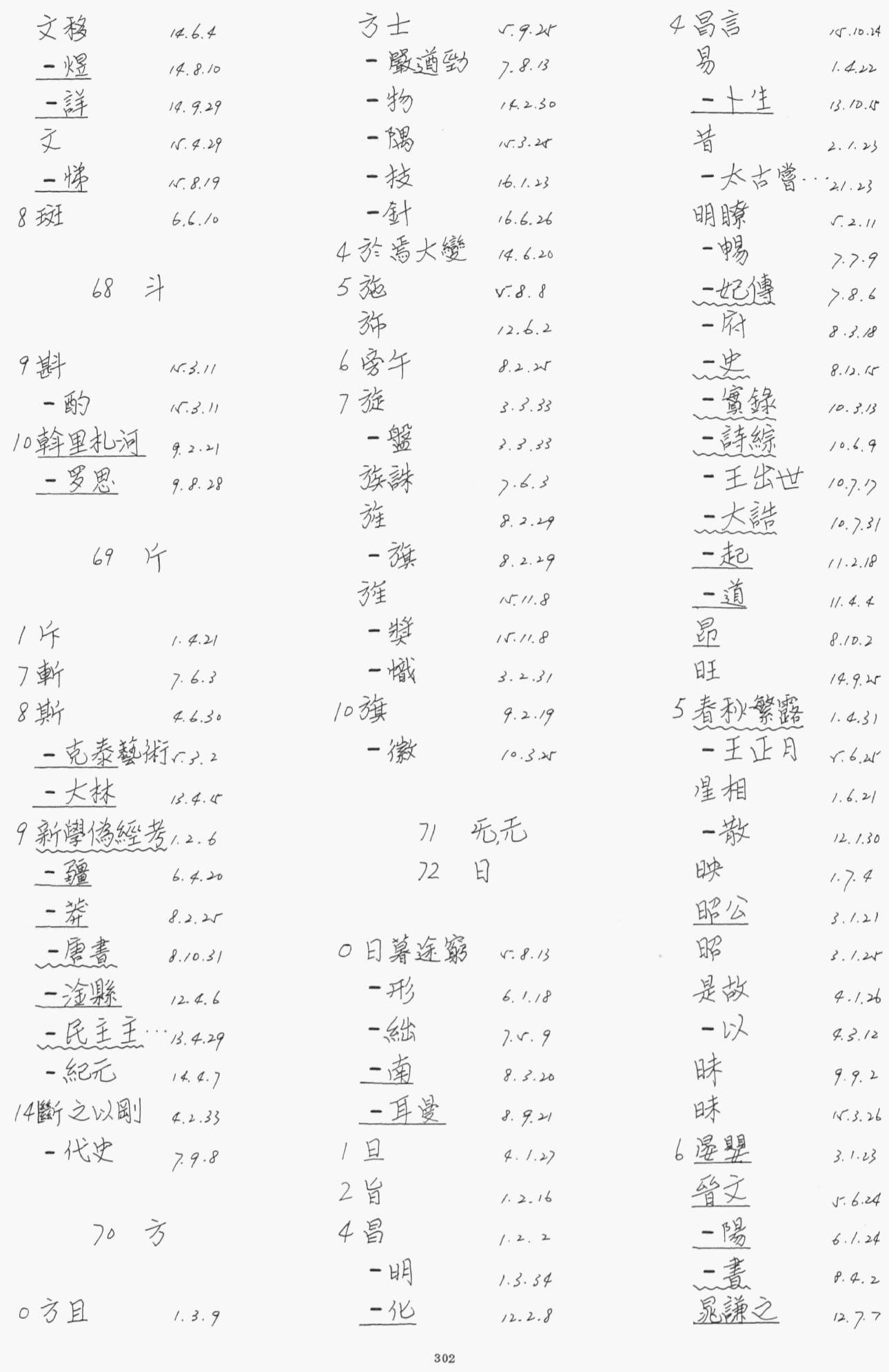




\begin{tabular}{|c|c|c|c|c|c|}
\hline 6时忌 & 11.5 .32 & 8曾 & 7.7 .5 & 7 朗然 & 16.2 .5 \\
\hline 7 晤 & 14.7 .2 & 一國潘 & 14.9 .18 & 望栄地密 & 16.3 .27 \\
\hline 8 智識 & 2.1 .34 & 一廉 & 15.1 .34 & 8 朝 & 4.6 .24 \\
\hline 一略 & 6.2 .3 & 最佳 & 14.6 .5 & 一儀 & 4.6 .24 \\
\hline 晶 & 7.1 .23 & 一號通貫 & 15.3 .23 & 朝 & 6.5 .26 \\
\hline 晰 & 14.9 .13 & 替 & s. 6.15 & 一粢 & 6.5 .26 \\
\hline 景鿆 & 11.4 .8 & 9 畜同館 & 14.3 .10 & 一野 & 7.8 .25 \\
\hline 9睱 & 6.6 .18 & 一銜 & 14.3 .17 & 一廷 & 8.6 .21 \\
\hline 10暫 & 2.6 .16 & 一晤 & 14.7 .2 & 一令夕改 & 11.6 .18 \\
\hline 暢 & 4.5 .26 & 一敷 & 4.6.17 & & \\
\hline 11 暴 & 3. 1.22 & 會 & 8.3 .16 & 75 & 水 \\
\hline 暴 & 9.4 .19 & 瞞 & 8.4 .4 & & \\
\hline 一露 & 9.4 .19 & \multirow{3}{*}{\multicolumn{2}{|c|}{74 月 }} & 水简 & 5.3.33 \\
\hline 掌 & $r .8 .13$ & & & - 崖 & r.5./1 \\
\hline 12暹 & 9.9 .27 & & & 一华(等)黎 & 9.5 .8 \\
\hline 娔 & 12.2 .18 & O月令 & 1.2 .23 & 一蘭 & 14.2 .32 \\
\hline 一出古城山 & $L 1 / 2.2 .18$ & 2 有 & 2.5 .19 & /未始 & 6.7 .3 \\
\hline 14曠 & 10.4 .26 & 一狄 & $2 . \sqrt{3} 33$ & 本註 & 8.2 .4 \\
\hline & & 一扈 & 2.5 .33 & 札 & 7.8 .14 \\
\hline \multirow{2}{*}{\multicolumn{2}{|c|}{73 日 }} & 一皇 & 2.5 .33 & 一未合 & 9.2 .28 \\
\hline & & 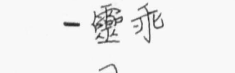 & 7.4 .28 & 末疾 & 12.3 .26 \\
\hline 2 曲意 & 6.1 .29 & 一司 & 10.3 .33 & 一流 & 15.7 .13 \\
\hline 一折 & 7.7 .9 & 一司差貧。 & 10.3 .33 & 一流之失 & 15.7 .13 \\
\hline 一解 & 13.1 .20 & 一奇 & 11.4 .14 & 2 朱提 & 5.2 .26 \\
\hline 了更 & 6.5 .9 & 一同病費 & 11.6 .4 & 朱 & $7.9 \cdot 19$ \\
\hline - 定律令 & 6.6 .32 & 一的放矢 & 13.5 .9 & 朱。 & 8.5 .17 \\
\hline 更 & 10.1 .25 & 一机栈) & 13.11 .19 & 一元璋 & 10.1 .5 \\
\hline 更 & 12.7 .24 & 一捷于反。 & 15.4 .23 & - 腼方 & 11.3 .2 \\
\hline - 事 & 16.3 .26 & 4 朋 & 11.3 .34 & 一棣 & 12.6 .30 \\
\hline 6書際 & 7.4 .13 & - 黨 & 11.4 .4 & 一一新 & $15.7 .1^{-}$ \\
\hline 7曹噼 & 7.6 .25 & 6月关 & 2.2 .21 & 一穆 & 16.3 .11 \\
\hline - 仁 & 8.7 .15 & 稝 & 7.6 .11 & 一買厔 & 16.3 .19 \\
\hline 一珹 & 11.3 .17 & 稝 & 16.2 .29 & 3 杜 & $4 \cdot 3 \cdot 18$ \\
\hline 8 曾 & 4.4 .31 & 7 朗 & 16.2 .5 & 杜 & \.7.17 \\
\hline
\end{tabular}




\begin{tabular}{|c|c|c|c|c|c|}
\hline 了圭如晦 & 6.2 .3 & 了坟 & 11.5 .21 & 5 柄 & 5.8 .19 \\
\hline 一淹 & 6.3 .34 & 一黎 & 12.4 .33 & 染 & 9.6 .28 \\
\hline 一甫 & 7.6 .20 & 杲 & 13.2 .26 & 栅 & 8.9.10 \\
\hline 一牧 & 7.6 .21 & 杠 & 12.6 .2 & 相形冒絀 & 11.4 .22 \\
\hline 一偱 & $7.9 . r$ & 4 析 & 1.3 .2 & 林 & 15.8 .20 \\
\hline 束 & 8.2 .29 & 枉 & 1.6 .5 & 6 柴紹 & 6. 1.24 \\
\hline 一䋠 & 11.432 & 一費心偻 & 13.7 .18 & 紫 & 12.5 .17 \\
\hline 李衡 & 3.4 .21 & 東西交错 & $5.7 \cdot 8$ & 一墟 & 12.8 .5 \\
\hline 一牧 & $4.4 \cdot 7$ & 一窝 & 6.1 .32 & 校 & 1.5 .19 \\
\hline 一峪 & 5.3 .14 & 一漢明商 & 8.3 .8 & 一景 & 8.1 .18 \\
\hline 一克 & r. 6.54 & 一郡 & 8.3 .16 & 一聯 & 8.2 .19 \\
\hline 一青力 & $6.5=30$ & 一平 & 8.11 .29 & －䧳准 & 16.3 .7 \\
\hline 一密 & 6. $1: 30$ & & 16.2 .16 & 案 & 2.5 .33 \\
\hline 一靖 & $6 \cdot 1 \cdot 32$ & 一方朔 & 16.3 .19 & 挑 & 3.2 .22 \\
\hline 一延青 & 7.6 .11 & 果 & 6.2 .1 & 株 & 3. 4.21 \\
\hline 一白 & 7.6 .20 & 一毅都尉 & 6.4 .34 & 桎 & 7,130 \\
\hline 一商隐 & 7.6 .21 & 一謀石軌 & 11.8 .23 & 一梏 & 7.1 .30 \\
\hline 一射 & $7 \cdot 7 \cdot 13$ & 枕 & 7.7 .22 & 桑田 & 6.5 .16 \\
\hline 一敬鬼 & 7.7 .13 & 恼 & 10.3 .34 & 核 & 7.9 .7 \\
\hline 一娃傳 & 7.7 .23 & & 10.3 .34 & 白䜌彎 & 8.3 .24 \\
\hline 一思言川 & 7.8 .28 & & 6.2 .34 & 一圭 & 8.5.18 \\
\hline 一专甫 & $7 \cdot 9.23$ & & 8.4 .11 & 栲栳䊾 & 9.2 .21 \\
\hline 一流 & 8.5 .24 & 一則徐 & 14.3 .21 & 根河 & 9.2 .16 \\
\hline 一雄 & 8.5 .28 & 松 & 12.4 .33 & 一蟠汝穎 & 10.4 .2 \\
\hline 一全 & $9 \cdot 8: 4$ & 穼每 & 11.5 .8 & 格致 & 15.7 .28 \\
\hline 一垍 & 10.2 .10 & 杭州 & 12.6 .14 & 㭋海 & 12.3 .29 \\
\hline 一思噈 & 10.7 .13 & 枚皇 & 16.3 .19 & 一良 & 10.6 .17 \\
\hline 一煜 & 11.2 .19 & 5 柳宗元 & 7.7 .13 & フ梓 & 3.4 .21 \\
\hline 一心傅 & 12.8 .7 & 一放傅 & 7.7 .22 & 梅原末治 & 5.3.13 \\
\hline 一大釗 & 13.3 .21 & 一集 & 16.3 .20 & 條算 & 7.9 .9 \\
\hline 一湯童 & 15.3 .9 & 查理曼 & 3.3 .27 & 梏 & 7.1 .30 \\
\hline 一宗善 & 15.3 .22 & 柱 & 4.2 .17 & 粱書 & 7.7 .9 \\
\hline 一象衡 & 15.3 .28 & 一石遂㑑 & 4.2 .18 & 一肃 & 7.7 .12 \\
\hline 朽 & 5.8 .4 & - 下 & 16.3 .3 & 一㫃超 & 8.5 .8 \\
\hline
\end{tabular}




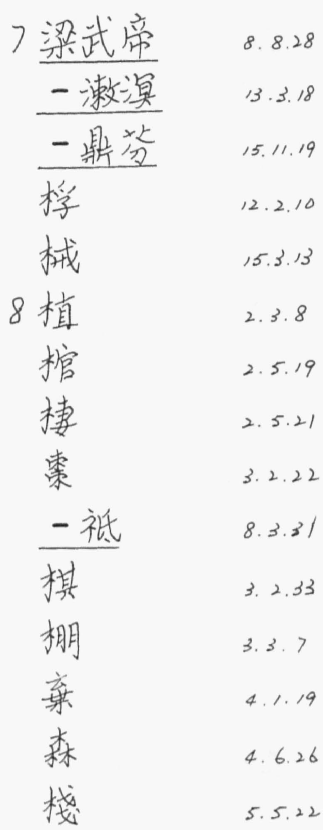

一道5.5.22

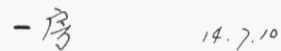

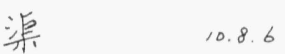

植 11.8 .7

一扶祭柱11.8.7

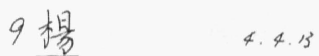

－黑 4.4.13

一文幹

一资

6. 1.33

一惠之

7.5 .12

一素

8.9.31

一安儿完)

一害

一䖌

栺

一模

楮

10 您

一取
10 榭

䌽㼂

一禄

榜

檴

椎

一係

榛

無

構

$1 /$ 模

一不着

椿

椿

玟重

㿟

一等有

秥

惦

一棟

一紐

標譩

标(慓

一榜

栭

祭

概

螕

横

12 石矞

机(機)

機警
12 撨

8. 2.19

13 檀香山

2. 2.14

䄈

一夕卜

档(樘)

檔

14 檻

一車

7. 3.30

7.3.30

7. 8.14

7.5 .17

11. 3.

11. 3. 1

10. 6.11

10.6 .11

11.3 .30

1. 3.31

,.3.31

1.6 .8

5.4 .2

15 㭊陽

2. 0.4

18 權德重

5. 7.11

一其暧重 7.3 .13

一贵

11. 4.34

權

14.4 .11

76 欠

2 次

12.4 .11

4 欣

1.5 .29

一欣

15.10 .22

5 称

13. 9.28

8 欺

一独

,. 15

1. 5.27

16.0 .45

10.3.7

欽察

14.51

一天監

9. 8.20

䣄

14.2.30

13. 2.1

15.8 .12

一定

14.3. 1

一差大压

14.3. 1

11.8 .7

9 歇

$$
\text { 一業。 }
$$

10 歌公真

14.3 .21

$1 /$ 厥

8,1

3. 4.2,

一陽詢

7. 7.11

一陽领

7. 8.16

9. 5.4

10.1 .26 


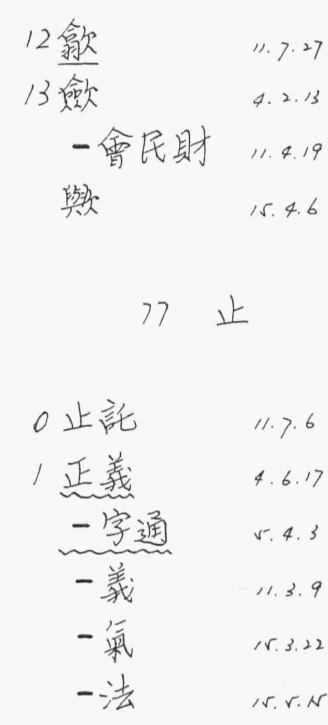

2 此人主所……8.9 3 步驟

1.1 .24

一垂統領 14.3 .3

一我

S. 3.10

4 歧

一視

10. 4.16

一誤

10.4 .16

武德

14.8.31

一后

6.1. 1

一帝

7.2 .17

一仙

5 㱟

9 藏市(幣) 9.4 .4

78 歹
6 殊途而同歸心１.19

殖

一㠇

ง. 3.26

ง. 3.26

8 殖

一民地

2.3 .33

殘暴

2. 3.33

一星嗱微注12.2.19

12 恽

17 多敬戴

r. 10.16

- 灭(减) 9.2 .9

9.2 .9

79 设

6 段

一李紀

3.2 .15

一虚書契 2.4 .28

一墟文化5.1.32

一寞

7. . . 25

7 殺狘

4. 4.6

杀( 耤)人越货9.8.3

8 殻

4.1 .34

9 殿

3. 1.18

毁

ร. 5.15

一减

2. 2.,

$1 /$ 愿品

11.7 .10

一留

11.7 .10

毅

7.5. 11

一然

7.6. 11

2 死力

8.2.

5 䏩

4.2 .11

殆

15.6 .15

殂

6.6 .26

6 殊

2.3 .28
80

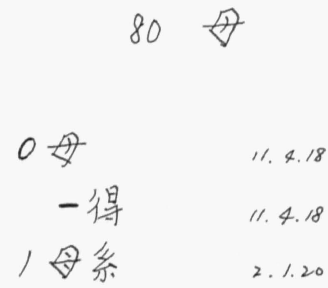

2. 1.20
了每餐

3. 3.16

一下愈況, 5.24 4 毒

6. 1.34

$$
\begin{array}{cc}
\text { O 比附 } & 7.3 .20 \\
\text { 比 } & 8.2 .5 \\
\text { - 婡 } & 11.6 .14 \\
\text { 比 } & 12.4 .7
\end{array}
$$

82 毛

毛澤東 3.4.8

一奇 16.4 .22

83 氏

○代族社會 2.120 ，民隠

7.6 .29

一犨

15. 9.10
4 疼

一周

6 氣息

- 象

- 度

一筫

一态曹唫7.6.2

一舒而光 10.32 气(弹)派

13. 6.31

一節

15. 8.20 


\begin{tabular}{|c|c|c|c|c|c|}
\hline 85 ㄱ & & 4 没入 & s.r. 9 & 5 河套 & 9.2 .19 \\
\hline ○水硍 & 3.4 .23 & 波 & 12.1 .18 & 一朔生, 灵。 & $9 \cdot 9.16$ \\
\hline 一經注 & 5.6 .15 & 沈佺期 & 7.6 .20 & 一前为(原).. & 9.4 .30 \\
\hline 一襅 & 9.4 .25 & 一泰 & 8.8 .24 & 二洛 & 10.4 .2 \\
\hline | 永嘉 & 8.8 .34 & 沈 & 10.128 & 一渠 & 10.8 .6 \\
\hline 一嘉之謡 & 8.8 .34 & 一盗三 & 10.7 .20 & 沾 & 11.8 .20 \\
\hline 一熙 & 8.10 .15 & 一懷遠 & 12.1 .21 & 一光 & 11.8 .20 \\
\hline 一樂 & 10.4 .33 & 一遼 & 12.4 .16 & 泊 & 1.8 .9 \\
\hline 一熹 & 22.3 .3 & 一㷛禎 & 5.3.9 & 泣 & 3. 5. 8 \\
\hline 3 汗 & 3.2 .15 & 沙 & 9.7."1 & 沽 & 14.6 .18 \\
\hline 江山 & 6.1 .26 & 一骦 & 12.4 .2 & 法度 & s. 1.34 \\
\hline 一左 & 7. 6.11 & 一明 & 16.5 .11 & 一西斯 & s.M.A \\
\hline 一湖 & 7.6 .31 & 沃 & g.r.se & 泰始 & 8.5.6 \\
\hline 一陵之役 & 8.10 .16 & - \pm & 9.r. 25 & 泰州 & 9.2 .17 \\
\hline 一陰 & 10.6 .21 & 沃 & I.S.N & 泰 & 14.6 .27 \\
\hline 一蜜府 & 11.3 .22 & 一灌 & , 2.r., & 一西 & 14.6.27 \\
\hline 一右 & 11.7 .23 & 泣 & 9.5. 18 & 泚 & 8.12 .1 \\
\hline 二湘 & 12.4 .3 & 一梁 & 12.6 .14 & 波斯 & 9.1 .28 \\
\hline 一陵 & 12.7 .99 & 汪 & 7.6 .22 & 泯 & 4.223 \\
\hline 一䆝 & 14.4 .5 & 一古 & 9.5. 9 & 一除 & 7.4 .27 \\
\hline 一窝條約 & 14.4 .5 & 汰 & 6.6 .31 & 泉州 & 9.9 .26 \\
\hline 汛 & 8.9 .1 & 泛 & 5.3 .24 & 泗州 & 10.2 .3 \\
\hline 一海南渡 & 8.9. 1 & 泛 & 6.3 .6 & 6 洛陽 & 3.2 .9 \\
\hline 一地 & 14.2 .23 & 一舟 & 6.3 .6 & 洛 & 11.9 .33 \\
\hline 污 & 10.4 .8 & 泛 & s.inis & 一學 & 11.4 .33 \\
\hline 汝 & 12.3 .7 & 一泛 & 15.11,1s & 洫 & 4.3.3 \\
\hline 迆州 & 12.3 .12 & 5 治 & 1.3 .34 & 洪 & 7.1 .26 \\
\hline 4 沘水 & 8.4 .1 & 一權 & 16.4 .23 & 一流減合 & 7.1 .26 \\
\hline 沓 & 1.3 .23 & 沿革 & 8.1 .1 & 一遇 & 7.7 .25 \\
\hline 沉 & 1.5 .33 & 注疏 & 5.2 .7 & 一澤 & 9.7."11 \\
\hline 一悶 & 1.5 .33 & 河内 & 5. 7.25 & 一擬 & 11.8 .22 \\
\hline 没 & 4.2 .20 & 一朝 & 7.6 .11 & 洑 & 12.2 .23 \\
\hline 一落 & 4.2 .20 & 一間 & 8.4 .10 & 派拉㗬 & 13.2 .29 \\
\hline
\end{tabular}




$\begin{array}{cc}6 \text { 津 } & 14.19 \\ \text { 洽 } & 16.111 \\ \text { 洩 } & 15.4 .9 \\ \text { 一沓 } & 15.4 .9 \\ \text { 洗 } & 11.5 .31 \\ \text { 一胉 } & 11.5 .31 \\ \text { 洞主 } & 11.2 .17 \\ \text { 洵 } & 7.732\end{array}$

一离卓誡 7.7 .32

7 流傅

流

一域

一弊

流

一麗

一涕

一浪

一完主義

一濞

谁

一之以㽬

流陽

海中撈月 2.4.17

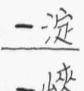

4. 7.9

一塽

一敦

一南

涉及

一袋

消耗

一長

浪

$$
\text { 一曹 }
$$

泿
7 搌

焉

一矢本旨

一敕

11.8 .7

浮

一栕

一粱

浩

一如烟海

7.6.18

2.). 11

12.3 .33

2. 5.20

浙東學派10.2.13

浙

14.3.27

酒斾停空杜12.6.2

涕

涎

浚

8.6.6

9. 8.3

8 清理

9.2 .17

$\begin{array}{ll}\text { 一水泰次 } & 10.24 \\ \text { 一寒 } & 11.8 .20\end{array}$

一逸江

一盟

12.2 .21

一呚

14.3. 8

一遇

一策

添

淆

学

淫

一佚

一袷

16. 1.21

16. 5.14

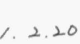

1.4 .2

2. 5.22

4.2.31

4. 6.18

字于髧

16.5 .18

一熙

涼

淪

一 亡 4. 6.0
8 淮南葛褁術5.9.25 深拒固絶 r.10.2 一沈

10.1 .25

渡

淡水

12. 2.24

谈

混清

14.9.4

湿

泾

$$
\text { 一源 }
$$

15.7 .8

晹

- 刑

7. 3.7

7. 6.22

7. 2.4

湫

一险翼虎

7. 2.4 望

$$
\text { 一没 }
$$

2.6 .10

4.3. 2

3. 1.23

湮

$$
\text { 一塞 }
$$

3.1 .23

游枚

一手好間 9.3.28

一方

12.4 .3

渾源縣政 3.14 海

一渾曋覀9.9.2

湖州

11.4 .25

一廣㿟督 14.320 湘中曾臺…22.4.16 渝 14.1 .21 湊(琫) 16.5.31 湙 11.725 一经 11. 7.25 渠

- 坫 $8.4,16$ 渤海 8.4 .16 9. $\sqrt{17}$ 


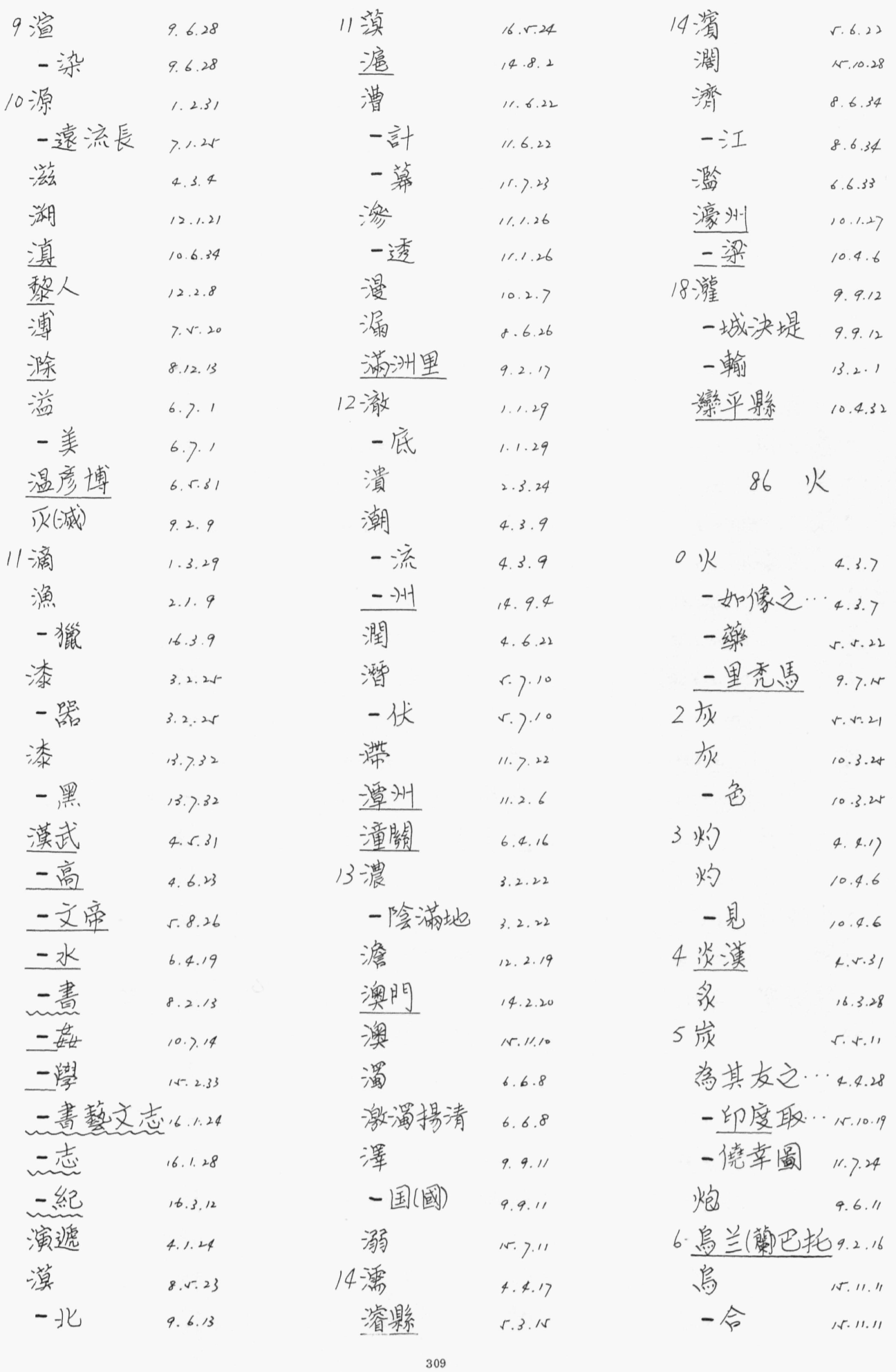




\begin{tabular}{|c|c|c|c|c|c|}
\hline 7 烹 & 4.4 .6 & 12 燃 & $r .4 .5$ & 92 & 牙 \\
\hline 焉 & 4.s.r & 一料 & r.4.r & & \\
\hline 焉 & 14.6 .20 & 13 營 & 10.2 .10 & ○牙人 & 12.8 .4 \\
\hline 烽 & 8.2 .19 & 15爆 & 6.2 .10 & & \\
\hline$-火$ & 8.2 .19 & 一發 & 6.2 .10 & 93 & 牛, 牛 \\
\hline 8 焚 & 1.3 .18 & 16 燃 & 6.3 .18 & & \\
\hline 一諸王城。 & 3.1 .28 & 爐 & 7.8 .24 & 0生金 & 8.7 .17 \\
\hline 一算 & 10.4 .2 & 爛 & 15.3 .12 & $\frac{\text { 一鑑 }}{-3}$ & 14.4 .3 \\
\hline 然而 & 1.4 .13 & & & 一筷 & 14.9 .3 \\
\hline 经 & 16.134 & 87 & 爪 & 3 牠 & 8.3 .30 \\
\hline 無可置疑 & 6.7 .1 & 份味 & & 4 救 & \\
\hline & 6.7 .6 & 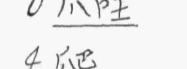 & 9.9 .27 & 牧 & 2.8 .27 \\
\hline 一庸 & 7.4 .29 & 14 舀 & 13.2 .23 & 一伯 & 7.3 .29 \\
\hline $\begin{array}{l}\text { 一端 } \\
\text { 一端萬状 }\end{array}$ & 10.4 .3 & & 4.3 .20 & $\begin{array}{l}5 \text { 牲 } \\
\text { 柢 }\end{array}$ & 2.4 .29 \\
\hline 9 煮 & $\begin{array}{l}10.4 .3 \\
12.3 .30\end{array}$ & 88 & 父 & 6特别 & $\begin{array}{l}14.5 .5 \\
.5 .1 .21\end{array}$ \\
\hline 繁 & 13.3 .28 & & & 一简 & 14.7 .1 \\
\hline 炤會 & 14.4 .29 & 89 & 文 & 特 & N. 5.7 \\
\hline 煌 & 13.9 .13 & & & 7 率 & 1.3 .28 \\
\hline 煙 & 14.3 .18 & 7 傸 & 3.2 .18 & 一涉 & 1.3 .28 \\
\hline 焕 & 7.2 .12 & 10 雯雅 & 2.2 .20 & 一强 & 13.9 .32 \\
\hline 一然一新 & 7.2 .12 & 一来北 & 8.10 .6 & 捂 & 14.5 .3 \\
\hline 10熙 & 3.2 .26 & 雨 & 16.4 .27 & 8 犁 & 5.4 .18 \\
\hline 一来攘往 & 3.2 .26 & 9 & 4 & 10塥 & 11.7 .3 \\
\hline $\begin{array}{l}\text { 一罗 } \\
\text { 一豐紹聖 }\end{array}$ & $\begin{array}{l}11.4 .27 \\
115.34\end{array}$ & 90 & $r$ & $94-$ & 犬可 \\
\hline / 熟悉 & 10.1 .21 & 91 & 片 & & \\
\hline 一黎 & 12.2 .9 & & & OK & 3.3 .9 \\
\hline 12苤总熒趣 & 1.3 .21 & 0尾 & 14.9 .11 & 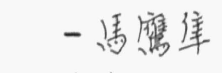 & 6.7 .6 \\
\hline 二云(雲)十。 & $\cdot 9.3 .22$ & 一言 & s.s. & 4 狱人 & 5.6 .30 \\
\hline 燕 & 11.7 .3 & 4 版圆 & 6.3 .19 & 㹠 & $12 . r .1$ \\
\hline 一搞 & 11.7 .3 & 8 牌 & 1.3 .13 & 状摩 & 7.6 .31 \\
\hline 一見 & 16.3 .4 & 9 牒 & 7.4 .15 & 6 狡 & 2.3 .24 \\
\hline 燋 & 1.3 .23 & 15債 & 11.7 .7 & 狩 & 9.6 .7 \\
\hline
\end{tabular}




\begin{tabular}{|c|c|}
\hline 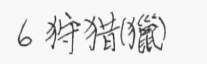 & 9.6 .7 \\
\hline ７狼 & 16.5 .29 \\
\hline 一犋 & 16.5 .29 \\
\hline 犋 & 16.5 .29 \\
\hline 疢 & 10.4 .14 \\
\hline 一義 & 10.4 .16 \\
\hline 一鄉 & 10. 5.18 \\
\hline 8 猝 & 15.6 .8 \\
\hline 猛安謀克 & $9 \cdot 5 \cdot 18$ \\
\hline 猖 & 10.4 .4 \\
\hline 9 猶 & 2.2 .11 \\
\hline-3 & 2.2 .11 \\
\hline 猶 & 4.4.2 \\
\hline 唒 & 4.4 .18 \\
\hline 猶 & 4.2 .30 \\
\hline 唒 & 15.3 .16 \\
\hline 10殷 & 10.7 .31 \\
\hline 猿 & 12.4 .33 \\
\hline 11 獄 & 4.3 .4 \\
\hline 狺文 & d. 6.29 \\
\hline 12 獠 & 12.4 .18 \\
\hline 㖘炊 & 10.4 .4 \\
\hline 13猲 & $7 \cdot 7.12$ \\
\hline 14 猚 & 1.2 .9 \\
\hline 15 㺝 & 2.1 .18 \\
\hline 噌犬 & 3. 3.34 \\
\hline 16 献 & 2.2 .20 \\
\hline
\end{tabular}

95 玄

○玄武䣙

6.1 .14 一弉 7.9.25 6 率由舊章 6.3 .24 㳯

10. 5.10
6 涼土之濱…14.2.13

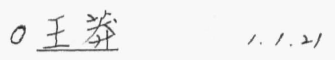

一子朝年1.28

一成維年. 7.6

一珪 6.2.13

一世充 6.5.30

一善之 6.6.17

王 7.7 .15

一维要 7.8 .28

一玄策 7.9 .26

- 允 8.3.25

一械早年,

王 10.2.20

一保保年年1

一氏 11.4 .28

一安石 “. 3

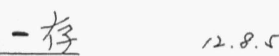

一文成定2.3

一先謙兵.2.31

一仁俊年 5.8 .24

一荆公 16.4 .22

玉龙(龍)桀9.9.11

海 11.2 .8

一堂仙 16.3 .29

5 珍

一玩

3. 2.29

玻璃

3.2 .29

珊蛮篮教 9.7 .29

6 珠 3.2 .29

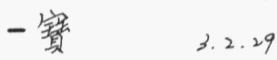

班孟壁 4.5.24
7 现身説法

琉球

14.2 .16

理金

1.4 .33

一宗

11.8. 11

理

一潘院

12.3 .23

一残

14. 1.34

琅躯

15.2 .32

8 琴

琦善

舕

9 瑟

10 琑

一細

5. 8.9

3.2 .14

14. $3-28$

8.8.31

3.2 .14

12.5.1

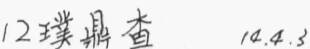
13 環

一境

- 泸

一球

15鳃州

$--y_{1}$

14.9. 4

97 枩

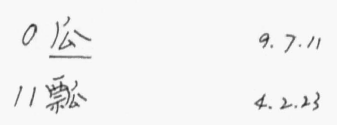

98 瓦

0 瓦

2.5 .19

一棺

2.4 .19

一解

4.3 .27

一普韦(傽)勃13.2.21 6 瓷 5.3.30 


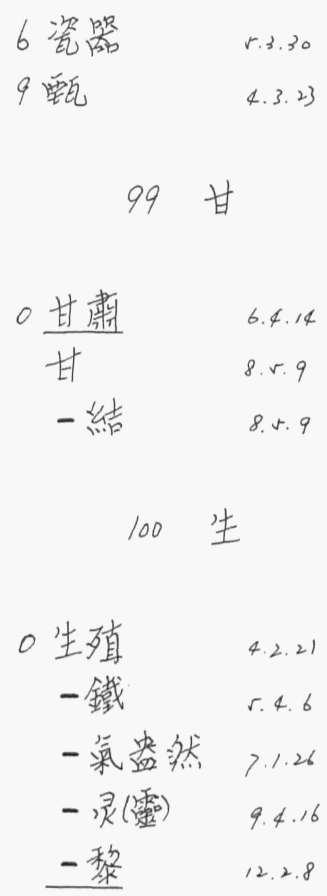

$$
101 \text { 用 }
$$

○用…学粶1 4 . 4.29

一夏戀夷 N. 4.9

$$
102 \text { 田 }
$$

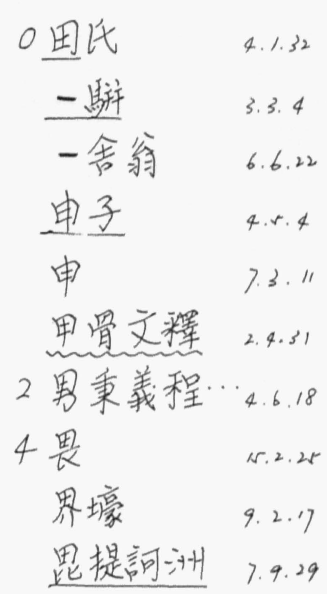

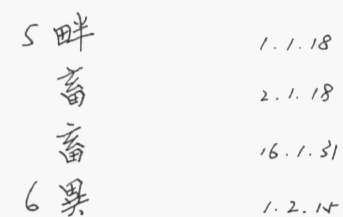

一同

1. 2.15

一彩

11. 8.28

果

略

一放

7 畫

畨

一遇

畨

8 當叙

2.1 .28

6. 2.3

8.1. 1

4. 3.29

1. 5. 4

5. 6.10

6. $v-9$

暏

10 畿

一輔

4. 4.4

4. 4.31

10.4 .24

14.9 .9

14 觬

一囯

$5.2,16$

is 4.11

撑

15.8 .33

17 賏

7.3 .26
5 病

疾

6 痕

一跡

了痛质

10.7 .13

一心疾首 15.6 .14 10 瘠

11.4 .16

12凉( 㾦)

9.6 .13

13 搱

14 癁

1. 6.24

一結

1.1 .13

1.1 .13
>發

一源

一揮嗇致 6.5 .27

一越

7.6. 11

一凡起例 7.9 .10

一丧

8.). 1

登州

14.9 .3
7 疏

4.4.25

䟽

6.6 .22

一閣

$7 \cdot 4 \cdot 8$

一放妍妙

一義

$7.8 \cdot 14$

11.3 .9

$$
104 F
$$

5 湔

症

1. 6.24

+. 9.15
106 每

○白居易 1.6 .21

一沟河 9.3 .23

一骨年 9.4.16

一婵教 10.121

一鹿洞 11.2 .6

白 16.2.11

| 百脃之貶1 1. . 11

一里悔幾…10.5.

一科全书書 13.9 .33

一科全书派1 3.9 .33 
/ 百旅弯放…13.12.18

一年樹人16.6.18

$$
\begin{array}{ll}
2 \text { 息 } & 3.3 .33 \\
\text { 泉 } & 7.5 .32
\end{array}
$$

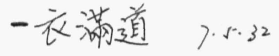

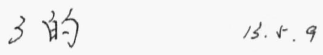
4 皆

4. 1.13

一考二餐……7.28

皇甫湜７.7.13

一陵碑 10.2.33

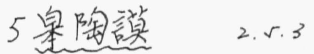

10 自

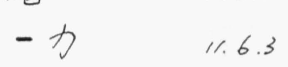

10) 皮

108 四

3盉

11.8 .25

5 益

4.2 .9

一税

7. 5.18

夃

盎

4. 4.13

7 盗

7.1 .26

8 盟

11.2 .34

9 監

一督

一生

2.2 .33

3.3 .30

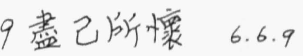
10 盤

3. 3.33

盤

5.3.32

盤

一剥

8.11 .20

11盧絳
川盧植

16.3.11

109 目，四

○目年1.21

3 直諌

直

一粼

直

一是

直

盽眙

相

- Ep

6. .23

12. 7.21

14.3.28

s. 11.25

s.11.2r

16.3 .16

10.2 .3

1. 5.4

3.2 .6

一形之下

4.3.24

$\frac{- \pm}{\text { - 尚 }}$

5. 1.20

5. 4.23

7. 6.27

一映成趣7.8.4

省

6.3 .27

省

一彩

一坦

目少

目分

有

6.6 .32

12.4.11

14.5 .13

12.2 .19

8. 1.34

9. 4.19

5 目玄

一弟並滛2.5. .

真

9.9 .27

6 眼界

眷

7 着着的

着

一着
7 着想

12.4 .23

着

14.9 .28

8 督我

4.3.16

一剩

8.3. 7

一護

8.8 .12

一挴

14.2.

目建

4.4.17

11 瞠

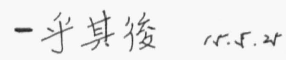

12 目尞

13 瞻

1.2 .31

一部洲 7.9 .29

2.4 .4

一仰

14.2 .33

矇

s: 2.8

一䑤

N. 2.8

睦陀尼 7.9.29

一秋自

13. 3.22

110 予

○予

9.4 .19

一盾

9. 4.19

一片論

13.8 .22

6 枒

11.3 .30

19称賴

6.5. 3

111 矢

O矢

2.3 .9

尔

10.2.32

一p否認

10.2 .32

2 余

2.1 .23

了知

6.6.3

一人美任 6.5.22 


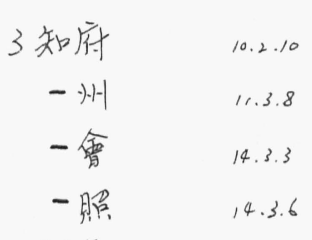

7短長

$$
112 \text { 石 }
$$

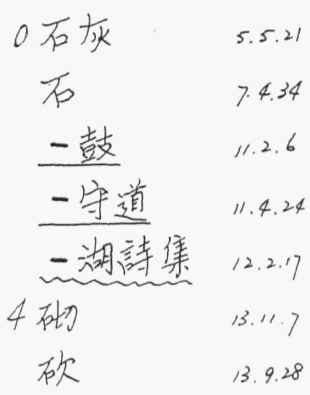

5 破綻

砲

紫

砥

$$
\text { 一磂 }
$$$$
7 \text { 硬 }
$$$$
8 \text { 石周 }
$$$$
\text { 一保 }
$$$$
3.14
$$$$
3.1 .14
$$$$
\text { 碎 }
$$

碑

$$
1.2 .7
$$$$
7.6 .12
$$$$
9 \text { 磌 }
$$

一然

16.2 .8

10 磁

16.2 .8

$$
\text { 嘫 }
$$

一鋸

喽

3.4 .23

7.6 .3

$7 \cdot 6 \cdot 3$

/ 䄷

6. .24

- 炎(减) 13. 9.14

磚
12 砝

一淮

13礎

14䂠疋

石龎

$$
113 \text { 示齐 }
$$

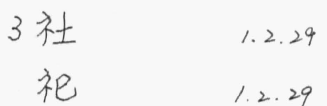

5 神底

1. 2.20

一秘

一武

5.8 .15

一龍

一仙

6.1 .25

6. 4.26

7.7 .17

一宗

一武明

11.6 .23

祚

彽

一閣

16.3 .6

6 祭

一先人塚

2.5. 10

崇蜜

祧

8 禄

森

一兵

一煙

一衛

8.3.20

11.5 .26

7.6 .23

4.2 .21

7. 5.23

7. 5.23

14.3 .18

10.6 .31

9 螎兮福所倚 9.7 .19

11 蒘

4.2. 30

胣行祡)

12 祮
12 螎讓

13 䄚孔

6.1 .32

\section{$1 / 4$ 河}

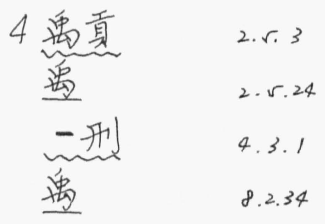

115 禾

本

2.3.8

2 厸法

13.10.4

3 秉

v. 9.13

一政

$5 \cdot 9 \cdot 13$

一公

$14 . \sqrt{ } \cdot 2$

4 秋澤修三 13.4 .3 科领

科

7. 9.10

一名

8. 7.14

一差乘冒…11.6.33

5 枺

2.3.8

秘

一密

2. 1.31

一魚

2. 1.31

一軎

v. 4.22

$7 \cdot 2 \cdot 7$

租

3. 4.11

秦

一始皇泟江

一式淮式 5.3 .18

一獻公 5.7 .11

一孝公年. . 12

$\begin{array}{ll}\text { - 惠王 } & \text { 5.7.22 }\end{array}$ 


\begin{tabular}{|c|c|c|c|c|c|}
\hline \multirow{2}{*}{5 泰紀 } & \multirow{2}{*}{$\begin{array}{l}r .2 .21 \\
10.2 .11\end{array}$} & \multicolumn{2}{|c|}{4 突厥 9.4 .8} & \multicolumn{2}{|c|}{$1 / 8$ 秎, 소 } \\
\hline & & 一厩世系 & $9 \cdot 9.20$ & & \\
\hline$\overline{\text { 秩 }}$ & 6.3 .19 & - 兰(简菓) & 9.9 .21 & 3 笔 & 3.2 .14 \\
\hline 一序 & 6.3 .19 & 6 窒 & 14.8 .25 & \multicolumn{2}{|c|}{4 笑稿是與龎12.4.18 } \\
\hline 秩 & 16.2 .6 & 7 窘 & 4.2 .17 & 5 第五琦 & $7 \cdot v: 17$ \\
\hline 6 移 & 2.1 .32 & 8 窟 & 3.3 .8 & 第 & s. 7.29 \\
\hline 一轉 & $\sqrt{3.6}$ & 10 䆖 & 15.2 .6 & 答 & 7.6 .2 \\
\hline 一交 & 14.2 .7 & 一稘 & s. 2.6 & 待 & $6 \cdot r \cdot r$ \\
\hline ７狶 & 2.1 .24 & 窮 & $|r\rangle .4$. & 一契 & 6.5 .5 \\
\hline 程知食 & 6.5.30 & //窩 & 11.3 .3 & 一片年 & 9.6 .12 \\
\hline 一万裁 & 8.2 .12 & 一笘 & 11.3 .3 & 6 筆削 & $1, \sqrt{1.2}$ \\
\hline 一来 & $1 \sqrt{1.2 .32}$ & 13 竄 & 1.1 .24 & 笨 & 3.2 .14 \\
\hline 一伊川 & 16.5 .14 & 15 竇氏 & 6.1 .23 & 柋士 & V. 2.22 \\
\hline 8稚 & 2.4 .31 & 16 㝭(灶) & 7.5 .17 & 策 & 6.2 .32 \\
\hline 9 種子 & 2.2 .4 & 17 窲 & 3.2 .12 & - 畵 & 8.4 .11 \\
\hline 称(畄)伯称侄 & 9.4 .4 & 一揣婳咑 & 5.2 .20 & 有分 & 12.3 .27 \\
\hline 10 稷 & 1.2 .29 & & & 等 & 12.3 .5 \\
\hline & 3.3.3 & 117 & & 7 钧 & 12.2 .20 \\
\hline 一下先生 & 16.1 .27 & & & 一籍轉 & $=12.2 .20$ \\
\hline 䅰 & 16.4 .24 & ０立足點 & 1.4 .28 & 䬣睘 & $4 \cdot 5.1$ \\
\hline 竞粱傅 & 1.2 .27 & 一㭶政 & 4. 3.3 & 一度 & 6.3 .8 \\
\hline 橴 & 2.3 .10 & 5 竝 & 4.2 .34 & 一制 & 14.3 .22 \\
\hline 一雨 & 15.8 .17 & 6 章太炎 & 1.4 .26 & 䞮 & 14.2 .33 \\
\hline 稻 & 3.3 .3 & 一萧喜 & 3. 3.12 & 一宴 & 14.2 .33 \\
\hline 找 & 8.6 .14 & 一溶 & 10.2 .14 & 䞮 & Ir. 4.20 \\
\hline / / 穆险 & 14.8 .14 & 一京 & 14.8 .33 & 金 & 1.6 .21 \\
\hline 一宗 & is.r. 12 & 章 & 15.10 .6 & 8 管子 & 3.1 .33 \\
\hline 13稳固 & $4.1 \cdot 16$ & 9 端 & 4.3 .4 & 一轄 & 3.3 .32 \\
\hline 穠 & 7.6 .24 & 一州 & 12.2 .12 & $-\frac{3}{7}$ & 4.v.15 \\
\hline 17㯖侯 & 4.4 .1 & 一䔝 & 15.4 .3 & 管 & 4.6 .30 \\
\hline & & 竭 & 4.3.33 & 一係 & 11.6 .7 \\
\hline 116 穴 & & 一誠 & 7.1 .20 & 箕 & 12.5 .1 \\
\hline & & 15 競 & 8.6 .30 & 秩 & 16.2 .21 \\
\hline 3 空張郡目 & 7.3 .27 & - 登 & N. 2.10 & 一束 & 16.2 .21 \\
\hline
\end{tabular}




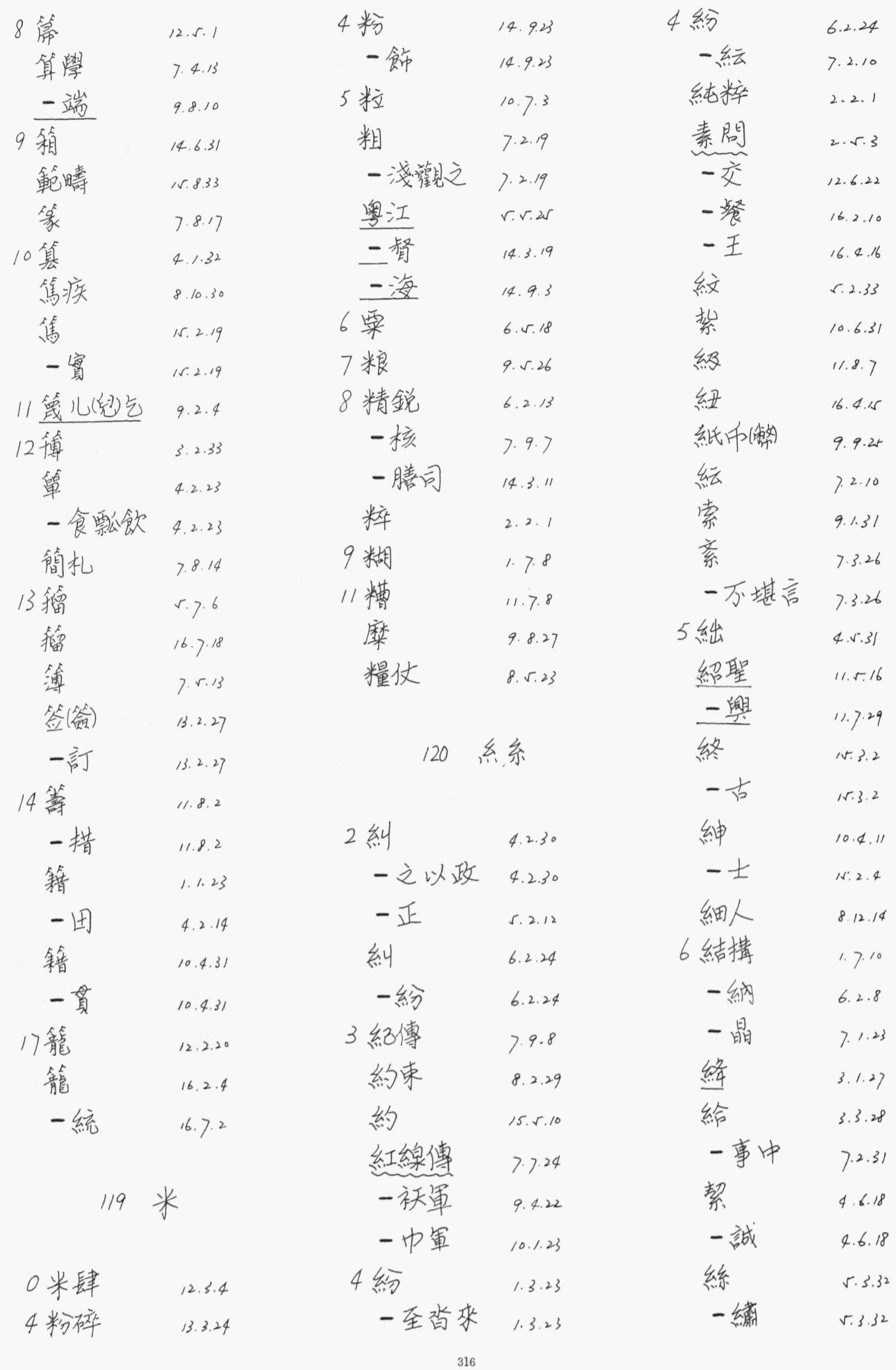




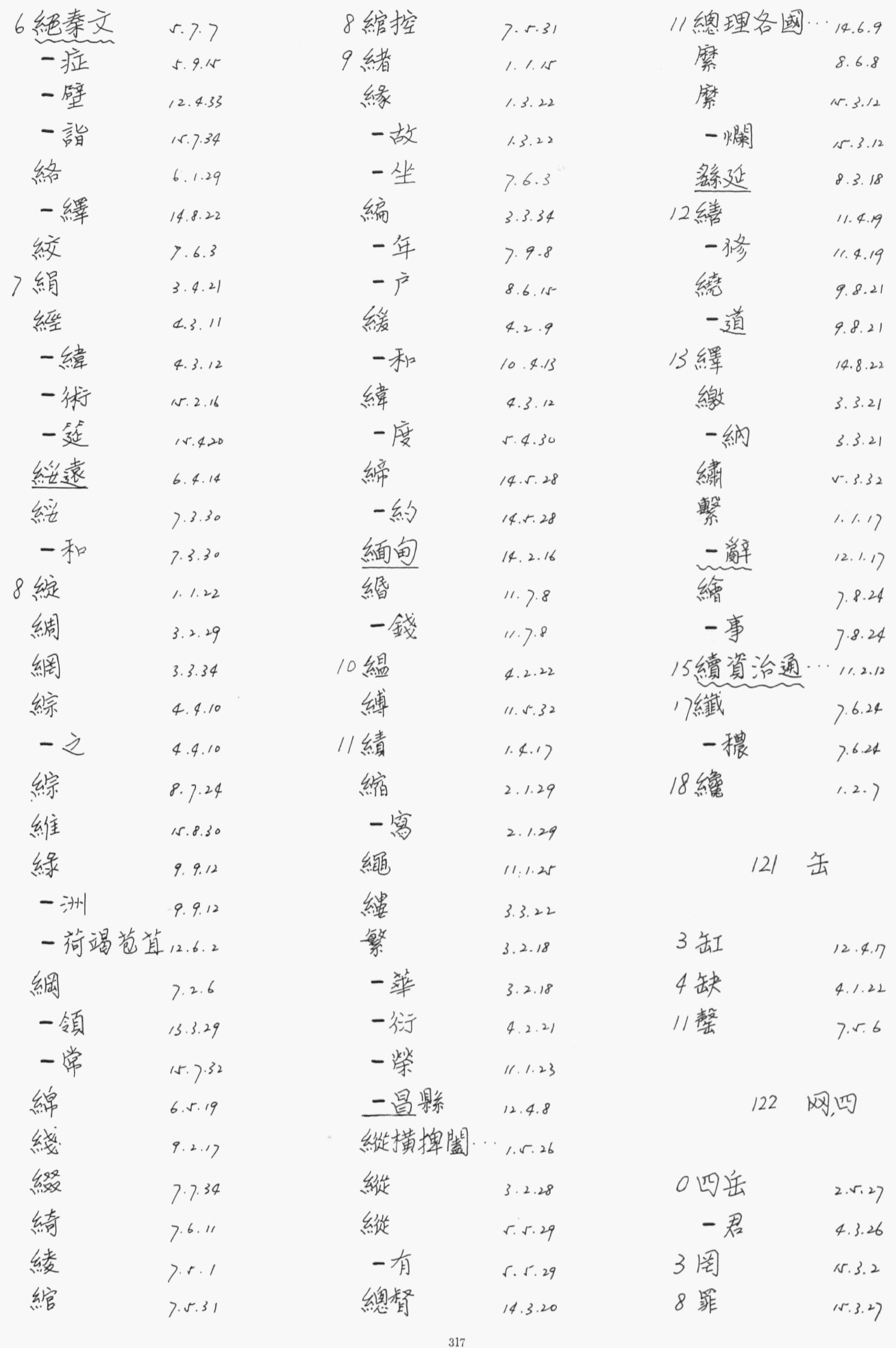


9 署

一置

署

署

一理

罰

10 罷絀

罷

12 䍜

14 羅振王

\begin{tabular}{ll} 
一馬 & 5.1 .20 \\
\hline 一㙯 & 6.5 .32 \\
\hline 罗(羅) & 9.6 .9 \\
一源 & 12.4 .2
\end{tabular}

123 羊

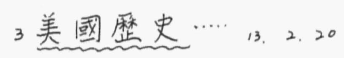

4 着

6 盖本

7 义(義)

義

一女

一挙

一律

群(憵)

- 小.

羡

10 域之

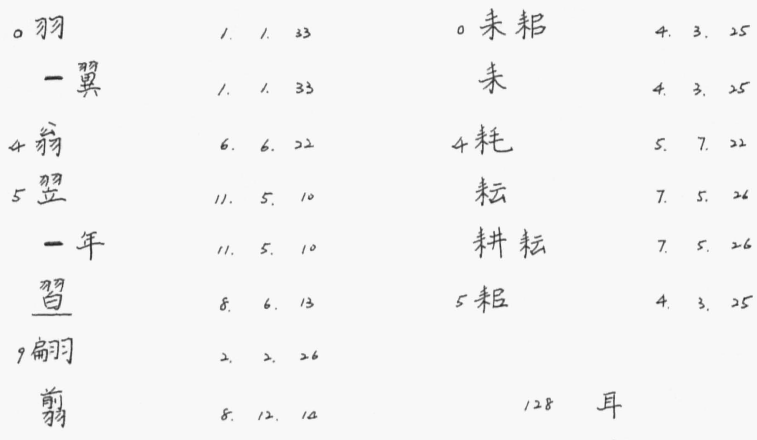

10 翰林16.3.22

一林院 16.3.22

翼

翼

14 䊒

15. 3. 27

13. 2.29

125 老
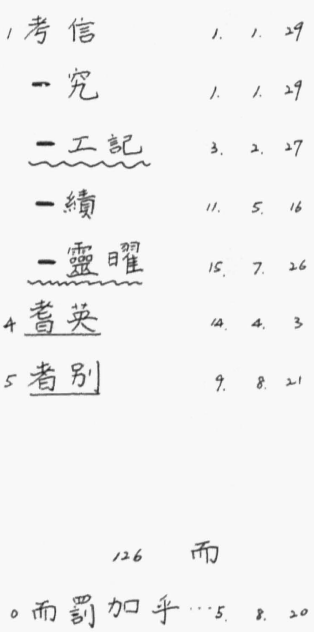

。耳

一需目染10.21

3 耳

一魯禾

4 耽罗

5 聊

6 咕

$$
\text { 一聒 }
$$

7 聖哲

一人

一駕

一祖 15.4. 27

一躬

聘

11. 䇤

坆

瞥色犬馬3.3.9

- 教

聯絡年, 29

一䋁

7. 7.34

12.聶㣰娘傅7.7.24 13 職田 11.3. 24

職 


\begin{tabular}{|c|c|c|c|c|c|c|c|c|c|c|}
\hline 13 職志 & 7 & 6. & 30 & 6脈 & 5 & 7. & 6 & 8 藏洪 & 8. & 2. 15 \\
\hline 16 蕙・慎 & 8. & 10. & 2 & 㔛 & 6. & 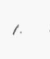 & 28 & " 臨 & 4. & 2. 32 \\
\hline & & & & 7 脚 & 1. & . & 25 & 一畄 & 3. & 2. 9 \\
\hline & & & & 一寨 & 8. & 11. & 29 & 一之以敬 & 4. & 2. 32 \\
\hline & & & & 脱稿 & 14. & 1.2 & 20 & 一濠 & 10. & 5. 15 \\
\hline $129 \quad$ 事 & & & & 一節 & 15 & 2. & 15 & & & \\
\hline 7䐅聿 & 3. & 1. 2 & 25 & 8. 腑 & 15. & 8. & 17 & & & \\
\hline 肆 & 12. & 3. & 4 & 腆 & 1 & 7. & 4 & & & \\
\hline 一應 & 16. & 6. 33 & 32 & 腐朽 & 9 & 3. 2 & 29 & 132 自 & & \\
\hline 8 肃 & 5. & 6. 3 & 30 & 9 腥 & 4. & 7. & 6 & 。自給自足 & 3. & 3. 28 \\
\hline 一 清 & 5. & 6. 3 & 30 & 腹 & 10. & 6. 2 & 24 & 自量 & 6. & 6. 5 \\
\hline 肅 & 7. & 2. ' & 18 & 一地 & 10. & 6. 2 & 24 & 一知之明 & 6 & 7. 9 \\
\hline 肇 & 6. & 7. & 7. & 腰 & 9. & 3. 2 & 28 & 一萳 & 7. & 1. 31 \\
\hline 一造區夏 & 6. & 7. & 7. & " 膠 & is. & 10. & 33 & 一蓼呵翼 & 8. & 12. 14 \\
\hline 筆 & 9. & 7. & 12 & 一膠 & 15. & 10. & 33 & - 蒙 & 9. & 3. 2 \\
\hline & & & & 膜 & 16. & 4. & 5 & 一詡 & 1. & 2. 22 \\
\hline & & & & 一拜 & 16 & s. & 12 & 一強不息 & 15. & 5. 31 \\
\hline 130 肉 & & & & 滕 & 16. & 4. 3 & 33 & 4 臭 & 7. & 2. 12 \\
\hline 3 时 & 7. & 2. 3 & 33 & 12 淢 & 3. & 3. ' & 10 & 臬 & 4. & 9. 9 \\
\hline 4 肩 & 3. & 2. ' & 15 & 譜 & 11 & 8. & 5 & & & \\
\hline 肯 構 & $" 1$ & 3. & 30 & 一费 & $1 "$ & 8 & 5 & & & \\
\hline 股 & 15. & ". & 4 & 13月膽 & 1 & 2. & 6 & & & \\
\hline 育長融和 & 7. & 1.2 & 23 & 臆 & 13. & 7. 1 & 13 & 133 至 & & \\
\hline 5. 肥 & 2. & 2. & $b$ & - 䪨 & 13. & 7. & 13 & 。至元 & 9. & 7. 22 \\
\hline 胡瑗 & "l. & 4. & 24 & 15 臘 & 12. & 3. & 28 & 一和 & 12. & 2. 13 \\
\hline 一適之 & 13. & 3. 1 & 18 & 17 月㵴 & 15 & 8. 1 & 17 & 4 致 & 1 & 4. 1 \\
\hline 一林翼 & 15. & 2. 2 & 26 & 一 腑 & 15 & 8. & 17 & 一用 & 1. & 4. 1 \\
\hline 一美 & 8. & & 18 & & & & & 8 黨㥶 & 10. & 3. 32 \\
\hline 胎 & 2. & 33 & 33 & & & & & 10 臻 & 7. & 7.30 \\
\hline 一兒 & 2. & 3. 3 & 33 & 131 & 臣 & & & & & \\
\hline 胥 & 15. & 2. & 1 & 。臣庶 & 2. & 33 & 31 & & & \\
\hline 一吏 & 15. & 2 & , & 一宰 & 4. & 3. 3 & 30 & $134 \quad \Leftrightarrow$ & & \\
\hline 脉(脈) & 13. & 41 & 12 & 2卧 & 9. & , , & 24 & 舆夫區别… & 4. & 42 \\
\hline 一絡 & 13. & 4. & 12 & $\begin{array}{l}\text { - 内 } \\
\end{array}$ & 9. & 1.2 & 24 & 舅 & 8. & 4.3 \\
\hline
\end{tabular}



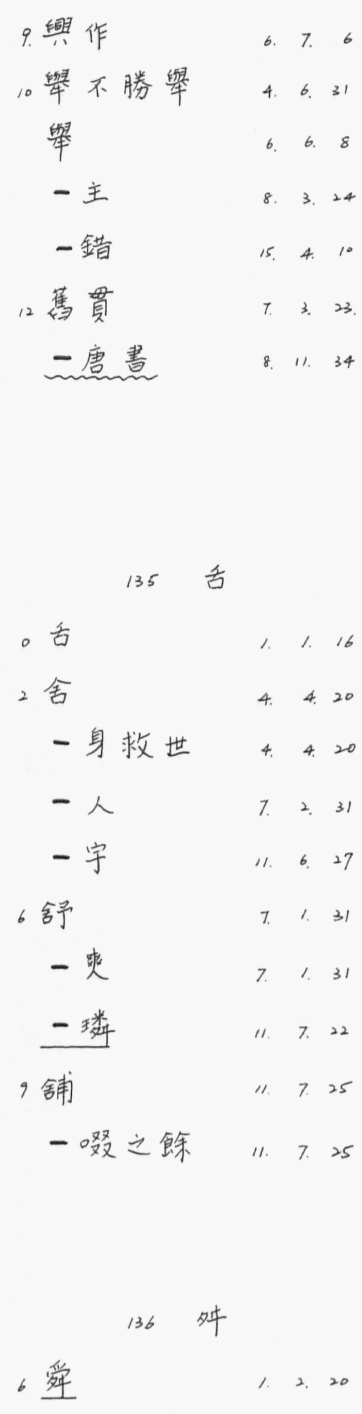

西典 2.5. 27

王至孝 7.8.6

8 舞䌘11.72

137 舟

。舟

一山 14. 3. 25
7 艇

$$
\text { 一澳 }
$$

14 艦

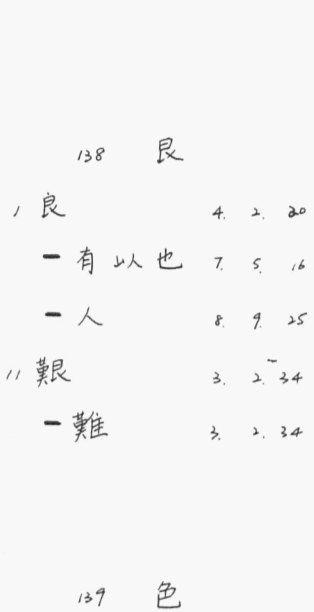

。色楞格河，2.4

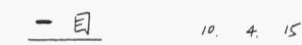

19 慗色

- 情

㠿色

一羡

$140 \quad 44(x+)$

2 艾

菬陂里, 11

4 花花世界。 31

一紋 5. 33

一刺子模，7.33

- 石

一沙納然。

㫚

一秼

4 芽
5 第

一棚

- 山

苑

苟

苟

一延殘喘9.4.5 范氏

一宣子

一最生

4. 3. 17

4. 3. 17

8. 5. 29

一延城

9. 9.13

一祖幹

一仲淹

一成大

一蟲

苦椔

苖

一道潤

茂

英雄記

- 州

二法聯軍

若存若亡

苛

- 刻

苞苴

6苟毛

一卿

一爽

荒

一診

一涼

荒

一無
10. 2. 12

11. 2. 11

2. 2.17

6. 6. 24

5. 5. 21

8. 7.13

9. 5. 1

1. 26

8. 7.13

12. 6.4

14. 1.25

9. 3.8
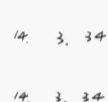

12. 6.2

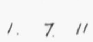

4. 6.27

8. 3. 24

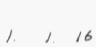

1,16

3. 3. 7

9. 9.12

9. 4.12 


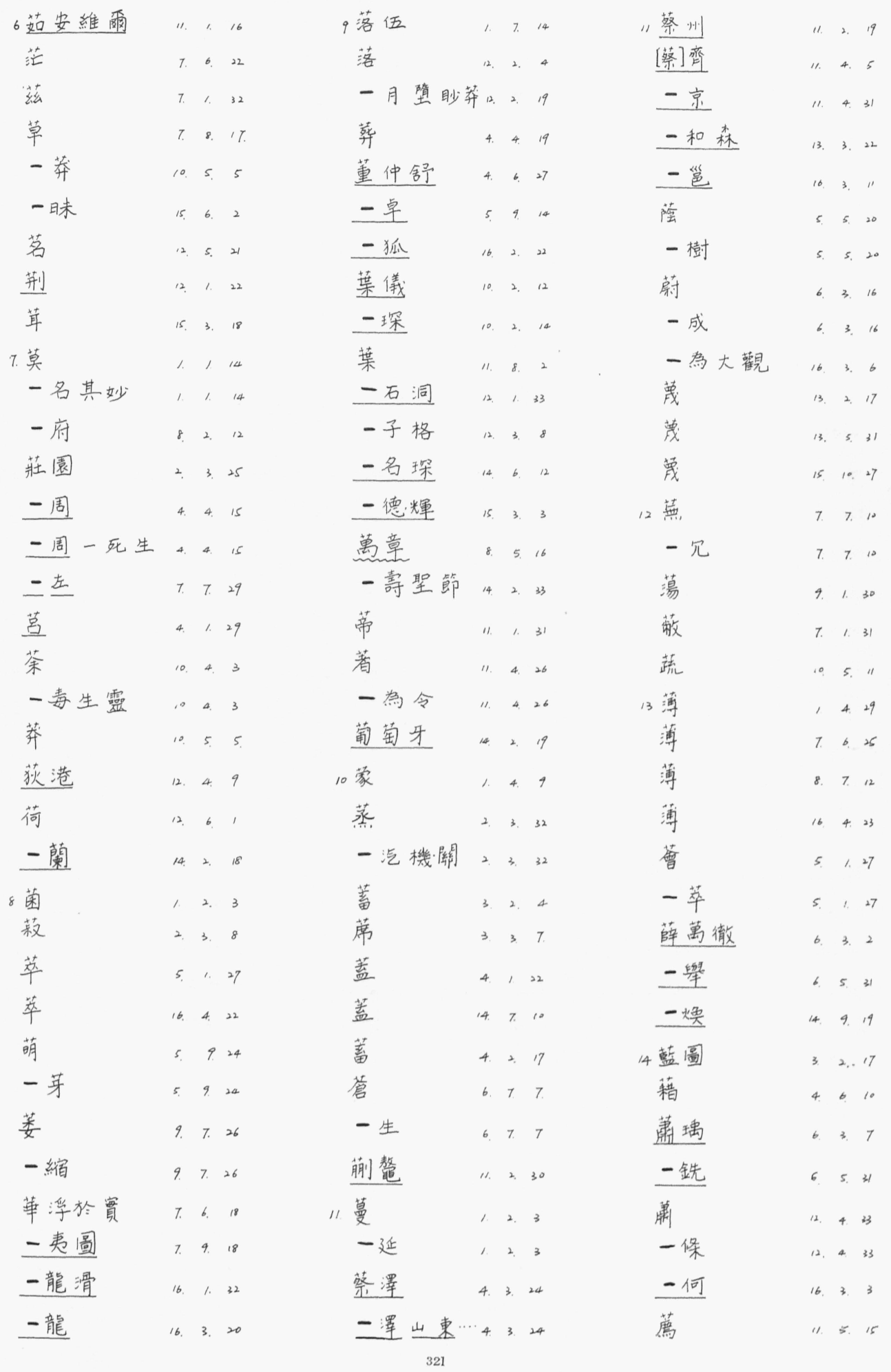




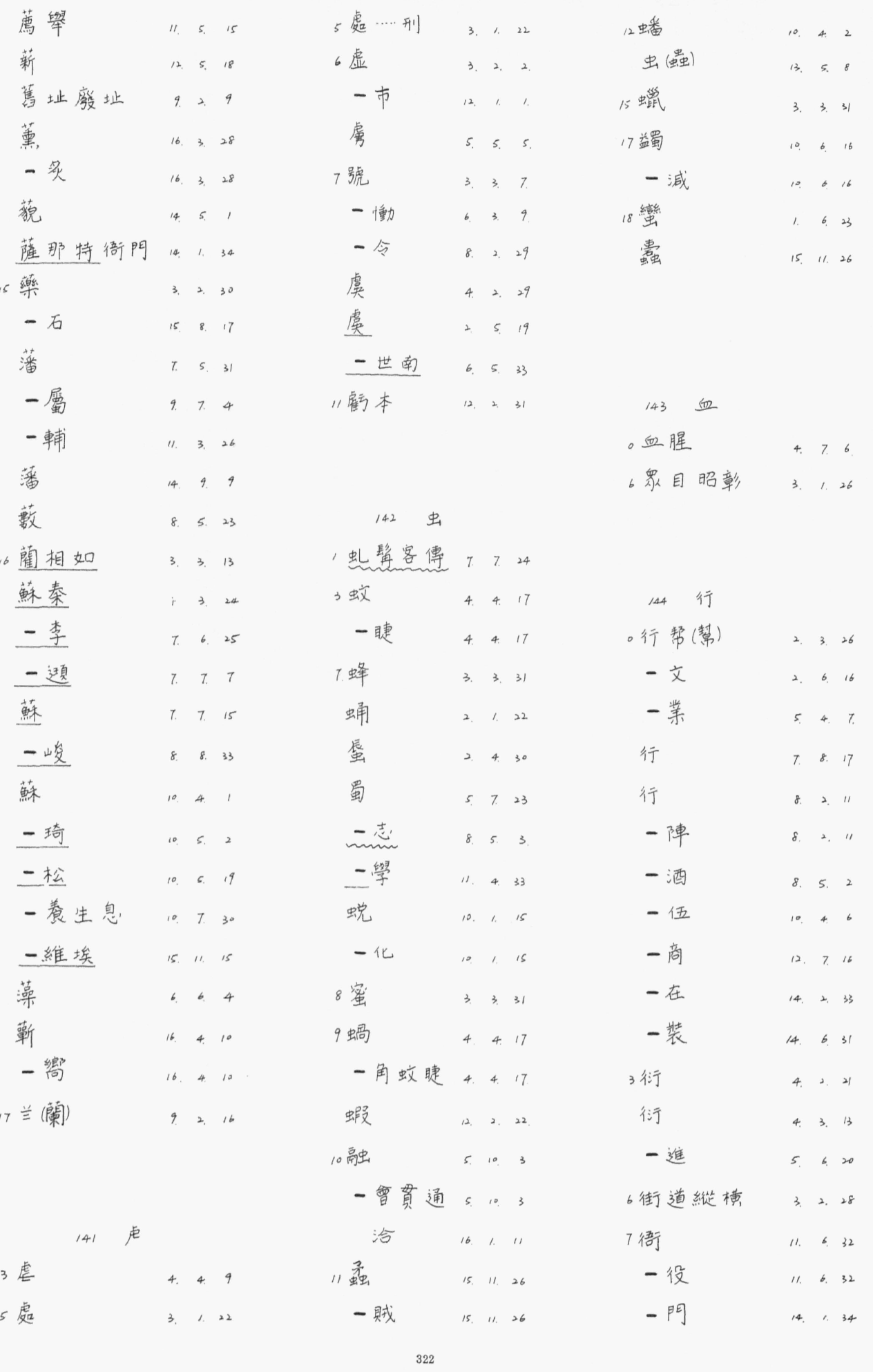




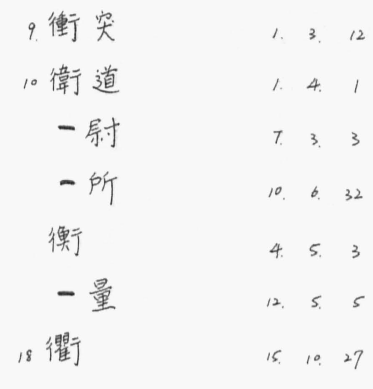

。衣鈫緼袍

$$
145 \text { 褯, }
$$

一飯

2 表

一拜

一徽

一文

- 章

4衽

袂

衰

- 颓

一微

袁紹

一逢

患

5 祀

被

6 裁

7 装飾

補救

$$
\text { 一償 }
$$

裕

里(裹)海

8 裴短 $\frac{9 \text { 褚遂良 }}{- \text { 亮 }}$

一亮

褚成博

堡

一揚

裨

- 益

袘

$$
\text { 一販 }
$$

$1 /$ 襄

$$
\text { 一乵辛 }
$$

16 襲

襲
14 袄( 襖)
- 县

4 規

- 摹

覓

9 者胃

11 唓

17 觀摩

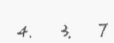

4. 2. 28

7. 6.

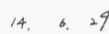

10. 3. 32

$4 \quad 20$

11. 4.20

12. 214

2. 2.14

14. 9.14

14. 9.14

9. 4.22

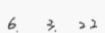

8. 7,

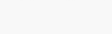

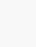

146 西，西

。西洋

一我

149 高

一班牙

一伯利亞

572

。角觝

6 解

$$
\frac{\text { 一夥 }}{\text { 一體 }}
$$

7 觝

148角

\section{角}

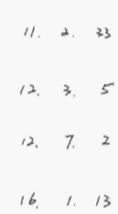

11 233
13 覈

14 霸

19 覊

一域

- 夏

- 辽

- 安

要害

䁶

147 見

。見

一尊為
。言奪笔李7.6.25

一必由表

一路

15. 5,13

一官

2訂正

計吏

3 毫

討厭

訖

一未安定7. 5. 19

4 設施

- 奇监幻

5. 8.8

7. 7.18

許敬宗雨 96

許

一都
8. 3. 21

8. 3.31 


\begin{tabular}{|c|c|c|c|c|c|c|c|c|c|c|c|}
\hline 4許元 & 10. & 2. & 13. & 6詬 & 15. & 2. 1 & 14 & 9.諸葛㵙 & 11 & 3. & 2 \\
\hline - 行 & 12. & 4. & 28. & 一病 & 15. & 2. & 14 & 一色係官…… & " & 6. & 5 \\
\hline 訟 & 8 & 11. & 13 & 7 誕 & 1. & 6. & 5 & 一蕃志 & 12. & 2. & 7 \\
\hline 訛 & 10. & 5. & 31. & 誠 & 4. & 1.25 & 25 & 諜 & 3 & & 27 \\
\hline 詎 & 15. & 7. & 13 & 一 然 & 5 & 7. 2 & 29 & 諧 & s. & 3. & 10 \\
\hline 5. 評議霄 & 2. & 2. & 29 & 誨 & 4. & 2. 32 & 32 & 諱 & 6 & 1.2 & 21 \\
\hline 訫 & 4. & 2. & 13 & 説 & 4. & 4. 19 & 19 & 諫 & 6. & 5. 2 & 23 \\
\hline 一訶 & 4. & 4. & 22. & 誦 & 4. & 6. 7 & 7. & 一猙 & 6. & 6 & 6 \\
\hline 詒 & 4. & 2. & 27 & 誘 & 7. & 4. 27 & 27 & 一議大夫 & 16. & 3. 1 & "1 \\
\hline 一書賛之 & 4. & 2. & 28 & 誥 & 7. & 7. 28 & 28 & 諷 & 7 & 6. 3 & 30 \\
\hline 訶 & 4. & 4. & 22 & 誌 & 7. & 7. 2 & 28 & 諦 & 7 & 3. & 21 \\
\hline 些 & 4. & 6. & 15 & 誓 & 8. & 4. 2 & 24 & 一考深思 & 7. & 3. 2 & 21 \\
\hline 一議 & 7. & 2. & 20 & 語 & 12. & 3. 1 & 10 & 謔 & 11. & 3. 3 & 30 \\
\hline 詛楚文 & 5 & 7. & 7. & 㟇藏 & 13. & 5. 3 & 31 & 諾 & 14. & 7. & 28 \\
\hline 詛 & 9 & 7. & 30 & 言巫 & 15 & 3. 2 & 26 & 諳 & 14. & ?. 1 & 19 \\
\hline 詔 & 7. & 2. & 22 & 8 課 & 4. & 2. & 9 & 一悉 & 14. & 9. & 19 \\
\hline 一翠 & 7. & 4. & 22 & 一以一定….... & 4. & 2. & 9 & 10 影 & 4. & 3. & 3. \\
\hline 一復徭役 & 8 & 5. & 6 & 課 & 5. & 8. ' & 19 & 謎 & 5. & 1. & 32 \\
\hline 詐 & 8 & 10. & 6 & 一君臣之能 & 5. & 8. 1 & 19 & 謝赫 & 7. & 8. & 22 \\
\hline 詞訟 & 11 & 3. & 30 & - 口 & 8. & 103 & 30 & "謬 & I. & . & 16 \\
\hline 6誅 & , & , & 18 & 誼 & 4. & . 8 & 8 & 謹 & 8 & 10. & 33 \\
\hline - 滅 & , & \%. & 18 & 猙 & 6. & 6. 6 & 6 & 謨 & 15 & 3. & 7. \\
\hline 詹何 & 4. & 4. & 15 & 諞唯往 来 & 7. & 2. 24 & 24 & 12 譜 & , & 3. & 20 \\
\hline 一何先識 & 4. & 4. & 15 & - 斷 & 12. & 5. 3. & 30 & 譏 & 3. & 4. & 28 \\
\hline 誇 & 5 & 2. & 22 & 一坛 & 13. & 3. 1 & 17 & 一薄 & 16. & 4. & 23 \\
\hline 一張 & 5. & 2. & 22 & 請款 & 14. & 3. 2 & 28 & 識㤠鉒精通 & 6. & 6. & 4 \\
\hline 詢 & 6. & 6 & 20 & 諉 & 15. & 102 & 21 & 識 音 & 10. & 3 & 7 \\
\hline 詣 & 7. & 6 & 17 & 言非 & 16. & 4. 2 & 22 & 譚廷䘫 & 14. & 6 & 15 \\
\hline 詣 & 8. & 3. & 15 & 9諸候 & 2. & 3. 2 & 26 & 13 議岳篇 & 2. & 6 & 10 \\
\hline 詳明政術 & $T$. & 4. & 12 & 諸 & 3. & 1. 2 & 27 & 一郎 & 12. & 3. & "1 \\
\hline 一贍 & 7. & 9. & 24 & 一子爭鳴 & 4. & 5.2 & 23 & 譬 & 5 & 7. & 5 \\
\hline 該 & 7. & 6. & 25 & 一葛亮 & 4. & 6. 3 & 30 & 一如 & 5. & 7. & 5 \\
\hline 詡 & 11 & 2. & 22 & 一監 & 7. & 2. & 11 & 警戒 & 11 & 3. & 27 \\
\hline 詰 & 15. & i. & 26 & 一葛誕 & 8. & 7.1 & 12 & 14 留 & 5 & 2. & 28 \\
\hline 一難 & 15. & ؛ & 26 & 一萣恪 & 8 & $\delta$. & 5 & 辯証法 & 13 & 11 & 33 \\
\hline
\end{tabular}


14 護軍

一法

16 彎遷

一態

一革

一通

5. 2, 13

信誰

$16,6,2$

I. 5, 22

1. 6.22

7. 1,25

16, 3. 7
14, 3. 69 9.予象章

9. 豫草
豫
豫
弱
10 逐国

151 豆

9頭路

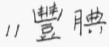

$1,3.32$
$11,7.4$

152 豖

。豖

12, 5.15

5 象州

12. 6.12

- 數

15, 7,32

6 券

- 食

7 豪

一商富賈

- 右

一傑

一俠

$8,10,32$

$8,10,32$

9 予象

153 第

3 豹

一飾

一幨

6 貌高

一高所埒

8. 5. 19

8. 5,19

8. 5. 19

8, 12,16

8. 12.16

154 具

。县尔

\section{一加尔湖}

2 真

一箭之麻

真

-

一観

冥

- 用

- 元

冥

3 貢

一獻

一舉

椇計

員司

4 責盖

- 成

$2,4,24$

7. 6.11

7. 7. 11

$15,7,2$

3. 3.24
貝民窟

一窘

貫

一澈

典

颠

一夫

令邪

宔

一婪

一污

貨色

具名

貲

12, 6. 5

7. 634

7.6 .34

8. 3.18

8. $4 \quad 10$

9. 8.3

10. 4.8

$13,3.3$

5 貴賻不衍

3. 4.21

一遊子弟7.4.19

一於清綺 7. 6. 11

貿

一易

5. 5,28

具占

5. 5.28

一補

11. 7.7

貽

- 軎

㖵

6 賈

一誼

3. 2.23

一躵

4. 6,29

一公彦

7. 7.15

曹

䀫

具各

瓷助

- 源

資
8. 4.27

$11,3.1$

4. 3. 4

4. 3. 4

5 6., 1

5. 7.23

8. 3. 18 


\begin{tabular}{|c|c|c|c|c|c|c|c|c|c|c|}
\hline 6戝 & 8 & 7. 1 & 18 & 賽夷實合 & 9. & 7. 34 & 4 & 7 趙 & $s$ & 7. 4 \\
\hline 賃 & "I, & 7. 12 & 12 & 一廟 & 12 & 2. 24 & & 一鞅 & 5. & 6. 32 \\
\hline 賅 & 15. & 7. 2 & 28 & 賺 & 13 & 2. 28 & & 一充國 & 8 & 2. 17 \\
\hline 7 賬 & 8 & 6. 33 & 33 & 12 贈 & 5. & 2. 28 & & 一 翼 & 8 & 3. 14 \\
\hline 一贍 & 8. & 6. 3. & 34 & 13䀶 & 7. & 9. 24 & & 一均用 & 10. & $2, \ldots 3$ \\
\hline 䆩 & 10, & 1. 28 & 28 & 賒 & 8. & 6. 34 & & 一鐵寒兄 & $" 1$ & 8. 1 \\
\hline 賕 & ", & 3. 2 & 2 & 一養 & 11 & 3. 24 & & 一汝适 & 12 & 2. 7 \\
\hline 一謝 & 11. & 3. & 2 & 7 贜 & 10 & 7. 34 & & 10 堨 & 4. & 3. 15 \\
\hline 竇横 & 12, & 3. 3 & 30 & 一官 & 10. & 7. 34 & & 一勢 & 5 & 3. 31 \\
\hline 8 贅 & 2 & b. & 5 & 草垻 & 15. & 2. 3 & & & & \\
\hline 一俊 & 4. & 3. 2 & 25 & 一南 & 15 & 2. 3 & & & & \\
\hline 一能 & 6 & 5. 2 & 22 & & & & & 157 足 & & \\
\hline - 良方正 & 7. & 4. 1 & "1 & 155 赤 & & & & 。足 & ', & 4. 28 \\
\hline - 否 & 15. & 4,32 & 32 & 。赤 & 10 & 3. 2 & & 5 距 & 6. & 5. 8 \\
\hline 荗 & 3 & 1. 2 & 22 & - 子 & 10. & 4. 15 & & 一離 & 6. & 5. 8 \\
\hline 䑗 & 4, & 1. 31 & 31 & 4赦 & 8 & 5. 7 & 7 & 跋 & 7 & 7. 24 \\
\hline 一客真 & "1, & 2. " & 14 & & & & & 一扈 & 7. & 7. 24 \\
\hline 賞賜 & 4. & 13 & 31 & & & & & 6 跡 & 1 & 5. 22 \\
\hline 一存乎慎法 & 5. & 8. 2 & 20 & & & & & 路 & " & 4. 6 \\
\hline 一責 & 8, & 8,2 & 22 & 156 走 & & & & 一易·波拿…… & 13. & 11.34 \\
\hline 䳢 & 4. & 2. & 11 & 。走頭不是. & , & 6. 10 & 10 & 8 踢 & 3. & 2,31 \\
\hline 賦 & 15: & 3. 3 & 31 & 一卒 & 7 & 6. 34 & 4 & 踏 & 9. & 4. 19 \\
\hline 一性 & is: & 3. & 31 & 掛 & 6. & 2. 8 & 8 & 一进 & 9. & 4. 19 \\
\hline 趩 & 8 & 82 & 22 & 一聞召見 & "1. & 2. 15 & 5 & 一破鐵鞋…… & 13. & 6. 12 \\
\hline 貿明 & 8. & 4. & 26 & 3 起義 & 9. & 4. 21 & -1 & 践 & 15. & 3. 7 \\
\hline - 裴 & 8 & s. & 9 & 一留 & 12, & 8. 9 & 9 & - 履 & 16, & 6. 20 \\
\hline 9 睹 & 3. & 2. 3 & 30 & - 家 & 16. & $3 \quad 14$ & 14 & 踞 & 16. & 5. 16 \\
\hline 一博 & 3. & 2. 3 & 30 & 5超克 & 2 & 4. 5 & 5 & 9踵 & 4. & 4. 20 \\
\hline 賴 & 4. & 3. 3 & 32 & 趁虚 & 12 & 2. 12 & 12 & 踰 & 9 & 7. 15 \\
\hline 賴 & ". & 2. 3 & 31 & 越祚 & 16 & $6 \quad 24$ & 24 & 10 蹋 & 3. & 2. 1 \\
\hline 10 賏 & 1. & 4 & 27 & $T$ 趙 & 3 & 2. 9 & 9 & 一鞠 & 3. & 21 \\
\hline 贅 & 7. & 4. & 29 & 二 氏 & 4. & 311 & 17 & 12 躈 & 11 & 8. 1 \\
\hline - 言 & 7. & 4. & 29 & 一孟 & 4. & 4. & 5 & 14 跃躍) & 13. & 4. 1 \\
\hline 却 & 8. & 5. & 18 & 一盾 & 4. & 4. & 8 & 蹈 & 16. & 4. 1 \\
\hline
\end{tabular}




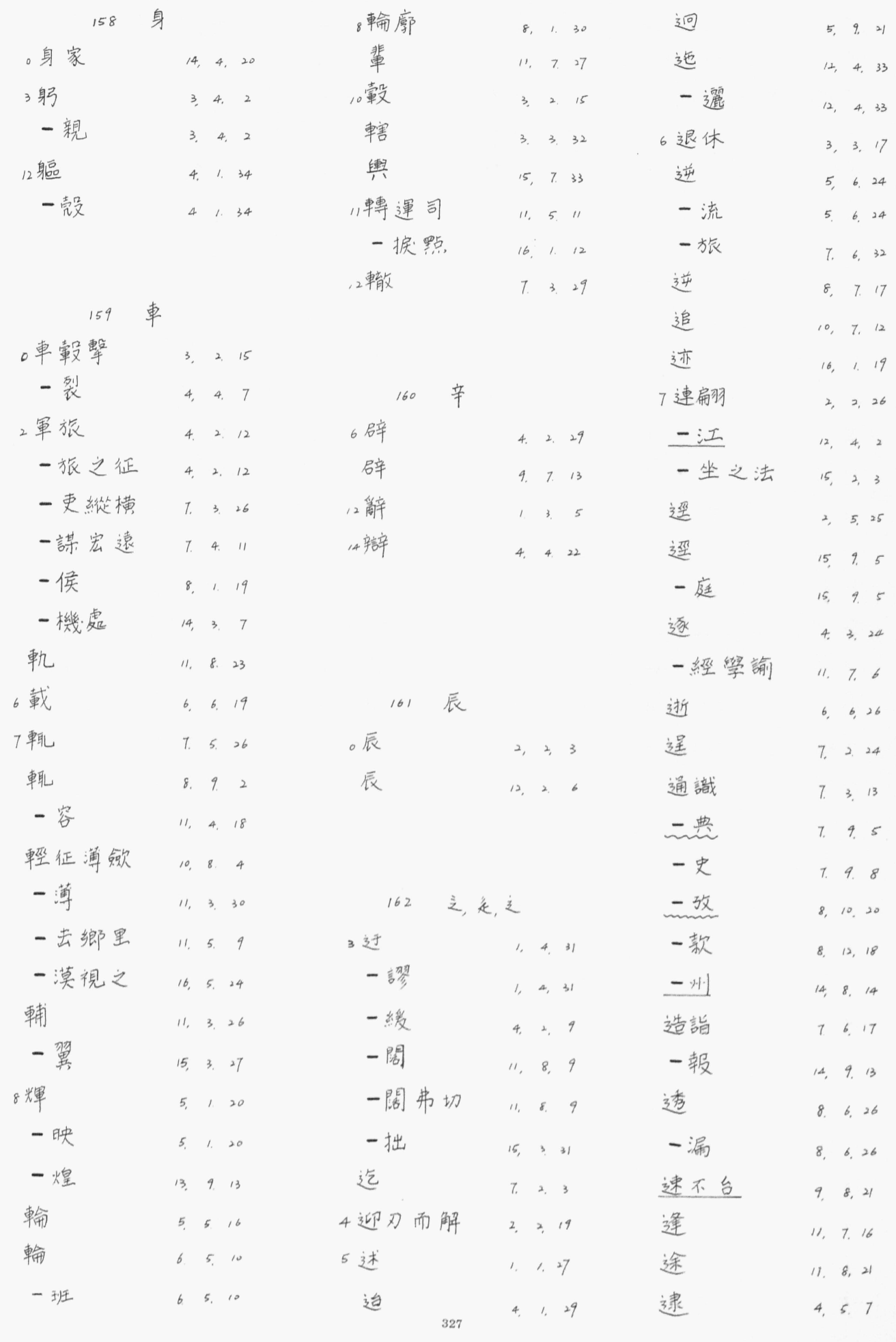




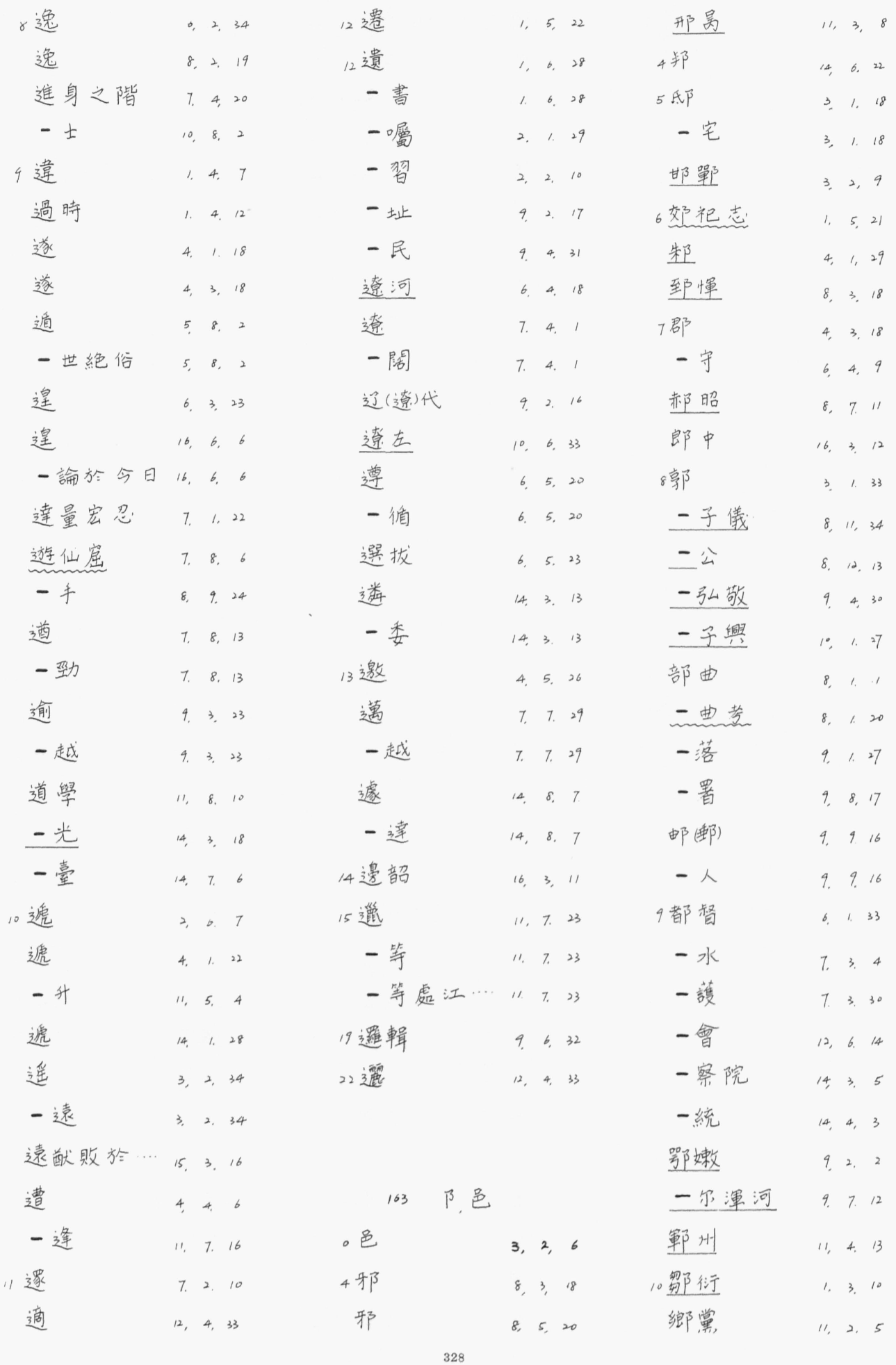


榔黨之學11.2.5 一里

川臨趴

鲉

12 粼

一近

郝㭌

鄭

二其火乎 4.3.7

一康成 $8,4,28$

一像

关澊队和

鄄州

奠哣

- 重

一去

登涏楨

19 震随元

11.5. 9

3. 2,10

7. 7.31

11. 1. 28

3. 1.14

3. 1.14

3. 1.28

$3.1,30$

8. 8.5

9. 4.29

10. 5. 2
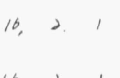

16. 2.19

4. 3. 31

7. 9.12
一視儒生

164 西

。酉

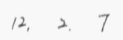

2 酋

2, 2, 29

一長

2. 2. 29

3配偶

酎

- 金

酌

一金

5 酢

6 酪

酬

$$
\text { 一酢 }
$$

7 酷

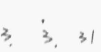

7. 6.27

7. 6,28

4. 6. 16
酷戻寡恩

酷

8 醋

醇

- 化

醉

13 醴陵

17 釀

一酒

18 雷

165

。番色

采石

采

13 采睪

釋

釋

$$
\text { - 子 }
$$

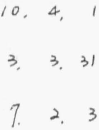

7. 2. 3

12, 2.24

12, 4. 10

12, 3. 30

12, 3. 30

$14,8,9$

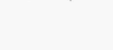

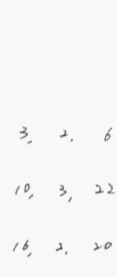

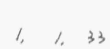

4. 3. 25

1., 2, ,

1. 8.22

166 里

3 重兵

一擔

一陽

整

- 整

一革卛通

一捐

- 然

。金玉其事…4...19 金朝

一世宗9.2.18

一冥裙 9.4.30

一哀宗9.6.5

一葉

一某表文14,2,29

一遭石室16,3.4

一馬門

2 針

一對

4 鈔

金少

5 鉛

- 印

鈎

鉋

金艮

鉅

。铜

一馬大栏

锐

一意

1. 712

街

铨

一選

一授

7 锋

銷

金肖

- 售

12. 7.13

鋸

鉝力

鋪

9. 916 


\begin{tabular}{|c|c|c|c|c|c|c|c|c|c|c|}
\hline 7 鋪牛 & 9. & 9 & 16 & 鋉 & 6, & 6,4 & 4 & 開基 & 15. & 5. 25 \\
\hline 鋪 & 12, & 8. & 23 & 15 镰 & 5 & 4. 4 & 4 & - 益 & 16, & 3. 17 \\
\hline 一張 & 12, & 8. & 23 & 17 鑲 & 5 & 3.23 & 23 & 一宗 & 16 & 5. 9 \\
\hline 8喜戔穆(富四) & , & 3. & 20 & 一青铜 & 5. & 3. 23 & 23 & 間詍 & 3. & 1. 27 \\
\hline 一玄同 & , & 4 & 34 & 全月(镭) & 13, & 4,15 & 15 & 間 & 12 & 2. 14 \\
\hline 一師窗四 & 1 & . & 29 & 19 鑽 & $T$ & 7. 12 & 12 & 一日 & 12 & 2. 14 \\
\hline 一易 & 12, & 2 & $" 1$ & 一仰 & 7. & 7. 12 & 12 & 閑 & 4. & 2.30 \\
\hline 錐 & 8 & 3. & 4 & & & & & 閑 & 7. & 6. 24 \\
\hline 一刀之末 & 8 & 3. & 4 & 168 長, 㫳 & & & & 一叚 & 7. & 6. 24 \\
\hline 金岡 & 5. & 4 & 7. & 。長江 & 2 & 4. 8 & 8 & 6 閣 & 6. & b. 29 \\
\hline 錯 & 5. & 7. & 8 & 一沙 & 5 & 3. 25 & 25 & 閣 & 16 & 3. 4 \\
\hline 錦 & 6. & 7. & 5 & 一安 & 5 & 5. 32 & 32 & 閥 & $T$. & 4. 20 \\
\hline 一紼 & 6. & 7. & 5. & 一䋇無忌 & 6. & 2. 25 & 25 & 閬 & 9 & 3. 33 \\
\hline 9 鍵 & 1. & 5. & 13 & 长(長) & 9 & 1.29 & 29 & 盛 & $"$ & 5. 1 \\
\hline 金契 & 2. & 4. 2 & 23 & 長州 & 10 & 5. 21 & 21 & 一學 & 11. & 5. ! \\
\hline 鍊 & 5. & 4. & 5 & 一白山 & 11 & 8. 24 & 24 & 闗 & 15 & 10.26 \\
\hline 鍫 & 5. & 4. & 19 & 一老 & 12, & 6. 11 & " & 閣 & 15. & 2. 8 \\
\hline 鍾離 & $\delta$ & 4 & 1 & 一蘆 & 14 & 8. 19 & 19 & 一閻 & 15. & 2. 8 \\
\hline 鍾離令 & $"$ ". & 8. 2 & 23 & & & & & 閶 & 15, & 2. 8 \\
\hline 10 鎮 & 3. & 1.2 & 22 & & & & & 9闇 & 6 & 2. 12 \\
\hline 一兵 & 7. & 5. 2 & 24 & $169 \quad 89$ & & & & 閣 & 7. & 1. 18 \\
\hline 一海管理 & 9 & 7. & 10 & 。門户 & ', & 4. 11 & 10 & 閧 & 15, & 19. 34 \\
\hline 一江 & 10. & 2,1 & " & 一閥 & 7. & 4. 2 & 20 & 10祭 & 4. & 5. 26 \\
\hline 鎖 & 9 & 9. & 7 & 一牌 & 15. & 2. 3 & 3 & 聞星 & "l. & 2. 15 \\
\hline "鏑 & 1, & 4. & 14 & 3閉 & 3. & 4. 1 & ' & 閶 & $"$ & 6. 14 \\
\hline 鏡 & 5 & 3. 2 & 28 & 一臂自守 & 3. & 4. 1 & 1 & 閭 & 15, & 3. 18 \\
\hline - 鑑 & 5. & 3. 2 & 28 & 4開幕 & 2 & 4. 17 & 7 & 一算 & 15. & 3. 18 \\
\hline 12 鐃 & 8 & 4. ， & 26 & 一阶陌 & $\Delta$ & 5. 33 & 3 & "關里㫗 & 4. & 4. 14 \\
\hline 13鐮 & 5. & 4. & 18 & 一疆䦣土 & 5 & 2. 16 & 16 & 一叉子貴清 & 4. & 4. 14 \\
\hline 鐸 & 8 & 4. 2 & 26 & - 元 & 7. & 2. 26 & 26 & 一白 & 5 & 6. 30 \\
\hline 鉄鐵木真 & 9 & 3, & 1 & 开開)封 & $?$ & 4. 20 & 20 & - 涉 & & 4. 5 \\
\hline 14金尌 & 3. & 3. & 25 & －辟 & 9. & 7. 13 & 13 & -中 & 8 & 7. 7 \\
\hline 鑑 & 5 & 2. & 10 & 一元全盛日 & $?$ & 7. 24 & 4 & 一中侯 & 8 & 7. 14 \\
\hline 一别 & 5. & 2. & ', & 一禧 & & 3. 19 & & - 防 & 14 & 3. 21 \\
\hline
\end{tabular}


12 閔

- 明

闡

13隦

16. 6. 8

閚

4. 4, 23

5. 2, 16

皇昌

170 阝, 阜

3 許

4 防御

5 附庸

一鿖

阻礙

阿尔泰

一里派

一不勒噶热，９．２０

- 斗

$15,10.31$

陂

一渠

6 降

降

陌

陔鉒丵考

婳

7 陕西

一西道

陟

除

㛗

一殿日期

陶

一希聖

一安
8 陶希聖

陸陽家

一結系客

陸機

一游

陳叔達

陳

一子昂

一整

的畫

一量

一登元

一埜先

一遇

一支諒

一修

一傅良

一請

一王

䧟

陪

一臣

9 階級甄域

隅

阹文带

而畫

一焬帝

隆

一起

队(隊)

- 伍

隄

一岸

陽
13. 3.29

4. 63

$10,1,88$

6. 6.16

12, 5,17

6. 3. 7

7. 7.8

7. 7.10

8. 3. 33

8. 6. 32

8. 5,23

8. 9. 23

$8,12.17$

10. 2,11

10. 3. 29

10. 5.2

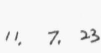

14. 2. 4

15. 2. 32

9. 2.6

14. 2. 5

14. 2. 5.

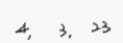

172 住

2 隼

4 雅

一 正

一量

雄厚

一渾

集結

雇

5 痽子

二(風翔)

雍
$12,8,26$

3,23

12, 2, 2

3. 1.18

11. 8,7 .

$2,3.9$

6. 2,29

$5,6,9$

6. 1.21

6. 1.21

6. 4. 20

71 逮

2. 3. 12

4, 3. 16

4. 3. 19

6. 4. 32

7. 5. 28

7. 8,17 
5 㒕容

雉

10 隻展周

一武之皮

案隹霸

一塄

“離宫

一間

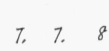

8, 5, 17

2, 2. 20

8, 5,19

5. 8. 12

7. 2.10

3. 3. 11

1511.28

173 雨, 雨

。雨

3 雪

4 雲岡

一巢集

5 零加 - 等 …

一星

7 震

一淿千古

15, 10. 24

4. 31

7. 8,31

12. 4.16

霄

一壤懸隔 15,4.14

8 霍

一心王傮

3. 4.16

9 霜

月露由

霸

16 需公

灵(䨐)

一山憬

䨐

一威

一魂
12, 5, 3

b. 5,16

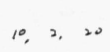

4. 4,8

9. 4. 16

$12,8,3$

16, 1. 33

16. 1.33

16. 4. 11
。青銅器

一箱森隹記

靖郭君

靖

一難

立青

175 非

。非吾徒

一儒篇

8 靡

㦄

一歲㛊有

176 面

177 革

2革力掯

了靯

6鞋

鞤

8 革米

9 鞭

一辟入蓑

一長莫及

12 革畺
2. 4.21

12. 1.27

3. 2.5

4. 3. 3

12, 6. 30

15. 3,22

4. 2. 13

4, 4, 22

4. 4. 19

9. 3.27

15, 10, 27

180 音

5 音召州

10 音員

一語

13 响(響)

導(导)
9. 5,20

5. 20 


\begin{tabular}{|c|c|c|c|c|c|c|c|c|c|c|c|}
\hline 一时(時) & 9 & 3. & 10 & 14 㬎面職 & 16. & 2,6 & 6 & 5飾小説从. & & 4. & 5. 2 \\
\hline 預 & 7. & 2 & 8 & 16 虚真 & 6, & 3. 4 & 4 & 一鬥具 & & 8. & 2. 19 \\
\hline 瑱 & 9 & ؛ & 33 & & & & & 飽 & & 10 & 1. 25 \\
\hline 一古非今 & 13. & 11. & 33 & & & & & 一更世故 & & 10. & 1. 25 \\
\hline 填 & 10. & 2. & 8 & 182 風 & & & & 6 食尊處㑑 & & 2 & 3. 22 \\
\hline 一強 & 10. & 2. & 8 & 。風光 & 3 & 2. 22 & 22 & 一廉 & & 14. & 9. 12 \\
\hline 填 & 15, & 5. & 5 & 一馬牛不 … & 3. & 4. 22 & 22 & 餉 & & $1 "$ & 7. 18 \\
\hline 一固 & 15. & 5. & 5 & 一人 & 7. & 6. 19 & 19 & 7 餒 & & I. & 4. 11 \\
\hline 5 颇 & 6 & 2. & 7 & 一尚 & 7. & 6. 34 & & 䬸 & & 3. & 3. 1 \\
\hline 6頡 & 4. & 4. & 12 & 一靡 & 7. & 7. 21 & & 餘笪真 & & 7. & 2. \\
\hline 7 磌緒 & 1. & 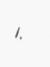 & 15 & 一操 & $"$ ". & 2,31 & & 一千 & & 12 & 5. 1 \\
\hline 一顱 & 6. & 3. & 4 & 一紀 & "1. & 5. 29 & 9 & 8 館閣 & & 16. & 3. 1 \\
\hline 䆏 & 5. & 3. & 1 & 一土 & 15, & 8. 15 & & 一睵 & & 16. & 3. 16 \\
\hline 一障墮級 & $"$ & 8. & 7 & 一潮 & 15. 1 & 10. 27 & & 10 螕 & & 15. & 11.9 \\
\hline 頻 & 6. & 3. 2 & 23 & 5䖝台風 & 5 & 6. 9 & & 一庮 & & 15. & 11. \\
\hline 一仍 & 6. & 3. & 23 & & & & & 餜 & & 16. & 2. \\
\hline 嵊 & $"$ ". & 4. & 5 & & & & & 一羊 & & 16. & 2.2 \\
\hline 8 顆 & 14 & 9. & 14 & & & & & "1饁 & & 4. & 7 \\
\hline 9顓瑱 & I. & 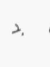 & 19 & 183 飛 & & & & 一饌 & & 4. & 7.6 \\
\hline 顔回 & 4 & 2. & 22 & & & & & 饉 & & 9 & 3. 1 \\
\hline 一謝 & 7. & 6. & 25 & & & & & 12 㙁巽 & & 4. & 76 \\
\hline 一真卿 & 7. & 8. & 18 & & & & & 饒 & & 7. & 5. 18 \\
\hline 一師古 & 8 & 2. & 14 & 184 食, 食 & & & & - 州 & & 8 & 6. 33 \\
\hline 額 & 5 & 8 & 31 & 。食客 & 3. & 3. 14 & 14 & 餓 & & 8. & 6. 33 \\
\hline 一尔古䋁 & 9 & 2 & 3 & 一货志 & 5. & 4. is & 15 & 17䭙 & & 12, & 5,12 \\
\hline 額! & 11 & 2. & 14 & 二华半月利 & 12,1 & 1. 24 & 24 & & & & \\
\hline 10 顛 & 10. & 7. & 3. & 2 飢 & 3. & 3. & 7 & & & & \\
\hline 一覆 & 10 & 7. & 30 & 讱䶿)䭊 & q. & 3. 1 & 19 & 185 & 首 & & \\
\hline 一倒 & 15. & 11 & 25 & 4 领 & 3. & 2. 3 & 30 & & & & \\
\hline 12 顧 & 4. & 7. & 6 & 飫 & 7. & b. 1 & 17 & & & & \\
\hline 顾(雇頁) & ? & 5 & 33 & - 聞 & 7. & 6. 17 & 7 & & & & \\
\hline 擮惜 & 9. & 5 & 33 & 䬢 & 14. & 9.2 & 23 & 186 & & & \\
\hline 顾惜 & 9. & 5 & 33 & - 令 & 14. & 9. 2 & 23 & 。番啤 & & 10 & 4. \\
\hline 14 㬎真 & 16. & 2 & 6 & 5 飾 & 4. & 5. 2 & 26 & & & & \\
\hline
\end{tabular}




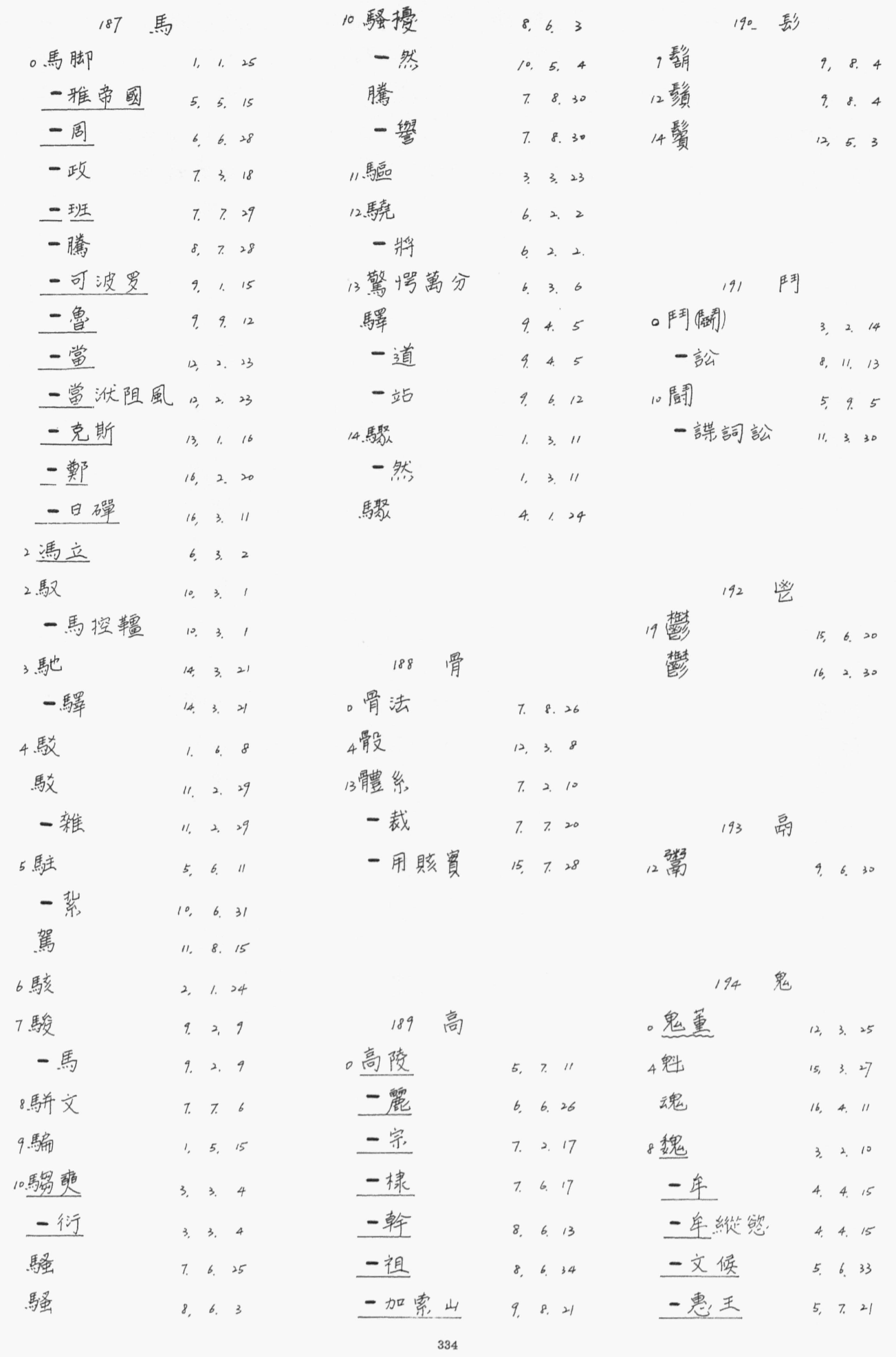




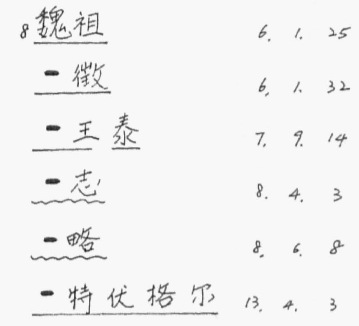

195 魚

。苗豆皆成椿 $12,4.18$

4 曹候乎4 48

一變聖道

一哀

$\begin{array}{lll}5 \text { 䰻 } & 12.5 .10 \\ \text { 6鮮 } & \text { 4. } 5.25 \\ \text { 一 及政治 } & \text { 4. 5. } 25 \\ \text { 鮮 } & \text { 13. } 2.44\end{array}$

$198 \quad$ 鹿

199 春

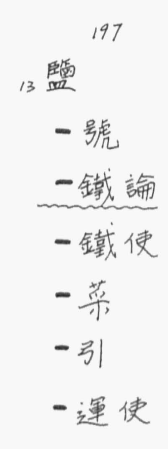

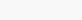

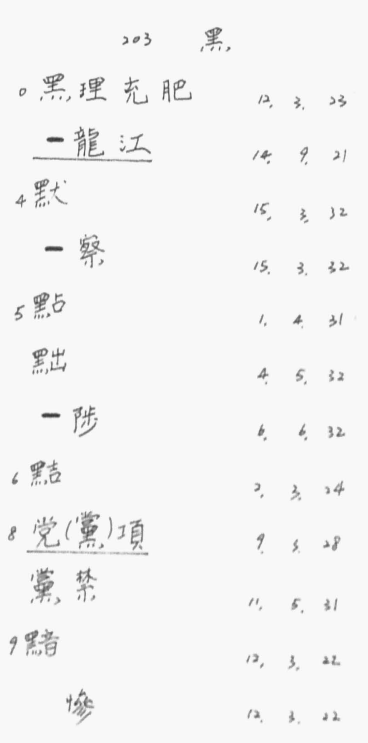
。黑理充肥

党( 填

掌, 禁

黯

1
3
3
3
4
4
4

202 番

$2,3,8$

3. 2.29

3. 2.29

5. 5. 11

7. 5.17

118.25

12, , 8

14.20

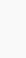




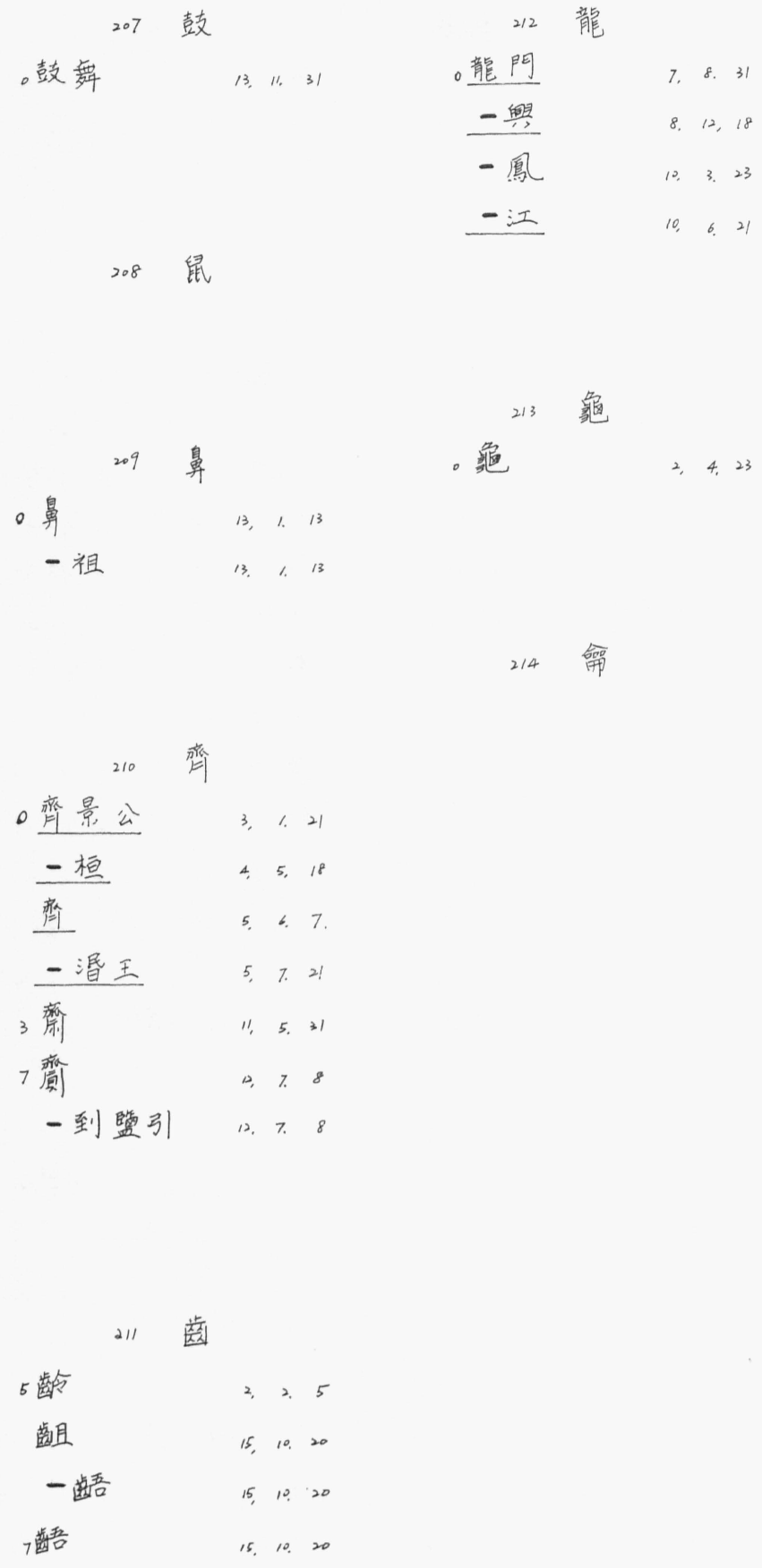

214 俞

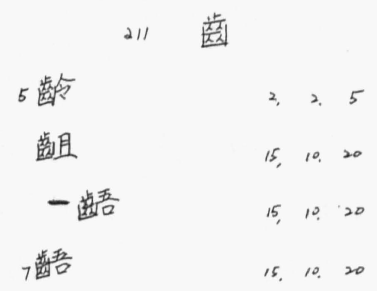

